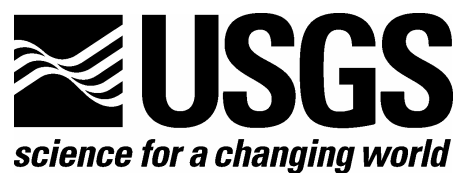

In cooperation with the National Park Service

\title{
Field Evaluations of Sampling Methods for Long-Term Monitoring of Upland Ecosystems on the Colorado Plateau
}

By Mark E. Miller, Dana L. Witwicki, Rebecca K. Mann, and Nicole J. Tancreto

2007

Open-File Report 2007-1243

U.S. Department of the Interior U.S. Geological Survey 


\section{U.S. Department of the Interior DIRK KEMPTHORNE, Secretary}

\section{U.S. Geological Survey \\ Mark D. Myers, Director}

U.S. Geological Survey, Reston, Virginia 2007

For product and ordering information:

World Wide Web: http://www.usgs.gov/pubprod

Telephone: 1-888-ASK-USGS

For more information on the USGS - the Federal source for science about the Earth, its natural and living resources, natural hazards, and the environment:

World Wide Web: http://www.usgs.gov

Telephone: 1-888-ASK-USGS

Suggested citation:

Miller, Mark E., Witwicki, Dana L., Mann, Rebecca K., and Tancreto, Nicole J., 2007, Field evaluations of sampling methods for long-term monitoring of upland ecosystems on the Colorado Plateau: U.S. Geological Survey Open-File Report 2007-1243, 188 p. [http://pubs.usgs.gov/of/2007/1243/].

Any use of trade, product, or firm names is for descriptive purposes only and does not imply endorsement by the U.S. Government.

Although this report is in the public domain, permission must be secured from the individual copyright owners to reproduce any copyrighted material contained within this report. 


\section{Contents}

Abstract

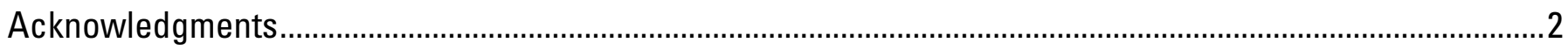

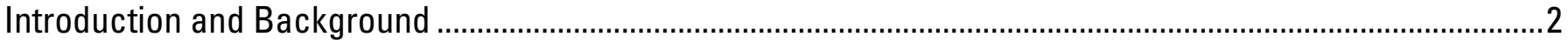

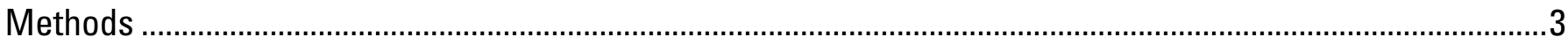

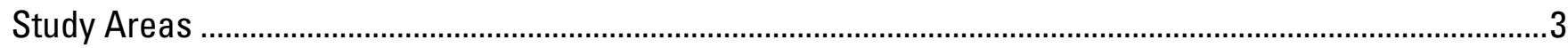

Field Sampling

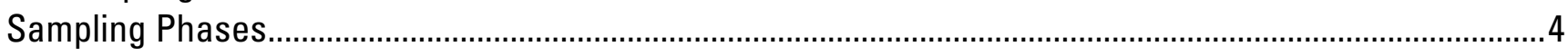

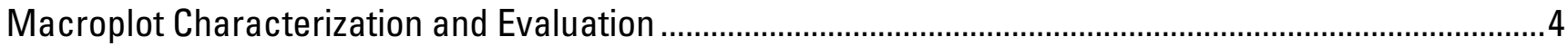

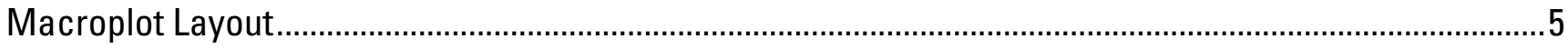

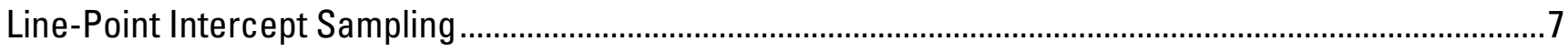

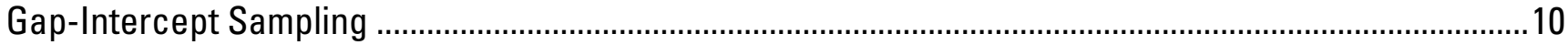

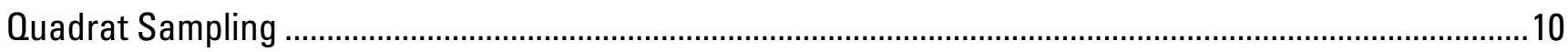

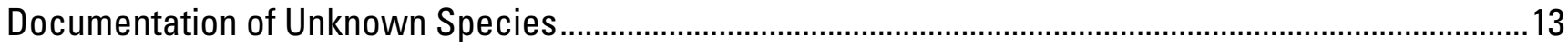

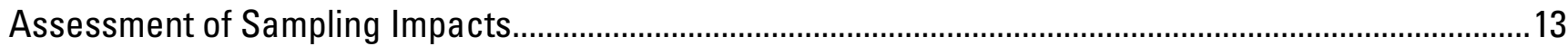

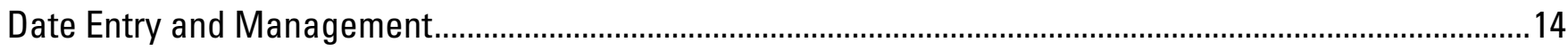

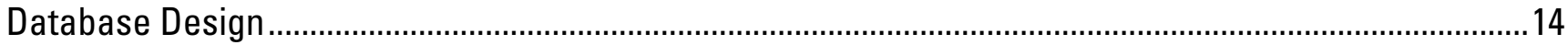

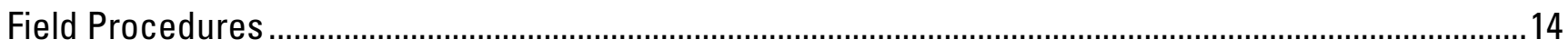

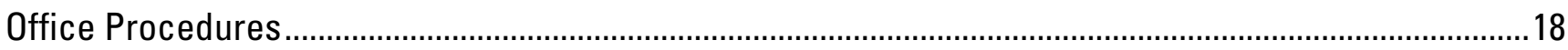

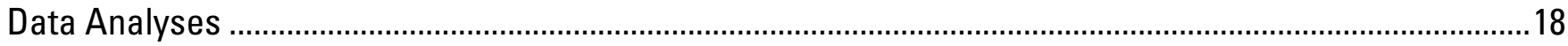

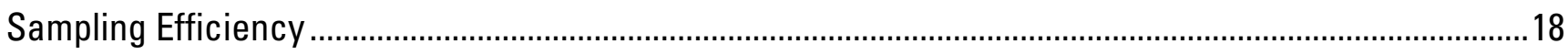

Among-Method Trends in Cover Estimates .......................................................................................... 19

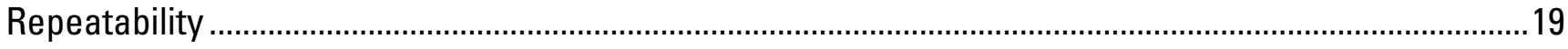

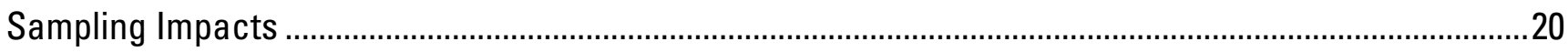

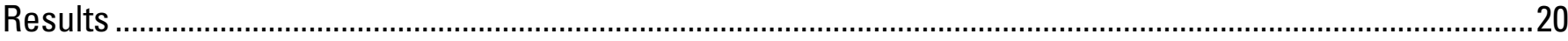

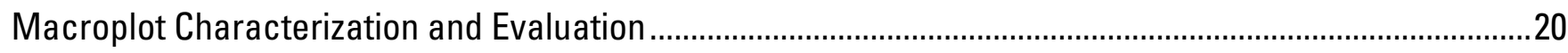

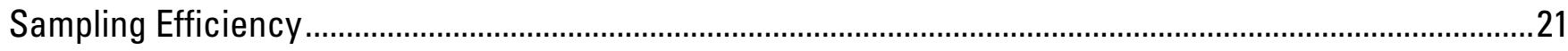

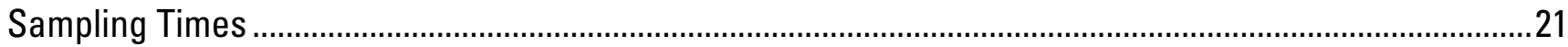

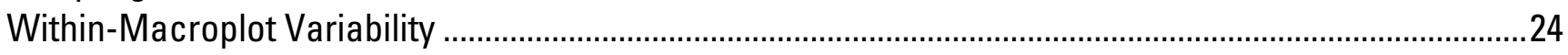

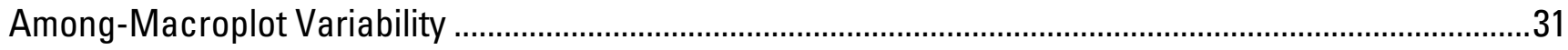

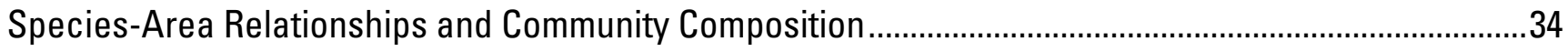

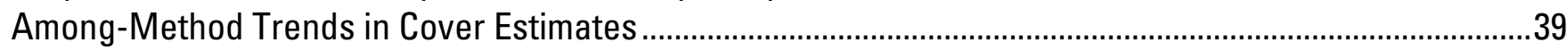

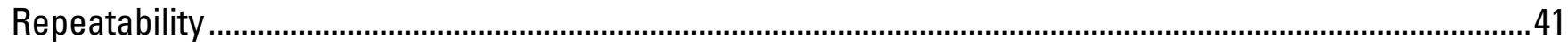

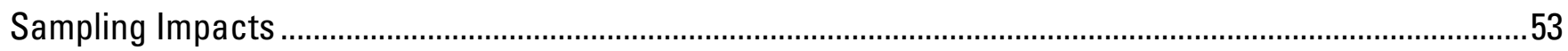

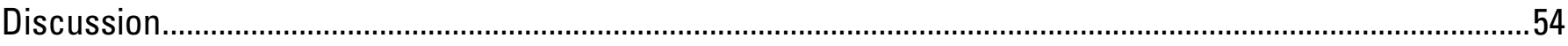

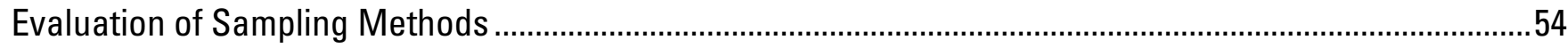

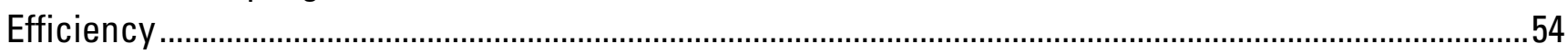

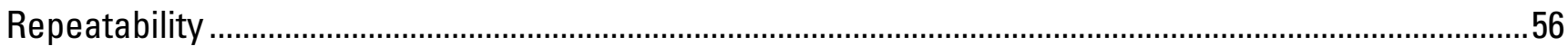

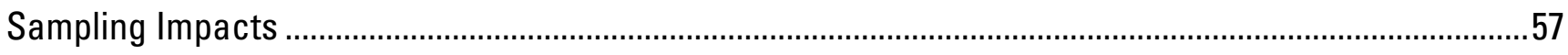

Issues Associated with Electronic Data Entry and Management ............................................................58

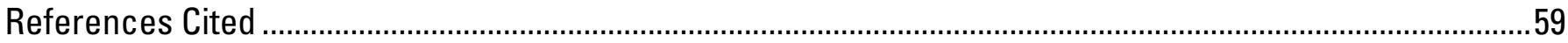

Appendix A—Species List and Species Occurrence by Ecological Site.....................................................61

Appendix B-Within-Macroplot Variability of Cover Estimates by Sampling Technique and

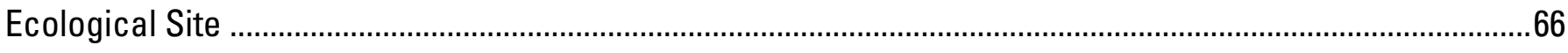

Appendix C-Summaries of Frequency and Cover Estimates by Macroplot and Sampling Technique..........78 
Appendix D-Among-Macroplot Variation in Selected Cover Measures by Ecological Site

Appendix E-Mean Species-Area and Compositional Curves by Ecological Site ...........................................139

Appendix F-Between-Observer Differences in Estimates of Cover and Density ...........................................151

Appendix G—Nested Frequency Data by Ecological Site ............................................................................... 161

\section{Figures}

Figure 1. Standard macroplot and transect layout used during the 2005 field season.........................6

Figure 2. Transect layouts used for comparing repeatability and efficiency of square and rectangular quadrats during Phase 1 sampling.

Figure 3. Transect lengths and types of sampling conducted during Phases 2 (a) and 3 (b)..............7

Figure 4. Dimensions of square and rectangular nested quadrats that were evaluated during Phase 1 , and of square quadrats that were used during Phases 2 and 3.

Figure 5. Photographic key to soil-surface categories used for describing degrees of biological soil crust development on the basis of relative soil darkness (J. Belnap, unpublished). 13

Figure 6. Main effects of (a) ecological site, (b) cover category (total live understory canopy, individual species, and soil-surface features), and (c) sampling method on log-transformed CV values describing within-plot variability in cover measures. Bars indicate 95 percent confidence intervals. Within each panel, values with the same letter are not significantly different by Tukey's HSD test. See table 1 for ecological site codes.

Figure 7. Interactive effects of ecological site and cover category (total live understory canopy, individual plant species, and soil-surface features) on log-transformed CV values describing withinplot variability in cover measures. Bars indicate 95 percent confidence intervals for means. See table 1 for ecological site codes.

Figure 8. Median numbers ( \pm 25 percentiles) of subsamples required for 20 percent precision in macroplot-level estimates of (a) total live understory canopy cover, (b) live cover of individual plant species, and (c) cover of surface features across 11 ecological sites sampled on the Colorado Plateau in Utah and Arizona. In (a), there is no difference among median values obtained via different sampling methods (Kruskal-Wallis $\mathrm{H}=5.89, \mathrm{df}=2, \mathrm{n}=33, \mathrm{p}=0.0525$ ). In (b), median values from $10-\mathrm{m}^{2}$ quadrats and line-point intercepts are significantly different from one another (KruskalWallis $\mathrm{H}=15.41, \mathrm{df}=2, \mathrm{n}=94, \mathrm{p}=0.0004)$. In (c), there is no significant difference among medians from different methods (Kruskal-Wallis $\mathrm{H}=3.08, \mathrm{df}=2, \mathrm{n}=98, \mathrm{p}=0.2139$ ).

Figure 9. Time required to estimate total live understory cover using (a) the line-point intercept technique, (b) $1-\mathrm{m}^{2}$ quadrats, and (c) $10-\mathrm{m}^{2}$ quadrats in relation to cover estimates derived from the same sampling techniques. Points are labeled by ecological site codes (see table 1 for key to codes) and symbolized to indicate the general physiognomic structure of the sampled plant community. Ecological sites underlined in (a) are those where line-point intercepts were used to estimate cover of overstory vegetation above $2-\mathrm{m}$ in height, in addition to understory vegetation and soil-surface features.

Figure 10. Median numbers of hours ( \pm 25 percentiles) required for subsampling to achieve 20 percent precision in macroplot-level estimates of (a) total live understory canopy cover, (b) live cover of individual plant species, and (c) cover of surface features across 11 ecological sites sampled on the Colorado Plateau in Utah and Arizona. For each cover category, there is no significant difference among median sampling times for different sampling methods (a. Kruskal- 
Wallis $H=0.95, d f=2, n=33, p=0.6216$; b. Kruskal-Wallis $H=4.51$, $d f=2, n=94, p=0.1045 ; c$. Kruskal-Wallis $\mathrm{H}=1.68, \mathrm{df}=2, \mathrm{n}=98, \mathrm{p}=0.4327$ ).

Figure 11. Main effects of cover category (total live understory canopy, individual species, and surface features) on log-transformed CV values describing among-macroplot variability in cover estimates across 11 ecological sites sampled on the Colorado Plateau in Utah and Arizona. Values with different letters are significantly different from one another (Tukey's HSD test, between MS = $0.6231, \mathrm{df}=216, \mathrm{p}<0.01$ for all pair-wise comparisons).

Figure 12. Median numbers ( \pm 25 percentiles) of macroplots required for 20 percent precision in ecological-site-level estimates of (a) total live understory canopy cover, (b) cover of individual plant species, and (c) cover of surface features across 11 ecological sites sampled on the Colorado Plateau in Utah and Arizona. For each cover category, there is no significant difference among median macroplot numbers for different sampling methods (a. Kruskal-Wallis $\mathrm{H}=0.95, \mathrm{df}=2, \mathrm{n}=33$, $\mathrm{p}=0.6218$; b. Kruskal-Wallis $\mathrm{H}=1.38, \mathrm{df}=2, \mathrm{n}=96, \mathrm{p}=0.5005$; c. Kruskal-Wallis $\mathrm{H}=3.05, \mathrm{df}=2, \mathrm{n}=$ $96, p=0.2174)$.

Figure 13. Median ratios of within-to-among macroplot variability (based on log-transformed CV values) for estimates of (a) total live understory canopy cover, (b) live cover of individual plant species, and (c) cover of surface features across 11 ecological sites sampled on the Colorado Plateau in Utah and Arizona. For each cover category, there is no significant difference among median ratios for different sampling methods (a. Kruskal-Wallis $\mathrm{H}=2.39$, df $=2, \mathrm{n}=33, \mathrm{p}=0.3033$; $\mathrm{b}$. Kruskal-Wallis $H=4.33, d f=2, n=96, p=0.1147$; c. Kruskal-Wallis $H=3.05, d f=2, n=96, p=0.3941$ ).

Figure 14. Log-transformed species richness data (mean numbers of unique species detected in 15 quadrats) in relation to ecological site and quadrat size (a) for all species detected, and (b) excluding infrequent species that occurred in only one $10-\mathrm{m}^{2}$ quadrat from the $10-\mathrm{m}^{2}$ data. (See table 1 for key to ecological site codes.)

Figure 15. Estimated total live understory canopy cover (standardized means) by method averaged across 11 ecological sites on the Colorado Plateau. Bars indicate 95 percent confidence intervals. Values with different letters are significantly different by Tukey's HSD test.

Figure 16. Estimated total live understory canopy cover (standardized means) by method and 11 Colorado Plateau ecological sites. Bars indicate 95 percent confidence intervals for means. See table 1 for ecological site codes.

Figure 17. Effect of sampling method on cover estimates (standardized means) for selected surface features (litter, biological soil crust, and bare soil) across 11 ecological sites on the Colorado Plateau. Means with different letters are significantly different by Tukey's HSD test.

Figure 18. Effects of sampling method on cover estimates (standardized means) for (a) surface litter, (b) unstable bare soil, and (c) biological soil crusts (moss, lichen, and cyanobacteria combined) at eight Colorado Plateau ecological sites.

Figure 19. Scatterplot of average wind speed $\left(\mathrm{m} \mathrm{s}^{-1}\right)$ vs. absolute difference between two observers' estimates of grass cover based on use of the line-point intercept sampling technique at eight Colorado Plateau ecological sites $(r=0.07, p=0.55, n=70)$.

Figure 20. Photograph (left) of destabilized soil and trampled biological soil crusts on unsampled side of transect in Arches National Park (Semidesert Shallow Sandy Loam ecological site), and (right) trampled plants on unsampled side of transect in Wupatki National Monument (Limy Upland ecological site). 


\section{Tables}

1. Ecological sites, associated NRCS soil surveys and soil map units, and macroplots sampled during Phases 2 and 3 of the 2005 field season...

2. Phases of sampling conducted during the 2005 field season...........................................................

3. Measures recorded during line-point intercept sampling. ..........................................................

4. Definitions of plant material and plant status ..............................................................................

5. Categories of soil-surface disturbances described during line-point sampling and quadrat sampling.

6. Soil crust categories used during line-point sampling and quadrat sampling.................................9

7. Definitions used for gap-intercept sampling

8. Cover-class scale used to estimate cover in $10-\mathrm{m}^{2}$ quadrats.........................................................11

9. Size classes used for recording shrub and tree density

10. Soil-surface categories used for estimating cover and development of biological soil crusts in $25 \mathrm{~cm} \times 25 \mathrm{~cm}$ quadrats on the basis of relative soil darkness.

11. Evaluation matrix for rating sampling impacts, considering the entire macroplot visit and all sampling procedures combined.

12. Explanations of sampling procedures for purposes of impact assessment.................................17

13. Impact-assessment ratings for individual sampling procedures.

14. Summary of macroplots that were relocated following site characterization and prior to sampling.

15. Mean times for setting up and reading frequency (freq), cover (cov), and density (dens) in 1- $\mathrm{m}^{2}$ and $10-\mathrm{m}^{2}$ quadrats.

16. Mean times for sampling line-point intercept transects, basal- and canopy-gaps transects, and biological soil crust (BSC) frames.

17. Analysis of variance for effects of ecological site, cover category (total live understory canopy, individual species, and soil-surface features), and sampling method on log-transformed CV values describing within-macroplot variability in cover measures.

18. Results of multiple-regression models evaluating significance of subsample size, frequency, and mean cover as predictors of log-transformed CV values describing within-macroplot variability in cover measures.

19. Summary of mean estimates for total live understory canopy cover for each of 11 Colorado Plateau ecological sites, within-macroplot variation in cover estimates summarized across $n$ macroplots within each ecological site, subsample sizes required to achieve 10 and 20 percent precision in estimates of macroplot-level means, and estimated amounts of sampling time required to achieve those degrees of precision.

20. Analysis of variance for effects of cover category (total live understory canopy, individual species, and surface features) and sampling method on log-transformed CV values describing among-macroplot variability in cover estimates.

21. Among-macroplot variation in estimates of total live understory canopy cover for 11 ecological sites (n macroplots per ecological site), macroplot sample sizes required to achieve 10 and 20 percent precision in estimates of site-level means, and ratios of within-to-among CV values.

22. Species richness data for several ecological sites on the Colorado Plateau, based on 10- $\mathrm{m}^{2}$ and 1 - $\mathrm{m}^{2}$ quadrats.. 
23. Analysis of variance for effects of ecological site and quadrat size on log-transformed values for the number of unique species detected in $1510-\mathrm{m}^{2}$ and $1-\mathrm{m}^{2}$ quadrats during Phase 3 sampling.

24. Analysis of variance for effects of ecological site and quadrat size on log-transformed values for the number of unique species detected in $1510-\mathrm{m}^{2}$ and $1-\mathrm{m}^{2}$ quadrats during Phase 3 sampling, excluding infrequent species that occurred in only one $10-\mathrm{m}^{2}$ quadrat from the $10-\mathrm{m}^{2}$ data. 38

25. Analysis of variance for effects of ecological site and sampling method on total live understory cover (standardized means) at 11 Colorado Plateau ecological sites. 39

26. Analysis of variance for effect of sampling method on standardized mean cover of surface features at 11 Colorado Plateau ecological sites.

27. Analysis of variance for effects of sampling method $\left(1-\mathrm{m}^{2}\right.$ quadrats, $10-\mathrm{m}^{2}$ quadrats, and linepoint intercept), observer, and cover category (species POFE, OUGA, SYOR2, and total live understory canopy cover) on mean arcsin-transformed plant canopy cover values for the Brushy Loam ecological site at Mesa Verde National Park.....

28. Analysis of variance for effects of sampling method $\left(1-\mathrm{m}^{2}\right.$ quadrats, $10-\mathrm{m}^{2}$ quadrats, and linepoint intercept), observer, and cover category (species CHLE4, HENE5, PLJA, and total live understory canopy cover) on mean arcsin-transformed plant canopy cover values for the Limy Upland, 25-33" ecological site at Grand Canyon National Park.

29. Analysis of variance for effects of sampling method $\left(1-\mathrm{m}^{2}\right.$ quadrats, $10-\mathrm{m}^{2}$ quadrats, and linepoint intercept), observer, and cover category (species POFE, POTR5, UNGRCA1, and total live understory canopy cover) on mean arcsin-transformed plant canopy cover values for the Loamy Hills, 25-33" pz ecological site at Grand Canyon National Park.

30. Analysis of variance for effects of sampling method (1- $\mathrm{m}^{2}$ quadrats, $10-\mathrm{m}^{2}$ quadrats, and linepoint intercept), observer, and cover category (species JUOS, PIED, POFE, and total live understory canopy cover) on mean arcsin-transformed plant canopy cover values for the Loamy Mesa Top PJ ecological site at Mesa Verde National Park.

31. Analysis of variance for effects of sampling method $\left(1-\mathrm{m}^{2}\right.$ quadrats, $10-\mathrm{m}^{2}$ quadrats, and linepoint intercept), observer, and cover category (species ATCO, GIIN2, ORHY, and total live understory canopy cover) on mean arcsin-transformed plant canopy cover values for the Semidesert Alkali Sandy Loam (Alkali Sacaton) ecological site at Capitol Reef National Park.

32. Analysis of variance for effects of sampling method (1- $\mathrm{m}^{2}$ quadrats, $10-\mathrm{m}^{2}$ quadrats, and linepoint intercept), observer, and cover category (species ARTR2, BRTE, STCO4, and total live understory canopy cover) on mean arcsin-transformed plant canopy cover values for the Semidesert Loam (Wyoming Big Sagebrush) ecological site in Dinosaur National Monument.

33. Analysis of variance for effects of sampling method (1- $\mathrm{m}^{2}$ quadrats, $10-\mathrm{m}^{2}$ quadrats, and linepoint intercept), observer, and cover category (species CORA, FEOC3, STLO4, and total live understory canopy cover) on arcsin-transformed means of plant canopy cover for the Semidesert Shallow Sandy Loam PJ ecological site at Arches and Canyonlands National Parks.

34. Analysis of variance for effects of sampling method (1- $\mathrm{m}^{2}$ quadrats, $10-\mathrm{m}^{2}$ quadrats, and linepoint intercept), observer, and cover category (species CEMO2, COWR2, JUOS, and total live understory canopy cover) on arcsin-transformed means of plant canopy cover for the Upland Shallow Loam (Pinyon-Utah Juniper) ecological site at Capitol Reef National Park.

35. Analysis of variance for effects of sampling method $\left(1-\mathrm{m}^{2}\right.$ quadrats, $10-\mathrm{m}^{2}$ quadrats, and linepoint intercept), ecological site (BL, LU, LH, LMT, SASL, SL, SShSL, and UShL), and observer on arcsin-transformed means of litter cover data.. 
36. Results of Wilcoxon tests evaluating effects of observer on estimates of cover for four types of soil crust (undifferentiated, dark cyanobacteria, lichen, and moss) sampled with $10-\mathrm{m}^{2}$ quadrats, 1 $\mathrm{m}^{2}$ quadrats, and line-point intercept techniques at Colorado Plateau ecological sites where biological soil crusts were common.

37. Results of Wilcoxon tests evaluating effects of observer on estimates of biological soil crust cover based on the characterization of soil darkness (see table 10 and fig. 5) in $25 \mathrm{~cm} \times 25 \mathrm{~cm}$ BSC frames at Colorado Plateau ecological sites where biological soil crusts were common.

38. Results of Wilcoxon tests evaluating effects of observer on estimates of shrub density by species and height class at Colorado Plateau ecological sites.

39. Results of Wilcoxon tests evaluating effects of observer on estimates of tree density by species and size class at Colorado Plateau ecological sites.

40. Median impact-assessment ratings for procedures at 11 Colorado Plateau ecological sites ......55

41. Median impact-assessment ratings for types of impacts (broken branches, trampled plants, destabilized soils, trampled biological soil crusts, and quadrat-frame imprint) in quadrats, on the sampled side of the transect tape, and on the unsampled side of the transect tape at 11 Colorado Plateau ecological sites

42. Summary of comparisons among cover-sampling techniques in relation to repeatability between observers, efficiency, and sampling impacts on soils and vegetation 


\title{
Field Evaluations of Sampling Methods for Long- Term Monitoring of Upland Ecosystems on the Colorado Plateau
}

\author{
By Mark E. Miller, Dana L. Witwicki, Rebecca K. Mann, and Nicole J. Tancreto
}

\begin{abstract}
To inform planning for long-term ecological monitoring, we sampled vegetation and soilsurface attributes across a range of terrestrial ecosystems (physiognomic types) in seven National Park Service units on the Colorado Plateau. Primary objectives were (1) to evaluate a suite of sampling methods according to measures of repeatability, efficiency, and impacts on plot conditions; and (2) to characterize within- and among-plot variability in monitoring measures. This work was designed to support NPS staff in selecting the combination of methods that best meets their monitoring objectives and resource constraints. We found no differences among cover-estimation techniques in terms of repeatability between observers (measurement precision). Estimates for total live understory canopy cover, cover of individual species, and cover of soil-surface features were highly repeatable between observers for $10-\mathrm{m}^{2}$ quadrats, $1-\mathrm{m}^{2}$ quadrats, and line-point intercept sampling methods. Estimates of shrub and tree density in 10$\mathrm{m}^{2}$ quadrats also were repeatable between observers, although sample sizes for were small for many species. At 10 of 11 ecological sites, we found that sampling with $10-\mathrm{m}^{2}$ quadrats was the most efficient cover-estimation technique with respect to within-plot variability in cover estimates and numbers of subsamples required to estimate plot-level cover with 20 percent precision. According to these same measures, sampling with $1-\mathrm{m}^{2}$ quadrats was the least efficient cover-estimation technique at eight of 11 ecological sites. The line-point technique was most efficient at eight of 11 ecological sites in terms of the amount of time required to estimate total plot-level cover with 20 percent precision - largely because $10-\mathrm{m}^{2}$ quadrats were more time consuming and $1-\mathrm{m}^{2}$ quadrats had greater within-plot variability relative to line-point sampling. However, there was no statistical difference among methods with respect to median subsampling times for 20 percent precision. There also were no differences among methods with respect to mean and median measures of among-plot variability in total live understory canopy cover. But among-plot variability was least for the line-point technique at seven of 11 ecological sites. Sampling activities had greatest impacts on plot conditions at macroplots where there was a high degree of cover by biological and physical soil crusts. Of all sampling procedures, $10-\mathrm{m}^{2}$ quadrat sampling, line-point sampling, and gap-intercept sampling had the most impacts on soil conditions due to trampling of soil crusts by the field team.
\end{abstract}

\footnotetext{
${ }^{1}$ Authors are Research Ecologist, Plant Ecologist, and Biologist, U.S. Geological Survey, Southwest Biological Science Center; and Data Manager, National Park Service, Southern Colorado Plateau Inventory and Monitoring Network.
} 


\section{Acknowledgments}

Funding for this work was provided by the National Park Service (Northern Colorado Plateau and Southern Colorado Plateau Inventory and Monitoring Networks) and the U.S. Geological Survey (Southwest Biological Science Center and the Status and Trends Program). Recommendations from Steve Garman, Lisa Thomas, Chris Lauver, and Thom O'Dell improved the study design. Tonya Troxler assisted with the preparation of tables and figures. Charles Drost and Kathryn Thomas provided review comments that improved the quality of this report.

\section{Introduction and Background}

This project involved field evaluations of a limited suite of measures and measurement techniques for long-term monitoring of terrestrial ecosystems characteristic of the Colorado Plateau region. The project was designed to support the Northern and Southern Colorado Plateau Networks (NCPN and SCPN, respectively) of the National Park Service's Inventory and Monitoring Program (NPS I\&M Program). In conjunction with the I\&M Program, ecoregional networks of NPS units have been charged with the task of identifying "vital signs" to be monitored for the purpose of tracking long-term trends in the "health" or condition of park ecosystems. Collectively, the NCPN and SCPN have identified an integrated suite of vital signs for tracking resource conditions in 35 NPS units located in the Colorado Plateau region of Utah, Arizona, Colorado, and New Mexico. To inform the selection of monitoring methods most suited to NPS monitoring objectives for these parks, the NCPN and SCPN required field evaluations of measures and measurement techniques across the range of ecosystems likely to be monitored.

Following were general objectives of this project.

1. Collect and analyze field data to evaluate a limited suite of measures and measurement techniques for their relative suitability in effectively and efficiently meeting NPS monitoring needs across the range of ecosystems likely to be monitored.

2. Characterize within- and among-macroplot variability in monitoring measures to inform NPS planning for operational monitoring.

3. On the basis of site soil, landscape, and vegetation characteristics, evaluate the accuracy of stratification data used to select field sites for sampling.

This report summarizes data collected during the 2005 field season, emphasizing comparisons among sampling methods in terms of (1) sampling efficiency (defined with respect to time and within- and among-macroplot variability in cover measures), (2) relative trends or differences in cover estimates derived from different sampling methods, (3) between-observer repeatability in measures of cover and density, and (4) sampling impacts on soil and vegetation attributes. In addition, we briefly address issues associated with the accuracy of spatial data used for selecting macroplot locations and challenges associated with data-collection and datamanagement systems used during the 2005 field season. 


\section{Methods}

\section{Study Areas}

Study areas were selected to sample particular ecological sites ${ }^{2}$ delineated by soil map units in soil surveys produced by the U.S. Department of Agriculture, Natural Resources Conservation Service (NRCS). Target ecological sites were identified jointly by USGS and NPS to represent the range of physiognomic types likely to be included in NCPN and SCPN monitoring plans (table 1). NPS staff subsequently determined coordinates for centroids of macroplots to be sampled during the 2005 season.

Table 1. Ecological sites, associated NRCS soil surveys and soil map units, and macroplots sampled during Phases 2 and 3 of the 2005 field season. (See table 2 for descriptions of sampling phases.)

\begin{tabular}{|c|c|c|c|c|c|c|c|c|}
\hline \multicolumn{3}{|c|}{ NRCS ecological site } & \multirow{3}{*}{$\begin{array}{l}\text { NRCS soil } \\
\text { survey area } \\
\text { (citation) }\end{array}$} & \multirow{3}{*}{$\begin{array}{c}\text { NRCS } \\
\text { soil map } \\
\text { unit }\end{array}$} & \multirow[b]{3}{*}{ Macroplot } & \multirow{3}{*}{$\begin{array}{l}\text { Sampling } \\
\text { phase }\end{array}$} & \multirow{2}{*}{\multicolumn{2}{|c|}{$\begin{array}{c}\text { Location of macroplot } \\
\text { center (NAD83) }\end{array}$}} \\
\hline \multirow[b]{2}{*}{ Name } & \multirow{2}{*}{$\begin{array}{c}\text { Code for } \\
\text { this } \\
\text { project }\end{array}$} & \multirow{2}{*}{$\begin{array}{c}\text { Physiog- } \\
\text { nomic } \\
\text { structure }\end{array}$} & & & & & & \\
\hline & & & & & & & UTM mE & UTM mN \\
\hline \multirow{5}{*}{ Brushy Loam } & \multirow{5}{*}{$\mathrm{BL}$} & \multirow{5}{*}{ Shrubland } & \multirow{5}{*}{$\begin{array}{c}\text { CO671 } \\
(\text { NRCS 2001a) }\end{array}$} & \multirow{3}{*}{131} & MEVE1 & 2 & 730064 & 4131866 \\
\hline & & & & & MEVE6 & 3 & 725179 & 4127097 \\
\hline & & & & & MEVE7 & 3 & 723803 & 4127722 \\
\hline & & & & 13 & MEVE2 & 2 & 729978 & 4129690 \\
\hline & & & & 79 & MEVE5 & 3 & 724964 & 4127964 \\
\hline \multirow{2}{*}{$\begin{array}{l}\text { Desert Sand (Sand } \\
\text { Sagebrush) }\end{array}$} & \multirow{2}{*}{ DS } & \multirow{2}{*}{ Grassland } & \multirow{2}{*}{$\begin{array}{c}\text { UT633 } \\
(\text { SCS 1991) }\end{array}$} & \multirow{2}{*}{80} & CANY1 & 2 & 611824 & 4225106 \\
\hline & & & & & CANY2b & 2 & 610505 & 4223529 \\
\hline \multirow{5}{*}{$\begin{array}{l}\text { Limy Upland, 6-10" } \\
\text { pz }\end{array}$} & \multirow{5}{*}{ LU } & \multirow{5}{*}{ Grassland } & \multirow{5}{*}{$\begin{array}{c}\text { AZ631 } \\
(\text { SCS 1983) }\end{array}$} & \multirow{5}{*}{56} & WUPA1 & 2 & 452750 & 3936806 \\
\hline & & & & & WUPA2 & 2 & 458382 & 3937598 \\
\hline & & & & & WUPA5 & 3 & 457109 & 3935314 \\
\hline & & & & & WUPA6 & 3 & 451957 & 3934304 \\
\hline & & & & & WUPA7 & 3 & 452545 & 3935929 \\
\hline \multirow{5}{*}{$\begin{array}{l}\text { Loamy Hills, 25- } \\
\text { 33" pz }\end{array}$} & \multirow{5}{*}{ LH } & & & 53 & GRCA3 & 2 & 400825 & 4019411 \\
\hline & & & & 51 & GRCA4 & 2 & 405721 & 4009147 \\
\hline & & Forest & $\begin{array}{c}\text { ALCUI } \\
(\mathrm{NRCS} 2003)\end{array}$ & 51 & GRCA6 & 3 & 404566 & 4009215 \\
\hline & & & (INRCS 2UU3) & 52 & GRCA5 & 3 & 403933 & 4010688 \\
\hline & & & & 52 & GRCA7 & 3 & 404913 & 4007824 \\
\hline Loamy Hills, Cold, & $\mathrm{H} \mathrm{H}$ & & $\mathrm{AZZ701}$ & 49 & GRCA1 & 2 & 400496 & 4021102 \\
\hline $25-33^{\prime \prime} p z$ & $\mathrm{LHC}$ & Forest & (NRCS 2003) & 53 & GRCA2 & 2 & 404425 & 4011908 \\
\hline & & & & 111 & MEVE3 & 2 & 719717 & 4116890 \\
\hline & & & & 77 & MEVE4 & 2 & 719690 & 4117457 \\
\hline Loamy Ivesa rop & LMT & Woodland & 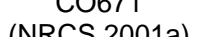 & & MEVE8 & 3 & 724589 & 4117373 \\
\hline & & & & 76 & MEVE10 & 3 & 723590 & 4115712 \\
\hline & & & & 10 & MEVE9 & 3 & 722950 & 4116950 \\
\hline & & & & & CARE1 & 2 & 475775 & 4257151 \\
\hline Semidesert Alkali & & & & & CARE2b & 2 & 475612 & 4257531 \\
\hline Sandy Loam & SASL & Grassland & $\begin{array}{c}01685 \\
\text { (NRCS } 2004)\end{array}$ & 200 & CARE5 & 3 & 483223 & 4253447 \\
\hline (Alkali Sacaton) & & & & & CARE6 & 3 & 482135 & 4253991 \\
\hline & & & & & CARE7 & 3 & 481694 & 4254064 \\
\hline & & & & & DINO1 & 2 & 654965 & 4487760 \\
\hline Semidesert Loam & & & & & DINO2b & 2 & 647936 & 4476988 \\
\hline (Wyoming Big & SL & Shrubland & $\begin{array}{c}\text { CO692 } \\
\text { (NRCS } 2001 \mathrm{~h})\end{array}$ & 1 & DINO3 & 3 & 644018 & 4483816 \\
\hline Sagebrush) & & & & & DINO4b & 3 & 653726 & 4476991 \\
\hline & & & & & DINO5 & 3 & 675330 & 4482005 \\
\hline
\end{tabular}

\footnotetext{
${ }^{2}$ An ecological site is defined as a kind of land with specific physical characteristics which differs from other kinds of land in its ability to produce distinctive kinds and amounts of vegetation and in its response to management (SRM Task Group 1995, Creque et al. 1999). Soil surveys produced by NRCS correlate ecological sites with particular soil series.
} 
Table 1.-Continued

\begin{tabular}{|c|c|c|c|c|c|c|c|c|}
\hline \multicolumn{3}{|c|}{ NRCS ecological site } & \multirow{3}{*}{$\begin{array}{l}\text { NRCS soil } \\
\text { survey area } \\
\text { (citation) }\end{array}$} & \multirow{3}{*}{$\begin{array}{l}\text { NRCS } \\
\text { soil map } \\
\text { unit }\end{array}$} & \multirow[b]{3}{*}{ Macroplot } & \multirow{3}{*}{$\begin{array}{l}\text { Sampling } \\
\text { phase }\end{array}$} & \multirow{2}{*}{\multicolumn{2}{|c|}{$\begin{array}{l}\text { Location of macroplot } \\
\text { center (NAD83) }\end{array}$}} \\
\hline \multirow[b]{2}{*}{ Name } & \multirow{2}{*}{$\begin{array}{l}\text { Code for } \\
\text { this } \\
\text { project }\end{array}$} & \multirow{2}{*}{$\begin{array}{l}\text { Physiog- } \\
\text { nomic } \\
\text { structure }\end{array}$} & & & & & & \\
\hline & & & & & & & UTM mE & UTM mN \\
\hline \multirow{7}{*}{$\begin{array}{l}\text { Semidesert } \\
\text { Shallow Sandy } \\
\text { Loam PJ }\end{array}$} & \multirow{7}{*}{ SShSL } & \multirow{7}{*}{ Shrubland } & \multirow{5}{*}{$\begin{array}{c}\text { UT624 } \\
\text { (SCS 1989) }\end{array}$} & \multirow{5}{*}{51} & ARCH1b & 2 & 620922 & 4292242 \\
\hline & & & & & $\mathrm{ARCH} 2$ & 2 & 622000 & 4291604 \\
\hline & & & & & $\mathrm{ARCH} 3$ & 3 & 618798 & 4289007 \\
\hline & & & & & $\mathrm{ARCH} 4 \mathrm{~b}$ & 3 & 623265 & 4285247 \\
\hline & & & & & ARCH5 & 3 & 624686 & 4283478 \\
\hline & & & \multirow{2}{*}{$\begin{array}{c}\text { UT633 } \\
\text { (SCS 1991) }\end{array}$} & \multirow{2}{*}{71} & CANY3 & 2 & 604432 & 4259261 \\
\hline & & & & & CANY4 & 2 & 602370 & 4255471 \\
\hline \multirow{2}{*}{$\begin{array}{l}\text { Shallow Loamy, } \\
10-14 " \text { pz }\end{array}$} & \multirow{2}{*}{ ShL } & \multirow{2}{*}{ Grassland } & \multirow{2}{*}{$\begin{array}{c}\text { AZ631 } \\
(\mathrm{SCS} 1983)\end{array}$} & 61 & WUPA3 & 2 & 455525 & 3937298 \\
\hline & & & & 60 & WUPA4 & 2 & 463894 & 3934278 \\
\hline \multirow{5}{*}{$\begin{array}{l}\text { Upland Shallow } \\
\text { Loam (Pinyon- } \\
\text { Utah Juniper) }\end{array}$} & \multirow{5}{*}{ UShL } & \multirow{5}{*}{ Woodland } & \multirow{5}{*}{$\begin{array}{c}\text { UT685 } \\
\text { (NRCS 2004) }\end{array}$} & \multirow{5}{*}{310} & CARE3 & 2 & 483656 & 4224951 \\
\hline & & & & & CARE4b & 2 & 483364 & 4223871 \\
\hline & & & & & CARE10 & 3 & 483584 & 4223149 \\
\hline & & & & & CARE8 & 3 & 484724 & 4220446 \\
\hline & & & & & CARE9 & 3 & 484314 & 4220771 \\
\hline
\end{tabular}

\section{Field Sampling}

\section{Sampling Phases}

Sampling during the 2005 field season was conducted in three phases (table 2).

Following the conclusion of Phase 1, NPS made the decision to use square quadrats during Phase 2 and Phase 3 sampling. Data from Phase 1 are not presented in this report.

\section{Macroplot Characterization and Evaluation}

Soil and geomorphic characteristics of all preselected and sampled macroplots were described during Phases 2 and 3 using standard protocols developed by NRCS (Schoeneberger et al. 2002). The purpose of this process was to guide the observers in determining whether soil and landscape characteristics at a given location matched those associated with the target soil and ecological site. Thorough site characterization requires description of soil characteristics through the uppermost $1 \mathrm{~m}$ of the soil profile. However, for purposes of this project, site characterization was based only on surface properties. No soil pits were dug or samples collected, though a small amount of topsoil was separated using a \#10 sieve in the field to characterize the surface soil texture, effervescence, and size and abundance of rock fragments greater than $2 \mathrm{~mm}$ in diameter.

In general, the site characterization process involved describing the soil and site properties of the area associated with the macroplot centroid and spanned by the three 50-m or $70-\mathrm{m}$ transects. The macroplot centroid was located by navigating with a GPS unit to a set of pre-determined, randomly-selected UTM coordinates within the target soil map unit. The aspect and azimuth were also given for the NCPN locations or determined by the field crew for the SCPN locations. If a significant soil or geomorphic boundary crossed the macroplot area, the description was focused on the area in which the centroid itself was located. Characterization was conducted approximately 1-2 m down-slope from the centroid to avoid trampling the area sampled by the middle transect.

There were three possible outcomes of the characterization process. If characterization indicated that the location matched the target ecological site and that all transects occurred on the same soil and geomorphic surface, the area was sampled. If the location did not match the target ecological site or if significant portions of the transects did not all fall on the targeted ecological site, the sampling location was relocated to a nearby area (within $250 \mathrm{~m}$ ) in the target soil map 
unit. After relocation, the same characterization procedure was repeated at the new centroid. If the characterized location did not match the target ecological site and no acceptable location could be found nearby, the sampling crew navigated to a new set of pre-selected coordinates within the ecological site.

Table 2. Phases of sampling conducted during the 2005 field season.

\begin{tabular}{|c|c|c|c|}
\hline Phase & Objectives & $\begin{array}{l}\text { Locations I } \\
\text { ecosystems }\end{array}$ & Timing \\
\hline $\begin{array}{l}\text { Phase } 1 \text { - } \\
\text { Training and } \\
\text { preliminary } \\
\text { testing }\end{array}$ & $\begin{array}{l}\text { 1. Train team members: safety and first aid, plant and biological-soil-crust } \\
\text { identification, soil and site characterization, plot layout, sampling and data-entry } \\
\text { procedures. } \\
\text { 2. Determine whether square or rectangular quadrats are most repeatable with } \\
\text { respect to frequency and density measures and least variable with respect to } \\
\text { cover, frequency and density measures. Only one quadrat shape will be carried } \\
\text { forth into subsequent phases. } \\
\text { 3. Practice line-intercept and line-point sampling. } \\
\text { 4. Determine optimal / efficient sequencing of sampling procedures to be used } \\
\text { during Phases } 2 \text { and } 3 \text {. }\end{array}$ & $\begin{array}{l}\text { - Bureau of Land } \\
\text { Management and } \\
\text { Forest Service } \\
\text { land vicinity of } \\
\text { Moab } \\
\text { - Grassland, } \\
\text { shrubland, } \\
\text { woodland, and } \\
\text { forest } \\
\text { ecosystems }\end{array}$ & June \\
\hline $\begin{array}{l}\text { Phase } 2 \text { - } \\
\text { Over } \\
\text { sampling }\end{array}$ & $\begin{array}{l}\text { 1. Conduct high-intensity sampling to evaluate variability of measures in relation } \\
\text { to sample size: } \\
\text { - Line-point sampling for cover and understory canopy height } \\
\text { - Quadrat sampling for cover ( } 1-\mathrm{m}^{2} \text { and } 10-\mathrm{m}^{2} \text { quadrats) } \\
\text { - Nested-quadrat sampling for frequency } \\
\text { - Quadrat sampling for density } \\
\text { 2. Sample to evaluate within- and among-site variability in canopy- and basal- } \\
\text { gap measures. } \\
\text { 3. Evaluate accuracy of spatial data used for selecting study sites. } \\
\text { 4. Time all procedures. } \\
\text { 5. Qualitatively evaluate plot impacts associated with different sampling } \\
\text { techniques. }\end{array}$ & $\begin{array}{l}\text { - NPS units in } \\
\text { NCPN and SCPN } \\
-2 \text { replicate sets } \\
\text { of full range of } \\
\text { ecosystems }\end{array}$ & $\begin{array}{l}\text { July - mid- } \\
\text { September }\end{array}$ \\
\hline $\begin{array}{l}\text { Phase } 3 \text { - } \\
\text { Repeated } \\
\text { sampling }\end{array}$ & $\begin{array}{l}\text { 1. Conduct repeat sampling to evaluate repeatability of cover measures } \\
\text { obtained through line-point sampling and two methods of quadrat sampling. } \\
\text { 2. Sample to evaluate within- and among-site variability in canopy- and basal- } \\
\text { gap measures, frequency measures, and shrub density measures. } \\
\text { 3. Evaluate accuracy of spatial data used for selecting study sites. } \\
\text { 4. Time all procedures. } \\
\text { 5. Qualitatively evaluate plot impacts associated with different sampling } \\
\text { techniques. }\end{array}$ & $\begin{array}{l}\text { - NPS units in } \\
\text { NCPN and SCPN } \\
\text { - } 3 \text { replicate sets } \\
\text { of full range of } \\
\text { ecosystems }\end{array}$ & $\begin{array}{l}\text { Late- } \\
\text { September } \\
\text { - mid- } \\
\text { November }\end{array}$ \\
\hline
\end{tabular}

\section{Macroplot Layout}

Prior to the field season, NPS determined that the standard plot layout would consist of a 1-ha macroplot and three 50-m transects separated by $25 \mathrm{~m}$ (fig. 1). Transects used during Phases 1 and 2 were 70-m long to accommodate a larger number of subsamples per macroplot (figs. 2 and 3). During Phase 3, 50-m transects were used (fig. 3). Transects were marked temporarily with a 50-m tape and pin flags, but were not permanently marked. Transects were used for gap intercept and line-point intercept sampling, and for guiding the placement of quadrats used for sampling cover, frequency, and density. Transects were oriented parallel to the 
hillslope contour to minimize potential effects of linear soil disturbances on hillslope hydrologic processes. Field observers traversed the down-slope side of the transect when sampling.

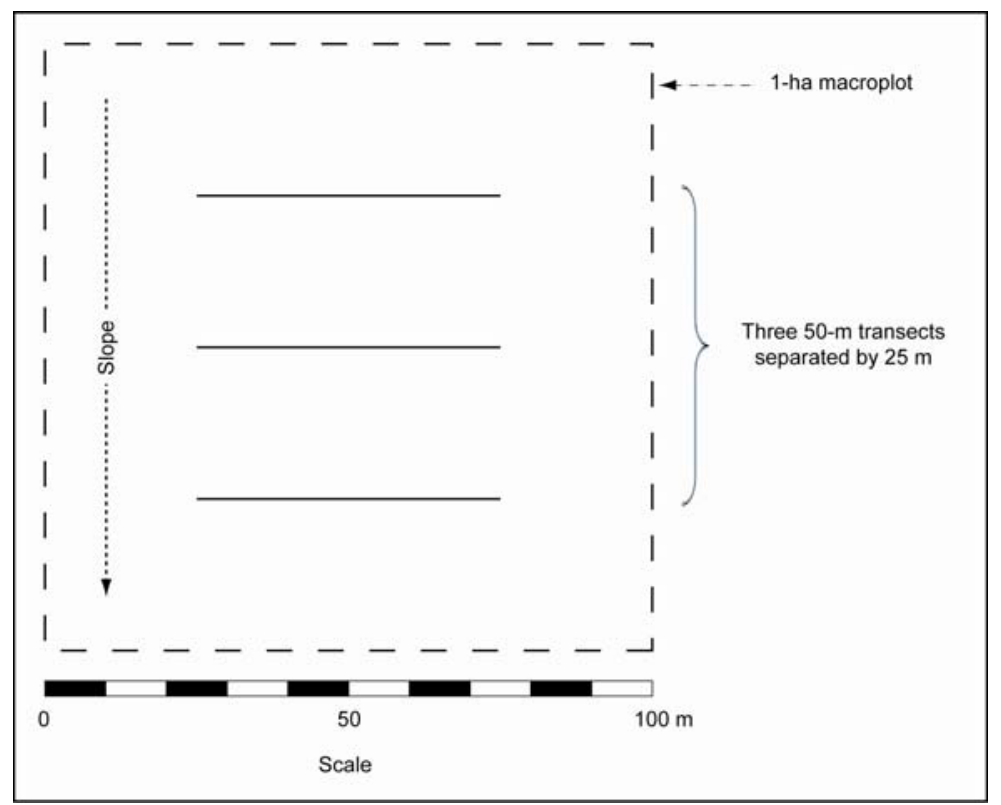

Figure 1. Standard macroplot and transect layout used during the 2005 field season.

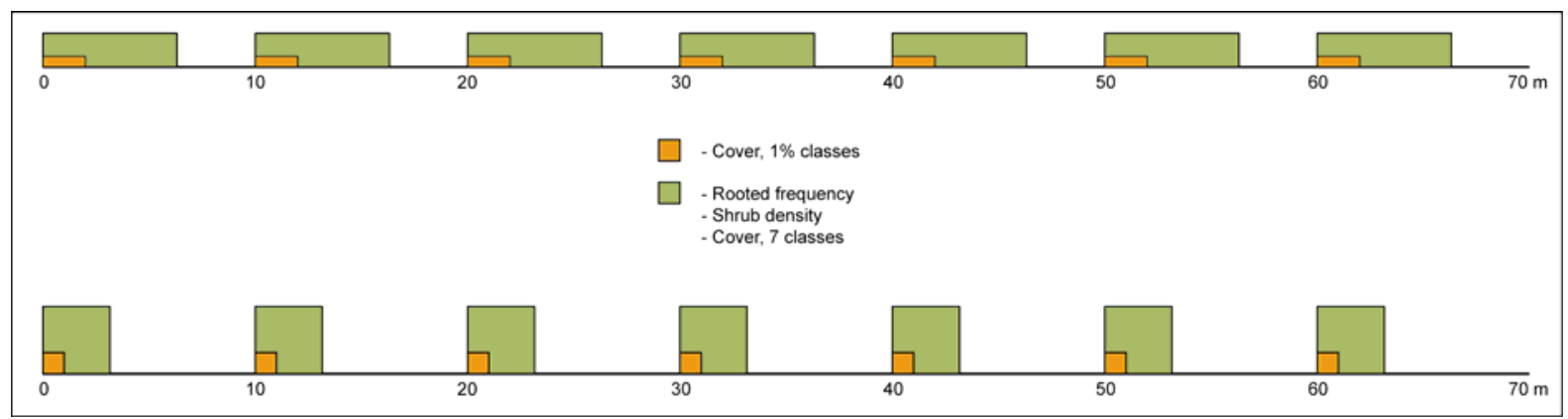

Figure 2. Transect layouts used for comparing repeatability and efficiency of square and rectangular quadrats during Phase 1 sampling.

The method of laying out the transect lines was standardized for all three Phases. The tape was generally stretched taut and anchored at both ends with a steel pin. The tape was also anchored in the middle if necessitated by windy conditions or uneven terrain. Where significant topography (e.g., hills, ditches) crossed the transect line, the tape was pinned down to maintain a relatively even tape height as the terrain rose and fell beneath it and to ensure that it could be replaced in nearly the same position. During Phases 1 and 3, pin flags also were placed precisely at the start, middle, and end points of the transect line to ensure repeatability when the tape was pulled and replaced (under the assumption that transects will be permanently marked during operational monitoring). After tape placement and photographic documentation, the general sequence of sampling events was line-point intercept sampling, gap-intercept sampling, then quadrat-based sampling. Gap sampling was not conducted during Phase 3. 


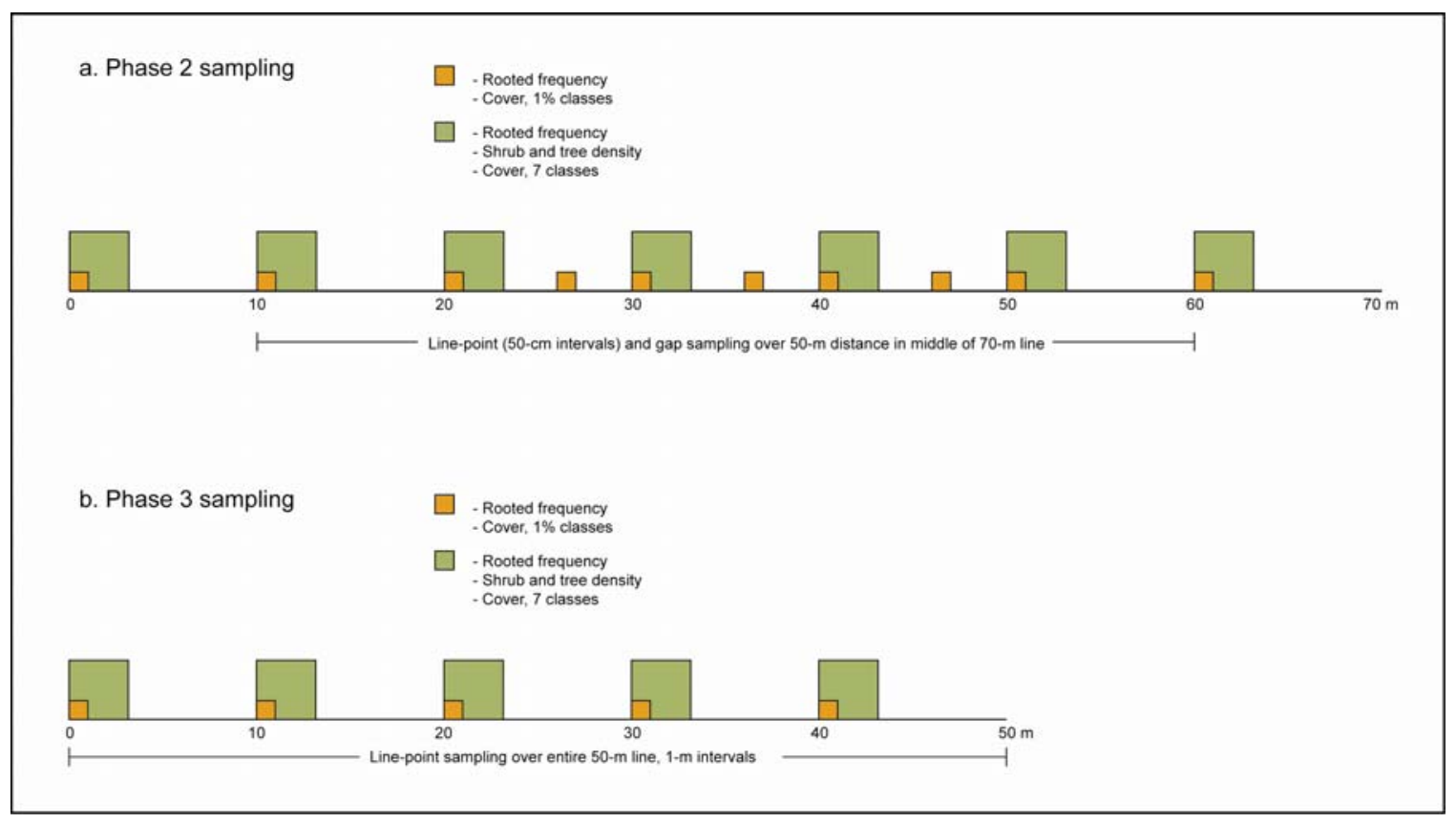

Figure 3. Transect lengths and types of sampling conducted during Phases 2 (a) and 3 (b).

During Phase 3, the transect tape was removed and then replaced between repeat sampling events by different observers. An exception to this practice was made at the Mesa Verde Brushy Loam and Loamy Mesa Top PJ ecological sites (macroplots MEVE5 - MEVE10). The transect tape was not removed and replaced between repeat sampling events at these sites because dense shrubs made the process exceptionally time-consuming.

For visual documentation of site characteristics and vegetation, a set of digital photographs was taken of each transect sampled during the course of the 2005 field season. After a transect line was placed and prior to sampling, a photoboard was placed at the 0 -m mark, facing away from the transect line. One or two photographs were taken looking along the transect (towards the endpoint), from eye-level (1.5 - $2 \mathrm{~m}$ from the ground) at a vantage point located $5 \mathrm{~m}$ from the photoboard. If vegetation or topography prevented a 5-m distance, the photograph was taken as close as possible to 5-m mark and the actual distance was recorded. All photographs were taken with a Nikon Coolpix 4500 camera (4.0 megapixels). The first photograph was taken with no zoom. If a second was taken, the view was zoomed in to include just enough vertical scope to see the start and endpoints of the transect with no extra landscape. Photographs from the following transects were lost or not taken: BLM3-3, ARCH1-3, MEVE12, MEVE2-1, CANY3-2, CARE4-1, WUPA4-2, GRCA2-2, GRCA2-3, GRCA3-3. Additional photographs were taken at selected macroplots to document sampling impacts.

\section{Line-Point Intercept Sampling}

Line-point intercept sampling was used to estimate the cover of understory vegetation and soil-surface features. Methods generally followed those described by Herrick et al. (2005; hereafter referred to as the "Jornada manual"). Points were sampled over a 50-m span of each transect at 50-cm intervals during Phase 2 and $1-\mathrm{m}$ intervals during Phase 3 . At each sampling point, a 1-mm diameter, $90-\mathrm{cm}$ long metal pin was placed by dropping it from breast height. Measures identified in table 3 were recorded on the basis of pin contacts at each placement. Data 
were read from the top of the pin down and each species or other measure was only recorded once no matter how many times it intercepted the pin. Each plant hit was recorded by species as live photosynthetic, live non-photosynthetic, or standing dead (see definitions in table 4). Where cover occurred above the height of the pin (but less than $2 \mathrm{~m}$ ) the point was projected upward to describe those hits. Likewise, if the pin struck a woody stem above ground level, the pin was held in position, the woody stem hit was recorded, and the point was then projected downward to describe the other hits below, including the soil-surface hit. The height of the uppermost canopy hit was measured from ground level using a vertical measuring tape placed next to the pin.

Table 3. Measures recorded during line-point intercept sampling.

\begin{tabular}{|l|}
\hline Line-point intercept measures \\
\hline $\begin{array}{l}\text { Canopy cover \%, live photosynthetic vascular plant tissue by species } \\
\text { (understory shrubs and herbaceous) }\end{array}$ \\
\hline $\begin{array}{l}\text { Canopy cover \%, live non-photosynthetic vascular plant tissue by species } \\
\text { (understory shrubs and herbaceous) }\end{array}$ \\
\hline Basal cover \% by vascular plant species (all taxa) \\
\hline Cover \%, standing dead vascular plants by species (all taxa) \\
\hline Overstory canopy cover \% \\
\hline $\begin{array}{l}\text { Cover \%, biological soil crust by functional / morphological group (dark } \\
\text { cyanobacteria, moss and lichen) }\end{array}$ \\
\hline Litter \% (<2.5 cm \\
\hline Woody debris \% ( $2.5 \mathrm{~cm})$ \\
\hline Animal scat \% \\
\hline Rock \% by size class (<20 mm in diameter, or $>20$ mm in diameter) \\
\hline Bare soil \%, undifferentiated crust \\
\hline Bare soil \%, loose sediment \\
\hline $\begin{array}{l}\text { Soil-surface disturbance \%, coded by type (e.g., ant mound, wildlife excavation, } \\
\text { ungulate hoof print, human footprint) }\end{array}$ \\
\hline Canopy height cm, uppermost understory intercept \\
\hline
\end{tabular}

Occurrences of soil-surface disturbances and soil crusts also were recorded during linepoint intercept sampling. Soil-surface disturbances were described on the basis of nine categories (table 5). Soil crusts were described on the basis of four categories (table 6). 
Table 4. Definitions of plant material and plant status.

\begin{tabular}{|c|c|}
\hline Term & Definition \\
\hline Duff & $\begin{array}{l}\text { Partially decomposed plant litter. It consists of decomposing leaves and other organic } \\
\text { material (from Herrick et al. 2005). }\end{array}$ \\
\hline Litter & $\begin{array}{l}\text { The top layer of the forest, shrubland, or grassland floor, directly above the duff layer, } \\
\text { including freshly fallen leaves, needles, bark flakes, cone scales, fruits (including acorns and } \\
\text { cones), dead matted grass and other vegetative parts that are little altered in structure by } \\
\text { decomposition. Does not include larger twigs and stems }>2.5 \mathrm{~cm} \text { in diameter. }\end{array}$ \\
\hline Woody debris & Any woody material larger than $2.5 \mathrm{~cm}$ in diameter. \\
\hline $\begin{array}{l}\text { Live, photosynthetic } \\
\text { plants }\end{array}$ & $\begin{array}{l}\text { Plant material still attached to a rooted plant that is live and actively photosynthetic. This } \\
\text { includes all green plant parts. }\end{array}$ \\
\hline $\begin{array}{l}\text { Live, non- } \\
\text { photosynthetic plants }\end{array}$ & $\begin{array}{l}\text { Plant material still attached to a rooted plant that is not live and actively photosynthetic. This } \\
\text { includes non-photosynthetic tissues such as woody stems and flowers, as well as plant parts } \\
\text { that were live and photosynthetic in current growing season, but senesced after spring growth } \\
\text { and now appear brown. }\end{array}$ \\
\hline Standing dead plants & $\begin{array}{l}\text { Dead plant material still attached to a rooted plant. All standing dead vegetation produced in } \\
\text { previous (not the current) growing season(s) not in contact with the soil surface. }\end{array}$ \\
\hline
\end{tabular}

Table 5. Categories of soil-surface disturbances described during line-point sampling and quadrat sampling.

\begin{tabular}{|l|l|}
\hline Soil disturbance & Description \\
\hline Undifferentiated disturbance & A disturbance with indeterminate origin \\
\hline Ant mound & Holes and mounds caused by ants \\
\hline Wildlife excavation & Holes and mounds caused by animals \\
\hline Wildlife track & $\begin{array}{l}\text { Any noticeable tracks, marks, or trails left by animals } \\
\text { passing through the area }\end{array}$ \\
\hline Livestock track/trail & $\begin{array}{l}\text { Any noticeable tracks, marks, or trails left by livestock } \\
\text { passing through the area }\end{array}$ \\
\hline Human track/trail & $\begin{array}{l}\text { Any noticeable tracks, marks, or trails left by humans } \\
\text { passing through the area }\end{array}$ \\
\hline Bicycle & Disturbances caused by bicycles \\
\hline Motor vehicle & Disturbances caused by any motor vehicle \\
\hline Other anthropogenic & $\begin{array}{l}\text { Human-caused surface disturbance not defined by } \\
\text { other categories }\end{array}$ \\
\hline
\end{tabular}

Table 6. Soil crust categories used during line-point sampling and quadrat sampling.

\begin{tabular}{|l|l|}
\hline Category & Definition \\
\hline $\begin{array}{l}\text { Undifferentiated } \\
\text { crust }\end{array}$ & $\begin{array}{l}\text { Physical crust and/or weak cyanobacterial crust; may be characterized by slight } \\
\text { microtopographic development }\end{array}$ \\
\hline Cyanobacteria & $\begin{array}{l}\text { Soil obviously darkened by cyanobacteria; usually with significant microtopographic } \\
\text { development }\end{array}$ \\
\hline Lichen & Any species, morphological type, or color \\
\hline Moss & Any species, morphological type, or color \\
\hline
\end{tabular}


Where cover occurred greater than $2 \mathrm{~m}$ above the ground (e.g., Brushy Loam and Loamy Mesa Top PJ ecological sites in Mesa Verde, Loamy Hills and Loamy Hills, Cold, ecological sites in Grand Canyon, and the Upland Shallow Loam ecological site in Capitol Reef), a canopy densitometer (Geographic Resource Solutions, http://www.grsgis.com/densitometer/) was used to estimate overstory canopy cover. The densitometer was placed directly over the dropped pin and held level with the use of leveling bubbles embedded in the sampling device. The device uses mirrors and aligning rings to direct the user's line of sight directly upward from where it was held. Species observed through the densitometer were recorded as overstory hits. All overstory layers detected through the viewer were reported. The plant status of all overstory layers was recorded as seen through the densitometer, rather than attempting to estimate plant status as it would be at the topmost portion of the hit. Height of the top-most species was not measured when an overstory layer was present at the point.

During Phase 3, wind speed was measured with a hand-held anemometer at the beginning and end of each line-point sampling event by different observers. These data were collected to evaluate whether between-observer repeatability of cover estimates from line-point sampling was affected by wind speed.

\section{Gap-Intercept Sampling}

During Phase 2, a line-intercept sampling method was used to collect data describing the size-class distribution of gaps between plant bases (basal gap sampling) and between plant canopies (canopy gap sampling). Methods and definitions followed those outlined in the Jornada manual (table 7), with one modification. For canopy gaps, the Jornada method was modified to record three distinct classes along the line: shrub (woody canopies $<2 \mathrm{~m}$ tall), other vegetation, and canopy gap. Other vegetation included all suffrutescent and herbaceous species except for annual forbs. All attached plant material was counted as canopy regardless of live or dead status.

Table 7. Definitions used for gap-intercept sampling (from Herrick et al. 2005).

\begin{tabular}{|l|l|}
\hline Term & Definition \\
\hline Plant canopy & $\begin{array}{l}\text { Canopy is recorded any time } 50 \% \text { or more of any 3-cm segment of tape } \\
\text { intercepts live or dead plant canopy (above-ground plant parts) based on } \\
\text { a vertical projection from canopy to ground. }\end{array}$ \\
\hline Plant base & $\begin{array}{l}\text { Any plant stem emerging from the soil surface along the graduated edge } \\
\text { of the tape that would force an ant walking along the line on the soil to } \\
\text { step off the line to get around it (minimum diameter of base }=1 \mathrm{~mm} \text { ). }\end{array}$ \\
\hline Canopy gap & Gap occurs any time there is at least $20 \mathrm{~cm}$ without plant canopy. \\
\hline Basal gap & Gap occurs any time there is at least $20 \mathrm{~cm}$ without a plant base. \\
\hline
\end{tabular}

\section{Quadrat Sampling}

Quadrat sampling was conducted during all three phases of the project to estimate frequency and cover of understory vegetation and soil-surface features, and to estimate density of selected woody species. Quadrats consisted of nested frames measuring $0.01 \mathrm{~m}^{2}, 0.1 \mathrm{~m}^{2}, 1 \mathrm{~m}^{2}$, and $10 \mathrm{~m}^{2}$ in area (fig. 4). The $1-\mathrm{m}^{2}$ quadrat frame was constructed of half-inch PVC pipe and marked on all sides with tape to demarcate $10-\mathrm{cm}$ increments. Colored-tape bands on the $1-\mathrm{m}^{2}$ frame marked the corners of the $0.01-\mathrm{m}^{2}$ and $0.1-\mathrm{m}^{2}$ quadrats. Rope and steel pins were used to lay out the $10-\mathrm{m}^{2}$ frame. During all sampling phases, rooted frequency of vascular plants and 
occurrence frequency of biological soil crusts (table 6), soil-disturbance features (table 5), and scat (wildlife vs. livestock) were recorded at every level of nested quadrats. Frequency sampling was followed by cover sampling in the $1-\mathrm{m}^{2}$ quadrat (to nearest 1 percent) and then by cover sampling in the $10-\mathrm{m}^{2}$ quadrat (by seven cover classes; table 8 ). For quadrat sampling, estimates of vegetation cover were restricted to live foliar cover of understory vegetation less than $2 \mathrm{~m}$ tall.

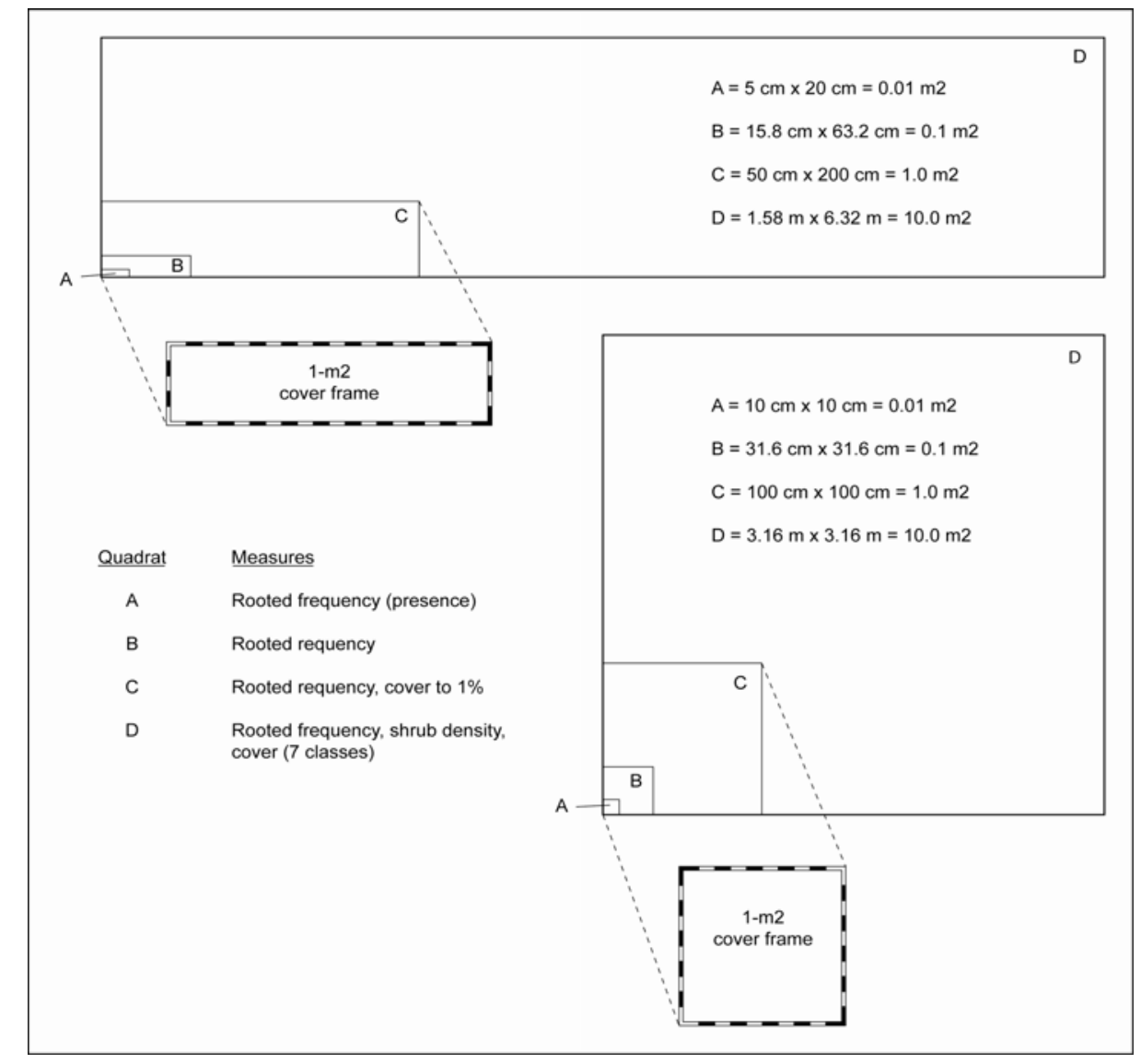

Figure 4. Dimensions of square and rectangular nested quadrats that were evaluated during Phase 1, and of square quadrats that were used during Phases 2 and 3.

Table 8. Cover-class scale used to estimate cover in $10-\mathrm{m}^{2}$ quadrats.

\begin{tabular}{|c|c|c|}
\hline Cover class & Range of cover (\%) & Class midpoints (\%) \\
\hline 1 & $<1$ & 0.5 \\
\hline 2 & $1-5$ & 3.0 \\
\hline 3 & $5-10$ & 7.5 \\
\hline 4 & $10-25$ & 17.5 \\
\hline 5 & $25-50$ & 37.5 \\
\hline 6 & $50-75$ & 62.5 \\
\hline 7 & $75-100$ & 87.5 \\
\hline
\end{tabular}

After cover sampling, densities of selected woody species were estimated in the $10-\mathrm{m}^{2}$ quadrats. During site characterization and prior to sampling the macroplot, the dominant shrubs and trees to be counted for density were determined. Quercus gambelii and Juniperus osteosperma existed in both shrub and tree growth forms across ecological sites but were consistently counted as trees. During sampling, individual plants were counted only if stems 
were at least halfway rooted in the quadrat (as for rooted frequency). For plants with multiple stems, individuals were counted only if at least one stem and half of the canopy were located within the quadrat. Individuals were categorized by size class (table 9). Some species, especially the shrubs Artemisia tridentata and Coleogyne ramosissima, showed evidence of multiple stems (sometimes due to burial of plant bases by eolian sand), making it difficult to discern true individuals. In such cases, we applied the rule that if two stems were less than 25 $\mathrm{cm}$ apart, they would be identified as a single counting unit, unless it was readily apparent that the stems originated from separate individuals, such as small seedlings sprouting near a larger shrub.

Table 9. Size classes used for recording shrub and tree density ( $\mathrm{dbh}=$ diameter at breast height; drc = diameter at root crown). Tree size classes follow those used by the National Park Service fire program (NPS 2003).

\begin{tabular}{|c|c|c|}
\hline \multirow{2}{*}{$\begin{array}{c}\text { Shrub } \\
\text { height classes }\end{array}$} & \multicolumn{2}{|c|}{ Tree } \\
\cline { 1 - 1 }$<10 \mathrm{~cm}$ & Class & Criteria \\
\cline { 1 - 1 } $10-25 \mathrm{~cm}$ & Seedling & $\begin{array}{c}<1.37 \mathrm{~m} \text { tall OR }<2.5 \\
\mathrm{~cm} \mathrm{dbh} / \mathrm{drc}\end{array}$ \\
\cline { 1 - 1 } $25-50 \mathrm{~cm}$ & Pole & $\begin{array}{c}>=1.37 \mathrm{~m} \text { tall AND } \\
2.5-15 \mathrm{~cm} \mathrm{dbh} / \mathrm{drc}\end{array}$ \\
\cline { 1 - 1 } $50 \mathrm{~cm}-1 \mathrm{~m}$ & Overstory & $\mathrm{dbh} / \mathrm{drc}>15 \mathrm{~cm}$ \\
\cline { 1 - 1 } $1-2 \mathrm{~m}$ & & \\
\cline { 1 - 1 }$>2 \mathrm{~m}$ & & \\
\hline
\end{tabular}

After a transect was completed for $1-\mathrm{m}^{2}$ and $10-\mathrm{m}^{2}$ quadrat sampling, an additional technique was used to estimate the cover and development of biological soil crusts (BSCs) on the basis of relative soil darkness. A $25 \mathrm{~cm}$ x $25 \mathrm{~cm}$ frame (hereafter referred to as a BSC frame) was placed adjacent to the transect tape at 2-m intervals and the predominant soil-surface cover (excluding litter and plant bases) was assigned one of seven soil-surface categories (table 10) and an ordinal cover class (table 8). A photographic key (fig. 5) was used as an aid in characterizing the relative darkness of crusted soils. This technique was used at all ecological sites where biological soil crusts were common (all macroplots excluding those associated with Brushy Loam, Limy Upland, Shallow Loamy, Loamy Hills, and Loamy Hills, Cold, ecological sites).

Table 10. Soil-surface categories used for estimating cover and development of biological soil crusts in $25 \mathrm{~cm} \times 25 \mathrm{~cm}$ quadrats on the basis of relative soil darkness. Darkness categories for crusted soils are illustrated in figure 5 .

\begin{tabular}{|l|l|}
\hline $\begin{array}{l}\text { Uncrusted or } \\
\text { crusted soil }\end{array}$ & Soil-surface category \\
\hline Uncrusted & Bare soil (loose sediment) \\
\hline \multirow{4}{*}{ Crusted } & Darkness 1 \\
\cline { 2 - 2 } & Darkness 2 \\
\cline { 2 - 2 } & Darkness 3 \\
\cline { 2 - 2 } & Darkness 4 \\
\cline { 2 - 2 } & Darkness 5 \\
\cline { 2 - 2 } & Darkness 6 \\
\hline
\end{tabular}




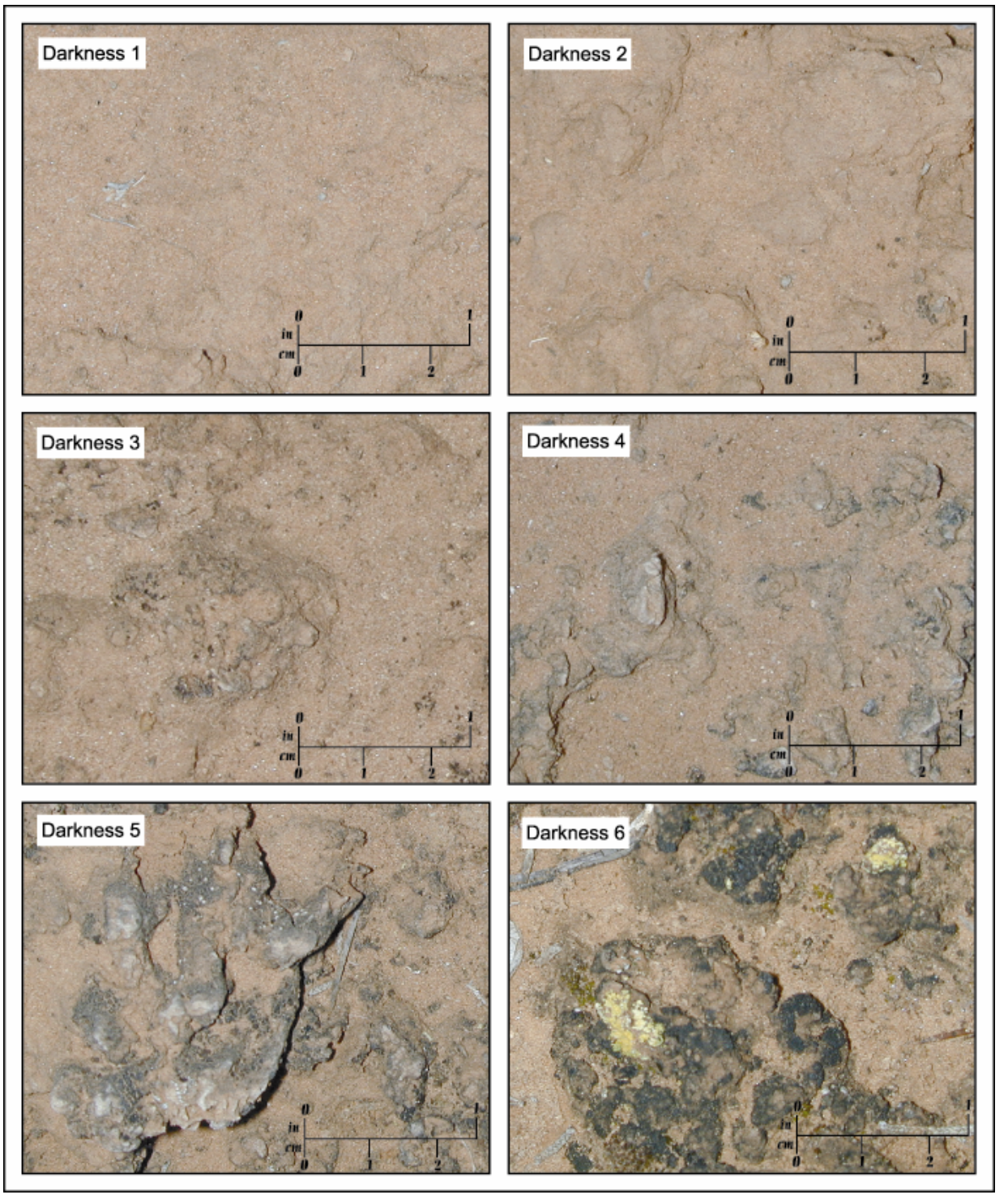

Figure 5. Photographic key to soil-surface categories used for describing degrees of biological soil crust development on the basis of relative soil darkness (J. Belnap, unpublished).

\section{Documentation of Unknown Species}

Field observers were challenged by the need to become familiar with the flora of a broad range of ecological sites. For purposes of consistency in describing the identity of unknown taxa over the course of the season, small specimens of unknown taxa were collected at each park and labeled with standardized codes (see Appendix A). These specimens were used throughout Phases 2 and 3 to ensure that the same taxa were not described by different identification codes.

\section{Assessment of Sampling Impacts}

After all sampling procedures were completed at a macroplot location, the field team used a standard protocol to assess types and degrees of sampling impacts on soil and vegetation. 
The intent of the assessment was to provide information to allow an evaluation of the relative significance of adverse sampling impacts among ecological sites and sampling procedures.

To document impacts caused directly by the overall sampling process, a set of specific observer-caused impacts was assessed. The impacts were assigned a rating according to the degree to which they occurred on the unsampled side of the transect tape, on the sampled side of the transect (but outside of the quadrats), and within the quadrats specifically. Possible ratings ranged from none (no impact caused from specified factor) to high (specified factor having an extreme impact on the site). An evaluation matrix was constructed to aid in this process (table 11). Observer-caused impacts included trampled biological soil crusts (referring only to crusts exhibiting dark cyanobacteria, soil lichens, and mosses), trampled plants, broken branches, destabilized soils (referring to undifferentiated soil crust and bare, loose soil), and quadrat imprints.

Each particular sampling procedure (table 12) also was evaluated to determine the direct causes of the sampling impacts. In this evaluation, a relative degree of responsibility for the adverse impacts that occurred on a site (all impacts combined) was assigned for each sampling procedure. The degree of responsibility again ranged from none to high (table 13). For example, if trampling impacts were rated as extreme, the relative significance of the different sampling procedures as contributors to the extreme degree of trampling on the site was determined.

The final step of the impact-assessment process was to document species affected by the sampling process. If individuals of certain plant species appeared to have been particularly impacted by trampling or breaking of branches, they were identified in the data-entry table.

\section{Date Entry and Management}

\section{Database Design}

To house and manage data collected throughout the course of the project, the NPS SCPN data-management team developed a database using Microsoft Access software and partnered with USGS to develop data-management protocols and provide ongoing technical support. To facilitate timely incorporation of field data into the database, data were recorded electronically in the field with a Panasonic Toughbook 01 Pocket PC and collected into a Microsoft PocketAccess database, operated in conjunction with Sprint DB Pro interface software.

\section{Field Procedures}

Field data collection involved entering data into each of several component database tables, including electronic forms for location definition, site characterization, point-intercept data, frequency data, quadrat-based cover data, and density data. Reference tables were generated for each park in the form of pick lists, based on NPS Inventory and Monitoring species lists. Species encountered during field work were drawn from these pick lists; those species not appearing on the lists and unidentifiable species were given a code name based on the park in which they occurred, a series number, and brief descriptors. Each primary event table contained a start and stop time function allowing for the timing of all data-collection processes. The tables also displayed the collected data immediately, making it available for editing if necessary. The database was backed up several times throughout a day onto an external storage card using SunnySoft Backup Manager software. On the occasion that the database was unavailable or when programming errors prevented the use of the database, the field crew recorded data onto equivalent paper forms and later transferred the data to a corrected database. 
Table 11. Evaluation matrix for rating sampling impacts, considering the entire macroplot visit and all sampling procedures combined (BSCs = biological soil crusts).

\begin{tabular}{|c|c|c|c|c|c|c|c|}
\hline \multirow[b]{2}{*}{$\begin{array}{l}\text { Sampling } \\
\text { impact }\end{array}$} & \multirow[b]{2}{*}{ Comments } & \multicolumn{6}{|c|}{ Degree of impact } \\
\hline & & None & Slight & $\begin{array}{l}\text { Slight to } \\
\text { moderate }\end{array}$ & Moderate & $\begin{array}{c}\text { Moderate } \\
\text { to extreme }\end{array}$ & Extreme \\
\hline $\begin{array}{l}\text { Trampled } \\
\text { BSCs }\end{array}$ & $\begin{array}{l}\text { Refers to trampling } \\
\text { impacts on dark } \\
\text { cyanobacteria, soil } \\
\text { lichens, and/or soil } \\
\text { mosses. Impacts to } \\
\text { undifferentiated crusts are } \\
\text { evaluated under } \\
\text { "destabilized soils." If } \\
\text { BSCs are trampled, soils } \\
\text { also are destabilized. The } \\
\text { opposite is not necessarily } \\
\text { true. }\end{array}$ & $\begin{array}{l}\text { No BSCs were } \\
\text { trampled } \\
\text { (or no BSCs on } \\
\text { site) }\end{array}$ & $\begin{array}{l}\text { Some trampling impacts } \\
\text { occurred, but impacts } \\
\text { were very slight } \\
\text { because BSCs were } \\
\text { relatively uncommon on } \\
\text { site or it was otherwise } \\
\text { possible to avoid } \\
\text { trampling them. } \\
\text { OR there appeared to } \\
\text { be no long-lasting } \\
\text { damage. }\end{array}$ & Intermediate & $\begin{array}{l}\text { Trampling of well- } \\
\text { developed BSCs was } \\
\text { unavoidable in some } \\
\text { portions of the site, } \\
\text { resulting in significant } \\
\text { and persistent damage } \\
\text { - but extent of this } \\
\text { damage was limited to } \\
\text { about half of initial } \\
\text { footprints. } \\
\text { Subsequent steps in } \\
\text { same location may } \\
\text { have had less impact } \\
\text { because the damage } \\
\text { already was done. }\end{array}$ & Intermediate & $\begin{array}{l}\text { Well-developed BSCs } \\
\text { were abundant on the site } \\
\text { and it was impossible to } \\
\text { avoid trampling them. } \\
\text { Trampling resulted in } \\
\text { significant, persistent } \\
\text { damage to BSCs along all } \\
\text { three transects. (Envision } \\
\text { persistent damage with } \\
\text { nearly every initial step } \\
\text { taken on the site. } \\
\text { Subsequent steps in same } \\
\text { location may have had } \\
\text { less impact because the } \\
\text { damage already was } \\
\text { done.) }\end{array}$ \\
\hline $\begin{array}{l}\text { Trampled } \\
\text { plants }\end{array}$ & $\begin{array}{l}\text { Refers to plant impacts } \\
\text { attributable to feet, } \\
\text { whether they are stepped } \\
\text { upon (truly trampled) or } \\
\text { kicked. Plant impacts } \\
\text { attributable to frame } \\
\text { placement are also } \\
\text { included, if these are } \\
\text { somehow analogous to } \\
\text { trampling. } \\
\text { Emphasis is on lasting } \\
\text { impacts to plant } \\
\text { performance (e.g., stem } \\
\text { die-back, lost } \\
\text { photosynthetic area, } \\
\text { damaged reproductive } \\
\text { structures.) }\end{array}$ & $\begin{array}{l}\text { No plants were } \\
\text { trampled }\end{array}$ & $\begin{array}{l}\text { Plants were trampled, } \\
\text { but probably had no } \\
\text { lasting impacts on plant } \\
\text { performance } \\
\text { OR, a very small } \\
\text { number of plants were } \\
\text { trampled to the degree } \\
\text { that there might have } \\
\text { been lasting impacts on } \\
\text { plant performance. }\end{array}$ & Intermediate & $\begin{array}{l}\text { Many plants were } \\
\text { trampled (impossible to } \\
\text { avoid), and about half } \\
\text { of trampling events } \\
\text { probably resulted in } \\
\text { lasting impacts on plant } \\
\text { performance. } \\
\text { OR trampling of plants } \\
\text { was somewhat } \\
\text { common (not } \\
\text { ubiquitous) and } \\
\text { probably resulted in } \\
\text { lasting impacts on plant } \\
\text { performance in most } \\
\text { cases. }\end{array}$ & Intermediate & $\begin{array}{l}\text { Many plants were trampled } \\
\text { throughout the site (nearly } \\
\text { impossible to avoid } \\
\text { continuous trampling), } \\
\text { AND trampling likely had } \\
\text { lasting impacts on plant } \\
\text { performance in most } \\
\text { cases. }\end{array}$ \\
\hline
\end{tabular}




\section{Table 11.-Continued}

\begin{tabular}{|c|c|c|c|c|c|c|c|}
\hline \multirow[b]{2}{*}{$\begin{array}{l}\text { Sampling } \\
\text { impact }\end{array}$} & \multirow[b]{2}{*}{ Comments } & \multicolumn{6}{|c|}{ Degree of impact } \\
\hline & & None & Slight & $\begin{array}{l}\text { Slight to } \\
\text { moderate }\end{array}$ & Moderate & $\begin{array}{l}\text { Moderate } \\
\text { to extreme }\end{array}$ & Extreme \\
\hline $\begin{array}{l}\text { Broken } \\
\text { branches }\end{array}$ & $\begin{array}{l}\text { Plant impacts attributable } \\
\text { to body movement } \\
\text { beneath or between } \\
\text { branches of woody plants } \\
\text { - e.g., fighting your way } \\
\text { through dense shrubs, } \\
\text { sapling trees, or low- } \\
\text { hanging branches. } \\
\text { Emphasis is on lasting } \\
\text { impacts to plant } \\
\text { performance (e.g., stem } \\
\text { die-back, lost } \\
\text { photosynthetic area, } \\
\text { damaged reproductive } \\
\text { structures.) }\end{array}$ & $\begin{array}{l}\text { No branches were } \\
\text { broken }\end{array}$ & $\begin{array}{l}\text { Branches were broken, } \\
\text { but probably had no } \\
\text { lasting impacts on plant } \\
\text { performance. } \\
\text { OR, a very small } \\
\text { number of branches } \\
\text { were broken to the } \\
\text { degree that there might } \\
\text { have been lasting } \\
\text { impacts on plant } \\
\text { performance. }\end{array}$ & Intermediate & $\begin{array}{l}\text { Many branches were } \\
\text { broken (impossible to } \\
\text { avoid), and about half } \\
\text { of events probably } \\
\text { resulted in lasting } \\
\text { impacts on plant } \\
\text { performance. } \\
\text { OR broken branches } \\
\text { were somewhat } \\
\text { common (not } \\
\text { ubiquitous) and } \\
\text { probably resulted in } \\
\text { lasting impacts on plant } \\
\text { performance in most } \\
\text { cases. }\end{array}$ & Intermediate & $\begin{array}{l}\text { Many branches were } \\
\text { broken throughout the site } \\
\text { (nearly impossible to avoid } \\
\text { continuous breaking), AND } \\
\text { likely had lasting impacts } \\
\text { on plant performance in } \\
\text { most cases. }\end{array}$ \\
\hline
\end{tabular}


Table 12. Explanations of sampling procedures for purposes of impact assessment.

\begin{tabular}{|c|c|}
\hline Sampling procedure & Comments \\
\hline Travel to macroplot & Refers to the overland trek to the macroplot \\
\hline Site characterization & Refers to all activities associated with site characterization, including texturing soil etc. \\
\hline Plot establishment & Refers to activities associated with laying out transects - e.g., locating endpoints and centers of transects, laying out the transect tape. \\
\hline $1-m^{2}$ quadrat sampling & $\begin{array}{l}\text { Refers to placement and sampling of 1- } \mathrm{m}^{2} \text { quadrats for frequency and cover, as well as to moving the quadrat frame from one location to the next } \\
\text { down the transect. }\end{array}$ \\
\hline 10-m² quadrat sampling & $\begin{array}{l}\text { Refers to placement and sampling of } 10-\mathrm{m}^{2} \text { quadrats for frequency, cover and density, as well as to moving the quadrat frame from one location to } \\
\text { the next down the transect. }\end{array}$ \\
\hline Line-point intercept sampling & Refers to point sampling along the transect - e.g., placing the pin, measuring intercept heights, and walking the transect. \\
\hline Gap-intercept sampling & Refers to sampling canopy and basal gaps along line-intercept transect. \\
\hline Pin placement & Refers to staking of tape and $10-\mathrm{m}^{2}$ quadrat frames with chaining pins \\
\hline Cumulative travel on line & Refers to impacts associated with repeated, cumulative travel up and down the transect line for all sampling procedures combined. \\
\hline
\end{tabular}

Table 13. Impact-assessment ratings for individual sampling procedures.

\begin{tabular}{|c|c|c|c|c|c|}
\hline \multicolumn{6}{|c|}{ Degree of responsibility foroverall impacts on a site } \\
\hline None & Slight & $\begin{array}{l}\text { Slight to } \\
\text { moderate }\end{array}$ & Moderate & $\begin{array}{l}\text { Moderate to } \\
\text { high }\end{array}$ & High \\
\hline $\begin{array}{l}\text { No observable impact } \\
\text { attributable to this } \\
\text { procedure }\end{array}$ & $\begin{array}{l}\text { Some impacts were } \\
\text { attributable to this } \\
\text { procedure, but it had a } \\
\text { slight impact overall. }\end{array}$ & Intermediate & $\begin{array}{l}\text { This procedure was responsible for a significant degree } \\
\text { of impact on this site. It was not the primary contributor } \\
\text { to extreme impacts, but it may have been the primary } \\
\text { contributor to moderate impacts. }\end{array}$ & Intermediate & $\begin{array}{l}\text { This procedure was the } \\
\text { primary contributor to } \\
\text { extreme impacts. }\end{array}$ \\
\hline
\end{tabular}




\section{Office Procedures}

Upon return to the office following each data-collection trip, the PocketAccess database was synchronized or transferred from the Pocket PC to a desktop computer and converted to an Access database using Microsoft ActiveSync software. A cradle or a direct line connected the Pocket PC to the computer. During Phase 3, a separate database was created for each park visit to minimize file sizes and data-transfer times. These visit-specific databases were then integrated into the single master Access database after every trip. After each data collection Phase, the data were reviewed using standardized quality control and quality assurance methods. A thorough quality check was conducted at the end of the field season and queries were developed to generate data tables for use in statistical analyses and summarization.

\section{Data Analyses}

Data were summarized and analyzed to evaluate how sampling efficiency (sampling times, within- and among-plot variability in cover estimates, and measures of community composition), selected cover estimates, and repeatability (measurement precision) differed among sampling techniques and ecological sites. Unless specified otherwise, all statistical analyses were performed with Statistica v.6.1 (Statsoft, Inc. 2004) for Windows, and p-values $\leq$ 0.05 were considered statistically significant.

\section{Sampling Efficiency}

As a standardized measure of variability, the coefficient of variation (CV) was used as a primary metric for describing and comparing within- and among-plot variability in cover estimates provided by different sampling techniques:

$$
\mathrm{CV}=100 * \text { (sample standard deviation / sample mean) }
$$

Analysis of variance (ANOVA; Zar 1999) was used to evaluate effects of ecological site, cover category (total live understory canopy, individual species, and soil-surface features), and sampling method on log-transformed CV values (using the natural log, ln) describing withinmacroplot variability and among-plot variability. Tukey's honestly significant difference (HSD) post-hoc test was used to evaluate differences among treatments with significant main effects (Zar 1999). In addition, multiple regression techniques (Zar 1999) were used to evaluate the significance of subsample size, frequency, and mean within-plot cover values as predictors of log-transformed CV values provided by different sampling techniques.

The relative efficiency of different sampling techniques also was evaluated by comparing numbers of subsamples and samples required for estimating within- and among-plot mean cover values with 10 and 20 percent precision. For these analyses, we define estimation precision as one-half the width of the 95 percent confidence interval for the mean, expressed as a percentage of the mean. Sample-size estimates were calculated using the software package PASS (Power and Sample Size; NCSS, Kaysville, Utah, http://www.ncss.com/). Data for mean sampling times (minutes per quadrat for $1-\mathrm{m}^{2}$ and $10-\mathrm{m}^{2}$ quadrats; minutes per 10-pt group for line-point intercept sampling) by ecological site were used to estimate amounts of time required for different sampling techniques to achieve 10 and 20 percent precision in within-plot cover estimates. Non-parametric Kruskal-Wallis analyses (Zar 1999) were used to test null hypotheses of no differences among median numbers of subsamples and among median numbers of hours 
required for different sampling methods to estimate mean within-plot cover values and amongplot cover values with 20 percent precision. Kruskal-Wallis analyses also were used to test null hypotheses of no difference among median ratios of within-to-among macroplot variability (based on log-transformed CV values) for cover estimates provided by different sampling techniques.

Finally, 10- $\mathrm{m}^{2}$ and $1-\mathrm{m}^{2}$ quadrat sampling techniques were compared on the basis of species-area curves, compositional curves, and numbers of vascular plant species (richness) detected per macroplot. Mean species-area and compositional curves were developed on an ecological-site basis using the software package PCORD v.4.34 (McCune and Mefford 1999). Species-area curves describe how mean numbers of unique species detected increase with increasing numbers of subsample quadrats. Compositional curves describe how increasing numbers of subsamples cause mean estimates of community composition to change in relation to community composition quantified on the basis of the full set of subsamples. For this particular analysis, community dissimilarity was described on the basis of Sørensen's distance index (McCune and Grace 2002). ANOVA was used to evaluate effects of ecological site and quadrat size on log-transformed species-richness values (natural log transformation) for macroplots sampled during Phase 3. This analysis was repeated after excluding from the $10-\mathrm{m}^{2}$ data those species that occurred in only one $10-\mathrm{m}^{2}$ quadrat at a given macroplot. The intent of this approach was to determine whether effects of quadrat size on species-richness estimates could be accounted for solely by low-frequency species detected in $10-\mathrm{m}^{2}$ quadrats.

\section{Among-Method Trends in Cover Estimates}

Data collected during this study could not be used to evaluate the accuracy of cover estimates provided by different sampling methods because true cover values were not determined. Nevertheless, we analyzed cover data to evaluate whether there were any relative trends in cover estimates provided by the different methods. ANOVA techniques were used to evaluate effects of ecological site and sampling method on estimates of total live understory canopy cover and cover of selected soil-surface features. For these analyses, means were standardized by calculating the ratio of the observed mean value for a particular sampling method and cover measure to the among-method mean value for the same measure.

\section{Repeatability}

The main focus of the repeatability analysis was to evaluate between-observer repeatability (measurement precision) of different sampling methods, and to assess whether repeatability of methods varied among ecological sites or types of measures (e.g., total plant cover, individual species cover, surface-feature cover, and density). Data were separated into four types: canopy cover, soil crust cover, other surface cover, and shrub and tree density. Cover and density were summarized for each transect sampled during Phase 3 ( $n=9$ transects for each ecological site). All data were analyzed separately for each ecological site unless otherwise noted.

For each ecological site, a factorial ANOVA was used to evaluate effects of observer and sampling method on litter cover, total live understory canopy cover, and cover of three dominant plant species. Data were arcsine-square-root (arcsin) transformed to improve normality and variance, assumptions of parametric statistics. The lack of normality in the distribution of soil crust data could not be corrected with the arcsin transformation. Therefore, non-parametric Wilcoxon paired-sample tests (Zar 1999) were performed for each soil crust type (undifferentiated crust, cyanobacteria, lichen, and moss) to evaluate effects of observer on cover 
estimates derived from $1-\mathrm{m}^{2}$ quadrats, $10-\mathrm{m}^{2}$ quadrats, and line-point intercept transects. Wilcoxon tests also were used to evaluate effects of observer on estimates of biological soil crust cover using the BSC frame (table 10 and fig. 5). For shrub and tree density, Wilcoxon tests evaluated effects of observer on mean counts per quadrat for each size class of each species across all ecological sites combined.

To evaluate effects of wind on repeatability of line-point intercept canopy cover, absolute differences between observers' cover estimates were regressed on average wind speeds for both observers combined. Separate regression analyses were performed for woody plants and for herbaceous plants.

\section{Sampling Impacts}

Sampling impacts on plot conditions were evaluated on the basis of numeric scores assigned to qualitative impact ratings $(0=$ none, $1=$ slight, $2=$ slight to moderate, $3=$ moderate, $4=$ moderate to extreme, $5=$ extreme). Kruskal-Wallis tests were used to determine differences in impact ratings (1) among sampling procedures, (2) among ecological sites, and (3) among unsampled and sampled sides of the transect and within quadrats.

\section{Results}

\section{Macroplot Characterization and Evaluation}

Based on the macroplot characterization process, 15 of the total 48 sampled macroplots were relocated away from the predetermined centroids provided by NPS (table 14). Ten macroplots were relocated due to being located on or near the wrong soil and ecological site. Of the ten, only one macroplot (DINO2b) had to be moved to an entirely new set of coordinates because the target soil and ecological site were nowhere in the area. All other macroplots were close enough to the target soil and ecological site that they were shifted to a nearby location. Seven macroplots were shifted due to a physical barrier (two predetermined centroids were both on the wrong soil and too close to a physical barrier). Physical barriers primarily included roads and steep cliff bands. In one case, the centroid was located within a paved campground.

The field team found that it was relatively straightforward to evaluate soil and ecological site characteristics on the basis of observable field attributes in most cases. The most difficult locations to assess were at Wupatki National Monument, where soil depth was a key attribute for distinguishing ecological sites. This attribute could not be evaluated on the basis of surface features alone. Although the field team was able to successfully evaluate site characteristics in most cases, they would have benefited from additional training and experience in soilgeomorphic concepts underlying the notion of ecological sites. In some cases, decisions to relocate macroplots may have been based on excessive reliance on vegetation characteristics rather than on soil-geomorphic characteristics. 
Table 14. Summary of macroplots that were relocated following site characterization and prior to sampling.

\begin{tabular}{|c|c|c|c|}
\hline Ecological site & Macroplot & Reason for relocation & Details \\
\hline $\begin{array}{l}\text { Desert Sand (Sand } \\
\text { Sagebrush) }\end{array}$ & CANY2b & $\begin{array}{l}\text { Close to wrong soil type, which } \\
\text { was influenced by alluvial } \\
\text { groundwater }\end{array}$ & $\begin{array}{l}\text { Plot moved farther away from Salt Creek to avoid } \\
\text { influence of ground water on vegetation composition. }\end{array}$ \\
\hline \multirow{2}{*}{$\begin{array}{l}\text { Limy Upland, 6-10" } \\
\text { pz }\end{array}$} & WUPA1 & Wrong soil type & $\begin{array}{l}\text { Plot shifted about } 100 \mathrm{~m} \text { further down the valley } \\
\text { because the original point crossed a cliff band. }\end{array}$ \\
\hline & WUPA2 & Wrong soil type & $\begin{array}{l}\text { Plot moved to a location about } 100 \mathrm{~m} \text { into the valley to } \\
\text { avoid including shallow soils in the macroplot. }\end{array}$ \\
\hline $\begin{array}{l}\text { Loamy Hills, 25-33" } \\
\text { pz }\end{array}$ & GRCA7 & Physical barrier: on the road & $\begin{array}{l}\text { The predetermined centroid was located at a campsite } \\
\text { so the plot was shifted about } 100 \text { m away to be just } \\
\text { outside the campground. }\end{array}$ \\
\hline \multirow{2}{*}{$\begin{array}{l}\text { Semidesert Alkali } \\
\text { Sandy Loam (Alkali } \\
\text { Sacaton) }\end{array}$} & CARE1 & Close to wrong soil type & Plot moved to avoid proximity to rocky hillslope. \\
\hline & CARE2b & $\begin{array}{l}\text { Close to wrong soil type } \\
\text { (drainage) }\end{array}$ & $\begin{array}{l}\text { Plot moved about } 100 \mathrm{~m} \text { south to avoid crossing a } \\
\text { large wash. }\end{array}$ \\
\hline \multirow{4}{*}{$\begin{array}{l}\text { Semidesert Loam } \\
\text { (Wyoming Big } \\
\text { Sagebrush) }\end{array}$} & DINO1 & Physical barrier: on the road & $\begin{array}{l}\text { This plot was shifted about } 50 \mathrm{~m} \text { to avoid sampling on } \\
\text { top of the road. }\end{array}$ \\
\hline & DINO2b & Wrong soil type and on the road & $\begin{array}{l}\text { Original plot location appeared to be in the wrong soil } \\
\text { type. A new location was selected to avoid sampling } \\
\text { on a road. }\end{array}$ \\
\hline & DINO4b & Wrong soil type & $\begin{array}{l}\text { Plot location moved downslope away from edge of soil } \\
\text { map unit. Outside of the map unit, the soil appeared to } \\
\text { be too gravelly and the vegetation exhibited no } \\
\text { remnant sagebrush (the target vegetation). }\end{array}$ \\
\hline & DINO5 & Wrong soil type & $\begin{array}{l}\text { Centroid was located in a gully, right at the edge of a } \\
\text { different soil map unit, so the macroplot was relocated } \\
\text { on a sagebrush- dominated bench, about } 50 \mathrm{~m} \text { to the } \\
\text { east. }\end{array}$ \\
\hline \multirow{3}{*}{$\begin{array}{l}\text { Semidesert Shallow } \\
\text { Sandy Loam PJ }\end{array}$} & $\mathrm{ARCH} 1 \mathrm{~b}$ & Wrong soil type & Soil at predetermined location was much too deep. \\
\hline & $\mathrm{ARCH} 4 \mathrm{~b}$ & Wrong soil type and on the road & $\begin{array}{l}\text { Original location was on road and in wrong soil type. } \\
\text { Centroid shifted nearby to correct soil type off of road. }\end{array}$ \\
\hline & CANY4 & Physical barrier: too close to cliff & Plot was moved further from the cliff edge. \\
\hline \multirow{2}{*}{$\begin{array}{l}\text { Upland Shallow } \\
\text { Loam (Pinyon-Utah } \\
\text { Juniper) }\end{array}$} & CARE4b & Physical barrier: too close to cliff & $\begin{array}{l}\text { Plot location was moved up and out of the canyon to } \\
\text { avoid } 2 \text { cliffbands. }\end{array}$ \\
\hline & CARE9 & Physical barrier: too close to cliff & $\begin{array}{l}\text { Shifted the plot location about } 15 \mathrm{~m} \text { upslope to avoid } \\
\text { sampling on the cliff. }\end{array}$ \\
\hline
\end{tabular}

Prior to the field season, NCPN staff provided predetermined transect orientations based on analyses of digital elevation models (DEMs). As intended, these generally aligned with hillslope contours observed in the field. However, some differences occurred between the predetermined orientations and those based on field observations of aspect and contour probably because the scale of topographic variation in the field was finer than that depicted in DEMs. An extreme example of this difference could be seen at macroplot CARE7, where the predetermined aspect was oriented down a large valley slope whereas the ground-level aspect appeared to follow the slope along the side of the valley wall.

\section{Sampling Efficiency}

\section{Sampling Times}

Across all ecological sites, the mean amount of time required for setting up and reading frequency and cover in $10-\mathrm{m}^{2}$ quadrats ( $8.2 \mathrm{~min}$ per quadrat) was approximately twice that 
Table 15. Mean times for setting up and reading frequency (freq), cover (cov), and density (dens) in 1- $\mathrm{m}^{2}$ and 10- $\mathrm{m}^{2}$ quadrats. Set-up times for $1-\mathrm{m}^{2}$ quadrats were not measured but are estimated here for comparative purposes. Data do not include time required for transect layout.

\begin{tabular}{|c|c|c|c|c|c|c|c|c|c|c|c|}
\hline \multirow[b]{3}{*}{ Ecological site } & \multirow{3}{*}{$\begin{array}{c}\text { No. of } \\
\text { macro- } \\
\text { plots }\end{array}$} & \multicolumn{10}{|c|}{ Mean times by ecological site (min per quadrat) } \\
\hline & & \multicolumn{4}{|c|}{$1-\mathrm{m}^{2}$ quadrats } & \multicolumn{6}{|c|}{$10-\mathrm{m}^{2}$ quadrats } \\
\hline & & $\begin{array}{l}\text { Set-up } \\
\text { (s) }\end{array}$ & $\begin{array}{c}\text { Freq } \\
(f)^{*}\end{array}$ & $\begin{array}{c}\text { Cov } \\
\text { (c) }\end{array}$ & $\begin{array}{c}\text { Total } \\
(s+f+c)\end{array}$ & $\begin{array}{l}\text { Set-up } \\
\text { (s) }\end{array}$ & $\begin{array}{c}\text { Freq } \\
(f)^{*}\end{array}$ & $\begin{array}{l}\text { Cov } \\
\text { (c) }\end{array}$ & $\begin{array}{c}\text { Total } \\
(s+f+c)\end{array}$ & $\begin{array}{l}\text { Dens } \\
\text { (d) }\end{array}$ & $\begin{array}{c}\text { Total } \\
(s+f+c+d)\end{array}$ \\
\hline Brushy Loam & 5 & 1.0 & 2.2 & 2.3 & 5.5 & 3.9 & 5.6 & 2.8 & 12.3 & 2.7 & 15.0 \\
\hline Desert Sand (Sand Sagebrush) & 2 & 0.5 & 1.9 & 2.2 & 4.6 & 2.3 & 3.9 & 2.6 & 8.8 & 0.3 & 9.1 \\
\hline Limy Upland, 6-10" pz & 5 & 0.5 & 1.2 & 2.0 & 3.7 & 2.0 & 3.0 & 2.3 & 7.3 & 0.3 & 7.6 \\
\hline Loamy Hills, 25-33" pz & 5 & 0.5 & 0.8 & 1.5 & 4.1 & 2.4 & 2.5 & 2.0 & 8.9 & 0.7 & 10.8 \\
\hline Loamy Hills, Cold, 25-33" pz & 2 & 0.5 & 1.4 & 2.2 & 2.8 & 2.8 & 3.9 & 2.6 & 7.3 & 1.9 & 8.0 \\
\hline Loamy Mesa Top PJ & 5 & 0.5 & 1.1 & 1.9 & 3.5 & 3.3 & 3.1 & 2.2 & 8.6 & 0.9 & 9.5 \\
\hline Semidesert Alkali Sandy Loam (Alkali Sacaton) & 5 & 0.5 & 1.9 & 2.0 & 4.4 & 1.8 & 4.6 & 2.4 & 8.8 & 0.9 & 9.7 \\
\hline Semidesert Loam (Wyoming Big Sagebrush) & 5 & 0.5 & 1.9 & 2.4 & 4.8 & 2.1 & 3.9 & 2.5 & 8.4 & 2.4 & 10.9 \\
\hline Semidesert Shallow Sandy Loam (PJ) & 7 & 0.5 & 1.4 & 1.9 & 3.8 & 2.5 & 3.3 & 2.0 & 7.9 & 1.2 & 9.1 \\
\hline Shallow Loamy, 10-14" pz & 2 & 0.5 & 1.1 & 1.7 & 3.4 & 2.2 & 2.4 & 2.0 & 6.5 & 0.2 & 6.7 \\
\hline Upland Shallow Loam (Pinyon-Utah Juniper) & 5 & 0.5 & 0.5 & 1.7 & 2.8 & 2.3 & 1.5 & 1.5 & 5.3 & 0.3 & 5.6 \\
\hline Mean & & 0.55 & 1.40 & 1.98 & 3.93 & 2.51 & 3.43 & 2.26 & 8.20 & 1.08 & 9.28 \\
\hline $\mathrm{sd}$ & & 0.15 & 0.53 & 0.26 & 0.84 & 0.62 & 1.14 & 0.36 & 1.77 & 0.89 & 2.49 \\
\hline CV & & 27.64 & 38.09 & 13.06 & 21.31 & 24.87 & 33.17 & 16.10 & 21.62 & 82.11 & 26.88 \\
\hline
\end{tabular}

* includes time to read frequency in nested smaller quadrats 
Table 16. Mean times for sampling line-point intercept transects, basal- and canopy-gaps transects, and biological soil crust (BSC) frames. Data do not include time required for transect layout. Sites identified in bold italics are those where line-point intercepts were used to estimate cover of overstory vegetation above 2-m in height, in addition to understory vegetation and soil-surface features.

\begin{tabular}{|c|c|c|c|c|c|c|}
\hline \multirow[b]{2}{*}{ Ecological site } & \multicolumn{2}{|c|}{ Line-point intercept } & \multicolumn{2}{|c|}{ Basal and canopy gaps } & \multicolumn{2}{|c|}{ BSC frames } \\
\hline & No. of transects & $\begin{array}{l}\text { Min per } 10-p t \\
\text { group }\end{array}$ & $\begin{array}{c}\text { No. of } \\
\text { transects }\end{array}$ & $\begin{array}{l}\text { Min per } 50-\mathrm{m} \\
\text { transect }\end{array}$ & $\begin{array}{c}\text { No. of } \\
\text { transects }\end{array}$ & $\begin{array}{l}\text { Sec per } \\
\text { frame }\end{array}$ \\
\hline Brushy Loam & 13 & 5.0 & 3 & 31.8 & - & - \\
\hline Desert Sand (Sand Sagebrush) & 6 & 3.6 & 6 & 23.6 & - & - \\
\hline Limy Upland, 6-10" pz & 12 & 3.3 & 5 & 34.6 & - & - \\
\hline Loamy Hills, 25-33" pz & 14 & 4.0 & - & - & - & - \\
\hline Loamy Hills, Cold, 25-33" pz & 6 & 5.7 & - & - & - & - \\
\hline Loamy Mesa Top PJ & 14 & 4.2 & 6 & 27.4 & 14 & 20.8 \\
\hline Semidesert Alkali Sandy Loam (Alkali Sacaton) & 14 & 2.4 & 4 & 24.4 & 15 & 20.5 \\
\hline Semidesert Loam (Wyoming Big Sagebrush) & 13 & 3.9 & 6 & 41.2 & 11 & 24.9 \\
\hline Semidesert Shallow Sandy Loam (PJ) & 20 & 2.5 & 12 & 19.9 & 17 & 29.2 \\
\hline Shallow Loamy, 10-14" pz & 5 & 3.0 & 5 & 31.5 & - & - \\
\hline Upland Shallow Loam (Pinyon-Utah Juniper) & 14 & 2.3 & 6 & 5.2 & - & - \\
\hline Mean & & 3.62 & & 26.63 & & 23.38 \\
\hline $\mathrm{sd}$ & & 1.09 & & 10.27 & & 3.44 \\
\hline CV & & 30.13 & & 38.57 & & 14.71 \\
\hline
\end{tabular}


required for $1-\mathrm{m}^{2}$ quadrats (3.9 min per quadrat; table 15). For both quadrat sizes, mean sampling times were greatest at the Brushy Loam ecological site in Mesa Verde National Park due to dense shrubland vegetation. Mean amounts of time required to sample densities of shrubs and trees in $10-\mathrm{m}^{2}$ quadrats varied in relation to the abundance of woody plants and ranged from 2.7 min per quadrat in Brushy Loam shrublands of Mesa Verde to 0.2 min per quadrat in Shallow Loamy desert grasslands of Wupatki National Monument. Across all sites, mean sampling times for line-point intercept transects (3.6 min per 10-pt group) were similar to those for $1-\mathrm{m}^{2}$ quadrats (table 16). Combined sampling of basal and canopy gaps along $50-\mathrm{m}$ transects required an average of 26.6 min per transect across all ecological sites. Sampling biological soil crust cover with the BSC frame (table 10, fig. 5) required approximately 23.4 sec per frame, on average.

\section{Within-Macroplot Variability}

Ecological site, cover category (total live understory canopy, individual species, and soilsurface features), and sampling method all had significant effects on log-transformed CV values describing within-macroplot variability in cover measures (table 17). In addition, there was a statistically significant interaction between ecological site and cover category (table 17). The Upland Shallow Loam ecological site at Capitol Reef National Park was characterized by the greatest degree of within-macroplot variability in cover measures (fig. 6a), but otherwise there were no clear among-site trends in within-plot variability. Total live understory canopy cover was least variable within macroplots and individual species' cover was most variable, when averaged across all ecological sites (fig. 6b). This general pattern was strongly reflected at some ecological sites (e.g., Brushy Loam at Mesa Verde and Limy Upland at Wupatki), but was weakly represented or not apparent at other ecological sites (e.g., Semidesert Shallow Sandy Loam at Arches and Canyonlands, and the Upland Shallow Loam at Capitol Reef) (fig. 7). Of the sampling methods, $10-\mathrm{m}^{2}$ quadrats exhibited the least within-macroplot variability in cover measures, and there was no statistical difference between $1-\mathrm{m}^{2}$ quadrats and line-point intercepts with respect to this measure (fig. 6c).

Table 17. Analysis of variance for effects of ecological site, cover category (total live understory canopy, individual species, and soil-surface features), and sampling method on log-transformed CV values describing within-macroplot variability in cover measures.

\begin{tabular}{lccccc}
\hline Effect & $\mathrm{SS}$ & $\mathrm{df}$ & $\mathrm{MS}$ & $\mathrm{F}$ & $\mathrm{p}$ \\
\hline Ecological site & 36.722 & 10 & 3.672 & 7.919 & $<0.0001$ \\
Cover category & 75.154 & 2 & 37.577 & 81.034 & $<0.0001$ \\
Method & 15.795 & 2 & 7.898 & 17.031 & $<0.0001$ \\
Ecological site*Category & 30.102 & 20 & 1.505 & 3.246 & $<0.0001$ \\
Ecological site*Method & 10.828 & 20 & 0.541 & 1.168 & 0.275 \\
${\text { Category }{ }^{\star} \text { Method }}_{\text {Ecological site }{ }^{\star} \text { Category }{ }^{\star} \text { Method }}$ & 1.919 & 4 & 0.480 & 1.035 & 0.388 \\
Error & 4.103 & 40 & 0.103 & 0.221 & 1.000 \\
\hline
\end{tabular}



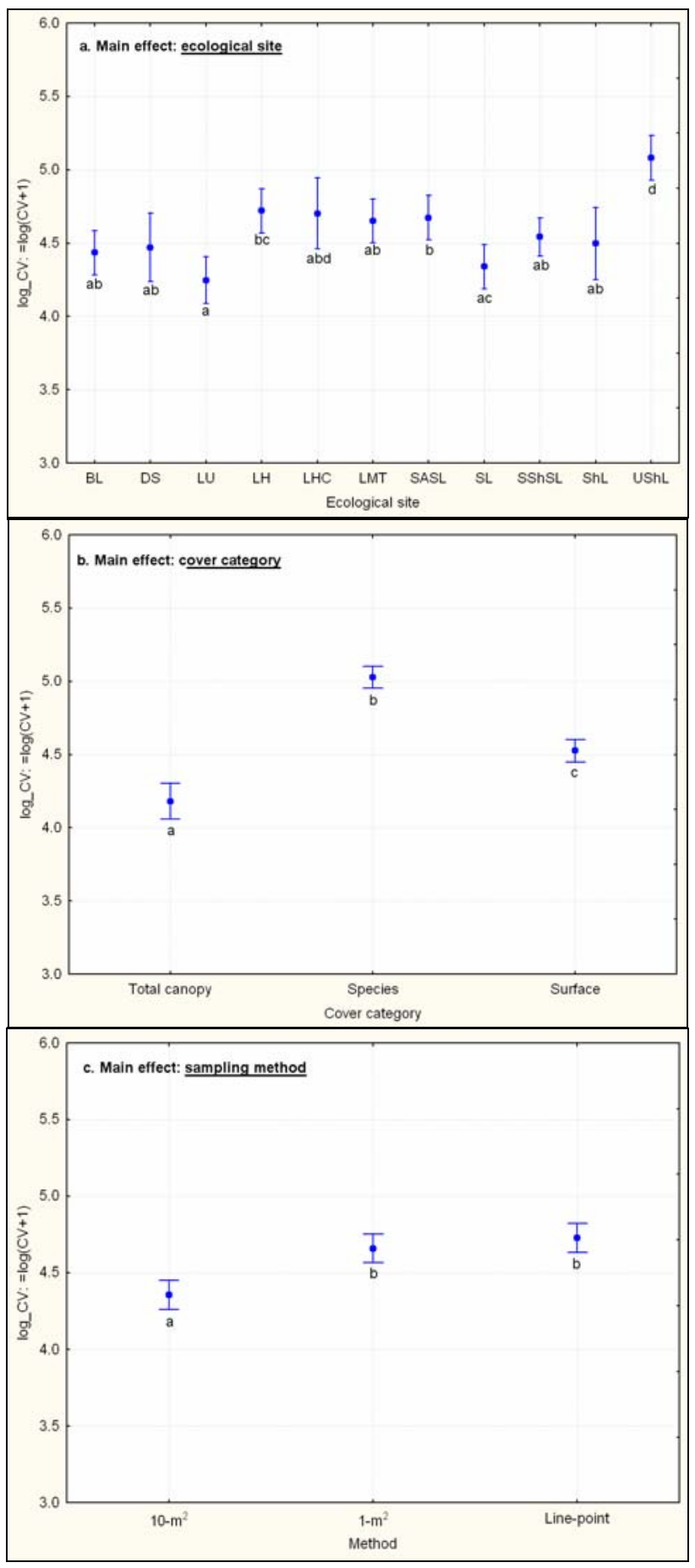

Figure 6. Main effects of (a) ecological site, (b) cover category (total live understory canopy, individual species, and soil-surface features), and (c) sampling method on log-transformed CV values describing within-plot variability in cover measures. Bars indicate 95 percent confidence intervals. Within each panel, values with the same letter are not significantly different by Tukey's HSD test. See table 1 for ecological site codes. 


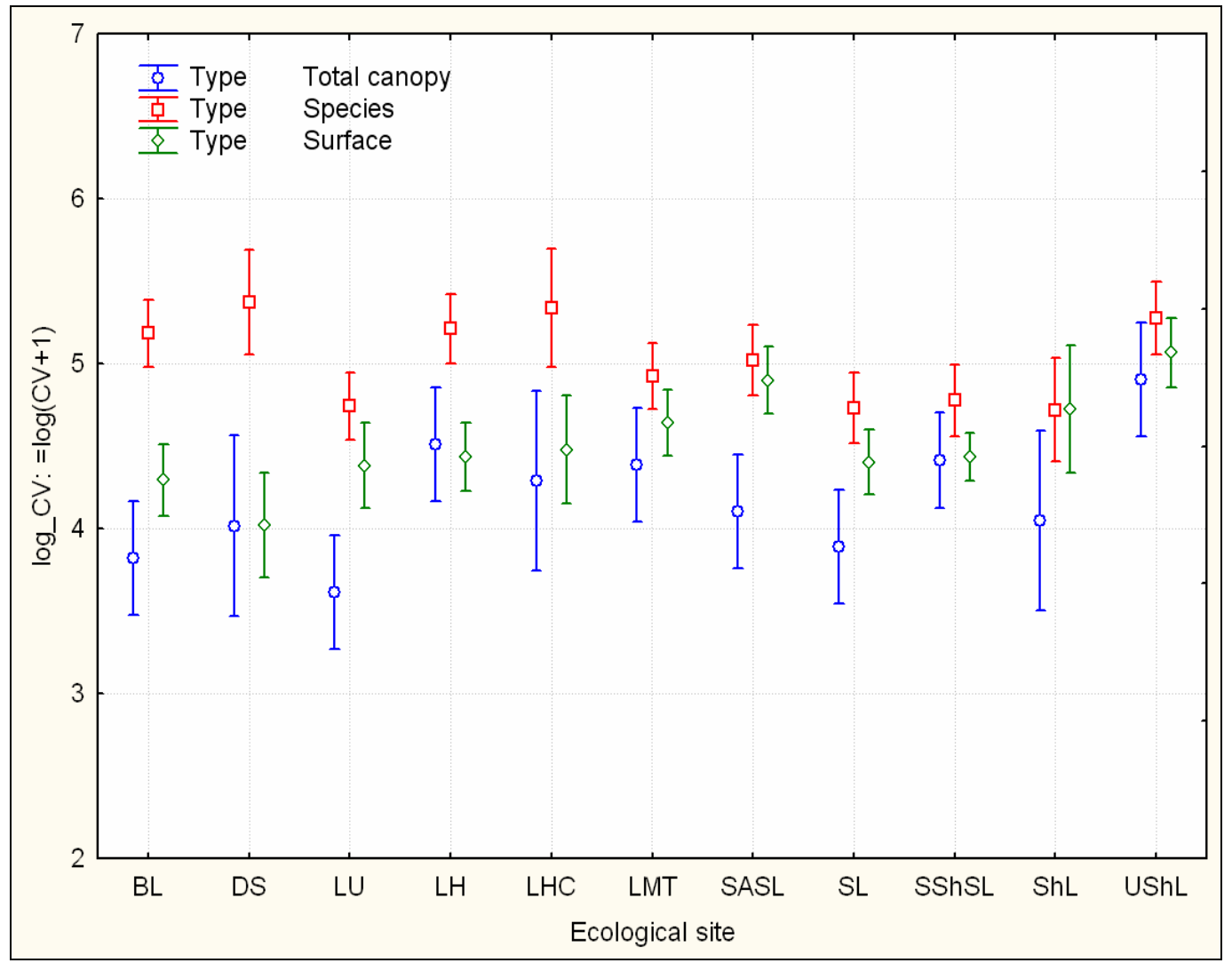

Figure 7. Interactive effects of ecological site and cover category (total live understory canopy, individual plant species, and soil-surface features) on log-transformed CV values describing within-plot variability in cover measures. Bars indicate 95 percent confidence intervals for means. See table 1 for ecological site codes.

In multiple regression models for all sampling methods combined and for each method separately, frequency, mean cover, and subsample size all were significant predictors of logtransformed CV values for within-macroplot cover measures (table 18). Of these, frequency tended to have the greatest effect (with the exception of $10-\mathrm{m}^{2}$ quadrats), whereas subsample size consistently had the least (albeit significant) effect as indicated by standardized regression coefficients (Beta values). In models for individual sampling methods, the importance of frequency as a predictor of within-plot CV values increased with decreasing quadrat area. The fit of the overall regression model also increased with decreasing quadrat area, as reflected by adjusted $\mathrm{R}^{2}$ values.

Table 19 summarizes means and measures of within-macroplot variability for total live understory canopy cover estimated by three different sampling methods at each of 11 ecological sites. (Appendix B presents 11 ecological-site-level tables with measures of average withinmacroplot variability and associated sample size estimates for a broader range of cover measures.) Except for the Loamy Mesa Top PJ ecological site at Mesa Verde, mean within-plot $\mathrm{CV}$ values for total live understory canopy cover were lowest for $10-\mathrm{m}^{2}$ quadrats at all ecological sites. Mean CV values were highest for $1-\mathrm{m}^{2}$ quadrats at eight of the 11 ecological sites and highest for line-point intercepts at three of the 11 ecological sites. Among-method patterns in numbers of subsamples required to estimate mean cover values with 10 and 20 percent precision were similar to those for mean CV values. Subsample numbers were lowest for $10-\mathrm{m}^{2}$ quadrats 
at all ecological sites except the Upland Shallow Loam site at Capitol Reef. Subsample numbers for $1-\mathrm{m}^{2}$ quadrats were highest for eight of the 11 ecological sites. Across all ecological sites combined, there was no difference among methods in median numbers of subsamples required to estimate mean plot-level cover of total understory vegetation (fig. 8a) or surface features (fig. 8c) with 20 percent precision. The median number of subsamples required to estimate individual species' cover with 20 percent precision was lower for $10-\mathrm{m}^{2}$ quadrats than for line-point intercept transects (fig. 8b).

Table 18. Results of multiple-regression models evaluating significance of subsample size, frequency, and mean cover as predictors of log-transformed CV values describing withinmacroplot variability in cover measures.

\begin{tabular}{|c|c|c|c|c|c|c|c|}
\hline \multirow{3}{*}{$\begin{array}{l}\text { Model 1: } \\
\text { All methods combined } \\
n=931\end{array}$} & \multicolumn{2}{|l|}{ Model results } & \multicolumn{5}{|c|}{ Standardized regression coefficients } \\
\hline & & Value & Indep. var. & Beta & SE & $\mathrm{t}(927)$ & p-level \\
\hline & Multiple R & 0.85 & Subsample $n$ & 0.081 & 0.017 & 4.63 & $<0.0001$ \\
\hline & Multiple $\mathrm{R}^{2}$ & 0.73 & Freq & -0.536 & 0.020 & -26.98 & $<0.0001$ \\
\hline & Adjusted $\mathrm{R}^{2}$ & 0.73 & Mean & -0.447 & 0.020 & -22.58 & $<0.0001$ \\
\hline & $F(3,927)$ & 827.74 & & & & & \\
\hline & $\mathrm{p}$ & $<0.0001$ & & & & & \\
\hline \multirow{7}{*}{$\begin{array}{l}\frac{\text { Model 2: }}{10-m^{2} \text { quadrats }} \\
n=321\end{array}$} & \multicolumn{2}{|l|}{ Model results } & \multicolumn{5}{|c|}{ Standardized regression coefficients } \\
\hline & & Value & Indep. var. & Beta & SE & $\mathrm{t}(317)$ & p-level \\
\hline & Multiple R & 0.77 & Subsample $\mathrm{n}$ & 0.098 & 0.036 & 2.73 & 0.0068 \\
\hline & Multiple $\mathrm{R}^{2}$ & 0.60 & Freq & -0.447 & 0.038 & -11.64 & $<0.0001$ \\
\hline & Adjusted $\mathrm{R}^{2}$ & 0.59 & Mean & -0.488 & 0.038 & -12.67 & $<0.0001$ \\
\hline & $F(3,317)$ & 156.77 & & & & & \\
\hline & $\mathrm{p}$ & $<0.0001$ & & & & & \\
\hline
\end{tabular}

\begin{tabular}{|c|c|c|c|c|c|c|c|}
\hline \multirow{3}{*}{$\begin{array}{l}\frac{\text { Model 3: }}{1-m^{2} \text { quadrats }} \\
n=318\end{array}$} & \multicolumn{2}{|l|}{ Model results } & \multicolumn{5}{|c|}{ Standardized regression coefficients } \\
\hline & & Value & Indep. var. & Beta & $\mathrm{SE}$ & $\mathrm{t}(314)$ & p-leve \\
\hline & Multiple R & 0.83 & Subsample $n$ & 0.094 & 0.032 & 2.96 & 0.0033 \\
\hline & Multiple $\mathrm{R}^{2}$ & 0.69 & Freq & -0.538 & 0.036 & -15.12 & $<0.0001$ \\
\hline & Adjusted $\mathrm{R}^{2}$ & 0.68 & Mean & -0.430 & 0.036 & -12.03 & $<0.0001$ \\
\hline & $F(3,314)$ & 230.00 & & & & & \\
\hline & $\mathrm{p}$ & $<0.0001$ & & & & & \\
\hline
\end{tabular}

Model 4:

Line-point intercept $\mathrm{n}=292$

\begin{tabular}{lr}
\multicolumn{2}{l}{ Model results } \\
\hline \multicolumn{2}{l}{ Value } \\
\hline Multiple R & 0.97 \\
Multiple $\mathrm{R}^{2}$ & 0.93 \\
Adjusted $\mathrm{R}^{2}$ & 0.93 \\
$\mathrm{~F}(3,288)$ & 1342.26 \\
$\mathrm{p}$ & $<0.0001$ \\
\hline
\end{tabular}

Standardized regression coefficients

\begin{tabular}{lrrrr}
\hline Indep. var. & Beta & SE & $\mathrm{t}(288)$ & p-level \\
\hline Subsample n & 0.032 & 0.016 & 2.07 & 0.0396 \\
Freq & -0.685 & 0.026 & -26.74 & $<0.0001$ \\
Mean & -0.326 & 0.026 & -12.74 & $<0.0001$ \\
\hline
\end{tabular}


Table 19. Summary of mean estimates for total live understory canopy cover for each of 11 Colorado Plateau ecological sites, withinmacroplot variation in cover estimates summarized across $n$ macroplots within each ecological site, subsample sizes required to achieve 10 and 20 percent precision in estimates of macroplot-level means, and estimated amounts of sampling time required to achieve those degrees of precision. Subsample sizes for line-point sampling refer to numbers of 10-point groups. Sites identified in bold italics are those where line-point intercepts were used to estimate cover of overstory vegetation above $2 \mathrm{~m}$ tall, in addition to understory vegetation and soil-surface features.

\begin{tabular}{|c|c|c|c|c|c|c|c|c|c|c|c|c|c|c|}
\hline \multirow[b]{2}{*}{ Ecological site } & \multirow{2}{*}{$\begin{array}{l}\text { Physiog- } \\
\text { namic } \\
\text { structure }\end{array}$} & \multirow[b]{2}{*}{$\mathbf{n}$} & \multirow[b]{2}{*}{ Method } & \multirow[b]{2}{*}{$\begin{array}{l}\text { Mean } \\
\text { cover }\end{array}$} & \multicolumn{5}{|c|}{$\begin{array}{l}\text { Within-macroplot variation in cover estimates } \\
\text { (summarized across macroplots) }\end{array}$} & \multicolumn{2}{|c|}{$\begin{array}{c}\text { Subsample size } \\
\text { (by precision) }\end{array}$} & \multirow{2}{*}{$\begin{array}{c}\text { Unit } \\
\text { time } \\
\text { (min) }\end{array}$} & \multicolumn{2}{|c|}{$\begin{array}{l}\text { Subsample time } \\
\text { (hrs by precision) }\end{array}$} \\
\hline & & & & & Mean sd & Min sd & Max sd & $\begin{array}{l}\text { Mean } \\
\text { freq* }\end{array}$ & Mean CV & $10 \%$ & $20 \%$ & & $10 \%$ & $20 \%$ \\
\hline \multirow{3}{*}{ Brushy Loam } & \multirow{3}{*}{ Shrubland } & \multirow{3}{*}{5} & $10-m^{2}$ & 49.7 & 18.1 & 7.4 & 24.0 & 100.0 & 36.5 & 54 & 16 & 12.3 & 11.1 & 3.3 \\
\hline & & & $1-m^{2}$ & 43.4 & 26.2 & 10.8 & 37.3 & 100.0 & 60.1 & 143 & 38 & 5.5 & 13.1 & 3.5 \\
\hline & & & Line-point & 52.8 & 23.7 & 16.4 & 33.2 & 98.7 & 45.5 & 80 & 22 & 5.0 & 6.7 & 1.8 \\
\hline \multirow{3}{*}{$\begin{array}{l}\text { Desert Sand (Sand } \\
\text { Sagebrush) }\end{array}$} & \multirow{3}{*}{ Grassland } & \multirow{3}{*}{2} & $10-m^{2}$ & 13.4 & 3.7 & 3.4 & 4.0 & 100.0 & 27.7 & 32 & 10 & 8.8 & 4.7 & 1.5 \\
\hline & & & $1-m^{2}$ & 12.3 & 7.7 & 6.5 & 8.8 & 100.0 & 61.9 & 151 & 40 & 4.6 & 11.6 & 3.1 \\
\hline & & & Line-point & 11.7 & 11.1 & 10.2 & 12.1 & 68.3 & 95.4 & 350 & 90 & 3.6 & 21.0 & 5.4 \\
\hline \multirow{3}{*}{ Limy Upland, 6-10" pz } & \multirow{3}{*}{ Grassland } & \multirow{3}{*}{5} & $10-m^{2}$ & 23.6 & 6.0 & 3.9 & 8.0 & 100.0 & 26.5 & 28 & 9 & 7.3 & 3.4 & 1.1 \\
\hline & & & $1-m^{2}$ & 16.0 & 5.3 & 3.1 & 8.8 & 100.0 & 33.1 & 45 & 15 & 3.7 & 2.8 & 0.9 \\
\hline & & & Line-point & 26.7 & 15.8 & 13.0 & 18.7 & 93.3 & 59.9 & 138 & 37 & 3.3 & 7.6 & 2.0 \\
\hline \multirow{3}{*}{$\begin{array}{l}\text { Loamy Hills, 25-33" } \\
\text { pz }\end{array}$} & \multirow{3}{*}{ Forest } & \multirow{3}{*}{5} & $10-m^{2}$ & 19.7 & 15.8 & 3.0 & 32.2 & 100.0 & 74.8 & 248 & 65 & 8.9 & 36.8 & 9.6 \\
\hline & & & $1-m^{2}$ & 23.8 & 27.1 & 5.2 & 52.8 & 94.7 & 120.4 & 502 & 128 & 4.1 & 34.3 & 8.7 \\
\hline & & & Line-point & 16.9 & 13.8 & 9.6 & 23.3 & 72.0 & 90.6 & 257 & 67 & 4 & 17.1 & 4.5 \\
\hline \multirow{3}{*}{$\begin{array}{l}\text { Loamy Hills, Cold, } \\
25-33^{\prime \prime} p z\end{array}$} & \multirow{3}{*}{ Forest } & \multirow{3}{*}{2} & $10-m^{2}$ & 48.8 & 31.6 & 29.3 & 33.9 & 100.0 & 64.9 & 164 & 43 & 7.3 & 20.0 & 5.2 \\
\hline & & & $1-m^{2}$ & 57.3 & 42.5 & 33.7 & 51.2 & 100.0 & 78.3 & 211 & 56 & 2.8 & 9.8 & 2.6 \\
\hline & & & Line-point & 25.7 & 18.9 & 17.9 & 19.9 & 85.0 & 74.5 & 209 & 55 & 5.7 & 19.9 & 5.2 \\
\hline & & & $10-m^{2}$ & 32.7 & 20.2 & 11.7 & 31.3 & 91.2 & 157.9 & 149 & 39 & 8.6 & 21.4 & 5.6 \\
\hline Loamy Mesa Top PJ & Woodland & 5 & $1-m^{2}$ & 29.6 & 31.1 & 15.2 & 49.8 & 58.7 & 198.8 & 425 & 109 & 3.5 & 24.8 & 6.4 \\
\hline & & & Line-point & 20.7 & 15.5 & 11.6 & 18.3 & 46.7 & 133.4 & 215 & 57 & 4.2 & 15.1 & 4.0 \\
\hline Semidesert Alkali & & & $10-m^{2}$ & 20.3 & 8.8 & 4.5 & 16.9 & 100.0 & 45.5 & 75 & 21 & 8.8 & 11.0 & 3.1 \\
\hline Sandy Loam (Alkali & Grassland & 5 & $1-m^{2}$ & 18.1 & 12.7 & 6.1 & 20.1 & 98.7 & 72.8 & 193 & 50 & 4.4 & 14.2 & 3.7 \\
\hline Sacaton) & & & Line-point & 25.4 & 16.4 & 11.9 & 19.4 & 85.3 & 71.7 & 163 & 43 & 2.4 & 6.5 & 1.7 \\
\hline Semidesert Loam & & & $10-m^{2}$ & 32.2 & 11.1 & 7.9 & 16.9 & 100.0 & 36.6 & 49 & 14 & 8.4 & 6.9 & 2.0 \\
\hline (Wyoming Big & Shrubland & 5 & $1-m^{2}$ & 20.2 & 13.0 & 9.1 & 19.4 & 100.0 & 67.9 & 163 & 43 & 4.8 & 13.0 & 3.4 \\
\hline Sagebrush) & & & Line-point & 53.8 & 22.8 & 20.3 & 25.5 & 98.7 & 48.4 & 72 & 20 & 3.9 & 4.7 & 1.3 \\
\hline & & & $10-m^{2}$ & 18.8 & 11.7 & 6.0 & 18.4 & 98.6 & 65.1 & 152 & 40 & 7.9 & 20.0 & 5.3 \\
\hline Semidesert Shallow & Shrubland & 7 & $1-m^{2}$ & 16.4 & 14.7 & 10.2 & 25.1 & 96.7 & 96.0 & 311 & 81 & 3.8 & 19.7 & 5.1 \\
\hline & & & Line-point & 13.3 & 13.2 & 7.0 & 23.6 & 66.7 & 102.3 & 380 & 98 & 2.5 & 15.8 & 4.1 \\
\hline & & & $10-m^{2}$ & 18.3 & 7.4 & 5.8 & 9.0 & 100.0 & 43.0 & 66 & 19 & 6.5 & 7.2 & 2.1 \\
\hline Shallow Loamy, 10- & Grassland & 2 & $1-m^{2}$ & 17.2 & 13.8 & 10.7 & 17.0 & 100.0 & 87.4 & 250 & 65 & 3.4 & 14.2 & 3.7 \\
\hline & & & Line-point & 27.3 & 12.8 & 9.6 & 16.0 & 90.0 & 54.9 & 88 & 24 & 3 & 4.4 & 1.2 \\
\hline Upland Shallow & & & $10-m^{2}$ & 16.5 & 19.7 & 11.3 & 29.3 & 96.0 & 117.4 & 546 & 139 & 5.3 & 48.2 & 12.3 \\
\hline Loam (Pinyon-Utah & Woodland & 5 & $1-m^{2}$ & 15.4 & 24.5 & 18.9 & 30.8 & 88.7 & 176.4 & 976 & 244 & 2.8 & 45.5 & 11.4 \\
\hline Juniper) & & & Line-point & 11.7 & 13.3 & 9.2 & 15.4 & 56.0 & 126.3 & 491 & 126 & 2.3 & 18.8 & 4.8 \\
\hline
\end{tabular}

* frequency for line-point sampling was calculated on the basis of 10-point groups 


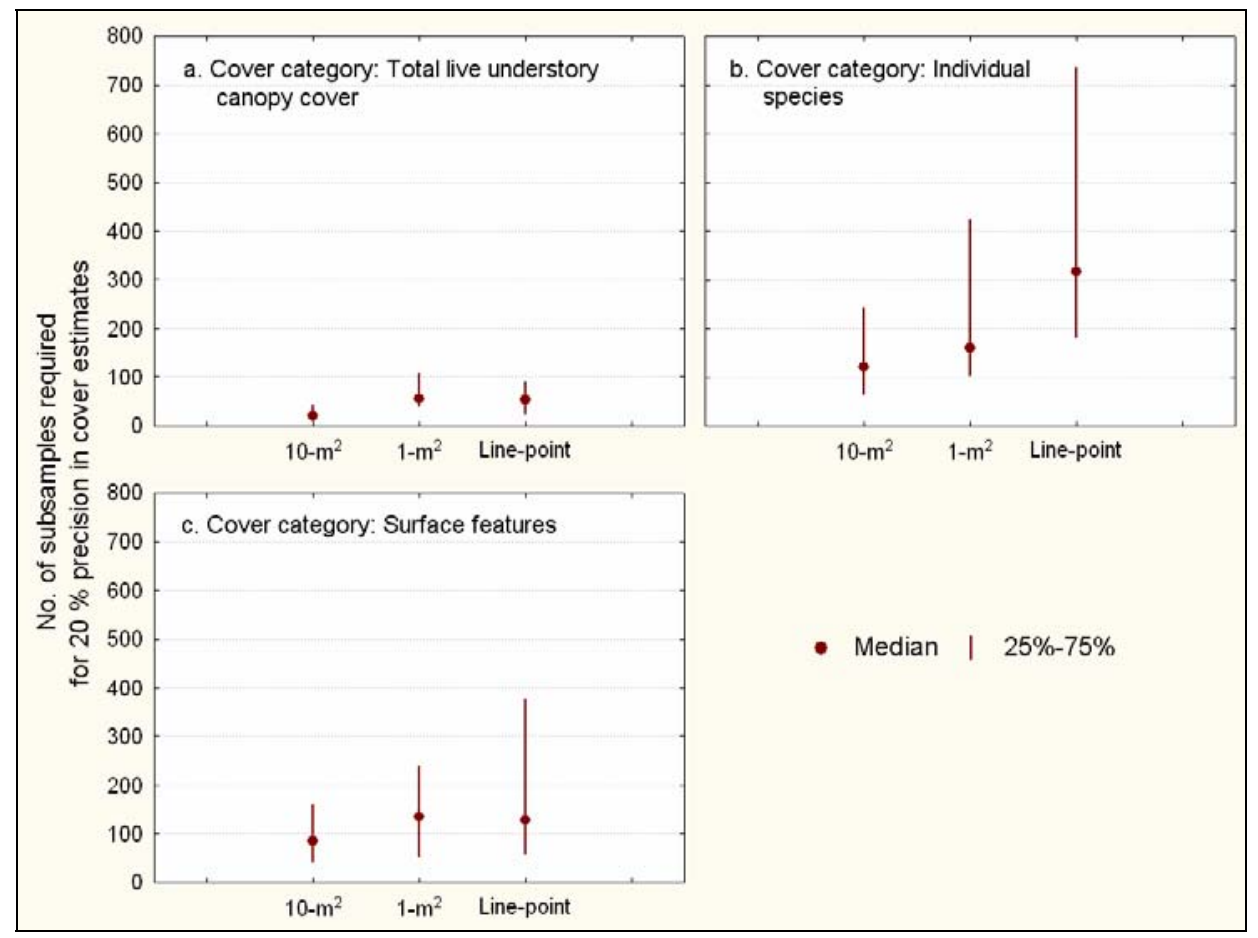

Figure 8. Median numbers ( \pm 25 percentiles) of subsamples required for 20 percent precision in macroplot-level estimates of (a) total live understory canopy cover, (b) live cover of individual plant species, and (c) cover of surface features across 11 ecological sites sampled on the Colorado Plateau in Utah and Arizona. In (a), there is no difference among median values obtained via different sampling methods (Kruskal-Wallis $\mathrm{H}=5.89$, $d f=2, n=33, p=0.0525)$. In (b), median values from 10- $\mathrm{m}^{2}$ quadrats and line-point intercepts are significantly different from one another (Kruskal-Wallis $\mathrm{H}=15.41, \mathrm{df}=2, \mathrm{n}=94, \mathrm{p}=0.0004$ ). In (c), there is no significant difference among medians from different methods (Kruskal-Wallis $\mathrm{H}=3.08, \mathrm{df}=2, \mathrm{n}=98, \mathrm{p}=$ $0.2139)$.

Per-unit sampling times from tables 15 and 16 and subsample sizes from table 19 were used to estimate total amounts of subsampling time required for the three methods to estimate mean total live understory canopy cover with 10 and 20 percent precision (table 19, fig. 9). (Amounts of time required for transect layout and density sampling were not included in this analysis.) Total subsample times were lowest for line-point intercept transects at eight of the 11 ecological sites - including all sites with shrubland and woodland physiognomic structure, two of four sites with grassland structure, and one of two sites with forest structure. Subsample times also were lowest for line-point intercepts at four of five sites where points were used to estimate cover of overstory vegetation taller than $2 \mathrm{~m}$ in addition to cover of understory vegetation and surface features. Total subsample times were highest for $10-\mathrm{m}^{2}$ quadrats at four ecological sites, for $1-\mathrm{m}^{2}$ quadrats at five ecological sites, and for line-point intercept transects at three ecological sites. Across all ecological sites, the mean subsample time for 20 percent precision was lowest and individual times were least variable for line-point intercept transects (mean $=3.3 \mathrm{hrs}, \mathrm{CV}=$ 50.9 ) relative to $10-\mathrm{m}^{2}$ quadrats (mean $=4.6 \mathrm{hrs}, \mathrm{CV}=76.1$ ) and $1-\mathrm{m}^{2}$ quadrats (mean $=4.8 \mathrm{hrs}$, $\mathrm{CV}=63.0$ ). This result was strongly influenced by high subsample times for $10-\mathrm{m}^{2}$ and $1-\mathrm{m}^{2}$ quadrats at the Loamy Hills and Upland Shallow Loam ecological sites at Grand Canyon and 

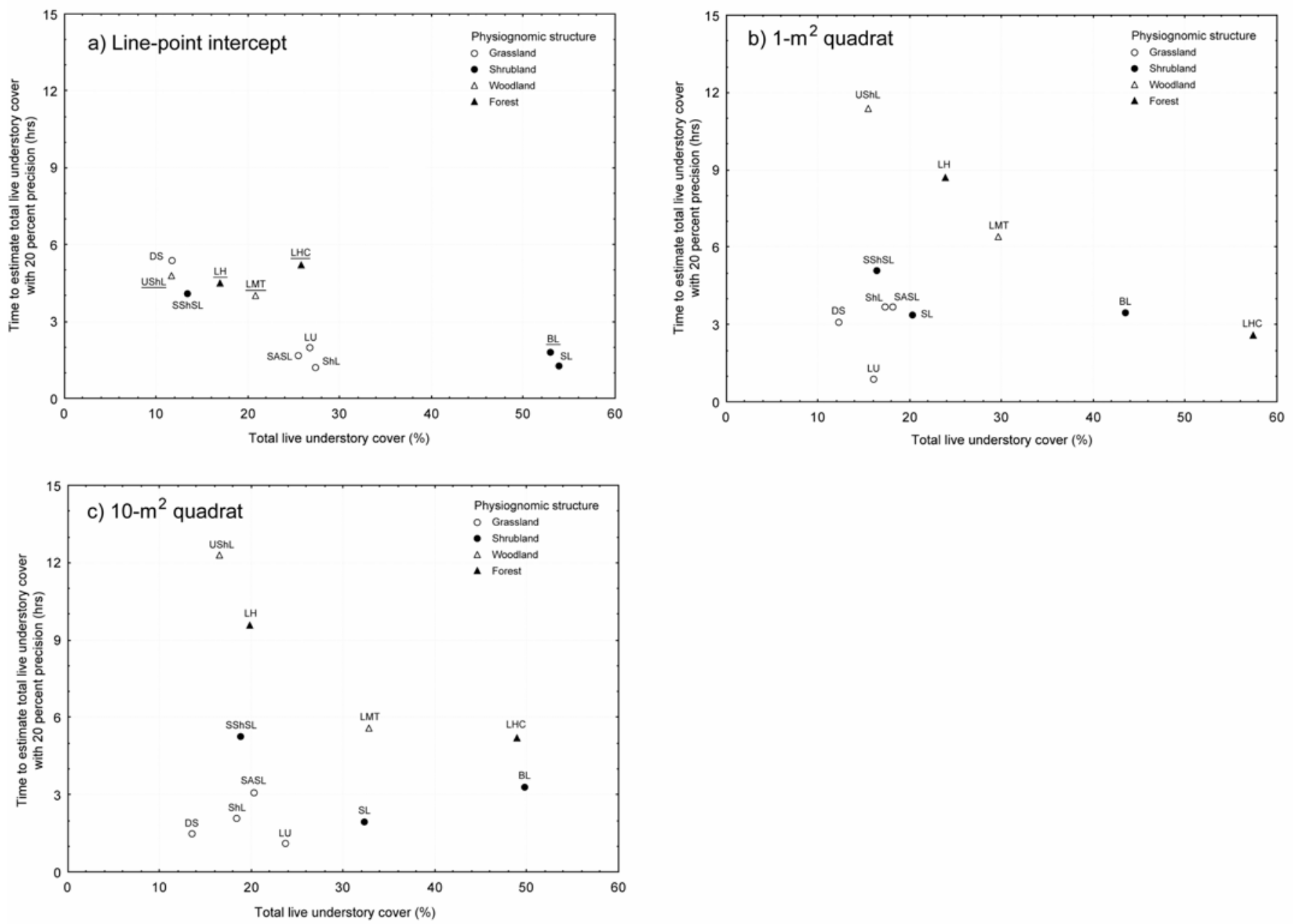

Figure 9. Time required to estimate total live understory cover using (a) the line-point intercept technique, (b) 1- $\mathrm{m}^{2}$ quadrats, and (c) 10$\mathrm{m}^{2}$ quadrats in relation to cover estimates derived from the same sampling techniques. Points are labeled by ecological site codes (see table 1 for key to codes) and symbolized to indicate the general physiognomic structure of the sampled plant community. Ecological sites underlined in (a) are those where line-point intercepts were used to estimate cover of overstory vegetation above 2-m in height, in addition to understory vegetation and soil-surface features. 
Capitol Reef, respectively. Statistical analyses on the basis of median values indicate no significant differences among methods for median amounts of time required to estimate total live understory canopy cover (fig. 10a), cover of individual species (fig. 10b), or cover of surface features (fig. 10c) with 20 percent precision. For total live understory canopy cover, median sampling times for 20 percent precision were $3.3,3.7$, and 4.0 hours for $10-\mathrm{m}^{2}$ quadrats, $1-\mathrm{m}^{2}$ quadrats, and line-intercept transects, respectively. (Appendix C presents 48 tables summarizing actual within-macroplot variability by macroplot, but without sample size estimates.)

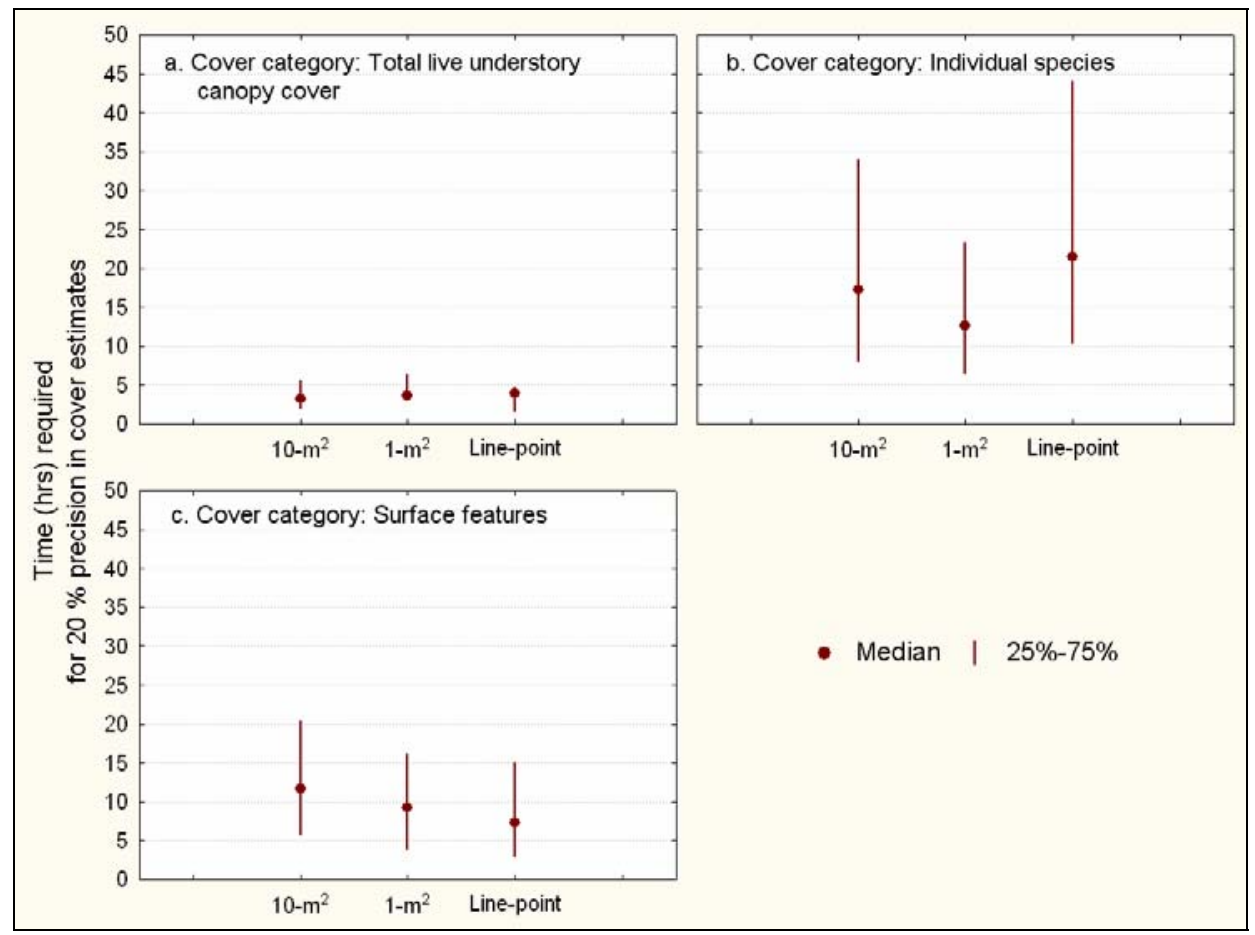

Figure 10. Median numbers of hours ( \pm 25 percentiles) required for subsampling to achieve 20 percent precision in macroplot-level estimates of (a) total live understory canopy cover, (b) live cover of individual plant species, and (c) cover of surface features across 11 ecological sites sampled on the Colorado Plateau in Utah and Arizona. For each cover category, there is no significant difference among median sampling times for different sampling methods (a. KruskalWallis $H=0.95, d f=2, n=33, p=0.6216$; b. Kruskal-Wallis $H=4.51$, $d f=2, n=94, p=0.1045$; . Kruskal-Wallis $\mathrm{H}=1.68, \mathrm{df}=2, \mathrm{n}=98, \mathrm{p}=0.4327$ ).

\section{Among-Macroplot Variability}

Numbers of macroplots sampled per ecological site during the 2005 field season were small, ranging from two to five. Despite these small sample sizes, here we present preliminary summaries and analyses of among-macroplot variability in cover measures. Across all ecological sites, mean among-plot variation (measured on basis of log-transformed CV values) was least for total live understory canopy cover and greatest for cover of individual species (table 20, fig. 11). Although sampling method did not have a statistically significant effect on amongplot variability in cover measures (table 20), among-plot CV values for total live understory canopy cover were lowest for line-point intercept transects at seven of 11 ecological sites and highest for $10-\mathrm{m}^{2}$ quadrats at six of 11 sites (table 21 ). This same pattern was evident for 
numbers of macroplot samples required for different sampling methods to estimate site-level total live understory canopy cover with 10 and 20 percent precision (table 21). Across all ecological sites, the mean number of macroplots for 20 percent precision was lowest for linepoint intercept transects $($ mean $=15.6, \mathrm{CV}=91.4)$ relative to $10-\mathrm{m}^{2}$ quadrats $($ mean $=17.5, \mathrm{CV}=$ 63.5 ) and $1-\mathrm{m}^{2}$ quadrats (mean $\left.=20.9, \mathrm{CV}=95.1\right)$. This result was highly influenced by high numbers of macroplots for $10-\mathrm{m}^{2}$ and $1-\mathrm{m}^{2}$ quadrats at the Loamy Hills ecological site at Grand Canyon. Statistical analyses on the basis of median values indicate no significant differences among methods for the median number of macroplot samples required to estimate total live understory canopy cover with 20 percent precision (fig. 12). Median numbers of macroplots for 20 percent precision in ecological-site-level estimates of total live understory canopy cover were 13,16 , and 17 for $10-\mathrm{m}^{2}$ quadrats, $1-\mathrm{m}^{2}$ quadrats, and line-intercept transects, respectively. (See Appendix D for tables summarizing among-plot variability for a broader range of cover measures on an ecological site basis, but without sample-size estimates.)

Table 20. Analysis of variance for effects of cover category (total live understory canopy, individual species, and surface features) and sampling method on log-transformed CV values describing among-macroplot variability in cover estimates.

\begin{tabular}{lccccc}
\hline Effect & $\mathrm{SS}$ & $\mathrm{df}$ & $\mathrm{MS}$ & $\mathrm{F}$ & $\mathrm{p}$ \\
\hline Cover category & 27.618 & 2 & 13.809 & 22.163 & $<0.0001$ \\
Method & 0.009 & 2 & 0.005 & 0.007 & 0.993 \\
Category ${ }^{\star}$ Method & 2.743 & 4 & 0.686 & 1.101 & 0.357 \\
Error & 134.581 & 216 & 0.623 & & \\
\hline
\end{tabular}

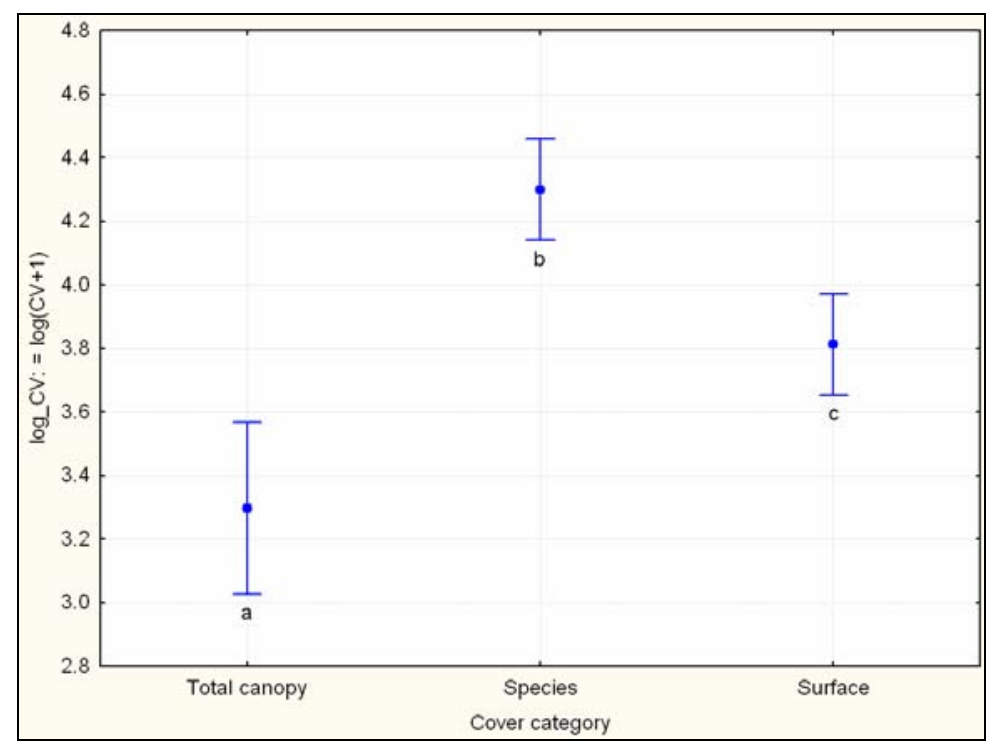

Figure 11. Main effects of cover category (total live understory canopy, individual species, and surface features) on log-transformed CV values describing among-macroplot variability in cover estimates across 11 ecological sites sampled on the Colorado Plateau in Utah and Arizona. Values with different letters are significantly different from one another (Tukey's HSD test, between $\mathrm{MS}=0.6231, \mathrm{df}=216, \mathrm{p}<0.01$ for all pair-wise comparisons). 
Table 21. Among-macroplot variation in estimates of total live understory canopy cover for 11 ecological sites (n macroplots per ecological site), macroplot sample sizes required to achieve 10 and 20 percent precision in estimates of site-level means, and ratios of within-to-among CV values.

\begin{tabular}{|c|c|c|c|c|c|c|c|c|c|c|c|c|}
\hline \multirow[b]{2}{*}{ Ecological site } & \multirow{2}{*}{$\begin{array}{l}\text { Physiog- } \\
\text { namic } \\
\text { structure }\end{array}$} & \multirow[b]{2}{*}{$\mathbf{n}$} & \multirow[b]{2}{*}{ Method } & \multirow{2}{*}{$\begin{array}{l}\text { Mean } \\
\text { cover }\end{array}$} & \multicolumn{5}{|c|}{ Among-macroplot variation in cover estimates } & \multicolumn{2}{|c|}{$\begin{array}{c}\text { Sample size } \\
\text { (by precision) }\end{array}$} & \multirow{2}{*}{$\begin{array}{c}\text { CV ratio } \\
\text { (within:among) }\end{array}$} \\
\hline & & & & & sd & Min & $\operatorname{Max}$ & Range & CV & $10 \%$ & $20 \%$ & \\
\hline \multirow{3}{*}{ Brushy Loam } & \multirow{3}{*}{ Shrubland } & \multirow{3}{*}{5} & $10-m^{2}$ & 49.7 & 16.0 & 28.4 & 71.2 & 42.8 & 32.2 & 42 & 13 & 1.1 \\
\hline & & & $1-m^{2}$ & 43.4 & 13.7 & 25.8 & 62.6 & 36.8 & 31.6 & 42 & 13 & 1.9 \\
\hline & & & Line-point & 52.8 & 3.3 & 48.7 & 56.0 & 7.3 & 6.2 & 4 & 3 & 7.3 \\
\hline \multirow{3}{*}{$\begin{array}{l}\text { Desert Sand (Sand } \\
\text { Sagebrush) }\end{array}$} & \multirow{3}{*}{ Grassland } & \multirow{3}{*}{2} & $10-m^{2}$ & 13.4 & 0.4 & 13.1 & 13.7 & 0.6 & 3.3 & 3 & 3 & 8.5 \\
\hline & & & $1-m^{2}$ & 12.3 & 0.3 & 12.1 & 12.5 & 0.4 & 2.3 & 3 & 3 & 27.0 \\
\hline & & & Line-point & 11.7 & 0.0 & 11.7 & 11.7 & 0.0 & 0.0 & 2 & 2 & - \\
\hline \multirow{3}{*}{ Limy Upland, 6-10" pz } & \multirow{3}{*}{ Grassland } & \multirow{3}{*}{5} & $10-m^{2}$ & 23.6 & 6.7 & 18.0 & 34.4 & 16.4 & 28.3 & 34 & 11 & 0.9 \\
\hline & & & $1-m^{2}$ & 16.0 & 3.5 & 11.7 & 20.1 & 8.4 & 21.6 & 21 & 7 & 1.5 \\
\hline & & & Line-point & 26.7 & 4.4 & 21.3 & 31.3 & 10.0 & 16.5 & 13 & 6 & 3.6 \\
\hline \multirow{3}{*}{ Loamy Hills, 25-33" pz } & \multirow{3}{*}{ Forest } & \multirow{3}{*}{5} & $10-m^{2}$ & 19.7 & 11.6 & 5.6 & 35.2 & 29.5 & 58.9 & 136 & 36 & 1.3 \\
\hline & & & $1-m^{2}$ & 23.8 & 20.9 & 5.1 & 57.5 & 52.4 & 87.8 & 297 & 77 & 1.4 \\
\hline & & & Line-point & 16.9 & 7.1 & 8.0 & 24.3 & 16.3 & 42.2 & 71 & 20 & 2.1 \\
\hline \multirow{3}{*}{$\begin{array}{l}\text { Loamy Hills, Cold, 25-33" } \\
\text { pz }\end{array}$} & \multirow{3}{*}{ Forest } & \multirow{3}{*}{2} & $10-m^{2}$ & 48.8 & 7.4 & 43.6 & 54.0 & 10.5 & 15.2 & 12 & 5 & 4.3 \\
\hline & & & $1-m^{2}$ & 57.3 & 28.2 & 37.4 & 77.3 & 39.9 & 49.2 & 96 & 26 & 1.6 \\
\hline & & & Line-point & 25.7 & 2.8 & 23.7 & 27.7 & 4.0 & 11.0 & 8 & 4 & 6.8 \\
\hline \multirow{3}{*}{ Loamy Mesa Top PJ } & \multirow{3}{*}{ Woodland } & & $10-m^{2}$ & 32.7 & 15.2 & 20.9 & 55.7 & 34.8 & 46.5 & 86 & 24 & 3.4 \\
\hline & & 5 & $1-m^{2}$ & 29.6 & 12.7 & 13.2 & 43.7 & 30.5 & 42.7 & 73 & 21 & 4.7 \\
\hline & & & Line-point & 20.7 & 3.5 & 17.3 & 26.7 & 9.3 & 17.0 & 14 & 6 & 7.8 \\
\hline & & & $10-m^{2}$ & 20.3 & 10.3 & 7.3 & 35.5 & 28.2 & 50.9 & 102 & 28 & 0.9 \\
\hline Semidesert Alkali Sandy & Grassland & 5 & $1-m^{2}$ & 18.1 & 6.6 & 7.1 & 24.6 & 17.5 & 36.5 & 54 & 16 & 2.0 \\
\hline & & & Line-point & 25.4 & 10.1 & 11.3 & 37.3 & 26.0 & 40.0 & 64 & 18 & 1.8 \\
\hline Semidesert Loam & & & $10-m^{2}$ & 32.2 & 15.5 & 20.7 & 59.4 & 38.7 & 48.0 & 92 & 25 & 0.8 \\
\hline (Wyoming Big & Shrubland & 5 & $1-m^{2}$ & 20.2 & 9.4 & 14.0 & 36.6 & 22.6 & 46.6 & 86 & 24 & 1.5 \\
\hline Sagebrush) & & & Line-point & 53.8 & 24.9 & 34.0 & 96.3 & 62.3 & 46.3 & 85 & 24 & 1.0 \\
\hline & & & $10-m^{2}$ & 18.8 & 4.8 & 13.7 & 28.2 & 14.5 & 25.5 & 28 & 9 & 2.6 \\
\hline Semidesert Shallow & Shrubland & 7 & $1-m^{2}$ & 16.4 & 5.4 & 10.5 & 24.0 & 13.5 & 33.1 & 45 & 14 & 2.9 \\
\hline & & & Line-point & 13.3 & 5.7 & 6.7 & 21.7 & 15.0 & 42.7 & 73 & 21 & 2.4 \\
\hline & & & $10-m^{2}$ & 18.3 & 9.5 & 11.5 & 25.0 & 13.5 & 52.1 & 107 & 29 & 0.8 \\
\hline Shallow Loamy, 10-14" & Grassland & 2 & $1-m^{2}$ & 17.2 & 4.7 & 13.9 & 20.5 & 6.6 & 27.3 & 32 & 10 & 3.2 \\
\hline & & & Line-point & 27.3 & 19.3 & 13.7 & 41.0 & 27.3 & 70.7 & 195 & 51 & 0.8 \\
\hline & & & $10-m^{2}$ & 16.5 & 4.4 & 10.2 & 21.2 & 11.0 & 26.4 & 30 & 10 & 4.4 \\
\hline Upland Snallow Loam & Woodland & 5 & $1-m^{2}$ & 15.4 & 6.3 & 7.2 & 21.1 & 13.9 & 40.9 & 67 & 19 & 4.3 \\
\hline (PInyon-clan Jumper) & & & Line-point & 11.7 & 4.5 & 4.7 & 16.0 & 11.3 & 38.7 & 60 & 17 & 3.3 \\
\hline
\end{tabular}




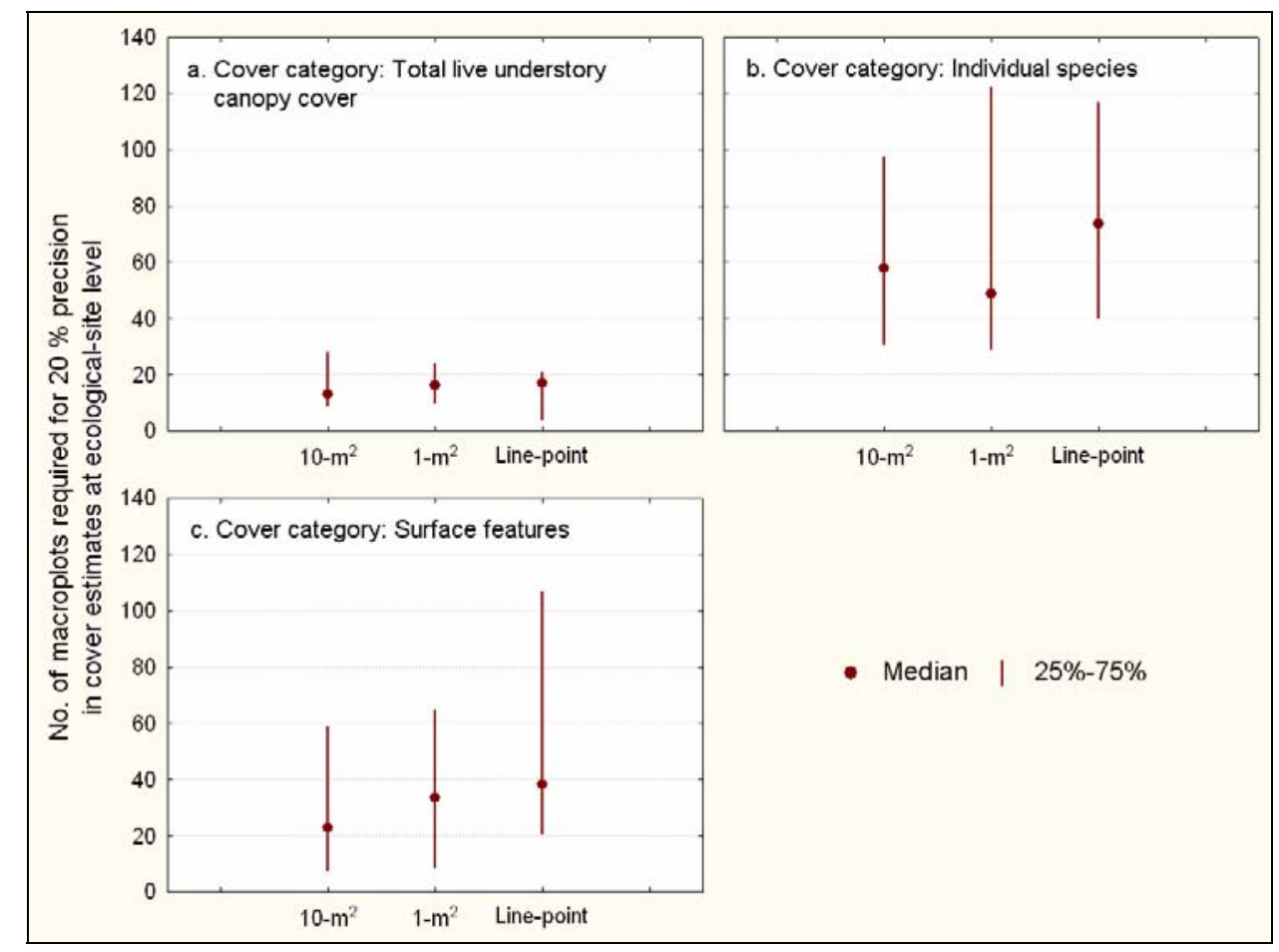

Figure 12. Median numbers ( \pm 25 percentiles) of macroplots required for 20 percent precision in ecological-site-level estimates of (a) total live understory canopy cover, (b) cover of individual plant species, and (c) cover of surface features across 11 ecological sites sampled on the Colorado Plateau in Utah and Arizona. For each cover category, there is no significant difference among median macroplot numbers for different sampling methods (a. Kruskal-Wallis $\mathrm{H}=0.95$, $\mathrm{df}=$ $2, \mathrm{n}=33, \mathrm{p}=0.6218$; $\mathrm{b}$. Kruskal-Wallis $\mathrm{H}=1.38, \mathrm{df}=2, \mathrm{n}=96, \mathrm{p}=0.5005$; . Kruskal-Wallis $\mathrm{H}=3.05$, $\mathrm{df}=2, \mathrm{n}=96, \mathrm{p}=0.2174)$.

Table 21 also summarizes ratios of within-plot CV values to among-plot CV values for total live understory canopy cover by sampling method and ecological site. Across all sites and methods, the average within:among ratio was 3.7:1, indicating greater within-plot variability than among plot variability. The within:among ratio was lowest for $10-\mathrm{m}^{2}$ quadrats at seven of 11 ecological sites and highest for line-point intercept transects at six of 11 ecological sites. Mean within:among $\mathrm{CV}$ ratios were $2.6,4.7$, and 3.7 for $10-\mathrm{m}^{2}$ quadrats, $1-\mathrm{m}^{2}$ quadrats, and lineintercept transects, respectively. There were no significant differences among methods in median within:among CV ratios for total live understory canopy cover (fig. 13a),cover of individual species (fig. 13b), and cover of surface features (fig. 13c). Median within:among CV ratios for total live understory cover were $1.2,2.0$, and 3.3 for $10-\mathrm{m}^{2}$ quadrats, $1-\mathrm{m}^{2}$ quadrats, and line-point intercept transects, respectively.

\section{Species-Area Relationships and Community Composition}

This section summarizes differences between $10-\mathrm{m}^{2}$ and $1-\mathrm{m}^{2}$ quadrats in terms of species-area relationships and community composition. Point-based data are not included in these comparisons because of the superiority of quadrat-based sampling for objectives related to detection of infrequent species. As expected on the basis of sampling area, more unique species were detected in $10-\mathrm{m}^{2}$ quadrats than in $1-\mathrm{m}^{2}$ quadrats at all macroplots (table 22). Ecological 
site and quadrat size both had significant effects on log-transformed species richness in macroplots where subsample sizes were 15 for both sizes of quadrat (table 23, fig. 14a). At these macroplots, ratios of numbers of species detected in $10-\mathrm{m}^{2}$ quadrats to numbers detected in $1-\mathrm{m}^{2}$ quadrats ranged from a low of 1.3 at Brushy Loam, Semidesert Alkali Sandy Loam, and Semidesert Loam ecological sites, to a high of 1.8 at Loamy Hills and Semidesert Shallow Sandy Loam ecological sites (table 22). When infrequent species occurring in only one $10-\mathrm{m}^{2}$ quadrat were excluded from the $10-\mathrm{m}^{2}$ quadrat data, quadrat size no longer had a statistically significant effect on log-transformed species richness (table 24, fig. 14b). This indicates that the advantage of $10-\mathrm{m}^{2}$ quadrats relative to $1-\mathrm{m}^{2}$ quadrats was largely attributable to the ability of the larger quadrats to detect species with a $10-\mathrm{m}^{2}$ frequency of 6.7 percent. However, excluding infrequent species occurring in only one $10-\mathrm{m}^{2}$ quadrat, ratios of species detected in $10-\mathrm{m}^{2}$ quadrats to those detected in $1-\mathrm{m}^{2}$ quadrats were still greater than one at most ecological sites. See Appendix E for a set of figures showing mean species-area and compositional curves (mean Sørensen distances) by ecological site, including separate figures for curves including all species and for curves excluding infrequent species with only one quadrat occurrence.

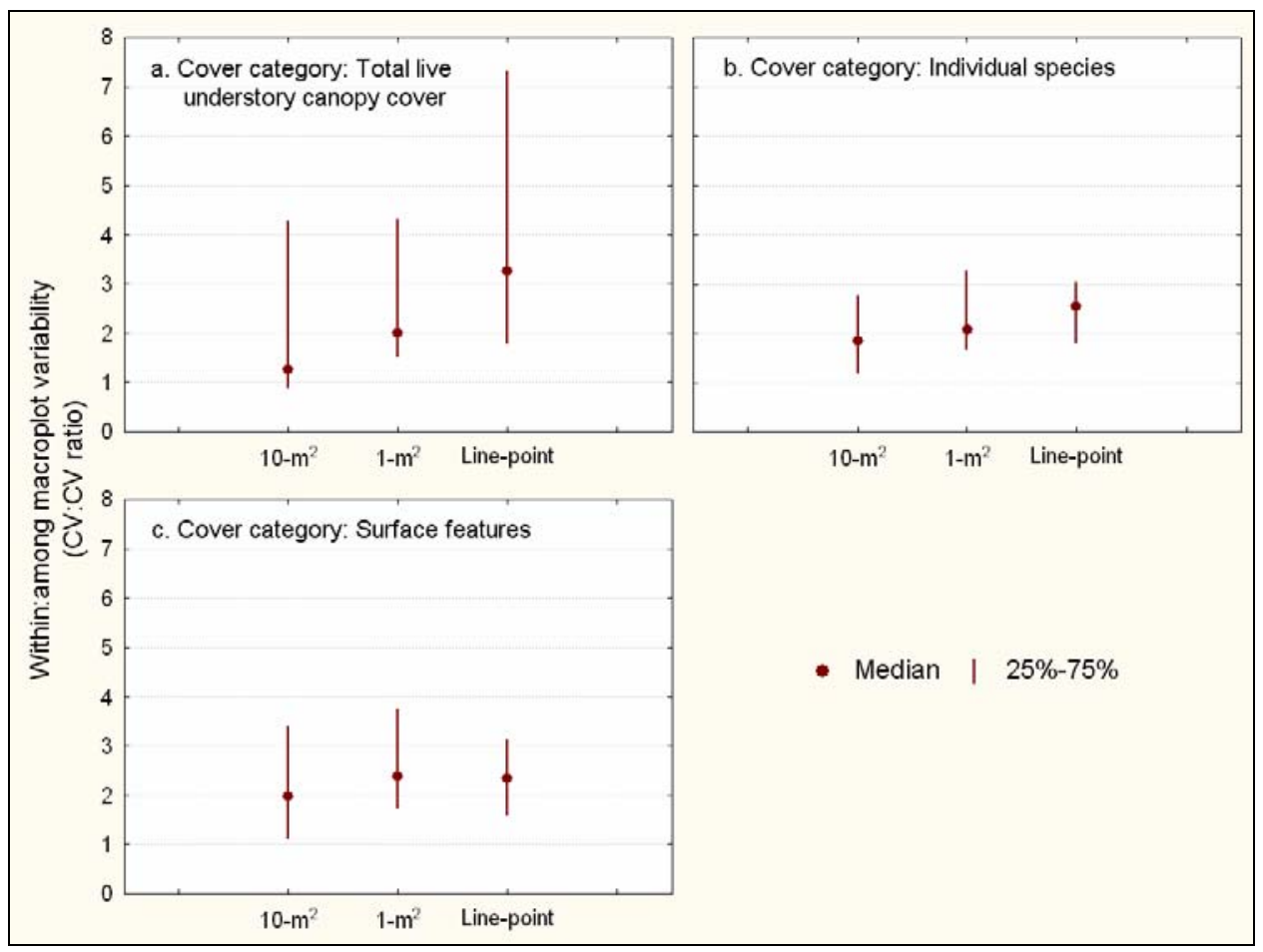

Figure 13. Median ratios of within-to-among macroplot variability (based on log-transformed CV values) for estimates of (a) total live understory canopy cover, (b) live cover of individual plant species, and (c) cover of surface features across 11 ecological sites sampled on the Colorado Plateau in Utah and Arizona. For each cover category, there is no significant difference among median ratios for different sampling methods (a. Kruskal-Wallis $H=2.39$, $d f=2, n=33, p=0.3033$; b. Kruskal-Wallis $H=4.33$, $d f=2, n=96, p=0.1147$; c. Kruskal-Wallis $H=3.05, d f=2, n=96, p=$ 0.3941). 
Table 22. Species richness data for several ecological sites on the Colorado Plateau, based on 10- $\mathrm{m}^{2}$ and $1-\mathrm{m}^{2}$ quadrats. For each size quadrat, columns show observed numbers of unique vascular plant species, jacknife estimates of total species per macroplot, numbers of infrequent species found in only one quadrat, and remaining numbers of species after excluding those infrequent species with only 1 quadrat occurrence. Last three columns show ratios of $10-\mathrm{m}^{2}$ values to $1-\mathrm{m}^{2}$ values, using all observed species (Obs.), and excluding infrequent species (Excl.). Means, coefficients of variation (CV), and ratios are based on macroplots with $1510-\mathrm{m}^{2}$ and $1-\mathrm{m}^{2}$ quadrats.

\begin{tabular}{|c|c|c|c|c|c|c|c|c|c|c|c|c|c|c|}
\hline \multirow[b]{2}{*}{$\begin{array}{l}\text { Ecological } \\
\text { site }\end{array}$} & \multirow[b]{2}{*}{ Macroplot } & \multicolumn{5}{|c|}{ 10-m² quadrats } & \multicolumn{5}{|c|}{ 1-m² quadrats } & \multicolumn{3}{|c|}{$10-m^{2}: 1-m^{2}$ ratio } \\
\hline & & $\begin{array}{l}\text { No. } \\
\text { quads }\end{array}$ & $\begin{array}{l}\text { Obs. } \\
\text { no. } \\
\text { spp. } \\
\text { (a) }\end{array}$ & $\begin{array}{c}\text { Jacknife } \\
\text { estimate } \\
\text { of total } \\
\text { spp. }\end{array}$ & $\begin{array}{l}\text { Infreq. } \\
\text { spp. } \\
\text { in } \\
\text { only } 1 \\
\text { quad }\end{array}$ & $\begin{array}{l}\text { No. spp. } \\
\text { excluding } \\
\text { infrequent } \\
\text { (b) }\end{array}$ & $\begin{array}{c}\text { No. } \\
\text { quads }\end{array}$ & $\begin{array}{l}\text { Obs. } \\
\text { no. } \\
\text { spp. } \\
\text { (c) }\end{array}$ & $\begin{array}{c}\text { Jacknife } \\
\text { estimate } \\
\text { of total } \\
\text { spp. }\end{array}$ & $\begin{array}{l}\text { Infreq. } \\
\text { spp. } \\
\text { in } \\
\text { only } 1 \\
\text { quad }\end{array}$ & $\begin{array}{l}\text { No. spp. } \\
\text { excluding } \\
\text { infrequent } \\
\text { (d) }\end{array}$ & $\begin{array}{l}\text { Obs.:Obs. } \\
\text { (a:c) }\end{array}$ & $\begin{array}{c}\text { Excl.:Obs. } \\
\text { (b:c) }\end{array}$ & $\begin{array}{c}\text { Excl.:Excl. } \\
\text { (b:d) }\end{array}$ \\
\hline \multirow{7}{*}{$\begin{array}{l}\text { Brushy } \\
\text { Loam }\end{array}$} & MEVE 1 & 21 & 28 & 33.7 & 6 & 22 & 30 & 21 & 28.7 & 8 & 13 & - & - & - \\
\hline & MEVE2 & 21 & 41 & 49.6 & 9 & 32 & 30 & 29 & 32.9 & 4 & 25 & - & - & - \\
\hline & MEVE5 & 15 & 42 & 51.3 & 10 & 32 & 15 & 29 & 37.4 & 9 & 20 & 1.4 & 1.1 & 1.6 \\
\hline & MEVE6 & 15 & 38 & 42.7 & 5 & 33 & 15 & 32 & 41.3 & 10 & 22 & 1.2 & 1.0 & 1.5 \\
\hline & MEVE7b & 15 & 31 & 35.7 & 5 & 26 & 15 & 24 & 28.7 & 5 & 19 & 1.3 & 1.1 & 1.4 \\
\hline & Mean & 15 & 37.0 & 43.2 & 6.7 & 30.3 & 15 & 28.3 & 35.8 & 8.0 & 20.3 & 1.3 & 1.1 & 1.5 \\
\hline & $\mathrm{CV}$ & - & 15.0 & 18.1 & 43.3 & 12.5 & - & 14.3 & 18.0 & 33.1 & 7.5 & 10.0 & 3.5 & 7.8 \\
\hline \multirow{2}{*}{$\begin{array}{l}\text { Desert } \\
\text { Sand }\end{array}$} & CANY1 & 21 & 23 & 24.9 & 2 & 21 & 30 & 22 & 26.8 & 5 & 17 & - & - & - \\
\hline & CANY2b & 21 & 25 & 30.7 & 4 & 21 & 30 & 22 & 23.9 & 2 & 20 & - & - & - \\
\hline \multirow{7}{*}{$\begin{array}{l}\text { Limy } \\
\text { Upland }\end{array}$} & WUPA1 & 21 & 22 & 25.8 & 4 & 18 & 30 & 19 & 22.9 & 4 & 15 & - & - & - \\
\hline & WUPA2 & 21 & 23 & 30.6 & 8 & 15 & 30 & 15 & 18.9 & 4 & 11 & - & - & - \\
\hline & WUPA5 & 15 & 16 & 19.7 & 4 & 12 & 15 & 9 & 10.9 & 2 & 7 & 1.8 & 1.3 & 1.7 \\
\hline & WUPA6 & 15 & 21 & 26.6 & 6 & 15 & 15 & 17 & 20.7 & 4 & 13 & 1.2 & 0.9 & 1.2 \\
\hline & WUPA7 & 15 & 18 & 24.5 & 7 & 11 & 15 & 11 & 15.7 & 5 & 6 & 1.6 & 1.0 & 1.8 \\
\hline & Mean & 15 & 18.3 & 23.6 & 5.7 & 12.7 & 15 & 12.3 & 15.8 & 3.7 & 8.7 & 1.5 & 1.1 & 1.6 \\
\hline & CV & - & 13.7 & 15.0 & 27.0 & 16.4 & - & 33.8 & 31.1 & 41.7 & 43.7 & 18.2 & 21.8 & 23.2 \\
\hline \multirow{7}{*}{$\begin{array}{l}\text { Loamy } \\
\text { Hills }\end{array}$} & GRCA3 & 21 & 14 & 15.9 & 2 & 12 & 30 & 12 & 14.9 & 3 & 9 & - & - & - \\
\hline & GRCA4 & 21 & 37 & 49.4 & 13 & 24 & 30 & 27 & 36.7 & 10 & 17 & - & - & - \\
\hline & GRCA5 & 15 & 26 & 37.2 & 12 & 14 & 15 & 14 & 18.7 & 5 & 9 & 1.9 & 1.0 & 1.6 \\
\hline & GRCA6 & 15 & 28 & 35.5 & 8 & 20 & 15 & 15 & 19.7 & 5 & 10 & 1.9 & 1.3 & 2.0 \\
\hline & GRCA7 & 15 & 16 & 17.9 & 2 & 14 & 15 & 10 & 13.7 & 4 & 6 & 1.6 & 1.4 & 2.3 \\
\hline & Mean & 15 & 23.3 & 30.2 & 7.3 & 16.0 & 15 & 13.0 & 17.4 & 4.7 & 8.3 & 1.8 & 1.2 & 2.0 \\
\hline & $\mathrm{CV}$ & - & 27.6 & 35.4 & 68.6 & 21.7 & - & 20.4 & 18.5 & 12.4 & 25.0 & 8.5 & 17.2 & 19.9 \\
\hline \multirow{2}{*}{$\begin{array}{l}\text { Loamy } \\
\text { Hills Cold }\end{array}$} & GRCA1 & 21 & 21 & 24.8 & 4 & 17 & 30 & 18 & 19.9 & 2 & 16 & - & - & - \\
\hline & GRCA2 & 21 & 30 & 36.7 & 7 & 23 & 30 & 22 & 28.8 & 7 & 15 & - & - & - \\
\hline \multirow{7}{*}{$\begin{array}{l}\text { Loamy } \\
\text { Mesa Top } \\
\text { PJ }\end{array}$} & MEVE3 & 21 & 21 & 27.7 & 7 & 14 & 30 & 18 & 26.7 & 9 & 9 & - & - & - \\
\hline & MEVE4 & 21 & 29 & 34.7 & 6 & 23 & 30 & 21 & 28.7 & 8 & 13 & - & - & - \\
\hline & MEVE8 & 15 & 16 & 17.9 & 2 & 14 & 15 & 11 & 16.6 & 6 & 5 & 1.5 & 1.3 & 2.8 \\
\hline & MEVE9 & 15 & 26 & 33.5 & 8 & 18 & 15 & 14 & 18.7 & 5 & 9 & 1.9 & 1.3 & 2.0 \\
\hline & MEVE10 & 15 & 33 & 41.4 & 9 & 24 & 15 & 25 & 34.3 & 10 & 15 & 1.3 & 1.0 & 1.6 \\
\hline & Mean & 15 & 25.0 & 30.9 & 6.3 & 18.7 & 15 & 16.7 & 23.2 & 7.0 & 9.7 & 1.5 & 1.2 & 2.1 \\
\hline & $\mathrm{CV}$ & - & 34.2 & 38.7 & 59.8 & 27.0 & - & 44.2 & 41.7 & 37.8 & 52.1 & 18.1 & 15.7 & 28.6 \\
\hline
\end{tabular}


Table 22.-Continued

\begin{tabular}{|c|c|c|c|c|c|c|c|c|c|c|c|c|c|c|}
\hline \multirow[b]{2}{*}{$\begin{array}{l}\text { Ecological } \\
\text { site }\end{array}$} & \multirow[b]{2}{*}{ Macroplot } & \multicolumn{5}{|c|}{ 10- $\mathrm{m}^{2}$ quadrats } & \multicolumn{5}{|c|}{ 1-m² quadrats } & \multicolumn{3}{|c|}{$10-m^{2}: 1-m^{2}$ ratio } \\
\hline & & $\begin{array}{c}\text { No. } \\
\text { quads }\end{array}$ & $\begin{array}{l}\text { Obs. } \\
\text { no. } \\
\text { spp. } \\
\text { (a) }\end{array}$ & $\begin{array}{c}\text { Jacknife } \\
\text { estimate } \\
\text { of total } \\
\text { spp. }\end{array}$ & $\begin{array}{l}\text { Infreq. } \\
\text { spp. } \\
\text { in } \\
\text { only } 1 \\
\text { quad }\end{array}$ & $\begin{array}{l}\text { No. spp. } \\
\text { excluding } \\
\text { infrequent } \\
\text { (b) }\end{array}$ & $\begin{array}{l}\text { No. } \\
\text { quads }\end{array}$ & $\begin{array}{l}\text { Obs. } \\
\text { no. } \\
\text { spp. } \\
\text { (c) }\end{array}$ & $\begin{array}{c}\text { Jacknife } \\
\text { estimate } \\
\text { of total } \\
\text { spp. }\end{array}$ & $\begin{array}{l}\text { Infreq. } \\
\text { spp. } \\
\text { in } \\
\text { only } 1 \\
\text { quad }\end{array}$ & $\begin{array}{l}\text { No. spp. } \\
\text { excluding } \\
\text { infrequent } \\
\text { (d) }\end{array}$ & $\begin{array}{l}\text { Obs.:Obs. } \\
\text { (a:c) }\end{array}$ & $\begin{array}{c}\text { Excl.:Obs. } \\
\text { (b:c) }\end{array}$ & $\begin{array}{c}\text { Excl.:Excl. } \\
\text { (b:d) }\end{array}$ \\
\hline \multirow{7}{*}{$\begin{array}{l}\text { Semidesert } \\
\text { Alkali } \\
\text { Sandy } \\
\text { Loam }\end{array}$} & CARE1 & 21 & 42 & 46.8 & 5 & 37 & 30 & 36 & 37.9 & 2 & 34 & - & - & - \\
\hline & CARE2 & 21 & 38 & 43.7 & 6 & 32 & 30 & 27 & 29.9 & 3 & 24 & - & - & - \\
\hline & CARE5 & 15 & 43 & 49.5 & 7 & 36 & 15 & 33 & 41.4 & 9 & 24 & 1.3 & 1.1 & 1.5 \\
\hline & CARE6 & 15 & 28 & 35.5 & 8 & 20 & 15 & 23 & 35.1 & 13 & 10 & 1.2 & 0.9 & 2.0 \\
\hline & CARE7 & 15 & 38 & 45.5 & 8 & 30 & 15 & 28 & 34.5 & 7 & 21 & 1.4 & 1.1 & 1.4 \\
\hline & Mean & 15 & 36.3 & 43.5 & 7.7 & 28.7 & 15 & 28.0 & 37.0 & 9.7 & 18.3 & 1.3 & 1.0 & 1.6 \\
\hline & $\mathrm{CV}$ & - & 21.0 & 16.6 & 7.5 & 28.2 & - & 17.9 & 10.3 & 31.6 & 40.2 & 5.5 & 12.1 & 19.0 \\
\hline \multirow{7}{*}{$\begin{array}{l}\text { Semidesert } \\
\text { Loam }\end{array}$} & DINO1 & 21 & 29 & 37.6 & 9 & 20 & 30 & 25 & 32.7 & 8 & 17 & - & - & - \\
\hline & DINO2b & 21 & 14 & 15 & 1 & 13 & 30 & 15 & 19.8 & 5 & 10 & - & - & - \\
\hline & DINO3 & 15 & 28 & 33.6 & 6 & 22 & 15 & 22 & 29.5 & 8 & 14 & 1.3 & 1.0 & 1.6 \\
\hline & DINO4b & 15 & 21 & 23.8 & 3 & 18 & 15 & 18 & 24.5 & 7 & 11 & 1.2 & 1.0 & 1.6 \\
\hline & DINO5 & 15 & 20 & 23.7 & 4 & 16 & 15 & 14 & 14.9 & 1 & 13 & 1.4 & 1.1 & 1.2 \\
\hline & Mean & 15 & 23.0 & 27.0 & 4.3 & 18.7 & 15 & 18.0 & 23.0 & 5.3 & 12.7 & 1.3 & 1.0 & 1.5 \\
\hline & $\mathrm{CV}$ & - & 19.0 & 21.0 & 35.3 & 16.4 & - & 22.2 & 32.3 & 71.0 & 12.1 & 10.2 & 7.9 & 14.7 \\
\hline \multirow{9}{*}{$\begin{array}{l}\text { Semidesert } \\
\text { Shallow } \\
\text { Sandy } \\
\text { Loam }\end{array}$} & $\mathrm{ARCH} 1 \mathrm{~b}$ & 21 & 24 & 28.8 & 5 & 19 & 30 & 19 & 25.8 & 7 & 12 & - & - & - \\
\hline & ARCH2 & 21 & 17 & 24.6 & 8 & 9 & 30 & 12 & 15.9 & 4 & 8 & - & - & - \\
\hline & CANY3 & 21 & 36 & 46.5 & 11 & 25 & 30 & 28 & 35.7 & 8 & 20 & - & - & - \\
\hline & CANY4 & 21 & 29 & 31.9 & 3 & 26 & 30 & 27 & 35.7 & 9 & 18 & - & - & - \\
\hline & $\mathrm{ARCH} 3$ & 15 & 22 & 31.3 & 10 & 12 & 15 & 8 & 9.9 & 2 & 6 & 2.8 & 1.5 & 2.0 \\
\hline & $\mathrm{ARCH} 4 \mathrm{~b}$ & 15 & 21 & 25.7 & 5 & 16 & 15 & 14 & 19.6 & 6 & 8 & 1.5 & 1.1 & 2.0 \\
\hline & ARCH5 & 15 & 15 & 16.9 & 2 & 13 & 15 & 13 & 14.9 & 2 & 11 & 1.2 & 1.0 & 1.2 \\
\hline & Mean & 15 & 19.3 & 24.6 & 5.7 & 13.7 & 15 & 11.7 & 14.8 & 3.3 & 8.3 & 1.8 & 1.2 & 1.7 \\
\hline & $\mathrm{CV}$ & - & 19.6 & 29.5 & 71.3 & 15.2 & - & 27.6 & 32.8 & 69.3 & 30.2 & 46.6 & 21.2 & 27.3 \\
\hline \multirow{2}{*}{$\begin{array}{l}\text { Shallow } \\
\text { Loamy }\end{array}$} & WUPA3 & 21 & 24 & 31.6 & 8 & 16 & 30 & 15 & 16.9 & 2 & 13 & - & - & - \\
\hline & WUPA4 & 21 & 21 & 25.8 & 5 & 16 & 30 & 16 & 21.8 & 6 & 10 & - & - & - \\
\hline \multirow{7}{*}{$\begin{array}{l}\text { Upland } \\
\text { Shallow } \\
\text { Loam }\end{array}$} & CARE3 & 21 & 34 & 49.2 & 16 & 18 & 30 & 23 & 32.7 & 10 & 13 & - & - & - \\
\hline & CARE4b & 21 & 15 & 17.9 & 3 & 12 & 30 & 14 & 21.7 & 8 & 6 & - & - & - \\
\hline & CARE8 & 15 & 20 & 23.7 & 4 & 16 & 15 & 17 & 23.5 & 7 & 10 & 1.2 & 0.9 & 1.6 \\
\hline & CARE9 & 15 & 18 & 23.6 & 6 & 12 & 15 & 8 & 10.8 & 3 & 5 & 2.3 & 1.5 & 2.4 \\
\hline & CARE10 & 15 & 13 & 15.8 & 3 & 10 & 15 & 11 & 15.7 & 5 & 6 & 1.2 & 0.9 & 1.7 \\
\hline & Mean & 15 & 17.0 & 21.0 & 4.3 & 12.7 & 15 & 12.0 & 16.7 & 5.0 & 7.0 & 1.5 & 1.1 & 1.9 \\
\hline & $\mathrm{CV}$ & - & 21.2 & 21.5 & 35.3 & 24.1 & - & 38.2 & 38.4 & 40.0 & 37.8 & 40.2 & 29.8 & 23.5 \\
\hline
\end{tabular}


Table 23. Analysis of variance for effects of ecological site and quadrat size on log-transformed values for the number of unique species detected in $1510-\mathrm{m}^{2}$ and $1-\mathrm{m}^{2}$ quadrats during Phase 3 sampling.

\begin{tabular}{lccccc}
\hline Effect & SS & df & MS & F & $p$ \\
\hline Ecological site & 4.203 & 7 & 0.600 & 9.690 & $<0.0001$ \\
Quad size & 1.597 & 1 & 1.597 & 25.770 & $<0.0002$ \\
Ecological site*Quad size & 0.133 & 7 & 0.019 & 0.306 & 0.9459 \\
Error & 1.983 & 32 & 0.062 & & \\
\hline
\end{tabular}

Table 24. Analysis of variance for effects of ecological site and quadrat size on log-transformed values for the number of unique species detected in $1510-\mathrm{m}^{2}$ and $1-\mathrm{m}^{2}$ quadrats during Phase 3 sampling, excluding infrequent species that occurred in only one $10-\mathrm{m}^{2}$ quadrat from the $10-\mathrm{m}^{2}$ data.

\begin{tabular}{lccccc}
\hline Effect & $\mathrm{SS}$ & $\mathrm{df}$ & $\mathrm{MS}$ & $\mathrm{F}$ & $\mathrm{p}$ \\
\hline Ecological site & 4.837 & 7 & 0.691 & 12.300 & $<0.0001$ \\
Quad size & 0.102 & 1 & 0.102 & 1.809 & 0.1881 \\
Ecological site*Quad size & 0.046 & 7 & 0.007 & 0.117 & 0.9966 \\
Error & 1.798 & 32 & 0.056 & & \\
\hline
\end{tabular}

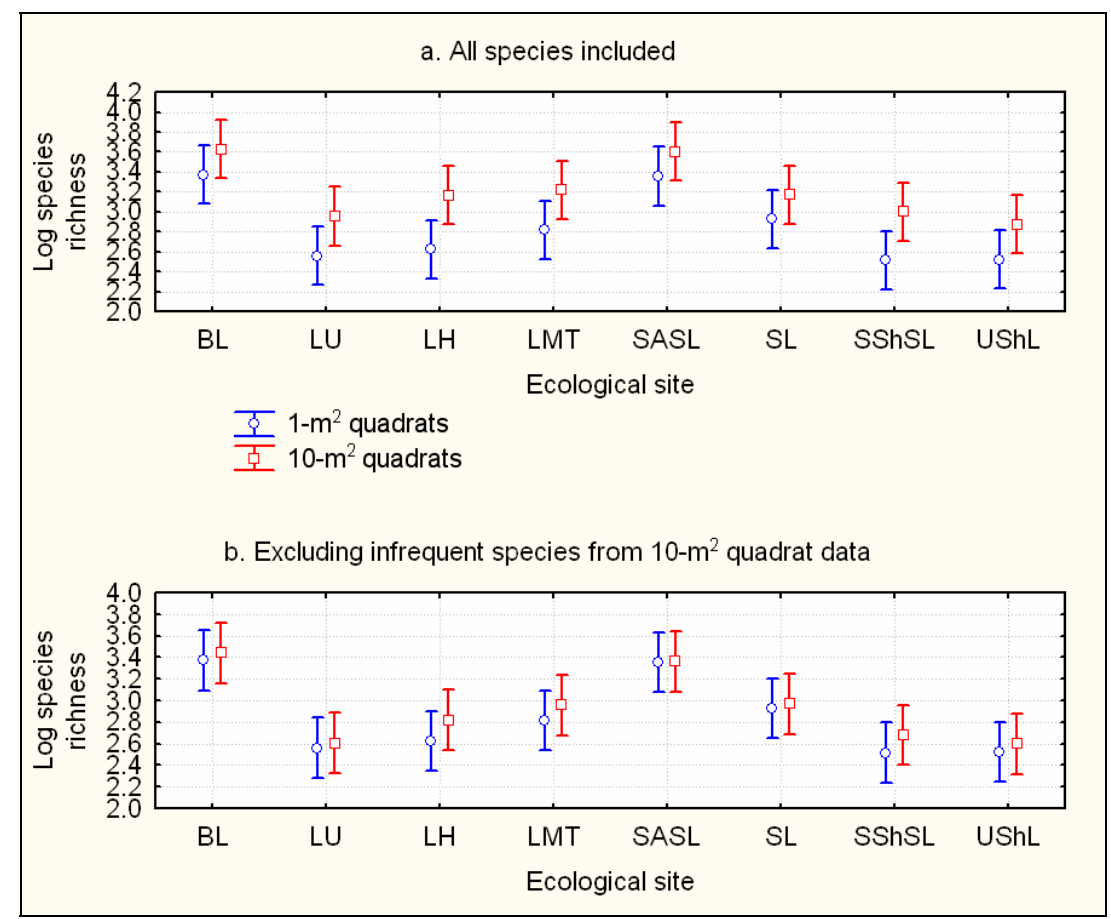

Figure 14. Log-transformed species richness data (mean numbers of unique species detected in 15 quadrats) in relation to ecological site and quadrat size (a) for all species detected, and (b) excluding infrequent species that occurred in only one $10-\mathrm{m}^{2}$ quadrat from the $10-\mathrm{m}^{2}$ data. (See table 1 for key to ecological site codes.) 


\section{Among-Method Trends in Cover Estimates}

This section summarizes relative trends in cover estimates provided by different sampling methods. To facilitate comparisons of trends across ecological sites with different amounts of vegetative cover, means were standardized by calculating the ratio of the observed mean value for a particular method and measure to the among-method mean cover value for the same measure (see tables in Appendix $\mathrm{C}$ for these data). Across all ecological sites, sampling method had a significant effect on standardized mean values for total live understory canopy cover (table 25). Post-hoc analyses indicated that mean cover values from $1-\mathrm{m}^{2}$ quadrats were lower than those provided by $10-\mathrm{m}^{2}$ quadrats and line-intercept transects, and that there was no difference between mean cover values provided by the latter two methods (fig. 15). Although ecological site did not have a significant effect on standardized mean cover values (an expected artifact of the standardization process), ecological site and sampling method did have a significant interaction effect (table 25, fig. 15). Line-point intercept transects tended to yield higher cover estimates than quadrats at ecological sites with significant amounts of grass cover (Limy Upland, Semidesert Alkali Sandy Loam, Semidesert Loam, and Shallow Loamy). Particularly noteworthy are high point-based cover estimates for cheatgrass (Bromus tectorum, or BRTE) at the Semidesert Loam ecological site in Dinosaur National Monument (SL in Figure 15; also see table B8 in Appendix B). At this site, cover estimates for cheatgrass were 30.1 percent for points, 11.9 percent for $10-\mathrm{m}^{2}$ quadrats, and 7.3 percent for $1-\mathrm{m}^{2}$ quadrats (table B8). After excluding Semidesert Loam data from the ANOVA, $10-\mathrm{m}^{2}$ quadrats were found to provide higher mean values for total live understory canopy cover than $1-\mathrm{m}^{2}$ quadrats and points across remaining ecological sites, and there was no statistical difference between mean cover values for the latter two methods.

Table 25. Analysis of variance for effects of ecological site and sampling method on total live understory cover (standardized means) at 11 Colorado Plateau ecological sites.

\begin{tabular}{lccccc}
\hline Effect & SS & df & MS & $F$ & $p$ \\
\hline Ecological site & 0.000 & 10 & 0.000 & 0.000 & 1.000 \\
Method & 0.248 & 2 & 0.124 & 3.475 & 0.034 \\
Ecological site*Method & 4.906 & 20 & 0.245 & 6.865 & $<0.0001$ \\
Error & 3.966 & 111 & 0.036 & & \\
\hline
\end{tabular}

Across all ecological sites, sampling method also had a significant effect on standardized mean cover of surface features (table 26) - with line-point intercepts yielding higher mean values than quadrats (fig. 17). This finding was driven by higher point-based values for bare soil (fig. $18 \mathrm{~b}$ ) that resulted from different methodological approaches between point- and quadrat-based sampling. If a pin were to hit an unembedded piece of litter sitting on the surface of bare (uncrusted) soil, bare soil would show up in the data as the surface feature and litter would appear as a canopy layer above the bare soil. In contrast, quadrat-based sampling would simply report a value for litter cover. Thus the main point to draw from figures 17 and 18 is that $10-\mathrm{m}^{2}$ and $1-\mathrm{m}^{2}$ quadrats do not differ significantly with respect to cover estimates for surface features. 


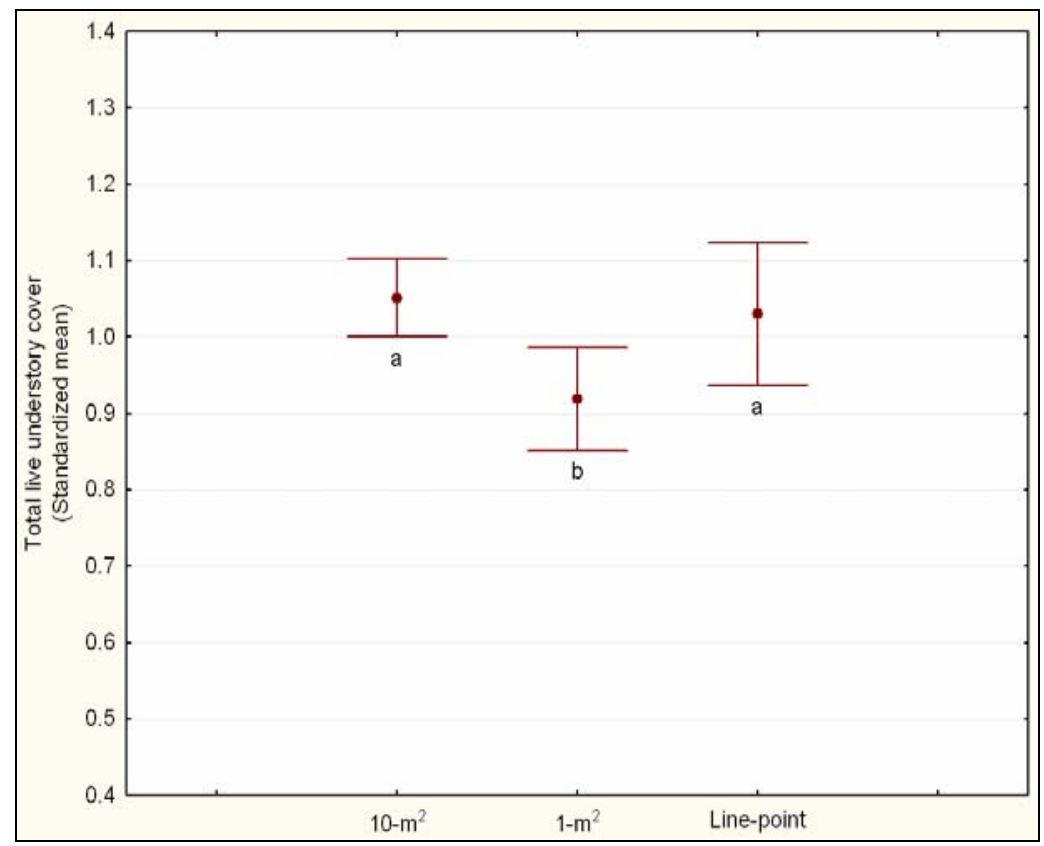

Figure 15. Estimated total live understory canopy cover (standardized means) by method averaged across 11 ecological sites on the Colorado Plateau. Bars indicate 95 percent confidence intervals. Values with different letters are significantly different by Tukey's HSD test.

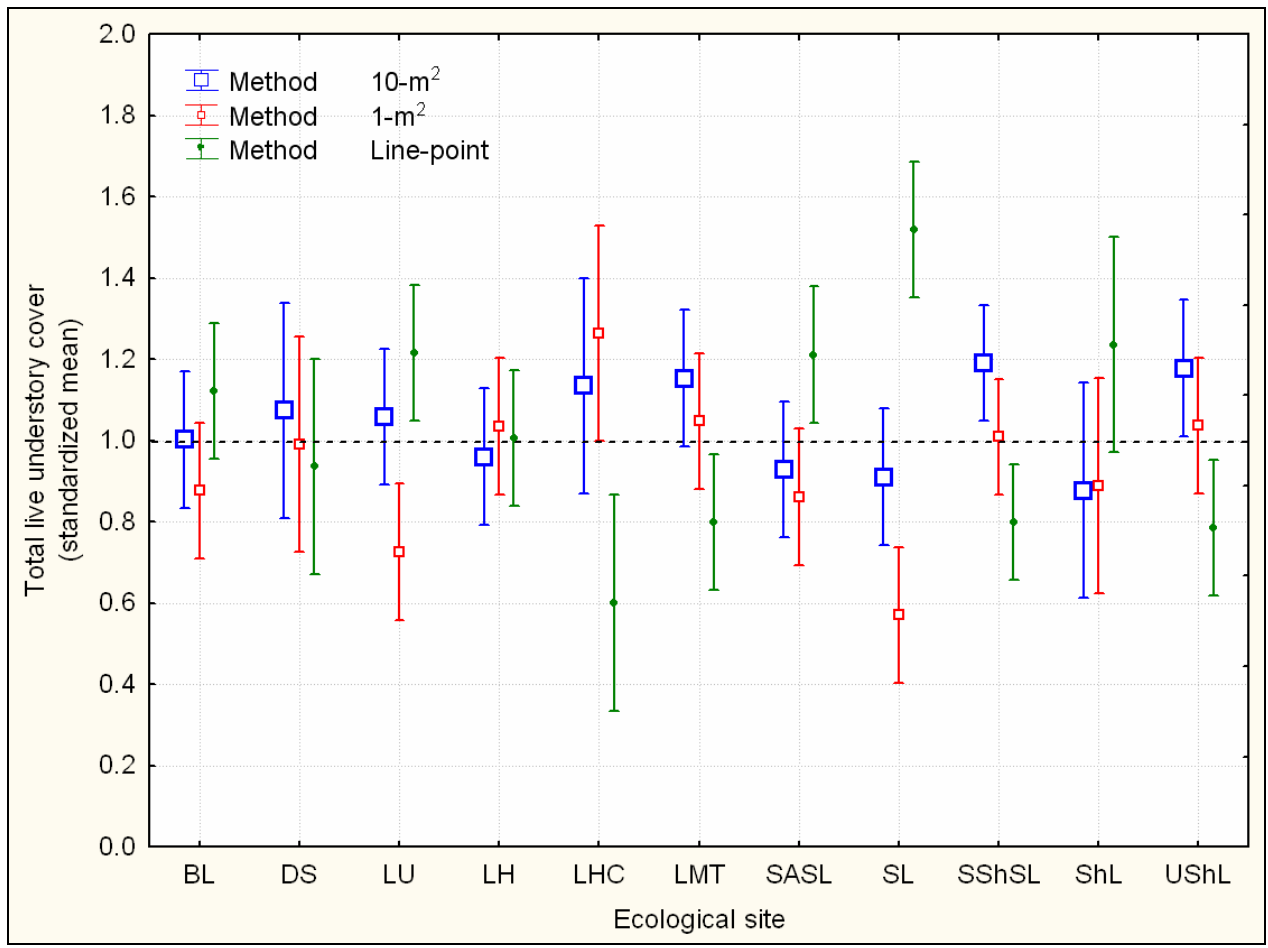

Figure 16. Estimated total live understory canopy cover (standardized means) by method and 11 Colorado Plateau ecological sites. Bars indic ate 95 percent confidence intervals for means. See table 1 for ecological site codes. 
Table 26. Analysis of variance for effect of sampling method on standardized mean cover of surface features at 11 Colorado Plateau ecological sites.

\begin{tabular}{lccccc}
\hline Effect & SS & df & MS & F & $p$ \\
\hline Method & 14.230 & 2 & 7.115 & 23.004 & $<0.0001$ \\
Error & 132.682 & 429 & 0.309 & & \\
\hline
\end{tabular}

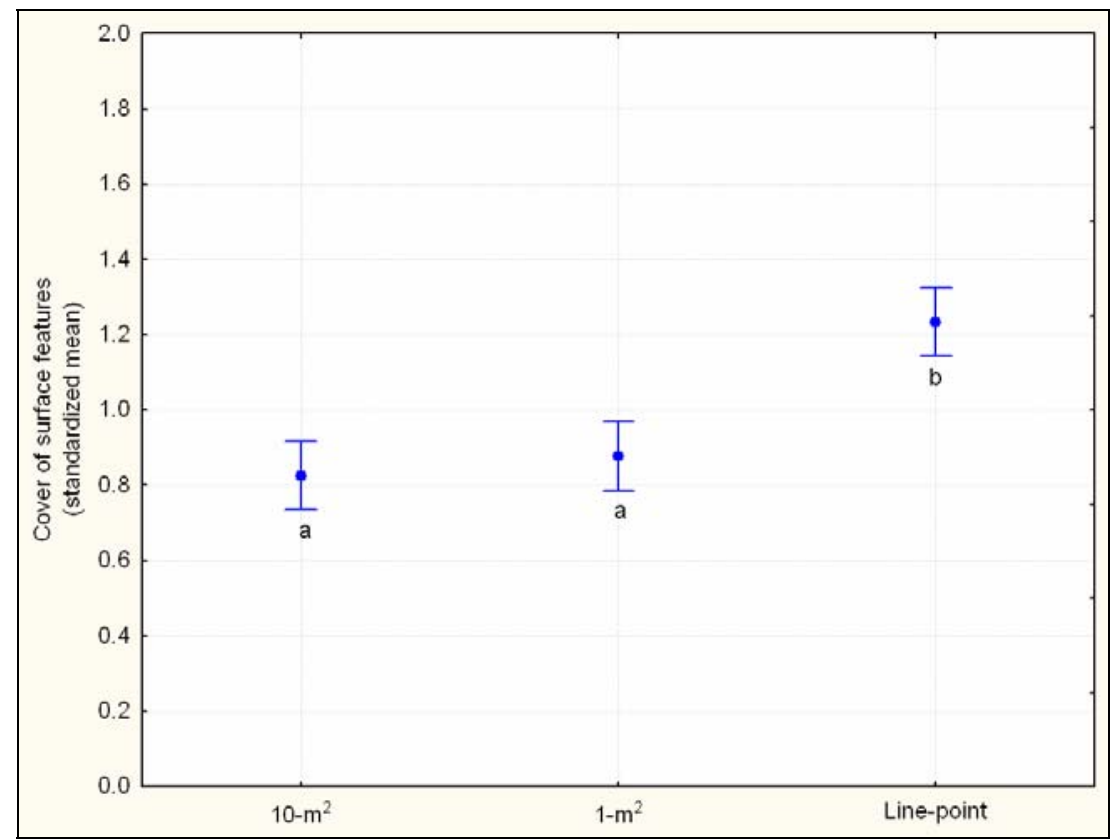

Figure 17. Effect of sampling method on cover estimates (standardized means) for selected surface features (litter, biological soil crust, and bare soil) across 11 ecological sites on the Colorado Plateau. Means with different letters are significantly different by Tukey's HSD test.

\section{Repeatability}

This section describes effects of sampling methods and ecological site on differences between two observers' estimates of cover and density. Tables 27-34 summarize analyses of variance (ANOVA) evaluating effects of sampling method, observer, and cover category (individual species and total live understory canopy) on arcsin-transformed means of plant canopy cover for eight ecological sites sampled during Phase 3. In these analyses, the observerby-method interaction indicates whether there was a significant difference among methods in terms of repeatability between observers. (Tables summarizing actual differences between observers' cover estimates can be found in Appendix F.) Effects of observer and observer-bymethod interactions were statistically significant for the Semidesert Shallow Sandy Loam ecological site at Arches National Park (tables 33 and F1) where line-point estimates for blackbrush (Coleogyne ramosissima, CORA) cover differed between observers. Inspection of the data suggests that this difference was attributable to a difference between observers in their interpretation of "standing dead" blackbrush versus "live non-photosynthetic" blackbrush, rather than an actual difference in cover estimates. Effects of observer and observer-by-method interaction on mean arcsin-transformed litter cover were not statistically significant (table 35). 
We found no statistical relationships between wind-speed measures and differences between two observers' cover estimates for woody plants, herbaceous plants, or grasses using the line-point intercept technique (fig. 19).

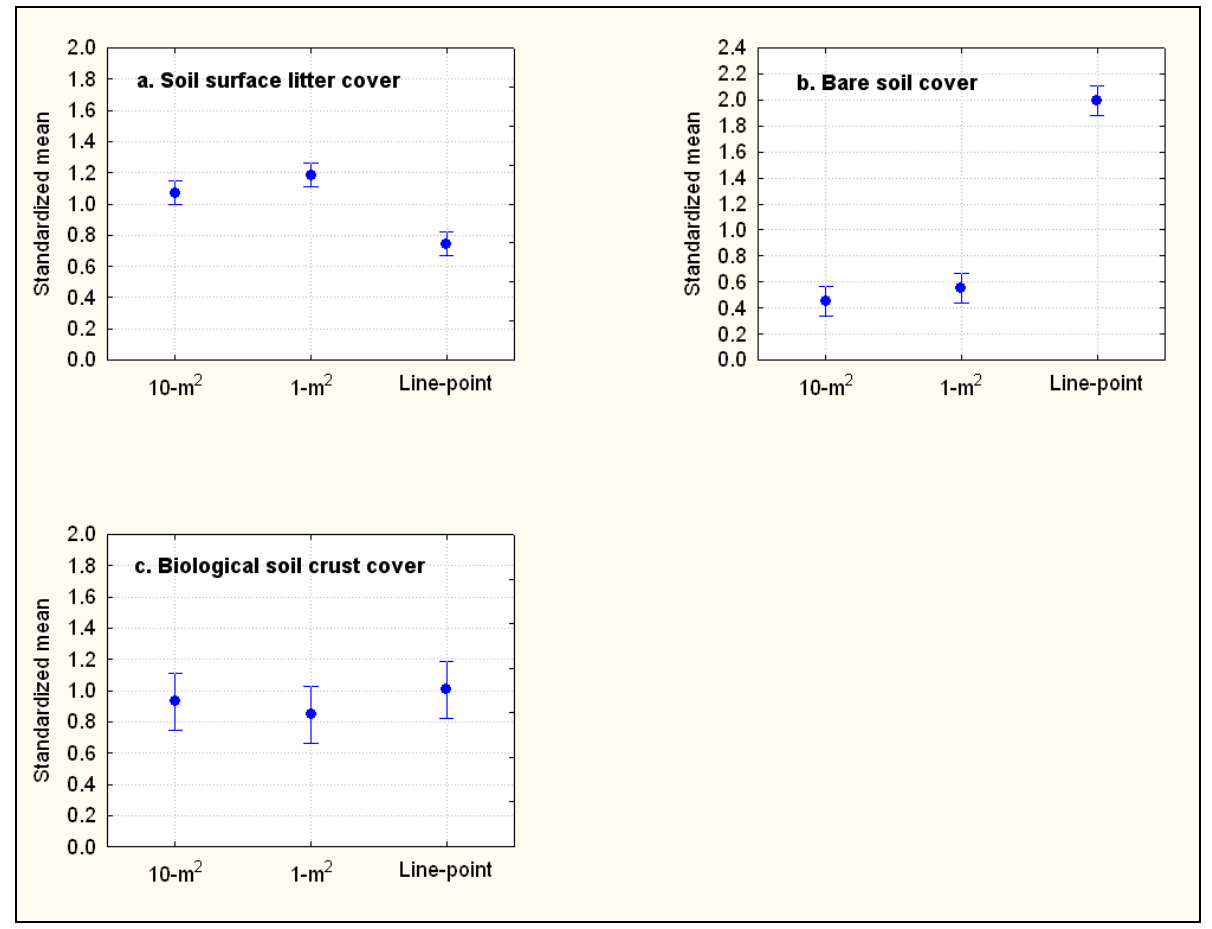

Figure 18. Effects of sampling method on cover estimates (standardized means) for (a) surface litter, (b) unstable bare soil, and (c) biological soil crusts (moss, lichen, and cyanobacteria combined) at eight Colorado Plateau ecological sites.

Table 27. Analysis of variance for effects of sampling method $\left(1-\mathrm{m}^{2}\right.$ quadrats, $10-\mathrm{m}^{2}$ quadrats, and line-point intercept), observer, and cover category (species POFE, QUGA, SYOR2, and total live understory canopy cover) on mean arcsin-transformed plant canopy cover values for the Brushy Loam ecological site at Mesa Verde National Park. See Appendix A for key to species codes.

\begin{tabular}{lrrrrr}
\hline Effect & SS & df & MS & F & p \\
\hline Sampling Method & 1.034 & 2 & 0.517 & 16.008 & $<0.0001$ \\
Observer & $<0.0001$ & 1 & $<0.0001$ & 0.001 & 0.982 \\
Cover category & 14.395 & 3 & 4.798 & 148.537 & $<0.0001$ \\
Sampling Method ${ }^{*}$ Observer & 0.033 & 2 & 0.016 & 0.504 & 0.605 \\
${\text { Sampling Method }{ }^{*} \text { Cover category }}_{\text {Observer*Cover category }}$ & 0.773 & 6 & 0.129 & 3.989 & 0.001 \\
${\text { Sampling Method }{ }^{\star} \text { Observer }{ }^{*} \text { Cover cat. }}_{\text {Error }}^{0.020}$ & 3 & 0.007 & 0.210 & 0.889 \\
& 0.067 & 6 & 0.011 & 0.347 & 0.911 \\
\hline
\end{tabular}


Table 28. Analysis of variance for effects of sampling method $\left(1-\mathrm{m}^{2}\right.$ quadrats, $10-\mathrm{m}^{2}$ quadrats, and line-point intercept), observer, and cover category (species CHLE4, HENE5, PLJA, and total live understory canopy cover) on mean arcsin-transformed plant canopy cover values for the Limy Upland, 25-33" ecological site at Grand Canyon National Park. See Appendix A for key to species codes.

\begin{tabular}{|c|c|c|c|c|c|}
\hline Effect & SS & df & MS & $\mathbf{F}$ & $\mathbf{p}$ \\
\hline Sampling Method & 0.333 & 2 & 0.167 & 14.845 & $<0.0001$ \\
\hline Observer & 0.001 & 1 & 0.001 & 0.061 & 0.805 \\
\hline Cover category & 3.071 & 3 & 1.024 & 91.204 & $<0.0001$ \\
\hline Sampling Method ${ }^{\star}$ Observer & 0.022 & 2 & 0.011 & 0.982 & 0.376 \\
\hline Sampling Method ${ }^{*}$ Cover category & 0.230 & 6 & 0.038 & 3.416 & 0.003 \\
\hline Observer*Cover category & 0.010 & 3 & 0.003 & 0.308 & 0.820 \\
\hline Sampling Method ${ }^{\star}$ Observer ${ }^{\star}$ Cover cat. & 0.009 & 6 & 0.002 & 0.140 & 0.991 \\
\hline Error & 2.155 & 192 & 0.011 & & \\
\hline
\end{tabular}

Table 29. Analysis of variance for effects of sampling method $\left(1-\mathrm{m}^{2}\right.$ quadrats, $10-\mathrm{m}^{2}$ quadrats, and line-point intercept), observer, and cover category (species POFE, POTR5, UNGRCA1, and total live understory canopy cover) on mean arcsin-transformed plant canopy cover values for the Loamy Hills, 25-33"pz ecological site at Grand Canyon National Park. See Appendix A for key to species codes.

\begin{tabular}{lrrrrr}
\hline Effect & SS & df & MS & F & p \\
\hline Sampling Method & 0.355 & 2 & 0.177 & 20.300 & $<0.0001$ \\
Observer & 0.001 & 1 & 0.001 & 0.125 & 0.724 \\
Cover category & 2.808 & 3 & 0.936 & 107.130 & $<0.0001$ \\
Sampling Method ${ }^{\star}$ Observer & 0.001 & 2 & 0.0004 & 0.041 & 0.960 \\
${\text { Sampling Method }{ }^{*} \text { Cover category }}_{\text {Observer*Cover category }}$ & 0.242 & 6 & 0.040 & 4.608 & $<0.0001$ \\
Sampling Method ${ }^{\star}$ Observer ${ }^{\star}$ Cover cat. & 0.010 & 3 & 0.003 & 0.376 & 0.770 \\
Error & 0.024 & 6 & 0.004 & 0.464 & 0.834 \\
\hline
\end{tabular}

Table 30. Analysis of variance for effects of sampling method $\left(1-\mathrm{m}^{2}\right.$ quadrats, $10-\mathrm{m}^{2}$ quadrats, and line-point intercept), observer, and cover category (species JUOS, PIED, POFE, and total live understory canopy cover) on mean arcsin-transformed plant canopy cover values for the Loamy Mesa Top PJ ecological site at Mesa Verde National Park. See Appendix A for key to species codes.

\begin{tabular}{lrrrrr}
\hline Effect & SS & df & MS & F & p \\
\hline Sampling Method & 0.195 & 2 & 0.097 & 6.149 & 0.003 \\
Observer & 0.015 & 1 & 0.015 & 0.925 & 0.337 \\
Cover category & 3.280 & 3 & 1.093 & 69.098 & $<0.0001$ \\
Sampling Method ${ }^{\star}$ Observer & 0.012 & 2 & 0.006 & 0.394 & 0.675 \\
Sampling Method ${ }^{\star}$ Cover category & 0.140 & 6 & 0.023 & 1.472 & 0.190 \\
Observer*Cover category & 0.000 & 3 & $<0.0001$ & 0.001 & 1.000 \\
Sampling Method ${ }^{\star}$ Observer ${ }^{\star}$ Cover cat. & 0.018 & 6 & 0.003 & 0.188 & 0.980 \\
Error & 3.038 & 192 & 0.016 & & \\
\hline
\end{tabular}


Table 31. Analysis of variance for effects of sampling method $\left(1-\mathrm{m}^{2}\right.$ quadrats, $10-\mathrm{m}^{2}$ quadrats, and line-point intercept), observer, and cover category (species ATCO, GIIN2, ORHY, and total live understory canopy cover) on mean arcsin-transformed plant canopy cover values for the Semidesert Alkali Sandy Loam (Alkali Sacaton) ecological site at Capitol Reef National Park. See Appendix A for key to species codes.

\begin{tabular}{lrrrrr}
\hline Effect & SS & df & MS & F & p \\
\hline Sampling Method & 0.002 & 2 & 0.001 & 0.157 & 0.855 \\
Observer & 0.0005 & 1 & 0.0005 & 0.082 & 0.775 \\
Cover category & 4.838 & 3 & 1.613 & 279.354 & $<0.0001$ \\
Sampling Method ${ }^{\star}$ Observer & 0.004 & 2 & 0.002 & 0.369 & 0.692 \\
Sampling Method ${ }^{\star}$ Cover category & 0.133 & 6 & 0.022 & 3.839 & 0.001 \\
Observer*Cover category & 0.001 & 3 & 0.0004 & 0.065 & 0.978 \\
Sampling Method ${ }^{\star}$ Observer*Cover cat. & 0.007 & 6 & 0.001 & 0.188 & 0.980 \\
Error & 1.108 & 192 & 0.006 & & \\
\hline
\end{tabular}

Table 32. Analysis of variance for effects of sampling method $\left(1-\mathrm{m}^{2}\right.$ quadrats, $10-\mathrm{m}^{2}$ quadrats, and line-point intercept), observer, and cover category (species ARTR2, BRTE, STCO4, and total live understory canopy cover) on mean arcsin-transformed plant canopy cover values for the Semidesert Loam (Wyoming Big Sagebrush) ecological site in Dinosaur National Monument. See Appendix A for key to species codes.

\begin{tabular}{lrrrrr}
\hline Effect & SS & df & MS & F & p \\
\hline Sampling Method & 1.254 & 2 & 0.627 & 50.279 & $<0.0001$ \\
Observer & $<0.0001$ & 1 & $<0.0001$ & 0.004 & 0.951 \\
Cover category & 5.887 & 3 & 1.962 & 157.322 & $<0.0001$ \\
Sampling Method ${ }^{\star}$ Observer & 0.024 & 2 & 0.012 & 0.967 & 0.382 \\
Sampling Method ${ }^{*}$ Cover category & 1.107 & 6 & 0.185 & 14.793 & $<0.0001$ \\
Observer*Cover category & 0.004 & 3 & 0.001 & 0.113 & 0.952 \\
Sampling Method ${ }^{\star}$ Observer*Cover cat. & 0.013 & 6 & 0.002 & 0.178 & 0.982 \\
Error & 2.395 & 192 & 0.012 & & \\
\hline
\end{tabular}

Table 33. Analysis of variance for effects of sampling method $\left(1-\mathrm{m}^{2}\right.$ quadrats, $10-\mathrm{m}^{2}$ quadrats, and line-point intercept), observer, and cover category (species CORA, FEOC3, STLO4, and total live understory canopy cover) on arcsin-transformed means of plant canopy cover for the Semidesert Shallow Sandy Loam PJ ecological site at Arches and Canyonlands National Parks. See Appendix A for key to species codes.

\begin{tabular}{lrrrrr}
\hline Effect & SS & df & MS & F & p \\
\hline Sampling Method & 0.102 & 2 & 0.051 & 12.163 & $<0.0001$ \\
Observer & 0.017 & 1 & 0.017 & 4.094 & 0.044 \\
Cover category & 4.829 & 3 & 1.610 & 382.362 & $<0.0001$ \\
Sampling Method ${ }^{*}$ Observer & 0.027 & 2 & 0.013 & 3.151 & 0.045 \\
Sampling Method ${ }^{\star}$ Cover category & 0.063 & 6 & 0.010 & 2.483 & 0.025 \\
Observer*Cover category $_{\text {Sampling Method }{ }^{\star} \text { Observer }{ }^{*} \text { Cover cat. }}$ & 0.011 & 3 & 0.004 & 0.893 & 0.446 \\
Error & 0.017 & 6 & 0.003 & 0.687 & 0.661 \\
\hline
\end{tabular}


Table 34. Analysis of variance for effects of sampling method $\left(1-\mathrm{m}^{2}\right.$ quadrats, $10-\mathrm{m}^{2}$ quadrats, and line-point intercept), observer, and cover category (species CEMO2, COWR2, JUOS, and total live understory canopy cover) on arcsin-transformed means of plant canopy cover for the Upland Shallow Loam (Pinyon-Utah Juniper) ecological site at Capitol Reef National Park. See Appendix A for key to species codes.

\begin{tabular}{lrrrrr}
\hline Effect & SS & df & MS & F & p \\
\hline Sampling Method & 0.285 & 2 & 0.142 & 9.516 & $<0.0001$ \\
Observer & 0.034 & 1 & 0.034 & 2.245 & 0.136 \\
Cover category & 2.819 & 3 & 0.940 & 62.848 & $<0.0001$ \\
Sampling Method ${ }^{\star}$ Observer & 0.007 & 2 & 0.004 & 0.240 & 0.787 \\
Sampling Method ${ }^{\star}$ Cover category & 0.166 & 6 & 0.028 & 1.846 & 0.092 \\
${\text { Observer }{ }^{\star} \text { Cover category }}_{\text {Sampling Method }{ }^{\star} \text { Observer }{ }^{\star} \text { Cover cat. }}$ & 0.018 & 3 & 0.006 & 0.394 & 0.757 \\
Error & 0.006 & 6 & 0.001 & 0.067 & 0.999 \\
\hline
\end{tabular}

Table 35. Analysis of variance for effects of sampling method $\left(1-\mathrm{m}^{2}\right.$ quadrats, $10-\mathrm{m}^{2}$ quadrats, and line-point intercept), ecological site (BL, LU, LH, LMT, SASL, SL, SShSL, and UShL), and observer on arcsin-transformed means of litter cover data. See table 1 for key to ecological site codes.

\begin{tabular}{lrrrrr}
\hline Effect & SS & df & MS & F & p \\
\hline Sampling Method & 2.251 & 2 & 1.126 & 66.758 & $<0.0001$ \\
Ecological Site & 47.334 & 7 & 6.762 & 401.071 & $<0.0001$ \\
Observer & 0.001 & 1 & 0.001 & 0.086 & 0.770 \\
Sampling Method* Ecological Site & 1.482 & 14 & 0.106 & 6.277 & $<0.0001$ \\
Sampling Method* Observer $^{*}$ & 0.056 & 2 & 0.028 & 1.661 & 0.191 \\
Ecological Site *Observer & 0.031 & 7 & 0.004 & 0.260 & 0.969 \\
Sampling Method* Ecological Site *Observer & 0.049 & 14 & 0.003 & 0.207 & 0.999 \\
Error & 6.474 & 384 & 0.017 & & \\
\hline
\end{tabular}




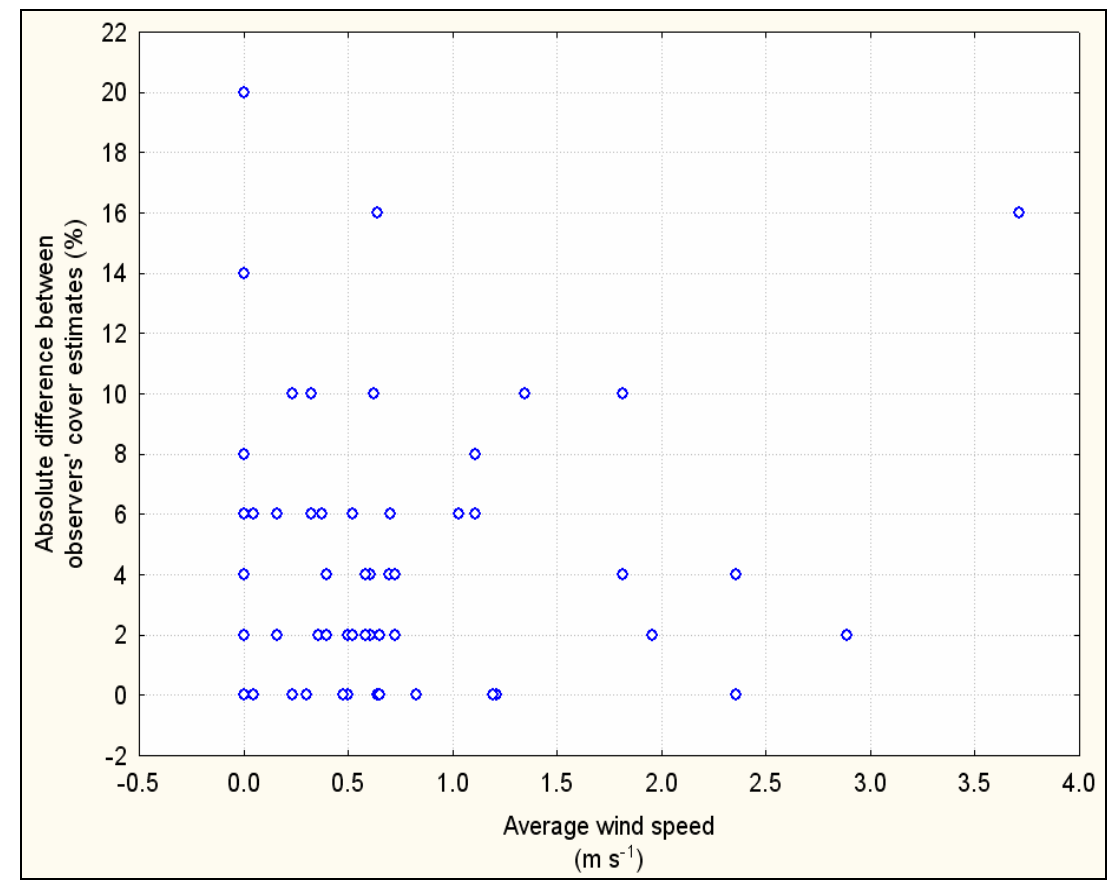

Figure 19. Scatterplot of average wind speed $\left(\mathrm{m} \mathrm{s}^{-1}\right)$ vs. absolute difference between two observers' estimates of grass cover based on use of the line-point intercept sampling technique at eight Colorado Plateau ecological sites $(r=0.07, p=0.55, n=70)$.

Table 36 summarizes results of Wilcoxon tests evaluating effects of observer on cover estimates for four types of soil crust (undifferentiated crust, dark cyanobacteria, lichen, and moss) for $10-\mathrm{m}^{2}, 1-\mathrm{m}^{2}$, and line-point intercept sampling methods at ecological sites where biological soil crusts were common. At the Upland Shallow Loam (Pinyon-Utah Juniper) ecological site at Capitol Reef National Park (tables 36 and F2), estimates of undifferentiated crust cover based on 1- $\mathrm{m}^{2}$ quadrats and line-point intercepts both differed between observers. Observer 1 estimated lower undifferentiated crust cover than observer 2 for both $1-\mathrm{m}^{2}$ quadrats and line-point intercepts. At this same site, estimates of moss cover in $10-\mathrm{m}^{2}$ quadrats also were significantly different between observers (tables 36 and F2). The soil at this ecological site was extremely rocky with very low levels of biological soil crust cover.

Table 37 summarizes results of Wilcoxon tests evaluating effects of observer on estimates of biological soil crust cover based on use of the $25 \mathrm{~cm}$ x $25 \mathrm{~cm}$ BSC frame at ecological sites where biological soil crusts were common. No significant differences were found between observers' cover estimates for five soil-surface categories related to soil darkness and biological soil crust development. Appendix table F3 summarizes additional data collected with the BSC frame.

Tables 38 and 39 summarize results of Wilcoxon tests evaluating effects of observer on estimates of shrub and tree density by species and size class. No significant differences were found between observers' estimates of shrub and tree density. Appendix table F7 reports shrub and tree density for transects sampled during Phase 3. 
Table 36. Results of Wilcoxon tests evaluating effects of observer on estimates of cover for four types of soil crust (undifferentiated, dark cyanobacteria, lichen, and moss) sampled with 10- $\mathrm{m}^{2}$ quadrats, $1-\mathrm{m}^{2}$ quadrats, and line-point intercept techniques at Colorado Plateau ecological sites where biological soil crusts were common. Bold values indicate statistically significant differences between observers' cover estimates.

\begin{tabular}{|c|c|c|c|c|c|c|c|c|}
\hline \multirow{2}{*}{$\begin{array}{r}\text { Type of soil crust } \\
\text { Ecological site } \\
\end{array}$} & \multirow[b]{2}{*}{ Sampling method } & \multicolumn{2}{|c|}{ Rank sum } & \multirow[b]{2}{*}{$\mathbf{u}$} & \multirow[b]{2}{*}{ z } & \multirow[b]{2}{*}{ p-level } & \multirow[b]{2}{*}{ n } & \multirow{2}{*}{$\begin{array}{r}2 * 1 \text { sided } \\
\text { exact } p \\
\end{array}$} \\
\hline & & Observer 1 & Observer 2 & & & & & \\
\hline \multicolumn{9}{|l|}{ Undifferentiated crust } \\
\hline \multirow{3}{*}{ Loamy Mesa Top PJ } & $10-m^{2}$ & 89 & 82 & 37 & 0.31 & 0.76 & 9 & 0.80 \\
\hline & $1-m^{2}$ & 83 & 88 & 38 & -0.22 & 0.83 & 9 & 0.86 \\
\hline & Line-point & 97 & 75 & 30 & 0.97 & 0.33 & 9 & 0.34 \\
\hline \multirow{3}{*}{ Semidesert Alkali Sandy Loam (Alkali Sacaton) } & $10-m^{2}$ & 83 & 88 & 38 & -0.22 & 0.83 & 9 & 0.86 \\
\hline & $1-m^{2}$ & 75 & 96 & 30 & -0.93 & 0.35 & 9 & 0.39 \\
\hline & Line-point & 105 & 66 & 21 & 1.72 & 0.09 & 9 & 0.09 \\
\hline \multirow{3}{*}{ Semidesert Loam (Wyoming Big Sagebrush) } & $10-m^{2}$ & 79 & 92 & 34 & -0.57 & 0.57 & 9 & 0.60 \\
\hline & $1-m^{2}$ & 82 & 89 & 37 & -0.31 & 0.76 & 9 & 0.80 \\
\hline & Line-point & 93 & 78 & 33 & 0.66 & 0.51 & 9 & 0.55 \\
\hline \multirow{3}{*}{ Semidesert Shallow Sandy Loam (PJ) } & $10-m^{2}$ & 96 & 76 & 31 & 0.88 & 0.38 & 9 & 0.39 \\
\hline & $1-m^{2}$ & 98 & 74 & 29 & 1.06 & 0.29 & 9 & 0.30 \\
\hline & Line-point & 97 & 75 & 30 & 0.97 & 0.33 & 9 & 0.34 \\
\hline \multirow{3}{*}{ Upland Shallow Loam (Pinyon-Utah Juniper) } & $10-m^{2}$ & 93 & 79 & 34 & 0.62 & 0.54 & 9 & 0.55 \\
\hline & $1-m^{2}$ & 60 & 112 & 15 & -2.30 & 0.02 & 9 & 0.02 \\
\hline & Line-point & 61 & 110 & 16 & -2.16 & 0.03 & 9 & 0.03 \\
\hline \multicolumn{9}{|l|}{ Dark cyanobacteria } \\
\hline \multirow{3}{*}{ Loamy Mesa Top PJ } & $10-m^{2}$ & 77 & 94 & 32 & -0.75 & 0.45 & 9 & 0.49 \\
\hline & $1-m^{2}$ & 71 & 101 & 26 & -1.32 & 0.19 & 9 & 0.19 \\
\hline & Line-point & 78 & 93 & 33 & -0.66 & 0.51 & 9 & 0.55 \\
\hline
\end{tabular}




\section{Table 36.-Continued}

\begin{tabular}{|c|c|c|c|c|c|c|c|c|}
\hline \multirow{2}{*}{$\begin{array}{l}\text { Type of soil crust } \\
\text { Ecological site }\end{array}$} & \multirow[b]{2}{*}{ Sampling method } & \multicolumn{2}{|c|}{ Rank sum } & \multirow[b]{2}{*}{$\mathbf{U}$} & \multirow[b]{2}{*}{ z } & \multirow[b]{2}{*}{ p-level } & \multirow[b]{2}{*}{$\mathbf{n}$} & \multirow{2}{*}{$\begin{array}{r}2 * 1 \text { sided } \\
\text { exact } p\end{array}$} \\
\hline & & Observer 1 & Observer 2 & & & & & \\
\hline \multirow{3}{*}{ Semidesert Alkali Sandy Loam (Alkali Sacaton) } & $10-m^{2}$ & 84 & 87 & 39 & -0.13 & 0.89 & 9 & 0.93 \\
\hline & $1-m^{2}$ & 80 & 92 & 35 & -0.53 & 0.60 & 9 & 0.60 \\
\hline & Line-point & 40 & 39 & 18 & 0.08 & 0.94 & 6 & 0.94 \\
\hline \multirow{3}{*}{ Semidesert Loam (Wyoming Big Sagebrush) } & $10-m^{2}$ & 73 & 98 & 28 & -1.10 & 0.27 & 9 & 0.30 \\
\hline & $1-m^{2}$ & 74 & 97 & 29 & -1.02 & 0.31 & 9 & 0.34 \\
\hline & Line-point & 34 & 44 & 13 & -0.80 & 0.42 & 6 & 0.48 \\
\hline \multirow{3}{*}{ Semidesert Shallow Sandy Loam (PJ) } & $10-m^{2}$ & 65 & 107 & 20 & -1.85 & 0.06 & 9 & 0.06 \\
\hline & $1-m^{2}$ & 74 & 97 & 29 & -1.02 & 0.31 & 9 & 0.34 \\
\hline & Line-point & 58 & 79 & 22 & -1.10 & 0.27 & 8 & 0.28 \\
\hline \multicolumn{9}{|l|}{ Lichen } \\
\hline \multirow{3}{*}{ Loamy Mesa Top PJ } & $10-m^{2}$ & 85 & 87 & 39.5 & -0.09 & 0.93 & 9 & 0.93 \\
\hline & $1-\mathrm{m}^{2}$ & 79 & 92 & 34 & -0.57 & 0.57 & 9 & 0.60 \\
\hline & Line-point & 17 & 20 & 7 & -0.43 & 0.67 & 4 & 0.69 \\
\hline \multirow{3}{*}{ Semidesert Alkali Sandy Loam (Alkali Sacaton) } & $10-m^{2}$ & 82 & 89 & 37 & -0.31 & 0.76 & 9 & 0.80 \\
\hline & $1-m^{2}$ & 76 & 96 & 31 & -0.88 & 0.38 & 9 & 0.39 \\
\hline & Line-point & 3 & 7 & 0 & -1.55 & 0.12 & 2 & 0.33 \\
\hline \multirow{3}{*}{ Semidesert Loam (Wyoming Big Sagebrush) } & $10-m^{2}$ & 3 & 7 & 0 & -1.55 & 0.12 & 2 & 0.33 \\
\hline & $1-m^{2}$ & 82 & 89 & 37 & -0.31 & 0.76 & 9 & 0.80 \\
\hline & Line-point & 33 & 46 & 12 & -1.04 & 0.30 & 6 & 0.31 \\
\hline \multirow{3}{*}{ Semidesert Shallow Sandy Loam (PJ) } & $10-m^{2}$ & 90 & 81 & 36 & 0.40 & 0.69 & 9 & 0.73 \\
\hline & $1-\mathrm{m}^{2}$ & 82 & 89 & 37 & -0.31 & 0.76 & 9 & 0.80 \\
\hline & Line-point & 3 & 7 & 0 & -1.55 & 0.12 & 2 & 0.33 \\
\hline
\end{tabular}




\section{Table 36.-Continued}

\begin{tabular}{|c|c|c|c|c|c|c|c|c|}
\hline \multirow{2}{*}{$\begin{array}{c}\text { Type of soil crust } \\
\text { Ecological site }\end{array}$} & \multirow[b]{2}{*}{ Sampling method } & \multicolumn{2}{|c|}{ Rank sum } & \multirow[b]{2}{*}{$\mathbf{U}$} & \multirow[b]{2}{*}{$\mathbf{z}$} & \multirow[b]{2}{*}{ p-level } & \multirow[b]{2}{*}{$\mathbf{n}$} & \multirow{2}{*}{$\begin{array}{r}2 * 1 \text { sided } \\
\text { exact } \mathrm{p}\end{array}$} \\
\hline & & Observer 1 & Observer 2 & & & & & \\
\hline \multicolumn{9}{|l|}{ Moss } \\
\hline \multirow{3}{*}{ Loamy Mesa Top PJ } & $10-m^{2}$ & 81 & 91 & 36 & -0.44 & 0.66 & 9 & 0.67 \\
\hline & $1-m^{2}$ & 87 & 85 & 40 & 0.09 & 0.93 & 9 & 0.93 \\
\hline & Line-point & 69 & 68 & 32 & 0.05 & 0.96 & 8 & 0.96 \\
\hline \multirow{3}{*}{ Semidesert Alkali Sandy Loam (Alkali Sacaton) } & $10-m^{2}$ & 71 & 100 & 26 & -1.28 & 0.20 & 9 & 0.22 \\
\hline & $1-m^{2}$ & 7 & 14 & 1 & -1.53 & 0.13 & 3 & 0.20 \\
\hline & Line-point & --- & --- & --- & --- & --- & 1 & --- \\
\hline \multirow{3}{*}{ Semidesert Loam (Wyoming Big Sagebrush) } & $10-m^{2}$ & 83 & 89 & 38 & -0.26 & 0.79 & 9 & 0.80 \\
\hline & $1-m^{2}$ & 75 & 96 & 30 & -0.93 & 0.35 & 9 & 0.39 \\
\hline & Line-point & 82 & 89 & 37 & -0.31 & 0.76 & 9 & 0.80 \\
\hline \multirow{3}{*}{ Semidesert Shallow Sandy Loam (PJ) } & $10-m^{2}$ & 74 & 98 & 29 & -1.06 & 0.29 & 9 & 0.30 \\
\hline & $1-m^{2}$ & 67 & 104 & 22 & -1.63 & 0.10 & 9 & 0.11 \\
\hline & Line-point & 83 & 89 & 38 & -0.26 & 0.79 & 9 & 0.80 \\
\hline \multirow{3}{*}{ Upland Shallow Loam (Pinyon-Utah Juniper) } & $10-m^{2}$ & 60 & 112 & 15 & -2.30 & 0.02 & 9 & 0.02 \\
\hline & $1-m^{2}$ & 66 & 106 & 21 & -1.77 & 0.08 & 9 & 0.08 \\
\hline & Line-point & 3 & 7 & 0 & -1.55 & 0.12 & 2 & 0.33 \\
\hline
\end{tabular}


Table 37. Results of Wilcoxon tests evaluating effects of observer on estimates of biological soil crust cover based on the characterization of soil darkness (see table 10 and fig. 5) in $25 \mathrm{~cm}$ x $25 \mathrm{~cm} \mathrm{BSC}$ frames at Colorado Plateau ecological sites where biological soil crusts were common.

\begin{tabular}{|c|c|c|c|c|c|c|c|c|}
\hline \multirow{2}{*}{$\begin{array}{l}\text { Soil-surface } \\
\text { category }\end{array}$} & \multirow[b]{2}{*}{ Ecological site } & \multicolumn{2}{|c|}{ Rank sum } & \multirow[b]{2}{*}{ u } & \multirow[b]{2}{*}{ z } & \multirow[b]{2}{*}{ p-level } & \multirow[b]{2}{*}{$\mathbf{n}$} & \multirow{2}{*}{$\begin{array}{r}2 * 1 \text { sided } \\
\text { exact } p \\
\end{array}$} \\
\hline & & Observer 1 & Observer 2 & & & & & \\
\hline \multirow{4}{*}{ Darkness 1} & Loamy Mesa Top PJ & 5 & 5 & 2 & 0 & 1.00 & 2 & 1.00 \\
\hline & Semidesert Alkali Sandy Loam (Alkali Sacaton) & 75 & 61 & 25 & 0.74 & 0.46 & 8 & 0.51 \\
\hline & Semidesert Shallow Sandy Loam (PJ) & 73 & 64 & 28 & 0.47 & 0.64 & 8 & 0.65 \\
\hline & Upland Shallow Loam (Pinyon-Utah Juniper) & 89 & 83 & 38 & 0.26 & 0.79 & 9 & 0.80 \\
\hline \multirow{5}{*}{ Darkness 2} & Loamy Mesa Top PJ & 85 & 87 & 40 & -0.09 & 0.93 & 9 & 0.93 \\
\hline & Semidesert Alkali Sandy Loam (Alkali Sacaton) & 80 & 91 & 35 & -0.49 & 0.63 & 9 & 0.67 \\
\hline & Semidesert Loam (Wyoming Big Sagebrush) & 102 & 70 & 25 & 1.41 & 0.16 & 9 & 0.16 \\
\hline & Semidesert Shallow Sandy Loam (PJ) & 85 & 86 & 40 & -0.04 & 0.96 & 9 & 1.00 \\
\hline & Upland Shallow Loam (Pinyon-Utah Juniper) & 3 & 7 & 0 & -1.55 & 0.12 & 2 & 0.33 \\
\hline \multirow{4}{*}{ Darkness 3} & Loamy Mesa Top PJ & 83 & 88 & 38 & -0.22 & 0.83 & 9 & 0.86 \\
\hline & Semidesert Alkali Sandy Loam (Alkali Sacaton) & 58 & 78 & 22 & -1.05 & 0.29 & 8 & 0.33 \\
\hline & Semidesert Loam (Wyoming Big Sagebrush) & 72 & 99 & 27 & -1.19 & 0.23 & 9 & 0.26 \\
\hline & Semidesert Shallow Sandy Loam (PJ) & 61 & 76 & 25 & -0.79 & 0.43 & 8 & 0.44 \\
\hline Darkness 4 & Loamy Mesa Top PJ & 50 & 56 & 22 & -0.38 & 0.70 & 7 & 0.71 \\
\hline Darkness 5 & Loamy Mesa Top PJ & 5 & 5 & 2 & 0 & 1.00 & 2 & 1.00 \\
\hline
\end{tabular}


Table 38. Results of Wilcoxon tests evaluating effects of observer on estimates of shrub density by species and height class at Colorado Plateau ecological sites. See Appendix A for key to species codes.

\begin{tabular}{|c|c|c|c|c|c|c|c|c|}
\hline \multirow[b]{2}{*}{ Species } & \multirow[b]{2}{*}{ Height class (cm) } & \multicolumn{2}{|c|}{ Rank Sum } & \multirow[b]{2}{*}{$\mathbf{U}$} & \multirow[b]{2}{*}{ z } & \multirow[b]{2}{*}{ p-level } & \multirow[b]{2}{*}{$\mathbf{n}$} & \multirow[b]{2}{*}{$2 * 1$ sided exact $p$} \\
\hline & & Observer 1 & Observer 2 & & & & & \\
\hline \multirow{7}{*}{ AMUT } & $0-10$ & 21 & 15 & 5 & 0.87 & 0.39 & 4 & 0.49 \\
\hline & $10-25$ & 48 & 30 & 9 & 1.44 & 0.15 & 6 & 0.18 \\
\hline & $25-50$ & 116 & 94 & 39 & 0.83 & 0.41 & 10 & 0.44 \\
\hline & $50-100$ & 150 & 151 & 72 & -0.03 & 0.98 & 12 & 0.98 \\
\hline & $100-200$ & 156 & 144 & 66 & 0.35 & 0.73 & 12 & 0.76 \\
\hline & $>200$ & 5 & 5 & 2 & 0.00 & 1.00 & 2 & 1.00 \\
\hline & All combined & 2281 & 1998 & 917 & 1.10 & 0.27 & 46 & 0.27 \\
\hline \multirow{5}{*}{ ARBI3 } & $0-10$ & 5 & 5 & 2 & 0.00 & 1.00 & 2 & 1.00 \\
\hline & $10-25$ & --- & --- & --- & --- & --- & 1 & --- \\
\hline & $25-50$ & 7 & 4 & 1 & 1.16 & 0.25 & 2 & 0.33 \\
\hline & $50-100$ & --- & --- & -- & --- & --- & 1 & --- \\
\hline & All combined & 45 & 34 & 13 & 0.88 & 0.38 & 6 & 0.39 \\
\hline \multirow{5}{*}{ ARTR2 } & 0-10 & 57 & 48 & 20 & 0.57 & 0.57 & 7 & 0.62 \\
\hline & $10-25$ & 109 & 101 & 46 & 0.30 & 0.76 & 10 & 0.80 \\
\hline & $25-50$ & 158 & 143 & 65 & 0.43 & 0.67 & 12 & 0.67 \\
\hline & $50-100$ & 157 & 143 & 65 & 0.40 & 0.69 & 12 & 0.71 \\
\hline & All combined & 2499 & 2352 & 1127 & 0.52 & 0.60 & 49 & 0.61 \\
\hline \multirow{3}{*}{ ATCA2 } & $25-50$ & 5 & 5 & 2 & 0.00 & 1.00 & 2 & 1.00 \\
\hline & $50-100$ & 10 & 11 & 4 & -0.22 & 0.83 & 3 & 1.00 \\
\hline & All combined & 27 & 29 & 12 & -0.21 & 0.83 & 5 & 0.84 \\
\hline \multirow{5}{*}{ ATCO } & $0-10$ & 142 & 111 & 45 & 1.02 & 0.31 & 11 & 0.33 \\
\hline & $10-25$ & 68 & 68 & 32 & 0.00 & 1.00 & 8 & 1.00 \\
\hline & $25-50$ & 96 & 76 & 31 & 0.88 & 0.38 & 9 & 0.39 \\
\hline & $50-100$ & --- & --- & --- & --- & --- & 1 & --- \\
\hline & All combined & 921 & 790 & 355 & 1.02 & 0.31 & 29 & 0.31 \\
\hline \multirow{3}{*}{ BEFR } & $10-25$ & --- & --- & --- & --- & --- & 1 & --- \\
\hline & 50-100 & 12 & 9 & 3 & 0.65 & 0.51 & 3 & 0.70 \\
\hline & All combined & 18 & 18 & 8 & 0.00 & 1.00 & 4 & 1.00 \\
\hline \multirow{5}{*}{ CHNA2 } & $10-25$ & 11 & 11 & 5 & 0.00 & 1.00 & 3 & 1.00 \\
\hline & $25-50$ & 73 & 64 & 28 & 0.47 & 0.64 & 8 & 0.65 \\
\hline & $50-100$ & 17 & 19 & 7 & -0.29 & 0.77 & 4 & 0.89 \\
\hline & $100-200$ & --- & --- & --- & --- & --- & 1 & --- \\
\hline & All combined & 262 & 267 & 126 & -0.09 & 0.92 & 16 & 0.93 \\
\hline \multirow{5}{*}{ CORA } & $0-10$ & 20 & 17 & 7 & 0.43 & 0.67 & 4 & 0.69 \\
\hline & $10-25$ & 60 & 45 & 17 & 0.96 & 0.34 & 7 & 0.38 \\
\hline & $25-50$ & 91 & 81 & 36 & 0.44 & 0.66 & 9 & 0.67 \\
\hline & 50-100 & 90 & 81 & 36 & 0.40 & 0.69 & 9 & 0.73 \\
\hline & All combined & 893 & 818 & 383 & 0.58 & 0.56 & 29 & 0.57 \\
\hline \multirow{4}{*}{ PUME } & $25-50$ & & & & & & 1 & \\
\hline & $50-100$ & 12 & 9 & 3 & 0.65 & 0.51 & 3 & 0.70 \\
\hline & $100-200$ & 5 & 5 & 2 & 0.00 & 1.00 & 2 & 1.00 \\
\hline & All combined & 42 & 37 & 16 & 0.40 & 0.69 & 6 & 0.70 \\
\hline
\end{tabular}




\section{Table 38.-Continued}

\begin{tabular}{|c|c|c|c|c|c|c|c|c|}
\hline \multirow[b]{2}{*}{ Species } & \multirow[b]{2}{*}{ Height class $(\mathrm{cm})$} & \multicolumn{2}{|c|}{ Rank Sum } & \multirow[b]{2}{*}{$\mathbf{U}$} & \multirow[b]{2}{*}{$\mathbf{z}$} & \multirow[b]{2}{*}{ p-level } & \multirow[b]{2}{*}{$\mathbf{n}$} & \multirow[b]{2}{*}{$2 * 1$ sided exact $p$} \\
\hline & & Observer 1 & Observer 2 & & & & & \\
\hline \multirow{4}{*}{ PUTR2 } & $0-10$ & 18 & 18 & 8 & 0.00 & 1.00 & 4 & 1.00 \\
\hline & $25-50$ & 25 & 12 & 2 & 1.88 & 0.06 & 4 & 0.06 \\
\hline & $50-100$ & 13 & 23 & 3 & -1.44 & 0.15 & 4 & 0.20 \\
\hline & All combined & 156 & 144 & 66 & 0.35 & 0.73 & 12 & 0.76 \\
\hline \multirow{7}{*}{ SAVE4 } & $0-10$ & 18 & 18 & 8 & 0.00 & 1.00 & 4 & 1.00 \\
\hline & $10-25$ & 17 & 20 & 7 & -0.43 & 0.67 & 4 & 0.69 \\
\hline & $25-50$ & 74 & 63 & 27 & 0.58 & 0.56 & 8 & 0.57 \\
\hline & $50-100$ & 107 & 104 & 49 & 0.11 & 0.91 & 10 & 0.91 \\
\hline & $100-200$ & 16 & 20 & 6 & -0.58 & 0.56 & 4 & 0.69 \\
\hline & $>200$ & --- & --- & --- & --- & --- & 1 & --- \\
\hline & All combined & 983 & 970 & 474 & 0.09 & 0.93 & 31 & 0.93 \\
\hline \multirow{4}{*}{ SHRO } & $25-50$ & --- & --- & --- & --- & --- & 1 & --- \\
\hline & $50-100$ & --- & --- & --- & --- & --- & 1 & --- \\
\hline & $100-200$ & 5 & 5 & 2 & 0.00 & 1.00 & 2 & 1.00 \\
\hline & All combined & 18 & 18 & 8 & 0.00 & 1.00 & 4 & 1.00 \\
\hline \multirow{6}{*}{ SYOR2 } & $0-10$ & --- & --- & --- & --- & --- & --- & --- \\
\hline & $10-25$ & 11 & 11 & 5 & 0.00 & 1.00 & 3 & 1.00 \\
\hline & $25-50$ & 8 & 13 & 2 & -1.09 & 0.28 & 3 & 0.40 \\
\hline & $50-100$ & 11 & 10 & 4 & 0.22 & 0.83 & 3 & 1.00 \\
\hline & $100-200$ & 10 & 12 & 4 & -0.44 & 0.66 & 3 & 0.70 \\
\hline & All combined & 145 & 155 & 67 & -0.29 & 0.77 & 12 & 0.80 \\
\hline
\end{tabular}

Table 39. Results of Wilcoxon tests evaluating effects of observer on estimates of tree density by species and size class at Colorado Plateau ecological sites. See Appendix A for key to species codes.

\begin{tabular}{|c|c|c|c|c|c|c|c|c|}
\hline \multirow[b]{2}{*}{ Species } & \multirow[b]{2}{*}{ Size class } & \multicolumn{2}{|c|}{ Rank Sum } & \multirow[b]{2}{*}{$\mathbf{U}$} & \multirow[b]{2}{*}{$\mathbf{Z}$} & \multirow[b]{2}{*}{ p-level } & \multirow[b]{2}{*}{$\mathbf{n}$} & \multirow[b]{2}{*}{$2 * 1$ sided exact $p$} \\
\hline & & Observer 1 & Observer 2 & & & & & \\
\hline $\mathrm{ABCO}$ & Seedling & 5 & 5 & 2 & 0.00 & 1.00 & 2 & --- \\
\hline \multirow{4}{*}{ JuOS } & Seedling & 275 & 253 & 117 & 0.41 & 0.68 & 16 & 0.70 \\
\hline & Pole & 152 & 149 & 71 & 0.09 & 0.93 & 12 & 0.93 \\
\hline & Overstory & 120 & 90 & 35 & 1.13 & 0.26 & 10 & 0.28 \\
\hline & All combined & 1555 & 1372 & 631 & 0.95 & 0.34 & 38 & 0.34 \\
\hline \multirow{4}{*}{ PIED } & Seedling & 170 & 182 & 79 & -0.31 & 0.76 & 13 & 0.76 \\
\hline & Pole & 89 & 82 & 37 & 0.31 & 0.76 & 9 & 0.80 \\
\hline & Overstory & 5 & 5 & 2 & 0.00 & 1.00 & 2 & --- \\
\hline & Total & 582 & 595 & 282 & -0.13 & 0.89 & 24 & 0.89 \\
\hline \multirow{3}{*}{ PIEN } & Seedling & --- & --- & --- & --- & --- & 1 & --- \\
\hline & Pole & 5 & 5 & 2 & 0.00 & 1.00 & 2 & 1.00 \\
\hline & All combined & 11 & 11 & 5 & 0.00 & 1.00 & 3 & 1.00 \\
\hline \multirow{3}{*}{ PIPO } & Pole & --- & --- & --- & --- & --- & 1 & -- \\
\hline & Overstory & 25 & 30 & 10 & -0.52 & 0.60 & 5 & 0.69 \\
\hline & All combined & 36 & 42 & 15 & -0.48 & 0.63 & 6 & 0.70 \\
\hline
\end{tabular}


Table 39.-Continued

\begin{tabular}{|c|c|c|c|c|c|c|c|c|}
\hline \multirow[b]{2}{*}{ Species } & \multirow[b]{2}{*}{ Size class } & \multicolumn{2}{|c|}{ Rank Sum } & \multirow[b]{2}{*}{ U } & \multirow[b]{2}{*}{ Z } & \multirow[b]{2}{*}{ p-level } & \multirow[b]{2}{*}{$\mathbf{n}$} & \multirow[b]{2}{*}{ 2*1sided exact $p$} \\
\hline & & Observer 1 & Observer 2 & & & & & \\
\hline \multirow{4}{*}{ POTR5 } & Seedling & 52 & 53 & 24 & -0.06 & 0.95 & 7 & 1.00 \\
\hline & Pole & 19 & 18 & 8 & 0.14 & 0.89 & 4 & 0.89 \\
\hline & Overstory & --- & --- & --- & --- & --- & 1 & -- \\
\hline & All combined & 150 & 150 & 72 & 0.00 & 1.00 & 12 & 1.00 \\
\hline \multirow{3}{*}{ QUGA } & Seedling & 20 & 16 & 6 & 0.58 & 0.56 & 4 & 0.69 \\
\hline & Pole & --- & --- & --- & --- & --- & 1 & -- \\
\hline & All combined & 29 & 26 & 11 & 0.31 & 0.75 & 5 & 0.84 \\
\hline
\end{tabular}

\section{Sampling Impacts}

Sampling impacts on soil and vegetation conditions depended on the structure of plant communities at ecological sites and the types and amounts of soil crusts that were present. Ecological sites most impacted by our sampling procedures (Desert Sand at Canyonlands, Loamy Mesa Top PJ at Mesa Verde, Semidesert Alkali Sandy Loam at Capitol Reef, Semidesert Loam at Dinosaur, and Semidesert Shallow Sandy Loam at Arches and Canyonlands) were those with biological soil crusts and undifferentiated soil crusts (table 40). At these ecological sites, destabilized soils and trampled biological soil crusts were the most common types of impact. Figure 20 illustrates trampling impacts on soils at Arches National Park and on vegetation at Wupatki National Monument.

Sampling resulted in few broken branches, except at sites where dense shrubs or trees had to be penetrated in order to sample. A slight degree of plant trampling occurred at most ecological sites. Some sites had little sampling impact (Limy Upland at Wupatki, Loamy Hills at Grand Canyon, Shallow Loamy at Wupatki, and Upland Shallow Loam at Capitol Reef) due to low cover of plants and biological soil crusts, and/or due to armoring of soils by cinders or rock.
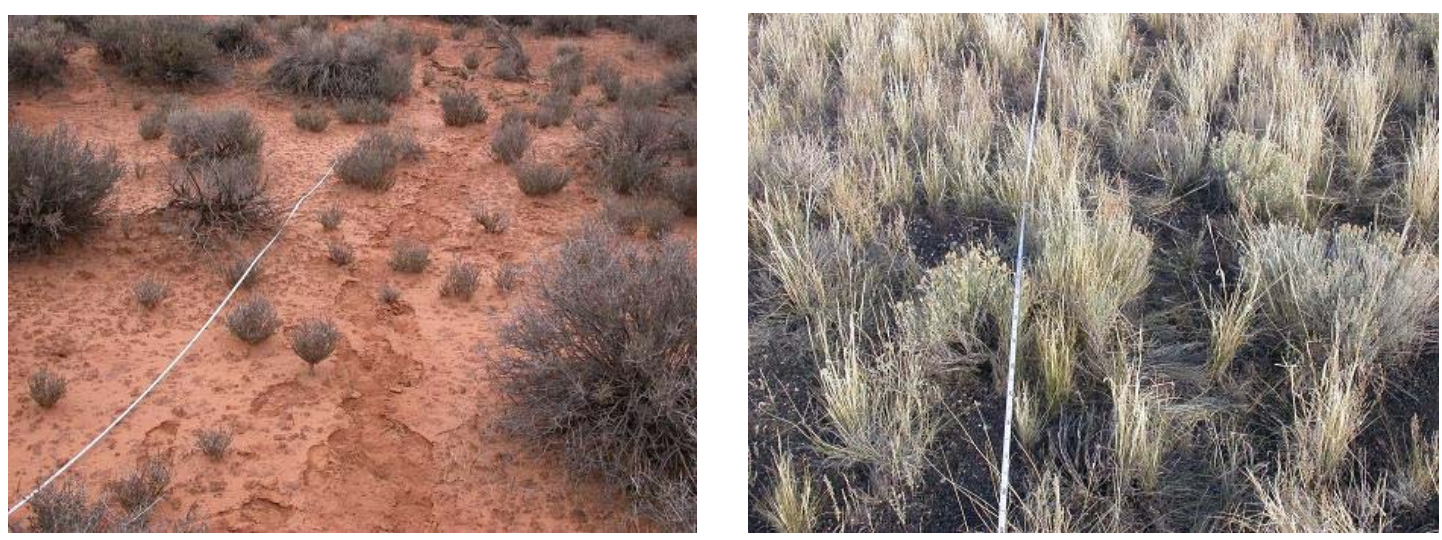

Figure 20. Photograph (left) of destabilized soil and trampled biological soil crusts on unsampled side of transect in Arches National Park (Semidesert Shallow Sandy Loam ecological site), and (right) trampled plants on unsampled side of transect in Wupatki National Monument (Limy Upland ecological site). 
Sampling methods and procedures varied in terms of their impacts on site conditions (table 40). Line-point intercept sampling, 10- $\mathrm{m}^{2}$ quadrat sampling, and gap-intercept sampling nearly always created the most impact, although travel to macroplots caused a large degree of impact where undifferentiated soil crusts and biological soil crusts were trampled while enroute to macroplots located relatively far from roads. Impacts also varied by location (table 41), with greatest impacts along the unsampled side of the transect and least impacts within quadrats. This was most noticeable at sites with extensive undifferentiated soil crusts and biological soil crusts, where trampled foot paths formed along the unsampled side of the transect and around the perimeter of $10-\mathrm{m}^{2}$ quadrats (fig. 20).

\section{Discussion}

\section{Evaluation of Sampling Methods}

A primary objective of this project was to evaluate a suite of sampling methods according to measures of repeatability, efficiency, and impacts on plot conditions across a range of upland ecosystems likely to be monitored in Colorado Plateau NPS units. In this section and in table 42 we summarize results of these evaluations.

\section{Efficiency}

We evaluated the efficiency of cover-estimation techniques on the basis of several measures including per-unit subsampling times, within-plot CV values for total live understory canopy cover, numbers of subsamples and amounts of time required to estimate plot-level cover with 20 percent precision, among-plot $\mathrm{CV}$ values for total live understory cover, numbers of macroplot samples required to estimate site-level cover with 20 percent precision, and numbers of species detected per macroplot and ecological site.

Across all ecological sites combined, we found few unambiguous trends in the efficiency of cover-estimation techniques. The amount of time required to sample cover in one $10-\mathrm{m}^{2}$ quadrat was about twice that required for one 1- $\mathrm{m}^{2}$ quadrat and one 10-pt group of line-point intercepts. On the basis of within-plot $\mathrm{CV}$ values and numbers of subsamples required to estimate total plot-level cover with 20 percent precision, $10-\mathrm{m}^{2}$ quadrats were most efficient and $1-\mathrm{m}^{2}$ quadrats least efficient at 10 and eight of 11 ecological sites, respectively. The line-point technique was most efficient at eight of 11 ecological sites in terms of the amount of time required to estimate total plot-level cover with 20 percent precision - largely because $10-\mathrm{m}^{2}$ quadrats were more time consuming and $1-\mathrm{m}^{2}$ quadrats had greater within-plot variability relative to line-point sampling. Mean quadrat subsampling times were highly influenced by results at two ecological sites, and across all sites there was no statistical difference among methods with respect to median subsampling times for 20 percent precision. We also found no difference among methods with respect to mean and median CV values describing among-plot variability in total live understory cover. Nevertheless, the line-point technique had the lowest among-plot CV values for 7 of 11 ecological sites.

For monitoring objectives requiring the detection of infrequent species, quadrat-based techniques are superior to point-based techniques because of greater areal coverage. For species detection, we found that the relative advantage of $10-\mathrm{m}^{2}$ quadrats over $1-\mathrm{m}^{2}$ quadrats varied among ecological sites. Across all ecological sites, we also found that this detection advantage 
Table 40. Median impact-assessment ratings for procedures at 11 Colorado Plateau ecological sites $(0=$ none, $1=$ slight, $2=$ slight to moderate, $3=$ moderate, $4=$ moderate to extreme, $5=$ extreme). See table 1 for key to ecological site codes.

\begin{tabular}{|c|c|c|c|c|c|c|c|c|c|c|c|}
\hline \multirow[b]{2}{*}{ Procedure } & \multicolumn{11}{|c|}{ Ecological site } \\
\hline & BL & DS & LU & LH & LHC & LMT & SASL & SL & SShSL & ShL & UShL \\
\hline Travel to macroplot & 0 & 2.5 & 1 & 0 & 1 & 2 & 2 & 1 & 1.5 & 0.5 & 1 \\
\hline Site characterization & 0 & 1 & 0 & 0 & 1 & 1 & 1 & 0 & 1 & 0 & 0 \\
\hline Plot establishment & 0 & 1.5 & 0 & 0 & 1 & 2 & 1 & 1 & 2 & 0 & 0 \\
\hline 1- $\mathrm{m}^{2}$ quadrat sampling & 0 & 1 & 0 & 0 & 0 & 0 & 1 & 0 & 1 & 0.5 & 0 \\
\hline 10-m² quadrat sampling & 1 & 2.5 & 1 & 0 & 1 & 2 & 3 & 2 & 3 & 0.5 & 1 \\
\hline Line-point intercept sampling & 0 & 2.5 & 1 & 0 & 1 & 1 & 3 & 1 & 3 & 0.5 & 1 \\
\hline Gap-intercept sampling & 0 & 2 & 0 & 0 & 0 & 0 & 3 & 0 & 2.5 & 0.5 & 0 \\
\hline Pin placement & 0 & 0.5 & 0 & 0 & 0 & 1 & 1 & 0 & 1 & 0 & 0 \\
\hline Cumulative travel on line & 1 & 3 & 1 & 1 & 2 & 4 & 3 & 2 & 3.5 & 0.5 & 1 \\
\hline
\end{tabular}

Table 41. Median impact-assessment ratings for types of impacts (broken branches, trampled plants, destabilized soils, trampled biological soil crusts, and quadrat-frame imprint) in quadrats, on the sampled side of the transect tape, and on the unsampled side of the transect tape at 11 Colorado Plateau ecological sites $(0=$ none, $1=$ slight, $2=$ slight to moderate, $3=$ moderate, $4=$ moderate to extreme, $5=$ extreme). See table 1 for key to ecological site codes.

\begin{tabular}{|c|c|c|c|c|c|c|c|c|c|c|c|c|}
\hline \multirow[b]{2}{*}{ Type of impact } & \multirow[b]{2}{*}{ Impact location } & \multicolumn{11}{|c|}{ Ecological site } \\
\hline & & BL & DS & LU & LH & LHC & LMT & SASL & SL & SShSL & ShL & UShL \\
\hline \multirow{3}{*}{ Broken branches } & In quadrats & 0 & 0 & 0 & 0 & 0 & 0 & 0 & 0 & 0 & 0 & 0 \\
\hline & Sampled side of transect & 0 & 0 & 0 & 0 & 0 & 0 & 0 & 0 & 0 & 0 & 0 \\
\hline & Unsampled side of transect & 0 & 0 & 0 & 0 & 0 & 1 & 0 & 1 & 0 & 0 & 0 \\
\hline \multirow{3}{*}{ Trampled plants } & In quadrats & 0 & 0 & 0 & 0 & 1 & 1 & 1 & 0 & 0 & 0 & 0 \\
\hline & Sampled side of transect & 1 & 0 & 1 & 1 & 1.5 & 1 & 1 & 0 & 0 & 0 & 0 \\
\hline & Unsampled side of transect & 1 & 1 & 1 & 1 & 2 & 1 & 1 & 1 & 0 & 0.5 & 0 \\
\hline \multirow{3}{*}{ Destabilized soils } & In quadrats & 0 & 1 & 0 & 0 & 0 & 2 & 2 & 1 & 1 & 0 & 0 \\
\hline & Sampled side of transect & 1 & 2 & 0 & 0 & 0 & 3 & 2 & 2 & 3 & 0 & 1 \\
\hline & Unsampled side of transect & 1 & 3 & 0 & 0 & 0.5 & 3 & 3 & 2 & 4 & 0 & 1 \\
\hline \multirow{3}{*}{ Trampled BSCs } & In quadrats & 0 & 1 & 0 & 0 & 0 & 1 & 0 & 1 & 0 & 0 & 0 \\
\hline & Sampled side of transect & 0 & 3 & 0 & 0 & 0 & 2 & 1 & 1 & 2 & 0 & 0 \\
\hline & Unsampled side of transect & 0 & 3 & 0 & 0 & 0 & 3 & 1 & 2 & 2 & 0 & 0 \\
\hline Quadrat imprint & In quadrats & 0 & 1 & 0 & 0 & 0 & 1 & 1 & 0 & 1 & 0 & 0 \\
\hline
\end{tabular}


could largely be accounted for by species with 6.7 percent frequency (or less) in $10-\mathrm{m}^{2}$ quadrats. That is, after excluding these very infrequent species from $10-\mathrm{m}^{2}$ quadrat data, we found no difference between 10- and 1- $\mathrm{m}^{2}$ quadrats in terms of mean estimates of site-level species richness.

Table 42. Summary of comparisons among cover-sampling techniques in relation to repeatability between observers, efficiency, and sampling impacts on soils and vegetation ( 0 indicates no clear difference among techniques; -- indicates worst technique[s]; + indicates best technique[s]).

\begin{tabular}{|c|c|c|c|}
\hline \multirow[b]{2}{*}{ Evaluation criteria } & \multicolumn{3}{|c|}{ Cover-sampling technique } \\
\hline & \multirow[t]{2}{*}{$\begin{array}{c}\text { Line-point } \\
\text { intercept }\end{array}$} & \multirow[t]{2}{*}{$\begin{array}{c}1-\mathrm{m}^{2} \\
\text { quadrats }\end{array}$} & \multirow[t]{2}{*}{$\begin{array}{c}10-\mathrm{m}^{2} \\
\text { quadrats }\end{array}$} \\
\hline Efficiency & & & \\
\hline Per-unit subsampling time & + & + & -- \\
\hline Within-plot CV values for total live understory canopy cover & & -- & + \\
\hline $\begin{array}{l}\text { Time to estimate within-plot total live understory canopy cover with } 20 \text { percent } \\
\text { precision }\end{array}$ & + & 0 & 0 \\
\hline Among-plot CV values for total live understory canopy cover & + & 0 & 0 \\
\hline Species detection (all species) & -- & & + \\
\hline Species detection (frequent species) & -- & + & + \\
\hline Repeatability between observers (measurement precision) & 0 & 0 & 0 \\
\hline Sampling impacts on soil and vegetation & -- & + & -- \\
\hline
\end{tabular}

\section{Repeatability}

We found no differences among cover-estimation techniques in terms of observer repeatability (measurement precision). Cover estimates were highly repeatable between observers for $10-\mathrm{m}^{2}$ quadrats, $1-\mathrm{m}^{2}$ quadrats, and line-point intercept sampling methods. Statistically significant differences between observers' cover estimates were found only in three cases: (1) line-point estimates of blackbrush cover at the Semidesert Shallow Sandy Loam PJ ecological site at Arches National Park, (2) line-point and 1-m² quadrat estimates of undifferentiated soil crust at the Upland Shallow Loam ecological site at Capitol Reef National Park, and (3) 10- $\mathrm{m}^{2}$ quadrat estimates of moss cover at the same Upland Shallow Loam ecological site. Differences in blackbrush cover estimates were due to the observers' differing interpretations of line-point intercepts as "standing dead" vs. "live non-photosynthetic." Repeatability in such cases can be improved by ensuring that observers use a standardized decision-making process for determining the status ("standing dead" vs. "live nonphotosynthetic") of plant intercepts. For undifferentiated soil crust and moss cover at the Upland Shallow Loam ecological site, absolute differences in mean cover estimates between observers were low for $1-\mathrm{m}^{2}$ and $10-\mathrm{m}^{2}$ quadrats, respectively (table F2).

Because one member of the two-person field team recorded the other member's cover estimates, repeat sampling events were not fully independent of one another. This was 
particularly true for quadrat-based sampling because repeat events sampled the same quadrat space. However, it is unlikely that this sampling approach significantly affected the results. Although it was easy for the second observer to remember unique or infrequent species detected by the first observer, actual cover estimates could not be easily recalled. Independence of repeat observations was not an issue with line-point sampling, since it is highly improbable that the exact same points were resampled during repeat events. This factor explains why differences between observers' cover estimates tended to be slightly greater for line-point sampling than for quadrat-based sampling (Appendix F).

We found that density measures also were repeatable between observers. Our analyses did not detect significant differences in density estimates between observers for any tree or shrub species. The power of our analyses may have been affected by small sample sizes because counts for many species such as Gambel oak (Quercus gambelii, QUGA) were low $(\mathrm{n}<10)$. Additional data may be necessary for a more robust evaluation of the repeatability of density measures. Some shrubs were extremely difficult to sample for density because of their multistemmed growth habit. Gambel oak in the Brushy Loam ecological site at Mesa Verde was particularly challenging with respect to density sampling. First, it was difficult to classify as either a shrub or a tree. (We consistently called it a tree in this analysis.) Older specimens may have one or a few main stems and can appear "tree like," but younger plants exist as dense, multistemmed shrubs. Second, in the dense shrub form it is extremely difficult to distinguish individual plants or stems as unique counting units. Counting Gambel oak stems in dense stands was tedious and time consuming, sometimes taking longer than 10 minutes per quadrat. It also was time consuming to count high numbers of big sagebrush (Artemisia tridentata, ARTR2) seedlings (up to 474 seedlings in one $10-\mathrm{m}^{2}$ quadrat) encountered at one Semidesert Loam macroplot in Dinosaur National Monument. To facilitate future density sampling in such cases, we recommend the use of 25- or 50-unit counting categories when individual stem counts exceed a threshold value such as 100 per $10-\mathrm{m}^{2}$ quadrat.

\section{Sampling Impacts}

As expected, sampling activities had greatest impacts on soil and vegetation conditions at macroplots where there was a high degree of cover by biological or undifferentiated soil crusts. Impacts occurred primarily on paths on the unsampled sides of transects and around the perimeters of $10-\mathrm{m}^{2}$ quadrats. Of all sampling procedures, $10-\mathrm{m}^{2}$ quadrat sampling, line-point sampling, and gap-intercept sampling had the most impacts. Sampling $10-\mathrm{m}^{2}$ quadrats resulted in foot paths surrounding all sides of the quadrat, although observers could choose and walk paths of least impact when moving from one quadrat location to the next. In contrast, line-point sampling at 50-cm and 1-m intervals and continuous gap-intercept sampling forced observers to trample crusts and plants in a continuous path very close to the tape, allowing little flexibility to minimize trampling impacts. Repeated travel back and forth along transects had the greatest cumulative impacts, but these impacts could be minimized by carefully stepping in previous footprints where possible. Although $1-\mathrm{m}^{2}$ quadrats had the least impacts in this study, impacts would be expected to increase proportionally if sampling objectives required a larger number of subsamples (perhaps placed at smaller intervals along the transect) in order to compensate for the fact that $1-\mathrm{m}^{2}$ quadrats typically had the highest within-plot CV values for total live understory canopy cover. 


\section{Issues Associated with Electronic Data Entry and Management}

As described above, a Pocket PC was used to collect and store data in a database during the field season with the goal of facilitating real-time data analyses and reducing the amount of time required for post-season data entry. When transferred to a desktop computer, the database format provided immediate access and easy manipulation of data for purposes of review during the field season. Ideally, savings realized by eliminating post-season data entry are not offset by time delays attributable to recording data on the hand-held device or by complications associated with computer hardware or software. In reality, there were time costs associated with use of the Pocket PC for data entry, and cumulative technical complications slowed the pace of data collection to such a degree that the number of macroplots sampled over the course of the season was reduced relative to what might have been accomplished in the absence of such complications. Following are several issues encountered over the course of the field season.

1. The database program that we used requires an expert in data management to design the database and to resolve problems which inevitably arise when adopting new techniques. These problems likely will become less significant as sampling and datamanagement protocols are refined, but technical complications always will occur to some degree - requiring contingencies to resolve issues without compromising the quality or quantity of data collected by field teams.

2. Data can be lost from the computer. This can occur from an error in the back-up method, a power outage and subsequent operating system reset, and accidental deletions when the wrong key is pushed. Data loss also can occur while collecting data on paper, but it may be prevented in both cases with adequate safeguards. On the Pocket PC, it must be ensured that the field crew is properly trained in back-up procedures and is diligent and careful while recording data. During the 2005 field season, a back-up error caused data for an entire macroplot (Capitol Reef, Phase 2) to be lost - requiring that the plot be resampled in its entirety during a subsequent visit to the park. Because of the potential for power loss, system resets, and data loss, we recommend that future field crews be equipped with a laptop computer with a backup copy of the most recent database, connection cables, and CDs for software that may need to be reloaded on the hand-held. The likelihood of data loss also may be minimized in the future by ensuring that the field crew has multiple batteries and reliable procedures for charging batteries in remote settings.

3. Computer-based methods require training time for field crews. This may require only a couple of days to initially learn the programs and procedures, but there also is a certain amount of comfort and speed only obtained after weeks or months of sampling. During the 2005 season, the field crew was still becoming familiar with operation of the Pocket PC two-thirds of the way through the field season.

4. The actual time required to enter data with the Pocket PC while in the field is dependent upon several factors - the memory capacity and processor speed of the hand-held computer, the size (thus speed) of the program in relation to memory capacity, the size of the dataset, and the design of data-entry forms (e.g., the length of drop-down menus and pick-lists). When data were recorded by hand in field books during the 2005 season, sampling proceeded at a pace 10-20 percent faster than when using the Pocket PC. Excessive file size (i.e., running the PocketAccess database with all data accumulated during the entire field season) and long pick-lists were 
major factors slowing data entry with the Pocket PC. When procedures were modified to address these factors, the pace of sampling increased considerably.

5. When data are collected on paper due to technical issues with the Pocket PC, entry of data into the database in the office can be very time consuming. Data entry in the office was very slow because data entry forms were designed specifically for the small, Pocket PC format using Sprint DB Pro interface software. In the future we recommend that alternative data entry forms (e.g., in Microsoft Access) be developed to facilitate direct entry of data into the project database when necessary.

6. Data transfers between the Pocket PC and a desktop computer can be time consuming, particularly if the system is designed so that all accumulated data must be transferred during each synchronization event. We recommend that systems be designed so that a minimum amount of data must be transferred between the Pocket $\mathrm{PC}$ and the desktop during synchronization.

Overall, the Pocket PC did provide data accessibility more quickly than had the crew recorded and entered data by hand, in spite of the various technical challenges that were encountered. However, the pace of field work delayed quality-assurance work until after the end of the field season. As a result, "real-time" data analyses were hampered by various issues (e.g., mislabeled data, missing data, consistency in species identification and naming across plots) that could not be fully resolved until data collection was completed. The handheld computer seemed to withstand the rigors of fieldwork, and it promises to be a useful tool for facilitating the collection and management of large data sets.

\section{References Cited}

Creque, J. A., S. D. Bassett, and N. E. West. 1999. Viewpoint: Delineating ecological sites. Journal of Range Management 52: 546-549.

Herrick, J. E., J. W. Van Zee, K. M. Havstad, L. M. Burkett, and W. G. Whitford. 2005. Monitoring manual for grassland, shrubland and savanna ecosystems. Volume I: Quick start. Las Cruces, NM: USDA-ARS Jornada Experimental Range. 36 p.

McCune, B. and M. J. Mefford. 1999. PC-ORD. Multivariate Analysis of Ecological Data. Version 4.34. Gleneden Beach, OR: MjM Software.

McCune, B. P., and J. B. Grace. 2002. Analysis of ecological communities. Gleneden Beach, OR: MjM Software Design. 300 p.

NPS (U.S.D.I. National Park Service). 2003. Fire monitoring handbook. Boise, ID: Fire Management Program Center, National Interagency Fire Center. 274 p.

NRCS (U.S.D.A. Natural Resources Conservation Service). 2001a. Soil survey of Cortez Area, Colorado, parts of Dolores and Montezuma counties. Denver: U.S. Department of Agriculture, Natural Resources Conservation Service. 627 p.

NRCS (U.S.D.A. Natural Resources Conservation Service). 2001b. Soil survey of Dinosaur National Monument, Colorado and Utah. Denver: U.S. Department of Agriculture, Natural Resources Conservation Service. 381 p.

NRCS (U.S.D.A. Natural Resources Conservation Service). 2003. Soil survey of Grand Canyon area, Arizona, parts of Coconino and Mohave counties. Phoenix: U.S. Department of Agriculture, Natural Resources Conservation Service. 602 p.

NRCS (U.S.D.A. Natural Resources Conservation Service). 2004. Draft soil survey report for Capitol Reef National Park (soil survey area UT685). Salt Lake City: U.S. Department of Agriculture, Natural Resources Conservation Service. 389 p. 
Schoeneberger, P. J., D. A. Wysocki, E. C. Benham, and W. D. Broderson, eds. 2002. Field book for describing and sampling soils, version 2.0. U.S. Department of Agriculture, Natural Resources Conservation Service, National Soil Survey Center, Lincoln, NE.

SCS (U.S.D.A. Soil Conservation Service). 1983. Soil survey of Coconino County, Azizona, central part. Phoenix: U.S. Department of Agriculture, Natural Resources Conservation Service. 212 p.

SCS (U.S.D.A. Soil Conservation Service). 1989. Soil survey of Grand County, Utah, central part. Salt Lake City: U.S. Department of Agriculture, Natural Resources Conservation Service. 200 p.

SCS (U.S.D.A. Soil Conservation Service). 1991. Soil survey of Canyonlands area, Utah, parts of Grand and San Juan counties. Salt Lake City: U.S. Department of Agriculture, Natural Resources Conservation Service. 293 p.

SRM Task Group (Society for Range Management Task Group on Unity in Concepts and Terminology Committee). 1995. New concepts for assessment of rangeland condition. Journal of Range Management 48: 271-282.

StatSoft, Inc. 2004. STATISTICA (data analysis software system), version 6. www.statsoft.com. Zar, J. H. 1999. Biostatistical analysis. Fourth edition. Upple Saddle River, NJ: Prentice Hall. $663 \mathrm{p}$. 


\section{Appendix A-Species List and Species Occurrence by Ecological Site}

[Species codes are from the U.S. Department of Agriculture, Natural Resources Conservation Service, PLANTS database (http://plants.usda.gov, June 2005), National Plant Data Center, Baton Rouge, LA 70874-4490 USA.

\begin{tabular}{|c|c|c|c|c|c|c|c|c|c|c|c|c|c|}
\hline Species code & Species name & Family name & 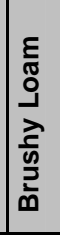 & 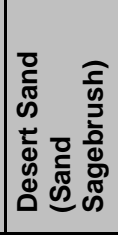 & 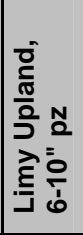 & 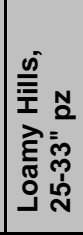 & 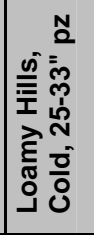 & 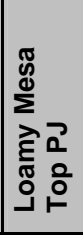 & 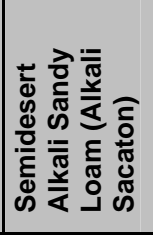 & 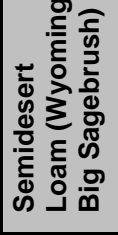 & 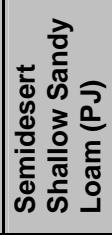 & 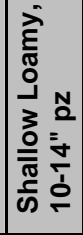 & 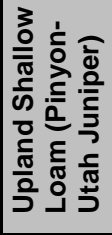 \\
\hline $\mathrm{ABCO}$ & Abies concolor & Pinaceae & & & & $\mathrm{x}$ & $\mathrm{X}$ & & & & & & \\
\hline ABFR2 & Abronia fragrans & Nyctaginaceae & & $X$ & & & & & & & & & \\
\hline$A B L A$ & Abies lasiocarpa & Pinaceae & & & & $x$ & $\mathrm{X}$ & & & & & & \\
\hline $\mathrm{ACHY}$ & Achnatherum hymenoides & Poaceae & & & $\mathrm{x}$ & & & & & & & $\mathrm{X}$ & \\
\hline ACMI2 & Achillea millefolium & Asteraceae & $X$ & & & $\mathrm{x}$ & $\mathrm{X}$ & & & & & & \\
\hline AGCR & Agropyron cristatum & Poaceae & $x$ & & & & & & & & & & \\
\hline AGSM & Agropyron smithii & Poaceae & & & & & & & & $x$ & & & \\
\hline ALAC4 & Allium acuminatum & Liliaceae & $x$ & & & & & & & & & & \\
\hline AMAC2 & Ambrosia acanthicarpa & Asteraceae & & & & & & & $x$ & & & & \\
\hline AMUT & Amelanchier utahensis & Rosaceae & $X$ & & & & & & & & & & $\mathrm{X}$ \\
\hline ANPA5 & Antennaria parvifolia & Asteraceae & & & & $x$ & $x$ & & & & & & \\
\hline ARBI3 & Artemisia bigelovii & Asteraceae & $\mathrm{X}$ & & & & & & $x$ & & $\mathrm{x}$ & & \\
\hline ARDR4 & Artemisia dracunculus & Asteraceae & $x$ & & & & & & $x$ & & & & \\
\hline ARFI2 & Artemisia filifolia & Asteraceae & & & & & & & $\mathrm{x}$ & & $\mathrm{X}$ & & \\
\hline ARNO4 & Artemisia nova & Asteraceae & & & & & & & & & $\mathrm{x}$ & & \\
\hline ARPU9 & Aristida purpurea & Poaceae & & $\mathrm{x}$ & $\mathrm{X}$ & & & & & & & & \\
\hline ARTR2 & Artemisia tridentata & Asteraceae & & & & & & $x$ & $\mathrm{x}$ & $\mathrm{X}$ & & & \\
\hline ASMA10 & Asclepias macrosperma & Asclepiadaceae & & & & & & & & & $x$ & & \\
\hline ASMO7 & Astragalus mollissimus & Fabaceae & & & & & & & & $\mathrm{x}$ & $\mathrm{X}$ & & \\
\hline ATCA2 & Atriplex canescens & Chenopodiaceae & & $\mathrm{X}$ & & & & & $\mathrm{x}$ & $\mathrm{X}$ & $\mathrm{x}$ & $\mathrm{X}$ & \\
\hline ATCO & Atriplex confertifolia & Chenopodiaceae & & & & & & & $x$ & $x$ & & & \\
\hline BASA3 & Balsamorhiza sagittata & Asteraceae & $X$ & & & & & & & & & & \\
\hline BEFR & Berberis fremontii & Berberidaceae & & & & & & & & & & & $\mathrm{X}$ \\
\hline $\mathrm{BOCU}$ & Bouteloua curtipendula & Poaceae & & & $\mathrm{X}$ & & & & & & & & \\
\hline BOER4 & Bouteloua eriopoda & Poaceae & & & $\mathrm{X}$ & & & & $\mathrm{x}$ & & & $x$ & \\
\hline BOGR2 & Bouteloua gracilis & Poaceae & & & $\mathrm{x}$ & & & & $x$ & & & & \\
\hline BRIN2 & Bromus inermis & Poaceae & & & & $x$ & $\mathrm{x}$ & & $X$ & & & & \\
\hline
\end{tabular}




\begin{tabular}{|c|c|c|c|c|c|c|c|c|c|c|c|c|c|}
\hline Species code & Species name & Family name & 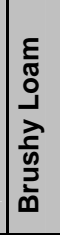 & 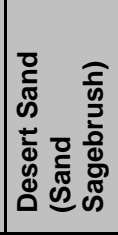 & 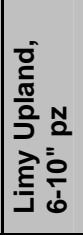 & 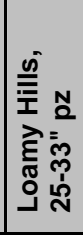 & 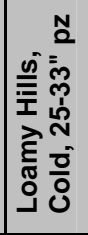 & 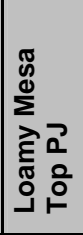 & 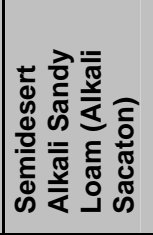 & 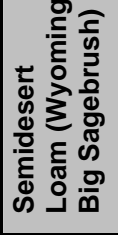 & 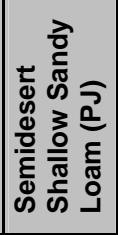 & 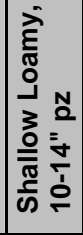 & 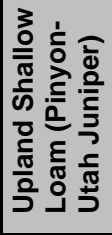 \\
\hline BRTE & Bromus tectorum & Poaceae & $\mathrm{X}$ & $\mathrm{X}$ & $\mathrm{X}$ & $\mathrm{X}$ & & $\mathrm{X}$ & $\mathrm{x}$ & $\mathrm{X}$ & $\mathrm{X}$ & & $\mathrm{X}$ \\
\hline CANU3 & Calochortus nuttallii & Liliaceae & $\mathrm{X}$ & & & & & $x$ & & $\mathrm{x}$ & $\mathrm{X}$ & & \\
\hline CANU4 & Carduus nutans & Asteraceae & $\mathrm{X}$ & & & & & $\mathrm{x}$ & & & & & \\
\hline CEMO2 & Cercocarpus montanus & Rosaceae & $\mathrm{X}$ & & & & & & & & & & $\mathrm{X}$ \\
\hline CELA4 & Ceratoides lanata & Chenopodiaceae & & $x$ & & & & & $x$ & $\mathrm{x}$ & & & \\
\hline CHAL7 & Chenopodium album & Chenopodiaceae & $\mathrm{X}$ & $\mathrm{X}$ & & $\mathrm{x}$ & & $\mathrm{x}$ & $\mathrm{x}$ & & $\mathrm{x}$ & & $x$ \\
\hline CHLE4 & Chenopodium leptophyllum & Chenopodiaceae & $\mathrm{X}$ & & $\mathrm{X}$ & & & $\mathrm{x}$ & $\mathrm{x}$ & $\mathrm{x}$ & & $\mathrm{X}$ & \\
\hline CHNA2 & Chrysothamnus nauseosus & Asteraceae & & & $x$ & & & & $x$ & $x$ & & $\mathrm{x}$ & \\
\hline CHST & Chaenactis stevioides & Asteraceae & & $\mathrm{X}$ & & & & & $\mathrm{x}$ & & $\mathrm{X}$ & & \\
\hline $\mathrm{CHVI8}$ & Chrysothamnus viscidiflorus & Asteraceae & $\mathrm{X}$ & & & & & & & & $\mathrm{X}$ & & $\bar{x}$ \\
\hline COME5 & Cowania mexicana & Rosaceae & & & & & & & & & & & $\mathrm{X}$ \\
\hline CORA & Coleogyne ramosissima & Rosaceae & & $x$ & & & & & & & $\mathrm{X}$ & & \\
\hline COUM & Comandra umbellata & Santalaceae & $\mathrm{X}$ & & & & & & & & & & \\
\hline COWR2 & Cordylanthus wrightii & Scrophulariaceae & & & & & & $x$ & $x$ & & $\mathrm{x}$ & & $x$ \\
\hline $\mathrm{CRCl} 3$ & Cryptantha cinerea & Boraginaceae & & & $\mathrm{X}$ & & & & & & & $\mathrm{X}$ & \\
\hline CRFL5 & Cryptantha flava & Boraginaceae & & & & & & & & & & & $\mathrm{X}$ \\
\hline DAFL & Dalea flavescens & Fabaceae & & & & & & & & & $\mathrm{X}$ & & \\
\hline DEPI & Descurainia pinnata & Brassicaceae & $x$ & & $x$ & & & $\mathrm{X}$ & $x$ & $x$ & $x$ & $\mathrm{X}$ & $\mathrm{X}$ \\
\hline ELEL5 & Elymus elymoides & Poaceae & $\mathrm{X}$ & & $x$ & $x$ & $x$ & $x$ & & & $x$ & $\mathrm{X}$ & \\
\hline EPAN & Epilobium angustifolium & Onagraceae & & & & $\mathrm{x}$ & & & & & & & \\
\hline EPVI & Ephedra viridis & Ephedraceae & & $\mathrm{X}$ & & & & & & & $x$ & $x$ & $x$ \\
\hline ERCE2 & Eriogonum cernuum & Polygonaceae & & $x$ & & & & & $x$ & $x$ & $x$ & & $x$ \\
\hline ERCO14 & Eriogonum corymbosum & Polygonaceae & & & & & & & & & $\mathrm{X}$ & & \\
\hline ERFO3 & Erigeron formosissimus & Asteraceae & & & & & $x$ & & & & & & \\
\hline ERIN4 & Eriogonum inflatum & Polygonaceae & & & & & & & $x$ & & $x$ & & \\
\hline ERMI4 & Eriogonum microthecum & Polygonaceae & & & & & & & & & $x$ & & $x$ \\
\hline ERUM & Eriogonum umbellatum & Polygonaceae & $x$ & & & & & $x$ & & & & & \\
\hline ESVI2 & Escobaria vivipara & Cactaceae & & & & & & $\mathrm{X}$ & & & & & \\
\hline EUFE2 & Euphorbia fendleri & Euphorbiaceae & & & & & & & & & $x$ & & \\
\hline FEOC3 & Festuca octoflora & Poaceae & & $x$ & & & & & & & $\bar{x}$ & & \\
\hline FERU & Fendlera rupicola & Hydrangeaceae & $x$ & & & & & & & & & & \\
\hline FRAN2 & Fraxinus anomala & Oleaceae & & & & & & & & & $\mathrm{X}$ & & $\mathrm{X}$ \\
\hline
\end{tabular}




\begin{tabular}{|c|c|c|c|c|c|c|c|c|c|c|c|c|c|}
\hline Species code & Species name & Family name & 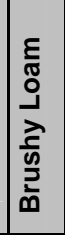 & 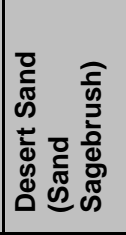 & 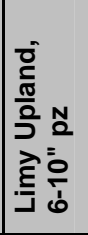 & 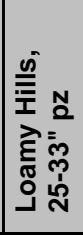 & 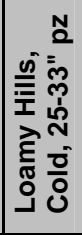 & 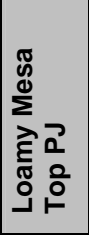 & 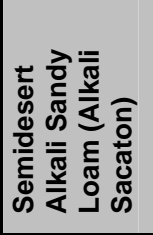 & 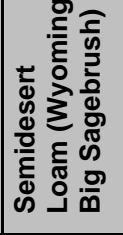 & 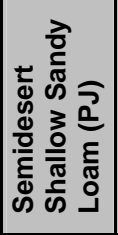 & 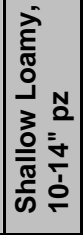 & 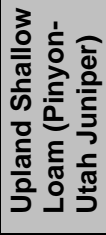 \\
\hline FRVI & Fragaria virginiana & Rosaceae & & & & $\mathrm{X}$ & $\mathrm{X}$ & & & & & & \\
\hline GACO5 & Gaura coccinea & Onagraceae & & & & & & & & & & $\mathrm{X}$ & \\
\hline GAPI & Gaillardia pinnatifida & Asteraceae & & $\mathrm{X}$ & & & & & & & & & \\
\hline GECA3 & Geranium caespitosum & Geraniaceae & & & & $\mathrm{X}$ & $\mathrm{x}$ & & & & & & \\
\hline GIIN2 & Gilia inconspicua & Polemoniaceae & & & $x$ & & & & $\mathrm{X}$ & $\mathrm{X}$ & $x$ & $\mathrm{X}$ & $x$ \\
\hline GOOB2 & Goodyera oblongifolia & Orchidaceae & & & & $x$ & $\mathrm{X}$ & & & & & & \\
\hline GUSA2 & Gutierrezia sarothrae & Asteraceae & & & & & & $\mathrm{X}$ & $\mathrm{x}$ & $\mathrm{x}$ & $\mathrm{X}$ & $\mathrm{X}$ & $\mathrm{X}$ \\
\hline HAGL & Halogeton glomeratus & Chenopodiaceae & & & & & & & $x$ & & & & \\
\hline HECO26 & Hesperostipa comata & Poaceae & $\mathrm{x}$ & & & & & $\mathrm{X}$ & & & & & \\
\hline HENE5 & Hesperostipa neomexicana & Poaceae & & & $\bar{x}$ & & & & & & & $\bar{x}$ & \\
\hline HIJA & Hilaria jamesii & Poaceae & & $\mathrm{X}$ & & & & & $\bar{x}$ & $\bar{x}$ & $\bar{X}$ & & $\bar{x}$ \\
\hline HYAC4 & Hymenoxys acaulis & Asteraceae & & & & & & & & & $\mathrm{x}$ & & \\
\hline IPAG & Ipomopsis aggregata & Polemoniaceae & $\mathrm{X}$ & & & & & & & & & & \\
\hline JUCO6 & Juniperus communis & Cupressaceae & & & & $\mathrm{X}$ & $x$ & & & & & & \\
\hline JUMO & Juniperus monosperma & Cupressaceae & & & $\mathrm{x}$ & & & & & & & $\bar{x}$ & \\
\hline JUOS & Juniperus osteosperma & Cupressaceae & $\mathrm{X}$ & & & & & $\mathrm{X}$ & & $\mathrm{X}$ & $\mathrm{X}$ & & $\mathrm{X}$ \\
\hline KOMA & Koeleria macrantha & Poaceae & $\mathrm{x}$ & & & & & $\mathrm{x}$ & & & & & \\
\hline LAOC3 & Lappula occidentalis & Boraginaceae & & $x$ & $x$ & & & $x$ & $x$ & $x$ & $x$ & & \\
\hline LARE & Lappula redowskii & Boraginaceae & & & & & & & & $x$ & & & \\
\hline LASE & Lactuca serriola & Asteraceae & & & & & & & & $\mathrm{X}$ & & & \\
\hline LATA & Lactuca tatarica & Asteraceae & $x$ & & & & & $x$ & & & & & \\
\hline LEMO2 & Lepidium montanum & Brassicaceae & & & & & & & & & $x$ & & \\
\hline LEPE2 & Lepidium perfoliatum & Brassicaceae & & & & & & $\mathrm{X}$ & & & $\mathrm{X}$ & & \\
\hline LEPU & Leptodactylon pungens & Polemoniaceae & & & & & & $x$ & & $x$ & & & \\
\hline LIAR3 & Linum aristatum & Linaceae & & $\mathrm{X}$ & & & & & $\mathrm{x}$ & & & & \\
\hline LUAR3 & Lupinus argenteus & Fabaceae & & & & $\mathrm{x}$ & & & & & & & \\
\hline LUCA & Lupinus caudatus & Fabaceae & $\mathrm{x}$ & & & & & $\mathrm{X}$ & & & & & \\
\hline MACA2 & Machaeranthera canescens & Asteraceae & & $\mathrm{X}$ & & & & & $x$ & & & & \\
\hline MAFR3 & Mahonia fremontii & Berberidaceae & & & & & & & & & $\bar{X}$ & & \\
\hline MARE11 & Mahonia repens & Berberidaceae & $\mathrm{x}$ & & & $\bar{x}$ & $\mathrm{x}$ & & & & & & \\
\hline MATA2 & Machaeranthera tanacetifolia & Asteraceae & & & & & & & $x$ & & & & \\
\hline MEAL6 & Mentzelia albicaulis & Loasaceae & & $\mathrm{X}$ & $\mathrm{X}$ & & & & $\mathrm{x}$ & & $\mathrm{X}$ & $x$ & \\
\hline
\end{tabular}




\begin{tabular}{|c|c|c|c|c|c|c|c|c|c|c|c|c|c|}
\hline Species code & Species name & Family name & 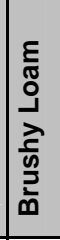 & 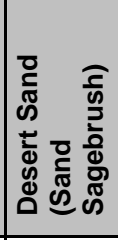 & 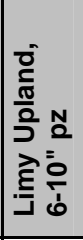 & 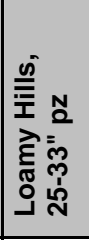 & 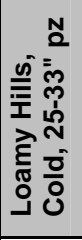 & 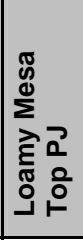 & 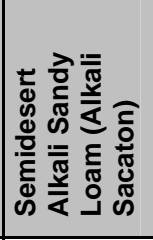 & 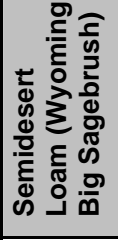 & 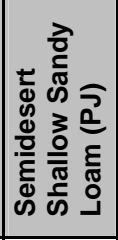 & 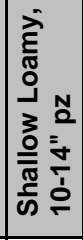 & 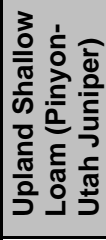 \\
\hline MUSQ & Munroa squarrosa & Poaceae & & & & & & & $\mathrm{X}$ & & & & \\
\hline OECE2 & Oenothera cespitosa & Onagraceae & & & & & & & $\mathrm{X}$ & & $\mathrm{X}$ & & \\
\hline OEPA & Oenothera pallida & Onagraceae & & $x$ & & & & & $x$ & & & & \\
\hline OPER & Opuntia erinacea & Cactaceae & & & $x$ & & & $x$ & $x$ & $x$ & $\mathrm{X}$ & $x$ & \\
\hline OPPO & Opuntia polyacantha & Cactaceae & & $\mathrm{X}$ & & & & & & & $x$ & & \\
\hline ORHY & Oryzopsis hymenoides & Poaceae & & & & & & & $\mathrm{X}$ & $x$ & & & $x$ \\
\hline PAMY & Paxistima myrsinites & Celastraceae & $x$ & & & & & & & & & & \\
\hline PASM & Pascopyrum smithii & Poaceae & $x$ & & & & & & & & & & \\
\hline PEPU7 & Petradoria pumila & Asteraceae & $\mathrm{x}$ & & & & & $x$ & & & $x$ & & $x$ \\
\hline PHCR & Phacelia crenulata & Hydrophyllaceae & & & $\mathrm{X}$ & & & & $x$ & & $x$ & & \\
\hline PHHE2 & Phacelia heterophylla & Hydrophyllaceae & $\mathrm{X}$ & & & & & & & & & & \\
\hline PIED & Pinus edulis & Pinaceae & $\mathrm{x}$ & & & & $x$ & $x$ & & & $\mathrm{X}$ & & $\mathrm{X}$ \\
\hline PIEN & Picea engelmannii & Pinaceae & & & & $x$ & $x$ & & & & & & \\
\hline PIPO & Pinus ponderosa & Pinaceae & & & & $\mathrm{x}$ & $x$ & & & & & & \\
\hline PLJA & Pleuraphis jamesii & Poaceae & & & $x$ & & & & & & & $\mathrm{x}$ & \\
\hline PLPA2 & Plantago patagonica & Plantaginaceae & & $\mathrm{X}$ & & & & & $\mathrm{X}$ & $\mathrm{X}$ & $x$ & & \\
\hline POFE & Poa fendleriana & Poaceae & $x$ & & & $x$ & $\mathrm{X}$ & $x$ & & & $x$ & & $x$ \\
\hline POSA12 & Poa sandbergii & Poaceae & & & & & & & & & & & $\mathrm{x}$ \\
\hline POSE & Poa secunda & Poaceae & & & & & & & & $\mathrm{X}$ & & & \\
\hline POTR5 & Populus tremuloides & Salicaceae & & & & $\mathrm{X}$ & $x$ & & & & & & \\
\hline PSME & Pseudotsuga menziesii & Pinaceae & & & & $\bar{x}$ & $x$ & & & & & & \\
\hline PSSP & Psilostrophe sparsiflora & Asteraceae & & & $\mathrm{X}$ & & & & & & & & \\
\hline PTAQ & Pteridium aquilinum & Dennstaedtiaceae & & & & $\mathrm{x}$ & $\mathrm{x}$ & & & & & & \\
\hline PUME & Purshia mexicana & Rosaceae & & & & & & & & & $\mathrm{X}$ & & $\mathrm{X}$ \\
\hline PUTR2 & Purshia tridentata & Rosaceae & $x$ & & & & & $\mathrm{X}$ & & & & & $\mathrm{x}$ \\
\hline $\mathrm{PYCH}$ & Pyrola chlorantha & Pyrolaceae & & & & $x$ & $x$ & & & & & & \\
\hline QUGA & Quercus gambelii & Fagaceae & $x$ & & & & & & & & & & \\
\hline RATE & Ranunculus testiculatus & Ranunculaceae & & & & & & $x$ & & $\bar{X}$ & $\mathrm{X}$ & & \\
\hline SAIB & Salsola iberica & Chenopodiaceae & & & & & & & $x$ & $\mathrm{X}$ & & & \\
\hline SAKA & Salsola kali & Chenopodiaceae & & & $x$ & & & & & & & $x$ & \\
\hline SAPA8 & Salsola paulsenii & Chenopodiaceae & & $\mathrm{X}$ & & & & & $\mathrm{X}$ & & & & \\
\hline SAPE10 & Salsola pestifer & Chenopodiaceae & & $x$ & & & & & & & $X$ & & \\
\hline
\end{tabular}




\begin{tabular}{|c|c|c|c|c|c|c|c|c|c|c|c|c|c|}
\hline Species code & Species name & Family name & 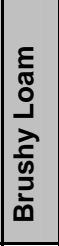 & 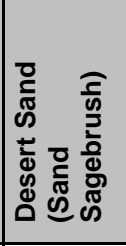 & 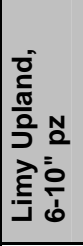 & 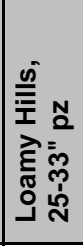 & 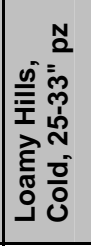 & 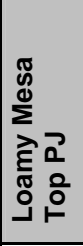 & 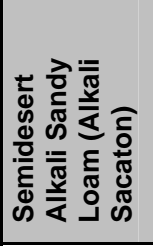 & 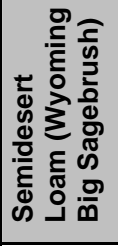 & 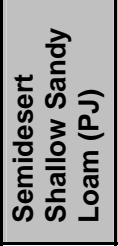 & 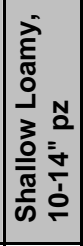 & 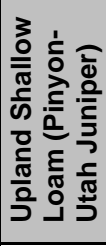 \\
\hline SAVE4 & Sarcobatus vermiculatus & Chenopodiaceae & & & & & & & $\mathrm{X}$ & $\mathrm{X}$ & & & \\
\hline $\mathrm{SCWH}$ & Sclerocactus whipplei & Cactaceae & & & & & & & & & $\mathrm{X}$ & & \\
\hline SEMU3 & Senecio multilobatus & Asteraceae & & & & $x$ & $x$ & $x$ & & & $\mathrm{x}$ & & \\
\hline SHRO & Shepherdia rotundifolia & Elaeagnaceae & & & & & & & & & & & $x$ \\
\hline SIAL2 & Sisymbrium altissimum & Brassicaceae & $\mathrm{X}$ & & & & & & & $x$ & & & \\
\hline SIHY & Sitanion hystrix & Poaceae & & & & & & & $x$ & $x$ & & & $\mathrm{x}$ \\
\hline SISC7 & Silene scouleri & Caryophyllaceae & & & & & $\mathrm{x}$ & & & & & & \\
\hline SPAI & Sporobolus airoides & Poaceae & & & $x$ & & & & $x$ & & & $x$ & \\
\hline SPCO & Sphaeralcea coccinea & Malvaceae & $x$ & $\mathrm{X}$ & & & & $x$ & $\mathrm{X}$ & $\mathrm{x}$ & $\mathrm{X}$ & & \\
\hline SPCO4 & Sporobolus contractus & Poaceae & & & & & & & $x$ & & & & \\
\hline SPCR & Sporobolus cryptandrus & Poaceae & & & & & & & $x$ & & & & \\
\hline SPGR2 & Sphaeralcea grossulariifolia & Malvaceae & & $\mathrm{X}$ & & & & & & & & & \\
\hline SPHA & Sphaeralcea hastulata & Malvaceae & & & $\mathrm{X}$ & & & & & & & & \\
\hline SPPA2 & Sphaeralcea parvifolia & Malvaceae & & & $x$ & & & & $x$ & & & $x$ & \\
\hline STCO4 & Stipa comata & Poaceae & & & & & & & & $\mathrm{X}$ & & & \\
\hline STEX & Stephanomeria exigua & Asteraceae & & $\mathrm{X}$ & & & & & & & $\mathrm{X}$ & & \\
\hline STHY6 & Stipa hymenoides & Poaceae & & $\bar{X}$ & & & & $\mathrm{X}$ & & & $\bar{X}$ & & \\
\hline STLO4 & Streptanthella longirostris & Brassicaceae & $\mathrm{X}$ & $\bar{X}$ & & & & $\mathrm{x}$ & $\mathrm{X}$ & $\mathrm{X}$ & $\mathrm{x}$ & & \\
\hline STPI & Stanleya pinnata & Brassicaceae & & & & & & & & & & $\mathrm{X}$ & $x$ \\
\hline SYOR2 & Symphoricarpos oreophilus & Caprifoliaceae & $\mathrm{X}$ & & & $\mathrm{X}$ & & & & & & & \\
\hline TESP2 & Tetradymia spinosa & Asteraceae & & & & & & & $x$ & & & & \\
\hline THFE & Thalictrum fendleri & Ranunculaceae & & & & $\mathrm{X}$ & & & & & & & \\
\hline THSU & Thelesperma subnudum & Asteraceae & & & & & & & $x$ & & & & \\
\hline TOAN & Townsendia annua & Asteraceae & & $\mathrm{x}$ & & & & & & & & & \\
\hline UNGRCA1 & unkGRCA1 (Carex sp.) & Cyperaceae & & & & $x$ & $\mathrm{x}$ & & & & & & \\
\hline VUOC & Vulpia octoflora & Poaceae & & & & & & & $x$ & $\mathrm{X}$ & & & \\
\hline WYAR & Wyethia arizonica & Asteraceae & $\mathrm{X}$ & & & & & & & & & & \\
\hline YUBA & Yucca baccata & Agavaceae & $x$ & & & & & $x$ & & & $\mathrm{X}$ & & \\
\hline YUHA & Yucca harrimaniae & Agavaceae & & & & & & & & & $\mathrm{X}$ & & \\
\hline ZIGR & Zinnia grandiflora & Asteraceae & & & $x$ & & & & & & & & \\
\hline ZIPA2 & Zigadenus paniculatus & Liliaceae & & & & & & & & $x$ & $\mathrm{X}$ & & \\
\hline
\end{tabular}




\section{Appendix B-Within-Macroplot Variability of Cover Estimates by Sampling Technique and Ecological Site}

\begin{tabular}{|l|c|c|}
\hline Ecological site & Table & Page \\
\hline Brushy Loam & B1 & 67 \\
\hline Desert Sand (Sand Sagebrush) & B2 & 68 \\
\hline Limy Upland, 6-10" pz & B3 & 69 \\
\hline Loamy Hills, 25-33" pz & B4 & 70 \\
\hline Loamy Hills, Cold, 25-33" pz & B5 & 71 \\
\hline Loamy Mesa Top PJ & B6 & 72 \\
\hline Semidesert Alkali Sandy Loam (Alkali Sacaton) & B7 & 73 \\
\hline Semidesert Loam (Wyoming Big Sagebrush) & B8 & 74 \\
\hline Semidesert Shallow Sandy Loam PJ & B9 & 75 \\
\hline Shallow Loamy, 10-14" pz & B10 & 76 \\
\hline Upland Shallow Loam (Pinyon-Utah Juniper) & B11 & 77 \\
\hline
\end{tabular}


Table B1. Summary of mean cover estimates for selected cover measures across five Brushy Loam macroplots at Mesa Verde National Park, within-macroplot variation in cover estimates summarized across macroplots, subsample sizes required to achieve 10 and 20 percent precision in estimates of macroplot-level means, and estimated amounts of sampling time required to achieve those degrees of precision. See Appendix $C$ for macroplot-level tables summarizing within-plot variability. See Appendix A for key to species codes (BSC = biological soil crust).

\begin{tabular}{|c|c|c|c|c|c|c|c|c|c|c|c|c|}
\hline \multicolumn{13}{|c|}{ Brushy Loam ecological site, $n=5$ macroplots } \\
\hline \multirow[b]{2}{*}{ Measure } & \multirow[b]{2}{*}{ Method } & \multirow[b]{2}{*}{$\begin{array}{l}\text { Mean } \\
\text { cover }\end{array}$} & \multicolumn{5}{|c|}{$\begin{array}{c}\text { Within-macroplot variation in cover estimates } \\
\text { (summarized across macroplots) }\end{array}$} & \multicolumn{2}{|c|}{$\begin{array}{l}\text { Subsample size } \\
\text { (by precision) }\end{array}$} & \multirow[b]{2}{*}{$\begin{array}{l}\text { Unit time } \\
\text { (min) }\end{array}$} & \multicolumn{2}{|c|}{$\begin{array}{l}\text { Subsample time } \\
\text { (hrs by precision) }\end{array}$} \\
\hline & & & Mean sd & Min sd & Max sd & $\begin{array}{l}\text { Mean } \\
\text { freq* }\end{array}$ & Mean CV & $10 \%$ & $20 \%$ & & $10 \%$ & $20 \%$ \\
\hline \multirow{3}{*}{$\begin{array}{c}\text { Total live } \\
\text { understory } \\
\text { canopy } \\
\text { cover }\end{array}$} & $10-m^{2}$ & 49.7 & 18.1 & 7.4 & 24.0 & 100.0 & 36.5 & 54 & 16 & 12.3 & 11.1 & 3.3 \\
\hline & $1-\mathrm{m}^{2}$ & 43.4 & 26.2 & 10.8 & 37.3 & 100.0 & 60.1 & 143 & 38 & 5.5 & 13.1 & 3.5 \\
\hline & Line-point & 52.8 & 23.7 & 16.4 & 33.2 & 98.7 & 45.5 & 81 & 22 & 5.0 & 6.8 & 1.8 \\
\hline \multirow[b]{3}{*}{ AMUT } & $10-m^{2}$ & 6.5 & 10.9 & 4.5 & 18.7 & 56.8 & 205.5 & 1077 & 270 & 12.3 & 220.8 & 55.4 \\
\hline & $1-m^{2}$ & 3.2 & 9.2 & 0.4 & 22.3 & 25.3 & 259.7 & 3216 & 804 & 5.5 & 294.8 & 73.7 \\
\hline & Line-point & 5.2 & 9.2 & 2.6 & 15.4 & 26.7 & 227.7 & 1198 & 300 & 5.0 & 99.8 & 25.0 \\
\hline \multirow[b]{3}{*}{ POFE } & $10-m^{2}$ & 9.6 & 8.8 & 0.2 & 22.6 & 62.7 & 145.0 & 324 & 84 & 12.3 & 66.4 & 17.2 \\
\hline & $1-m^{2}$ & 7.6 & 10.2 & 0.2 & 32.2 & 52.7 & 219.3 & 684 & 174 & 5.5 & 62.7 & 16.0 \\
\hline & Line-point & 8.8 & 11.3 & 2.5 & 18.1 & 42.7 & 173.8 & 635 & 162 & 5.0 & 52.9 & 13.5 \\
\hline \multirow[b]{3}{*}{ QUGA } & $10-m^{2}$ & 14.5 & 13.3 & 4.5 & 24.2 & 46.9 & 213.3 & 320 & 83 & 12.3 & 65.6 & 17.0 \\
\hline & $1-m^{2}$ & 16.2 & 20.7 & 2.6 & 35.7 & 39.3 & 237.6 & 633 & 161 & 5.5 & 58.0 & 14.8 \\
\hline & Line-point & 14.5 & 14.4 & 2.6 & 27.4 & 44.7 & 188.4 & 384 & 99 & 5.0 & 32.0 & 8.3 \\
\hline \multirow[b]{3}{*}{ Bare soil } & $10-m^{2}$ & 14.3 & 9.9 & 5.2 & 13.9 & 95.8 & 88.4 & 190 & 50 & 12.3 & 39.0 & 10.3 \\
\hline & $1-m^{2}$ & 16.8 & 17.1 & 9.3 & 28.4 & 79.3 & 158.8 & 398 & 102 & 5.5 & 36.5 & 9.4 \\
\hline & Line-point & 41.3 & 18.9 & 15.2 & 21.8 & 83.3 & 79.8 & 83 & 23 & 5.0 & 6.9 & 1.9 \\
\hline \multirow[b]{3}{*}{ Litter } & $10-m^{2}$ & 70.4 & 15.8 & 8.8 & 22.1 & 100.0 & 25.3 & 22 & 8 & 12.3 & 4.5 & 1.6 \\
\hline & $1-m^{2}$ & 75.4 & 19.8 & 10.5 & 31.4 & 100.0 & 29.6 & 30 & 10 & 5.5 & 2.8 & 0.9 \\
\hline & Line-point & 52.3 & 18.7 & 9.8 & 23.9 & 95.3 & 49.1 & 52 & 15 & 5.0 & 4.3 & 1.3 \\
\hline \multirow[b]{3}{*}{ BSC } & $10-m^{2}$ & 0.2 & 0.6 & 0.2 & 0.9 & 21.0 & 214.7 & 3998 & 1005 & 12.3 & 819.6 & 206.0 \\
\hline & $1-m^{2}$ & 0.1 & 0.4 & 0.2 & 0.8 & 7.3 & 380.7 & 6777 & 1695 & $\begin{array}{c}12.0 \\
5.5\end{array}$ & 621.2 & 155.4 \\
\hline & Line-point & 0.2 & 2.2 & 1.8 & 2.6 & 2.0 & 467.5 & 46482 & 11621 & 5.0 & 3873.5 & 968.4 \\
\hline
\end{tabular}


Table B2. Summary of mean cover estimates for selected cover measures across two Desert Sand macroplots at Canyonlands National Park, within-macroplot variation in cover estimates summarized across macroplots, subsample sizes required to achieve 10 and 20 percent precision in estimates of macroplot-level means, and estimated amounts of sampling time required to achieve those degrees of precision. See Appendix $C$ for macroplot-level tables summarizing within-plot variability. See Appendix A for key to species codes (BSC = biological soil crust).

\begin{tabular}{|c|c|c|c|c|c|c|c|c|c|c|c|c|}
\hline \multicolumn{13}{|c|}{ Desert Sand (Sand Sagebrush) ecological site, $n=2$ macroplots } \\
\hline \multirow[b]{2}{*}{ Measure } & \multirow[b]{2}{*}{ Method } & \multirow[b]{2}{*}{$\begin{array}{l}\text { Mean } \\
\text { cover }\end{array}$} & \multicolumn{5}{|c|}{$\begin{array}{c}\text { Within-macroplot variation in cover estimates } \\
\text { (summarized across macroplots) } \\
\end{array}$} & \multicolumn{2}{|c|}{$\begin{array}{l}\text { Subsample size } \\
\text { (by precision) } \\
\end{array}$} & \multirow[b]{2}{*}{$\begin{array}{l}\text { Unit time } \\
\text { (min) }\end{array}$} & \multicolumn{2}{|c|}{$\begin{array}{l}\text { Subsample time } \\
\text { (hrs by precision) }\end{array}$} \\
\hline & & & Mean sd & Min sd & Max sd & $\begin{array}{l}\text { Mean } \\
\text { freq* }\end{array}$ & Mean CV & $10 \%$ & $20 \%$ & & $10 \%$ & $20 \%$ \\
\hline \multirow{3}{*}{$\begin{array}{c}\text { Total live } \\
\text { understory } \\
\text { canopy } \\
\text { cover }\end{array}$} & $10-m^{2}$ & 13.4 & 3.7 & 3.4 & 4.0 & 100.0 & 27.7 & 32 & 10 & 8.8 & 4.7 & 1.5 \\
\hline & $1-m^{2}$ & 12.3 & 7.7 & 6.5 & 8.8 & 100.0 & 61.9 & 151 & 40 & 4.6 & 11.6 & 3.1 \\
\hline & Line-point & 11.7 & 11.1 & 10.2 & 12.1 & 68.3 & 95.4 & 350 & 90 & 3.6 & 21.0 & 5.4 \\
\hline \multirow[b]{3}{*}{ ATCA2 } & $10-m^{2}$ & 1.5 & 2.3 & 2.3 & 2.3 & 50.0 & 170.8 & 973 & 243 & 8.8 & 142.7 & 35.6 \\
\hline & $1-m^{2}$ & 1.7 & 7.1 & 5.1 & 9.1 & 11.7 & 426.8 & 7174 & 1794 & 4.6 & 550.0 & 137.5 \\
\hline & Line-point & 1.3 & 3.7 & 2.5 & 4.8 & 11.7 & 311.3 & 2944 & 736 & 3.6 & 176.6 & 44.2 \\
\hline \multirow[b]{3}{*}{ HIJA } & $10-m^{2}$ & 1.7 & 2.3 & 2.2 & 2.4 & 57.1 & 148.5 & 659 & 168 & 8.8 & 96.7 & 24.6 \\
\hline & $1-m^{2}$ & 1.1 & 2.1 & 1.6 & 2.5 & 35.0 & 194.2 & 1309 & 348 & 4.6 & 100.4 & 26.7 \\
\hline & Line-point & 1.2 & 4.4 & 3.1 & 5.7 & 8.3 & 366.8 & 5412 & 1354 & 3.6 & 324.7 & 81.2 \\
\hline \multirow[b]{3}{*}{ STHY6 } & $10-m^{2}$ & 0.6 & 0.7 & 0.2 & 1.1 & 69.0 & 115.1 & 418 & 107 & 8.8 & 61.3 & 15.7 \\
\hline & $1-m^{2}$ & 0.5 & 0.5 & 0.3 & 0.7 & 40.0 & 192.2 & 389 & 100 & 4.6 & 29.8 & 7.7 \\
\hline & Line-point & 1.8 & 3.3 & 1.8 & 4.8 & 18.3 & 345.8 & 1253 & 313 & 3.6 & 75.2 & 18.8 \\
\hline \multirow[b]{3}{*}{ Litter } & $10-m^{2}$ & 6.9 & 4.4 & 3.4 & 5.3 & 100.0 & 63.0 & 158 & 42 & 8.8 & 23.2 & 6.2 \\
\hline & $1-m^{2}$ & 6.6 & 5.1 & 4.7 & 5.5 & 100.0 & 78.2 & 231 & 61 & 4.6 & 17.7 & 4.7 \\
\hline & Line-point & 8.3 & 8.9 & 7.2 & 10.7 & 56.7 & 108.3 & 441 & 113 & 3.6 & 26.5 & 6.8 \\
\hline \multirow{3}{*}{$\begin{array}{c}\text { Undifferen } \\
\text { tiated } \\
\text { crust } \\
\end{array}$} & $10-m^{2}$ & 67.6 & 14.7 & 12.4 & 17.0 & 97.6 & 22.1 & 21 & 8 & 8.8 & 3.1 & 1.2 \\
\hline & $1-m^{2}$ & 79.1 & 10.6 & 10.2 & 11.0 & 100.0 & 13.4 & 10 & 5 & 4.6 & 0.8 & 0.4 \\
\hline & Line-point & 81.5 & 14.6 & 14.1 & 15.1 & 100.0 & 18.0 & 15 & 6 & 3.6 & 0.9 & 0.4 \\
\hline \multirow[b]{3}{*}{ BSC } & $10-m^{2}$ & 4.3 & 3.9 & 0.9 & 7.0 & 92.9 & 91.4 & 325 & 84 & 8.8 & 47.7 & 12.3 \\
\hline & $1-m^{2}$ & 4.8 & 4.4 & 1.6 & 7.1 & 70.0 & 113.8 & 326 & 84 & 4.6 & 25.0 & 6.4 \\
\hline & Line-point & 6.7 & 7.6 & 3.8 & 11.5 & 40.0 & 162.9 & 504 & 129 & 3.6 & 30.2 & 7.7 \\
\hline
\end{tabular}

* frequency for line-point sampling was calculated on the basis of 10-point groups 
Table B3. Summary of mean cover estimates for selected cover measures across five Limy Upland macroplots at Wupatki National Monument, within-macroplot variation in cover estimates summarized across macroplots, subsample sizes required to achieve 10 and 20 percent precision in estimates of macroplot-level means, and estimated amounts of sampling time required to achieve those degrees of precision. See Appendix $C$ for macroplot-level tables summarizing within-plot variability. See Appendix A for key to species codes.

\begin{tabular}{|c|c|c|c|c|c|c|c|c|c|c|c|c|}
\hline \multicolumn{13}{|c|}{ Limy Upland, 6-10" pz ecological site, $n=5$ macroplots } \\
\hline \multirow[b]{2}{*}{ Measure } & \multirow[b]{2}{*}{ Method } & \multirow[b]{2}{*}{$\begin{array}{l}\text { Mean } \\
\text { cover }\end{array}$} & \multicolumn{5}{|c|}{$\begin{array}{c}\text { Within-macroplot variation in cover estimates } \\
\text { (summarized across macroplots) }\end{array}$} & \multicolumn{2}{|c|}{$\begin{array}{l}\text { Subsample size } \\
\text { (by precision) }\end{array}$} & \multirow[b]{2}{*}{$\begin{array}{l}\text { Unit time } \\
\text { (min) }\end{array}$} & \multicolumn{2}{|c|}{$\begin{array}{l}\text { Subsample time } \\
\text { (hrs by precision) }\end{array}$} \\
\hline & & & Mean sd & Min sd & Max sd & $\begin{array}{l}\text { Mean } \\
\text { freq* }^{*}\end{array}$ & Mean CV & $10 \%$ & $20 \%$ & & $10 \%$ & $20 \%$ \\
\hline \multirow{3}{*}{$\begin{array}{c}\text { Total live } \\
\text { understory } \\
\text { canopy } \\
\text { cover }\end{array}$} & $10-m^{2}$ & 23.6 & 6.0 & 3.9 & 8.0 & 100.0 & 26.5 & 28 & 9 & 7.3 & 3.4 & 1.1 \\
\hline & $1-m^{2}$ & 16.0 & 5.3 & 3.1 & 8.8 & 100.0 & 33.1 & 45 & 15 & 3.7 & 2.8 & 0.9 \\
\hline & Line-point & 26.7 & 15.8 & 13.0 & 18.7 & 93.3 & 59.9 & 138 & 37 & 3.3 & 7.6 & 2.0 \\
\hline \multirow[b]{3}{*}{ CHLE4 } & $10-m^{2}$ & 5.1 & 3.6 & 1.8 & 6.3 & 92.0 & 92.0 & 187 & 49 & 7.3 & 22.8 & 6.0 \\
\hline & $1-m^{2}$ & 3.5 & 2.1 & 1.4 & 2.9 & 80.0 & 95.8 & 142 & 38 & 3.7 & 8.8 & 2.3 \\
\hline & Line-point & 3.6 & 6.6 & 3.1 & 10.1 & 27.3 & 184.5 & 1280 & 320 & 3.3 & 70.4 & 17.6 \\
\hline \multirow[b]{3}{*}{ HENE5 } & $10-m^{2}$ & 3.7 & 3.0 & 1.8 & 6.5 & 84.8 & 125.1 & 248 & 65 & 7.3 & 30.2 & 7.9 \\
\hline & $1-m^{2}$ & 2.8 & 2.3 & 1.0 & 3.6 & 65.3 & 150.9 & 258 & 75 & 3.7 & 15.9 & 4.6 \\
\hline & Line-point & 6.5 & 8.9 & 6.8 & 12.5 & 40.0 & 130.7 & 720 & 183 & 3.3 & 39.6 & 10.1 \\
\hline \multirow[b]{3}{*}{ PLJA } & $10-m^{2}$ & 4.4 & 3.4 & 1.7 & 6.1 & 74.5 & 149.0 & 233 & 61 & 7.3 & 28.3 & 7.4 \\
\hline & $1-m^{2}$ & 2.3 & 1.8 & 0.8 & 3.2 & 70.0 & 132.0 & 237 & 62 & 3.7 & 14.6 & 3.8 \\
\hline & Line-point & 6.7 & 7.4 & 1.8 & 11.0 & 44.7 & 226.8 & 462 & 118 & 3.3 & 25.4 & 6.5 \\
\hline \multirow[b]{3}{*}{ Bare soil } & $10-m^{2}$ & 7.3 & 5.0 & 0.9 & 12.8 & 100.0 & 67.4 & 181 & 48 & 7.3 & 22.0 & 5.8 \\
\hline & $1-m^{2}$ & 7.3 & 6.2 & 1.3 & 14.0 & 97.3 & 87.4 & 282 & 73 & 3.7 & 17.4 & 4.5 \\
\hline & Line-point & 16.3 & 12.5 & 5.1 & 26.4 & 59.3 & 112.0 & 227 & 59 & 3.3 & 12.5 & 3.2 \\
\hline \multirow[b]{3}{*}{ Litter } & $10-m^{2}$ & 6.6 & 4.4 & 2.4 & 6.0 & 100.0 & 64.9 & 167 & 44 & 7.3 & 20.3 & 5.4 \\
\hline & $1-m^{2}$ & 7.1 & 4.9 & 2.6 & 9.7 & 100.0 & 66.3 & 181 & 47 & 3.7 & 11.2 & 2.9 \\
\hline & Line-point & 3.6 & 10.2 & 9.2 & 11.2 & 21.3 & 116.5 & 3084 & 771 & 3.3 & 169.6 & 42.4 \\
\hline
\end{tabular}

* frequency for line-point sampling was calculated on the basis of 10-point groups 
Table B4. Summary of mean cover estimates for selected cover measures across five Loamy Hills macroplots at Grand Canyon National Park, within-macroplot variation in cover estimates summarized across macroplots, subsample sizes required to achieve 10 and 20 percent precision in estimates of macroplot-level means, and estimated amounts of sampling time required to achieve those degrees of precision. See Appendix $C$ for macroplot-level tables summarizing within-plot variability. See Appendix A for key to species codes (BSC = biological soil crust).

\begin{tabular}{|c|c|c|c|c|c|c|c|c|c|c|c|c|}
\hline \multicolumn{13}{|c|}{ Loamy Hills, 25-33" pz ecological site, $n$ = 5 macroplots } \\
\hline \multirow[b]{2}{*}{ Measure } & \multirow[b]{2}{*}{ Method } & \multirow[b]{2}{*}{$\begin{array}{l}\text { Mean } \\
\text { cover }\end{array}$} & \multicolumn{5}{|c|}{$\begin{array}{c}\text { Within-macroplot variation in cover estimates } \\
\text { (summarized across macroplots) }\end{array}$} & \multicolumn{2}{|c|}{$\begin{array}{l}\text { Subsample size } \\
\text { (by precision) }\end{array}$} & \multirow[b]{2}{*}{$\begin{array}{l}\text { Unit time } \\
\text { (min) }\end{array}$} & \multicolumn{2}{|c|}{$\begin{array}{l}\text { Subsample time } \\
\text { (hrs by precision) }\end{array}$} \\
\hline & & & Mean sd & Min sd & Max sd & $\begin{array}{l}\text { Mean } \\
\text { freq* }^{*}\end{array}$ & Mean CV & $10 \%$ & $20 \%$ & & $10 \%$ & $20 \%$ \\
\hline \multirow{3}{*}{$\begin{array}{c}\text { Total live } \\
\text { understory } \\
\text { canopy } \\
\text { cover }\end{array}$} & $10-m^{2}$ & 19.7 & 15.8 & 3.0 & 32.2 & 100.0 & 74.8 & 248 & 65 & 8.9 & 36.8 & 9.6 \\
\hline & $1-m^{2}$ & 23.8 & 27.1 & 5.2 & 52.8 & 94.7 & 120.4 & 502 & 128 & 4.1 & 34.3 & 8.7 \\
\hline & Line-point & 16.9 & 13.8 & 9.6 & 23.3 & 72.0 & 90.6 & 257 & 67 & 4.0 & 17.1 & 4.5 \\
\hline \multirow[b]{3}{*}{ POFE } & $10-m^{2}$ & 0.5 & 1.0 & 0.1 & 2.1 & 39.6 & 230.9 & 1451 & 363 & 8.9 & 215.2 & 53.8 \\
\hline & $1-m^{2}$ & 0.4 & 0.7 & 0.3 & 1.2 & 25.3 & 220.8 & 1280 & 320 & 4.1 & 87.5 & 21.9 \\
\hline & Line-point & 1.5 & 3.7 & 1.8 & 4.9 & 15.3 & 282.4 & 2238 & 560 & 4.0 & 149.2 & 37.3 \\
\hline \multirow[b]{3}{*}{ POTR5 } & $10-m^{2}$ & 2.6 & 3.7 & 0.2 & 6.7 & 55.2 & 176.0 & 775 & 197 & 8.9 & 115.0 & 29.2 \\
\hline & $1-m^{2}$ & 4.1 & 10.5 & 0.4 & 19.5 & 36.7 & 261.7 & 2551 & 638 & 4.1 & 174.3 & 43.6 \\
\hline & Line-point & 1.8 & 4.4 & 2.6 & 6.4 & 16.0 & 251.1 & 2285 & 572 & 4.0 & 152.3 & 38.1 \\
\hline \multirow{3}{*}{$\begin{array}{l}\text { UNGRCA1 } \\
\text { (Carex sp.) }\end{array}$} & $10-m^{2}$ & 1.4 & 1.7 & 0.2 & 2.5 & 74.7 & 142.7 & 529 & 135 & 8.9 & 78.5 & 20.0 \\
\hline & $1-m^{2}$ & 1.2 & 1.5 & 0.4 & 2.1 & 54.7 & 177.2 & 586 & 150 & 4.1 & 40.0 & 10.3 \\
\hline & Line-point & 6.5 & 10.0 & 5.2 & 12.6 & 40.0 & 123.4 & 925 & 232 & 4.0 & 61.7 & 15.5 \\
\hline \multirow[b]{3}{*}{ Bare soil } & $10-m^{2}$ & 1.5 & 1.9 & 1.3 & 2.3 & 72.2 & 126.9 & 571 & 145 & 8.9 & 84.7 & 21.5 \\
\hline & $1-m^{2}$ & 1.9 & 3.2 & 1.4 & 6.6 & 53.3 & 157.5 & 1059 & 265 & 4.1 & 72.4 & 18.1 \\
\hline & Line-point & 14.9 & 17.1 & 9.0 & 28.0 & 49.3 & 138.0 & 502 & 128 & 4.0 & 33.5 & 8.5 \\
\hline \multirow[b]{3}{*}{ Litter } & $10-m^{2}$ & 74.8 & 11.8 & 8.8 & 20.1 & 100.0 & 16.6 & 12 & 5 & 8.9 & 1.8 & 0.7 \\
\hline & $1-m^{2}$ & 80.1 & 15.6 & 5.2 & 22.6 & 99.3 & 20.2 & 18 & 7 & 4.1 & 1.2 & 0.5 \\
\hline & Line-point & 69.3 & 22.1 & 15.5 & 36.3 & 98.7 & 33.2 & 42 & 13 & 4.0 & 2.8 & 0.9 \\
\hline \multirow[b]{3}{*}{ BSC } & $10-m^{2}$ & 0.7 & 1.3 & 0.1 & 4.1 & 36.8 & 275.1 & 1242 & 310 & 8.9 & 184.2 & 46.0 \\
\hline & $1-m^{2}$ & 0.6 & 1.5 & 0.3 & 3.5 & 23.3 & 291.1 & 2498 & 625 & 4.1 & 170.7 & 42.7 \\
\hline & Line-point & 0.3 & 2.9 & 1.8 & 4.0 & 2.0 & 475.2 & 46261 & 11609 & 4.0 & 3084.1 & 773.9 \\
\hline
\end{tabular}


Table B5. Summary of mean cover estimates for selected cover measures across two Loamy Hills, Cold, macroplots at Grand Canyon National Park, within-macroplot variation in cover estimates summarized across macroplots, subsample sizes required to achieve 10 and 20 percent precision in estimates of macroplot-level means, and estimated amounts of sampling time required to achieve those degrees of precision. See Appendix $C$ for macroplot-level tables summarizing within-plot variability. See Appendix A for key to species codes (BSC = biological soil crust).

\begin{tabular}{|c|c|c|c|c|c|c|c|c|c|c|c|c|}
\hline \multicolumn{13}{|c|}{ Loamy Hills, Cold, 25-33" pz ecological site, $n=2$ macroplots } \\
\hline \multirow[b]{2}{*}{ Measure } & \multirow[b]{2}{*}{ Method } & \multirow[b]{2}{*}{$\begin{array}{l}\text { Mean } \\
\text { cover }\end{array}$} & \multicolumn{5}{|c|}{$\begin{array}{c}\text { Within-macroplot variation in cover estimates } \\
\text { (summarized across macroplots) }\end{array}$} & \multicolumn{2}{|c|}{$\begin{array}{c}\text { Subsample size } \\
\text { (by precision) }\end{array}$} & \multirow[b]{2}{*}{$\begin{array}{l}\text { Unit time } \\
\text { (min) }\end{array}$} & \multicolumn{2}{|c|}{$\begin{array}{l}\text { Subsample time } \\
\text { (hrs by precision) }\end{array}$} \\
\hline & & & Mean sd & Min sd & Max sd & $\begin{array}{l}\text { Mean } \\
\text { freq* }\end{array}$ & Mean CV & $10 \%$ & $20 \%$ & & $10 \%$ & $20 \%$ \\
\hline \multirow{3}{*}{$\begin{array}{c}\text { Total live } \\
\text { understory } \\
\text { canopy } \\
\text { cover } \\
\end{array}$} & $10-m^{2}$ & 48.8 & 31.6 & 29.3 & 33.9 & 100.0 & 64.9 & 164 & 43 & 7.3 & 20.0 & 5.2 \\
\hline & $1-m^{2}$ & 57.3 & 42.5 & 33.7 & 51.2 & 100.0 & 78.3 & 211 & 56 & 2.8 & 9.8 & 2.6 \\
\hline & Line-point & 25.7 & 18.9 & 17.9 & 19.9 & 85.0 & 74.5 & 209 & 55 & 5.7 & 19.9 & 5.2 \\
\hline \multirow[b]{3}{*}{$\mathrm{ABCO}$} & $10-m^{2}$ & 8.6 & 25.8 & 25.8 & 25.8 & 31.0 & 149.5 & 3432 & 858 & 7.3 & 417.6 & 104.4 \\
\hline & $1-m^{2}$ & 12.9 & 29.6 & 29.6 & 29.6 & 33.3 & 115.1 & 2036 & 509 & 2.8 & 95.0 & 23.8 \\
\hline & Line-point & 4.5 & 11.8 & 11.8 & 11.8 & 23.3 & 131.6 & 2664 & 666 & 5.7 & 253.1 & 63.3 \\
\hline \multirow[b]{3}{*}{ PIEN } & $10-m^{2}$ & 6.9 & 15.7 & 13.6 & 17.8 & 28.6 & 311.7 & 2004 & 501 & 7.3 & 243.8 & 61.0 \\
\hline & $1-m^{2}$ & 8.3 & 26.1 & 26.1 & 26.1 & 21.7 & 157.9 & 3831 & 958 & 2.8 & 178.8 & 44.7 \\
\hline & Line-point & 4.2 & 8.1 & 3.7 & 12.5 & 20.0 & 355.4 & 1445 & 362 & 5.7 & 137.3 & 34.4 \\
\hline \multirow[b]{3}{*}{ POTR5 } & $10-m^{2}$ & 4.7 & 9.3 & 5.2 & 13.3 & 59.5 & 186.3 & 1478 & 370 & 7.3 & 179.8 & 45.0 \\
\hline & $1-m^{2}$ & 6.2 & 13.5 & 8.3 & 18.7 & 38.3 & 210.8 & 1805 & 452 & 2.8 & 84.2 & 21.1 \\
\hline & Line-point & 1.0 & 3.0 & 2.5 & 3.5 & 10.0 & 319.9 & 3458 & 865 & 5.7 & 328.5 & 82.2 \\
\hline \multirow[b]{3}{*}{ Bare soil } & $10-m^{2}$ & 2.5 & 4.0 & 4.0 & 4.0 & 83.3 & 160.4 & 984 & 246 & 7.3 & 119.7 & 29.9 \\
\hline & $1-m^{2}$ & 1.8 & 3.3 & 2.3 & 4.4 & 51.7 & 183.9 & 1323 & 331 & 2.8 & 61.7 & 15.4 \\
\hline & Line-point & 4.0 & 9.2 & 5.8 & 12.5 & 21.7 & 226.8 & 2024 & 506 & 5.7 & 192.3 & 48.1 \\
\hline \multirow[b]{3}{*}{ Litter } & $10-m^{2}$ & 70.2 & 15.3 & 14.4 & 16.1 & 100.0 & 21.7 & 21 & 8 & 7.3 & 2.6 & 1.0 \\
\hline & $1-m^{2}$ & 80.4 & 13.4 & 12.6 & 14.2 & 100.0 & 16.7 & 14 & 6 & 2.8 & 0.7 & 0.3 \\
\hline & Line-point & 81.3 & 16.9 & 16.4 & 17.3 & 100.0 & 20.7 & 19 & 7 & 5.7 & 1.8 & 0.7 \\
\hline \multirow[b]{3}{*}{ BSC } & $10-m^{2}$ & 1.1 & 1.3 & 0.7 & 1.9 & 78.6 & 132.3 & 593 & 151 & 7.3 & 72.1 & 18.4 \\
\hline & $1-m^{2}$ & 1.2 & 3.0 & 2.9 & 3.1 & 41.7 & 317.6 & 2454 & 613 & 2.8 & 114.5 & 28.6 \\
\hline & Line-point & 1.0 & 4.8 & 4.8 & 4.8 & 8.3 & 242.1 & 8999 & 2250 & 5.7 & 854.9 & 213.8 \\
\hline
\end{tabular}

* frequency for line-point sampling was calculated on the basis of 10-point groups 
Table B6. Summary of mean cover estimates for selected cover measures across five Loamy Mesa Top PJ macroplots at Mesa Verde National Park, within-macroplot variation in cover estimates summarized across macroplots, subsample sizes required to achieve 10 and 20 percent precision in estimates of macroplot-level means, and estimated amounts of sampling time required to achieve those degrees of precision. See Appendix $C$ for macroplot-level tables summarizing within-plot variability. See Appendix A for key to species codes (BSC = biological soil crust).

\begin{tabular}{|c|c|c|c|c|c|c|c|c|c|c|c|c|}
\hline \multicolumn{13}{|c|}{ Loamy Mesa Top PJ ecological site, $n=5$ macroplots } \\
\hline \multirow[b]{2}{*}{ Measure } & \multirow[b]{2}{*}{ Method } & \multirow[b]{2}{*}{$\begin{array}{l}\text { Mean } \\
\text { cover }\end{array}$} & \multicolumn{5}{|c|}{$\begin{array}{c}\text { Within-macroplot variation in cover estimates } \\
\text { (summarized across macroplots) }\end{array}$} & \multicolumn{2}{|c|}{$\begin{array}{c}\text { Subsample size } \\
\text { (by precision) }\end{array}$} & \multirow[b]{2}{*}{$\begin{array}{l}\text { Unit time } \\
\text { (min) }\end{array}$} & \multicolumn{2}{|c|}{$\begin{array}{l}\text { Subsample time } \\
\text { (hrs by precision) }\end{array}$} \\
\hline & & & Mean sd & Min sd & Max sd & $\begin{array}{l}\text { Mean } \\
\text { freq* }\end{array}$ & Mean CV & $10 \%$ & $20 \%$ & & $10 \%$ & $20 \%$ \\
\hline \multirow{3}{*}{$\begin{array}{c}\text { Total live } \\
\text { understory } \\
\text { canopy } \\
\text { cover } \\
\end{array}$} & $10-m^{2}$ & 32.7 & 20.2 & 11.7 & 31.3 & 91.2 & 157.9 & 149 & 39 & 8.6 & 21.4 & 5.6 \\
\hline & $1-m^{2}$ & 29.6 & 31.1 & 15.2 & 49.8 & 58.7 & 198.8 & 425 & 109 & 3.5 & 24.8 & 6.4 \\
\hline & Line-point & 20.7 & 15.5 & 11.6 & 18.3 & 46.7 & 133.4 & 215 & 57 & 4.2 & 15.1 & 4.0 \\
\hline \multirow[b]{3}{*}{ JUOS } & $10-m^{2}$ & 7.7 & 11.9 & 6.0 & 17.4 & 67.2 & 162.4 & 903 & 226 & 8.6 & 129.4 & 32.4 \\
\hline & $1-m^{2}$ & 9.8 & 18.6 & 6.1 & 32.4 & 36.7 & 214.2 & 1396 & 349 & 3.5 & 81.4 & 20.4 \\
\hline & Line-point & 3.4 & 5.8 & 4.1 & 7.8 & 28.0 & 179.8 & 1134 & 284 & 4.2 & 79.4 & 19.9 \\
\hline \multirow[b]{3}{*}{ PIED } & $10-m^{2}$ & 12.4 & 13.8 & 7.7 & 23.8 & 73.7 & 128.6 & 473 & 121 & 8.6 & 67.8 & 17.3 \\
\hline & $1-m^{2}$ & 10.9 & 21.9 & 10.5 & 27.5 & 36.7 & 207.4 & 1566 & 392 & 3.5 & 91.4 & 22.9 \\
\hline & Line-point & 7.3 & 10.7 & 4.6 & 13.6 & 44.7 & 151.0 & 812 & 203 & 4.2 & 56.8 & 14.2 \\
\hline \multirow[b]{3}{*}{ POFE } & $10-m^{2}$ & 7.0 & 4.7 & 0.1 & 8.5 & 98.7 & 60.9 & 176 & 46 & 8.6 & 25.2 & 6.6 \\
\hline & $1-m^{2}$ & 4.7 & 5.0 & 0.5 & 8.3 & 85.3 & 106.7 & 420 & 108 & 3.5 & 24.5 & 6.3 \\
\hline & Line-point & 7.7 & 8.6 & 4.1 & 14.2 & 55.3 & 128.7 & 485 & 124 & 4.2 & 34.0 & 8.7 \\
\hline \multirow[b]{3}{*}{ Bare soil } & $10-m^{2}$ & 2.1 & 3.7 & 0.6 & 8.6 & 100.0 & 63.9 & 1191 & 298 & 8.6 & 170.7 & 42.7 \\
\hline & $1-m^{2}$ & 2.3 & 5.1 & 0.5 & 12.1 & 98.7 & 107.0 & 1908 & 477 & 3.5 & 111.3 & 27.8 \\
\hline & Line-point & 7.1 & 8.0 & 4.6 & 11.1 & 84.0 & 75.2 & 478 & 122 & 4.2 & 33.5 & 8.5 \\
\hline \multirow[b]{3}{*}{ Litter } & $10-m^{2}$ & 47.2 & 29.1 & 23.2 & 34.7 & 100.0 & 63.0 & 149 & 39 & 8.6 & 21.4 & 5.6 \\
\hline & $1-m^{2}$ & 50.5 & 34.0 & 29.7 & 39.0 & 100.0 & 71.7 & 178 & 47 & 3.5 & 10.4 & 2.7 \\
\hline & Line-point & 47.5 & 22.7 & 16.6 & 25.6 & 94.7 & 52.6 & 90 & 25 & 4.2 & 6.3 & 1.8 \\
\hline \multirow[b]{3}{*}{ BSC } & $10-m^{2}$ & 3.9 & 3.7 & 2.0 & 5.2 & 97.1 & 97.4 & 346 & 89 & 8.6 & 49.6 & 12.8 \\
\hline & $1-m^{2}$ & 5.4 & 7.8 & 1.9 & 14.9 & 77.3 & 132.5 & 796 & 202 & 3.5 & 46.4 & 11.8 \\
\hline & Line-point & 7.4 & 10.0 & 7.4 & 13.6 & 46.0 & 152.4 & 708 & 180 & 4.2 & 49.6 & 12.6 \\
\hline
\end{tabular}

* frequency for line-point sampling was calculated on the basis of 10-point groups 
Table B7. Summary of mean cover estimates for selected cover measures across five Semidesert Alkali Sandy Loam macroplots at Capitol Reef National Park, within-macroplot variation in cover estimates summarized across macroplots, subsample sizes required to achieve 10 and 20 percent precision in estimates of macroplot-level means, and estimated amounts of sampling time required to achieve those degrees of precision. See Appendix $C$ for macroplot-level tables summarizing within-plot variability. See Appendix A for key to species codes (BSC = biological soil crust).

\begin{tabular}{|c|c|c|c|c|c|c|c|c|c|c|c|c|}
\hline \multirow[b]{2}{*}{ Measure } & \multirow[b]{2}{*}{ Method } & \multirow[b]{2}{*}{$\begin{array}{l}\text { Mean } \\
\text { cover }\end{array}$} & \multicolumn{5}{|c|}{$\begin{array}{c}\text { Within-macroplot variation in cover estimates } \\
\text { (summarized across macroplots) }\end{array}$} & \multicolumn{2}{|c|}{$\begin{array}{c}\text { Subsample size } \\
\text { (by precision) }\end{array}$} & \multirow[b]{2}{*}{$\begin{array}{l}\text { Unit time } \\
\text { (min) }\end{array}$} & \multicolumn{2}{|c|}{$\begin{array}{l}\text { Subsample time } \\
\text { (hrs by precision) }\end{array}$} \\
\hline & & & Mean sd & Min sd & Max sd & $\begin{array}{l}\text { Mean } \\
\text { freq* }\end{array}$ & Mean CV & $10 \%$ & $20 \%$ & & $10 \%$ & $20 \%$ \\
\hline \multirow{3}{*}{$\begin{array}{l}\text { Total live } \\
\text { understory } \\
\text { canopy } \\
\text { cover }\end{array}$} & $10-m^{2}$ & 20.3 & 8.8 & 4.5 & 16.9 & 100.0 & 45.5 & 75 & 21 & 8.8 & 11.0 & 3.1 \\
\hline & $1-m^{2}$ & 18.1 & 12.7 & 6.1 & 20.1 & 98.7 & 72.8 & 193 & 50 & 4.4 & 14.2 & 3.7 \\
\hline & Line-point & 25.4 & 16.4 & 11.9 & 19.4 & 85.3 & 71.7 & 163 & 43 & 2.4 & 6.5 & 1.7 \\
\hline \multirow[b]{3}{*}{ ATCO } & $10-m^{2}$ & 2.6 & 3.1 & 1.0 & 5.2 & 71.6 & 138.2 & 554 & 141 & 8.8 & 81.3 & 20.7 \\
\hline & $1-m^{2}$ & 2.5 & 4.4 & 1.3 & 12.4 & 46.7 & 186.0 & 1178 & 295 & 4.4 & 86.4 & 21.6 \\
\hline & Line-point & 3.1 & 7.6 & 5.9 & 9.7 & 20.7 & 205.3 & 2378 & 595 & 2.4 & 95.1 & 23.8 \\
\hline \multirow[b]{3}{*}{ GIIN2 } & $10-m^{2}$ & 0.3 & 0.2 & 0.2 & 0.3 & 56.8 & 95.0 & 252 & 66 & 8.8 & 37.0 & 9.7 \\
\hline & $1-m^{2}$ & 0.4 & 0.5 & 0.4 & 0.5 & 38.7 & 140.0 & 567 & 145 & 4.4 & 41.6 & 10.6 \\
\hline & Line-point & 0.3 & 2.7 & 1.8 & 3.5 & 3.3 & 405.8 & 24697 & 6156 & 2.4 & 987.9 & 246.2 \\
\hline \multirow[b]{3}{*}{ ORHY } & $10-m^{2}$ & 0.5 & 0.5 & 0.1 & 0.8 & 86.1 & 85.7 & 310 & 80 & 8.8 & 45.5 & 11.7 \\
\hline & $1-m^{2}$ & 0.6 & 0.6 & 0.5 & 0.7 & 55.3 & 100.7 & 355 & 92 & 4.4 & 26.0 & 6.7 \\
\hline & Line-point & 1.2 & 3.8 & 2.5 & 6.6 & 10.0 & 307.5 & 3873 & 969 & 2.4 & 154.9 & 38.8 \\
\hline \multirow[b]{3}{*}{ Bare soil } & $10-m^{2}$ & 0.8 & 1.6 & 0.3 & 4.1 & 75.4 & 162.2 & 1337 & 335 & 8.8 & 196.1 & 49.1 \\
\hline & $1-m^{2}$ & 1.2 & 1.5 & 0.5 & 2.7 & 63.3 & 178.7 & 654 & 166 & 4.4 & 48.0 & 12.2 \\
\hline & Line-point & 4.3 & 6.6 & 2.6 & 8.6 & 33.3 & 201.8 & 892 & 223 & 2.4 & 35.7 & 8.9 \\
\hline \multirow[b]{3}{*}{ Litter } & $10-m^{2}$ & 9.7 & 7.0 & 1.2 & 9.3 & 98.7 & 78.1 & 203 & 54 & 8.8 & 29.8 & 7.9 \\
\hline & $1-m^{2}$ & 10.6 & 15.0 & 1.9 & 23.5 & 98.7 & 138.2 & 770 & 195 & 4.4 & 56.5 & 14.3 \\
\hline & Line-point & 5.5 & 7.5 & 2.6 & 11.3 & 37.3 & 182.6 & 723 & 184 & 2.4 & 28.9 & 7.4 \\
\hline \multirow[b]{3}{*}{ BSC } & $10-m^{2}$ & 1.8 & 1.5 & 0.4 & 4.3 & 78.7 & 94.4 & 273 & 71 & 8.8 & 40.0 & 10.4 \\
\hline & $1-m^{2}$ & 1.5 & 1.5 & 0.6 & 2.9 & 58.0 & 126.7 & 411 & 106 & 4.4 & 30.1 & 7.8 \\
\hline & Line-point & 3.3 & 6.5 & 3.5 & 9.7 & 22.7 & 233.9 & 1502 & 376 & 2.4 & 60.1 & 15.0 \\
\hline
\end{tabular}

* frequency for line-point sampling was calculated on the basis of 10-point groups 
Table B8. Summary of mean cover estimates for selected cover measures across five Semidesert Loam macroplots at Dinosaur National Monument, within-macroplot variation in cover estimates summarized across macroplots, subsample sizes required to achieve 10 and 20 percent precision in estimates of macroplot-level means, and estimated amounts of sampling time required to achieve those degrees of precision. See Appendix $C$ for macroplot-level tables summarizing within-plot variability. See Appendix A for key to species codes (BSC = biological soil crust).

\begin{tabular}{|c|c|c|c|c|c|c|c|c|c|c|c|c|}
\hline \multirow[b]{2}{*}{ Measure } & \multirow[b]{2}{*}{ Method } & \multirow[b]{2}{*}{$\begin{array}{l}\text { Mean } \\
\text { cover }\end{array}$} & \multicolumn{5}{|c|}{$\begin{array}{l}\text { Within-macroplot variation in cover estimates } \\
\text { (summarized across macroplots) }\end{array}$} & \multicolumn{2}{|c|}{$\begin{array}{l}\text { Subsample size } \\
\text { (by precision) }\end{array}$} & \multirow[b]{2}{*}{$\begin{array}{l}\text { Unit time } \\
\text { (min) }\end{array}$} & \multicolumn{2}{|c|}{$\begin{array}{l}\text { Subsample time } \\
\text { (hrs by precision) }\end{array}$} \\
\hline & & & Mean sd & Min sd & Max sd & $\begin{array}{l}\text { Mean } \\
\text { freq }^{*}\end{array}$ & Mean CV & $10 \%$ & $20 \%$ & & $10 \%$ & $20 \%$ \\
\hline \multirow{3}{*}{$\begin{array}{c}\text { Total live } \\
\text { understory } \\
\text { canopy } \\
\text { cover }\end{array}$} & $10-m^{2}$ & 32.2 & 11.1 & 7.9 & 16.9 & 100.0 & 36.6 & 49 & 14 & 8.4 & 6.9 & 2.0 \\
\hline & $1-m^{2}$ & 20.2 & 13.0 & 9.1 & 19.4 & 100.0 & 67.9 & 163 & 43 & 4.8 & 13.0 & 3.4 \\
\hline & Line-point & 53.8 & 22.8 & 20.3 & 25.5 & 98.7 & 48.4 & 72 & 20 & 3.9 & 4.7 & 1.3 \\
\hline \multirow[b]{3}{*}{ ARTR2 } & $10-m^{2}$ & 9.6 & 7.0 & 1.2 & 10.7 & 83.6 & 93.9 & 205 & 54 & 8.4 & 28.7 & 7.6 \\
\hline & $1-m^{2}$ & 5.3 & 7.0 & 0.7 & 10.2 & 58.0 & 223.0 & 674 & 171 & 4.8 & 53.9 & 13.7 \\
\hline & Line-point & 4.8 & 7.9 & 6.3 & 9.2 & 36.0 & 137.4 & 1044 & 261 & 3.9 & 67.9 & 17.0 \\
\hline \multirow[b]{3}{*}{ BRTE } & $10-m^{2}$ & 11.9 & 9.1 & 2.7 & 24.7 & 93.7 & 114.4 & 227 & 60 & 8.4 & 31.8 & 8.4 \\
\hline & $1-m^{2}$ & 7.3 & 7.7 & 1.6 & 22.0 & 77.3 & 140.0 & 431 & 111 & 4.8 & 34.5 & 8.9 \\
\hline & Line-point & 30.1 & 20.1 & 14.2 & 29.4 & 80.0 & 90.3 & 174 & 46 & 3.9 & 11.3 & 3.0 \\
\hline \multirow[b]{3}{*}{ STCO4 } & $10-m^{2}$ & 2.5 & 3.0 & 0.3 & 9.4 & 62.7 & 97.8 & 544 & 139 & 8.4 & 76.2 & 19.5 \\
\hline & $1-m^{2}$ & 1.3 & 1.6 & 0.5 & 3.4 & 48.0 & 134.5 & 568 & 145 & 4.8 & 45.4 & 11.6 \\
\hline & Line-point & 4.2 & 12.7 & 5.9 & 19.5 & 16.0 & 164.5 & 3518 & 880 & 3.9 & 228.7 & 57.2 \\
\hline \multirow[b]{3}{*}{ Bare soil } & $10-m^{2}$ & 0.7 & 0.7 & 0.2 & 1.9 & 72.0 & 93.5 & 372 & 96 & 8.4 & 52.1 & 13.4 \\
\hline & $1-m^{2}$ & 1.1 & 1.6 & 0.4 & 3.7 & 51.3 & 159.7 & 843 & 211 & 4.8 & 67.4 & 16.9 \\
\hline & Line-point & 10.5 & 10.6 & 4.9 & 15.9 & 57.3 & 109.2 & 394 & 101 & 3.9 & 25.6 & 6.6 \\
\hline \multirow[b]{3}{*}{ Litter } & $10-m^{2}$ & 34.2 & 14.3 & 9.3 & 22.0 & 98.7 & 46.7 & 70 & 20 & 8.4 & 9.8 & 2.8 \\
\hline & $1-m^{2}$ & 35.0 & 22.9 & 17.7 & 27.8 & 100.0 & 85.3 & 167 & 44 & 4.8 & 13.4 & 3.5 \\
\hline & Line-point & 29.8 & 16.5 & 13.0 & 20.3 & 83.3 & 69.5 & 121 & 32 & 3.9 & 7.9 & 2.1 \\
\hline \multirow[b]{3}{*}{ BSC } & $10-m^{2}$ & 5.5 & 5.5 & 1.1 & 12.9 & 100.0 & 88.2 & 384 & 99 & 8.4 & 53.8 & 13.9 \\
\hline & $1-m^{2}$ & 5.5 & 4.8 & 1.1 & 15.1 & 98.7 & 68.6 & 285 & 74 & 4.8 & 22.8 & 5.9 \\
\hline & Line-point & 12.1 & 11.6 & 6.3 & 20.4 & 60.0 & 107.6 & 356 & 92 & 3.9 & 23.1 & 6.0 \\
\hline
\end{tabular}


Table B9. Summary of mean cover estimates for selected cover measures across seven Semidesert Shallow Sandy Loam macroplots at Arches and Canyonlands National Parks, within-macroplot variation in cover estimates summarized across macroplots, subsample sizes required to achieve 10 and 20 percent precision in estimates of macroplot-level means, and estimated amounts of sampling time required to achieve those degrees of precision. See Appendix $\mathrm{C}$ for macroplot-level tables summarizing within-plot variability. See Appendix A for key to species codes $(B S C=$ biological soil crust).

\begin{tabular}{|c|c|c|c|c|c|c|c|c|c|c|c|c|}
\hline \multirow[b]{2}{*}{ Measure } & \multirow[b]{2}{*}{ Method } & \multirow[b]{2}{*}{$\begin{array}{l}\text { Mean } \\
\text { cover }\end{array}$} & \multicolumn{5}{|c|}{$\begin{array}{l}\text { Within-macroplot variation in cover estimates } \\
\text { (summarized across macroplots) }\end{array}$} & \multicolumn{2}{|c|}{$\begin{array}{c}\text { Subsample size } \\
\text { (by precision) }\end{array}$} & \multirow[b]{2}{*}{$\begin{array}{l}\text { Unit time } \\
\text { (min) }\end{array}$} & \multicolumn{2}{|c|}{$\begin{array}{l}\text { Subsample time } \\
\text { (hrs by precision) }\end{array}$} \\
\hline & & & Mean sd & Min sd & Max sd & $\begin{array}{l}\text { Mean } \\
\text { freq* }^{*}\end{array}$ & Mean CV & $10 \%$ & $20 \%$ & & $10 \%$ & $20 \%$ \\
\hline \multirow{3}{*}{$\begin{array}{c}\text { Total live } \\
\text { understory } \\
\text { canopy } \\
\text { cover }\end{array}$} & $10-m^{2}$ & 18.8 & 11.7 & 6.0 & 18.4 & 98.6 & 65.1 & 152 & 40 & 7.9 & 20.0 & 5.3 \\
\hline & $1-m^{2}$ & 16.4 & 14.7 & 10.2 & 25.1 & 96.7 & 96.0 & 311 & 81 & 3.8 & 19.7 & 5.1 \\
\hline & Line-point & 13.3 & 13.2 & 7.0 & 23.6 & 66.7 & 102.3 & 380 & 98 & 2.5 & 15.8 & 4.1 \\
\hline \multirow[b]{3}{*}{ CORA } & $10-m^{2}$ & 10.3 & 7.5 & 5.5 & 11.4 & 68.3 & 106.5 & 202 & 53 & 7.9 & 26.6 & 7.0 \\
\hline & $1-m^{2}$ & 9.2 & 9.8 & 4.8 & 12.9 & 72.4 & 130.7 & 438 & 112 & 3.8 & 27.7 & 7.1 \\
\hline & Line-point & 6.2 & 7.4 & 5.1 & 11.0 & 46.7 & 135.4 & 548 & 140 & 2.5 & 22.8 & 5.8 \\
\hline \multirow[b]{3}{*}{ FEOC3 } & $10-m^{2}$ & 0.5 & 0.8 & 0.1 & 4.4 & 68.8 & 108.9 & 961 & 241 & 7.9 & 126.5 & 31.7 \\
\hline & $1-m^{2}$ & 0.5 & 0.4 & 0.3 & 0.5 & 49.0 & 129.4 & 283 & 73 & 3.8 & 17.9 & 4.6 \\
\hline & Line-point & 0.9 & 4.1 & 2.5 & 8.3 & 7.1 & 320.0 & 7923 & 1981 & 2.5 & 330.1 & 82.5 \\
\hline \multirow[b]{3}{*}{ Bare soil } & $10-m^{2}$ & 1.0 & 1.2 & 0.0 & 4.0 & 88.8 & 92.1 & 572 & 146 & 7.9 & 75.3 & 19.2 \\
\hline & $1-m^{2}$ & 1.5 & 2.2 & 0.5 & 5.7 & 58.6 & 141.2 & 833 & 209 & 3.8 & 52.8 & 13.2 \\
\hline & Line-point & 4.3 & 7.3 & 4.6 & 10.1 & 29.5 & 198.7 & 1103 & 276 & 2.5 & 46.0 & 11.5 \\
\hline \multirow[b]{3}{*}{ Litter } & $10-m^{2}$ & 5.6 & 8.7 & 1.5 & 18.8 & 99.3 & 149.9 & 920 & 230 & 7.9 & 121.1 & 30.3 \\
\hline & $1-m^{2}$ & 6.0 & 12.0 & 1.4 & 23.7 & 99.0 & 181.5 & 1575 & 394 & 3.8 & 99.8 & 25.0 \\
\hline & Line-point & 3.6 & 7.3 & 2.6 & 18.1 & 19.5 & 303.4 & 1555 & 389 & 2.5 & 64.8 & 16.2 \\
\hline \multirow[b]{3}{*}{ Crusundi } & $10-m^{2}$ & 69.8 & 16.7 & 0.0 & 28.7 & 99.3 & 30.9 & 25 & 8 & 7.9 & 3.3 & 1.1 \\
\hline & $1-m^{2}$ & 73.7 & 19.7 & 5.6 & 33.4 & 96.7 & 29.9 & 30 & 10 & 3.8 & 1.9 & 0.6 \\
\hline & Line-point & 70.4 & 18.7 & 13.7 & 28.0 & 98.6 & 30.3 & 30 & 10 & 2.5 & 1.3 & 0.4 \\
\hline \multirow[b]{3}{*}{ BSC } & $10-m^{2}$ & 5.6 & 5.1 & 2.8 & 8.5 & 89.5 & 106.2 & 321 & 83 & 7.9 & 42.3 & 10.9 \\
\hline & $1-m^{2}$ & 6.3 & 6.5 & 2.3 & 11.6 & 81.0 & 113.9 & 400 & 103 & 3.8 & 25.3 & 6.5 \\
\hline & Line-point & 10.8 & 11.9 & 3.8 & 17.8 & 51.4 & 133.4 & 464 & 119 & 2.5 & 19.3 & 5.0 \\
\hline
\end{tabular}

* frequency for line-point sampling was calculated on the basis of 10-point groups 
Table B10. Summary of mean cover estimates for selected cover measures across two Shallow Loamy macroplots at Wupatki National Monument, within-macroplot variation in cover estimates summarized across macroplots, subsample sizes required to achieve 10 and 20 percent precision in estimates of macroplot-level means, and estimated amounts of sampling time required to achieve those degrees of precision. See Appendix $C$ for macroplot-level tables summarizing within-plot variability. See Appendix A for key to species codes.

\begin{tabular}{|c|c|c|c|c|c|c|c|c|c|c|c|c|}
\hline \multicolumn{13}{|c|}{ Shallow Loamy, 10-14" pz ecological site, $n=2$ macroplots } \\
\hline \multirow[b]{2}{*}{ Measure } & \multirow[b]{2}{*}{ Method } & \multirow[b]{2}{*}{$\begin{array}{l}\text { Mean } \\
\text { cover }\end{array}$} & \multicolumn{5}{|c|}{$\begin{array}{c}\text { Within-macroplot variation in cover estimates } \\
\text { (summarized across macroplots) }\end{array}$} & \multicolumn{2}{|c|}{$\begin{array}{c}\text { Subsample size } \\
\text { (by precision) }\end{array}$} & \multirow[b]{2}{*}{$\begin{array}{l}\text { Unit time } \\
(\min )\end{array}$} & \multicolumn{2}{|c|}{$\begin{array}{l}\text { Subsample time } \\
\text { (hrs by precision) }\end{array}$} \\
\hline & & & Mean sd & Min sd & Max sd & $\begin{array}{l}\text { Mean } \\
\text { freq* }\end{array}$ & Mean CV & $10 \%$ & $20 \%$ & & $10 \%$ & $20 \%$ \\
\hline \multirow{3}{*}{$\begin{array}{c}\text { Total live } \\
\text { understory } \\
\text { canopy } \\
\text { cover }\end{array}$} & $10-m^{2}$ & 18.3 & 7.4 & 5.8 & 9.0 & 100.0 & 43.0 & 66 & 19 & 6.5 & 7.2 & 2.1 \\
\hline & $1-m^{2}$ & 17.2 & 13.8 & 10.7 & 17.0 & 100.0 & 87.4 & 250 & 65 & 3.4 & 14.2 & 3.7 \\
\hline & Line-point & 27.3 & 12.8 & 9.6 & 16.0 & 90.0 & 54.9 & 88 & 24 & 3.0 & 4.4 & 1.2 \\
\hline \multirow[b]{3}{*}{ CHLE4 } & $10-m^{2}$ & 2.0 & 1.6 & 0.6 & 2.6 & 95.2 & 89.3 & 252 & 66 & 6.5 & 27.3 & 7.2 \\
\hline & $1-m^{2}$ & 1.7 & 2.2 & 1.2 & 3.1 & 71.7 & 124.1 & 625 & 159 & 3.4 & 35.4 & 9.0 \\
\hline & Line-point & 3.0 & 4.4 & 2.5 & 6.3 & 26.7 & 249.2 & 831 & 208 & 3.0 & 41.6 & 10.4 \\
\hline \multirow[b]{3}{*}{ HENE5 } & $10-m^{2}$ & 3.5 & 3.7 & 1.8 & 5.5 & 92.9 & 102.2 & 428 & 110 & 6.5 & 46.4 & 11.9 \\
\hline & $1-m^{2}$ & 2.3 & 2.1 & 1.3 & 2.9 & 81.7 & 92.2 & 335 & 87 & 3.4 & 19.0 & 4.9 \\
\hline & Line-point & 6.2 & 7.6 & 4.3 & 10.8 & 43.3 & 146.3 & 578 & 147 & 3.0 & 28.9 & 7.4 \\
\hline \multirow[b]{3}{*}{ PLJA } & $10-m^{2}$ & 4.5 & 3.4 & 2.3 & 4.4 & 100.0 & 77.6 & 210 & 55 & 6.5 & 22.8 & 6.0 \\
\hline & $1-m^{2}$ & 4.3 & 3.5 & 2.1 & 5.0 & 93.3 & 85.6 & 262 & 68 & 3.4 & 14.8 & 3.9 \\
\hline & Line-point & 7.2 & 8.7 & 6.8 & 10.7 & 48.3 & 128.2 & 572 & 146 & 3.0 & 28.6 & 7.3 \\
\hline \multirow[b]{3}{*}{ Bare soil } & $10-m^{2}$ & 1.8 & 1.7 & 1.2 & 2.2 & 100.0 & 93.7 & 349 & 90 & 6.5 & 37.8 & 9.8 \\
\hline & $1-m^{2}$ & 3.5 & 5.1 & 1.7 & 8.6 & 98.3 & 127.0 & 807 & 202 & 3.4 & 45.7 & 11.4 \\
\hline & Line-point & 9.3 & 11.4 & 8.6 & 14.3 & 50.0 & 149.0 & 579 & 147 & 3.0 & 29.0 & 7.4 \\
\hline \multirow[b]{3}{*}{ Litter } & $10-m^{2}$ & 6.4 & 5.1 & 4.7 & 5.6 & 92.9 & 81.5 & 251 & 65 & 6.5 & 27.2 & 7.0 \\
\hline & $1-m^{2}$ & 8.5 & 12.2 & 11.1 & 13.3 & 95.0 & 143.2 & 789 & 200 & 3.4 & 44.7 & 11.3 \\
\hline & Line-point & 8.8 & 9.5 & 8.9 & 10.1 & 56.7 & 114.7 & 444 & 114 & 3.0 & 22.2 & 5.7 \\
\hline
\end{tabular}

* frequency for line-point sampling was calculated on the basis of 10-point groups 
Table B11. Summary of mean cover estimates for selected cover measures across five Upland Shallow Loam macroplots at Capitol Reef National Parks, within-macroplot variation in cover estimates summarized across macroplots, subsample sizes required to achieve 10 and 20 percent precision in estimates of macroplot-level means, and estimated amounts of sampling time required to achieve those degrees of precision. See Appendix $C$ for macroplot-level tables summarizing within-plot variability. See Appendix A for key to species codes (BSC = biological soil crust).

\begin{tabular}{|c|c|c|c|c|c|c|c|c|c|c|c|c|}
\hline \multirow[b]{2}{*}{ Measure } & \multirow[b]{2}{*}{ Method } & \multirow[b]{2}{*}{$\begin{array}{l}\text { Mean } \\
\text { cover }\end{array}$} & \multicolumn{5}{|c|}{$\begin{array}{c}\text { Within-macroplot variation in cover estimates } \\
\text { (summarized across macroplots) }\end{array}$} & \multicolumn{2}{|c|}{$\begin{array}{c}\text { Subsample size } \\
\text { (by precision) }\end{array}$} & \multirow[b]{2}{*}{$\begin{array}{l}\text { Unit time } \\
\text { (min) }\end{array}$} & \multicolumn{2}{|c|}{$\begin{array}{l}\text { Subsample time } \\
\text { (hrs by precision) }\end{array}$} \\
\hline & & & Mean sd & Min sd & Max sd & $\begin{array}{l}\text { Mean } \\
\text { freq }^{*}\end{array}$ & Mean CV & $10 \%$ & $20 \%$ & & $10 \%$ & $20 \%$ \\
\hline \multirow{3}{*}{$\begin{array}{l}\text { Total live } \\
\text { understory } \\
\text { canopy } \\
\text { cover }\end{array}$} & $10-m^{2}$ & 16.5 & 19.7 & 11.3 & 29.3 & 96.0 & 117.4 & 546 & 139 & 5.3 & 48.2 & 12.3 \\
\hline & $1-m^{2}$ & 15.4 & 24.5 & 18.9 & 30.8 & 88.7 & 176.4 & 976 & 244 & 2.8 & 45.5 & 11.4 \\
\hline & Line-point & 11.7 & 13.3 & 9.2 & 15.4 & 56.0 & 126.3 & 491 & 126 & 2.3 & 18.8 & 4.8 \\
\hline \multirow[b]{3}{*}{ CEMO2 } & $10-m^{2}$ & 1.9 & 6.1 & 5.0 & 7.1 & 18.7 & 204.3 & 4159 & 1040 & 5.3 & 367.4 & 91.9 \\
\hline & $1-m^{2}$ & 1.3 & 5.5 & 1.4 & 12.3 & 12.0 & 252.6 & 6828 & 1709 & 2.8 & 318.6 & 79.8 \\
\hline & Line-point & 2.4 & 11.3 & 8.3 & 14.2 & 13.3 & 192.5 & 8456 & 2114 & 2.3 & 324.1 & 81.0 \\
\hline \multirow[b]{3}{*}{ COWR2 } & $10-m^{2}$ & 1.2 & 1.3 & 1.0 & 1.8 & 80.4 & 116.9 & 484 & 124 & 5.3 & 42.8 & 11.0 \\
\hline & $1-m^{2}$ & 1.1 & 1.2 & 0.8 & 2.3 & 63.3 & 115.1 & 482 & 124 & 2.8 & 22.5 & 5.8 \\
\hline & Line-point & 2.3 & 5.9 & 3.5 & 9.4 & 18.7 & 208.8 & 2424 & 606 & 2.3 & 92.9 & 23.2 \\
\hline \multirow[b]{3}{*}{ JuOS } & $10-m^{2}$ & 5.6 & 12.1 & 9.7 & 17.0 & 29.0 & 228.0 & 1792 & 448 & 5.3 & 158.3 & 39.6 \\
\hline & $1-m^{2}$ & 4.8 & 13.9 & 2.6 & 19.4 & 15.3 & 307.2 & 3168 & 792 & 2.8 & 147.8 & 37.0 \\
\hline & Line-point & 2.5 & 5.8 & 2.6 & 8.0 & 17.3 & 255.7 & 2022 & 506 & 2.3 & 77.5 & 19.4 \\
\hline \multirow[b]{3}{*}{ Bare soil } & $10-m^{2}$ & 1.1 & 1.4 & 0.1 & 2.5 & 95.8 & 108.1 & 588 & 150 & 5.3 & 51.9 & 13.3 \\
\hline & $1-m^{2}$ & 1.6 & 1.5 & 1.1 & 2.0 & 86.7 & 98.5 & 367 & 95 & 2.8 & 17.1 & 4.4 \\
\hline & Line-point & 15.3 & 13.5 & 10.1 & 19.4 & 72.7 & 96.8 & 300 & 78 & 2.3 & 11.5 & 3.0 \\
\hline \multirow[b]{3}{*}{ Litter } & $10-m^{2}$ & 16.8 & 22.1 & 9.9 & 28.1 & 100.0 & 142.2 & 667 & 170 & 5.3 & 58.9 & 15.0 \\
\hline & $1-m^{2}$ & 22.0 & 31.4 & 23.3 & 39.5 & 99.3 & 169.9 & 783 & 198 & 2.8 & 36.5 & 9.2 \\
\hline & Line-point & 6.8 & 11.4 & 5.9 & 16.4 & 32.7 & 209.9 & 1071 & 268 & 2.3 & 41.1 & 10.3 \\
\hline \multirow[b]{3}{*}{ BSC } & $10-m^{2}$ & 0.1 & 0.2 & 0.2 & 0.2 & 15.2 & 221.0 & 2661 & 666 & 5.3 & 235.1 & 58.8 \\
\hline & $1-m^{2}$ & 0.1 & 0.3 & 0.2 & 0.5 & 6.0 & 399.7 & 7197 & 1827 & 2.8 & 335.9 & 85.3 \\
\hline & Line-point & 0.2 & 2.2 & 1.8 & 2.5 & 2.0 & 464.1 & 45641 & 11411 & 2.3 & 1749.6 & 437.4 \\
\hline
\end{tabular}

* frequency for line-point sampling was calculated on the basis of 10-point groups 


\section{Appendix C-Summaries of Frequency and Cover Estimates by Macroplot and Sampling Technique}

\begin{tabular}{|c|c|c|c|c|}
\hline Ecological site & Macroplot & Phase & Table & Page \\
\hline \multirow{5}{*}{ Brushy Loam } & MEVE1 & 2 & C1 & 79 \\
\hline & MEVE2 & 2 & $\mathrm{C} 2$ & 80 \\
\hline & MEVE5 & 3 & C3 & 81 \\
\hline & MEVE6 & 3 & $\mathrm{C} 4$ & 82 \\
\hline & MEVE7b & 3 & $\mathrm{C5}$ & 83 \\
\hline \multirow{2}{*}{ Desert Sand (Sand Sagebrush) } & CANY1 & 2 & C6 & 84 \\
\hline & CANY2b & 2 & $\mathrm{C} 7$ & 85 \\
\hline \multirow{5}{*}{ Limy Upland, 6-10" pz } & WUPA1 & 2 & $\mathrm{C} 8$ & 86 \\
\hline & WUPA2 & 2 & C9 & 87 \\
\hline & WUPA5 & 3 & C10 & 88 \\
\hline & WUPA6 & 3 & C11 & 89 \\
\hline & WUPA7 & 3 & C12 & 90 \\
\hline \multirow{5}{*}{ Loamy Hills, 25-33" pz } & GRCA3 & 2 & C13 & 91 \\
\hline & GRCA4 & 2 & C14 & 92 \\
\hline & GRCA5 & 3 & C15 & 93 \\
\hline & GRCA6 & 3 & C16 & 94 \\
\hline & GRCA7 & 3 & C17 & 95 \\
\hline \multirow{2}{*}{ Loamy Hills, Cold, 25-33" pz } & GRCA1 & 2 & C18 & 96 \\
\hline & GRCA2 & 2 & C19 & 97 \\
\hline \multirow{5}{*}{ Loamy Mesa Top PJ } & MEVE3 & 2 & $\mathrm{C} 20$ & 98 \\
\hline & MEVE4 & 2 & C21 & 99 \\
\hline & MEVE8 & 3 & $\mathrm{C} 22$ & 100 \\
\hline & MEVE9 & 3 & C23 & 101 \\
\hline & MEVE10 & 3 & C24 & 102 \\
\hline \multirow{5}{*}{$\begin{array}{l}\text { Semidesert Alkali Sandy Loam } \\
\text { (Alkali Sacaton) }\end{array}$} & CARE1 & 2 & C25 & 103 \\
\hline & CARE2 & 2 & C26 & 104 \\
\hline & CARE5 & 3 & $\mathrm{C} 27$ & 105 \\
\hline & CARE6 & 3 & C28 & 106 \\
\hline & CARE7 & 3 & C29 & 107 \\
\hline \multirow{5}{*}{$\begin{array}{l}\text { Semidesert Loam (Wyoming Big } \\
\text { Sagebrush) }\end{array}$} & DINO1 & 2 & C30 & 108 \\
\hline & DINO2b & 2 & C31 & 109 \\
\hline & DINO3 & 3 & C32 & 110 \\
\hline & DINO4b & 3 & C33 & 111 \\
\hline & DINO5 & 3 & C34 & 112 \\
\hline \multirow{7}{*}{$\begin{array}{l}\text { Semidesert Shallow Sandy Loam } \\
\text { PJ }\end{array}$} & ARCH1b & 2 & C35 & 113 \\
\hline & ARCH2 & 2 & C36 & 114 \\
\hline & $\mathrm{ARCH} 3$ & 3 & C37 & 115 \\
\hline & $\mathrm{ARCH} 4 \mathrm{~b}$ & 3 & C38 & 116 \\
\hline & ARCH5 & 3 & C39 & 117 \\
\hline & CANY3 & 2 & C40 & 118 \\
\hline & CANY4 & 2 & C41 & 119 \\
\hline \multirow{2}{*}{ Shallow Loamy, 10-14" pz } & WUPA3 & 2 & C42 & 120 \\
\hline & WUPA4 & 2 & C43 & 121 \\
\hline \multirow{5}{*}{$\begin{array}{l}\text { Upland Shallow Loam (Pinyon-Utah } \\
\text { Juniper) }\end{array}$} & CARE3 & 2 & C44 & 122 \\
\hline & CARE4b & 2 & C45 & 123 \\
\hline & CARE8 & 3 & C46 & 124 \\
\hline & CARE9 & 3 & C47 & 125 \\
\hline & CARE10 & 3 & C48 & 126 \\
\hline
\end{tabular}


Table C1. Summary of frequency (freq) and cover estimates in macroplot MEVE1 (Brushy Loam ecological site). For line-point sampling, 10-point groups were used as subsampling units for purposes of frequency calculations. Precision is defined as one-half the width of the 95 percent confidence interval. The standardized mean was calculated as the ratio of the mean for a particular method to the among-method mean. See Appendix A for keys to species codes (BSC = biological soil crust).

\begin{tabular}{|c|c|c|c|c|c|c|c|c|c|c|}
\hline \multirow[b]{2}{*}{ Measure } & \multirow[b]{2}{*}{ Method } & \multirow[b]{2}{*}{ Subsample $\mathrm{n}$} & \multirow[b]{2}{*}{ Freq } & \multicolumn{7}{|c|}{ Cover } \\
\hline & & & & Mean & sd & CV & Precision & $\begin{array}{l}\text { Precision } \% \\
\text { of mean }\end{array}$ & $\begin{array}{c}\text { Among- } \\
\text { method } \\
\text { mean }\end{array}$ & $\begin{array}{c}\text { Standardized } \\
\text { mean }\end{array}$ \\
\hline \multirow{3}{*}{$\begin{array}{c}\text { Total live } \\
\text { understory } \\
\text { canopy } \\
\text { cover }\end{array}$} & $10-m^{2}$ & 21 & 100.0 & 71.21 & 21.60 & 30.34 & 9.24 & 12.97 & & 1.16 \\
\hline & $1-m^{2}$ & 30 & 100.0 & 62.60 & 30.26 & 48.34 & 10.83 & 17.30 & 61.3 & 1.02 \\
\hline & Line-point & 30 & 93.3 & 50.00 & 33.22 & 66.44 & 11.89 & 23.77 & & 0.82 \\
\hline \multirow[b]{3}{*}{ AMUT } & $10-m^{2}$ & 21 & 71.4 & 15.45 & 18.67 & 120.84 & 7.99 & 51.68 & & 1.27 \\
\hline & $1-m^{2}$ & 30 & 46.7 & 10.77 & 22.31 & 207.18 & 7.98 & 74.14 & 12.2 & 0.88 \\
\hline & Line-point & 30 & 36.7 & 10.33 & 15.42 & 149.24 & 5.52 & 53.40 & & 0.85 \\
\hline \multirow[b]{3}{*}{ POFE } & $10-m^{2}$ & 21 & 57.1 & 0.29 & 0.25 & 88.74 & 0.11 & 37.95 & & 0.67 \\
\hline & $1-m^{2}$ & 30 & 33.3 & 0.33 & 0.48 & 143.84 & 0.17 & 51.47 & 0.4 & 0.78 \\
\hline & Line-point & 30 & 6.7 & 0.67 & 2.54 & 380.56 & 0.91 & 136.18 & & 1.56 \\
\hline \multirow[b]{3}{*}{ QUGA } & $10-m^{2}$ & 21 & 95.2 & 37.40 & 24.23 & 64.79 & 10.37 & 27.71 & & 1.07 \\
\hline & $1-m^{2}$ & 30 & 80.0 & 37.13 & 31.43 & 84.64 & 11.25 & 30.29 & 34.8 & 1.07 \\
\hline & Line-point & 30 & 80.0 & 30.00 & 27.42 & 91.39 & 9.81 & 32.70 & & 0.86 \\
\hline \multirow[b]{3}{*}{ Bare soil } & $10-m^{2}$ & 21 & 85.7 & 7.02 & 11.46 & 163.12 & 4.90 & 69.76 & & 1.09 \\
\hline & $1-m^{2}$ & 30 & 43.3 & 4.23 & 15.47 & 365.46 & 5.54 & 130.78 & 6.4 & 0.66 \\
\hline & Line-point & 30 & 30.0 & 8.00 & 17.69 & 221.18 & 6.33 & 79.15 & & 1.25 \\
\hline \multirow[b]{3}{*}{ Litter } & $10-m^{2}$ & 21 & 100.0 & 76.79 & 14.94 & 19.46 & 6.39 & 8.32 & & 0.92 \\
\hline & $1-m^{2}$ & 30 & 100.0 & 86.03 & 21.93 & 25.49 & 7.85 & 9.12 & 83.3 & 1.03 \\
\hline & Line-point & 30 & 100.0 & 87.00 & 18.96 & 21.80 & 6.79 & 7.80 & & 1.04 \\
\hline \multirow[b]{3}{*}{ BSC } & $10-m^{2}$ & 21 & 38.1 & 0.43 & 0.88 & 206.36 & 0.38 & 88.26 & & 1.62 \\
\hline & $1-m^{2}$ & 30 & 3.3 & 0.03 & 0.18 & 547.72 & 0.07 & 196.00 & 0.3 & 0.13 \\
\hline & Line-point & 30 & 3.3 & 0.33 & 1.83 & 547.72 & 0.65 & 196.00 & & 1.26 \\
\hline
\end{tabular}


Table C2. Summary of frequency (freq) and cover estimates in macroplot MEVE2 (Brushy Loam ecological site). For line-point sampling, 10-point groups were used as subsampling units for purposes of frequency calculations. Precision is defined as one-half the width of the 95 percent confidence interval. The standardized mean was calculated as the ratio of the mean for a particular method to the among-method mean. See Appendix A for keys to species codes (BSC = biological soil crust).

\begin{tabular}{|c|c|c|c|c|c|c|c|c|c|c|}
\hline \multirow[b]{2}{*}{ Measure } & \multirow[b]{2}{*}{ Method } & \multirow[b]{2}{*}{ Subsample $\mathbf{n}$} & \multirow[b]{2}{*}{ Freq } & \multicolumn{7}{|c|}{ Cover } \\
\hline & & & & Mean & sd & CV & Precision & $\begin{array}{l}\text { Precision \% } \\
\text { of mean }\end{array}$ & $\begin{array}{l}\text { Among- } \\
\text { method } \\
\text { mean }\end{array}$ & $\begin{array}{c}\text { Standardized } \\
\text { mean }\end{array}$ \\
\hline \multirow{3}{*}{$\begin{array}{l}\text { Total live } \\
\text { understory } \\
\text { canopy } \\
\text { cover }\end{array}$} & $10-m^{2}$ & 21 & 100.0 & 46.21 & 23.96 & 51.85 & 10.25 & 22.18 & & 0.93 \\
\hline & $1-m^{2}$ & 30 & 100.0 & 48.97 & 37.26 & 76.09 & 13.33 & 27.23 & 49.7 & 0.98 \\
\hline & Line-point & 30 & 100.0 & 54.00 & 27.24 & 50.45 & 9.75 & 18.05 & & 1.09 \\
\hline \multirow[b]{3}{*}{ AMUT } & $10-m^{2}$ & 21 & 52.4 & 3.60 & 8.30 & 230.95 & 3.55 & 98.78 & & 1.15 \\
\hline & $1-m^{2}$ & 30 & 26.7 & 2.80 & 7.80 & 278.45 & 2.79 & 99.64 & 3.1 & 0.89 \\
\hline & Line-point & 30 & 16.7 & 3.00 & 7.94 & 264.79 & 2.84 & 94.75 & & 0.96 \\
\hline \multirow[b]{3}{*}{ POFE } & $10-m^{2}$ & 21 & 9.5 & 0.05 & 0.15 & 315.83 & 0.06 & 135.08 & & 1.76 \\
\hline & $1-m^{2}$ & 30 & 3.3 & 0.03 & 0.18 & 547.72 & 0.07 & 196.00 & 0.0 & 1.24 \\
\hline & Line-point & 30 & 0.0 & 0.00 & - & - & - & - & & 0.00 \\
\hline \multirow[b]{3}{*}{ QUGA } & $10-m^{2}$ & 21 & 85.7 & 27.43 & 22.21 & 80.99 & 9.50 & 34.64 & & 0.91 \\
\hline & $1-m^{2}$ & 30 & 63.3 & 29.67 & 35.70 & 120.33 & 12.77 & 43.06 & 30.0 & 0.99 \\
\hline & Line-point & 30 & 83.3 & 33.00 & 25.62 & 77.63 & 9.17 & 27.78 & & 1.10 \\
\hline \multirow[b]{3}{*}{ Bare soil } & $10-m^{2}$ & 21 & 100.0 & 32.26 & 13.92 & 43.14 & 5.95 & 18.45 & & 0.80 \\
\hline & $1-m^{2}$ & 30 & 93.3 & 40.93 & 28.38 & 69.33 & 10.16 & 24.81 & 40.2 & 1.02 \\
\hline & Line-point & 30 & 100.0 & 47.33 & 21.80 & 46.06 & 7.80 & 16.48 & & 1.18 \\
\hline \multirow[b]{3}{*}{ Litter } & $10-m^{2}$ & 21 & 100.0 & 44.19 & 22.05 & 49.90 & 9.43 & 21.34 & & 0.94 \\
\hline & $1-m^{2}$ & 30 & 100.0 & 48.97 & 31.39 & 64.10 & 11.23 & 22.94 & 46.8 & 1.05 \\
\hline & Line-point & 30 & 96.7 & 47.33 & 23.92 & 50.53 & 8.56 & 18.08 & & 1.01 \\
\hline \multirow[b]{3}{*}{ BSC } & $10-m^{2}$ & 21 & 0.0 & 0.00 & - & - & - & - & & - \\
\hline & $1-m^{2}$ & 30 & 0.0 & 0.00 & - & - & - & - & 0.0 & - \\
\hline & Line-point & 30 & 0.0 & 0.00 & - & - & - & - & & - \\
\hline
\end{tabular}


Table C3. Summary of frequency (freq) and cover estimates in macroplot MEVE5 (Brushy Loam ecological site). For line-point sampling, 10-point groups were used as subsampling units for purposes of frequency calculations. Precision is defined as one-half the width of the 95 percent confidence interval. The standardized mean was calculated as the ratio of the mean for a particular method to the among-method mean. See Appendix A for keys to species codes (BSC = biological soil crust).

\begin{tabular}{|c|c|c|c|c|c|c|c|c|c|c|}
\hline \multirow[b]{2}{*}{ Measure } & \multirow[b]{2}{*}{ Method } & \multirow[b]{2}{*}{ Subsample $\mathbf{n}$} & \multirow[b]{2}{*}{ Freq } & \multicolumn{7}{|c|}{ Cover } \\
\hline & & & & Mean & sd & CV & Precision & $\begin{array}{l}\text { Precision \% } \\
\text { of mean }\end{array}$ & $\begin{array}{l}\text { Among- } \\
\text { method } \\
\text { mean }\end{array}$ & $\begin{array}{c}\text { Standardized } \\
\text { mean }\end{array}$ \\
\hline \multirow{3}{*}{$\begin{array}{l}\text { Total live } \\
\text { understory } \\
\text { canopy } \\
\text { cover }\end{array}$} & $10-m^{2}$ & 15 & 100.0 & 44.73 & 19.60 & 43.81 & 9.92 & 22.17 & & 0.98 \\
\hline & $1-m^{2}$ & 15 & 100.0 & 37.13 & 30.28 & 81.54 & 15.32 & 41.27 & 45.7 & 0.81 \\
\hline & Line-point & 15 & 100.0 & 55.33 & 17.67 & 31.94 & 8.94 & 16.16 & & 1.21 \\
\hline \multirow[b]{3}{*}{ AMUT } & $10-m^{2}$ & 15 & 60.0 & 8.20 & 18.17 & 221.54 & 9.19 & 112.12 & & 1.57 \\
\hline & $1-m^{2}$ & 15 & 13.3 & 0.13 & 0.35 & 263.90 & 0.18 & 133.55 & 5.2 & 0.03 \\
\hline & Line-point & 15 & 40.0 & 7.33 & 11.63 & 158.58 & 5.89 & 80.25 & & 1.40 \\
\hline \multirow[b]{3}{*}{ POFE } & $10-m^{2}$ & 15 & 73.3 & 15.03 & 22.56 & 150.04 & 11.41 & 75.93 & & 0.88 \\
\hline & $1-m^{2}$ & 15 & 73.3 & 20.87 & 32.24 & 154.50 & 16.32 & 78.19 & 17.1 & 1.22 \\
\hline & Line-point & 15 & 60.0 & 15.33 & 18.07 & 117.87 & 9.15 & 59.65 & & 0.90 \\
\hline \multirow[b]{3}{*}{ QUGA } & $10-m^{2}$ & 15 & 13.3 & 1.37 & 4.53 & 331.43 & 2.29 & 167.72 & & 0.68 \\
\hline & $1-m^{2}$ & 15 & 6.7 & 0.67 & 2.58 & 387.30 & 1.31 & 196.00 & 2.0 & 0.33 \\
\hline & Line-point & 15 & 26.7 & 4.00 & 8.28 & 207.02 & 4.19 & 104.76 & & 1.99 \\
\hline \multirow[b]{3}{*}{ Bare soil } & $10-m^{2}$ & 15 & 93.3 & 6.67 & 5.18 & 77.72 & 2.62 & 39.33 & & 0.21 \\
\hline & $1-m^{2}$ & 15 & 100.0 & 11.87 & 17.94 & 151.21 & 9.08 & 76.52 & 32.2 & 0.37 \\
\hline & Line-point & 15 & 100.0 & 78.00 & 21.11 & 27.07 & 10.68 & 13.70 & & 2.42 \\
\hline \multirow[b]{3}{*}{ Litter } & $10-m^{2}$ & 15 & 100.0 & 80.83 & 14.84 & 18.36 & 7.51 & 9.29 & & 1.36 \\
\hline & $1-m^{2}$ & 15 & 100.0 & 80.53 & 19.34 & 24.01 & 9.79 & 12.15 & 59.6 & 1.35 \\
\hline & Line-point & 15 & 80.0 & 17.33 & 20.86 & 120.36 & 10.56 & 60.91 & & 0.29 \\
\hline \multirow[b]{3}{*}{ BSC } & $10-m^{2}$ & 15 & 13.3 & 0.07 & 0.18 & 263.90 & 0.09 & 133.55 & & 1.50 \\
\hline & $1-m^{2}$ & 15 & 6.7 & 0.07 & 0.26 & 387.30 & 0.13 & 196.00 & 0.0 & 1.50 \\
\hline & Line-point & 15 & 0.0 & 0.00 & - & - & - & - & & 0.00 \\
\hline
\end{tabular}


Table C4. Summary of frequency (freq) and cover estimates in macroplot MEVE6 (Brushy Loam ecological site). For line-point sampling, 10-point groups were used as subsampling units for purposes of frequency calculations. Precision is defined as one-half the width of the 95 percent confidence interval. The standardized mean was calculated as the ratio of the mean for a particular method to the among-method mean. See Appendix A for keys to species codes (BSC = biological soil crust).

\begin{tabular}{|c|c|c|c|c|c|c|c|c|c|c|}
\hline \multirow[b]{2}{*}{ Measure } & \multirow[b]{2}{*}{ Method } & \multirow[b]{2}{*}{ Subsample $\mathbf{n}$} & \multirow[b]{2}{*}{ Freq } & \multicolumn{7}{|c|}{ Cover } \\
\hline & & & & Mean & sd & CV & Precision & $\begin{array}{l}\text { Precision \% } \\
\text { of mean }\end{array}$ & $\begin{array}{l}\text { Among- } \\
\text { method } \\
\text { mean }\end{array}$ & $\begin{array}{c}\text { Standardized } \\
\text { mean }\end{array}$ \\
\hline \multirow{3}{*}{$\begin{array}{l}\text { Total live } \\
\text { understory } \\
\text { canopy } \\
\text { cover }\end{array}$} & $10-m^{2}$ & 15 & 100.0 & 28.37 & 7.37 & 25.99 & 3.73 & 13.15 & & 0.83 \\
\hline & $1-m^{2}$ & 15 & 100.0 & 25.80 & 10.75 & 41.67 & 5.44 & 21.09 & 34.3 & 0.75 \\
\hline & Line-point & 15 & 100.0 & 48.67 & 24.16 & 49.65 & 12.23 & 25.13 & & 1.42 \\
\hline \multirow[b]{3}{*}{ AMUT } & $10-m^{2}$ & 15 & 13.3 & 1.37 & 4.53 & 331.43 & 2.29 & 167.72 & & 2.02 \\
\hline & $1-m^{2}$ & 15 & 0.0 & 0.00 & - & - & - & - & 0.7 & 0.00 \\
\hline & Line-point & 15 & 6.7 & 0.67 & 2.58 & 387.30 & 1.31 & 196.00 & & 0.98 \\
\hline \multirow[b]{3}{*}{ POFE } & $10-m^{2}$ & 15 & 73.3 & 2.30 & 2.51 & 108.94 & 1.27 & 55.13 & & 0.58 \\
\hline & $1-m^{2}$ & 15 & 53.3 & 2.20 & 3.32 & 150.95 & 1.68 & 76.39 & 3.9 & 0.56 \\
\hline & Line-point & 15 & 53.3 & 7.33 & 8.84 & 120.51 & 4.47 & 60.98 & & 1.86 \\
\hline \multirow[b]{3}{*}{ QUGA } & $10-m^{2}$ & 15 & 6.7 & 1.17 & 4.52 & 387.30 & 2.29 & 196.00 & & 0.93 \\
\hline & $1-m^{2}$ & 15 & 20.0 & 1.93 & 6.94 & 359.14 & 3.51 & 181.74 & 1.3 & 1.54 \\
\hline & Line-point & 15 & 6.7 & 0.67 & 2.58 & 387.30 & 1.31 & 196.00 & & 0.53 \\
\hline \multirow[b]{3}{*}{ Bare soil } & $10-m^{2}$ & 15 & 100.0 & 17.27 & 12.04 & 69.74 & 6.09 & 35.29 & & 0.61 \\
\hline & $1-m^{2}$ & 15 & 86.7 & 20.27 & 14.53 & 71.71 & 7.35 & 36.29 & 28.5 & 0.71 \\
\hline & Line-point & 15 & 100.0 & 48.00 & 15.21 & 31.69 & 7.70 & 16.04 & & 1.68 \\
\hline \multirow[b]{3}{*}{ Litter } & $10-m^{2}$ & 15 & 100.0 & 65.83 & 18.58 & 28.22 & 9.40 & 14.28 & & 1.10 \\
\hline & $1-m^{2}$ & 15 & 100.0 & 70.47 & 16.10 & 22.85 & 8.15 & 11.56 & 59.9 & 1.18 \\
\hline & Line-point & 15 & 100.0 & 43.33 & 9.76 & 22.52 & 4.94 & 11.40 & & 0.72 \\
\hline \multirow[b]{3}{*}{ BSC } & $10-m^{2}$ & 15 & 0.0 & 0.00 & - & - & - & - & & - \\
\hline & $1-m^{2}$ & 15 & 0.0 & 0.00 & - & - & - & - & 0.0 & - \\
\hline & Line-point & 15 & 0.0 & 0.00 & - & - & - & - & & - \\
\hline
\end{tabular}


Table C5. Summary of frequency (freq) and cover estimates in macroplot MEVE7b (Brushy Loam ecological site). For line-point sampling, 10-point groups were used as subsampling units for purposes of frequency calculations. Precision is defined as one-half the width of the 95 percent confidence interval. The standardized mean was calculated as the ratio of the mean for a particular method to the among-method mean. See Appendix A for keys to species codes (BSC = biological soil crust).

\begin{tabular}{|c|c|c|c|c|c|c|c|c|c|c|}
\hline \multirow[b]{2}{*}{ Measure } & \multirow[b]{2}{*}{ Method } & \multirow[b]{2}{*}{ Subsample $\mathbf{n}$} & \multirow[b]{2}{*}{ Freq } & \multicolumn{7}{|c|}{ Cover } \\
\hline & & & & Mean & sd & CV & Precision & $\begin{array}{l}\text { Precision \% } \\
\text { of mean }\end{array}$ & $\begin{array}{l}\text { Among- } \\
\text { method } \\
\text { mean }\end{array}$ & $\begin{array}{c}\text { Standardized } \\
\text { mean }\end{array}$ \\
\hline \multirow{3}{*}{$\begin{array}{l}\text { Total live } \\
\text { understory } \\
\text { canopy } \\
\text { cover }\end{array}$} & $10-m^{2}$ & 15 & 100.0 & 58.10 & 17.82 & 30.66 & 9.02 & 15.52 & & 1.11 \\
\hline & $1-m^{2}$ & 15 & 100.0 & 42.40 & 22.50 & 53.06 & 11.38 & 26.85 & 52.2 & 0.81 \\
\hline & Line-point & 15 & 100.0 & 56.00 & 16.39 & 29.26 & 8.29 & 14.81 & & 1.07 \\
\hline \multirow[b]{3}{*}{ AMUT } & $10-m^{2}$ & 15 & 86.7 & 3.93 & 4.84 & 122.95 & 2.45 & 62.22 & & 1.09 \\
\hline & $1-m^{2}$ & 15 & 40.0 & 2.20 & 6.36 & 289.12 & 3.22 & 146.31 & 3.6 & 0.61 \\
\hline & Line-point & 15 & 33.3 & 4.67 & 8.34 & 178.67 & 4.22 & 90.42 & & 1.30 \\
\hline \multirow[b]{3}{*}{ POFE } & $10-m^{2}$ & 15 & 100.0 & 30.37 & 18.62 & 61.33 & 9.42 & 31.04 & & 1.39 \\
\hline & $1-m^{2}$ & 15 & 100.0 & 14.60 & 14.53 & 99.55 & 7.36 & 50.38 & 21.9 & 0.67 \\
\hline & Line-point & 15 & 93.3 & 20.67 & 15.80 & 76.43 & 7.99 & 38.68 & & 0.94 \\
\hline \multirow[b]{3}{*}{ QUGA } & $10-m^{2}$ & 15 & 33.3 & 5.37 & 10.83 & 201.87 & 5.48 & 102.16 & & 0.75 \\
\hline & $1-m^{2}$ & 15 & 26.7 & 11.40 & 27.00 & 236.84 & 13.66 & 119.85 & 7.1 & 1.60 \\
\hline & Line-point & 15 & 26.7 & 4.67 & 8.34 & 178.67 & 4.22 & 90.42 & & 0.65 \\
\hline \multirow[b]{3}{*}{ Bare soil } & $10-m^{2}$ & 15 & 100.0 & 8.10 & 7.14 & 88.17 & 3.61 & 44.62 & & 0.60 \\
\hline & $1-m^{2}$ & 15 & 73.3 & 6.80 & 9.27 & 136.29 & 4.69 & 68.97 & 13.4 & 0.51 \\
\hline & Line-point & 15 & 86.7 & 25.33 & 18.46 & 72.89 & 9.34 & 36.89 & & 1.89 \\
\hline \multirow[b]{3}{*}{ Litter } & $10-m^{2}$ & 15 & 100.0 & 84.17 & 8.80 & 10.45 & 4.45 & 5.29 & & 1.04 \\
\hline & $1-m^{2}$ & 15 & 100.0 & 91.07 & 10.47 & 11.50 & 5.30 & 5.82 & 80.6 & 1.13 \\
\hline & Line-point & 15 & 100.0 & 66.67 & 20.24 & 30.36 & 10.24 & 15.36 & & 0.83 \\
\hline \multirow[b]{3}{*}{ BSC } & $10-m^{2}$ & 15 & 53.3 & 0.43 & 0.75 & 173.72 & 0.38 & 87.91 & & 0.87 \\
\hline & $1-m^{2}$ & 15 & 26.7 & 0.40 & 0.83 & 207.02 & 0.42 & 104.76 & 0.5 & 0.80 \\
\hline & Line-point & 15 & 6.7 & 0.67 & 2.58 & 387.30 & 1.31 & 196.00 & & 1.33 \\
\hline
\end{tabular}


Table C6. Summary of frequency (freq) and cover estimates in macroplot CANY1 (Desert Sand ecological site). For linepoint sampling, 10-point groups were used as subsampling units for purposes of frequency calculations. Precision is defined as one-half the width of the 95 percent confidence interval. The standardized mean was calculated as the ratio of the mean for a particular method to the among-method mean. See Appendix A for keys to species codes (BSC = biological soil crust).

\begin{tabular}{|c|c|c|c|c|c|c|c|c|c|c|}
\hline \multirow[b]{2}{*}{ Measure } & \multirow[b]{2}{*}{ Method } & \multirow[b]{2}{*}{ Subsample $n$} & \multirow[b]{2}{*}{ Freq } & \multicolumn{7}{|c|}{ Cover } \\
\hline & & & & Mean & sd & CV & Precision & $\begin{array}{c}\text { Precision \% } \\
\text { of mean }\end{array}$ & $\begin{array}{c}\text { Among- } \\
\text { method } \\
\text { mean }\end{array}$ & $\begin{array}{c}\text { Standardized } \\
\text { mean }\end{array}$ \\
\hline \multirow{3}{*}{$\begin{array}{c}\text { Total live } \\
\text { understory } \\
\text { canopy } \\
\text { cover }\end{array}$} & $10-m^{2}$ & 21 & 100.0 & 13.07 & 3.45 & 26.37 & 1.47 & 11.28 & & 1.06 \\
\hline & $1-m^{2}$ & 30 & 100.0 & 12.13 & 6.49 & 53.49 & 2.32 & 19.14 & 12.3 & 0.99 \\
\hline & Line-point & 30 & 63.3 & 11.67 & 12.06 & 103.36 & 4.31 & 36.99 & & 0.95 \\
\hline \multirow[b]{3}{*}{ ATCA2 } & $10-m^{2}$ & 21 & 66.7 & 1.83 & 2.30 & 125.67 & 0.99 & 53.75 & & 1.02 \\
\hline & $1-m^{2}$ & 30 & 13.3 & 1.57 & 5.13 & 327.48 & 1.84 & 117.19 & 1.8 & 0.87 \\
\hline & Line-point & 30 & 16.7 & 2.00 & 4.84 & 242.12 & 1.73 & 86.64 & & 1.11 \\
\hline \multirow[b]{3}{*}{ HIJA } & $10-m^{2}$ & 21 & 28.6 & 1.17 & 2.36 & 202.08 & 1.01 & 86.43 & & 1.00 \\
\hline & $1-m^{2}$ & 30 & 23.3 & 1.00 & 2.53 & 253.25 & 0.91 & 90.62 & 1.2 & 0.86 \\
\hline & Line-point & 30 & 6.7 & 1.33 & 5.71 & 428.51 & 2.04 & 153.34 & & 1.14 \\
\hline \multirow[b]{3}{*}{ STHY6 } & $10-m^{2}$ & 21 & 38.1 & 0.19 & 0.25 & 130.62 & 0.11 & 55.87 & & 0.92 \\
\hline & $1-m^{2}$ & 30 & 10.0 & 0.10 & 0.31 & 305.13 & 0.11 & 109.19 & 0.2 & 0.48 \\
\hline & Line-point & 30 & 3.3 & 0.33 & 1.83 & 547.72 & 0.65 & 196.00 & & 1.60 \\
\hline \multirow[b]{3}{*}{ Litter } & $10-m^{2}$ & 21 & 100.0 & 7.69 & 5.30 & 68.88 & 2.27 & 29.46 & & 0.90 \\
\hline & $1-\mathrm{m}^{2}$ & 30 & 100.0 & 7.53 & 5.53 & 73.35 & 1.98 & 26.25 & 8.5 & 0.88 \\
\hline & Line-point & 30 & 63.3 & 10.33 & 10.66 & 103.18 & 3.82 & 36.92 & & 1.21 \\
\hline \multirow{3}{*}{$\begin{array}{l}\text { Undifferenti } \\
\text { ated crust }\end{array}$} & $10-m^{2}$ & 21 & 100.0 & 72.02 & 12.44 & 17.27 & 5.32 & 7.39 & & 0.91 \\
\hline & $1-m^{2}$ & 30 & 100.0 & 80.90 & 10.18 & 12.58 & 3.64 & 4.50 & 79.2 & 1.02 \\
\hline & Line-point & 30 & 100.0 & 84.67 & 14.08 & 16.63 & 5.04 & 5.95 & & 1.07 \\
\hline \multirow[b]{3}{*}{ BSC } & $10-m^{2}$ & 21 & 85.7 & 1.02 & 0.93 & 90.68 & 0.40 & 38.78 & & 0.80 \\
\hline & $1-m^{2}$ & 30 & 50.0 & 1.13 & 1.61 & 142.34 & 0.58 & 50.93 & 1.3 & 0.89 \\
\hline & Line-point & 30 & 16.7 & 1.67 & 3.79 & 227.43 & 1.36 & 81.38 & & 1.31 \\
\hline
\end{tabular}


Table C7. Summary of frequency (freq) and cover estimates in macroplot CANY2b (Desert Sand ecological site). For line-point sampling, 10-point groups were used as subsampling units for purposes of frequency calculations. Precision is defined as one-half the width of the 95 percent confidence interval. The standardized mean was calculated as the ratio of the mean for a particular method to the among-method mean. See Appendix A for keys to species codes (BSC = biological soil crust).

\begin{tabular}{|c|c|c|c|c|c|c|c|c|c|c|}
\hline \multirow[b]{2}{*}{ Measure } & \multirow[b]{2}{*}{ Method } & \multirow[b]{2}{*}{ Subsample $\mathbf{n}$} & \multirow[b]{2}{*}{ Freq } & \multicolumn{7}{|c|}{ Cover } \\
\hline & & & & Mean & sd & CV & Precision & $\begin{array}{c}\text { Precision \% } \\
\text { of mean }\end{array}$ & $\begin{array}{l}\text { Among- } \\
\text { method } \\
\text { mean }\end{array}$ & $\begin{array}{c}\text { Standardized } \\
\text { mean }\end{array}$ \\
\hline \multirow{3}{*}{$\begin{array}{c}\text { Total live } \\
\text { understory } \\
\text { canopy } \\
\text { cover }\end{array}$} & $10-m^{2}$ & 21 & 100.0 & 13.69 & 3.98 & 29.09 & 1.70 & 12.44 & & 1.08 \\
\hline & $1-m^{2}$ & 30 & 100.0 & 12.53 & 8.82 & 70.40 & 3.16 & 25.19 & 12.6 & 0.99 \\
\hline & Line-point & 30 & 73.3 & 11.67 & 10.20 & 87.42 & 3.65 & 31.28 & & 0.92 \\
\hline \multirow[b]{3}{*}{ ATCA2 } & $10-m^{2}$ & 21 & 33.3 & 1.07 & 2.31 & 216.02 & 0.99 & 92.39 & & 0.93 \\
\hline & $1-m^{2}$ & 30 & 10.0 & 1.73 & 9.12 & 526.13 & 3.26 & 188.27 & 1.2 & 1.50 \\
\hline & Line-point & 30 & 6.7 & 0.67 & 2.54 & 380.56 & 0.91 & 136.18 & & 0.58 \\
\hline \multirow[b]{3}{*}{ HIJA } & $10-m^{2}$ & 21 & 85.7 & 2.29 & 2.17 & 94.99 & 0.93 & 40.63 & & 1.54 \\
\hline & $1-m^{2}$ & 30 & 46.7 & 1.17 & 1.58 & 135.21 & 0.56 & 48.38 & 1.5 & 0.79 \\
\hline & Line-point & 30 & 10.0 & 1.00 & 3.05 & 305.13 & 1.09 & 109.19 & & 0.67 \\
\hline \multirow[b]{3}{*}{ STHY6 } & $10-m^{2}$ & 21 & 100.0 & 1.10 & 1.09 & 99.62 & 0.47 & 42.61 & & 0.61 \\
\hline & $1-m^{2}$ & 30 & 70.0 & 0.93 & 0.74 & 79.25 & 0.26 & 28.36 & 1.8 & 0.52 \\
\hline & Line-point & 30 & 33.3 & 3.33 & 4.79 & 143.84 & 1.72 & 51.47 & & 1.87 \\
\hline \multirow[b]{3}{*}{ Litter } & $10-m^{2}$ & 21 & 100.0 & 6.05 & 3.45 & 57.04 & 1.48 & 24.39 & & 1.01 \\
\hline & $1-m^{2}$ & 30 & 100.0 & 5.63 & 4.68 & 83.06 & 1.67 & 29.72 & 6.0 & 0.94 \\
\hline & Line-point & 30 & 50.0 & 6.33 & 7.18 & 113.43 & 2.57 & 40.59 & & 1.05 \\
\hline \multirow{3}{*}{$\begin{array}{l}\text { Undifferenti } \\
\text { ated crust }\end{array}$} & $10-m^{2}$ & 21 & 95.2 & 63.10 & 16.99 & 26.93 & 7.27 & 11.52 & & 0.87 \\
\hline & $1-m^{2}$ & 30 & 100.0 & 77.37 & 10.98 & 14.20 & 3.93 & 5.08 & 72.9 & 1.06 \\
\hline & Line-point & 30 & 100.0 & 78.33 & 15.10 & 19.28 & 5.41 & 6.90 & & 1.07 \\
\hline \multirow[b]{3}{*}{ BSC } & $10-m^{2}$ & 21 & 100.0 & 7.55 & 6.95 & 92.13 & 2.97 & 39.40 & & 0.82 \\
\hline & $1-m^{2}$ & 30 & 90.0 & 8.37 & 7.13 & 85.24 & 2.55 & 30.50 & 9.2 & 0.91 \\
\hline & Line-point & 30 & 63.3 & 11.67 & 11.47 & 98.33 & 4.11 & 35.19 & & 1.27 \\
\hline
\end{tabular}


Table C8. Summary of frequency (freq) and cover estimates in macroplot WUPA1 (Limy Upland ecological site). For line-point sampling, 10-point groups were used as subsampling units for purposes of frequency calculations. Precision is defined as one-half the width of the 95 percent confidence interval. The standardized mean was calculated as the ratio of the mean for a particular method to the among-method mean. See Appendix A for keys to species codes.

\begin{tabular}{|c|c|c|c|c|c|c|c|c|c|c|}
\hline \multirow[b]{2}{*}{ Measure } & \multirow[b]{2}{*}{ Method } & \multirow[b]{2}{*}{ Subsample $n$} & \multirow[b]{2}{*}{ Freq } & \multicolumn{7}{|c|}{ Cover } \\
\hline & & & & Mean & sd & CV & Precision & $\begin{array}{c}\text { Precision \% } \\
\text { of mean }\end{array}$ & $\begin{array}{c}\text { Among- } \\
\text { method } \\
\text { mean }\end{array}$ & $\begin{array}{c}\text { Standardized } \\
\text { mean }\end{array}$ \\
\hline \multirow{3}{*}{$\begin{array}{c}\text { Total live } \\
\text { understory } \\
\text { canopy } \\
\text { cover }\end{array}$} & $10-m^{2}$ & 21 & 100.0 & 34.40 & 5.98 & 17.39 & 2.56 & 7.44 & & 1.20 \\
\hline & $1-m^{2}$ & 30 & 100.0 & 20.07 & 5.46 & 27.20 & 1.95 & 9.73 & 28.6 & 0.70 \\
\hline & Line-point & 30 & 90.0 & 31.33 & 16.34 & 52.16 & 5.85 & 18.67 & & 1.10 \\
\hline \multirow[b]{3}{*}{ CHLE4 } & $10-m^{2}$ & 21 & 100.0 & 10.71 & 6.26 & 58.45 & 2.68 & 25.00 & & 1.43 \\
\hline & $1-m^{2}$ & 30 & 100.0 & 5.40 & 2.82 & 52.29 & 1.01 & 18.71 & 7.5 & 0.72 \\
\hline & Line-point & 30 & 46.7 & 6.33 & 8.50 & 134.26 & 3.04 & 48.04 & & 0.85 \\
\hline \multirow[b]{3}{*}{ HENE5 } & $10-m^{2}$ & 21 & 100.0 & 1.79 & 1.79 & 100.40 & 0.77 & 42.94 & & 0.73 \\
\hline & $1-m^{2}$ & 30 & 53.3 & 1.27 & 1.82 & 143.54 & 0.65 & 51.36 & 2.5 & 0.51 \\
\hline & Line-point & 30 & 26.7 & 4.33 & 8.17 & 188.58 & 2.92 & 67.48 & & 1.76 \\
\hline \multirow[b]{3}{*}{ PLJA } & $10-m^{2}$ & 21 & 19.0 & 0.55 & 1.72 & 314.84 & 0.74 & 134.66 & & 1.35 \\
\hline & $1-m^{2}$ & 30 & 16.7 & 0.33 & 0.88 & 265.23 & 0.32 & 94.91 & 0.4 & 0.82 \\
\hline & Line-point & 30 & 3.3 & 0.33 & 1.83 & 547.72 & 0.65 & 196.00 & & 0.82 \\
\hline \multirow[b]{3}{*}{ Bare soil } & $10-m^{2}$ & 21 & 100.0 & 16.12 & 8.89 & 55.15 & 3.80 & 23.59 & & 0.66 \\
\hline & $1-\mathrm{m}^{2}$ & 30 & 100.0 & 16.67 & 13.97 & 83.84 & 5.00 & 30.00 & 24.5 & 0.68 \\
\hline & Line-point & 30 & 93.3 & 40.67 & 26.38 & 64.88 & 9.44 & 23.22 & & 1.66 \\
\hline \multirow[b]{3}{*}{ Litter } & $10-m^{2}$ & 21 & 100.0 & 7.43 & 4.70 & 63.26 & 2.01 & 27.06 & & 0.88 \\
\hline & $1-m^{2}$ & 30 & 100.0 & 6.83 & 3.93 & 57.53 & 1.41 & 20.59 & 8.4 & 0.81 \\
\hline & Line-point & 30 & 63.3 & 11.00 & 11.25 & 102.27 & 4.03 & 36.60 & & 1.31 \\
\hline
\end{tabular}


Table C9. Summary of frequency (freq) and cover estimates in macroplot WUPA2 (Limy Upland ecological site). For line-point sampling, 10-point groups were used as subsampling units for purposes of frequency calculations. Precision is defined as one-half the width of the 95 percent confidence interval. The standardized mean was calculated as the ratio of the mean for a particular method to the among-method mean. See Appendix A for keys to species codes.

\begin{tabular}{|c|c|c|c|c|c|c|c|c|c|c|}
\hline \multicolumn{11}{|c|}{ Limy Upland, 6-10" pz ecological site - WUPA 2 macroplot, Phase 2} \\
\hline \multirow[b]{2}{*}{ Measure } & \multirow[b]{2}{*}{ Method } & \multirow[b]{2}{*}{ Subsample $n$} & \multirow[b]{2}{*}{ Freq } & \multicolumn{7}{|c|}{ Cover } \\
\hline & & & & Mean & sd & CV & Precision & $\begin{array}{c}\text { Precision } \% \\
\text { of mean }\end{array}$ & $\begin{array}{c}\text { Among- } \\
\text { method } \\
\text { mean }\end{array}$ & $\begin{array}{c}\text { Standardized } \\
\text { mean }\end{array}$ \\
\hline \multirow{3}{*}{$\begin{array}{c}\text { Total live } \\
\text { understory } \\
\text { canopy } \\
\text { cover }\end{array}$} & $10-m^{2}$ & 21 & 100.0 & 25.79 & 7.04 & 27.30 & 3.01 & 11.68 & & 1.10 \\
\hline & $1-m^{2}$ & 30 & 100.0 & 18.17 & 8.75 & 48.19 & 3.13 & 17.24 & 23.5 & 0.77 \\
\hline & Line-point & 30 & 96.7 & 26.67 & 14.22 & 53.34 & 5.09 & 19.09 & & 1.13 \\
\hline \multirow[b]{3}{*}{ CHLE4 } & $10-m^{2}$ & 21 & 66.7 & 1.14 & 1.83 & 160.24 & 0.78 & 68.53 & & 1.19 \\
\hline & $1-m^{2}$ & 30 & 26.7 & 0.73 & 1.76 & 240.05 & 0.63 & 85.90 & 1.0 & 0.76 \\
\hline & Line-point & 30 & 10.0 & 1.00 & 3.05 & 305.13 & 1.09 & 109.19 & & 1.04 \\
\hline \multirow[b]{3}{*}{ HENE5 } & $10-m^{2}$ & 21 & 90.5 & 2.19 & 2.18 & 99.36 & 0.93 & 42.50 & & 0.81 \\
\hline & $1-m^{2}$ & 30 & 73.3 & 1.63 & 1.50 & 91.64 & 0.54 & 32.79 & 2.7 & 0.60 \\
\hline & Line-point & 30 & 33.3 & 4.33 & 6.79 & 156.67 & 2.43 & 56.06 & & 1.59 \\
\hline \multirow[b]{3}{*}{ PLJA } & $10-m^{2}$ & 21 & 100.0 & 9.64 & 6.06 & 62.81 & 2.59 & 26.86 & & 0.99 \\
\hline & $1-m^{2}$ & 30 & 100.0 & 5.53 & 3.23 & 58.46 & 1.16 & 20.92 & 9.7 & 0.57 \\
\hline & Line-point & 30 & 86.7 & 14.00 & 10.03 & 71.67 & 3.59 & 25.65 & & 1.44 \\
\hline \multirow[b]{3}{*}{ Bare soil } & $10-m^{2}$ & 21 & 100.0 & 14.67 & 12.79 & 87.20 & 5.47 & 37.30 & & 0.81 \\
\hline & $1-m^{2}$ & 30 & 100.0 & 12.67 & 11.16 & 88.14 & 4.00 & 31.54 & 18.1 & 0.70 \\
\hline & Line-point & 30 & 90.0 & 27.00 & 15.79 & 58.48 & 5.65 & 20.93 & & 1.49 \\
\hline \multirow[b]{3}{*}{ Litter } & $10-m^{2}$ & 21 & 100.0 & 7.21 & 4.80 & 66.50 & 2.05 & 28.44 & & 1.01 \\
\hline & $1-m^{2}$ & 30 & 100.0 & 7.30 & 4.28 & 58.58 & 1.53 & 20.96 & 7.2 & 1.02 \\
\hline & Line-point & 30 & 43.3 & 7.00 & 9.15 & 130.77 & 3.28 & 46.79 & & 0.98 \\
\hline
\end{tabular}


Table C10. Summary of frequency (freq) and cover estimates in macroplot WUPA5 (Limy Upland ecological site). For line-point sampling, 10-point groups were used as subsampling units for purposes of frequency calculations. Precision is defined as one-half the width of the 95 percent confidence interval. The standardized mean was calculated as the ratio of the mean for a particular method to the among-method mean. See Appendix A for keys to species codes.

\begin{tabular}{|c|c|c|c|c|c|c|c|c|c|c|}
\hline \multirow[b]{2}{*}{ Measure } & \multirow[b]{2}{*}{ Method } & \multirow[b]{2}{*}{ Subsample $n$} & \multirow[b]{2}{*}{ Freq } & \multicolumn{7}{|c|}{ Cover } \\
\hline & & & & Mean & sd & CV & Precision & $\begin{array}{c}\text { Precision \% } \\
\text { of mean }\end{array}$ & $\begin{array}{c}\text { Among- } \\
\text { method } \\
\text { mean }\end{array}$ & $\begin{array}{c}\text { Standardized } \\
\text { mean }\end{array}$ \\
\hline \multirow{3}{*}{$\begin{array}{c}\text { Total live } \\
\text { understory } \\
\text { canopy } \\
\text { cover }\end{array}$} & $10-m^{2}$ & 15 & 100.0 & 18.00 & 5.24 & 29.11 & 2.65 & 14.73 & & 0.87 \\
\hline & $1-m^{2}$ & 15 & 100.0 & 13.33 & 5.84 & 43.79 & 2.95 & 22.16 & 20.7 & 0.65 \\
\hline & Line-point & 15 & 100.0 & 30.67 & 18.70 & 60.96 & 9.46 & 30.85 & & 1.48 \\
\hline \multirow[b]{3}{*}{ CHLE4 } & $10-m^{2}$ & 15 & 93.3 & 7.37 & 3.55 & 48.16 & 1.80 & 24.37 & & 1.01 \\
\hline & $1-m^{2}$ & 15 & 100.0 & 6.60 & 2.87 & 43.54 & 1.45 & 22.03 & 7.3 & 0.90 \\
\hline & Line-point & 15 & 53.3 & 8.00 & 10.14 & 126.77 & 5.13 & 64.15 & & 1.09 \\
\hline \multirow[b]{3}{*}{ HENE5 } & $10-m^{2}$ & 15 & 33.3 & 0.63 & 1.91 & 302.05 & 0.97 & 152.86 & & 2.11 \\
\hline & $1-m^{2}$ & 15 & 6.7 & 0.27 & 1.03 & 387.30 & 0.52 & 196.00 & 0.3 & 0.89 \\
\hline & Line-point & 15 & 0.0 & 0.00 & - & - & - & - & & 0.00 \\
\hline \multirow[b]{3}{*}{ PLJA } & $10-m^{2}$ & 15 & 100.0 & 6.30 & 2.06 & 32.70 & 1.04 & 16.55 & & 1.03 \\
\hline & $1-m^{2}$ & 15 & 100.0 & 2.07 & 0.80 & 38.65 & 0.40 & 19.56 & 6.1 & 0.34 \\
\hline & Line-point & 15 & 73.3 & 10.00 & 8.45 & 84.52 & 4.28 & 42.77 & & 1.63 \\
\hline \multirow[b]{3}{*}{ Bare soil } & $10-m^{2}$ & 15 & 100.0 & 2.00 & 1.27 & 63.39 & 0.64 & 32.08 & & 0.58 \\
\hline & $1-\mathrm{m}^{2}$ & 15 & 100.0 & 2.33 & 1.29 & 55.33 & 0.65 & 28.00 & 3.4 & 0.68 \\
\hline & Line-point & 15 & 40.0 & 6.00 & 9.10 & 151.71 & 4.61 & 76.77 & & 1.74 \\
\hline \multirow[b]{3}{*}{ Litter } & $10-m^{2}$ & 15 & 100.0 & 8.37 & 6.04 & 72.16 & 3.06 & 36.51 & & 1.50 \\
\hline & $1-m^{2}$ & 15 & 100.0 & 8.33 & 9.69 & 116.23 & 4.90 & 58.82 & 5.6 & 1.50 \\
\hline & Line-point & 15 & 0.0 & 0.00 & - & - & - & - & & 0.00 \\
\hline
\end{tabular}


Table C11. Summary of frequency (freq) and cover estimates in macroplot WUPA6 (Limy Upland ecological site). For line-point sampling, 10-point groups were used as subsampling units for purposes of frequency calculations. Precision is defined as one-half the width of the 95 percent confidence interval. The standardized mean was calculated as the ratio of the mean for a particular method to the among-method mean. See Appendix A for keys to species codes.

\begin{tabular}{|c|c|c|c|c|c|c|c|c|c|c|}
\hline \multirow[b]{2}{*}{ Measure } & \multirow[b]{2}{*}{ Method } & \multirow[b]{2}{*}{ Subsample $n$} & \multirow[b]{2}{*}{ Freq } & \multicolumn{7}{|c|}{ Cover } \\
\hline & & & & Mean & sd & CV & Precision & $\begin{array}{c}\text { Precision \% } \\
\text { of mean }\end{array}$ & $\begin{array}{c}\text { Among- } \\
\text { method } \\
\text { mean }\end{array}$ & $\begin{array}{c}\text { Standardized } \\
\text { mean }\end{array}$ \\
\hline \multirow{3}{*}{$\begin{array}{c}\text { Total live } \\
\text { understory } \\
\text { canopy } \\
\text { cover }\end{array}$} & $10-m^{2}$ & 15 & 100.0 & 19.57 & 3.92 & 20.02 & 1.98 & 10.13 & & 1.01 \\
\hline & $1-m^{2}$ & 15 & 100.0 & 16.93 & 3.10 & 18.33 & 1.57 & 9.28 & 19.3 & 0.88 \\
\hline & Line-point & 15 & 93.3 & 21.33 & 13.02 & 61.03 & 6.59 & 30.89 & & 1.11 \\
\hline \multirow[b]{3}{*}{ CHLE4 } & $10-m^{2}$ & 15 & 100.0 & 4.53 & 4.21 & 92.89 & 2.13 & 47.01 & & 1.34 \\
\hline & $1-m^{2}$ & 15 & 100.0 & 2.93 & 1.44 & 49.01 & 0.73 & 24.80 & 3.4 & 0.87 \\
\hline & Line-point & 15 & 26.7 & 2.67 & 4.58 & 171.65 & 2.32 & 86.87 & & 0.79 \\
\hline \multirow[b]{3}{*}{ HENE5 } & $10-m^{2}$ & 15 & 100.0 & 4.93 & 2.56 & 51.94 & 1.30 & 26.29 & & 0.79 \\
\hline & $1-m^{2}$ & 15 & 100.0 & 5.20 & 3.65 & 70.17 & 1.85 & 35.51 & 6.3 & 0.83 \\
\hline & Line-point & 15 & 60.0 & 8.67 & 8.34 & 96.21 & 4.22 & 48.69 & & 1.38 \\
\hline \multirow[b]{3}{*}{ PLJA } & $10-m^{2}$ & 15 & 53.3 & 0.90 & 1.97 & 219.43 & 1.00 & 111.04 & & 0.70 \\
\hline & $1-m^{2}$ & 15 & 40.0 & 0.93 & 2.05 & 219.83 & 1.04 & 111.25 & 1.3 & 0.73 \\
\hline & Line-point & 15 & 13.3 & 2.00 & 5.61 & 280.31 & 2.84 & 141.85 & & 1.57 \\
\hline \multirow[b]{3}{*}{ Bare soil } & $10-m^{2}$ & 15 & 100.0 & 2.67 & 0.88 & 32.99 & 0.45 & 16.69 & & 0.84 \\
\hline & $1-\mathrm{m}^{2}$ & 15 & 100.0 & 2.87 & 2.29 & 80.06 & 1.16 & 40.51 & 3.2 & 0.90 \\
\hline & Line-point & 15 & 40.0 & 4.00 & 5.07 & 126.77 & 2.57 & 64.15 & & 1.26 \\
\hline \multirow[b]{3}{*}{ Litter } & $10-m^{2}$ & 15 & 100.0 & 3.87 & 2.42 & 62.68 & 1.23 & 31.72 & & 1.34 \\
\hline & $1-m^{2}$ & 15 & 100.0 & 4.80 & 2.62 & 54.67 & 1.33 & 27.67 & 2.9 & 1.66 \\
\hline & Line-point & 15 & 0.0 & 0.00 & - & - & - & - & & 0.00 \\
\hline
\end{tabular}


Table C12. Summary of frequency (freq) and cover estimates in macroplot WUPA7 (Limy Upland ecological site). For line-point sampling, 10-point groups were used as subsampling units for purposes of frequency calculations. Precision is defined as one-half the width of the 95 percent confidence interval. The standardized mean was calculated as the ratio of the mean for a particular method to the among-method mean. See Appendix A for keys to species codes.

\begin{tabular}{|c|c|c|c|c|c|c|c|c|c|c|}
\hline \multirow[b]{2}{*}{ Measure } & \multirow[b]{2}{*}{ Method } & \multirow[b]{2}{*}{ Subsample $n$} & \multirow[b]{2}{*}{ Freq } & \multicolumn{7}{|c|}{ Cover } \\
\hline & & & & Mean & sd & CV & Precision & $\begin{array}{c}\text { Precision \% } \\
\text { of mean }\end{array}$ & $\begin{array}{c}\text { Among- } \\
\text { method } \\
\text { mean }\end{array}$ & $\begin{array}{c}\text { Standardized } \\
\text { mean }\end{array}$ \\
\hline \multirow{3}{*}{$\begin{array}{c}\text { Total live } \\
\text { understory } \\
\text { canopy } \\
\text { cover }\end{array}$} & $10-m^{2}$ & 15 & 100.0 & 20.47 & 7.96 & 38.91 & 4.03 & 19.69 & & 1.11 \\
\hline & $1-m^{2}$ & 15 & 100.0 & 11.67 & 3.24 & 27.81 & 1.64 & 14.07 & 18.5 & 0.63 \\
\hline & Line-point & 15 & 86.7 & 23.33 & 16.76 & 71.84 & 8.48 & 36.35 & & 1.26 \\
\hline \multirow[b]{3}{*}{ CHLE4 } & $10-m^{2}$ & 15 & 100.0 & 1.97 & 1.97 & 100.08 & 1.00 & 50.65 & & 1.65 \\
\hline & $1-m^{2}$ & 15 & 73.3 & 1.60 & 1.50 & 93.90 & 0.76 & 47.52 & 1.2 & 1.35 \\
\hline & Line-point & 15 & 0.0 & 0.00 & - & - & - & - & & 0.00 \\
\hline \multirow[b]{3}{*}{ HENE5 } & $10-m^{2}$ & 15 & 100.0 & 9.03 & 6.47 & 71.63 & 3.27 & 36.25 & & 0.90 \\
\hline & $1-m^{2}$ & 15 & 93.3 & 5.67 & 3.52 & 62.09 & 1.78 & 31.42 & 10.0 & 0.57 \\
\hline & Line-point & 15 & 80.0 & 15.33 & 12.46 & 81.26 & 6.31 & 41.12 & & 1.53 \\
\hline \multirow[b]{3}{*}{ PLJA } & $10-m^{2}$ & 15 & 100.0 & 4.60 & 5.31 & 115.41 & 2.69 & 58.41 & & 0.96 \\
\hline & $1-m^{2}$ & 15 & 93.3 & 2.47 & 1.92 & 77.93 & 0.97 & 39.44 & 4.8 & 0.51 \\
\hline & Line-point & 15 & 46.7 & 7.33 & 11.00 & 149.97 & 5.57 & 75.89 & & 1.53 \\
\hline \multirow[b]{3}{*}{ Bare soil } & $10-m^{2}$ & 15 & 100.0 & 1.17 & 1.14 & 98.09 & 0.58 & 49.64 & & 0.50 \\
\hline & $1-\mathrm{m}^{2}$ & 15 & 86.7 & 1.87 & 2.42 & 129.44 & 1.22 & 65.50 & 2.3 & 0.80 \\
\hline & Line-point & 15 & 33.3 & 4.00 & 6.32 & 158.11 & 3.20 & 80.02 & & 1.71 \\
\hline \multirow[b]{3}{*}{ Litter } & $10-m^{2}$ & 15 & 100.0 & 6.37 & 3.80 & 59.70 & 1.92 & 30.21 & & 1.29 \\
\hline & $1-m^{2}$ & 15 & 100.0 & 8.47 & 3.78 & 44.61 & 1.91 & 22.58 & 4.9 & 1.71 \\
\hline & Line-point & 15 & 0.0 & 0.00 & - & - & - & - & & 0.00 \\
\hline
\end{tabular}


Table C13. Summary of frequency (freq) and cover estimates in macroplot GRCA3 (Loamy Hills ecological site). For line-point sampling, 10-point groups were used as subsampling units for purposes of frequency calculations. Precision is defined as one-half the width of the 95 percent confidence interval. The standardized mean was calculated as the ratio of the mean for a particular method to the among-method mean. See Appendix A for keys to species codes (BSC = biological soil crust).

\begin{tabular}{|c|c|c|c|c|c|c|c|c|c|c|}
\hline \multirow[b]{2}{*}{ Measure } & \multirow[b]{2}{*}{ Method } & \multirow[b]{2}{*}{ Subsample $n$} & \multirow[b]{2}{*}{ Freq } & \multicolumn{7}{|c|}{ Cover } \\
\hline & & & & Mean & sd & CV & Precision & $\begin{array}{c}\text { Precision \% } \\
\text { of mean }\end{array}$ & $\begin{array}{c}\text { Among- } \\
\text { method } \\
\text { mean }\end{array}$ & $\begin{array}{c}\text { Standardized } \\
\text { mean }\end{array}$ \\
\hline \multirow{3}{*}{$\begin{array}{c}\text { Total live } \\
\text { understory } \\
\text { vegetation }\end{array}$} & $10-m^{2}$ & 21 & 100.0 & 25.76 & 17.08 & 66.30 & 7.31 & 28.36 & & 1.23 \\
\hline & $1-\mathrm{m}^{2}$ & 30 & 93.3 & 28.90 & 39.58 & 136.94 & 14.16 & 49.00 & 20.9 & 1.38 \\
\hline & Line-point & 30 & 46.7 & 8.00 & 12.15 & 151.86 & 4.35 & 54.34 & & 0.38 \\
\hline \multirow[b]{3}{*}{ POFE } & $10-m^{2}$ & 21 & 0.0 & 0.00 & - & - & - & - & & - \\
\hline & $1-m^{2}$ & 30 & 0.0 & 0.00 & - & - & - & - & 0.0 & - \\
\hline & Line-point & 30 & 0.0 & 0.00 & - & - & - & - & & - \\
\hline \multirow[b]{3}{*}{ POTR5 } & $10-m^{2}$ & 21 & 71.4 & 4.02 & 5.25 & 130.59 & 2.25 & 55.85 & & 0.84 \\
\hline & $1-m^{2}$ & 30 & 63.3 & 7.97 & 19.47 & 244.46 & 6.97 & 87.48 & 4.8 & 1.67 \\
\hline & Line-point & 30 & 20.0 & 2.33 & 5.04 & 216.00 & 1.80 & 77.29 & & 0.49 \\
\hline \multirow[b]{3}{*}{ UNGRCA1 } & $10-m^{2}$ & 21 & 14.3 & 0.07 & 0.18 & 251.00 & 0.08 & 107.35 & & 1.25 \\
\hline & $1-m^{2}$ & 30 & 6.7 & 0.10 & 0.40 & 402.58 & 0.14 & 144.06 & 0.1 & 1.75 \\
\hline & Line-point & 30 & 0.0 & 0.00 & - & - & - & - & & 0.00 \\
\hline \multirow[b]{3}{*}{ Bare soil } & $10-m^{2}$ & 21 & 71.4 & 1.50 & 2.27 & 151.66 & 0.97 & 64.86 & & 0.47 \\
\hline & $1-m^{2}$ & 30 & 43.3 & 2.73 & 6.56 & 240.18 & 2.35 & 85.95 & 3.2 & 0.86 \\
\hline & Line-point & 30 & 33.3 & 5.33 & 9.73 & 182.48 & 3.48 & 65.30 & & 1.67 \\
\hline \multirow[b]{3}{*}{ Litter } & $10-m^{2}$ & 21 & 100.0 & 63.69 & 9.61 & 15.08 & 4.11 & 6.45 & & 0.89 \\
\hline & $1-m^{2}$ & 30 & 100.0 & 73.93 & 17.47 & 23.62 & 6.25 & 8.45 & 71.9 & 1.03 \\
\hline & Line-point & 30 & 100.0 & 78.00 & 18.27 & 23.42 & 6.54 & 8.38 & & 1.09 \\
\hline \multirow[b]{3}{*}{ BSC } & $10-m^{2}$ & 21 & 85.7 & 1.50 & 1.85 & 123.38 & 0.79 & 52.77 & & 1.14 \\
\hline & $1-m^{2}$ & 30 & 53.3 & 1.43 & 2.08 & 145.06 & 0.74 & 51.91 & 1.3 & 1.09 \\
\hline & Line-point & 30 & 6.7 & 1.00 & 4.03 & 402.58 & 1.44 & 144.06 & & 0.76 \\
\hline
\end{tabular}


Table C14. Summary of frequency (freq) and cover estimates in macroplot GRCA4 (Loamy Hills ecological site). For line-point sampling, 10-point groups were used as subsampling units for purposes of frequency calculations. Precision is defined as one-half the width of the 95 percent confidence interval. The standardized mean was calculated as the ratio of the mean for a particular method to the among-method mean. See Appendix A for keys to species codes (BSC = biological soil crust).

\begin{tabular}{|c|c|c|c|c|c|c|c|c|c|c|}
\hline \multirow[b]{2}{*}{ Measure } & \multirow[b]{2}{*}{ Method } & \multirow[b]{2}{*}{ Subsample $n$} & \multirow[b]{2}{*}{ Freq } & \multicolumn{7}{|c|}{ Cover } \\
\hline & & & & Mean & sd & CV & Precision & $\begin{array}{c}\text { Precision \% } \\
\text { of mean }\end{array}$ & $\begin{array}{c}\text { Among- } \\
\text { method } \\
\text { mean }\end{array}$ & $\begin{array}{c}\text { Standardized } \\
\text { mean }\end{array}$ \\
\hline \multirow{3}{*}{$\begin{array}{c}\text { Total live } \\
\text { understory } \\
\text { canopy } \\
\text { cover }\end{array}$} & $10-m^{2}$ & 21 & 100.0 & 35.17 & 32.20 & 91.57 & 13.77 & 39.16 & & 0.90 \\
\hline & $1-m^{2}$ & 30 & 100.0 & 57.47 & 52.82 & 91.91 & 18.90 & 32.89 & 39.0 & 1.47 \\
\hline & Line-point & 30 & 66.7 & 24.33 & 23.29 & 95.73 & 8.34 & 34.26 & & 0.62 \\
\hline \multirow[b]{3}{*}{ POFE } & $10-m^{2}$ & 21 & 4.8 & 0.02 & 0.11 & 458.26 & 0.05 & 196.00 & & 0.17 \\
\hline & $1-m^{2}$ & 30 & 6.7 & 0.07 & 0.25 & 380.56 & 0.09 & 136.18 & 0.1 & 0.47 \\
\hline & Line-point & 30 & 3.3 & 0.33 & 1.83 & 547.72 & 0.65 & 196.00 & & 2.36 \\
\hline \multirow[b]{3}{*}{ POTR5 } & $10-m^{2}$ & 21 & 71.4 & 2.76 & 5.37 & 194.36 & 2.30 & 83.13 & & 0.99 \\
\hline & $1-m^{2}$ & 30 & 26.7 & 5.60 & 18.13 & 323.83 & 6.49 & 115.88 & 2.8 & 2.01 \\
\hline & Line-point & 30 & 0.0 & 0.00 & - & - & - & - & & 0.00 \\
\hline \multirow{3}{*}{$\begin{array}{l}\text { UNGRCA1 } \\
\text { (Carex sp.) }\end{array}$} & $10-m^{2}$ & 21 & 85.7 & 1.57 & 2.23 & 142.04 & 0.95 & 60.75 & & 0.41 \\
\hline & $1-m^{2}$ & 30 & 80.0 & 1.47 & 1.72 & 117.05 & 0.61 & 41.88 & 3.8 & 0.39 \\
\hline & Line-point & 30 & 40.0 & 8.33 & 12.62 & 151.41 & 4.51 & 54.18 & & 2.20 \\
\hline \multirow[b]{3}{*}{ Bare soil } & $10-m^{2}$ & 21 & 76.2 & 1.64 & 2.27 & 138.18 & 0.97 & 59.10 & & 0.63 \\
\hline & $1-m^{2}$ & 30 & 50.0 & 1.50 & 2.58 & 172.21 & 0.92 & 61.62 & 2.6 & 0.58 \\
\hline & Line-point & 30 & 26.7 & 4.67 & 9.00 & 192.76 & 3.22 & 68.98 & & 1.79 \\
\hline \multirow[b]{3}{*}{ Litter } & $10-m^{2}$ & 21 & 100.0 & 61.31 & 20.12 & 32.81 & 8.60 & 14.03 & & 0.88 \\
\hline & $1-m^{2}$ & 30 & 96.7 & 74.90 & 21.40 & 28.57 & 7.66 & 10.22 & 69.5 & 1.08 \\
\hline & Line-point & 30 & 100.0 & 72.33 & 16.33 & 22.58 & 5.84 & 8.08 & & 1.04 \\
\hline \multirow[b]{3}{*}{ BSC } & $10-m^{2}$ & 21 & 71.4 & 1.93 & 4.12 & 213.84 & 1.76 & 91.46 & & 1.57 \\
\hline & $1-m^{2}$ & 30 & 50.0 & 1.43 & 3.51 & 244.91 & 1.26 & 87.64 & 1.2 & 1.16 \\
\hline & Line-point & 30 & 3.3 & 0.33 & 1.83 & 547.72 & 0.65 & 196.00 & & 0.27 \\
\hline
\end{tabular}


Table C15. Summary of frequency (freq) and cover estimates in macroplot GRCA5 (Loamy Hills ecological site). For line-point sampling, 10-point groups were used as subsampling units for purposes of frequency calculations. Precision is defined as one-half the width of the 95 percent confidence interval. The standardized mean was calculated as the ratio of the mean for a particular method to the among-method mean. See Appendix A for keys to species codes (BSC = biological soil crust).

\begin{tabular}{|c|c|c|c|c|c|c|c|c|c|c|}
\hline \multirow[b]{2}{*}{ Measure } & \multirow[b]{2}{*}{ Method } & \multirow[b]{2}{*}{ Subsample $n$} & \multirow[b]{2}{*}{ Freq } & \multicolumn{7}{|c|}{ Cover } \\
\hline & & & & Mean & sd & CV & Precision & $\begin{array}{c}\text { Precision \% } \\
\text { of mean }\end{array}$ & $\begin{array}{l}\text { Among- } \\
\text { method } \\
\text { mean }\end{array}$ & $\begin{array}{c}\text { Standardized } \\
\text { mean }\end{array}$ \\
\hline \multirow{3}{*}{$\begin{array}{c}\text { Total live } \\
\text { understory } \\
\text { canopy } \\
\text { cover }\end{array}$} & $10-m^{2}$ & 15 & 100.0 & 11.67 & 8.51 & 72.96 & 4.31 & 36.92 & & 0.84 \\
\hline & $1-m^{2}$ & 15 & 100.0 & 10.13 & 12.06 & 119.06 & 6.11 & 60.25 & 13.9 & 0.73 \\
\hline & Line-point & 15 & 93.3 & 20.00 & 11.34 & 56.69 & 5.74 & 28.69 & & 1.44 \\
\hline \multirow[b]{3}{*}{ POFE } & $10-m^{2}$ & 15 & 33.3 & 0.97 & 2.08 & 215.46 & 1.05 & 109.04 & & 0.69 \\
\hline & $1-m^{2}$ & 15 & 26.7 & 0.60 & 1.18 & 197.20 & 0.60 & 99.80 & 1.4 & 0.43 \\
\hline & Line-point & 15 & 26.7 & 2.67 & 4.58 & 171.65 & 2.32 & 86.87 & & 1.89 \\
\hline \multirow[b]{3}{*}{ POTR5 } & $10-m^{2}$ & 15 & 80.0 & 5.70 & 6.70 & 117.49 & 3.39 & 59.46 & & 1.07 \\
\hline & $1-m^{2}$ & 15 & 66.7 & 5.60 & 11.62 & 207.57 & 5.88 & 105.04 & 5.3 & 1.05 \\
\hline & Line-point & 15 & 40.0 & 4.67 & 6.40 & 137.13 & 3.24 & 69.40 & & 0.88 \\
\hline \multirow{3}{*}{$\begin{array}{l}\text { UNGRCA1 } \\
\text { (Carex sp.) }\end{array}$} & $10-m^{2}$ & 15 & 86.7 & 1.90 & 2.03 & 106.76 & 1.03 & 54.03 & & 0.45 \\
\hline & $1-m^{2}$ & 15 & 60.0 & 1.33 & 2.13 & 159.52 & 1.08 & 80.73 & 4.2 & 0.32 \\
\hline & Line-point & 15 & 53.3 & 9.33 & 11.63 & 124.60 & 5.89 & 63.05 & & 2.23 \\
\hline \multirow[b]{3}{*}{ Bare soil } & $10-m^{2}$ & 15 & 100.0 & 2.00 & 1.27 & 63.39 & 0.64 & 32.08 & & 0.19 \\
\hline & $1-m^{2}$ & 15 & 73.3 & 1.60 & 1.40 & 87.75 & 0.71 & 44.41 & 10.8 & 0.15 \\
\hline & Line-point & 15 & 73.3 & 28.67 & 26.15 & 91.22 & 13.23 & 46.16 & & 2.67 \\
\hline \multirow[b]{3}{*}{ Litter } & $10-m^{2}$ & 15 & 100.0 & 80.83 & 11.44 & 14.16 & 5.79 & 7.16 & & 1.04 \\
\hline & $1-m^{2}$ & 15 & 100.0 & 89.53 & 5.24 & 5.85 & 2.65 & 2.96 & 77.5 & 1.16 \\
\hline & Line-point & 15 & 100.0 & 62.00 & 23.96 & 38.65 & 12.13 & 19.56 & & 0.80 \\
\hline \multirow[b]{3}{*}{ BSC } & $10-m^{2}$ & 15 & 6.7 & 0.03 & 0.13 & 387.30 & 0.07 & 196.00 & & 3.00 \\
\hline & $1-m^{2}$ & 15 & 0.0 & 0.00 & - & - & - & - & 0.0 & 0.00 \\
\hline & Line-point & 15 & 0.0 & 0.00 & - & - & - & - & & 0.00 \\
\hline
\end{tabular}


Table C16. Summary of frequency (freq) and cover estimates in macroplot GRCA6 (Loamy Hills ecological site). For line-point sampling, 10-point groups were used as subsampling units for purposes of frequency calculations. Precision is defined as one-half the width of the 95 percent confidence interval. The standardized mean was calculated as the ratio of the mean for a particular method to the among-method mean. See Appendix A for keys to species codes (BSC = biological soil crust).

\begin{tabular}{|c|c|c|c|c|c|c|c|c|c|c|}
\hline \multirow[b]{2}{*}{ Measure } & \multirow[b]{2}{*}{ Method } & \multirow[b]{2}{*}{ Subsample $n$} & \multirow[b]{2}{*}{ Freq } & \multicolumn{7}{|c|}{ Cover } \\
\hline & & & & Mean & sd & CV & Precision & $\begin{array}{c}\text { Precision \% } \\
\text { of mean }\end{array}$ & $\begin{array}{l}\text { Among- } \\
\text { method } \\
\text { mean }\end{array}$ & $\begin{array}{c}\text { Standardized } \\
\text { mean }\end{array}$ \\
\hline \multirow{3}{*}{$\begin{array}{c}\text { Total live } \\
\text { understory } \\
\text { canopy } \\
\text { cover }\end{array}$} & $10-m^{2}$ & 15 & 100.0 & 20.37 & 18.34 & 90.06 & 9.28 & 45.57 & & 1.04 \\
\hline & $1-m^{2}$ & 15 & 100.0 & 17.20 & 26.09 & 151.71 & 13.21 & 76.77 & 19.6 & 0.88 \\
\hline & Line-point & 15 & 86.7 & 21.33 & 12.46 & 58.40 & 6.31 & 29.56 & & 1.09 \\
\hline \multirow[b]{3}{*}{ POFE } & $10-m^{2}$ & 15 & 66.7 & 0.50 & 0.73 & 146.39 & 0.37 & 74.08 & & 0.71 \\
\hline & $1-m^{2}$ & 15 & 20.0 & 0.27 & 0.59 & 222.61 & 0.30 & 112.65 & 0.7 & 0.38 \\
\hline & Line-point & 15 & 13.3 & 1.33 & 3.52 & 263.90 & 1.78 & 133.55 & & 1.90 \\
\hline \multirow[b]{3}{*}{ POTR5 } & $10-m^{2}$ & 15 & 33.3 & 0.17 & 0.24 & 146.39 & 0.12 & 74.08 & & 0.52 \\
\hline & $1-m^{2}$ & 15 & 13.3 & 0.13 & 0.35 & 263.90 & 0.18 & 133.55 & 0.3 & 0.41 \\
\hline & Line-point & 15 & 6.7 & 0.67 & 2.58 & 387.30 & 1.31 & 196.00 & & 2.07 \\
\hline \multirow{3}{*}{$\begin{array}{l}\text { UNGRCA1 } \\
\text { (Carex sp.) }\end{array}$} & $10-m^{2}$ & 15 & 100.0 & 1.93 & 2.48 & 128.15 & 1.25 & 64.85 & & 0.42 \\
\hline & $1-m^{2}$ & 15 & 66.7 & 1.87 & 1.88 & 100.97 & 0.95 & 51.10 & 4.6 & 0.41 \\
\hline & Line-point & 15 & 60.0 & 10.00 & 10.69 & 106.90 & 5.41 & 54.10 & & 2.17 \\
\hline \multirow[b]{3}{*}{ Bare soil } & $10-m^{2}$ & 15 & 53.3 & 1.23 & 2.09 & 169.85 & 1.06 & 85.95 & & 0.26 \\
\hline & $1-m^{2}$ & 15 & 46.7 & 1.80 & 2.68 & 148.78 & 1.36 & 75.29 & 4.8 & 0.38 \\
\hline & Line-point & 15 & 53.3 & 11.33 & 12.46 & 109.94 & 6.31 & 55.63 & & 2.37 \\
\hline \multirow[b]{3}{*}{ Litter } & $10-m^{2}$ & 15 & 100.0 & 84.17 & 8.80 & 10.45 & 4.45 & 5.29 & & 1.08 \\
\hline & $1-m^{2}$ & 15 & 100.0 & 75.80 & 22.61 & 29.83 & 11.44 & 15.10 & 78.0 & 0.97 \\
\hline & Line-point & 15 & 100.0 & 74.00 & 15.49 & 20.94 & 7.84 & 10.59 & & 0.95 \\
\hline \multirow[b]{3}{*}{ BSC } & $10-m^{2}$ & 15 & 6.7 & 0.03 & 0.13 & 387.30 & 0.07 & 196.00 & & 1.00 \\
\hline & $1-m^{2}$ & 15 & 6.7 & 0.07 & 0.26 & 387.30 & 0.13 & 196.00 & 0.0 & 2.00 \\
\hline & Line-point & 15 & 0.0 & 0.00 & - & - & - & - & & 0.00 \\
\hline
\end{tabular}


Table C17. Summary of frequency (freq) and cover estimates in macroplot GRCA7 (Loamy Hills ecological site). For line-point sampling, 10-point groups were used as subsampling units for purposes of frequency calculations. Precision is defined as one-half the width of the 95 percent confidence interval. The standardized mean was calculated as the ratio of the mean for a particular method to the among-method mean. See Appendix A for keys to species codes (BSC = biological soil crust).

\begin{tabular}{|c|c|c|c|c|c|c|c|c|c|c|}
\hline \multirow[b]{2}{*}{ Measure } & \multirow[b]{2}{*}{ Method } & \multirow[b]{2}{*}{ Subsample $n$} & \multirow[b]{2}{*}{ Freq } & \multicolumn{7}{|c|}{ Cover } \\
\hline & & & & Mean & sd & CV & Precision & $\begin{array}{c}\text { Precision \% } \\
\text { of mean }\end{array}$ & $\begin{array}{l}\text { Among- } \\
\text { method } \\
\text { mean }\end{array}$ & $\begin{array}{c}\text { Standardized } \\
\text { mean }\end{array}$ \\
\hline \multirow{3}{*}{$\begin{array}{c}\text { Total live } \\
\text { understory } \\
\text { canopy } \\
\text { cover }\end{array}$} & $10-m^{2}$ & 15 & 100.0 & 5.63 & 2.98 & 52.88 & 1.51 & 26.76 & & 0.79 \\
\hline & $1-m^{2}$ & 15 & 80.0 & 5.07 & 5.19 & 102.41 & 2.63 & 51.83 & 7.1 & 0.71 \\
\hline & Line-point & 15 & 66.7 & 10.67 & 9.61 & 90.11 & 4.86 & 45.60 & & 1.50 \\
\hline \multirow[b]{3}{*}{ POFE } & $10-m^{2}$ & 15 & 93.3 & 1.13 & 1.17 & 103.42 & 0.59 & 52.34 & & 0.61 \\
\hline & $1-m^{2}$ & 15 & 73.3 & 1.07 & 0.88 & 82.85 & 0.45 & 41.93 & 1.8 & 0.58 \\
\hline & Line-point & 15 & 33.3 & 3.33 & 4.88 & 146.39 & 2.47 & 74.08 & & 1.81 \\
\hline \multirow[b]{3}{*}{ POTR5 } & $10-m^{2}$ & 15 & 20.0 & 0.27 & 0.78 & 291.05 & 0.39 & 147.29 & & 0.29 \\
\hline & $1-m^{2}$ & 15 & 13.3 & 1.13 & 3.04 & 268.60 & 1.54 & 135.93 & 0.9 & 1.24 \\
\hline & Line-point & 15 & 13.3 & 1.33 & 3.52 & 263.90 & 1.78 & 133.55 & & 1.46 \\
\hline \multirow{3}{*}{$\begin{array}{l}\text { UNGRCA1 } \\
\text { (Carex sp.) }\end{array}$} & $10-m^{2}$ & 15 & 86.7 & 1.60 & 1.37 & 85.34 & 0.69 & 43.19 & & 0.62 \\
\hline & $1-m^{2}$ & 15 & 60.0 & 1.47 & 1.55 & 105.84 & 0.79 & 53.56 & 2.6 & 0.57 \\
\hline & Line-point & 15 & 46.7 & 4.67 & 5.16 & 110.66 & 2.61 & 56.00 & & 1.81 \\
\hline \multirow[b]{3}{*}{ Bare soil } & $10-m^{2}$ & 15 & 60.0 & 1.30 & 1.45 & 111.47 & 0.73 & 56.41 & & 0.14 \\
\hline & $1-m^{2}$ & 15 & 53.3 & 2.07 & 2.87 & 138.64 & 1.45 & 70.16 & 9.3 & 0.22 \\
\hline & Line-point & 15 & 60.0 & 24.67 & 28.00 & 113.50 & 14.17 & 57.44 & & 2.64 \\
\hline \multirow[b]{3}{*}{ Litter } & $10-m^{2}$ & 15 & 100.0 & 84.17 & 8.80 & 10.45 & 4.45 & 5.29 & & 1.09 \\
\hline & $1-m^{2}$ & 15 & 100.0 & 86.53 & 11.51 & 13.30 & 5.83 & 6.73 & 76.9 & 1.13 \\
\hline & Line-point & 15 & 93.3 & 60.00 & 36.25 & 60.42 & 18.35 & 30.58 & & 0.78 \\
\hline \multirow[b]{3}{*}{ BSC } & $10-m^{2}$ & 15 & 13.3 & 0.07 & 0.18 & 263.90 & 0.09 & 133.55 & & 1.50 \\
\hline & $1-m^{2}$ & 15 & 6.7 & 0.07 & 0.26 & 387.30 & 0.13 & 196.00 & 0.0 & 1.50 \\
\hline & Line-point & 15 & 0.0 & 0.00 & - & - & - & - & & 0.00 \\
\hline
\end{tabular}


Table C18. Summary of frequency (freq) and cover estimates in macroplot GRCA1 (Loamy Hills, Cold, ecological site). For line-point sampling, 10-point groups were used as subsampling units for purposes of frequency calculations.

Precision is defined as one-half the width of the 95 percent confidence interval. The standardized mean was calculated as the ratio of the mean for a particular method to the among-method mean. See Appendix A for keys to species codes (BSC = biological soil crust).

\begin{tabular}{|c|c|c|c|c|c|c|c|c|c|c|}
\hline \multirow[b]{2}{*}{ Measure } & \multirow[b]{2}{*}{ Method } & \multirow[b]{2}{*}{ Subsample $\mathbf{n}$} & \multirow[b]{2}{*}{ Freq } & \multicolumn{7}{|c|}{ Cover } \\
\hline & & & & Mean & sd & CV & Precision & $\begin{array}{l}\text { Precision \% } \\
\text { of mean }\end{array}$ & $\begin{array}{l}\text { Among- } \\
\text { method } \\
\text { mean }\end{array}$ & $\begin{array}{c}\text { Standardized } \\
\text { mean }\end{array}$ \\
\hline \multirow{3}{*}{$\begin{array}{c}\text { Total live } \\
\text { understory } \\
\text { canopy } \\
\text { cover }\end{array}$} & $10-m^{2}$ & 21 & 100.0 & 43.57 & 29.26 & 67.14 & 12.51 & 28.72 & & 1.25 \\
\hline & $1-m^{2}$ & 30 & 100.0 & 37.37 & 33.72 & 90.23 & 12.06 & 32.29 & 34.9 & 1.07 \\
\hline & Line-point & 30 & 86.7 & 23.67 & 19.91 & 84.13 & 7.12 & 30.10 & & 0.68 \\
\hline \multirow[b]{3}{*}{$\mathrm{ABCO}$} & $10-m^{2}$ & 21 & 0.0 & 0.00 & - & - & - & - & & - \\
\hline & $1-m^{2}$ & 30 & 0.0 & 0.00 & - & - & - & - & 0.0 & - \\
\hline & Line-point & 30 & 0.0 & 0.00 & - & - & - & - & & - \\
\hline \multirow[b]{3}{*}{ PIEN } & $10-m^{2}$ & 21 & 52.4 & 10.81 & 17.84 & 165.06 & 7.63 & 70.60 & & 0.93 \\
\hline & $1-m^{2}$ & 30 & 43.3 & 16.50 & 26.05 & 157.89 & 9.32 & 56.50 & 11.7 & 1.42 \\
\hline & Line-point & 30 & 36.7 & 7.67 & 12.51 & 163.14 & 4.48 & 58.38 & & 0.66 \\
\hline \multirow[b]{3}{*}{ POTR5 } & $10-m^{2}$ & 21 & 81.0 & 3.74 & 5.21 & 139.43 & 2.23 & 59.63 & & 1.19 \\
\hline & $1-m^{2}$ & 30 & 50.0 & 4.33 & 8.29 & 191.20 & 2.96 & 68.42 & 3.1 & 1.38 \\
\hline & Line-point & 30 & 13.3 & 1.33 & 3.46 & 259.31 & 1.24 & 92.79 & & 0.43 \\
\hline \multirow[b]{3}{*}{ Bare soil } & $10-m^{2}$ & 21 & 95.2 & 2.67 & 4.04 & 151.44 & 1.73 & 64.77 & & 1.05 \\
\hline & $1-m^{2}$ & 30 & 63.3 & 2.30 & 4.38 & 190.43 & 1.57 & 68.14 & 2.5 & 0.90 \\
\hline & Line-point & 30 & 20.0 & 2.67 & 5.83 & 218.73 & 2.09 & 78.27 & & 1.05 \\
\hline \multirow[b]{3}{*}{ Litter } & $10-m^{2}$ & 21 & 100.0 & 70.83 & 14.43 & 20.38 & 6.17 & 8.72 & & 0.91 \\
\hline & $1-m^{2}$ & 30 & 100.0 & 81.80 & 12.64 & 15.45 & 4.52 & 5.53 & 77.9 & 1.05 \\
\hline & Line-point & 30 & 100.0 & 81.00 & 17.29 & 21.35 & 6.19 & 7.64 & & 1.04 \\
\hline \multirow[b]{3}{*}{ BSC } & $10-m^{2}$ & 21 & 90.5 & 1.64 & 1.91 & 116.35 & 0.82 & 49.76 & & 0.92 \\
\hline & $1-m^{2}$ & 30 & 73.3 & 1.70 & 2.87 & 168.62 & 1.03 & 60.34 & 1.8 & 0.95 \\
\hline & Line-point & 30 & 16.7 & 2.00 & 4.84 & 242.12 & 1.73 & 86.64 & & 1.12 \\
\hline
\end{tabular}


Table C19. Summary of frequency (freq) and cover estimates in macroplot GRCA2 (Loamy Hills, Cold, ecological site). For line-point sampling, 10-point groups were used as subsampling units for purposes of frequency calculations.

Precision is defined as one-half the width of the 95 percent confidence interval. The standardized mean was calculated as the ratio of the mean for a particular method to the among-method mean. See Appendix A for keys to species codes (BSC = biological soil crust).

\begin{tabular}{|c|c|c|c|c|c|c|c|c|c|c|}
\hline \multirow[b]{2}{*}{ Measure } & \multirow[b]{2}{*}{ Method } & \multirow[b]{2}{*}{ Subsample $\mathbf{n}$} & \multirow[b]{2}{*}{ Freq } & \multicolumn{7}{|c|}{ Cover } \\
\hline & & & & Mean & sd & CV & Precision & $\begin{array}{l}\text { Precision \% } \\
\text { of mean }\end{array}$ & $\begin{array}{l}\text { Among- } \\
\text { method } \\
\text { mean }\end{array}$ & $\begin{array}{c}\text { Standardized } \\
\text { mean }\end{array}$ \\
\hline \multirow{3}{*}{$\begin{array}{c}\text { Total live } \\
\text { understory } \\
\text { canopy } \\
\text { cover }\end{array}$} & $10-m^{2}$ & 21 & 100.0 & 54.05 & 33.87 & 62.67 & 14.49 & 26.80 & & 1.02 \\
\hline & $1-m^{2}$ & 30 & 100.0 & 77.27 & 51.21 & 66.27 & 18.32 & 23.71 & 53.0 & 1.46 \\
\hline & Line-point & 30 & 83.3 & 27.67 & 17.94 & 64.85 & 6.42 & 23.21 & & 0.52 \\
\hline \multirow[b]{3}{*}{$\mathrm{ABCO}$} & $10-m^{2}$ & 21 & 61.9 & 17.24 & 25.76 & 149.46 & 11.02 & 63.92 & & 1.00 \\
\hline & $1-m^{2}$ & 30 & 66.7 & 25.73 & 29.62 & 115.10 & 10.60 & 41.19 & 17.3 & 1.49 \\
\hline & Line-point & 30 & 46.7 & 9.00 & 11.85 & 131.63 & 4.24 & 47.10 & & 0.52 \\
\hline \multirow[b]{3}{*}{ PIEN } & $10-m^{2}$ & 21 & 4.8 & 2.98 & 13.64 & 458.26 & 5.83 & 196.00 & & 2.45 \\
\hline & $1-m^{2}$ & 30 & 0.0 & 0.00 & - & - & - & - & 1.2 & 0.00 \\
\hline & Line-point & 30 & 3.3 & 0.67 & 3.65 & 547.72 & 1.31 & 196.00 & & 0.55 \\
\hline \multirow[b]{3}{*}{ POTR5 } & $10-m^{2}$ & 21 & 38.1 & 5.71 & 13.33 & 233.21 & 5.70 & 99.74 & & 1.18 \\
\hline & $1-m^{2}$ & 30 & 26.7 & 8.13 & 18.74 & 230.38 & 6.70 & 82.44 & 4.8 & 1.68 \\
\hline & Line-point & 30 & 6.7 & 0.67 & 2.54 & 380.56 & 0.91 & 136.18 & & 0.14 \\
\hline \multirow[b]{3}{*}{ Bare soil } & $10-m^{2}$ & 21 & 71.4 & 2.33 & 3.95 & 169.45 & 1.69 & 72.47 & & 0.78 \\
\hline & $1-m^{2}$ & 30 & 40.0 & 1.30 & 2.31 & 177.44 & 0.83 & 63.49 & 3.0 & 0.43 \\
\hline & Line-point & 30 & 23.3 & 5.33 & 12.52 & 234.77 & 4.48 & 84.01 & & 1.78 \\
\hline \multirow[b]{3}{*}{ Litter } & $10-m^{2}$ & 21 & 100.0 & 69.64 & 16.09 & 23.11 & 6.88 & 9.88 & & 0.91 \\
\hline & $1-m^{2}$ & 30 & 100.0 & 78.97 & 14.23 & 18.02 & 5.09 & 6.45 & 76.8 & 1.03 \\
\hline & Line-point & 30 & 100.0 & 81.67 & 16.42 & 20.10 & 5.87 & 7.19 & & 1.06 \\
\hline \multirow[b]{3}{*}{ BSC } & $10-m^{2}$ & 21 & 66.7 & 0.50 & 0.74 & 148.32 & 0.32 & 63.44 & & 1.29 \\
\hline & $1-m^{2}$ & 30 & 10.0 & 0.67 & 3.11 & 466.65 & 1.11 & 166.98 & 0.4 & 1.71 \\
\hline & Line-point & 30 & 0.0 & 0.00 & - & - & - & - & & 0.00 \\
\hline
\end{tabular}


Table C20. Summary of frequency (freq) and cover estimates in macroplot MEVE3 (Loamy Mesa Top PJ ecological site). For line-point sampling, 10-point groups were used as subsampling units for purposes of frequency calculations.

Precision is defined as one-half the width of the 95 percent confidence interval. The standardized mean was calculated as the ratio of the mean for a particular method to the among-method mean. See Appendix A for keys to species codes (BSC = biological soil crust).

\begin{tabular}{|c|c|c|c|c|c|c|c|c|c|c|}
\hline \multicolumn{11}{|c|}{ Loamy Mesa Top PJ ecological site - MEVE 3 macroplot, Phase 2} \\
\hline \multirow[b]{2}{*}{ Measure } & \multirow[b]{2}{*}{ Method } & \multirow[b]{2}{*}{ Subsample $\mathbf{n}$} & \multirow[b]{2}{*}{ Freq } & \multicolumn{7}{|c|}{ Cover } \\
\hline & & & & Mean & sd & CV & Precision & $\begin{array}{c}\text { Precision \% } \\
\text { of mean }\end{array}$ & $\begin{array}{c}\text { Among- } \\
\text { method } \\
\text { mean }\end{array}$ & $\begin{array}{c}\text { Standardized } \\
\text { mean }\end{array}$ \\
\hline \multirow{3}{*}{$\begin{array}{c}\text { Total live } \\
\text { understory } \\
\text { canopy } \\
\text { cover }\end{array}$} & $10-m^{2}$ & 21 & 100.0 & 41.07 & 24.62 & 59.95 & 10.53 & 25.64 & & 1.22 \\
\hline & $1-m^{2}$ & 30 & 100.0 & 40.10 & 38.61 & 96.29 & 13.82 & 34.46 & 33.6 & 1.19 \\
\hline & Line-point & 30 & 86.7 & 19.67 & 16.08 & 81.75 & 5.75 & 29.25 & & 0.59 \\
\hline \multirow[b]{3}{*}{ JUOS } & $10-m^{2}$ & 21 & 66.7 & 11.74 & 13.29 & 113.26 & 5.69 & 48.44 & & 1.20 \\
\hline & $1-m^{2}$ & 30 & 33.3 & 15.17 & 26.70 & 176.05 & 9.55 & 63.00 & 9.7 & 1.56 \\
\hline & Line-point & 30 & 20.0 & 2.33 & 5.04 & 216.00 & 1.80 & 77.29 & & 0.24 \\
\hline \multirow[b]{3}{*}{ PIED } & $10-m^{2}$ & 21 & 81.0 & 16.02 & 16.30 & 101.72 & 6.97 & 43.51 & & 1.21 \\
\hline & $1-m^{2}$ & 30 & 40.0 & 15.37 & 27.49 & 178.92 & 9.84 & 64.03 & 13.2 & 1.16 \\
\hline & Line-point & 30 & 40.0 & 8.33 & 13.41 & 160.95 & 4.80 & 57.59 & & 0.63 \\
\hline \multirow[b]{3}{*}{ POFE } & $10-m^{2}$ & 21 & 100.0 & 8.43 & 6.18 & 73.34 & 2.64 & 31.37 & & 1.15 \\
\hline & $1-m^{2}$ & 30 & 96.7 & 6.50 & 8.31 & 127.87 & 2.97 & 45.76 & 7.3 & 0.89 \\
\hline & Line-point & 30 & 53.3 & 7.00 & 8.37 & 119.52 & 2.99 & 42.77 & & 0.96 \\
\hline \multirow[b]{3}{*}{ Bare soil } & $10-m^{2}$ & 21 & 90.5 & 3.62 & 8.62 & 238.13 & 3.69 & 101.85 & & 0.68 \\
\hline & $1-m^{2}$ & 30 & 60.0 & 2.93 & 9.92 & 338.07 & 3.55 & 120.97 & 5.3 & 0.55 \\
\hline & Line-point & 30 & 53.3 & 9.33 & 11.12 & 119.15 & 3.98 & 42.64 & & 1.76 \\
\hline \multirow[b]{3}{*}{ Litter } & $10-m^{2}$ & 21 & 100.0 & 46.55 & 23.22 & 49.88 & 9.93 & 21.33 & & 0.90 \\
\hline & $1-m^{2}$ & 30 & 100.0 & 51.40 & 39.04 & 75.95 & 13.97 & 27.18 & 51.6 & 1.00 \\
\hline & Line-point & 30 & 93.3 & 57.00 & 25.21 & 44.23 & 9.02 & 15.83 & & 1.10 \\
\hline \multirow[b]{3}{*}{ BSC } & $10-m^{2}$ & 21 & 100.0 & 5.17 & 5.18 & 100.31 & 2.22 & 42.90 & & 0.77 \\
\hline & $1-m^{2}$ & 30 & 80.0 & 9.07 & 13.97 & 154.06 & 5.00 & 55.13 & 6.7 & 1.34 \\
\hline & Line-point & 30 & 36.7 & 6.00 & 11.92 & 198.65 & 4.27 & 71.09 & & 0.89 \\
\hline
\end{tabular}


Table C21. Summary of frequency (freq) and cover estimates in macroplot MEVE4 (Loamy Mesa Top PJ ecological site). For line-point sampling, 10-point groups were used as subsampling units for purposes of frequency calculations.

Precision is defined as one-half the width of the 95 percent confidence interval. The standardized mean was calculated as the ratio of the mean for a particular method to the among-method mean. See Appendix A for keys to species codes (BSC = biological soil crust).

\begin{tabular}{|c|c|c|c|c|c|c|c|c|c|c|}
\hline \multicolumn{11}{|c|}{ Loamy Mesa Top PJ ecological site - MEVE 4 macroplot, Phase 2} \\
\hline \multirow[b]{2}{*}{ Measure } & \multirow[b]{2}{*}{ Method } & \multirow[b]{2}{*}{ Subsample $\mathbf{n}$} & \multirow[b]{2}{*}{ Freq } & \multicolumn{7}{|c|}{ Cover } \\
\hline & & & & Mean & sd & CV & Precision & $\begin{array}{c}\text { Precision \% } \\
\text { of mean }\end{array}$ & $\begin{array}{c}\text { Among- } \\
\text { method } \\
\text { mean }\end{array}$ & $\begin{array}{c}\text { Standardized } \\
\text { mean }\end{array}$ \\
\hline \multirow{3}{*}{$\begin{array}{c}\text { Total live } \\
\text { understory } \\
\text { canopy } \\
\text { cover }\end{array}$} & $10-m^{2}$ & 21 & 100.0 & 55.71 & 31.30 & 56.19 & 13.39 & 24.03 & & 1.33 \\
\hline & $1-m^{2}$ & 30 & 100.0 & 43.67 & 49.82 & 114.10 & 17.83 & 40.83 & 42.0 & 1.04 \\
\hline & Line-point & 30 & 93.3 & 26.67 & 17.09 & 64.07 & 6.11 & 22.93 & & 0.63 \\
\hline \multirow[b]{3}{*}{ JUOS } & $10-m^{2}$ & 21 & 76.2 & 12.19 & 17.42 & 142.94 & 7.45 & 61.13 & & 0.97 \\
\hline & $1-m^{2}$ & 30 & 50.0 & 20.10 & 32.36 & 160.98 & 11.58 & 57.60 & 12.5 & 1.60 \\
\hline & Line-point & 30 & 40.0 & 5.33 & 7.76 & 145.51 & 2.78 & 52.07 & & 0.43 \\
\hline \multirow[b]{3}{*}{ PIED } & $10-m^{2}$ & 21 & 81.0 & 26.21 & 23.84 & 90.95 & 10.20 & 38.90 & & 1.72 \\
\hline & $1-m^{2}$ & 30 & 36.7 & 13.27 & 25.39 & 191.41 & 9.09 & 68.49 & 15.3 & 0.87 \\
\hline & Line-point & 30 & 43.3 & 6.33 & 10.66 & 168.35 & 3.82 & 60.24 & & 0.41 \\
\hline \multirow[b]{3}{*}{ POFE } & $10-m^{2}$ & 21 & 100.0 & 13.10 & 8.50 & 64.88 & 3.63 & 27.75 & & 1.16 \\
\hline & $1-m^{2}$ & 30 & 96.7 & 8.03 & 7.69 & 95.78 & 2.75 & 34.27 & 11.3 & 0.71 \\
\hline & Line-point & 30 & 76.7 & 12.67 & 11.12 & 87.80 & 3.98 & 31.42 & & 1.12 \\
\hline \multirow[b]{3}{*}{ Bare soil } & $10-m^{2}$ & 21 & 85.7 & 4.21 & 6.10 & 144.71 & 2.61 & 61.89 & & 0.94 \\
\hline & $1-m^{2}$ & 30 & 73.3 & 6.27 & 12.14 & 193.67 & 4.34 & 69.30 & 4.5 & 1.39 \\
\hline & Line-point & 30 & 26.7 & 3.00 & 5.35 & 178.33 & 1.91 & 63.81 & & 0.67 \\
\hline \multirow[b]{3}{*}{ Litter } & $10-m^{2}$ & 21 & 100.0 & 58.45 & 28.05 & 47.98 & 12.00 & 20.52 & & 0.89 \\
\hline & $1-m^{2}$ & 30 & 100.0 & 69.70 & 29.72 & 42.64 & 10.63 & 15.26 & 65.8 & 1.06 \\
\hline & Line-point & 30 & 100.0 & 69.33 & 16.60 & 23.94 & 5.94 & 8.57 & & 1.05 \\
\hline \multirow[b]{3}{*}{ BSC } & $10-m^{2}$ & 21 & 85.7 & 3.71 & 3.73 & 100.52 & 1.60 & 42.99 & & 0.97 \\
\hline & $1-m^{2}$ & 30 & 53.3 & 2.80 & 4.13 & 147.52 & 1.48 & 52.79 & 3.8 & 0.73 \\
\hline & Line-point & 30 & 33.3 & 5.00 & 8.20 & 164.00 & 2.93 & 58.69 & & 1.30 \\
\hline
\end{tabular}


Table C22. Summary of frequency (freq) and cover estimates in macroplot MEVE8 (Loamy Mesa Top PJ ecological site). For line-point sampling, 10-point groups were used as subsampling units for purposes of frequency calculations.

Precision is defined as one-half the width of the 95 percent confidence interval. The standardized mean was calculated as the ratio of the mean for a particular method to the among-method mean. See Appendix A for keys to species codes (BSC = biological soil crust).

\begin{tabular}{|c|c|c|c|c|c|c|c|c|c|c|}
\hline \multicolumn{11}{|c|}{ Loamy Mesa Top PJ ecological site - MEVE 8 macroplot, Phase 3} \\
\hline \multirow[b]{2}{*}{ Measure } & \multirow[b]{2}{*}{ Method } & \multirow[b]{2}{*}{ Subsample $\mathbf{n}$} & \multirow[b]{2}{*}{ Freq } & \multicolumn{7}{|c|}{ Cover } \\
\hline & & & & Mean & sd & CV & Precision & $\begin{array}{c}\text { Precision \% } \\
\text { of mean }\end{array}$ & $\begin{array}{c}\text { Among- } \\
\text { method } \\
\text { mean }\end{array}$ & $\begin{array}{c}\text { Standardized } \\
\text { mean }\end{array}$ \\
\hline \multirow{3}{*}{$\begin{array}{c}\text { Total live } \\
\text { understory } \\
\text { canopy } \\
\text { cover }\end{array}$} & $10-m^{2}$ & 15 & 100.0 & 23.77 & 14.59 & 61.37 & 7.38 & 31.06 & & 1.08 \\
\hline & $1-m^{2}$ & 15 & 100.0 & 21.60 & 26.38 & 122.14 & 13.35 & 61.81 & 22.0 & 0.98 \\
\hline & Line-point & 15 & 80.0 & 20.67 & 18.31 & 88.59 & 9.27 & 44.83 & & 0.94 \\
\hline \multirow[b]{3}{*}{ JUOS } & $10-m^{2}$ & 15 & 73.3 & 3.27 & 6.09 & 186.46 & 3.08 & 94.36 & & 0.79 \\
\hline & $1-m^{2}$ & 15 & 33.3 & 5.07 & 9.79 & 193.16 & 4.95 & 97.75 & 4.1 & 1.23 \\
\hline & Line-point & 15 & 26.7 & 4.00 & 7.37 & 184.20 & 3.73 & 93.21 & & 0.97 \\
\hline \multirow[b]{3}{*}{ PIED } & $10-m^{2}$ & 15 & 60.0 & 6.63 & 11.09 & 167.21 & 5.61 & 84.62 & & 1.01 \\
\hline & $1-m^{2}$ & 15 & 46.7 & 10.47 & 23.34 & 223.01 & 11.81 & 112.86 & 6.6 & 1.59 \\
\hline & Line-point & 15 & 26.7 & 2.67 & 4.58 & 171.65 & 2.32 & 86.87 & & 0.40 \\
\hline \multirow[b]{3}{*}{ POFE } & $10-m^{2}$ & 15 & 100.0 & 10.13 & 6.58 & 64.91 & 3.33 & 32.85 & & 1.11 \\
\hline & $1-m^{2}$ & 15 & 100.0 & 5.33 & 4.08 & 76.55 & 2.07 & 38.74 & 9.2 & 0.58 \\
\hline & Line-point & 15 & 80.0 & 12.00 & 14.24 & 118.69 & 7.21 & 60.06 & & 1.31 \\
\hline \multirow[b]{3}{*}{ Bare soil } & $10-m^{2}$ & 15 & 100.0 & 0.97 & 1.81 & 186.97 & 0.91 & 94.62 & & 0.18 \\
\hline & $1-m^{2}$ & 15 & 66.7 & 1.00 & 1.46 & 146.39 & 0.74 & 74.08 & 5.3 & 0.19 \\
\hline & Line-point & 15 & 80.0 & 14.00 & 10.56 & 75.40 & 5.34 & 38.16 & & 2.63 \\
\hline \multirow[b]{3}{*}{ Litter } & $10-m^{2}$ & 15 & 100.0 & 46.53 & 29.48 & 63.35 & 14.92 & 32.06 & & 0.98 \\
\hline & $1-m^{2}$ & 15 & 100.0 & 54.00 & 30.99 & 57.38 & 15.68 & 29.04 & 47.5 & 1.14 \\
\hline & Line-point & 15 & 93.3 & 42.00 & 23.36 & 55.62 & 11.82 & 28.15 & & 0.88 \\
\hline \multirow[b]{3}{*}{ BSC } & $10-m^{2}$ & 15 & 100.0 & 1.77 & 2.00 & 113.14 & 1.01 & 57.26 & & 0.64 \\
\hline & $1-m^{2}$ & 15 & 66.7 & 1.87 & 1.88 & 100.97 & 0.95 & 51.10 & 2.8 & 0.67 \\
\hline & Line-point & 15 & 33.3 & 4.67 & 7.43 & 159.26 & 3.76 & 80.60 & & 1.69 \\
\hline
\end{tabular}


Table C23. Summary of frequency (freq) and cover estimates in macroplot MEVE9 (Loamy Mesa Top PJ ecological site). For line-point sampling, 10-point groups were used as subsampling units for purposes of frequency calculations.

Precision is defined as one-half the width of the 95 percent confidence interval. The standardized mean was calculated as the ratio of the mean for a particular method to the among-method mean. See Appendix A for keys to species codes (BSC = biological soil crust).

\begin{tabular}{|c|c|c|c|c|c|c|c|c|c|c|}
\hline \multicolumn{11}{|c|}{ Loamy Mesa Top PJ ecological site - MEVE 9 macroplot, Phase 3} \\
\hline \multirow[b]{2}{*}{ Measure } & \multirow[b]{2}{*}{ Method } & \multirow[b]{2}{*}{ Subsample $\mathbf{n}$} & \multirow[b]{2}{*}{ Freq } & \multicolumn{7}{|c|}{ Cover } \\
\hline & & & & Mean & sd & CV & Precision & $\begin{array}{c}\text { Precision \% } \\
\text { of mean }\end{array}$ & $\begin{array}{c}\text { Among- } \\
\text { method } \\
\text { mean }\end{array}$ & $\begin{array}{c}\text { Standardized } \\
\text { mean }\end{array}$ \\
\hline \multirow{3}{*}{$\begin{array}{c}\text { Total live } \\
\text { understory } \\
\text { canopy } \\
\text { cover }\end{array}$} & $10-m^{2}$ & 15 & 100.0 & 20.90 & 18.67 & 89.32 & 9.45 & 45.20 & & 1.17 \\
\hline & $1-m^{2}$ & 15 & 93.3 & 13.20 & 15.21 & 115.26 & 7.70 & 58.33 & 17.8 & 0.74 \\
\hline & Line-point & 15 & 80.0 & 19.33 & 14.38 & 74.36 & 7.28 & 37.63 & & 1.09 \\
\hline \multirow[b]{3}{*}{ JUOS } & $10-m^{2}$ & 15 & 60.0 & 7.03 & 16.47 & 234.11 & 8.33 & 118.47 & & 1.80 \\
\hline & $1-m^{2}$ & 15 & 33.3 & 2.67 & 6.14 & 230.15 & 3.11 & 116.47 & 3.9 & 0.68 \\
\hline & Line-point & 15 & 20.0 & 2.00 & 4.14 & 207.02 & 2.10 & 104.76 & & 0.51 \\
\hline \multirow[b]{3}{*}{ PIED } & $10-m^{2}$ & 15 & 73.3 & 5.40 & 10.06 & 186.21 & 5.09 & 94.24 & & 0.81 \\
\hline & $1-m^{2}$ & 15 & 26.7 & 4.60 & 10.47 & 227.68 & 5.30 & 115.22 & 6.7 & 0.69 \\
\hline & Line-point & 15 & 60.0 & 10.00 & 13.63 & 136.28 & 6.90 & 68.96 & & 1.50 \\
\hline \multirow[b]{3}{*}{ POFE } & $10-m^{2}$ & 15 & 100.0 & 2.93 & 2.16 & 73.70 & 1.09 & 37.30 & & 0.80 \\
\hline & $1-m^{2}$ & 15 & 86.7 & 3.40 & 4.17 & 122.69 & 2.11 & 62.09 & 3.7 & 0.93 \\
\hline & Line-point & 15 & 46.7 & 4.67 & 5.16 & 110.66 & 2.61 & 56.00 & & 1.27 \\
\hline \multirow[b]{3}{*}{ Bare soil } & $10-m^{2}$ & 15 & 80.0 & 0.90 & 1.11 & 122.80 & 0.56 & 62.14 & & 0.33 \\
\hline & $1-m^{2}$ & 15 & 33.3 & 0.67 & 1.54 & 231.46 & 0.78 & 117.13 & 2.7 & 0.24 \\
\hline & Line-point & 15 & 46.7 & 6.67 & 8.16 & 122.47 & 4.13 & 61.98 & & 2.43 \\
\hline \multirow[b]{3}{*}{ Litter } & $10-m^{2}$ & 15 & 100.0 & 46.37 & 34.68 & 74.80 & 17.55 & 37.85 & & 1.14 \\
\hline & $1-m^{2}$ & 15 & 100.0 & 40.87 & 36.65 & 89.68 & 18.55 & 45.38 & 40.6 & 1.01 \\
\hline & Line-point & 15 & 93.3 & 34.67 & 22.64 & 65.30 & 11.46 & 33.04 & & 0.85 \\
\hline \multirow[b]{3}{*}{ BSC } & $10-m^{2}$ & 15 & 100.0 & 4.07 & 3.80 & 93.51 & 1.92 & 47.32 & & 0.67 \\
\hline & $1-m^{2}$ & 15 & 93.3 & 8.13 & 14.89 & 183.13 & 7.54 & 92.67 & 6.1 & 1.34 \\
\hline & Line-point & 15 & 40.0 & 6.00 & 9.10 & 151.71 & 4.61 & 76.77 & & 0.99 \\
\hline
\end{tabular}


Table C24. Summary of frequency (freq) and cover estimates in macroplot MEVE10 (Loamy Mesa Top PJ ecological site). For line-point sampling, 10-point groups were used as subsampling units for purposes of frequency calculations. Precision is defined as one-half the width of the 95 percent confidence interval. The standardized mean was calculated as the ratio of the mean for a particular method to the among-method mean. See Appendix A for keys to species codes (BSC = biological soil crust).

\begin{tabular}{|c|c|c|c|c|c|c|c|c|c|c|}
\hline \multirow[b]{2}{*}{ Measure } & \multirow[b]{2}{*}{ Method } & \multirow[b]{2}{*}{ Subsample $\mathbf{n}$} & \multirow[b]{2}{*}{ Freq } & \multicolumn{7}{|c|}{ Cover } \\
\hline & & & & Mean & sd & CV & Precision & $\begin{array}{c}\text { Precision \% } \\
\text { of mean }\end{array}$ & $\begin{array}{l}\text { Among- } \\
\text { method } \\
\text { mean }\end{array}$ & $\begin{array}{c}\text { Standardized } \\
\text { mean }\end{array}$ \\
\hline \multirow{3}{*}{$\begin{array}{c}\text { Total live } \\
\text { understory } \\
\text { canopy } \\
\text { cover }\end{array}$} & $10-m^{2}$ & 15 & 100.0 & 22.23 & 11.66 & 52.45 & 5.90 & 26.54 & & 0.97 \\
\hline & $1-m^{2}$ & 15 & 100.0 & 29.53 & 25.70 & 87.03 & 13.01 & 44.04 & 23.0 & 1.28 \\
\hline & Line-point & 15 & 80.0 & 17.33 & 11.63 & 67.09 & 5.89 & 33.95 & & 0.75 \\
\hline \multirow[b]{3}{*}{ JUOS } & $10-m^{2}$ & 15 & 60.0 & 4.47 & 6.03 & 135.02 & 3.05 & 68.33 & & 0.99 \\
\hline & $1-m^{2}$ & 15 & 33.3 & 5.80 & 18.03 & 310.84 & 9.12 & 157.30 & 4.5 & 1.28 \\
\hline & Line-point & 15 & 33.3 & 3.33 & 4.88 & 146.39 & 2.47 & 74.08 & & 0.74 \\
\hline \multirow[b]{3}{*}{ PIED } & $10-m^{2}$ & 15 & 73.3 & 7.90 & 7.66 & 96.91 & 3.87 & 49.04 & & 0.85 \\
\hline & $1-m^{2}$ & 15 & 33.3 & 10.67 & 23.05 & 216.05 & 11.66 & 109.34 & 9.3 & 1.15 \\
\hline & Line-point & 15 & 53.3 & 9.33 & 11.00 & 117.83 & 5.57 & 59.63 & & 1.00 \\
\hline \multirow[b]{3}{*}{ POFE } & $10-m^{2}$ & 15 & 93.3 & 0.47 & 0.13 & 27.66 & 0.07 & 14.00 & & 0.48 \\
\hline & $1-m^{2}$ & 15 & 46.7 & 0.47 & 0.52 & 110.66 & 0.26 & 56.00 & 1.0 & 0.48 \\
\hline & Line-point & 15 & 20.0 & 2.00 & 4.14 & 207.02 & 2.10 & 104.76 & & 2.05 \\
\hline \multirow[b]{3}{*}{ Bare soil } & $10-m^{2}$ & 15 & 100.0 & 0.67 & 0.65 & 96.82 & 0.33 & 49.00 & & 0.51 \\
\hline & $1-m^{2}$ & 15 & 60.0 & 0.60 & 0.51 & 84.52 & 0.26 & 42.77 & 1.3 & 0.46 \\
\hline & Line-point & 15 & 26.7 & 2.67 & 4.58 & 171.65 & 2.32 & 86.87 & & 2.03 \\
\hline \multirow[b]{3}{*}{ Litter } & $10-m^{2}$ & 15 & 100.0 & 38.20 & 30.25 & 79.18 & 15.31 & 40.07 & & 1.05 \\
\hline & $1-m^{2}$ & 15 & 100.0 & 36.40 & 33.79 & 92.83 & 17.10 & 46.98 & 36.4 & 1.00 \\
\hline & Line-point & 15 & 93.3 & 34.67 & 25.60 & 73.84 & 12.95 & 37.37 & & 0.95 \\
\hline \multirow[b]{3}{*}{ BSC } & $10-m^{2}$ & 15 & 100.0 & 4.83 & 3.84 & 79.52 & 1.95 & 40.24 & & 0.57 \\
\hline & $1-m^{2}$ & 15 & 93.3 & 5.07 & 3.88 & 76.61 & 1.96 & 38.77 & 8.4 & 0.60 \\
\hline & Line-point & 15 & 86.7 & 15.33 & 13.56 & 88.42 & 6.86 & 44.75 & & 1.82 \\
\hline
\end{tabular}


Table C25. Summary of frequency (freq) and cover estimates in macroplot CARE1 (Semidesert Alkali Sandy Loam ecological site). For line-point sampling, 10-point groups were used as subsampling units for purposes of frequency calculations. Precision is defined as one-half the width of the 95 percent confidence interval. The standardized mean was calculated as the ratio of the mean for a particular method to the among-method mean. See Appendix A for keys to species codes (BSC $=$ biological soil crust).

\begin{tabular}{|c|c|c|c|c|c|c|c|c|c|c|}
\hline \multirow[b]{2}{*}{ Measure } & \multirow[b]{2}{*}{ Method } & \multirow[b]{2}{*}{ Subsample $n$} & \multirow[b]{2}{*}{ Freq } & \multicolumn{7}{|c|}{ Cover } \\
\hline & & & & Mean & sd & CV & Precision & $\begin{array}{c}\text { Precision \% } \\
\text { of mean }\end{array}$ & $\begin{array}{l}\text { Among- } \\
\text { method } \\
\text { mean }\end{array}$ & $\begin{array}{c}\text { Standardized } \\
\text { mean }\end{array}$ \\
\hline \multirow{3}{*}{$\begin{array}{c}\text { Total live } \\
\text { understory } \\
\text { canopy } \\
\text { cover }\end{array}$} & $10-m^{2}$ & 21 & 100.0 & 23.33 & 7.02 & 30.09 & 3.00 & 12.87 & & 0.87 \\
\hline & $1-m^{2}$ & 30 & 100.0 & 19.50 & 6.93 & 35.52 & 2.48 & 12.71 & 26.7 & 0.73 \\
\hline & Line-point & 30 & 93.3 & 37.33 & 18.18 & 48.70 & 6.51 & 17.43 & & 1.40 \\
\hline \multirow[b]{3}{*}{ ATCO } & $10-m^{2}$ & 21 & 81.0 & 4.19 & 5.16 & 123.16 & 2.21 & 52.68 & & 1.06 \\
\hline & $1-m^{2}$ & 30 & 46.7 & 1.97 & 3.63 & 184.78 & 1.30 & 66.12 & 3.9 & 0.50 \\
\hline & Line-point & 30 & 36.7 & 5.67 & 9.71 & 171.43 & 3.48 & 61.34 & & 1.44 \\
\hline \multirow[b]{3}{*}{ GIIN2 } & $10-m^{2}$ & 21 & 47.6 & 0.24 & 0.26 & 107.47 & 0.11 & 45.97 & & 1.25 \\
\hline & $1-m^{2}$ & 30 & 33.3 & 0.33 & 0.48 & 143.84 & 0.17 & 51.47 & 0.2 & 1.75 \\
\hline & Line-point & 30 & 0.0 & 0.00 & - & - & - & - & & 0.00 \\
\hline \multirow[b]{3}{*}{ ORHY } & $10-m^{2}$ & 21 & 95.2 & 0.71 & 0.77 & 107.47 & 0.33 & 45.97 & & 0.45 \\
\hline & $1-m^{2}$ & 30 & 56.7 & 0.70 & 0.75 & 107.10 & 0.27 & 38.33 & 1.6 & 0.44 \\
\hline & Line-point & 30 & 23.3 & 3.33 & 6.61 & 198.27 & 2.36 & 70.95 & & 2.11 \\
\hline \multirow[b]{3}{*}{ Bare soil } & $10-m^{2}$ & 21 & 100.0 & 0.74 & 0.75 & 101.88 & 0.32 & 43.57 & & 0.32 \\
\hline & $1-m^{2}$ & 30 & 90.0 & 1.53 & 1.72 & 111.96 & 0.61 & 40.06 & 2.3 & 0.66 \\
\hline & Line-point & 30 & 36.7 & 4.67 & 7.30 & 156.49 & 2.61 & 56.00 & & 2.02 \\
\hline \multirow[b]{3}{*}{ Litter } & $10-m^{2}$ & 21 & 100.0 & 15.64 & 9.08 & 58.03 & 3.88 & 24.82 & & 1.32 \\
\hline & $1-m^{2}$ & 30 & 96.7 & 11.83 & 14.97 & 126.54 & 5.36 & 45.28 & 11.8 & 1.00 \\
\hline & Line-point & 30 & 43.3 & 8.00 & 11.26 & 140.81 & 4.03 & 50.39 & & 0.68 \\
\hline \multirow[b]{3}{*}{ BSC } & $10-m^{2}$ & 21 & 85.7 & 1.10 & 0.85 & 77.23 & 0.36 & 33.03 & & 1.06 \\
\hline & $1-m^{2}$ & 30 & 50.0 & 1.00 & 1.26 & 125.94 & 0.45 & 45.07 & 1.0 & 0.97 \\
\hline & Line-point & 30 & 6.7 & 1.00 & 4.03 & 402.58 & 1.44 & 144.06 & & 0.97 \\
\hline
\end{tabular}


Table C26. Summary of frequency (freq) and cover estimates in macroplot CARE2 (Semidesert Alkali Sandy Loam ecological site). For line-point sampling, 10-point groups were used as subsampling units for purposes of frequency calculations. Precision is defined as one-half the width of the 95 percent confidence interval. The standardized mean was calculated as the ratio of the mean for a particular method to the among-method mean. See Appendix A for keys to species codes (BSC $=$ biological soil crust).

\begin{tabular}{|c|c|c|c|c|c|c|c|c|c|c|}
\hline \multirow[b]{2}{*}{ Measure } & \multirow[b]{2}{*}{ Method } & \multirow[b]{2}{*}{ Subsample $\mathbf{n}$} & \multirow[b]{2}{*}{ Freq } & \multicolumn{7}{|c|}{ Cover } \\
\hline & & & & Mean & sd & CV & Precision & $\begin{array}{c}\text { Precision \% } \\
\text { of mean }\end{array}$ & $\begin{array}{l}\text { Among- } \\
\text { method } \\
\text { mean }\end{array}$ & $\begin{array}{c}\text { Standardized } \\
\text { mean }\end{array}$ \\
\hline \multirow{3}{*}{$\begin{array}{c}\text { Total live } \\
\text { understory } \\
\text { canopy } \\
\text { cover }\end{array}$} & $10-m^{2}$ & 21 & 100.0 & 35.48 & 16.87 & 47.55 & 7.21 & 20.34 & & 1.18 \\
\hline & $1-m^{2}$ & 30 & 100.0 & 24.60 & 14.49 & 58.91 & 5.19 & 21.08 & 30.1 & 0.82 \\
\hline & Line-point & 30 & 93.3 & 30.33 & 19.38 & 63.90 & 6.94 & 22.87 & & 1.01 \\
\hline \multirow[b]{3}{*}{ ATCO } & $10-m^{2}$ & 21 & 90.5 & 4.60 & 4.92 & 107.14 & 2.11 & 45.82 & & 0.90 \\
\hline & $1-m^{2}$ & 30 & 53.3 & 7.13 & 12.38 & 173.49 & 4.43 & 62.08 & 5.1 & 1.39 \\
\hline & Line-point & 30 & 26.7 & 3.67 & 6.69 & 182.37 & 2.39 & 65.26 & & 0.71 \\
\hline \multirow[b]{3}{*}{ GIIN2 } & $10-m^{2}$ & 21 & 42.9 & 0.21 & 0.25 & 118.32 & 0.11 & 50.61 & & 0.86 \\
\hline & $1-m^{2}$ & 30 & 20.0 & 0.20 & 0.41 & 203.42 & 0.15 & 72.79 & 0.2 & 0.80 \\
\hline & Line-point & 30 & 3.3 & 0.33 & 1.83 & 547.72 & 0.65 & 196.00 & & 1.34 \\
\hline \multirow[b]{3}{*}{ ORHY } & $10-m^{2}$ & 21 & 95.2 & 0.60 & 0.56 & 94.36 & 0.24 & 40.36 & & 0.96 \\
\hline & $1-m^{2}$ & 30 & 53.3 & 0.60 & 0.62 & 103.58 & 0.22 & 37.06 & 0.6 & 0.97 \\
\hline & Line-point & 30 & 6.7 & 0.67 & 2.54 & 380.56 & 0.91 & 136.18 & & 1.07 \\
\hline \multirow[b]{3}{*}{ Bare soil } & $10-m^{2}$ & 21 & 23.8 & 1.26 & 4.06 & 321.80 & 1.74 & 137.63 & & 0.68 \\
\hline & $1-m^{2}$ & 30 & 13.3 & 0.60 & 2.74 & 456.12 & 0.98 & 163.22 & 1.8 & 0.33 \\
\hline & Line-point & 30 & 23.3 & 3.67 & 8.09 & 220.56 & 2.89 & 78.92 & & 1.99 \\
\hline \multirow[b]{3}{*}{ Litter } & $10-m^{2}$ & 21 & 100.0 & 9.83 & 8.96 & 91.11 & 3.83 & 38.97 & & 1.11 \\
\hline & $1-m^{2}$ & 30 & 96.7 & 9.50 & 12.59 & 132.48 & 4.50 & 47.41 & 8.9 & 1.07 \\
\hline & Line-point & 30 & 56.7 & 7.33 & 7.40 & 100.87 & 2.65 & 36.09 & & 0.83 \\
\hline \multirow[b]{3}{*}{ BSC } & $10-m^{2}$ & 21 & 81.0 & 1.12 & 1.14 & 101.79 & 0.49 & 43.54 & & 0.39 \\
\hline & $1-m^{2}$ & 30 & 66.7 & 1.57 & 1.77 & 113.30 & 0.64 & 40.54 & 2.9 & 0.54 \\
\hline & Line-point & 30 & 33.3 & 6.00 & 9.68 & 161.41 & 3.47 & 57.76 & & 2.07 \\
\hline
\end{tabular}


Table C27. Summary of frequency (freq) and cover estimates in macroplot CARE5 (Semidesert Alkali Sandy Loam ecological site). For line-point sampling, 10-point groups were used as subsampling units for purposes of frequency calculations. Precision is defined as one-half the width of the 95 percent confidence interval. The standardized mean was calculated as the ratio of the mean for a particular method to the among-method mean. See Appendix A for keys to species codes (BSC $=$ biological soil crust).

\begin{tabular}{|c|c|c|c|c|c|c|c|c|c|c|}
\hline \multirow[b]{2}{*}{ Measure } & \multirow[b]{2}{*}{ Method } & \multirow[b]{2}{*}{ Subsample $\mathbf{n}$} & \multirow[b]{2}{*}{ Freq } & \multicolumn{7}{|c|}{ Cover } \\
\hline & & & & Mean & sd & CV & Precision & $\begin{array}{c}\text { Precision \% } \\
\text { of mean }\end{array}$ & $\begin{array}{l}\text { Among- } \\
\text { method } \\
\text { mean }\end{array}$ & $\begin{array}{c}\text { Standardized } \\
\text { mean }\end{array}$ \\
\hline \multirow{3}{*}{$\begin{array}{c}\text { Total live } \\
\text { understory } \\
\text { canopy } \\
\text { cover }\end{array}$} & $10-m^{2}$ & 15 & 100.0 & 19.17 & 9.04 & 47.17 & 4.58 & 23.87 & & 0.84 \\
\hline & $1-m^{2}$ & 15 & 100.0 & 20.93 & 20.14 & 96.20 & 10.19 & 48.68 & 22.9 & 0.91 \\
\hline & Line-point & 15 & 100.0 & 28.67 & 16.42 & 57.27 & 8.31 & 28.98 & & 1.25 \\
\hline \multirow[b]{3}{*}{ ATCO } & $10-m^{2}$ & 15 & 53.3 & 0.60 & 1.00 & 167.26 & 0.51 & 84.64 & & 1.35 \\
\hline & $1-m^{2}$ & 15 & 46.7 & 0.73 & 1.28 & 174.53 & 0.65 & 88.32 & 0.4 & 1.65 \\
\hline & Line-point & 15 & 0.0 & 0.00 & - & - & - & - & & 0.00 \\
\hline \multirow[b]{3}{*}{ GIIN2 } & $10-m^{2}$ & 15 & 73.3 & 0.37 & 0.23 & 62.42 & 0.12 & 31.59 & & 0.48 \\
\hline & $1-m^{2}$ & 15 & 60.0 & 0.60 & 0.51 & 84.52 & 0.26 & 42.77 & 0.8 & 0.78 \\
\hline & Line-point & 15 & 13.3 & 1.33 & 3.52 & 263.90 & 1.78 & 133.55 & & 1.74 \\
\hline \multirow[b]{3}{*}{ ORHY } & $10-m^{2}$ & 15 & 86.7 & 0.60 & 0.69 & 114.43 & 0.35 & 57.91 & & 0.69 \\
\hline & $1-m^{2}$ & 15 & 66.7 & 0.67 & 0.49 & 73.19 & 0.25 & 37.04 & 0.9 & 0.77 \\
\hline & Line-point & 15 & 13.3 & 1.33 & 3.52 & 263.90 & 1.78 & 133.55 & & 1.54 \\
\hline \multirow[b]{3}{*}{ Bare soil } & $10-m^{2}$ & 15 & 100.0 & 0.97 & 1.81 & 186.97 & 0.91 & 94.62 & & 0.38 \\
\hline & $1-m^{2}$ & 15 & 86.7 & 2.07 & 1.83 & 88.59 & 0.93 & 44.83 & 2.6 & 0.81 \\
\hline & Line-point & 15 & 40.0 & 4.67 & 6.40 & 137.13 & 3.24 & 69.40 & & 1.82 \\
\hline \multirow[b]{3}{*}{ Litter } & $10-m^{2}$ & 15 & 100.0 & 10.00 & 9.29 & 92.87 & 4.70 & 47.00 & & 1.08 \\
\hline & $1-m^{2}$ & 15 & 100.0 & 11.67 & 23.50 & 201.43 & 11.89 & 101.93 & 9.2 & 1.27 \\
\hline & Line-point & 15 & 33.3 & 6.00 & 9.86 & 164.27 & 4.99 & 83.13 & & 0.65 \\
\hline \multirow[b]{3}{*}{ BSC } & $10-m^{2}$ & 15 & 40.0 & 0.33 & 0.45 & 134.96 & 0.23 & 68.30 & & 1.67 \\
\hline & $1-m^{2}$ & 15 & 20.0 & 0.27 & 0.59 & 222.61 & 0.30 & 112.65 & 0.2 & 1.33 \\
\hline & Line-point & 15 & 0.0 & 0.00 & - & - & - & - & & 0.00 \\
\hline
\end{tabular}


Table C28. Summary of frequency (freq) and cover estimates in macroplot CARE6 (Semidesert Alkali Sandy Loam ecological site). For line-point sampling, 10-point groups were used as subsampling units for purposes of frequency calculations. Precision is defined as one-half the width of the 95 percent confidence interval. The standardized mean was calculated as the ratio of the mean for a particular method to the among-method mean. See Appendix A for keys to species codes (BSC $=$ biological soil crust).

\begin{tabular}{|c|c|c|c|c|c|c|c|c|c|c|}
\hline \multirow[b]{2}{*}{ Measure } & \multirow[b]{2}{*}{ Method } & \multirow[b]{2}{*}{ Subsample $\mathbf{n}$} & \multirow[b]{2}{*}{ Freq } & \multicolumn{7}{|c|}{ Cover } \\
\hline & & & & Mean & sd & CV & Precision & $\begin{array}{l}\text { Precision } \% \\
\text { of mean }\end{array}$ & $\begin{array}{l}\text { Among- } \\
\text { method } \\
\text { mean }\end{array}$ & $\begin{array}{c}\text { Standardized } \\
\text { mean }\end{array}$ \\
\hline \multirow{3}{*}{$\begin{array}{c}\text { Total live } \\
\text { understory } \\
\text { canopy } \\
\text { cover }\end{array}$} & $10-m^{2}$ & 15 & 100.0 & 7.27 & 4.46 & 61.43 & 2.26 & 31.09 & & 0.85 \\
\hline & $1-m^{2}$ & 15 & 93.3 & 7.07 & 6.13 & 86.82 & 3.10 & 43.93 & 8.6 & 0.83 \\
\hline & Line-point & 15 & 66.7 & 11.33 & 11.87 & 104.76 & 6.01 & 53.01 & & 1.32 \\
\hline \multirow[b]{3}{*}{ ATCO } & $10-m^{2}$ & 15 & 46.7 & 1.03 & 2.06 & 199.06 & 1.04 & 100.74 & & 0.67 \\
\hline & $1-m^{2}$ & 15 & 20.0 & 0.93 & 2.63 & 281.93 & 1.33 & 142.67 & 1.5 & 0.60 \\
\hline & Line-point & 15 & 20.0 & 2.67 & 5.94 & 222.61 & 3.00 & 112.65 & & 1.73 \\
\hline \multirow[b]{3}{*}{ GIIN2 } & $10-m^{2}$ & 15 & 33.3 & 0.17 & 0.24 & 146.39 & 0.12 & 74.08 & & 1.15 \\
\hline & $1-m^{2}$ & 15 & 26.7 & 0.27 & 0.46 & 171.65 & 0.23 & 86.87 & 0.1 & 1.85 \\
\hline & Line-point & 15 & 0.0 & 0.00 & - & - & - & - & & 0.00 \\
\hline \multirow[b]{3}{*}{ ORHY } & $10-m^{2}$ & 15 & 60.0 & 0.30 & 0.25 & 84.52 & 0.13 & 42.77 & & 1.42 \\
\hline & $1-m^{2}$ & 15 & 33.3 & 0.33 & 0.49 & 146.39 & 0.25 & 74.08 & 0.2 & 1.58 \\
\hline & Line-point & 15 & 0.0 & 0.00 & - & - & - & - & & 0.00 \\
\hline \multirow[b]{3}{*}{ Bare soil } & $10-m^{2}$ & 15 & 53.3 & 0.27 & 0.26 & 96.82 & 0.13 & 49.00 & & 0.67 \\
\hline & $1-m^{2}$ & 15 & 26.7 & 0.27 & 0.46 & 171.65 & 0.23 & 86.87 & 0.4 & 0.67 \\
\hline & Line-point & 15 & 6.7 & 0.67 & 2.58 & 387.30 & 1.31 & 196.00 & & 1.67 \\
\hline \multirow[b]{3}{*}{ Litter } & $10-m^{2}$ & 15 & 100.0 & 1.33 & 1.22 & 91.49 & 0.62 & 46.30 & & 1.07 \\
\hline & $1-m^{2}$ & 15 & 100.0 & 1.73 & 1.91 & 110.04 & 0.97 & 55.69 & 1.2 & 1.39 \\
\hline & Line-point & 15 & 6.7 & 0.67 & 2.58 & 387.30 & 1.31 & 196.00 & & 0.54 \\
\hline \multirow[b]{3}{*}{ BSC } & $10-m^{2}$ & 15 & 100.0 & 5.33 & 4.25 & 79.76 & 2.15 & 40.36 & & 0.97 \\
\hline & $1-m^{2}$ & 15 & 80.0 & 3.20 & 2.88 & 90.11 & 1.46 & 45.60 & 5.5 & 0.58 \\
\hline & Line-point & 15 & 60.0 & 8.00 & 8.62 & 107.74 & 4.36 & 54.52 & & 1.45 \\
\hline
\end{tabular}


Table C29. Summary of frequency (freq) and cover estimates in macroplot CARE7 (Semidesert Alkali Sandy Loam ecological site). For line-point sampling, 10-point groups were used as subsampling units for purposes of frequency calculations. Precision is defined as one-half the width of the 95 percent confidence interval. The standardized mean was calculated as the ratio of the mean for a particular method to the among-method mean. See Appendix A for keys to species codes (BSC $=$ biological soil crust).

\begin{tabular}{|c|c|c|c|c|c|c|c|c|c|c|}
\hline \multirow[b]{2}{*}{ Measure } & \multirow[b]{2}{*}{ Method } & \multirow[b]{2}{*}{ Subsample $\mathbf{n}$} & \multirow[b]{2}{*}{ Freq } & \multicolumn{7}{|c|}{ Cover } \\
\hline & & & & Mean & sd & CV & Precision & $\begin{array}{c}\text { Precision \% } \\
\text { of mean }\end{array}$ & $\begin{array}{l}\text { Among- } \\
\text { method } \\
\text { mean }\end{array}$ & $\begin{array}{c}\text { Standardized } \\
\text { mean }\end{array}$ \\
\hline \multirow{3}{*}{$\begin{array}{c}\text { Total live } \\
\text { understory } \\
\text { canopy } \\
\text { cover }\end{array}$} & $10-m^{2}$ & 15 & 100.0 & 16.27 & 6.70 & 41.20 & 3.39 & 20.85 & & 0.91 \\
\hline & $1-m^{2}$ & 15 & 100.0 & 18.27 & 15.82 & 86.62 & 8.01 & 43.83 & 18.0 & 1.02 \\
\hline & Line-point & 15 & 73.3 & 19.33 & 16.24 & 84.01 & 8.22 & 42.51 & & 1.08 \\
\hline \multirow[b]{3}{*}{ ATCO } & $10-m^{2}$ & 15 & 86.7 & 2.53 & 2.39 & 94.50 & 1.21 & 47.82 & & 0.99 \\
\hline & $1-m^{2}$ & 15 & 66.7 & 1.80 & 2.08 & 115.39 & 1.05 & 58.40 & 2.6 & 0.70 \\
\hline & Line-point & 15 & 20.0 & 3.33 & 8.16 & 244.95 & 4.13 & 123.96 & & 1.30 \\
\hline \multirow[b]{3}{*}{ GIIN2 } & $10-m^{2}$ & 15 & 86.7 & 0.43 & 0.18 & 40.60 & 0.09 & 20.55 & & 1.34 \\
\hline & $1-m^{2}$ & 15 & 53.3 & 0.53 & 0.52 & 96.82 & 0.26 & 49.00 & 0.3 & 1.66 \\
\hline & Line-point & 15 & 0.0 & 0.00 & - & - & - & - & & 0.00 \\
\hline \multirow[b]{3}{*}{ ORHY } & $10-m^{2}$ & 15 & 93.3 & 0.47 & 0.13 & 27.66 & 0.07 & 14.00 & & 0.78 \\
\hline & $1-m^{2}$ & 15 & 66.7 & 0.67 & 0.49 & 73.19 & 0.25 & 37.04 & 0.6 & 1.11 \\
\hline & Line-point & 15 & 6.7 & 0.67 & 2.58 & 387.30 & 1.31 & 196.00 & & 1.11 \\
\hline \multirow[b]{3}{*}{ Bare soil } & $10-m^{2}$ & 15 & 100.0 & 1.00 & 1.04 & 103.51 & 0.52 & 52.38 & & 0.29 \\
\hline & $1-m^{2}$ & 15 & 100.0 & 1.40 & 0.91 & 65.02 & 0.46 & 32.90 & 3.5 & 0.40 \\
\hline & Line-point & 15 & 60.0 & 8.00 & 8.62 & 107.74 & 4.36 & 54.52 & & 2.31 \\
\hline \multirow[b]{3}{*}{ Litter } & $10-m^{2}$ & 15 & 93.3 & 11.73 & 6.70 & 57.08 & 3.39 & 28.89 & & 1.00 \\
\hline & $1-m^{2}$ & 15 & 100.0 & 18.20 & 21.92 & 120.42 & 11.09 & 60.94 & 11.8 & 1.55 \\
\hline & Line-point & 15 & 46.7 & 5.33 & 6.40 & 119.99 & 3.24 & 60.72 & & 0.45 \\
\hline \multirow[b]{3}{*}{ BSC } & $10-m^{2}$ & 15 & 86.7 & 1.20 & 0.94 & 78.43 & 0.48 & 39.69 & & 0.95 \\
\hline & $1-m^{2}$ & 15 & 73.3 & 1.27 & 1.03 & 81.54 & 0.52 & 41.26 & 1.3 & 1.00 \\
\hline & Line-point & 15 & 13.3 & 1.33 & 3.52 & 263.90 & 1.78 & 133.55 & & 1.05 \\
\hline
\end{tabular}


Table C30. Summary of frequency (freq) and cover estimates in macroplot DINO1 (Semidesert Loam ecological site). For line-point sampling, 10-point groups were used as subsampling units for purposes of frequency calculations.

Precision is defined as one-half the width of the 95 percent confidence interval. The standardized mean was calculated as the ratio of the mean for a particular method to the among-method mean. See Appendix A for keys to species codes (BSC = biological soil crust).

\begin{tabular}{|c|c|c|c|c|c|c|c|c|c|c|}
\hline \multirow[b]{2}{*}{ Measure } & \multirow[b]{2}{*}{ Method } & \multirow[b]{2}{*}{ Subsample $n$} & \multirow[b]{2}{*}{ Freq } & \multicolumn{7}{|c|}{ Cover } \\
\hline & & & & Mean & sd & CV & Precision & $\begin{array}{c}\text { Precision \% } \\
\text { of mean }\end{array}$ & $\begin{array}{l}\text { Among- } \\
\text { method } \\
\text { mean }\end{array}$ & $\begin{array}{c}\text { Standardized } \\
\text { mean }\end{array}$ \\
\hline \multirow{3}{*}{$\begin{array}{c}\text { Total live } \\
\text { understory } \\
\text { canopy } \\
\text { cover }\end{array}$} & $10-m^{2}$ & 21 & 100.0 & 59.36 & 16.86 & 28.40 & 7.21 & 12.15 & & 0.93 \\
\hline & $1-m^{2}$ & 30 & 100.0 & 36.63 & 19.37 & 52.88 & 6.93 & 18.92 & 64.1 & 0.57 \\
\hline & Line-point & 30 & 100.0 & 96.33 & 23.56 & 24.46 & 8.43 & 8.75 & & 1.50 \\
\hline \multirow[b]{3}{*}{ ARTR2 } & $10-m^{2}$ & 21 & 47.6 & 0.71 & 1.16 & 162.02 & 0.49 & 69.30 & & 2.53 \\
\hline & $1-m^{2}$ & 30 & 3.3 & 0.13 & 0.73 & 547.72 & 0.26 & 196.00 & 0.3 & 0.47 \\
\hline & Line-point & 30 & 0.0 & 0.00 & - & - & - & - & & 0.00 \\
\hline \multirow[b]{3}{*}{ BRTE } & $10-m^{2}$ & 21 & 100.0 & 39.21 & 24.69 & 62.97 & 10.56 & 26.93 & & 0.98 \\
\hline & $1-m^{2}$ & 30 & 100.0 & 23.73 & 22.00 & 92.68 & 7.87 & 33.16 & 40.0 & 0.59 \\
\hline & Line-point & 30 & 100.0 & 57.00 & 29.38 & 51.54 & 10.51 & 18.44 & & 1.43 \\
\hline \multirow[b]{3}{*}{ STCO4 } & $10-m^{2}$ & 21 & 100.0 & 9.67 & 9.44 & 97.64 & 4.04 & 41.76 & & 0.92 \\
\hline & $1-m^{2}$ & 30 & 73.3 & 3.43 & 3.43 & 99.93 & 1.23 & 35.76 & 10.5 & 0.33 \\
\hline & Line-point & 30 & 60.0 & 18.33 & 19.49 & 106.31 & 6.97 & 38.04 & & 1.75 \\
\hline \multirow[b]{3}{*}{ Bare soil } & $10-m^{2}$ & 21 & 71.4 & 1.76 & 1.91 & 108.66 & 0.82 & 46.48 & & 0.28 \\
\hline & $1-m^{2}$ & 30 & 70.0 & 2.27 & 2.75 & 121.48 & 0.99 & 43.47 & 6.3 & 0.36 \\
\hline & Line-point & 30 & 66.7 & 15.00 & 15.92 & 106.13 & 5.70 & 37.98 & & 2.36 \\
\hline \multirow[b]{3}{*}{ Litter } & $10-m^{2}$ & 21 & 100.0 & 60.12 & 15.62 & 25.99 & 6.68 & 11.11 & & 0.97 \\
\hline & $1-m^{2}$ & 30 & 100.0 & 72.23 & 17.68 & 24.47 & 6.33 & 8.76 & 62.2 & 1.16 \\
\hline & Line-point & 30 & 96.7 & 54.33 & 20.29 & 37.34 & 7.26 & 13.36 & & 0.87 \\
\hline \multirow[b]{3}{*}{ BSC } & $10-m^{2}$ & 21 & 100.0 & 1.76 & 1.07 & 60.61 & 0.46 & 25.92 & & 0.62 \\
\hline & $1-m^{2}$ & 30 & 93.3 & 2.37 & 1.13 & 47.71 & 0.40 & 17.07 & 2.8 & 0.84 \\
\hline & Line-point & 30 & 36.7 & 4.33 & 6.26 & 144.48 & 2.24 & 51.70 & & 1.54 \\
\hline
\end{tabular}


Table C31. Summary of frequency (freq) and cover estimates in macroplot DINO2b (Semidesert Loam ecological site). For line-point sampling, 10-point groups were used as subsampling units for purposes of frequency calculations.

Precision is defined as one-half the width of the 95 percent confidence interval. The standardized mean was calculated as the ratio of the mean for a particular method to the among-method mean. See Appendix A for keys to species codes (BSC = biological soil crust).

\begin{tabular}{|c|c|c|c|c|c|c|c|c|c|c|}
\hline \multirow[b]{2}{*}{ Measure } & \multirow[b]{2}{*}{ Method } & \multirow[b]{2}{*}{ Subsample $\mathbf{n}$} & \multirow[b]{2}{*}{ Freq } & \multicolumn{7}{|c|}{ Cover } \\
\hline & & & & Mean & sd & CV & Precision & $\begin{array}{c}\text { Precision } \% \\
\text { of mean }\end{array}$ & $\begin{array}{l}\text { Among- } \\
\text { method } \\
\text { mean }\end{array}$ & $\begin{array}{c}\text { Standardized } \\
\text { mean }\end{array}$ \\
\hline \multirow{3}{*}{$\begin{array}{c}\text { Total live } \\
\text { understory } \\
\text { canopy } \\
\text { cover } \\
\end{array}$} & $10-m^{2}$ & 21 & 100.0 & 29.12 & 10.18 & 34.97 & 4.36 & 14.96 & & 0.85 \\
\hline & $1-m^{2}$ & 30 & 100.0 & 19.03 & 13.37 & 70.27 & 4.79 & 25.14 & 34.3 & 0.56 \\
\hline & Line-point & 30 & 100.0 & 54.67 & 20.47 & 37.44 & 7.32 & 13.40 & & 1.60 \\
\hline \multirow[b]{3}{*}{ ARTR2 } & $10-m^{2}$ & 30 & 90.5 & 13.24 & 8.49 & 64.13 & 3.63 & 27.43 & & 1.37 \\
\hline & $1-m^{2}$ & 30 & 80.0 & 9.03 & 8.24 & 91.22 & 2.95 & 32.64 & 9.6 & 0.94 \\
\hline & Line-point & 21 & 46.7 & 6.67 & 9.22 & 138.34 & 3.30 & 49.50 & & 0.69 \\
\hline \multirow[b]{3}{*}{ BRTE } & $10-m^{2}$ & 30 & 95.2 & 10.19 & 6.30 & 61.82 & 2.69 & 26.44 & & 0.53 \\
\hline & $1-m^{2}$ & 21 & 93.3 & 6.67 & 7.66 & 114.94 & 2.74 & 41.13 & 19.3 & 0.35 \\
\hline & Line-point & 30 & 100.0 & 41.00 & 19.71 & 48.08 & 7.05 & 17.21 & & 2.13 \\
\hline \multirow[b]{3}{*}{ STCO4 } & $10-m^{2}$ & 21 & 0.0 & 0.00 & - & - & - & - & & - \\
\hline & $1-m^{2}$ & 30 & 0.0 & 0.00 & - & - & - & - & 0.0 & - \\
\hline & Line-point & 30 & 0.0 & 0.00 & - & - & - & - & & - \\
\hline \multirow[b]{3}{*}{ Bare soil } & $10-m^{2}$ & 30 & 95.2 & 0.83 & 0.91 & 109.54 & 0.39 & 46.85 & & 0.22 \\
\hline & $1-m^{2}$ & 30 & 66.7 & 1.80 & 3.70 & 205.50 & 1.32 & 73.54 & 3.8 & 0.48 \\
\hline & Line-point & 21 & 46.7 & 8.67 & 10.74 & 123.95 & 3.84 & 44.35 & & 2.30 \\
\hline \multirow[b]{3}{*}{ Litter } & $10-m^{2}$ & 30 & 100.0 & 36.79 & 14.08 & 38.27 & 6.02 & 16.37 & & 0.96 \\
\hline & $1-m^{2}$ & 21 & 100.0 & 32.67 & 27.82 & 85.16 & 9.95 & 30.47 & 38.3 & 0.85 \\
\hline & Line-point & 30 & 100.0 & 45.33 & 17.56 & 38.74 & 6.29 & 13.86 & & 1.18 \\
\hline \multirow[b]{3}{*}{ BSC } & $10-m^{2}$ & 21 & 100.0 & 7.88 & 12.90 & 163.64 & 5.52 & 69.99 & & 1.12 \\
\hline & $1-m^{2}$ & 30 & 100.0 & 4.50 & 2.16 & 48.04 & 0.77 & 17.19 & 7.0 & 0.64 \\
\hline & Line-point & 30 & 56.7 & 8.67 & 9.73 & 112.29 & 3.48 & 40.18 & & 1.24 \\
\hline
\end{tabular}


Table C32. Summary of frequency (freq) and cover estimates in macroplot DINO3 (Semidesert Loam ecological site). For line-point sampling, 10-point groups were used as subsampling units for purposes of frequency calculations.

Precision is defined as one-half the width of the 95 percent confidence interval. The standardized mean was calculated as the ratio of the mean for a particular method to the among-method mean. See Appendix A for keys to species codes (BSC = biological soil crust).

\begin{tabular}{|c|c|c|c|c|c|c|c|c|c|c|}
\hline \multirow[b]{2}{*}{ Measure } & \multirow[b]{2}{*}{ Method } & \multirow[b]{2}{*}{ Subsample $n$} & \multirow[b]{2}{*}{ Freq } & \multicolumn{7}{|c|}{ Cover } \\
\hline & & & & Mean & sd & CV & Precision & $\begin{array}{c}\text { Precision \% } \\
\text { of mean }\end{array}$ & $\begin{array}{l}\text { Among- } \\
\text { method } \\
\text { mean }\end{array}$ & $\begin{array}{c}\text { Standardized } \\
\text { mean }\end{array}$ \\
\hline \multirow{3}{*}{$\begin{array}{c}\text { Total live } \\
\text { understory } \\
\text { canopy } \\
\text { cover }\end{array}$} & $10-m^{2}$ & 15 & 100.0 & 20.70 & 9.42 & 45.49 & 4.77 & 23.02 & & 0.79 \\
\hline & $1-m^{2}$ & 15 & 100.0 & 15.47 & 11.33 & 73.23 & 5.73 & 37.06 & 26.3 & 0.59 \\
\hline & Line-point & 15 & 100.0 & 42.67 & 25.49 & 59.73 & 12.90 & 30.23 & & 1.62 \\
\hline \multirow[b]{3}{*}{ ARTR2 } & $10-m^{2}$ & 15 & 93.3 & 9.73 & 10.72 & 110.16 & 5.43 & 55.75 & & 1.45 \\
\hline & $1-m^{2}$ & 15 & 73.3 & 5.13 & 10.22 & 199.05 & 5.17 & 100.73 & 6.7 & 0.76 \\
\hline & Line-point & 15 & 40.0 & 5.33 & 8.34 & 156.34 & 4.22 & 79.12 & & 0.79 \\
\hline \multirow[b]{3}{*}{ BRTE } & $10-m^{2}$ & 15 & 100.0 & 3.87 & 6.05 & 156.43 & 3.06 & 79.17 & & 0.46 \\
\hline & $1-m^{2}$ & 15 & 60.0 & 2.53 & 4.14 & 163.35 & 2.09 & 82.66 & 8.4 & 0.30 \\
\hline & Line-point & 15 & 66.7 & 18.67 & 20.66 & 110.66 & 10.45 & 56.00 & & 2.23 \\
\hline \multirow[b]{3}{*}{ STCO4 } & $10-m^{2}$ & 15 & 73.3 & 1.87 & 1.45 & 77.41 & 0.73 & 39.18 & & 1.38 \\
\hline & $1-m^{2}$ & 15 & 86.7 & 2.20 & 1.86 & 84.52 & 0.94 & 42.77 & 1.4 & 1.62 \\
\hline & Line-point & 15 & 0.0 & 0.00 & - & - & - & - & & 0.00 \\
\hline \multirow[b]{3}{*}{ Bare soil } & $10-m^{2}$ & 15 & 33.3 & 0.17 & 0.24 & 146.39 & 0.12 & 74.08 & & 0.05 \\
\hline & $1-m^{2}$ & 15 & 13.3 & 0.13 & 0.35 & 263.90 & 0.18 & 133.55 & 3.4 & 0.04 \\
\hline & Line-point & 15 & 73.3 & 10.00 & 8.45 & 84.52 & 4.28 & 42.77 & & 2.91 \\
\hline \multirow[b]{3}{*}{ Litter } & $10-m^{2}$ & 15 & 93.3 & 14.90 & 9.27 & 62.24 & 4.69 & 31.50 & & 0.89 \\
\hline & $1-m^{2}$ & 15 & 100.0 & 18.00 & 19.97 & 110.93 & 10.10 & 56.14 & 16.7 & 1.07 \\
\hline & Line-point & 15 & 60.0 & 17.33 & 18.31 & 105.63 & 9.27 & 53.46 & & 1.04 \\
\hline \multirow[b]{3}{*}{ BSC } & $10-m^{2}$ & 15 & 100.0 & 6.07 & 4.67 & 77.05 & 2.37 & 38.99 & & 0.96 \\
\hline & $1-m^{2}$ & 15 & 100.0 & 4.87 & 1.77 & 36.32 & 0.89 & 18.38 & 6.3 & 0.77 \\
\hline & Line-point & 15 & 53.3 & 8.00 & 9.41 & 117.64 & 4.76 & 59.53 & & 1.27 \\
\hline
\end{tabular}


Table C33. Summary of frequency (freq) and cover estimates in macroplot DINO4b (Semidesert Loam ecological site). For line-point sampling, 10-point groups were used as subsampling units for purposes of frequency calculations.

Precision is defined as one-half the width of the 95 percent confidence interval. The standardized mean was calculated as the ratio of the mean for a particular method to the among-method mean. See Appendix A for keys to species codes (BSC = biological soil crust).

\begin{tabular}{|c|c|c|c|c|c|c|c|c|c|c|}
\hline \multirow[b]{2}{*}{ Measure } & \multirow[b]{2}{*}{ Method } & \multirow[b]{2}{*}{ Subsample $\mathbf{n}$} & \multirow[b]{2}{*}{ Freq } & \multicolumn{7}{|c|}{ Cover } \\
\hline & & & & Mean & sd & CV & Precision & $\begin{array}{c}\text { Precision } \% \\
\text { of mean }\end{array}$ & $\begin{array}{l}\text { Among- } \\
\text { method } \\
\text { mean }\end{array}$ & $\begin{array}{c}\text { Standardized } \\
\text { mean }\end{array}$ \\
\hline \multirow{3}{*}{$\begin{array}{c}\text { Total live } \\
\text { understory } \\
\text { canopy } \\
\text { cover } \\
\end{array}$} & $10-m^{2}$ & 15 & 100.0 & 25.67 & 11.30 & 44.03 & 5.72 & 22.28 & & 0.95 \\
\hline & $1-m^{2}$ & 15 & 100.0 & 14.00 & 11.98 & 85.54 & 6.06 & 43.29 & 27.0 & 0.52 \\
\hline & Line-point & 15 & 100.0 & 41.33 & 20.31 & 49.13 & 10.28 & 24.86 & & 1.53 \\
\hline \multirow[b]{3}{*}{ ARTR2 } & $10-m^{2}$ & 15 & 93.3 & 7.83 & 6.62 & 84.50 & 3.35 & 42.76 & & 1.45 \\
\hline & $1-m^{2}$ & 15 & 60.0 & 4.40 & 7.41 & 168.51 & 3.75 & 85.27 & 5.4 & 0.81 \\
\hline & Line-point & 15 & 33.3 & 4.00 & 6.32 & 158.11 & 3.20 & 80.02 & & 0.74 \\
\hline \multirow[b]{3}{*}{ BRTE } & $10-m^{2}$ & 15 & 100.0 & 3.53 & 2.70 & 76.29 & 1.36 & 38.61 & & 0.33 \\
\hline & $1-m^{2}$ & 15 & 100.0 & 2.13 & 1.55 & 72.76 & 0.79 & 36.82 & 10.6 & 0.20 \\
\hline & Line-point & 15 & 93.3 & 26.00 & 16.39 & 63.03 & 8.29 & 31.90 & & 2.46 \\
\hline \multirow[b]{3}{*}{ STCO4 } & $10-m^{2}$ & 15 & 46.7 & 0.23 & 0.26 & 110.66 & 0.13 & 56.00 & & 1.62 \\
\hline & $1-m^{2}$ & 15 & 13.3 & 0.20 & 0.56 & 280.31 & 0.28 & 141.85 & 0.1 & 1.38 \\
\hline & Line-point & 15 & 0.0 & 0.00 & - & - & - & - & & 0.00 \\
\hline \multirow[b]{3}{*}{ Bare soil } & $10-m^{2}$ & 15 & 73.3 & 0.37 & 0.23 & 62.42 & 0.12 & 31.59 & & 0.07 \\
\hline & $1-m^{2}$ & 15 & 40.0 & 0.40 & 0.51 & 126.77 & 0.26 & 64.15 & 5.4 & 0.07 \\
\hline & Line-point & 15 & 66.7 & 15.33 & 13.02 & 84.91 & 6.59 & 42.97 & & 2.86 \\
\hline \multirow[b]{3}{*}{ Litter } & $10-m^{2}$ & 15 & 100.0 & 37.83 & 22.00 & 58.14 & 11.13 & 29.42 & & 1.28 \\
\hline & $1-m^{2}$ & 15 & 100.0 & 33.80 & 24.97 & 73.89 & 12.64 & 37.39 & 29.7 & 1.14 \\
\hline & Line-point & 15 & 80.0 & 17.33 & 13.35 & 76.99 & 6.75 & 38.96 & & 0.58 \\
\hline \multirow[b]{3}{*}{ BSC } & $10-m^{2}$ & 15 & 100.0 & 4.27 & 2.15 & 50.28 & 1.09 & 25.45 & & 0.48 \\
\hline & $1-m^{2}$ & 15 & 100.0 & 5.20 & 3.67 & 70.55 & 1.86 & 35.70 & 8.9 & 0.58 \\
\hline & Line-point & 15 & 86.7 & 17.33 & 12.23 & 70.55 & 6.19 & 35.70 & & 1.94 \\
\hline
\end{tabular}


Table C34. Summary of frequency (freq) and cover estimates in macroplot DINO5 (Semidesert Loam ecological site). For line-point sampling, 10-point groups were used as subsampling units for purposes of frequency calculations.

Precision is defined as one-half the width of the 95 percent confidence interval. The standardized mean was calculated as the ratio of the mean for a particular method to the among-method mean. See Appendix A for keys to species codes (BSC = biological soil crust).

\begin{tabular}{|c|c|c|c|c|c|c|c|c|c|c|}
\hline \multirow[b]{2}{*}{ Measure } & \multirow[b]{2}{*}{ Method } & \multirow[b]{2}{*}{ Subsample $n$} & \multirow[b]{2}{*}{ Freq } & \multicolumn{7}{|c|}{ Cover } \\
\hline & & & & Mean & sd & CV & Precision & $\begin{array}{c}\text { Precision \% } \\
\text { of mean }\end{array}$ & $\begin{array}{l}\text { Among- } \\
\text { method } \\
\text { mean }\end{array}$ & $\begin{array}{c}\text { Standardized } \\
\text { mean }\end{array}$ \\
\hline \multirow{3}{*}{$\begin{array}{c}\text { Total live } \\
\text { understory } \\
\text { canopy } \\
\text { cover }\end{array}$} & $10-m^{2}$ & 15 & 100.0 & 26.23 & 7.87 & 30.01 & 3.98 & 15.18 & & 1.04 \\
\hline & $1-m^{2}$ & 15 & 100.0 & 15.67 & 9.05 & 57.78 & 4.58 & 29.24 & 25.3 & 0.62 \\
\hline & Line-point & 15 & 93.3 & 34.00 & 24.14 & 71.01 & 12.22 & 35.93 & & 1.34 \\
\hline \multirow[b]{3}{*}{ ARTR2 } & $10-m^{2}$ & 15 & 93.3 & 16.33 & 7.95 & 48.70 & 4.03 & 24.65 & & 1.53 \\
\hline & $1-m^{2}$ & 15 & 73.3 & 7.73 & 8.40 & 108.68 & 4.25 & 55.00 & 10.7 & 0.72 \\
\hline & Line-point & 15 & 60.0 & 8.00 & 7.75 & 96.82 & 3.92 & 49.00 & & 0.75 \\
\hline \multirow[b]{3}{*}{ BRTE } & $10-m^{2}$ & 15 & 73.3 & 2.80 & 6.01 & 214.69 & 3.04 & 108.65 & & 0.70 \\
\hline & $1-m^{2}$ & 15 & 33.3 & 1.20 & 3.08 & 256.27 & 1.56 & 129.69 & 4.0 & 0.30 \\
\hline & Line-point & 15 & 40.0 & 8.00 & 14.24 & 178.03 & 7.21 & 90.10 & & 2.00 \\
\hline \multirow[b]{3}{*}{ STCO4 } & $10-m^{2}$ & 15 & 93.3 & 0.63 & 0.67 & 105.36 & 0.34 & 53.32 & & 0.48 \\
\hline & $1-m^{2}$ & 15 & 66.7 & 0.67 & 0.49 & 73.19 & 0.25 & 37.04 & 1.3 & 0.50 \\
\hline & Line-point & 15 & 20.0 & 2.67 & 5.94 & 222.61 & 3.00 & 112.65 & & 2.02 \\
\hline \multirow[b]{3}{*}{ Bare soil } & $10-m^{2}$ & 15 & 86.7 & 0.43 & 0.18 & 40.60 & 0.09 & 20.55 & & 0.29 \\
\hline & $1-m^{2}$ & 15 & 66.7 & 0.73 & 0.59 & 80.95 & 0.30 & 40.96 & 1.5 & 0.49 \\
\hline & Line-point & 15 & 33.3 & 3.33 & 4.88 & 146.39 & 2.47 & 74.08 & & 2.22 \\
\hline \multirow[b]{3}{*}{ Litter } & $10-m^{2}$ & 15 & 100.0 & 21.50 & 10.56 & 49.10 & 5.34 & 24.85 & & 1.19 \\
\hline & $1-m^{2}$ & 15 & 100.0 & 18.07 & 23.82 & 131.82 & 12.05 & 66.71 & 18.1 & 1.00 \\
\hline & Line-point & 15 & 80.0 & 14.67 & 13.02 & 88.77 & 6.59 & 44.92 & & 0.81 \\
\hline \multirow[b]{3}{*}{ BSC } & $10-m^{2}$ & 15 & 100.0 & 7.63 & 6.81 & 89.25 & 3.45 & 45.16 & & 0.57 \\
\hline & $1-m^{2}$ & 15 & 100.0 & 10.73 & 15.07 & 140.39 & 7.63 & 71.05 & 13.5 & 0.80 \\
\hline & Line-point & 15 & 66.7 & 22.00 & 20.42 & 92.84 & 10.34 & 46.98 & & 1.64 \\
\hline
\end{tabular}


Table C35. Summary of frequency (freq) and cover estimates in macroplot ARCH1b (Semidesert Shallow Sandy Loam ecological site). For line-point sampling, 10-point groups were used as subsampling units for purposes of frequency calculations. Precision is defined as one-half the width of the 95 percent confidence interval. The standardized mean was calculated as the ratio of the mean for a particular method to the among-method mean. See Appendix A for keys to species codes (BSC $=$ biological soil crust).

\begin{tabular}{|c|c|c|c|c|c|c|c|c|c|c|}
\hline \multirow[b]{2}{*}{ Measure } & \multirow[b]{2}{*}{ Method } & \multirow[b]{2}{*}{ Subsample $\mathbf{n}$} & \multirow[b]{2}{*}{ Freq } & \multicolumn{7}{|c|}{ Cover } \\
\hline & & & & Mean & sd & CV & Precision & $\begin{array}{c}\text { Precision \% } \\
\text { of mean }\end{array}$ & $\begin{array}{l}\text { Among- } \\
\text { method } \\
\text { mean }\end{array}$ & $\begin{array}{c}\text { Standardized } \\
\text { mean }\end{array}$ \\
\hline \multirow{3}{*}{$\begin{array}{l}\text { Total live } \\
\text { understory } \\
\text { canopy } \\
\text { cover }\end{array}$} & $10-m^{2}$ & 21 & 100.0 & 18.67 & 5.97 & 31.98 & 2.55 & 13.68 & & 1.26 \\
\hline & $1-m^{2}$ & 30 & 96.7 & 12.30 & 10.77 & 87.59 & 3.86 & 31.34 & 14.8 & 0.83 \\
\hline & Line-point & 30 & 73.3 & 13.33 & 12.95 & 97.16 & 4.64 & 34.77 & & 0.90 \\
\hline \multirow[b]{3}{*}{ CORA } & $10-m^{2}$ & 21 & 95.2 & 14.07 & 5.79 & 41.12 & 2.47 & 17.59 & & 1.29 \\
\hline & $1-m^{2}$ & 30 & 83.3 & 8.30 & 8.45 & 101.80 & 3.02 & 36.43 & 10.9 & 0.76 \\
\hline & Line-point & 30 & 63.3 & 10.33 & 10.98 & 106.26 & 3.93 & 38.03 & & 0.95 \\
\hline \multirow[b]{3}{*}{ FEOC3 } & $10-m^{2}$ & 21 & 23.8 & 0.12 & 0.22 & 183.30 & 0.09 & 78.40 & & 1.63 \\
\hline & $1-m^{2}$ & 30 & 10.0 & 0.10 & 0.31 & 305.13 & 0.11 & 109.19 & 0.1 & 1.37 \\
\hline & Line-point & 30 & 0.0 & 0.00 & - & - & - & - & & 0.00 \\
\hline \multirow[b]{3}{*}{ Bare soil } & $10-m^{2}$ & 21 & 76.2 & 1.45 & 1.39 & 95.47 & 0.59 & 40.83 & & 0.77 \\
\hline & $1-m^{2}$ & 30 & 50.0 & 1.20 & 2.07 & 172.87 & 0.74 & 61.86 & 1.9 & 0.64 \\
\hline & Line-point & 30 & 16.7 & 3.00 & 7.94 & 264.79 & 2.84 & 94.75 & & 1.59 \\
\hline \multirow[b]{3}{*}{ Litter } & $10-m^{2}$ & 21 & 100.0 & 2.02 & 3.73 & 184.13 & 1.59 & 78.75 & & 0.97 \\
\hline & $1-m^{2}$ & 30 & 96.7 & 3.23 & 7.16 & 221.49 & 2.56 & 79.26 & 2.1 & 1.55 \\
\hline & Line-point & 30 & 10.0 & 1.00 & 3.05 & 305.13 & 1.09 & 109.19 & & 0.48 \\
\hline \multirow{3}{*}{$\begin{array}{l}\text { Undiffer- } \\
\text { entiated } \\
\text { crust }\end{array}$} & $10-m^{2}$ & 21 & 100.0 & 72.98 & 21.03 & 28.82 & 8.99 & 12.33 & & 0.96 \\
\hline & $1-m^{2}$ & 30 & 96.7 & 71.90 & 27.11 & 37.70 & 9.70 & 13.49 & 76.3 & 0.94 \\
\hline & Line-point & 30 & 100.0 & 84.00 & 14.29 & 17.01 & 5.11 & 6.09 & & 1.10 \\
\hline \multirow[b]{3}{*}{ BSC } & $10-m^{2}$ & 21 & 52.4 & 1.60 & 2.80 & 175.81 & 1.20 & 75.19 & & 1.11 \\
\hline & $1-m^{2}$ & 30 & 33.3 & 1.03 & 2.25 & 217.86 & 0.81 & 77.96 & 1.4 & 0.72 \\
\hline & Line-point & 30 & 16.7 & 1.67 & 3.79 & 227.43 & 1.36 & 81.38 & & 1.16 \\
\hline
\end{tabular}


Table C35. Summary of frequency (freq) and cover estimates in macroplot ARCH2 (Semidesert Shallow Sandy Loam ecological site). For line-point sampling, 10-point groups were used as subsampling units for purposes of frequency calculations. Precision is defined as one-half the width of the 95 percent confidence interval. The standardized mean was calculated as the ratio of the mean for a particular method to the among-method mean. See Appendix A for keys to species codes (BSC $=$ biological soil crust).

\begin{tabular}{|c|c|c|c|c|c|c|c|c|c|c|}
\hline \multirow[b]{2}{*}{ Measure } & \multirow[b]{2}{*}{ Method } & \multirow[b]{2}{*}{ Subsample $\mathbf{n}$} & \multirow[b]{2}{*}{ Freq } & \multicolumn{7}{|c|}{ Cover } \\
\hline & & & & Mean & sd & CV & Precision & $\begin{array}{c}\text { Precision \% } \\
\text { of mean }\end{array}$ & $\begin{array}{l}\text { Among- } \\
\text { method } \\
\text { mean }\end{array}$ & $\begin{array}{c}\text { Standardized } \\
\text { mean }\end{array}$ \\
\hline \multirow{3}{*}{$\begin{array}{c}\text { Total live } \\
\text { understory } \\
\text { canopy } \\
\text { cover }\end{array}$} & $10-m^{2}$ & 21 & 100.0 & 28.24 & 12.23 & 43.33 & 5.23 & 18.53 & & 1.25 \\
\hline & $1-m^{2}$ & 30 & 100.0 & 24.00 & 14.44 & 60.15 & 5.17 & 21.52 & 22.5 & 1.07 \\
\hline & Line-point & 30 & 83.3 & 15.33 & 12.24 & 79.84 & 4.38 & 28.57 & & 0.68 \\
\hline \multirow[b]{3}{*}{ CORA } & $10-m^{2}$ & 21 & 100.0 & 22.88 & 11.36 & 49.65 & 4.86 & 21.23 & & 1.30 \\
\hline & $1-m^{2}$ & 30 & 96.7 & 19.60 & 12.89 & 65.77 & 4.61 & 23.54 & 17.6 & 1.11 \\
\hline & Line-point & 30 & 70.0 & 10.33 & 9.99 & 96.72 & 3.58 & 34.61 & & 0.59 \\
\hline \multirow[b]{3}{*}{ FEOC3 } & $10-m^{2}$ & 21 & 52.4 & 0.26 & 0.26 & 97.70 & 0.11 & 41.79 & & 1.49 \\
\hline & $1-m^{2}$ & 30 & 26.7 & 0.27 & 0.45 & 168.67 & 0.16 & 60.36 & 0.2 & 1.51 \\
\hline & Line-point & 30 & 0.0 & 0.00 & - & - & - & - & & 0.00 \\
\hline \multirow[b]{3}{*}{ Bare soil } & $10-m^{2}$ & 21 & 95.2 & 1.86 & 3.95 & 212.70 & 1.69 & 90.97 & & 0.45 \\
\hline & $1-m^{2}$ & 30 & 66.7 & 3.07 & 5.66 & 184.45 & 2.02 & 66.00 & 4.1 & 0.75 \\
\hline & Line-point & 30 & 53.3 & 7.33 & 8.28 & 112.87 & 2.96 & 40.39 & & 1.79 \\
\hline \multirow[b]{3}{*}{ Litter } & $10-m^{2}$ & 21 & 100.0 & 4.55 & 7.97 & 175.29 & 3.41 & 74.97 & & 1.29 \\
\hline & $1-m^{2}$ & 30 & 100.0 & 4.67 & 5.38 & 115.24 & 1.92 & 41.24 & 3.5 & 1.33 \\
\hline & Line-point & 30 & 6.7 & 1.33 & 5.71 & 428.51 & 2.04 & 153.34 & & 0.38 \\
\hline \multirow{3}{*}{$\begin{array}{c}\text { Undiffer- } \\
\text { entiated } \\
\text { crust }\end{array}$} & $10-m^{2}$ & 21 & 100.0 & 70.83 & 14.43 & 20.38 & 6.17 & 8.72 & & 0.94 \\
\hline & $1-m^{2}$ & 30 & 100.0 & 71.67 & 17.60 & 24.56 & 6.30 & 8.79 & 75.2 & 0.95 \\
\hline & Line-point & 30 & 100.0 & 83.00 & 13.68 & 16.49 & 4.90 & 5.90 & & 1.10 \\
\hline \multirow[b]{3}{*}{ BSC } & $10-m^{2}$ & 21 & 90.5 & 6.12 & 8.50 & 138.86 & 3.63 & 59.39 & & 0.98 \\
\hline & $1-m^{2}$ & 30 & 83.3 & 8.27 & 11.61 & 140.39 & 4.15 & 50.24 & 6.2 & 1.32 \\
\hline & Line-point & 30 & 33.3 & 4.33 & 7.28 & 167.98 & 2.60 & 60.11 & & 0.69 \\
\hline
\end{tabular}


Table C35. Summary of frequency (freq) and cover estimates in macroplot ARCH3 (Semidesert Shallow Sandy Loam ecological site). For line-point sampling, 10-point groups were used as subsampling units for purposes of frequency calculations. Precision is defined as one-half the width of the 95 percent confidence interval. The standardized mean was calculated as the ratio of the mean for a particular method to the among-method mean. See Appendix A for keys to species codes (BSC $=$ biological soil crust).

\begin{tabular}{|c|c|c|c|c|c|c|c|c|c|c|}
\hline \multirow[b]{2}{*}{ Measure } & \multirow[b]{2}{*}{ Method } & \multirow[b]{2}{*}{ Subsample $\mathbf{n}$} & \multirow[b]{2}{*}{ Freq } & \multicolumn{7}{|c|}{ Cover } \\
\hline & & & & Mean & sd & CV & Precision & $\begin{array}{l}\text { Precision \% } \\
\text { of mean }\end{array}$ & $\begin{array}{l}\text { Among- } \\
\text { method } \\
\text { mean }\end{array}$ & $\begin{array}{c}\text { Standardized } \\
\text { mean }\end{array}$ \\
\hline \multirow{3}{*}{$\begin{array}{l}\text { Total live } \\
\text { understory } \\
\text { canopy } \\
\text { cover }\end{array}$} & $10-m^{2}$ & 15 & 100.0 & 13.73 & 8.68 & 63.24 & 4.39 & 32.00 & & 1.33 \\
\hline & $1-m^{2}$ & 15 & 100.0 & 10.47 & 11.26 & 107.54 & 5.70 & 54.42 & 10.3 & 1.02 \\
\hline & Line-point & 15 & 46.7 & 6.67 & 8.16 & 122.47 & 4.13 & 61.98 & & 0.65 \\
\hline \multirow[b]{3}{*}{ CORA } & $10-m^{2}$ & 15 & 80.0 & 9.23 & 7.53 & 81.51 & 3.81 & 41.25 & & 1.28 \\
\hline & $1-m^{2}$ & 15 & 86.7 & 8.40 & 10.06 & 119.79 & 5.09 & 60.62 & 7.2 & 1.16 \\
\hline & Line-point & 15 & 40.0 & 4.00 & 5.07 & 126.77 & 2.57 & 64.15 & & 0.55 \\
\hline \multirow[b]{3}{*}{ FEOC3 } & $10-m^{2}$ & 15 & 80.0 & 0.40 & 0.21 & 51.75 & 0.10 & 26.19 & & 0.86 \\
\hline & $1-m^{2}$ & 15 & 33.3 & 0.33 & 0.49 & 146.39 & 0.25 & 74.08 & 0.5 & 0.71 \\
\hline & Line-point & 15 & 6.7 & 0.67 & 2.58 & 387.30 & 1.31 & 196.00 & & 1.43 \\
\hline \multirow[b]{3}{*}{ Bare soil } & $10-m^{2}$ & 15 & 93.3 & 0.47 & 0.13 & 27.66 & 0.07 & 14.00 & & 0.24 \\
\hline & $1-m^{2}$ & 15 & 66.7 & 0.67 & 0.49 & 73.19 & 0.25 & 37.04 & 1.9 & 0.34 \\
\hline & Line-point & 15 & 33.3 & 4.67 & 8.34 & 178.67 & 4.22 & 90.42 & & 2.41 \\
\hline \multirow[b]{3}{*}{ Litter } & $10-m^{2}$ & 15 & 100.0 & 2.73 & 4.77 & 174.48 & 2.41 & 88.30 & & 1.40 \\
\hline & $1-m^{2}$ & 15 & 100.0 & 2.47 & 3.83 & 155.41 & 1.94 & 78.65 & 2.0 & 1.26 \\
\hline & Line-point & 15 & 6.7 & 0.67 & 2.58 & 387.30 & 1.31 & 196.00 & & 0.34 \\
\hline \multirow{3}{*}{$\begin{array}{l}\text { Undiffer- } \\
\text { entiated } \\
\text { crust }\end{array}$} & $10-m^{2}$ & 15 & 100.0 & 85.83 & 6.45 & 7.52 & 3.27 & 3.81 & & 1.01 \\
\hline & $1-m^{2}$ & 15 & 100.0 & 86.27 & 9.19 & 10.66 & 4.65 & 5.39 & 84.9 & 1.02 \\
\hline & Line-point & 15 & 100.0 & 82.67 & 13.87 & 16.78 & 7.02 & 8.49 & & 0.97 \\
\hline \multirow[b]{3}{*}{ BSC } & $10-m^{2}$ & 15 & 93.3 & 3.33 & 2.96 & 88.68 & 1.50 & 44.88 & & 0.59 \\
\hline & $1-m^{2}$ & 15 & 80.0 & 3.67 & 3.11 & 84.79 & 1.57 & 42.91 & 5.7 & 0.65 \\
\hline & Line-point & 15 & 46.7 & 10.00 & 15.12 & 151.19 & 7.65 & 76.51 & & 1.76 \\
\hline
\end{tabular}


Table C38. Summary of frequency (freq) and cover estimates in macroplot ARCH4b (Semidesert Shallow Sandy Loam ecological site). For line-point sampling, 10-point groups were used as subsampling units for purposes of frequency calculations. Precision is defined as one-half the width of the 95 percent confidence interval. The standardized mean was calculated as the ratio of the mean for a particular method to the among-method mean. See Appendix A for keys to species codes (BSC $=$ biological soil crust).

\begin{tabular}{|c|c|c|c|c|c|c|c|c|c|c|}
\hline \multirow[b]{2}{*}{ Measure } & \multirow[b]{2}{*}{ Method } & \multirow[b]{2}{*}{ Subsample $\mathbf{n}$} & \multirow[b]{2}{*}{ Freq } & \multicolumn{7}{|c|}{ Cover } \\
\hline & & & & Mean & sd & CV & Precision & $\begin{array}{c}\text { Precision \% } \\
\text { of mean }\end{array}$ & $\begin{array}{l}\text { Among- } \\
\text { method } \\
\text { mean }\end{array}$ & $\begin{array}{c}\text { Standardized } \\
\text { mean }\end{array}$ \\
\hline \multirow{3}{*}{$\begin{array}{l}\text { Total live } \\
\text { understory } \\
\text { canopy } \\
\text { cover }\end{array}$} & $10-m^{2}$ & 15 & 100.0 & 15.87 & 12.88 & 81.15 & 6.52 & 41.07 & & 1.38 \\
\hline & $1-m^{2}$ & 15 & 100.0 & 11.20 & 12.36 & 110.40 & 6.26 & 55.87 & 11.5 & 0.98 \\
\hline & Line-point & 15 & 60.0 & 7.33 & 7.04 & 95.96 & 3.56 & 48.56 & & 0.64 \\
\hline \multirow[b]{3}{*}{ CORA } & $10-m^{2}$ & 15 & 53.3 & 7.33 & 7.99 & 108.93 & 4.04 & 55.12 & & 1.35 \\
\hline & $1-m^{2}$ & 15 & 80.0 & 4.93 & 4.82 & 97.65 & 2.44 & 49.42 & 5.4 & 0.91 \\
\hline & Line-point & 15 & 40.0 & 4.00 & 5.07 & 126.77 & 2.57 & 64.15 & & 0.74 \\
\hline \multirow[b]{3}{*}{ FEOC3 } & $10-m^{2}$ & 15 & 80.0 & 1.53 & 4.42 & 288.38 & 2.24 & 145.94 & & 2.30 \\
\hline & $1-m^{2}$ & 15 & 46.7 & 0.47 & 0.52 & 110.66 & 0.26 & 56.00 & 0.7 & 0.70 \\
\hline & Line-point & 15 & 0.0 & 0.00 & - & - & - & - & & 0.00 \\
\hline \multirow[b]{3}{*}{ Bare soil } & $10-m^{2}$ & 15 & 100.0 & 0.50 & 0.00 & 0.00 & 0.00 & 0.00 & & 0.16 \\
\hline & $1-m^{2}$ & 15 & 60.0 & 1.13 & 1.41 & 124.19 & 0.71 & 62.85 & 3.2 & 0.35 \\
\hline & Line-point & 15 & 46.7 & 8.00 & 10.14 & 126.77 & 5.13 & 64.15 & & 2.49 \\
\hline \multirow[b]{3}{*}{ Litter } & $10-m^{2}$ & 15 & 100.0 & 4.40 & 5.62 & 127.79 & 2.85 & 64.67 & & 1.01 \\
\hline & $1-m^{2}$ & 15 & 100.0 & 7.40 & 23.69 & 320.11 & 11.99 & 161.99 & 4.4 & 1.69 \\
\hline & Line-point & 15 & 13.3 & 1.33 & 3.52 & 263.90 & 1.78 & 133.55 & & 0.30 \\
\hline \multirow{3}{*}{$\begin{array}{l}\text { Undiffer- } \\
\text { entiated } \\
\text { crust }\end{array}$} & $10-m^{2}$ & 15 & 100.0 & 74.50 & 21.94 & 29.45 & 11.10 & 14.90 & & 1.06 \\
\hline & $1-m^{2}$ & 15 & 93.3 & 76.13 & 21.86 & 28.72 & 11.06 & 14.53 & 70.0 & 1.09 \\
\hline & Line-point & 15 & 100.0 & 59.33 & 22.19 & 37.40 & 11.23 & 18.93 & & 0.85 \\
\hline \multirow[b]{3}{*}{ BSC } & $10-m^{2}$ & 15 & 100.0 & 4.60 & 5.98 & 129.99 & 3.03 & 65.78 & & 0.70 \\
\hline & $1-m^{2}$ & 15 & 93.3 & 4.53 & 3.66 & 80.78 & 1.85 & 40.88 & 6.6 & 0.69 \\
\hline & Line-point & 15 & 53.3 & 10.67 & 12.23 & 114.64 & 6.19 & 58.01 & & 1.62 \\
\hline
\end{tabular}


Table C39. Summary of frequency (freq) and cover estimates in macroplot ARCH5 (Semidesert Shallow Sandy Loam ecological site). For line-point sampling, 10-point groups were used as subsampling units for purposes of frequency calculations. Precision is defined as one-half the width of the 95 percent confidence interval. The standardized mean was calculated as the ratio of the mean for a particular method to the among-method mean. See Appendix A for keys to species codes (BSC $=$ biological soil crust).

\begin{tabular}{|c|c|c|c|c|c|c|c|c|c|c|}
\hline \multirow[b]{2}{*}{ Measure } & \multirow[b]{2}{*}{ Method } & \multirow[b]{2}{*}{ Subsample $n$} & \multirow[b]{2}{*}{ Freq } & \multicolumn{7}{|c|}{ Cover } \\
\hline & & & & Mean & sd & CV & Precision & $\begin{array}{c}\text { Precision \% } \\
\text { of mean }\end{array}$ & $\begin{array}{l}\text { Among- } \\
\text { method } \\
\text { mean }\end{array}$ & $\begin{array}{c}\text { Standardized } \\
\text { mean }\end{array}$ \\
\hline \multirow{3}{*}{$\begin{array}{c}\text { Total live } \\
\text { understory } \\
\text { canopy } \\
\text { cover }\end{array}$} & $10-m^{2}$ & 15 & 100.0 & 18.40 & 8.44 & 45.85 & 4.27 & 23.20 & & 0.96 \\
\hline & $1-m^{2}$ & 15 & 100.0 & 20.67 & 10.17 & 49.23 & 5.15 & 24.91 & 19.2 & 1.07 \\
\hline & Line-point & 15 & 86.7 & 18.67 & 15.52 & 83.16 & 7.86 & 42.08 & & 0.97 \\
\hline \multirow[b]{3}{*}{ CORA } & $10-m^{2}$ & 15 & 73.3 & 12.83 & 8.01 & 62.42 & 4.05 & 31.59 & & 1.12 \\
\hline & $1-m^{2}$ & 15 & 93.3 & 13.67 & 12.03 & 88.01 & 6.09 & 44.54 & 11.5 & 1.19 \\
\hline & Line-point & 15 & 66.7 & 8.00 & 6.76 & 84.52 & 3.42 & 42.77 & & 0.70 \\
\hline \multirow[b]{3}{*}{ FEOC3 } & $10-m^{2}$ & 15 & 93.3 & 0.47 & 0.13 & 27.66 & 0.07 & 14.00 & & 0.26 \\
\hline & $1-m^{2}$ & 15 & 93.3 & 0.93 & 0.26 & 27.66 & 0.13 & 14.00 & 1.8 & 0.52 \\
\hline & Line-point & 15 & 26.7 & 4.00 & 8.28 & 207.02 & 4.19 & 104.76 & & 2.22 \\
\hline \multirow[b]{3}{*}{ Bare soil } & $10-m^{2}$ & 15 & 100.0 & 0.67 & 0.65 & 96.82 & 0.33 & 49.00 & & 0.46 \\
\hline & $1-m^{2}$ & 15 & 73.3 & 1.00 & 1.00 & 100.00 & 0.51 & 50.61 & 1.4 & 0.69 \\
\hline & Line-point & 15 & 26.7 & 2.67 & 4.58 & 171.65 & 2.32 & 86.87 & & 1.85 \\
\hline \multirow[b]{3}{*}{ Litter } & $10-m^{2}$ & 15 & 100.0 & 2.97 & 1.53 & 51.54 & 0.77 & 26.08 & & 1.43 \\
\hline & $1-m^{2}$ & 15 & 100.0 & 2.60 & 1.40 & 54.00 & 0.71 & 27.33 & 2.1 & 1.25 \\
\hline & Line-point & 15 & 6.7 & 0.67 & 2.58 & 387.30 & 1.31 & 196.00 & & 0.32 \\
\hline \multirow{3}{*}{$\begin{array}{l}\text { Undiffer- } \\
\text { entiated } \\
\text { crust }\end{array}$} & $10-m^{2}$ & 15 & 100.0 & 87.50 & 0.00 & 0.00 & 0.00 & 0.00 & & 1.06 \\
\hline & $1-m^{2}$ & 15 & 100.0 & 86.73 & 5.61 & 6.47 & 2.84 & 3.27 & 82.7 & 1.05 \\
\hline & Line-point & 15 & 100.0 & 74.00 & 15.95 & 21.55 & 8.07 & 10.91 & & 0.89 \\
\hline \multirow[b]{3}{*}{ BSC } & $10-m^{2}$ & 15 & 100.0 & 10.93 & 5.81 & 53.10 & 2.94 & 26.87 & & 0.93 \\
\hline & $1-m^{2}$ & 15 & 100.0 & 7.07 & 4.50 & 63.62 & 2.27 & 32.19 & 11.8 & 0.60 \\
\hline & Line-point & 15 & 73.3 & 17.33 & 15.34 & 88.49 & 7.76 & 44.78 & & 1.47 \\
\hline
\end{tabular}


Table C40. Summary of frequency (freq) and cover estimates in macroplot CANY3 (Semidesert Shallow Sandy Loam ecological site). For line-point sampling, 10-point groups were used as subsampling units for purposes of frequency calculations. Precision is defined as one-half the width of the 95 percent confidence interval. The standardized mean was calculated as the ratio of the mean for a particular method to the among-method mean. See Appendix A for keys to species codes (BSC = biological soil crust).

\begin{tabular}{|c|c|c|c|c|c|c|c|c|c|c|}
\hline \multirow[b]{2}{*}{ Measure } & \multirow[b]{2}{*}{ Method } & \multirow[b]{2}{*}{ Subsample $\mathbf{n}$} & \multirow[b]{2}{*}{ Freq } & \multicolumn{7}{|c|}{ Cover } \\
\hline & & & & Mean & sd & CV & Precision & $\begin{array}{l}\text { Precision \% } \\
\text { of mean }\end{array}$ & $\begin{array}{l}\text { Among- } \\
\text { method } \\
\text { mean }\end{array}$ & $\begin{array}{c}\text { Standardized } \\
\text { mean }\end{array}$ \\
\hline \multirow{3}{*}{$\begin{array}{l}\text { Total live } \\
\text { understory } \\
\text { canopy } \\
\text { cover }\end{array}$} & $10-m^{2}$ & 21 & 100.0 & 20.95 & 15.30 & 73.02 & 6.54 & 31.23 & & 0.99 \\
\hline & $1-m^{2}$ & 30 & 96.7 & 20.83 & 19.00 & 91.19 & 6.80 & 32.63 & 21.2 & 0.98 \\
\hline & Line-point & 30 & 70.0 & 21.67 & 23.65 & 109.14 & 8.46 & 39.06 & & 1.02 \\
\hline \multirow[b]{3}{*}{ CORA } & $10-m^{2}$ & 21 & 52.4 & 3.60 & 6.24 & 173.57 & 2.67 & 74.24 & & 0.89 \\
\hline & $1-m^{2}$ & 30 & 50.0 & 5.20 & 9.65 & 185.65 & 3.45 & 66.43 & 4.0 & 1.29 \\
\hline & Line-point & 30 & 23.3 & 3.33 & 6.61 & 198.27 & 2.36 & 70.95 & & 0.82 \\
\hline \multirow[b]{3}{*}{ FEOC3 } & $10-m^{2}$ & 21 & 90.5 & 0.45 & 0.15 & 33.25 & 0.06 & 14.22 & & 0.59 \\
\hline & $1-m^{2}$ & 30 & 83.3 & 0.83 & 0.38 & 45.49 & 0.14 & 16.28 & 0.8 & 1.09 \\
\hline & Line-point & 30 & 10.0 & 1.00 & 3.05 & 305.13 & 1.09 & 109.19 & & 1.31 \\
\hline \multirow[b]{3}{*}{ Bare soil } & $10-m^{2}$ & 21 & 57.1 & 0.29 & 0.25 & 88.74 & 0.11 & 37.95 & & 0.23 \\
\hline & $1-m^{2}$ & 30 & 26.7 & 0.73 & 1.57 & 214.67 & 0.56 & 76.82 & 1.2 & 0.60 \\
\hline & Line-point & 30 & 16.7 & 2.67 & 6.91 & 259.31 & 2.47 & 92.79 & & 2.17 \\
\hline \multirow[b]{3}{*}{ Litter } & $10-m^{2}$ & 21 & 100.0 & 13.12 & 18.78 & 143.15 & 8.03 & 61.22 & & 1.07 \\
\hline & $1-m^{2}$ & 30 & 96.7 & 11.30 & 21.47 & 189.96 & 7.68 & 67.98 & 12.3 & 0.92 \\
\hline & Line-point & 30 & 60.0 & 12.33 & 15.47 & 125.40 & 5.53 & 44.87 & & 1.01 \\
\hline \multirow{3}{*}{$\begin{array}{l}\text { Undiffer- } \\
\text { entiated } \\
\text { crust }\end{array}$} & $10-m^{2}$ & 21 & 100.0 & 66.55 & 24.32 & 36.55 & 10.40 & 15.63 & & 0.94 \\
\hline & $1-m^{2}$ & 30 & 100.0 & 76.80 & 23.12 & 30.11 & 8.27 & 10.77 & 71.0 & 1.08 \\
\hline & Line-point & 30 & 100.0 & 69.67 & 22.66 & 32.53 & 8.11 & 11.64 & & 0.98 \\
\hline \multirow[b]{3}{*}{ BSC } & $10-m^{2}$ & 21 & 95.2 & 4.33 & 3.52 & 81.13 & 1.50 & 34.70 & & 0.51 \\
\hline & $1-m^{2}$ & 30 & 86.7 & 7.60 & 9.07 & 119.38 & 3.25 & 42.72 & 8.4 & 0.90 \\
\hline & Line-point & 30 & 73.3 & 13.33 & 11.55 & 86.60 & 4.13 & 30.99 & & 1.58 \\
\hline
\end{tabular}


Table C41. Summary of frequency (freq) and cover estimates in macroplot CANY4 (Semidesert Shallow Sandy Loam ecological site). For line-point sampling, 10-point groups were used as subsampling units for purposes of frequency calculations. Precision is defined as one-half the width of the 95 percent confidence interval. The standardized mean was calculated as the ratio of the mean for a particular method to the among-method mean. See Appendix A for keys to species codes (BSC = biological soil crust).

\begin{tabular}{|c|c|c|c|c|c|c|c|c|c|c|}
\hline \multirow[b]{2}{*}{ Measure } & \multirow[b]{2}{*}{ Method } & \multirow[b]{2}{*}{ Subsample $n$} & \multirow[b]{2}{*}{ Freq } & \multicolumn{7}{|c|}{ Cover } \\
\hline & & & & Mean & sd & CV & Precision & $\begin{array}{c}\text { Precision \% } \\
\text { of mean }\end{array}$ & $\begin{array}{c}\text { Among- } \\
\text { method } \\
\text { mean }\end{array}$ & $\begin{array}{c}\text { Standardized } \\
\text { mean }\end{array}$ \\
\hline \multirow{3}{*}{$\begin{array}{c}\text { Total live } \\
\text { understory } \\
\text { canopy } \\
\text { cover }\end{array}$} & $10-m^{2}$ & 21 & 90.5 & 15.71 & 18.44 & 117.34 & 7.89 & 50.19 & & 1.15 \\
\hline & $1-m^{2}$ & 30 & 83.3 & 15.13 & 25.08 & 165.70 & 8.97 & 59.29 & 13.6 & 1.11 \\
\hline & Line-point & 30 & 46.7 & 10.00 & 12.87 & 128.65 & 4.60 & 46.04 & & 0.73 \\
\hline \multirow[b]{3}{*}{ CORA } & $10-m^{2}$ & 21 & 23.8 & 2.40 & 5.49 & 228.49 & 2.35 & 97.72 & & 0.70 \\
\hline & $1-m^{2}$ & 30 & 16.7 & 4.17 & 10.67 & 256.18 & 3.82 & 91.67 & 3.4 & 1.22 \\
\hline & Line-point & 30 & 23.3 & 3.67 & 7.65 & 208.61 & 2.74 & 74.65 & & 1.07 \\
\hline \multirow[b]{3}{*}{ FEOC3 } & $10-m^{2}$ & 21 & 61.9 & 0.31 & 0.25 & 80.38 & 0.11 & 34.38 & & 0.63 \\
\hline & $1-m^{2}$ & 30 & 50.0 & 0.50 & 0.51 & 101.71 & 0.18 & 36.40 & 0.5 & 1.02 \\
\hline & Line-point & 30 & 6.7 & 0.67 & 2.54 & 380.56 & 0.91 & 136.18 & & 1.35 \\
\hline \multirow[b]{3}{*}{ Bare soil } & $10-m^{2}$ & 21 & 100.0 & 1.43 & 1.76 & 123.39 & 0.75 & 52.77 & & 0.76 \\
\hline & $1-m^{2}$ & 30 & 66.7 & 2.57 & 3.06 & 119.18 & 1.09 & 42.65 & 1.9 & 1.36 \\
\hline & Line-point & 30 & 13.3 & 1.67 & 4.61 & 276.68 & 1.65 & 99.01 & & 0.88 \\
\hline \multirow[b]{3}{*}{ Litter } & $10-m^{2}$ & 21 & 95.2 & 9.62 & 18.55 & 192.86 & 7.93 & 82.49 & & 1.04 \\
\hline & $1-m^{2}$ & 30 & 100.0 & 10.00 & 21.41 & 214.06 & 7.66 & 76.60 & 9.2 & 1.09 \\
\hline & Line-point & 30 & 33.3 & 8.00 & 18.08 & 226.00 & 6.47 & 80.87 & & 0.87 \\
\hline \multirow{3}{*}{$\begin{array}{l}\text { Undiffer- } \\
\text { entiated } \\
\text { crust }\end{array}$} & $10-m^{2}$ & 21 & 95.2 & 30.60 & 28.69 & 93.78 & 12.27 & 40.11 & & 0.78 \\
\hline & $1-m^{2}$ & 30 & 86.7 & 46.70 & 33.36 & 71.42 & 11.94 & 25.56 & 39.1 & 1.19 \\
\hline & Line-point & 30 & 90.0 & 40.00 & 28.04 & 70.10 & 10.03 & 25.08 & & 1.02 \\
\hline \multirow[b]{3}{*}{ BSC } & $10-m^{2}$ & 21 & 95.2 & 8.14 & 6.16 & 75.68 & 2.64 & 32.37 & & 0.63 \\
\hline & $1-m^{2}$ & 30 & 90.0 & 12.23 & 11.08 & 90.59 & 3.97 & 32.42 & 12.9 & 0.95 \\
\hline & Line-point & 30 & 63.3 & 18.33 & 17.83 & 97.24 & 6.38 & 34.80 & & 1.42 \\
\hline
\end{tabular}


Table C42. Summary of frequency (freq) and cover estimates in macroplot WUPA3 (Shallow Loamy ecological site). For line-point sampling, 10-point groups were used as subsampling units for purposes of frequency calculations. Precision is defined as one-half the width of the 95 percent confidence interval. The standardized mean was calculated as the ratio of the mean for a particular method to the among-method mean. See Appendix A for keys to species codes.

\begin{tabular}{|c|c|c|c|c|c|c|c|c|c|c|}
\hline \multirow[b]{2}{*}{ Measure } & \multirow[b]{2}{*}{ Method } & \multirow[b]{2}{*}{ Subsample $\mathbf{n}$} & \multirow[b]{2}{*}{ Freq } & \multicolumn{7}{|c|}{ Cover } \\
\hline & & & & Mean & sd & CV & Precision & $\begin{array}{l}\text { Precision \% } \\
\text { of mean }\end{array}$ & $\begin{array}{l}\text { Among- } \\
\text { method } \\
\text { mean }\end{array}$ & $\begin{array}{c}\text { Standardized } \\
\text { mean }\end{array}$ \\
\hline \multirow{3}{*}{$\begin{array}{c}\text { Total live } \\
\text { understory } \\
\text { canopy } \\
\text { cover }\end{array}$} & $10-m^{2}$ & 21 & 100.0 & 25.02 & 8.99 & 35.94 & 3.85 & 15.37 & & 0.87 \\
\hline & $1-m^{2}$ & 30 & 100.0 & 20.50 & 10.66 & 51.98 & 3.81 & 18.60 & 28.8 & 0.71 \\
\hline & Line-point & 30 & 100.0 & 41.00 & 16.05 & 39.15 & 5.74 & 14.01 & & 1.42 \\
\hline \multirow[b]{3}{*}{ CHLE4 } & $10-m^{2}$ & 21 & 100.0 & 3.36 & 2.61 & 77.70 & 1.12 & 33.23 & & 0.91 \\
\hline & $1-m^{2}$ & 30 & 73.3 & 2.37 & 3.15 & 132.92 & 1.13 & 47.56 & 3.7 & 0.64 \\
\hline & Line-point & 30 & 46.7 & 5.33 & 6.29 & 117.90 & 2.25 & 42.19 & & 1.45 \\
\hline \multirow[b]{3}{*}{ HENE5 } & $10-m^{2}$ & 21 & 100.0 & 5.02 & 5.52 & 109.95 & 2.36 & 47.03 & & 0.83 \\
\hline & $1-m^{2}$ & 30 & 86.7 & 3.03 & 2.89 & 95.42 & 1.04 & 34.15 & 6.0 & 0.50 \\
\hline & Line-point & 30 & 63.3 & 10.00 & 10.83 & 108.28 & 3.87 & 38.75 & & 1.66 \\
\hline \multirow[b]{3}{*}{ PLJA } & $10-m^{2}$ & 21 & 100.0 & 6.40 & 4.39 & 68.58 & 1.88 & 29.33 & & 0.86 \\
\hline & $1-m^{2}$ & 30 & 100.0 & 6.30 & 4.98 & 79.00 & 1.78 & 28.27 & 7.5 & 0.84 \\
\hline & Line-point & 30 & 60.0 & 9.67 & 10.66 & 110.30 & 3.82 & 39.47 & & 1.30 \\
\hline \multirow[b]{3}{*}{ Bare soil } & $10-m^{2}$ & 21 & 100.0 & 2.12 & 2.16 & 101.74 & 0.92 & 43.51 & & 0.30 \\
\hline & $1-m^{2}$ & 30 & 100.0 & 4.60 & 8.56 & 186.10 & 3.06 & 66.59 & 7.0 & 0.66 \\
\hline & Line-point & 30 & 70.0 & 14.33 & 14.31 & 99.82 & 5.12 & 35.72 & & 2.04 \\
\hline \multirow[b]{3}{*}{ Litter } & $10-m^{2}$ & 21 & 90.5 & 5.38 & 4.70 & 87.26 & 2.01 & 37.32 & & 0.66 \\
\hline & $1-m^{2}$ & 30 & 93.3 & 7.77 & 11.11 & 143.08 & 3.98 & 51.20 & 8.2 & 0.95 \\
\hline & Line-point & 30 & 70.0 & 11.33 & 10.08 & 88.94 & 3.61 & 31.83 & & 1.39 \\
\hline
\end{tabular}


Table C43. Summary of frequency (freq) and cover estimates in macroplot WUPA4 (Shallow Loamy ecological site). For line-point sampling, 10-point groups were used as subsampling units for purposes of frequency calculations. Precision is defined as one-half the width of the 95 percent confidence interval. The standardized mean was calculated as the ratio of the mean for a particular method to the among-method mean. See Appendix A for keys to species codes.

\begin{tabular}{|c|c|c|c|c|c|c|c|c|c|c|}
\hline \multirow[b]{2}{*}{ Measure } & \multirow[b]{2}{*}{ Method } & \multirow[b]{2}{*}{ Subsample $\mathbf{n}$} & \multirow[b]{2}{*}{ Freq } & \multicolumn{7}{|c|}{ Cover } \\
\hline & & & & Mean & sd & CV & Precision & $\begin{array}{l}\text { Precision \% } \\
\text { of mean }\end{array}$ & $\begin{array}{l}\text { Among- } \\
\text { method } \\
\text { mean }\end{array}$ & $\begin{array}{c}\text { Standardized } \\
\text { mean }\end{array}$ \\
\hline \multirow{3}{*}{$\begin{array}{c}\text { Total live } \\
\text { understory } \\
\text { canopy } \\
\text { cover }\end{array}$} & $10-m^{2}$ & 21 & 100.0 & 11.55 & 5.79 & 50.14 & 2.48 & 21.44 & & 0.89 \\
\hline & $1-m^{2}$ & 30 & 100.0 & 13.87 & 17.02 & 122.72 & 6.09 & 43.91 & 13.0 & 1.06 \\
\hline & Line-point & 30 & 80.0 & 13.67 & 9.64 & 70.56 & 3.45 & 25.25 & & 1.05 \\
\hline \multirow[b]{3}{*}{ CHLE4 } & $10-m^{2}$ & 21 & 90.5 & 0.57 & 0.58 & 100.86 & 0.25 & 43.14 & & 0.74 \\
\hline & $1-m^{2}$ & 30 & 70.0 & 1.07 & 1.23 & 115.30 & 0.44 & 41.26 & 0.8 & 1.39 \\
\hline & Line-point & 30 & 6.7 & 0.67 & 2.54 & 380.56 & 0.91 & 136.18 & & 0.87 \\
\hline \multirow[b]{3}{*}{ HENE5 } & $10-m^{2}$ & 21 & 85.7 & 1.95 & 1.84 & 94.41 & 0.79 & 40.38 & & 1.02 \\
\hline & $1-m^{2}$ & 30 & 76.7 & 1.47 & 1.31 & 89.05 & 0.47 & 31.86 & 1.9 & 0.76 \\
\hline & Line-point & 30 & 23.3 & 2.33 & 4.30 & 184.36 & 1.54 & 65.97 & & 1.22 \\
\hline \multirow[b]{3}{*}{ PLJA } & $10-m^{2}$ & 21 & 100.0 & 2.69 & 2.33 & 86.67 & 1.00 & 37.07 & & 0.84 \\
\hline & $1-m^{2}$ & 30 & 86.7 & 2.30 & 2.12 & 92.16 & 0.76 & 32.98 & 3.2 & 0.71 \\
\hline & Line-point & 30 & 36.7 & 4.67 & 6.81 & 146.02 & 2.44 & 52.25 & & 1.45 \\
\hline \multirow[b]{3}{*}{ Bare soil } & $10-m^{2}$ & 21 & 100.0 & 1.45 & 1.24 & 85.65 & 0.53 & 36.63 & & 0.53 \\
\hline & $1-m^{2}$ & 30 & 96.7 & 2.47 & 1.68 & 67.95 & 0.60 & 24.31 & 2.8 & 0.90 \\
\hline & Line-point & 30 & 30.0 & 4.33 & 8.58 & 198.08 & 3.07 & 70.88 & & 1.58 \\
\hline \multirow[b]{3}{*}{ Litter } & $10-m^{2}$ & 21 & 95.2 & 7.33 & 5.56 & 75.78 & 2.38 & 32.41 & & 0.96 \\
\hline & $1-m^{2}$ & 30 & 96.7 & 9.27 & 13.28 & 143.33 & 4.75 & 51.29 & 7.6 & 1.21 \\
\hline & Line-point & 30 & 43.3 & 6.33 & 8.90 & 140.51 & 3.18 & 50.28 & & 0.83 \\
\hline
\end{tabular}


Table C44. Summary of frequency (freq) and cover estimates in macroplot CARE3 (Upland Shallow Loam ecological site). For line-point sampling, 10-point groups were used as subsampling units for purposes of frequency calculations. Precision is defined as one-half the width of the 95 percent confidence interval. The standardized mean was calculated as the ratio of the mean for a particular method to the among-method mean. See Appendix A for keys to species codes (BSC = biological soil crust).

\begin{tabular}{|c|c|c|c|c|c|c|c|c|c|c|}
\hline \multirow[b]{2}{*}{ Measure } & \multirow[b]{2}{*}{ Method } & \multirow[b]{2}{*}{ Subsample $\mathbf{n}$} & \multirow[b]{2}{*}{ Freq } & \multicolumn{7}{|c|}{ Cover } \\
\hline & & & & Mean & sd & CV & Precision & $\begin{array}{l}\text { Precision \% } \\
\text { of mean }\end{array}$ & $\begin{array}{l}\text { Among- } \\
\text { method } \\
\text { mean }\end{array}$ & $\begin{array}{c}\text { Standardized } \\
\text { mean }\end{array}$ \\
\hline \multirow{3}{*}{$\begin{array}{l}\text { Total live } \\
\text { understory } \\
\text { canopy } \\
\text { cover }\end{array}$} & $10-m^{2}$ & 21 & 100.0 & 20.02 & 24.10 & 120.35 & 10.31 & 51.47 & & 1.50 \\
\hline & $1-m^{2}$ & 30 & 93.3 & 10.13 & 19.95 & 196.92 & 7.14 & 70.47 & 13.4 & 0.76 \\
\hline & Line-point & 30 & 46.7 & 10.00 & 13.65 & 136.46 & 4.88 & 48.83 & & 0.75 \\
\hline \multirow[b]{3}{*}{ CEMO2 } & $10-m^{2}$ & 21 & 0.0 & 0.00 & - & - & - & - & & - \\
\hline & $1-m^{2}$ & 30 & 0.0 & 0.00 & - & - & - & - & 0.0 & - \\
\hline & Line-point & 30 & 0.0 & 0.00 & - & - & - & - & & - \\
\hline \multirow[b]{3}{*}{ COWR2 } & $10-m^{2}$ & 21 & 95.2 & 1.76 & 1.81 & 102.95 & 0.78 & 44.03 & & 0.66 \\
\hline & $1-m^{2}$ & 30 & 90.0 & 1.63 & 1.47 & 90.22 & 0.53 & 32.28 & 2.7 & 0.61 \\
\hline & Line-point & 30 & 30.0 & 4.67 & 9.37 & 200.81 & 3.35 & 71.86 & & 1.74 \\
\hline \multirow[b]{3}{*}{ JUOS } & $10-m^{2}$ & 21 & 42.9 & 8.76 & 17.01 & 194.10 & 7.27 & 83.02 & & 1.72 \\
\hline & $1-m^{2}$ & 30 & 10.0 & 3.83 & 14.42 & 376.30 & 5.16 & 134.65 & 5.1 & 0.75 \\
\hline & Line-point & 30 & 16.7 & 2.67 & 6.91 & 259.31 & 2.47 & 92.79 & & 0.52 \\
\hline \multirow[b]{3}{*}{ Bare soil } & $10-m^{2}$ & 21 & 85.7 & 0.90 & 1.06 & 116.73 & 0.45 & 49.93 & & 0.15 \\
\hline & $1-m^{2}$ & 30 & 80.0 & 1.23 & 1.10 & 89.54 & 0.40 & 32.04 & 5.9 & 0.21 \\
\hline & Line-point & 30 & 73.3 & 15.67 & 14.06 & 89.77 & 5.03 & 32.12 & & 2.64 \\
\hline \multirow[b]{3}{*}{ Litter } & $10-m^{2}$ & 21 & 100.0 & 16.24 & 25.15 & 154.87 & 10.76 & 66.24 & & 1.45 \\
\hline & $1-m^{2}$ & 30 & 100.0 & 13.63 & 25.84 & 189.53 & 9.25 & 67.82 & 11.2 & 1.22 \\
\hline & Line-point & 30 & 13.3 & 3.67 & 11.59 & 316.14 & 4.15 & 113.13 & & 0.33 \\
\hline \multirow[b]{3}{*}{ BSC } & $10-m^{2}$ & 21 & 28.6 & 0.14 & 0.23 & 162.02 & 0.10 & 69.30 & & 0.44 \\
\hline & $1-m^{2}$ & 30 & 13.3 & 0.17 & 0.46 & 276.68 & 0.17 & 99.01 & 0.3 & 0.51 \\
\hline & Line-point & 30 & 6.7 & 0.67 & 2.54 & 380.56 & 0.91 & 136.18 & & 2.05 \\
\hline
\end{tabular}


Table C45. Summary of frequency (freq) and cover estimates in macroplot CARE4b (Upland Shallow Loam ecological site). For line-point sampling, 10-point groups were used as subsampling units for purposes of frequency calculations. Precision is defined as one-half the width of the 95 percent confidence interval. The standardized mean was calculated as the ratio of the mean for a particular method to the among-method mean. See Appendix A for keys to species codes (BSC = biological soil crust).

\begin{tabular}{|c|c|c|c|c|c|c|c|c|c|c|}
\hline \multirow[b]{2}{*}{ Measure } & \multirow[b]{2}{*}{ Method } & \multirow[b]{2}{*}{ Subsample $\mathbf{n}$} & \multirow[b]{2}{*}{ Freq } & \multicolumn{7}{|c|}{ Cover } \\
\hline & & & & Mean & sd & CV & Precision & $\begin{array}{c}\text { Precision } \% \\
\text { of mean }\end{array}$ & $\begin{array}{l}\text { Among- } \\
\text { method } \\
\text { mean }\end{array}$ & $\begin{array}{c}\text { Standardized } \\
\text { mean }\end{array}$ \\
\hline \multirow{3}{*}{$\begin{array}{c}\text { Total live } \\
\text { understory } \\
\text { canopy } \\
\text { cover }\end{array}$} & $10-m^{2}$ & 21 & 100.0 & 15.14 & 20.83 & 137.57 & 8.91 & 58.84 & & 0.93 \\
\hline & $1-m^{2}$ & 30 & 96.7 & 20.17 & 30.81 & 152.77 & 11.02 & 54.67 & 16.2 & 1.24 \\
\hline & Line-point & 30 & 60.0 & 13.33 & 15.39 & 115.41 & 5.51 & 41.30 & & 0.82 \\
\hline \multirow[b]{3}{*}{ CEMO2 } & $10-m^{2}$ & 21 & 0.0 & 0.00 & - & - & - & - & & - \\
\hline & $1-m^{2}$ & 30 & 0.0 & 0.00 & - & - & - & - & 0.0 & - \\
\hline & Line-point & 30 & 0.0 & 0.00 & - & - & - & - & & - \\
\hline \multirow[b]{3}{*}{ COWR2 } & $10-m^{2}$ & 21 & 100.0 & 1.33 & 1.21 & 90.57 & 0.52 & 38.74 & & 0.66 \\
\hline & $1-m^{2}$ & 30 & 80.0 & 1.77 & 2.27 & 128.46 & 0.81 & 45.97 & 2.0 & 0.87 \\
\hline & Line-point & 30 & 23.3 & 3.00 & 5.96 & 198.65 & 2.13 & 71.09 & & 1.48 \\
\hline \multirow[b]{3}{*}{ JUOS } & $10-m^{2}$ & 21 & 28.6 & 5.74 & 11.83 & 206.16 & 5.06 & 88.17 & & 1.11 \\
\hline & $1-m^{2}$ & 30 & 20.0 & 6.43 & 18.64 & 289.70 & 6.67 & 103.67 & 5.2 & 1.24 \\
\hline & Line-point & 30 & 16.7 & 3.33 & 8.02 & 240.69 & 2.87 & 86.13 & & 0.64 \\
\hline \multirow[b]{3}{*}{ Bare soil } & $10-m^{2}$ & 21 & 100.0 & 1.52 & 2.18 & 142.83 & 0.93 & 61.09 & & 0.21 \\
\hline & $1-m^{2}$ & 30 & 86.7 & 2.10 & 2.01 & 95.53 & 0.72 & 34.18 & 7.4 & 0.28 \\
\hline & Line-point & 30 & 76.7 & 18.67 & 19.43 & 104.08 & 6.95 & 37.24 & & 2.51 \\
\hline \multirow[b]{3}{*}{ Litter } & $10-m^{2}$ & 21 & 100.0 & 16.00 & 22.54 & 140.86 & 9.64 & 60.25 & & 1.26 \\
\hline & $1-m^{2}$ & 30 & 96.7 & 19.13 & 30.28 & 158.23 & 10.83 & 56.62 & 12.7 & 1.51 \\
\hline & Line-point & 30 & 16.7 & 3.00 & 7.50 & 249.90 & 2.68 & 89.43 & & 0.24 \\
\hline \multirow[b]{3}{*}{ BSC } & $10-m^{2}$ & 21 & 14.3 & 0.07 & 0.18 & 251.00 & 0.08 & 107.35 & & 0.49 \\
\hline & $1-m^{2}$ & 30 & 3.3 & 0.03 & 0.18 & 547.72 & 0.07 & 196.00 & 0.1 & 0.23 \\
\hline & Line-point & 30 & 3.3 & 0.33 & 1.83 & 547.72 & 0.65 & 196.00 & & 2.28 \\
\hline
\end{tabular}


Table C46. Summary of frequency (freq) and cover estimates in macroplot CARE8 (Upland Shallow Loam ecological site). For line-point sampling, 10-point groups were used as subsampling units for purposes of frequency calculations. Precision is defined as one-half the width of the 95 percent confidence interval. The standardized mean was calculated as the ratio of the mean for a particular method to the among-method mean. See Appendix A for keys to species codes (BSC = biological soil crust).

\begin{tabular}{|c|c|c|c|c|c|c|c|c|c|c|}
\hline \multirow[b]{2}{*}{ Measure } & \multirow[b]{2}{*}{ Method } & \multirow[b]{2}{*}{ Subsample $\mathbf{n}$} & \multirow[b]{2}{*}{ Freq } & \multicolumn{7}{|c|}{ Cover } \\
\hline & & & & Mean & sd & CV & Precision & $\begin{array}{c}\text { Precision } \% \\
\text { of mean }\end{array}$ & $\begin{array}{l}\text { Among- } \\
\text { method } \\
\text { mean }\end{array}$ & $\begin{array}{c}\text { Standardized } \\
\text { mean }\end{array}$ \\
\hline \multirow{3}{*}{$\begin{array}{c}\text { Total live } \\
\text { understory } \\
\text { canopy } \\
\text { cover }\end{array}$} & $10-m^{2}$ & 15 & 93.3 & 15.97 & 13.00 & 81.40 & 6.58 & 41.19 & & 0.98 \\
\hline & $1-m^{2}$ & 15 & 93.3 & 18.33 & 26.16 & 142.69 & 13.24 & 72.21 & 16.3 & 1.12 \\
\hline & Line-point & 15 & 66.7 & 14.67 & 13.56 & 92.44 & 6.86 & 46.78 & & 0.90 \\
\hline \multirow[b]{3}{*}{ CEMO2 } & $10-m^{2}$ & 15 & 40.0 & 4.23 & 7.15 & 168.86 & 3.62 & 85.46 & & 1.32 \\
\hline & $1-m^{2}$ & 15 & 33.3 & 1.40 & 2.85 & 203.47 & 1.44 & 102.97 & 3.2 & 0.44 \\
\hline & Line-point & 15 & 26.7 & 4.00 & 8.28 & 207.02 & 4.19 & 104.76 & & 1.25 \\
\hline \multirow[b]{3}{*}{ COWR2 } & $10-m^{2}$ & 15 & 73.3 & 0.70 & 0.96 & 137.13 & 0.49 & 69.40 & & 0.50 \\
\hline & $1-m^{2}$ & 15 & 60.0 & 0.87 & 0.83 & 96.21 & 0.42 & 48.69 & 1.4 & 0.61 \\
\hline & Line-point & 15 & 26.7 & 2.67 & 4.58 & 171.65 & 2.32 & 86.87 & & 1.89 \\
\hline \multirow[b]{3}{*}{ JUOS } & $10-m^{2}$ & 15 & 26.7 & 5.33 & 10.85 & 203.45 & 5.49 & 102.96 & & 1.57 \\
\hline & $1-m^{2}$ & 15 & 13.3 & 0.87 & 2.64 & 304.86 & 1.34 & 154.28 & 3.4 & 0.25 \\
\hline & Line-point & 15 & 26.7 & 4.00 & 7.37 & 184.20 & 3.73 & 93.21 & & 1.18 \\
\hline \multirow[b]{3}{*}{ Bare soil } & $10-m^{2}$ & 15 & 100.0 & 1.17 & 1.14 & 98.09 & 0.58 & 49.64 & & 0.17 \\
\hline & $1-m^{2}$ & 15 & 100.0 & 1.80 & 1.78 & 98.94 & 0.90 & 50.07 & 6.8 & 0.27 \\
\hline & Line-point & 15 & 86.7 & 17.33 & 13.35 & 76.99 & 6.75 & 38.96 & & 2.56 \\
\hline \multirow[b]{3}{*}{ Litter } & $10-m^{2}$ & 15 & 100.0 & 20.03 & 25.01 & 124.83 & 12.66 & 63.17 & & 0.97 \\
\hline & $1-m^{2}$ & 15 & 100.0 & 31.00 & 39.47 & 127.32 & 19.97 & 64.43 & 20.6 & 1.51 \\
\hline & Line-point & 15 & 46.7 & 10.67 & 15.34 & 143.79 & 7.76 & 72.77 & & 0.52 \\
\hline \multirow[b]{3}{*}{ BSC } & $10-m^{2}$ & 15 & 13.3 & 0.07 & 0.18 & 263.90 & 0.09 & 133.55 & & 1.50 \\
\hline & $1-m^{2}$ & 15 & 6.7 & 0.07 & 0.26 & 387.30 & 0.13 & 196.00 & 0.0 & 1.50 \\
\hline & Line-point & 15 & 0.0 & 0.00 & - & - & - & - & & 0.00 \\
\hline
\end{tabular}


Table C47. Summary of frequency (freq) and cover estimates in macroplot CARE9 (Upland Shallow Loam ecological site). For line-point sampling, 10-point groups were used as subsampling units for purposes of frequency calculations. Precision is defined as one-half the width of the 95 percent confidence interval. The standardized mean was calculated as the ratio of the mean for a particular method to the among-method mean. See Appendix A for keys to species codes (BSC = biological soil crust).

\begin{tabular}{|c|c|c|c|c|c|c|c|c|c|c|}
\hline \multirow[b]{2}{*}{ Measure } & \multirow[b]{2}{*}{ Method } & \multirow[b]{2}{*}{ Subsample $\mathbf{n}$} & \multirow[b]{2}{*}{ Freq } & \multicolumn{7}{|c|}{ Cover } \\
\hline & & & & Mean & sd & CV & Precision & $\begin{array}{c}\text { Precision } \% \\
\text { of mean }\end{array}$ & $\begin{array}{l}\text { Among- } \\
\text { method } \\
\text { mean }\end{array}$ & $\begin{array}{c}\text { Standardized } \\
\text { mean }\end{array}$ \\
\hline \multirow{3}{*}{$\begin{array}{c}\text { Total live } \\
\text { understory } \\
\text { canopy } \\
\text { cover }\end{array}$} & $10-m^{2}$ & 15 & 93.3 & 10.23 & 11.25 & 109.94 & 5.69 & 55.63 & & 1.39 \\
\hline & $1-m^{2}$ & 15 & 80.0 & 7.20 & 18.92 & 262.75 & 9.57 & 132.97 & 7.4 & 0.98 \\
\hline & Line-point & 15 & 26.7 & 4.67 & 9.15 & 196.17 & 4.63 & 99.28 & & 0.63 \\
\hline \multirow[b]{3}{*}{ CEMO2 } & $10-m^{2}$ & 15 & 26.7 & 2.87 & 6.24 & 217.80 & 3.16 & 110.22 & & 2.58 \\
\hline & $1-m^{2}$ & 15 & 13.3 & 0.47 & 1.36 & 290.52 & 0.69 & 147.02 & 1.1 & 0.42 \\
\hline & Line-point & 15 & 0.0 & 0.00 & - & - & - & - & & 0.00 \\
\hline \multirow[b]{3}{*}{ COWR2 } & $10-m^{2}$ & 15 & 60.0 & 0.97 & 1.29 & 133.26 & 0.65 & 67.44 & & 1.85 \\
\hline & $1-m^{2}$ & 15 & 40.0 & 0.60 & 0.83 & 138.01 & 0.42 & 69.84 & 0.5 & 1.15 \\
\hline & Line-point & 15 & 0.0 & 0.00 & - & - & - & - & & 0.00 \\
\hline \multirow[b]{3}{*}{ JUOS } & $10-m^{2}$ & 15 & 20.0 & 3.03 & 9.73 & 320.69 & 4.92 & 162.29 & & 1.05 \\
\hline & $1-m^{2}$ & 15 & 6.7 & 5.00 & 19.36 & 387.30 & 9.80 & 196.00 & 2.9 & 1.72 \\
\hline & Line-point & 15 & 6.7 & 0.67 & 2.58 & 387.30 & 1.31 & 196.00 & & 0.23 \\
\hline \multirow[b]{3}{*}{ Bare soil } & $10-m^{2}$ & 15 & 93.3 & 0.47 & 0.13 & 27.66 & 0.07 & 14.00 & & 0.17 \\
\hline & $1-m^{2}$ & 15 & 73.3 & 1.07 & 1.22 & 114.64 & 0.62 & 58.01 & 2.7 & 0.39 \\
\hline & Line-point & 15 & 33.3 & 6.67 & 10.47 & 156.98 & 5.30 & 79.44 & & 2.44 \\
\hline \multirow[b]{3}{*}{ Litter } & $10-m^{2}$ & 15 & 100.0 & 5.40 & 9.92 & 183.73 & 5.02 & 92.98 & & 0.98 \\
\hline & $1-m^{2}$ & 15 & 100.0 & 8.53 & 23.33 & 273.39 & 11.81 & 138.35 & 5.5 & 1.54 \\
\hline & Line-point & 15 & 20.0 & 2.67 & 5.94 & 222.61 & 3.00 & 112.65 & & 0.48 \\
\hline \multirow[b]{3}{*}{ BSC } & $10-m^{2}$ & 15 & 20.0 & 0.10 & 0.21 & 207.02 & 0.10 & 104.76 & & 1.80 \\
\hline & $1-m^{2}$ & 15 & 6.7 & 0.07 & 0.26 & 387.30 & 0.13 & 196.00 & 0.1 & 1.20 \\
\hline & Line-point & 15 & 0.0 & 0.00 & - & - & - & - & & 0.00 \\
\hline
\end{tabular}


Table C48. Summary of frequency (freq) and cover estimates in macroplot CARE10 (Upland Shallow Loam ecological site). For line-point sampling, 10-point groups were used as subsampling units for purposes of frequency calculations. Precision is defined as one-half the width of the 95 percent confidence interval. The standardized mean was calculated as the ratio of the mean for a particular method to the among-method mean. See Appendix A for keys to species codes (BSC = biological soil crust).

\begin{tabular}{|c|c|c|c|c|c|c|c|c|c|c|}
\hline \multirow[b]{2}{*}{ Measure } & \multirow[b]{2}{*}{ Method } & \multirow[b]{2}{*}{ Subsample $n$} & \multirow[b]{2}{*}{ Freq } & \multicolumn{7}{|c|}{ Cover } \\
\hline & & & & Mean & sd & CV & Precision & $\begin{array}{c}\text { Precision } \% \\
\text { of mean }\end{array}$ & $\begin{array}{l}\text { Among- } \\
\text { method } \\
\text { mean }\end{array}$ & $\begin{array}{c}\text { Standardized } \\
\text { mean }\end{array}$ \\
\hline \multirow{3}{*}{$\begin{array}{c}\text { Total live } \\
\text { understory } \\
\text { canopy } \\
\text { cover }\end{array}$} & $10-m^{2}$ & 15 & 93.3 & 21.23 & 29.29 & 137.92 & 14.82 & 69.80 & & 1.09 \\
\hline & $1-m^{2}$ & 15 & 80.0 & 21.07 & 26.72 & 126.85 & 13.52 & 64.19 & 19.4 & 1.08 \\
\hline & Line-point & 15 & 80.0 & 16.00 & 14.54 & 90.88 & 7.36 & 45.99 & & 0.82 \\
\hline \multirow[b]{3}{*}{ CEMO2 } & $10-m^{2}$ & 15 & 26.7 & 2.20 & 4.97 & 226.10 & 2.52 & 114.42 & & 0.44 \\
\hline & $1-m^{2}$ & 15 & 13.3 & 4.67 & 12.32 & 263.90 & 6.23 & 133.55 & 5.0 & 0.94 \\
\hline & Line-point & 15 & 40.0 & 8.00 & 14.24 & 178.03 & 7.21 & 90.10 & & 1.61 \\
\hline \multirow[b]{3}{*}{ COWR2 } & $10-m^{2}$ & 15 & 73.3 & 1.03 & 1.25 & 120.58 & 0.63 & 61.02 & & 1.02 \\
\hline & $1-m^{2}$ & 15 & 46.7 & 0.67 & 0.82 & 122.47 & 0.41 & 61.98 & 1.0 & 0.66 \\
\hline & Line-point & 15 & 13.3 & 1.33 & 3.52 & 263.90 & 1.78 & 133.55 & & 1.32 \\
\hline \multirow[b]{3}{*}{ JUOS } & $10-m^{2}$ & 15 & 26.7 & 5.03 & 10.85 & 215.54 & 5.49 & 109.08 & & 1.00 \\
\hline & $1-m^{2}$ & 15 & 26.7 & 8.00 & 14.24 & 178.03 & 7.21 & 90.10 & 5.0 & 1.60 \\
\hline & Line-point & 15 & 20.0 & 2.00 & 4.14 & 207.02 & 2.10 & 104.76 & & 0.40 \\
\hline \multirow[b]{3}{*}{ Bare soil } & $10-m^{2}$ & 15 & 100.0 & 1.60 & 2.48 & 154.99 & 1.25 & 78.44 & & 0.23 \\
\hline & $1-m^{2}$ & 15 & 93.3 & 1.73 & 1.62 & 93.71 & 0.82 & 47.42 & 7.1 & 0.24 \\
\hline & Line-point & 15 & 93.3 & 18.00 & 10.14 & 56.34 & 5.13 & 28.51 & & 2.53 \\
\hline \multirow[b]{3}{*}{ Litter } & $10-m^{2}$ & 15 & 100.0 & 26.37 & 28.09 & 106.54 & 14.22 & 53.92 & & 1.01 \\
\hline & $1-m^{2}$ & 15 & 100.0 & 37.67 & 38.01 & 100.90 & 19.23 & 51.06 & 26.0 & 1.45 \\
\hline & Line-point & 15 & 66.7 & 14.00 & 16.39 & 117.06 & 8.29 & 59.24 & & 0.54 \\
\hline \multirow[b]{3}{*}{ BSC } & $10-m^{2}$ & 15 & 0.0 & 0.00 & - & - & - & - & & - \\
\hline & $1-m^{2}$ & 15 & 0.0 & 0.00 & - & - & - & - & 0.0 & - \\
\hline & Line-point & 15 & 0.0 & 0.00 & - & - & - & - & & - \\
\hline
\end{tabular}




\section{Appendix D-Among-Macroplot Variation in Selected Cover Measures by Ecological Site}

\begin{tabular}{|l|c|c|}
\hline Ecological site & Table & Page \\
\hline Brushy Loam & D1 & 128 \\
\hline Desert Sand (Sand Sagebrush) & D2 & 129 \\
\hline Limy Upland, 6-10" pz & D3 & 130 \\
\hline Loamy Hills, 25-33" pz & D4 & 131 \\
\hline Loamy Hills, Cold, 25-33" pz & D5 & 132 \\
\hline Loamy Mesa Top PJ & D6 & 133 \\
\hline Semidesert Alkali Sandy Loam (Alkali Sacaton) & D7 & 134 \\
\hline Semidesert Loam (Wyoming Big Sagebrush) & D8 & 135 \\
\hline Semidesert Shallow Sandy Loam PJ & D9 & 136 \\
\hline Shallow Loamy, 10-14" pz & D10 & 137 \\
\hline Upland Shallow Loam (Pinyon-Utah Juniper) & D11 & 138 \\
\hline
\end{tabular}


Table D1. Among-macroplot variation in selected cover measures for five Brushy Loam macroplots in Mesa Verde National Park, macroplot sample sizes required to achive 10 and $20 \%$ precision in estimates of ecological-site-level means, and ratios of within-to-among CV values. See Appendix A for keys to species codes (BSC = biological soil crust).

\begin{tabular}{|c|c|c|c|c|c|c|c|c|c|c|}
\hline \multicolumn{11}{|c|}{ Brushy Loam ecological site, $n=5$ macroplots } \\
\hline \multirow[b]{2}{*}{ Measure } & \multirow[b]{2}{*}{ Method } & \multirow{2}{*}{$\begin{array}{l}\text { Mean } \\
\text { cover }\end{array}$} & \multicolumn{5}{|c|}{ Among-macroplot variation in cover estimates } & \multicolumn{2}{|c|}{$\begin{array}{c}\text { Sample size } \\
\text { (by precision) }\end{array}$} & \multirow{2}{*}{$\begin{array}{c}\text { CV ratio } \\
\text { (within:among) }\end{array}$} \\
\hline & & & sd & Min & $\operatorname{Max}$ & Range & $\mathrm{CV}$ & $10 \%$ & $20 \%$ & \\
\hline \multirow{3}{*}{$\begin{array}{c}\text { Total live understory } \\
\text { canopy cover }\end{array}$} & $10-m^{2}$ & 49.7 & 16.0 & 28.4 & 71.2 & 42.8 & 32.2 & 42 & 13 & 1.1 \\
\hline & $1-\mathrm{m}^{2}$ & 43.4 & 13.7 & 25.8 & 62.6 & 36.8 & 31.6 & 42 & 13 & 1.9 \\
\hline & Line-point & 52.8 & 3.3 & 48.7 & 56.0 & 7.3 & 6.2 & 4 & 3 & 7.3 \\
\hline \multirow[b]{3}{*}{ AMUT } & $10-m^{2}$ & 6.5 & 5.6 & 1.4 & 15.5 & 14.1 & 85.7 & 286 & 74 & 2.4 \\
\hline & $1-\mathrm{m}^{2}$ & 3.2 & 4.4 & 0.0 & 10.8 & 10.8 & 138.9 & 727 & 184 & 1.9 \\
\hline & Line-point & 5.2 & 3.8 & 0.7 & 10.3 & 9.7 & 72.3 & 206 & 54 & 3.1 \\
\hline \multirow[b]{3}{*}{ POFE } & $10-m^{2}$ & 9.6 & 13.2 & 0.0 & 30.4 & 30.3 & 136.9 & 720 & 183 & 1.1 \\
\hline & $1-m^{2}$ & 7.6 & 9.5 & 0.0 & 20.9 & 20.8 & 125.4 & 605 & 154 & 1.7 \\
\hline & Line-point & 8.8 & 9.1 & 0.0 & 20.7 & 20.7 & 103.1 & 409 & 105 & 1.7 \\
\hline \multirow[b]{3}{*}{ QUGA } & $10-m^{2}$ & 14.5 & 16.8 & 1.2 & 37.4 & 36.2 & 115.3 & 511 & 131 & 1.8 \\
\hline & $1-m^{2}$ & 16.2 & 16.5 & 0.7 & 37.1 & 36.5 & 102.0 & 400 & 103 & 2.3 \\
\hline & Line-point & 14.5 & 15.7 & 0.7 & 33.0 & 32.3 & 108.2 & 451 & 115 & 1.7 \\
\hline \multirow[b]{3}{*}{ Bare soil } & $10-m^{2}$ & 14.3 & 11.0 & 6.7 & 32.3 & 25.6 & 76.9 & 228 & 60 & 1.1 \\
\hline & $1-m^{2}$ & 16.8 & 14.8 & 4.2 & 40.9 & 36.7 & 88.0 & 298 & 77 & 1.8 \\
\hline & Line-point & 41.3 & 26.4 & 8.0 & 78.0 & 70.0 & 63.9 & 160 & 42 & 1.2 \\
\hline \multirow[b]{3}{*}{ Litter } & $10-m^{2}$ & 70.4 & 16.2 & 44.2 & 84.2 & 40.0 & 23.0 & 23 & 8 & 1.1 \\
\hline & $1-m^{2}$ & 75.4 & 16.6 & 49.0 & 91.1 & 42.1 & 22.1 & 22 & 8 & 1.3 \\
\hline & Line-point & 52.3 & 26.2 & 17.3 & 87.0 & 69.7 & 50.0 & 99 & 27 & 1.0 \\
\hline \multirow[b]{3}{*}{ BSC } & $10-m^{2}$ & 0.2 & 0.2 & 0.0 & 0.4 & 0.4 & 121.4 & 588 & 151 & 1.8 \\
\hline & $1-m^{2}$ & 0.1 & 0.2 & 0.0 & 0.4 & 0.4 & 170.0 & 1111 & 278 & 2.2 \\
\hline & Line-point & 0.2 & 0.3 & 0.0 & 0.7 & 0.7 & 149.1 & 865 & 217 & 3.1 \\
\hline
\end{tabular}


Table D2. Among-macroplot variation in selected cover measures for two Desert Sand (Sand Sagebrush) macroplots in Canyonlands National Park, macroplot sample sizes required to achive 10 and 20\% precision in estimates of ecologicalsite-level means, and ratios of within-to-among CV values. See Appendix A for keys to species codes (BSC = biological soil crust).

\begin{tabular}{|c|c|c|c|c|c|c|c|c|c|c|}
\hline \multicolumn{11}{|c|}{ Desert Sand (Sand Sagebrush) ecological site, $n=2$ macroplots } \\
\hline \multirow[b]{2}{*}{ Measure } & \multirow[b]{2}{*}{ Method } & \multirow{2}{*}{$\begin{array}{l}\text { Mean } \\
\text { cover }\end{array}$} & \multicolumn{5}{|c|}{ Among-macroplot variation in cover estimates } & \multicolumn{2}{|c|}{$\begin{array}{c}\text { Sample size } \\
\text { (by precision) }\end{array}$} & \multirow{2}{*}{$\begin{array}{c}\text { CV ratio } \\
\text { (within:among) }\end{array}$} \\
\hline & & & sd & Min & $\operatorname{Max}$ & Range & $\mathrm{CV}$ & $10 \%$ & $20 \%$ & \\
\hline \multirow{3}{*}{$\begin{array}{l}\text { Total live understory } \\
\text { canopy cover }\end{array}$} & $10-m^{2}$ & 13.4 & 0.4 & 13.1 & 13.7 & 0.6 & 3.3 & 3 & 3 & 8.5 \\
\hline & $1-m^{2}$ & 12.3 & 0.3 & 12.1 & 12.5 & 0.4 & 2.3 & 3 & 3 & 27.0 \\
\hline & Line-point & 11.7 & 0.0 & 11.7 & 11.7 & 0.0 & 0.0 & 2 & 2 & - \\
\hline \multirow[b]{3}{*}{ ATCA2 } & $10-m^{2}$ & 1.5 & 0.5 & 1.1 & 1.8 & 0.8 & 37.1 & 56 & 16 & 4.6 \\
\hline & $1-m^{2}$ & 1.7 & 0.1 & 1.6 & 1.7 & 0.2 & 7.1 & 5 & 3 & 59.8 \\
\hline & Line-point & 1.3 & 0.9 & 0.7 & 2.0 & 1.3 & 70.7 & 194 & 51 & 4.4 \\
\hline \multirow[b]{3}{*}{ HIJA } & $10-m^{2}$ & 1.7 & 0.8 & 1.2 & 2.3 & 1.1 & 45.8 & 83 & 23 & 3.2 \\
\hline & $1-\mathrm{m}^{2}$ & 1.1 & 0.1 & 1.0 & 1.2 & 0.2 & 10.9 & 8 & 4 & 17.9 \\
\hline & Line-point & 1.2 & 0.2 & 1.0 & 1.3 & 0.3 & 20.2 & 19 & 7 & 18.2 \\
\hline \multirow[b]{3}{*}{ STHY6 } & $10-m^{2}$ & 0.6 & 0.6 & 0.2 & $\frac{1.0}{1.1}$ & 0.9 & $\begin{array}{l}20 . L \\
99.5\end{array}$ & 381 & $\frac{1}{98}$ & $\begin{array}{c}10.2 \\
1.2\end{array}$ \\
\hline & $1-\mathrm{m}^{2}$ & 0.5 & 0.6 & 0.1 & $\begin{array}{l}1.1 \\
0.9\end{array}$ & 0.8 & 114.0 & 501 & 128 & $\begin{array}{l}1.2 \\
1.7\end{array}$ \\
\hline & Line-point & 1.8 & 2.1 & 0.3 & 3.3 & 3.0 & $\frac{1.4 .0}{115.7}$ & 514 & 131 & 3.0 \\
\hline \multirow[b]{3}{*}{ Litter } & $10-m^{2}$ & 6.9 & 1.2 & 6.0 & 7.7 & 1.6 & 16.9 & 14 & 6 & 3.7 \\
\hline & $1-m^{2}$ & 6.6 & 1.3 & 5.6 & 7.5 & 1.9 & 20.4 & 19 & 7 & 3.8 \\
\hline & Line-point & 8.3 & 2.8 & 6.3 & 10.3 & 4.0 & 33.9 & 47 & 14 & 3.2 \\
\hline \multirow[b]{3}{*}{ Undifferentiated crust } & $10-m^{2}$ & 67.6 & 6.3 & 63.1 & 72.0 & 8.9 & 9.3 & 6 & 4 & 2.4 \\
\hline & $1-\mathrm{m}^{2}$ & 79.1 & 2.5 & 77.4 & 80.9 & 3.5 & 3.2 & 3 & 3 & 4.2 \\
\hline & Line-point & 81.5 & 4.5 & 78.3 & 84.7 & 6.3 & 5.5 & 4 & 3 & 3.3 \\
\hline \multirow[b]{3}{*}{ BSC } & $10-m^{2}$ & 4.3 & 4.6 & 1.0 & 7.5 & 6.5 & 107.6 & 446 & 114 & 0.8 \\
\hline & $1-\mathrm{m}^{2}$ & 4.8 & 5.1 & 1.1 & 8.4 & 7.2 & 107.7 & 445 & 114 & 1.1 \\
\hline & Line-point & 6.7 & 7.1 & 1.7 & 11.7 & 10.0 & 106.1 & 432 & 111 & 1.5 \\
\hline
\end{tabular}


Table D3. Among-macroplot variation in selected cover measures for five Limy Upland macroplots in Wupatki National Monument, macroplot sample sizes required to achive 10 and 20\% precision in estimates of ecological-site-level means, and ratios of within-to-among $C V$ values. See Appendix A for keys to species codes.

\begin{tabular}{|c|c|c|c|c|c|c|c|c|c|c|}
\hline \multicolumn{11}{|c|}{ Limy Upland, 6-10" pz ecological site, $n=5$ macroplots } \\
\hline \multirow[b]{2}{*}{ Measure } & \multirow[b]{2}{*}{ Method } & \multirow{2}{*}{$\begin{array}{l}\text { Mean } \\
\text { cover }\end{array}$} & \multicolumn{5}{|c|}{ Among-macroplot variation in cover estimates } & \multicolumn{2}{|c|}{$\begin{array}{c}\text { Sample size } \\
\text { (by precision) }\end{array}$} & \multirow{2}{*}{$\begin{array}{c}\text { CV ratio } \\
\text { (within:among) }\end{array}$} \\
\hline & & & sd & Min & Max & Range & $\mathrm{CV}$ & $10 \%$ & $20 \%$ & \\
\hline \multirow{3}{*}{$\begin{array}{l}\text { Total live understory } \\
\text { canopy cover }\end{array}$} & $10-m^{2}$ & 23.6 & 6.7 & 18.0 & 34.4 & 16.4 & 28.3 & 34 & 11 & 0.9 \\
\hline & $1-m^{2}$ & 16.0 & 3.5 & 11.7 & 20.1 & 8.4 & 21.6 & 21 & $\frac{1 \pm}{7}$ & 1.5 \\
\hline & Line-point & 26.7 & 4.4 & 21.3 & 31.3 & 10.0 & 16.5 & 13 & 6 & 3.6 \\
\hline \multirow[b]{3}{*}{ CHLE4 } & $10-m^{2}$ & 5.1 & 4.0 & 1.1 & 10.7 & 9.6 & 76.8 & 227 & 60 & 1.2 \\
\hline & $1-m^{2}$ & 3.5 & 2.5 & 0.7 & 6.6 & 5.9 & 72.1 & 202 & 53 & 1.3 \\
\hline & Line-point & 3.6 & 3.4 & 0.0 & 8.0 & 8.0 & 95.6 & 351 & 91 & 1.9 \\
\hline \multirow[b]{3}{*}{ HENE5 } & $10-m^{2}$ & 3.7 & 3.4 & 0.6 & 9.0 & 8.4 & 90.6 & 317 & 82 & 1.4 \\
\hline & $1-m^{2}$ & 2.8 & 2.5 & 0.3 & 5.7 & 5.4 & 87.5 & 293 & 76 & 1.7 \\
\hline & Line-point & 6.5 & 5.8 & 0.0 & 15.3 & 15.3 & 88.7 & 303 & 79 & 1.5 \\
\hline \multirow[b]{3}{*}{ PLJA } & $10-m^{2}$ & 4.4 & 3.8 & 0.5 & 9.6 & 9.1 & 86.8 & 290 & 75 & 1.7 \\
\hline & $1-m^{2}$ & 2.3 & 2.0 & 0.3 & 5.5 & 5.2 & 89.0 & 305 & 79 & 1.5 \\
\hline & Line-point & 6.7 & 5.6 & 0.3 & 14.0 & 13.7 & 83.7 & 270 & 70 & 2.7 \\
\hline \multirow[b]{3}{*}{ Bare soil } & $10-m^{2}$ & 7.3 & 7.4 & 1.2 & 16.1 & 15.0 & 101.1 & 393 & 101 & 0.7 \\
\hline & $1-m^{2}$ & 7.3 & 6.9 & 1.9 & 16.7 & 14.8 & 94.8 & 346 & 89 & 0.9 \\
\hline & Line-point & 16.3 & 16.7 & 4.0 & 40.7 & 36.7 & 102.3 & 403 & 103 & 1.1 \\
\hline \multirow[b]{3}{*}{ Litter } & $10-m^{2}$ & 6.6 & 1.7 & 3.9 & 8.4 & 4.5 & 25.7 & 28 & 9 & 2.5 \\
\hline & $1-m^{2}$ & 7.1 & 1.5 & 4.8 & 8.5 & 3.7 & 20.7 & 19 & 7 & 3.2 \\
\hline & Line-point & 3.6 & 5.1 & 0.0 & 11.0 & 11.0 & 142.5 & 781 & 198 & 0.8 \\
\hline
\end{tabular}


Table D4. Among-macroplot variation in selected cover measures for five Loamy Hills macroplots in Grand Canyon National Park, macroplot sample sizes required to achive 10 and 20\% precision in estimates of ecological-site-level means, and ratios of within-to-among CV values. See Appendix A for keys to species codes (BSC = biological soil crust).

\begin{tabular}{|c|c|c|c|c|c|c|c|c|c|c|}
\hline \multicolumn{11}{|c|}{ Loamy Hills, 25-33" pz ecological site, $n=5$ macroplots } \\
\hline \multirow[b]{2}{*}{ Measure } & \multirow[b]{2}{*}{ Method } & \multirow{2}{*}{$\begin{array}{l}\text { Mean } \\
\text { cover }\end{array}$} & \multicolumn{5}{|c|}{ Among-macroplot variation in cover estimates } & \multicolumn{2}{|c|}{$\begin{array}{c}\text { Sample size } \\
\text { (by precision) }\end{array}$} & \multirow{2}{*}{$\begin{array}{c}\text { CV ratio } \\
\text { (within:among) }\end{array}$} \\
\hline & & & sd & Min & Max & Range & $\mathbf{C V}$ & $10 \%$ & $20 \%$ & \\
\hline \multirow{3}{*}{$\begin{array}{c}\text { Total live understory } \\
\text { canopy cover }\end{array}$} & $10-m^{2}$ & 19.7 & 11.6 & 5.6 & 35.2 & 29.5 & 58.9 & 136 & 36 & 1.3 \\
\hline & $1-m^{2}$ & 23.8 & 20.9 & 5.1 & 57.5 & 52.4 & 87.8 & 297 & 77 & 1.4 \\
\hline & Line-point & 16.9 & 7.1 & 8.0 & 24.3 & 16.3 & 42.2 & 71 & 20 & 2.1 \\
\hline \multirow[b]{3}{*}{ POFE } & $10-m^{2}$ & 0.5 & 0.5 & 0.0 & 1.1 & 1.1 & 99.6 & 377 & 97 & 2.3 \\
\hline & $1-m^{2}$ & 0.4 & 0.4 & 0.0 & 1.1 & 1.1 & 109.9 & 465 & 119 & 2.0 \\
\hline & Line-point & 1.5 & 1.4 & 0.0 & 3.3 & 3.3 & 94.3 & 344 & 89 & 3.0 \\
\hline \multirow[b]{3}{*}{ POTR5 } & $10-m^{2}$ & 2.6 & 2.4 & 0.2 & 5.7 & 5.5 & 92.9 & 332 & 86 & 1.9 \\
\hline & $1-m^{2}$ & 4.1 & 3.3 & 0.1 & 8.0 & 7.8 & 81.1 & 254 & 66 & 3.2 \\
\hline & Line-point & 1.8 & 1.8 & 0.0 & 4.7 & 4.7 & 101.1 & 393 & 101 & 2.5 \\
\hline \multirow{3}{*}{$\begin{array}{l}\text { UNGRCA1 } \\
\text { (Carex sp.) }\end{array}$} & $10-m^{2}$ & 1.4 & 0.8 & 0.1 & 1.9 & 1.9 & 54.4 & 117 & 31 & 2.6 \\
\hline & $1-m^{2}$ & 1.2 & 0.7 & 0.1 & 1.9 & 1.8 & 53.9 & 114 & 31 & 3.3 \\
\hline & Line-point & 6.5 & 4.2 & 0.0 & 10.0 & 10.0 & 64.3 & 162 & 43 & 1.9 \\
\hline \multirow[b]{3}{*}{ Bare soil } & $10-m^{2}$ & 1.5 & 0.3 & 1.2 & 2.0 & 0.8 & 20.0 & 19 & 7 & 6.4 \\
\hline & $1-m^{2}$ & 1.9 & 0.5 & 1.5 & 2.7 & 1.2 & 25.4 & 27 & 9 & 6.2 \\
\hline & Line-point & 14.9 & 11.1 & 4.7 & 28.7 & 24.0 & 74.4 & 213 & 56 & 1.9 \\
\hline \multirow[b]{3}{*}{ Litter } & $10-m^{2}$ & 74.8 & 11.4 & 61.3 & 84.2 & 22.9 & 15.2 & 12 & 5 & 1.1 \\
\hline & $1-m^{2}$ & 80.1 & 7.3 & 73.9 & 89.5 & 15.6 & 9.1 & 6 & 4 & 2.2 \\
\hline & Line-point & 69.3 & 7.9 & 60.0 & 78.0 & 18.0 & 11.3 & 8 & 4 & 2.9 \\
\hline \multirow[b]{3}{*}{ BSC } & $10-m^{2}$ & 0.7 & 0.9 & 0.0 & 1.9 & 1.9 & 130.2 & 656 & 167 & 2.1 \\
\hline & $1-m^{2}$ & 0.6 & 0.8 & 0.0 & 1.4 & 1.4 & 126.9 & 617 & 157 & 2.3 \\
\hline & Line-point & 0.3 & 0.4 & 0.0 & 1.0 & 1.0 & 163.0 & 997 & 251 & 2.9 \\
\hline
\end{tabular}


Table D5. Among-macroplot variation in selected cover measures for two Loamy Hills, Cold, macroplots in Grand Canyon National Park, macroplot sample sizes required to achive 10 and $20 \%$ precision in estimates of ecological-sitelevel means, and ratios of within-to-among CV values. See Appendix A for keys to species codes (BSC = biological soil crust).

\begin{tabular}{|c|c|c|c|c|c|c|c|c|c|c|}
\hline \multicolumn{11}{|c|}{ Loamy Hills, Cold, 25-33" pz ecological site, $n$ = 2 macroplots } \\
\hline \multirow[b]{2}{*}{ Measure } & \multirow[b]{2}{*}{ Method } & \multirow{2}{*}{$\begin{array}{l}\text { Mean } \\
\text { cover }\end{array}$} & \multicolumn{5}{|c|}{ Among-macroplot variation in cover estimates } & \multicolumn{2}{|c|}{$\begin{array}{c}\text { Sample size } \\
\text { (by precision) }\end{array}$} & \multirow{2}{*}{$\begin{array}{c}\text { CV ratio } \\
\text { (within:among) }\end{array}$} \\
\hline & & & sd & Min & Max & Range & CV & $10 \%$ & $20 \%$ & \\
\hline \multirow{3}{*}{$\begin{array}{c}\text { Total live understory } \\
\text { canopy cover }\end{array}$} & $10-m^{2}$ & 48.8 & 7.4 & 43.6 & 54.0 & 10.5 & 15.2 & 12 & 5 & 4.3 \\
\hline & $1-\mathrm{m}^{2}$ & 57.3 & 28.2 & 37.4 & 77.3 & 39.9 & 49.2 & 96 & 26 & 1.6 \\
\hline & Line-point & 25.7 & 2.8 & 23.7 & 27.7 & 4.0 & 11.0 & 8 & 4 & 6.8 \\
\hline \multirow[b]{3}{*}{$\mathrm{ABCO}$} & $10-m^{2}$ & 8.6 & 12.2 & 0.0 & 17.2 & 17.2 & 141.4 & 769 & 195 & 1.1 \\
\hline & $1-m^{2}$ & 12.9 & 18.2 & 0.0 & 25.7 & 25.7 & 141.4 & 769 & 195 & 0.8 \\
\hline & Line-point & 4.5 & 6.4 & 0.0 & 9.0 & 9.0 & 141.4 & 768 & 195 & 0.9 \\
\hline \multirow[b]{3}{*}{ PIEN } & $10-m^{2}$ & 6.9 & 5.5 & 3.0 & 10.8 & 7.8 & 80.4 & 249 & 65 & 3.9 \\
\hline & $1-m^{2}$ & 8.3 & 11.7 & 0.0 & 16.5 & 16.5 & 141.4 & 769 & 195 & 1.1 \\
\hline & Line-point & 4.2 & 4.9 & 0.7 & 7.7 & 7.0 & 118.8 & 543 & 138 & 3.0 \\
\hline \multirow[b]{3}{*}{ POTR5 } & $10-m^{2}$ & 4.7 & 1.4 & 3.7 & 5.7 & 2.0 & 29.6 & 37 & 11 & 6.3 \\
\hline & $1-m^{2}$ & 6.2 & 2.7 & 4.3 & 8.1 & 3.8 & 43.1 & 74 & 21 & 4.9 \\
\hline & Line-point & 1.0 & 0.5 & 0.7 & 1.3 & 0.7 & 47.1 & 88 & 24 & 6.8 \\
\hline \multirow[b]{3}{*}{ Bare soil } & $10-m^{2}$ & 2.5 & 0.2 & 2.3 & 2.7 & 0.3 & 9.4 & 7 & 4 & 17.0 \\
\hline & $1-m^{2}$ & 1.8 & 0.7 & 1.3 & 2.3 & 1.0 & 39.3 & 63 & 18 & 4.7 \\
\hline & Line-point & 4.0 & 1.9 & 2.7 & 5.3 & 2.7 & 47.1 & 89 & 24 & 4.8 \\
\hline \multirow[b]{3}{*}{ Litter } & $10-m^{2}$ & 70.2 & 0.8 & 69.6 & 70.8 & 1.2 & 1.2 & 3 & 2 & 18.1 \\
\hline & $1-m^{2}$ & 80.4 & 2.0 & 79.0 & 81.8 & 2.8 & 2.5 & 3 & 3 & 6.7 \\
\hline & Line-point & 81.3 & 0.5 & 81.0 & 81.7 & 0.7 & 0.6 & 3 & 2 & 35.8 \\
\hline \multirow[b]{3}{*}{ BSC } & $10-m^{2}$ & 1.1 & 0.8 & 0.5 & 1.6 & 1.1 & 75.4 & 220 & 58 & 1.8 \\
\hline & $1-m^{2}$ & 1.2 & 0.7 & 0.7 & 1.7 & 1.0 & 61.7 & 149 & 39 & 5.1 \\
\hline & Line-point & 1.0 & 1.4 & 0.0 & 2.0 & 2.0 & 141.4 & 764 & 194 & 1.7 \\
\hline
\end{tabular}


Table D6. Among-macroplot variation in selected cover measures for five Loamy Mesa Top PJ macroplots in Mesa

Verde National Park, macroplot sample sizes required to achive 10 and $20 \%$ precision in estimates of ecological-site-level means, and ratios of within-to-among CV values. See Appendix A for keys to species codes (BSC = biological soil crust).

\begin{tabular}{|c|c|c|c|c|c|c|c|c|c|c|}
\hline \multicolumn{11}{|c|}{ Loamy Mesa Top PJ ecological site, $n=5$ macroplots } \\
\hline \multirow[b]{2}{*}{ Measure } & \multirow[b]{2}{*}{ Method } & \multirow{2}{*}{$\begin{array}{l}\text { Mean } \\
\text { cover }\end{array}$} & \multicolumn{5}{|c|}{ Among-macroplot variation in cover estimates } & \multicolumn{2}{|c|}{$\begin{array}{c}\text { Sample size } \\
\text { (by precision) }\end{array}$} & \multirow{2}{*}{$\begin{array}{c}\text { CV ratio } \\
\text { (within:among) }\end{array}$} \\
\hline & & & sd & Min & Max & Range & CV & $10 \%$ & $20 \%$ & \\
\hline \multirow{3}{*}{$\begin{array}{l}\text { Total live understory } \\
\text { canopy cover }\end{array}$} & $10-m^{2}$ & 32.7 & 15.2 & 20.9 & 55.7 & 34.8 & 46.5 & 86 & 24 & 3.4 \\
\hline & $1-\mathrm{m}^{2}$ & 29.6 & 12.7 & 13.2 & 43.7 & 30.5 & 42.7 & 73 & 21 & 4.7 \\
\hline & Line-point & 20.7 & 3.5 & 17.3 & 26.7 & 9.3 & 17.0 & 14 & 6 & 7.8 \\
\hline \multirow[b]{3}{*}{ JUOS } & $10-m^{2}$ & 7.7 & 4.1 & 3.3 & 12.2 & 8.9 & 52.9 & 110 & 30 & 3.1 \\
\hline & $1-m^{2}$ & 9.8 & 7.5 & 2.7 & 20.1 & 17.4 & 76.7 & 227 & 59 & 2.8 \\
\hline & Line-point & 3.4 & 1.3 & 2.0 & 5.3 & 3.3 & 39.5 & 63 & 18 & 4.6 \\
\hline \multirow[b]{3}{*}{ PIED } & $10-m^{2}$ & 12.4 & 8.8 & 5.4 & 26.2 & 20.8 & 70.4 & 193 & 50 & 1.8 \\
\hline & $1-m^{2}$ & 10.9 & 4.0 & 4.6 & 15.4 & 10.8 & 37.2 & 56 & 16 & 5.6 \\
\hline & Line-point & 7.3 & 3.0 & 2.7 & 10.0 & 7.3 & 40.3 & 65 & 19 & 3.7 \\
\hline \multirow[b]{3}{*}{ POFE } & $10-m^{2}$ & 7.0 & 5.2 & 0.5 & 13.1 & 12.6 & 74.2 & 212 & 56 & 0.8 \\
\hline & $1-m^{2}$ & 4.7 & 2.9 & 0.5 & 8.0 & 7.6 & 61.7 & 149 & 40 & 1.7 \\
\hline & Line-point & 7.7 & 4.6 & 2.0 & 12.7 & 10.7 & 60.2 & 142 & 38 & 2.1 \\
\hline \multirow[b]{3}{*}{ Bare soil } & $10-m^{2}$ & 2.1 & 1.7 & 0.7 & 4.2 & 3.5 & 82.0 & 259 & 67 & 0.8 \\
\hline & $1-m^{2}$ & 2.3 & 2.4 & 0.6 & 6.3 & 5.7 & 105.4 & 428 & 110 & 1.0 \\
\hline & Line-point & 7.1 & 4.7 & 2.7 & 14.0 & 11.3 & 66.2 & 171 & 45 & 1.1 \\
\hline \multirow[b]{3}{*}{ Litter } & $10-m^{2}$ & 47.2 & 7.2 & 38.2 & 58.5 & 20.3 & 15.3 & 12 & 5 & 4.1 \\
\hline & $1-m^{2}$ & 50.5 & 13.0 & 36.4 & 69.7 & 33.3 & 25.7 & 28 & 9 & 2.8 \\
\hline & Line-point & 47.5 & 15.2 & 34.7 & 69.3 & 34.7 & 32.0 & 42 & 13 & 1.6 \\
\hline \multirow[b]{3}{*}{ BSC } & $10-m^{2}$ & 3.9 & 1.3 & 1.8 & 5.2 & 3.4 & 34.1 & 47 & 14 & 2.9 \\
\hline & $1-m^{2}$ & 5.4 & 3.2 & 1.9 & 9.1 & 7.2 & 58.9 & 136 & 36 & 2.2 \\
\hline & Line-point & 7.4 & 4.5 & 4.7 & 15.3 & 10.7 & 60.5 & 143 & 38 & 2.5 \\
\hline
\end{tabular}


Table D7. Among-macroplot variation in selected cover measures for five Semidesert Alkali Sandy Loam macroplots in Capitol Reef National Park, macroplot sample sizes required to achive 10 and 20\% precision in estimates of ecologicalsite-level means, and ratios of within-to-among CV values. See Appendix A for keys to species codes (BSC = biological soil crust).

\begin{tabular}{|c|c|c|c|c|c|c|c|c|c|c|}
\hline \multicolumn{11}{|c|}{ Semidesert Alkali Sandy Loam (Alkali Sacaton) ecological site, $n=5$ macroplots } \\
\hline \multirow[b]{2}{*}{ Measure } & \multirow[b]{2}{*}{ Method } & \multirow{2}{*}{$\begin{array}{l}\text { Mean } \\
\text { cover }\end{array}$} & \multicolumn{5}{|c|}{ Among-macroplot variation in cover estimates } & \multicolumn{2}{|c|}{$\begin{array}{c}\text { Sample size } \\
\text { (by precision) }\end{array}$} & \multirow{2}{*}{$\begin{array}{c}\text { CV ratio } \\
\text { (within:among) }\end{array}$} \\
\hline & & & sd & Min & Max & Range & CV & $10 \%$ & $20 \%$ & \\
\hline \multirow{3}{*}{$\begin{array}{l}\text { Total live understory } \\
\text { canopy cover }\end{array}$} & $10-m^{2}$ & 20.3 & 10.3 & 7.3 & 35.5 & 28.2 & 50.9 & 102 & 28 & 0.9 \\
\hline & $1-\mathrm{m}^{2}$ & 18.1 & 6.6 & 7.1 & 24.6 & 17.5 & 36.5 & 54 & 16 & 2.0 \\
\hline & Line-point & 25.4 & 10.1 & 11.3 & 37.3 & 26.0 & 40.0 & 64 & 18 & 1.8 \\
\hline \multirow[b]{3}{*}{ ATCO } & $10-m^{2}$ & 2.6 & 1.8 & 0.6 & 4.6 & 4.0 & 69.5 & 188 & 49 & 2.0 \\
\hline & $1-m^{2}$ & 2.5 & 2.6 & 0.7 & 7.1 & 6.4 & 104.9 & 424 & 109 & 1.8 \\
\hline & Line-point & 3.1 & 2.0 & 0.0 & 5.7 & 5.7 & 66.7 & 175 & 46 & 3.1 \\
\hline \multirow[b]{3}{*}{ GIIN2 } & $10-m^{2}$ & 0.3 & 0.1 & 0.2 & 0.4 & 0.3 & 39.3 & 61 & 17 & 2.4 \\
\hline & $1-m^{2}$ & 0.4 & 0.2 & 0.2 & 0.6 & 0.4 & 44.6 & 77 & 22 & 3.1 \\
\hline & Line-point & 0.3 & 0.6 & 0.0 & 1.3 & 1.3 & 173.2 & 1166 & 291 & 2.3 \\
\hline \multirow[b]{3}{*}{ ORHY } & $10-m^{2}$ & 0.5 & 0.2 & 0.3 & 0.7 & 0.4 & 29.5 & 37 & 12 & 2.9 \\
\hline & $1-m^{2}$ & 0.6 & 0.1 & 0.3 & 0.7 & 0.4 & 25.2 & 28 & 9 & 4.0 \\
\hline & Line-point & 1.2 & 1.3 & 0.0 & 3.3 & 3.3 & 106.9 & 438 & 112 & 2.9 \\
\hline \multirow[b]{3}{*}{ Bare soil } & $10-m^{2}$ & 0.8 & 0.4 & 0.3 & 1.3 & 1.0 & 44.1 & 76 & 21 & 3.7 \\
\hline & $1-m^{2}$ & 1.2 & 0.7 & 0.3 & 2.1 & 1.8 & 62.2 & 152 & 40 & 2.9 \\
\hline & Line-point & 4.3 & 2.6 & 0.7 & 8.0 & 7.3 & 60.6 & 143 & 38 & 3.3 \\
\hline \multirow[b]{3}{*}{ Litter } & $10-m^{2}$ & 9.7 & 5.2 & 1.3 & 15.6 & 14.3 & 53.9 & 114 & 31 & 1.4 \\
\hline & $1-m^{2}$ & 10.6 & 5.9 & 1.7 & 18.2 & 16.5 & 55.9 & 123 & 33 & 2.5 \\
\hline & Line-point & 5.5 & 2.9 & 0.7 & 8.0 & 7.3 & 52.7 & 110 & 30 & 3.5 \\
\hline \multirow[b]{3}{*}{ BSC } & $10-m^{2}$ & 1.8 & 2.0 & 0.3 & 5.3 & 5.0 & 110.0 & 466 & 119 & 0.9 \\
\hline & $1-m^{2}$ & 1.5 & 1.1 & 0.3 & 3.2 & 2.9 & 74.3 & 215 & 56 & 1.7 \\
\hline & Line-point & 3.3 & 3.5 & 0.0 & 8.0 & 8.0 & 107.6 & 446 & 114 & 2.2 \\
\hline
\end{tabular}


Table D8. Among-macroplot variation in selected cover measures for five Semidesert Loam macroplots in Dinosaur National Monument, macroplot sample sizes required to achive 10 and $20 \%$ precision in estimates of ecological-site-level means, and ratios of within-to-among CV values. See Appendix A for keys to species codes (BSC = biological soil crust).

\begin{tabular}{|c|c|c|c|c|c|c|c|c|c|c|}
\hline \multirow[b]{2}{*}{ Measure } & \multirow[b]{2}{*}{ Method } & \multirow{2}{*}{$\begin{array}{l}\text { Mean } \\
\text { cover }\end{array}$} & \multicolumn{5}{|c|}{ Among-macroplot variation in cover estimates } & \multicolumn{2}{|c|}{$\begin{array}{c}\text { Sample size } \\
\text { (by precision) }\end{array}$} & \multirow{2}{*}{$\begin{array}{c}\text { CV ratio } \\
\text { (within:among) }\end{array}$} \\
\hline & & & sd & Min & Max & Range & CV & $10 \%$ & $20 \%$ & \\
\hline \multirow{3}{*}{$\begin{array}{l}\text { Total live understory } \\
\text { canopy cover }\end{array}$} & $10-m^{2}$ & 32.2 & 15.5 & 20.7 & 59.4 & 38.7 & 48.0 & 92 & 25 & 0.8 \\
\hline & $1-m^{2}$ & 20.2 & 9.4 & 14.0 & 36.6 & 22.6 & 46.6 & 86 & 24 & 1.5 \\
\hline & Line-point & 53.8 & 24.9 & 34.0 & 96.3 & 62.3 & 46.3 & 85 & 24 & 1.0 \\
\hline \multirow[b]{3}{*}{ ARTR2 } & $10-m^{2}$ & 9.6 & 5.9 & 0.7 & 16.3 & 15.6 & 62.0 & 150 & 40 & 1.5 \\
\hline & $1-m^{2}$ & 5.3 & 3.4 & 0.1 & 9.0 & 8.9 & 65.1 & 166 & 44 & 3.4 \\
\hline & Line-point & 4.8 & 3.1 & 0.0 & 8.0 & 8.0 & 63.9 & 160 & 42 & 2.1 \\
\hline \multirow[b]{3}{*}{ BRTE } & $10-m^{2}$ & 11.9 & 15.5 & 2.8 & 39.2 & 36.4 & 130.4 & 653 & 166 & 0.9 \\
\hline & $1-m^{2}$ & 7.3 & 9.4 & 1.2 & 23.7 & 22.5 & 130.3 & 653 & 166 & 1.1 \\
\hline & Line-point & 30.1 & 19.2 & 8.0 & 57.0 & 49.0 & 63.8 & 159 & 42 & 1.4 \\
\hline \multirow[b]{3}{*}{ STCO4 } & $10-m^{2}$ & 2.5 & 4.1 & 0.0 & 9.7 & 9.7 & 164.6 & 1040 & 260 & 0.6 \\
\hline & $1-m^{2}$ & 1.3 & 1.5 & 0.0 & 3.4 & 3.4 & 113.2 & 492 & 126 & 1.2 \\
\hline & Line-point & 4.2 & 8.0 & 0.0 & 18.3 & 18.3 & 190.1 & 1387 & 347 & 0.9 \\
\hline \multirow[b]{3}{*}{ Bare soil } & $10-m^{2}$ & 0.7 & 0.6 & 0.2 & 1.8 & 1.6 & 89.1 & 301 & 78 & 1.0 \\
\hline & $1-m^{2}$ & 1.1 & 0.9 & 0.1 & 2.3 & 2.1 & 86.5 & 286 & 74 & 1.8 \\
\hline & Line-point & 10.5 & 5.0 & 3.3 & 15.3 & 12.0 & 47.4 & 89 & 25 & 2.3 \\
\hline \multirow[b]{3}{*}{ Litter } & $10-m^{2}$ & 34.2 & 17.5 & 14.9 & 60.1 & 45.2 & 51.1 & 103 & 28 & 0.9 \\
\hline & $1-m^{2}$ & 35.0 & 22.2 & 18.0 & 72.2 & 54.2 & 63.5 & 158 & 42 & 1.3 \\
\hline & Line-point & 29.8 & 18.6 & 14.7 & 54.3 & 39.7 & 62.4 & 152 & 40 & 1.1 \\
\hline \multirow[b]{3}{*}{ BSC } & $10-m^{2}$ & 5.5 & 2.6 & 1.8 & 7.9 & 6.1 & 46.2 & 85 & 23 & 1.9 \\
\hline & $1-m^{2}$ & 5.5 & 3.1 & 2.4 & 10.7 & 8.4 & 56.2 & 124 & 33 & 1.2 \\
\hline & Line-point & 12.1 & 7.3 & 4.3 & 22.0 & 17.7 & 60.7 & 144 & 38 & 1.8 \\
\hline
\end{tabular}


Table D9. Among-macroplot variation in selected cover measures for seven Semidesert Shallow Sandy Loam macroplots in Arches and Canyonlands National Parks, macroplot sample sizes required to achive 10 and $20 \%$ precision in estimates of ecological-site-level means, and ratios of within-to-among CV values. See Appendix A for keys to species codes (BSC $=$ biological soil crust).

\begin{tabular}{|c|c|c|c|c|c|c|c|c|c|c|}
\hline \multirow[b]{2}{*}{ Measure } & \multirow[b]{2}{*}{ Method } & \multirow{2}{*}{$\begin{array}{l}\text { Mean } \\
\text { cover }\end{array}$} & \multicolumn{5}{|c|}{ Among-macroplot variation in cover estimates } & \multicolumn{2}{|c|}{$\begin{array}{c}\text { Sample size } \\
\text { (by precision) }\end{array}$} & \multirow{2}{*}{$\begin{array}{c}\text { CV ratio } \\
\text { (within:among) }\end{array}$} \\
\hline & & & sd & Min & Max & Range & CV & $10 \%$ & $20 \%$ & \\
\hline \multirow{3}{*}{$\begin{array}{l}\text { Total live understory } \\
\text { canopy cover }\end{array}$} & $10-m^{2}$ & 18.8 & 4.8 & 13.7 & 28.2 & 14.5 & 25.5 & 28 & 9 & 2.6 \\
\hline & $1-m^{2}$ & 16.4 & 5.4 & 10.5 & 24.0 & 13.5 & 33.1 & 45 & 14 & 2.9 \\
\hline & Line-point & 13.3 & 5.7 & 6.7 & 21.7 & 15.0 & 42.7 & 73 & 21 & 2.4 \\
\hline \multirow[b]{3}{*}{ CORA } & $10-m^{2}$ & 10.3 & 7.0 & 2.4 & 22.9 & 20.5 & 68.0 & 181 & 47 & 1.6 \\
\hline & $1-m^{2}$ & 9.2 & 5.6 & 4.2 & 19.6 & 15.4 & 61.1 & 146 & 39 & 2.1 \\
\hline & Line-point & 6.2 & 3.2 & 3.3 & 10.3 & 7.0 & 51.4 & 105 & 28 & 2.6 \\
\hline \multirow[b]{3}{*}{ FEOC3 } & $10-m^{2}$ & 0.5 & 0.5 & 0.1 & 1.5 & 1.4 & 92.6 & 332 & 86 & 1.2 \\
\hline & $1-m^{2}$ & 0.5 & 0.3 & 0.1 & 0.9 & 0.8 & 61.3 & 147 & 39 & 2.1 \\
\hline & Line-point & 0.9 & 1.4 & 0.0 & 4.0 & 4.0 & 157.3 & 946 & 237 & 2.0 \\
\hline \multirow[b]{3}{*}{ Bare soil } & $10-m^{2}$ & 1.0 & 0.6 & 0.3 & 1.9 & 1.6 & 64.6 & 161 & 42 & 1.4 \\
\hline & $1-m^{2}$ & 1.5 & 0.9 & 0.7 & 3.1 & 2.4 & 63.7 & 158 & 42 & 2.2 \\
\hline & Line-point & 4.3 & 2.5 & 1.7 & 8.0 & 6.3 & 57.9 & 132 & 35 & 3.4 \\
\hline \multirow[b]{3}{*}{ Litter } & $10-m^{2}$ & 5.6 & 4.1 & 2.0 & 13.1 & 11.1 & 73.7 & 209 & 55 & 2.0 \\
\hline & $1-m^{2}$ & 6.0 & 3.6 & 2.5 & 11.3 & 8.8 & 61.2 & 147 & 39 & 3.0 \\
\hline & Line-point & 3.6 & 4.7 & 0.7 & 12.3 & 11.7 & 128.6 & 635 & 161 & 2.4 \\
\hline \multirow[b]{3}{*}{ Undifferentiated crust } & $10-m^{2}$ & 69.8 & 18.9 & 30.6 & 87.5 & 56.9 & 27.1 & 31 & 10 & 1.1 \\
\hline & $1-m^{2}$ & 73.7 & 13.4 & 46.7 & 86.7 & 40.0 & 18.2 & 16 & 6 & 1.6 \\
\hline & Line-point & 70.4 & 16.1 & 40.0 & 84.0 & 44.0 & 22.9 & 23 & 8 & 1.3 \\
\hline \multirow[b]{3}{*}{ BSC } & $10-m^{2}$ & 5.6 & 3.1 & 1.6 & 10.9 & 9.3 & 56.2 & 124 & 33 & 1.9 \\
\hline & $1-m^{2}$ & 6.3 & 3.6 & 1.0 & 12.2 & 11.2 & 57.3 & 129 & 34 & 2.0 \\
\hline & Line-point & 10.8 & 6.2 & 1.7 & 18.3 & 16.7 & 57.5 & 130 & 35 & 2.3 \\
\hline
\end{tabular}


Table D10. Among-macroplot variation in selected cover measures for two Shallow Loamy macroplots in Wupatki National Monument, macroplot sample sizes required to achive 10 and $20 \%$ precision in estimates of ecological-site-level means, and ratios of within-to-among CV values. See Appendix A for keys to species codes.

\begin{tabular}{|c|c|c|c|c|c|c|c|c|c|c|}
\hline \multicolumn{11}{|c|}{ Shallow Loamy, 10-14" pz ecological site, $n=2$ macroplots } \\
\hline \multirow[b]{2}{*}{ Measure } & \multirow[b]{2}{*}{ Method } & \multirow{2}{*}{$\begin{array}{l}\text { Mean } \\
\text { cover }\end{array}$} & \multicolumn{5}{|c|}{ Among-macroplot variation in cover estimates } & \multicolumn{2}{|c|}{$\begin{array}{c}\text { Sample size } \\
\text { (by precision) }\end{array}$} & \multirow{2}{*}{$\begin{array}{c}\text { CV ratio } \\
\text { (within:among) }\end{array}$} \\
\hline & & & sd & Min & Max & Range & CV & $10 \%$ & $20 \%$ & \\
\hline \multirow{3}{*}{$\begin{array}{l}\text { Total live understory } \\
\text { canopy cover }\end{array}$} & $10-m^{2}$ & 18.3 & 9.5 & 11.5 & 25.0 & 13.5 & 52.1 & 107 & 29 & 0.8 \\
\hline & $1-m^{2}$ & 17.2 & 4.7 & 13.9 & 20.5 & 6.6 & 27.3 & 32 & 10 & 3.2 \\
\hline & Line-point & 27.3 & 19.3 & 13.7 & 41.0 & 27.3 & 70.7 & 195 & 51 & 0.8 \\
\hline \multirow[b]{3}{*}{ CHLE4 } & $10-m^{2}$ & 2.0 & 2.0 & 0.6 & 3.4 & 2.8 & 100.3 & 387 & 100 & 0.9 \\
\hline & $1-\mathrm{m}^{2}$ & 1.7 & 0.9 & 1.1 & 2.4 & 1.3 & 53.5 & 113 & 31 & 2.3 \\
\hline & Line-point & 3.0 & 3.3 & 0.7 & 5.3 & 4.7 & 110.0 & 465 & 119 & 2.3 \\
\hline \multirow[b]{3}{*}{ HENE5 } & $10-m^{2}$ & 3.5 & 2.2 & 2.0 & 5.0 & 3.1 & 62.3 & 152 & 40 & 1.6 \\
\hline & $1-m^{2}$ & 2.3 & 1.1 & 1.5 & 3.0 & 1.6 & 49.2 & 96 & 26 & 1.9 \\
\hline & Line-point & 6.2 & 5.4 & 2.3 & 10.0 & 7.7 & 87.9 & 297 & 77 & 1.7 \\
\hline \multirow[b]{3}{*}{ PLJA } & $10-m^{2}$ & 4.5 & 2.6 & 2.7 & 6.4 & 3.7 & 57.8 & 131 & 35 & 1.3 \\
\hline & $1-m^{2}$ & 4.3 & 2.8 & 2.3 & 6.3 & 4.0 & 65.8 & 169 & 45 & 1.3 \\
\hline & Line-point & 7.2 & 3.5 & 4.7 & 9.7 & 5.0 & 49.3 & 97 & 26 & 2.6 \\
\hline \multirow[b]{3}{*}{ Bare soil } & $10-m^{2}$ & 1.8 & 0.5 & 1.5 & 2.1 & 0.7 & 26.4 & 30 & 10 & 3.5 \\
\hline & $1-m^{2}$ & 3.5 & 1.5 & 2.5 & 4.6 & 2.1 & 42.7 & 73 & 21 & 3.0 \\
\hline & Line-point & 9.3 & 7.1 & 4.3 & 14.3 & 10.0 & 75.8 & 221 & 58 & 2.0 \\
\hline \multirow[b]{3}{*}{ Litter } & $10-m^{2}$ & 6.4 & 1.4 & 5.4 & 7.3 & 2.0 & 21.7 & 21 & 8 & 3.8 \\
\hline & $1-m^{2}$ & 8.5 & 1.1 & 7.8 & 9.3 & 1.5 & 12.5 & 9 & 4 & 11.5 \\
\hline & Line-point & 8.8 & 3.5 & 6.3 & 11.3 & 5.0 & 40.0 & 65 & 18 & 2.9 \\
\hline
\end{tabular}


Table D11. Among-macroplot variation in selected cover measures for two Upland Shallow Loam macroplots in Capitol Reef National Park, macroplot sample sizes required to achive 10 and $20 \%$ precision in estimates of ecological-site-level means, and ratios of within-to-among CV values. See Appendix A for keys to species codes (BSC = biological soil crust).

\begin{tabular}{|c|c|c|c|c|c|c|c|c|c|c|}
\hline \multicolumn{11}{|c|}{ Upland Shallow Loam (Pinyon-Utah Juniper) ecological site, $n=5$ macroplots } \\
\hline \multirow[b]{2}{*}{ Measure } & \multirow[b]{2}{*}{ Method } & \multirow{2}{*}{$\begin{array}{l}\text { Mean } \\
\text { cover }\end{array}$} & \multicolumn{5}{|c|}{ Among-macroplot variation in cover estimates } & \multicolumn{2}{|c|}{$\begin{array}{c}\text { Sample size } \\
\text { (by precision) }\end{array}$} & \multirow{2}{*}{$\begin{array}{c}\text { CV ratio } \\
\text { (within:among) }\end{array}$} \\
\hline & & & sd & Min & Max & Range & CV & $10 \%$ & $20 \%$ & \\
\hline \multirow{3}{*}{$\begin{array}{c}\text { Total live understory } \\
\text { canopy cover }\end{array}$} & $10-m^{2}$ & 16.5 & 4.4 & 10.2 & 21.2 & 11.0 & 26.4 & 30 & 10 & 4.4 \\
\hline & $1-\mathrm{m}^{2}$ & 15.4 & 6.3 & 7.2 & 21.1 & 13.9 & 40.9 & 67 & 19 & 4.3 \\
\hline & Line-point & 11.7 & 4.5 & 4.7 & 16.0 & 11.3 & 38.7 & 60 & 17 & 3.3 \\
\hline \multirow[b]{3}{*}{ CEMO2 } & $10-m^{2}$ & 1.9 & 1.8 & 0.0 & 4.2 & 4.2 & 99.4 & 381 & 98 & 2.1 \\
\hline & $1-m^{2}$ & 1.3 & 2.0 & 0.0 & 4.7 & 4.7 & 150.3 & 864 & 217 & 1.7 \\
\hline & Line-point & 2.4 & 3.6 & 0.0 & 8.0 & 8.0 & 149.1 & 855 & 214 & 1.3 \\
\hline \multirow[b]{3}{*}{ COWR2 } & $10-m^{2}$ & 1.2 & 0.4 & 0.7 & 1.8 & 1.1 & 35.0 & 51 & 15 & 3.3 \\
\hline & $1-m^{2}$ & 1.1 & 0.6 & 0.6 & 1.8 & 1.2 & 49.9 & 98 & 27 & 2.3 \\
\hline & Line-point & 2.3 & 1.8 & 0.0 & 4.7 & 4.7 & 75.6 & 219 & 58 & 2.8 \\
\hline \multirow[b]{3}{*}{ JUOS } & $10-m^{2}$ & 5.6 & 2.1 & 3.0 & 8.8 & 5.7 & 36.9 & 55 & 16 & 6.2 \\
\hline & $1-m^{2}$ & 4.8 & 2.7 & 0.9 & 8.0 & 7.1 & 56.1 & 124 & 33 & 5.5 \\
\hline & Line-point & 2.5 & 1.3 & 0.7 & 4.0 & 3.3 & 50.6 & 101 & 27 & 5.1 \\
\hline \multirow[b]{3}{*}{ Bare soil } & $10-m^{2}$ & 1.1 & 0.5 & 0.5 & 1.6 & 1.1 & 41.1 & 69 & 20 & 2.6 \\
\hline & $1-m^{2}$ & 1.6 & 0.4 & 1.1 & 2.1 & 1.0 & 26.8 & 31 & 10 & 3.7 \\
\hline & Line-point & 15.3 & 4.9 & 6.7 & 18.7 & 12.0 & 32.3 & 43 & 13 & 3.0 \\
\hline \multirow[b]{3}{*}{ Litter } & $10-m^{2}$ & 16.8 & 7.6 & 5.4 & 26.4 & 21.0 & 45.4 & 82 & 23 & 3.1 \\
\hline & $1-m^{2}$ & 22.0 & 12.1 & 8.5 & 37.7 & 29.1 & 55.0 & 119 & 32 & 3.1 \\
\hline & Line-point & 6.8 & 5.2 & 2.7 & 14.0 & 11.3 & 76.5 & 225 & 59 & 2.7 \\
\hline \multirow[b]{3}{*}{ BSC } & $10-m^{2}$ & 0.1 & 0.1 & 0.0 & 0.1 & 0.1 & 68.6 & 169 & 45 & 3.2 \\
\hline & $1-m^{2}$ & 0.1 & 0.1 & 0.0 & 0.2 & 0.2 & 93.5 & 309 & 81 & 4.3 \\
\hline & Line-point & 0.2 & 0.3 & 0.0 & 0.7 & 0.7 & 149.1 & 865 & 217 & 3.1 \\
\hline
\end{tabular}




\section{Appendix E-Mean Species-Area and Compositional Curves by Ecological Site}

\begin{tabular}{|l|c|c|}
\hline Ecological site & Figure & Page \\
\hline Brushy Loam & E1 & 140 \\
\hline Desert Sand (Sand Sagebrush) & E2 & 141 \\
\hline Limy Upland, 6-10" pz & E3 & 142 \\
\hline Loamy Hills, 25-33" pz & E4 & 143 \\
\hline Loamy Hills, Cold, 25-33" pz & E5 & 144 \\
\hline Loamy Mesa Top PJ & E6 & 145 \\
\hline Semidesert Alkali Sandy Loam (Alkali Sacaton) & E7 & 146 \\
\hline Semidesert Loam (Wyoming Big Sagebrush) & E8 & 147 \\
\hline Semidesert Shallow Sandy Loam PJ & E9 & 148 \\
\hline Shallow Loamy, 10-14" pz & E10 & 149 \\
\hline Upland Shallow Loam (Pinyon-Utah Juniper) & E11 & 150 \\
\hline
\end{tabular}




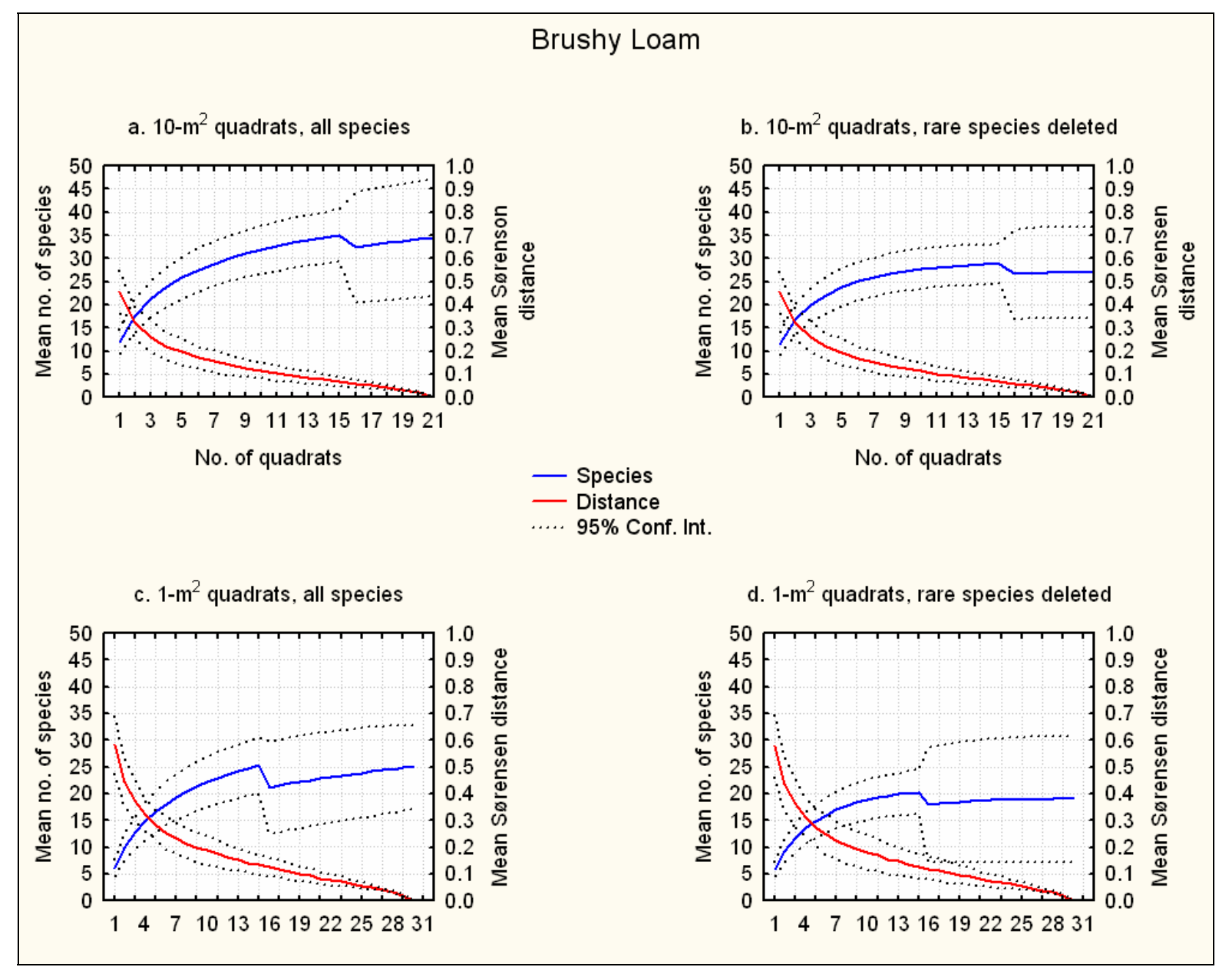

Figure E1. Mean species-area and compositional curves (mean Sørensen distances) for the Brushy Loam ecological site at Mesa Verde National Park for (a) 10- $\mathrm{m}^{2}$ quadrats, including all species; (b) 10- $\mathrm{m}^{2}$ quadrats, exluding rare (infrequent) species that occurred in only one subsample quadrat; (c) $1-\mathrm{m}^{2}$ quadrats, including all species; and (d) 1- $\mathrm{m}^{2}$ quadrats, excluding rare species. Species-area curves are based on data from five macroplots for quadrats 1-15 and two macroplots for quadrats $>15$. Compositional curves are based on data from two macroplots. 


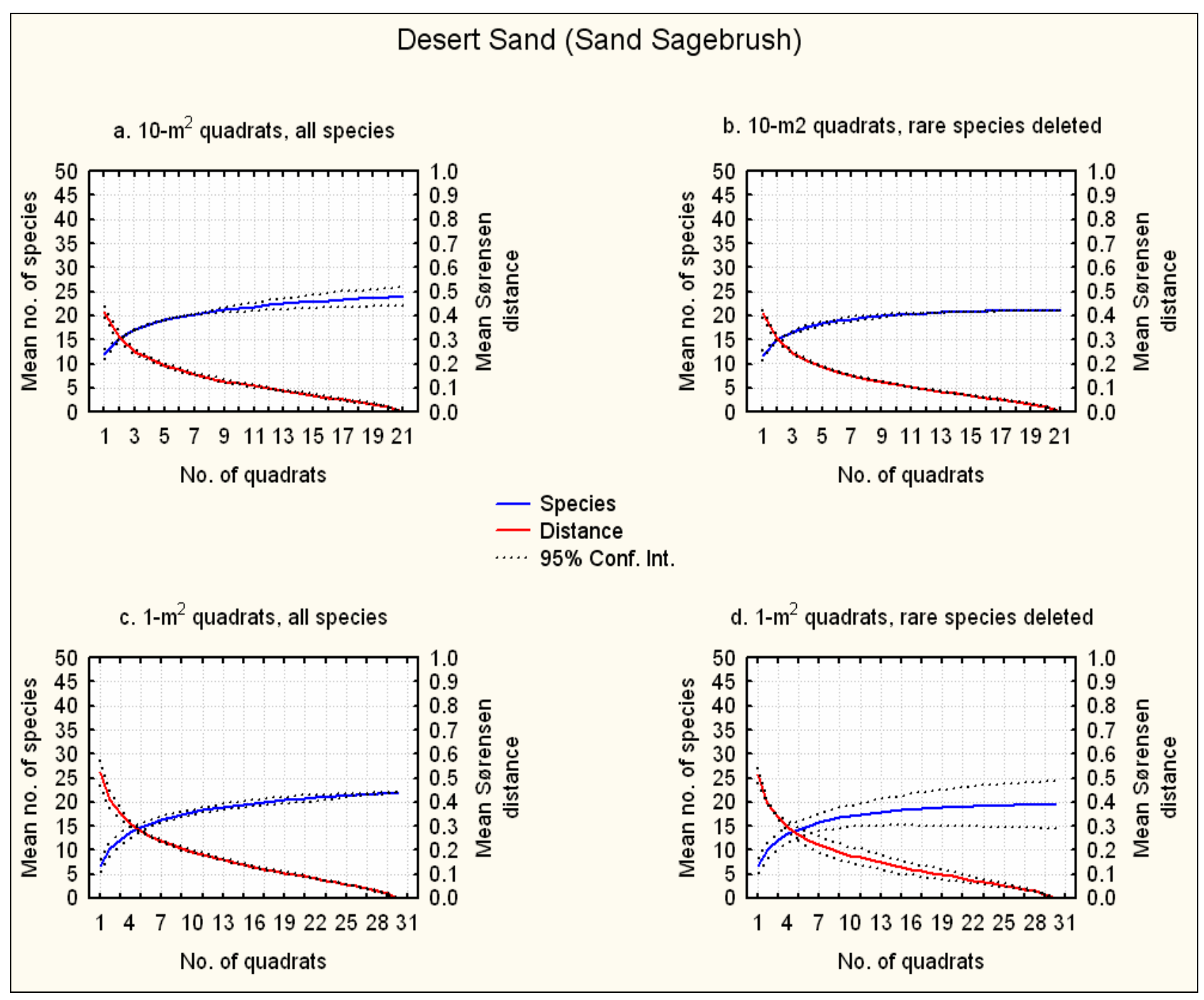

Figure E2. Mean species-area and compositional curves (mean Sørensen distances) for the Desert Sand ecological site at Canyonlands National Park for (a) 10- $\mathrm{m}^{2}$ quadrats, including all species; (b) 10- $\mathrm{m}^{2}$ quadrats, exluding rare (infrequent) species that occurred in only one subsample quadrat; (c) 1- $\mathrm{m}^{2}$ quadrats, including all species; and (d) 1-m ${ }^{2}$ quadrats, excluding rare species. All curves are based on data from two macroplots. 


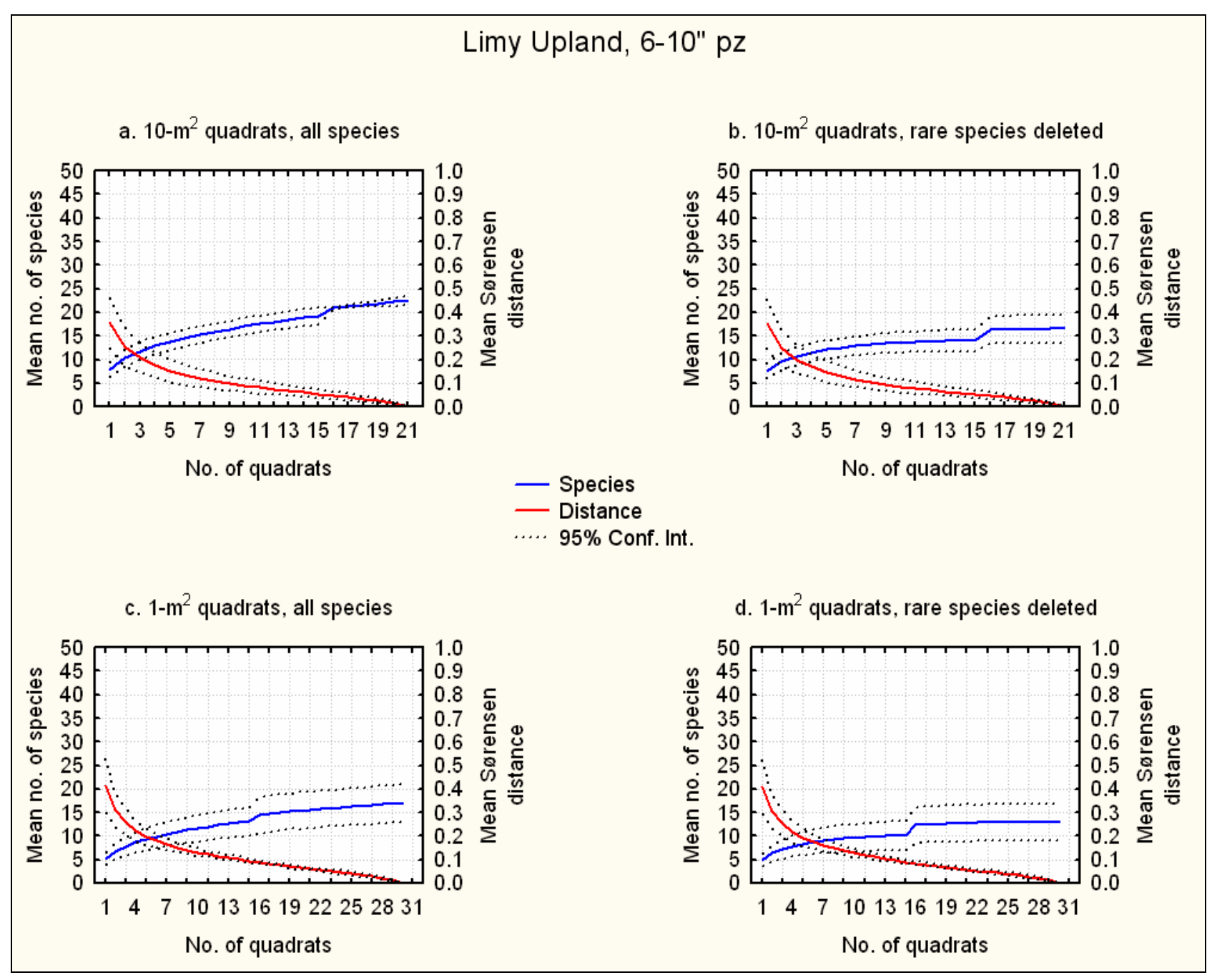

Figure E3. Mean species-area and compositional curves (mean Sørensen distances) for the Limy Upland ecological site at Mesa Verde National Park for (a) 10- $\mathrm{m}^{2}$ quadrats, including all species; (b) 10- $\mathrm{m}^{2}$ quadrats, exluding rare (infrequent) species that occurred in only one subsample quadrat; (c) 1- $\mathrm{m}^{2}$ quadrats, including all species; and (d) 1- $\mathrm{m}^{2}$ quadrats, excluding rare species. Species-area curves are based on data from five macroplots for quadrats 1-15 and two macroplots for quadrats $>15$. Compositional curves are based on data from two macroplots. 


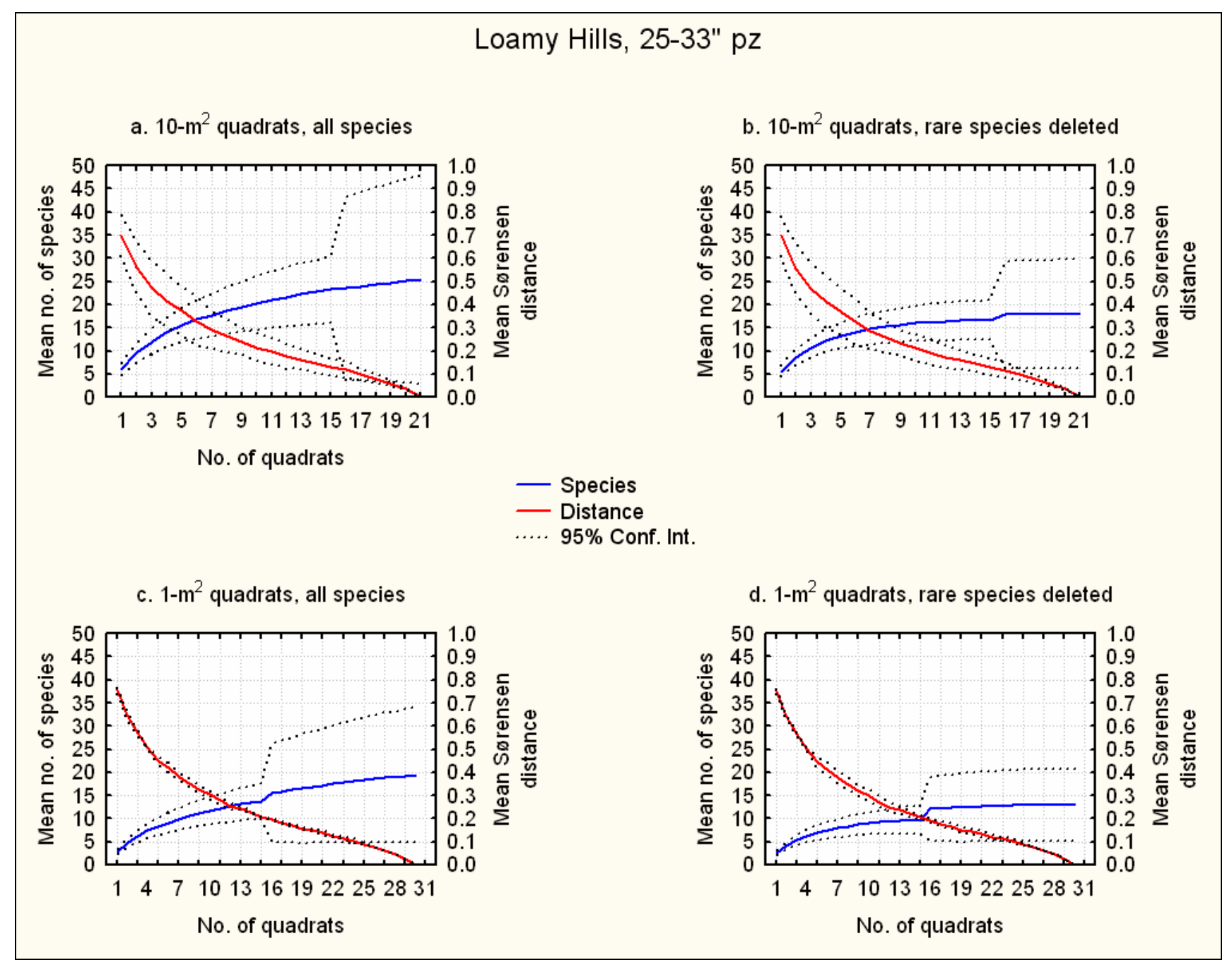

Figure E4. Mean species-area and compositional curves (mean Sørensen distances) for the Loamy Hills ecological site at Grand Canyon National Park for (a) $10-\mathrm{m}^{2}$ quadrats, including all species; (b) $10-\mathrm{m}^{2}$ quadrats, exluding rare (infrequent) species that occurred in only one subsample quadrat; (c) 1- $\mathrm{m}^{2}$ quadrats, including all species; and (d) 1- $\mathrm{m}^{2}$ quadrats, excluding rare species. Species-area curves are based on data from five macroplots for quadrats 1-15 and two macroplots for quadrats $>15$. Compositional curves are based on data from two macroplots. 


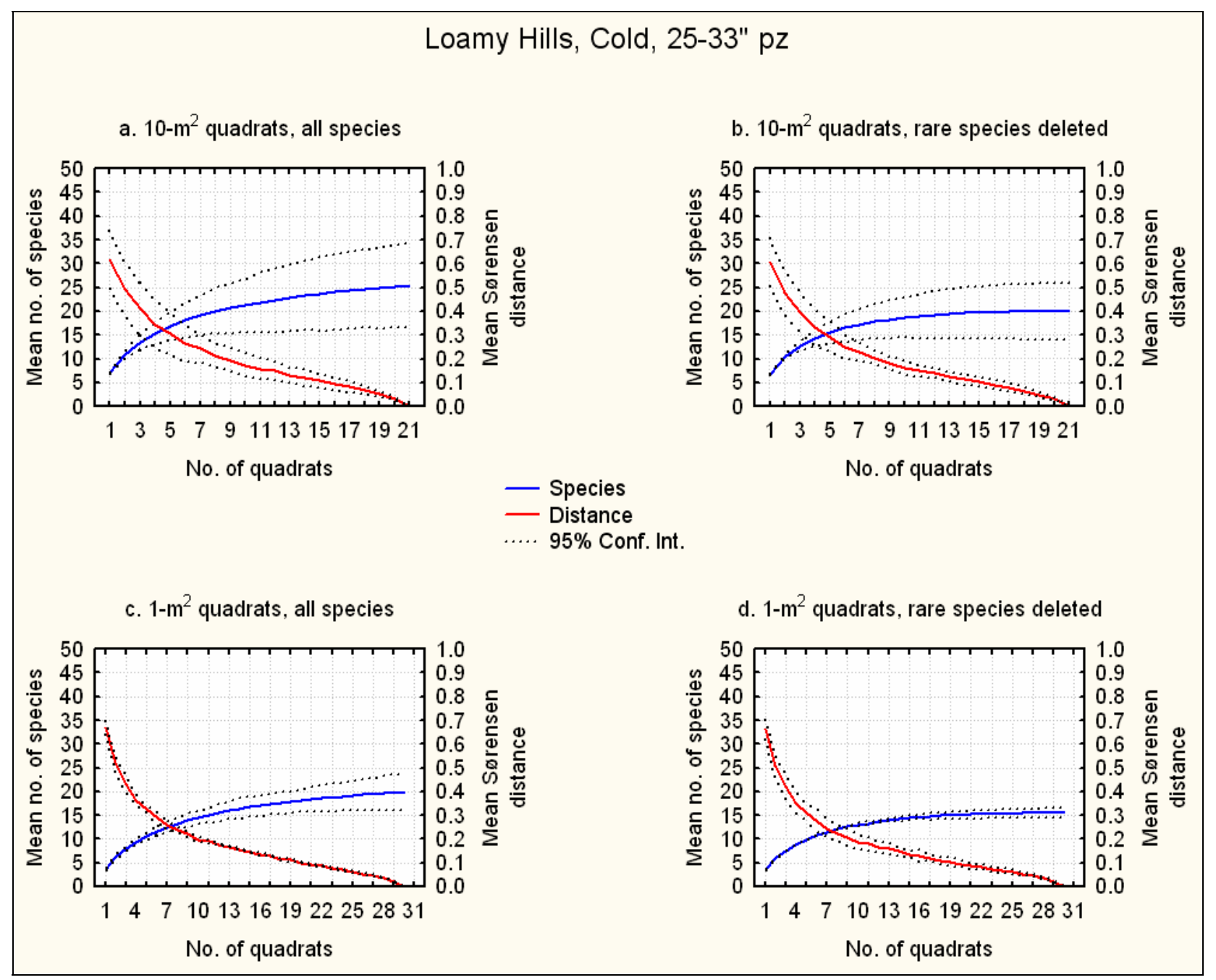

Figure E5. Mean species-area and compositional curves (mean Sørensen distances) for the Loamy Hills, Cold, ecological site at Grand Canyon National Park for (a) 10- $\mathrm{m}^{2}$ quadrats, including all species; (b) 10-m ${ }^{2}$ quadrats, exluding rare (infrequent) species that occurred in only one subsample quadrat; (c) 1- $\mathrm{m}^{2}$ quadrats, including all species; and (d) 1$\mathrm{m}^{2}$ quadrats, excluding rare species. Species-area curves are based on data from five macroplots for quadrats 1-15 and two macroplots for quadrats $>15$. Compositional curves are based on data from two macroplots. 


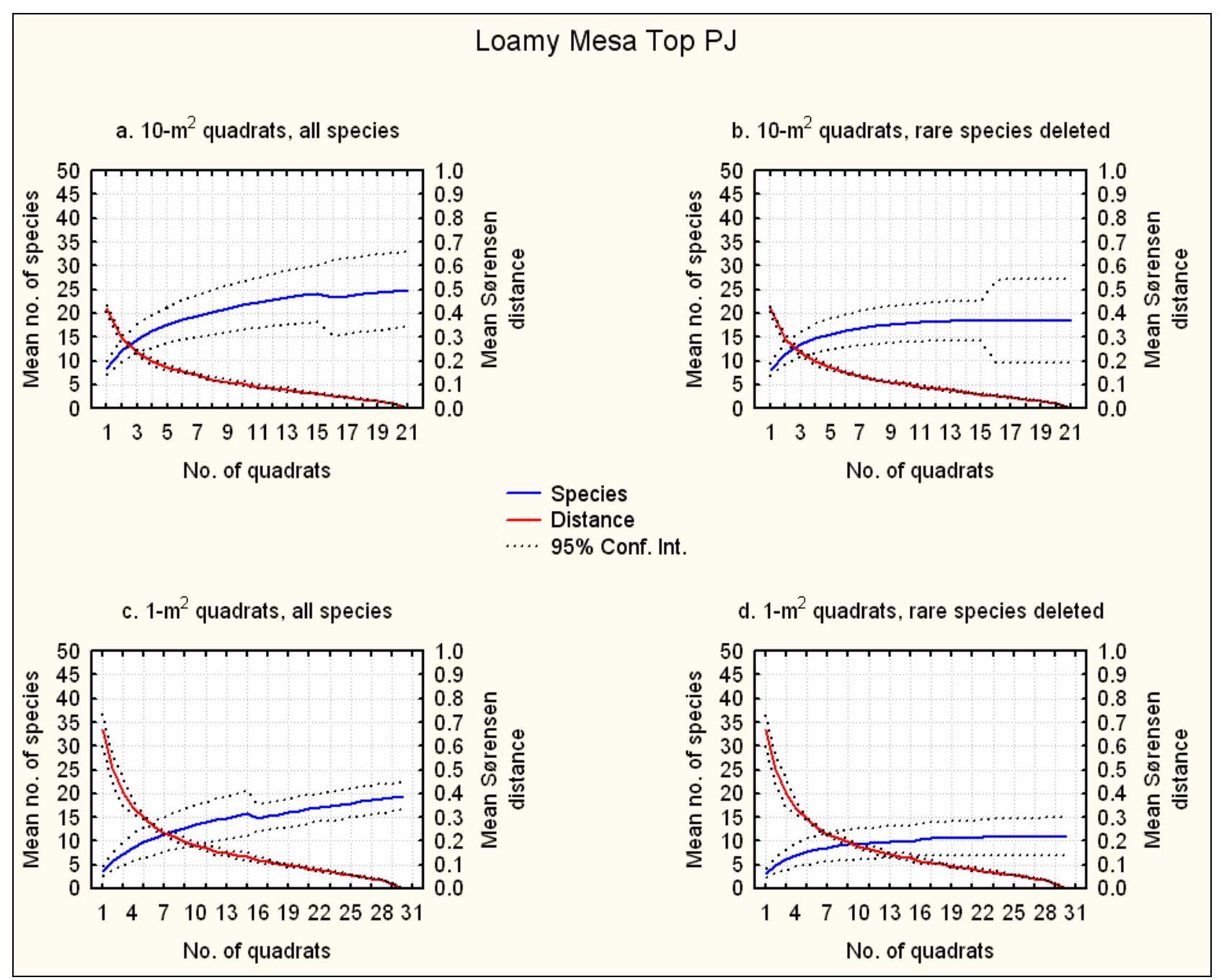

Figure E6. Mean species-area and compositional curves (mean Sørensen distances) for the Loamy Mesa Top PJ ecological site at Mesa Verde National Park for (a) $10-\mathrm{m}^{2}$ quadrats, including all species; (b) $10-\mathrm{m}^{2}$ quadrats, exluding rare (infrequent) species that occurred in only one subsample quadrat; (c) 1- $\mathrm{m}^{2}$ quadrats, including all species; and (d) 1$\mathrm{m}^{2}$ quadrats, excluding rare species. Species-area curves are based on data from five macroplots for quadrats 1-15 and two macroplots for quadrats $>15$. Compositional curves are based on data from two macroplots. 


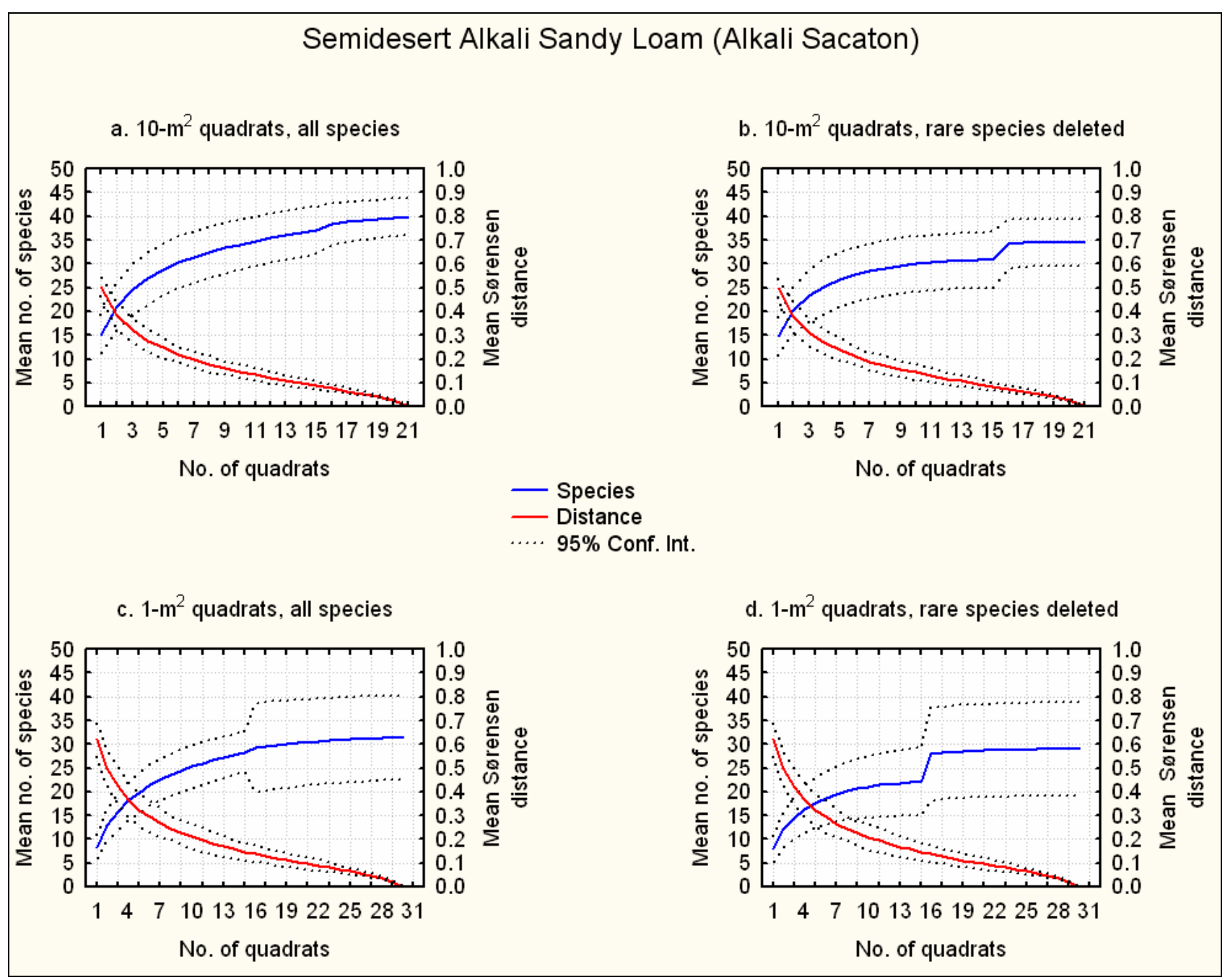

Figure E7. Mean species-area and compositional curves (mean Sørensen distances) for the Semidesert Alkali Sandy Loam ecological site at Capitol Reef National Park for (a) 10- $\mathrm{m}^{2}$ quadrats, including all species; (b) $10-\mathrm{m}^{2}$ quadrats, exluding rare (infrequent) species that occurred in only one subsample quadrat; (c) 1- $\mathrm{m}^{2}$ quadrats, including all species; and (d) $1-\mathrm{m}^{2}$ quadrats, excluding rare species. Species-area curves are based on data from five macroplots for quadrats 1-15 and two macroplots for quadrats $>15$. Compositional curves are based on data from two macroplots. 


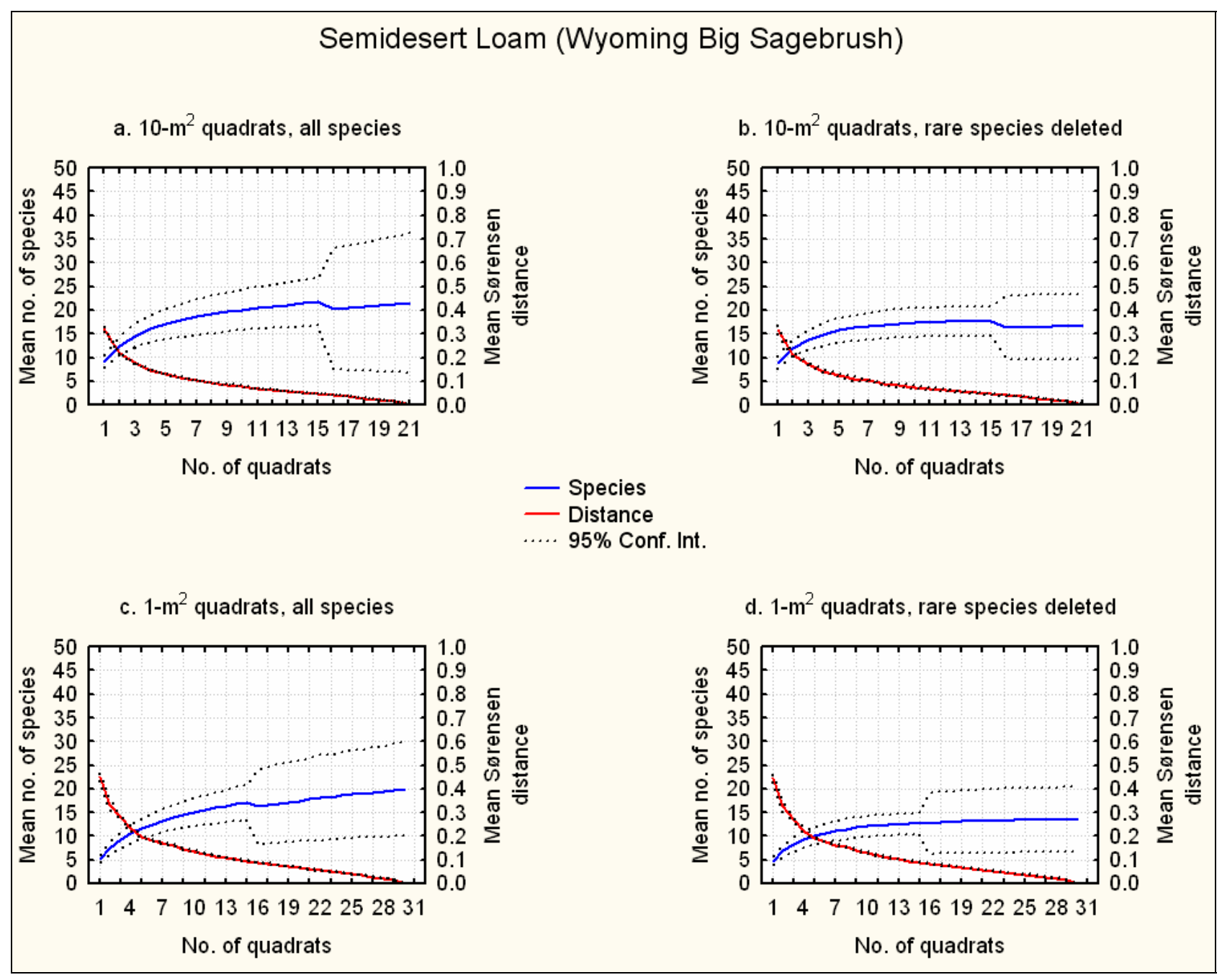

Figure E8. Mean species-area and compositional curves (mean Sørensen distances) for the Semidesert Loam ecological

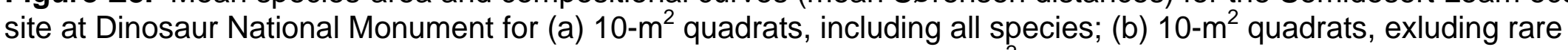
(infrequent) species that occurred in only one subsample quadrat; (c) 1- $\mathrm{m}^{2}$ quadrats, including all species; and (d) 1- $\mathrm{m}^{2}$ quadrats, excluding rare species. Species-area curves are based on data from five macroplots for quadrats 1-15 and two macroplots for quadrats $>15$. Compositional curves are based on data from two macroplots. 


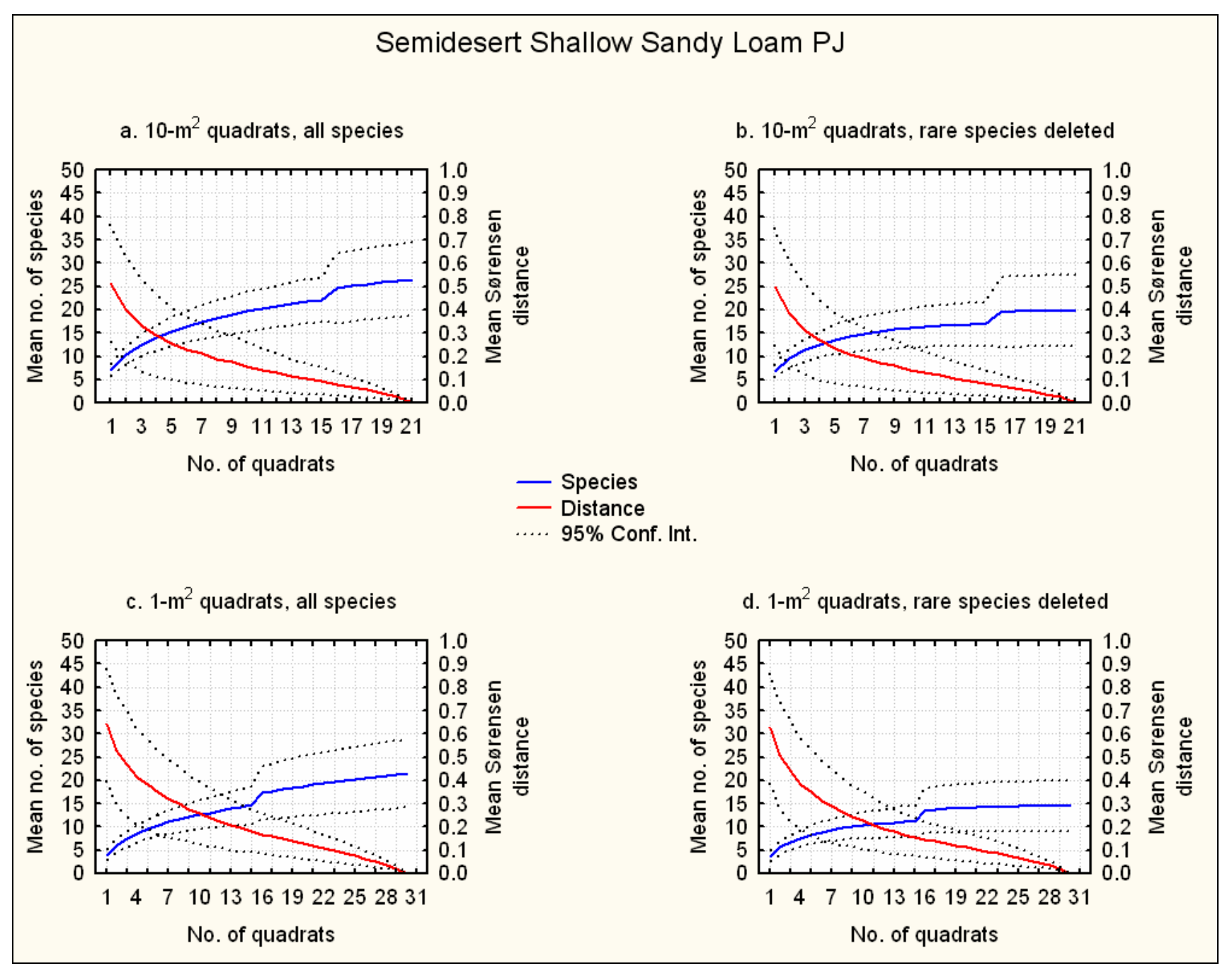

Figure E9. Mean species-area and compositional curves (mean Sørensen distances) for the Semidesert Shallow Sandy Loam ecological site at Arches and Canyonlands National Park for (a) $10-\mathrm{m}^{2}$ quadrats, including all species; (b) $10-\mathrm{m}^{2}$ quadrats, exluding rare (infrequent) species that occurred in only one subsample quadrat; (c) 1- $\mathrm{m}^{2}$ quadrats, including all species; and (d) $1-\mathrm{m}^{2}$ quadrats, excluding rare species. Species-area curves are based on data from seven macroplots for quadrats 1-15 and four macroplots for quadrats $>15$. Compositional curves are based on data from four macroplots. 


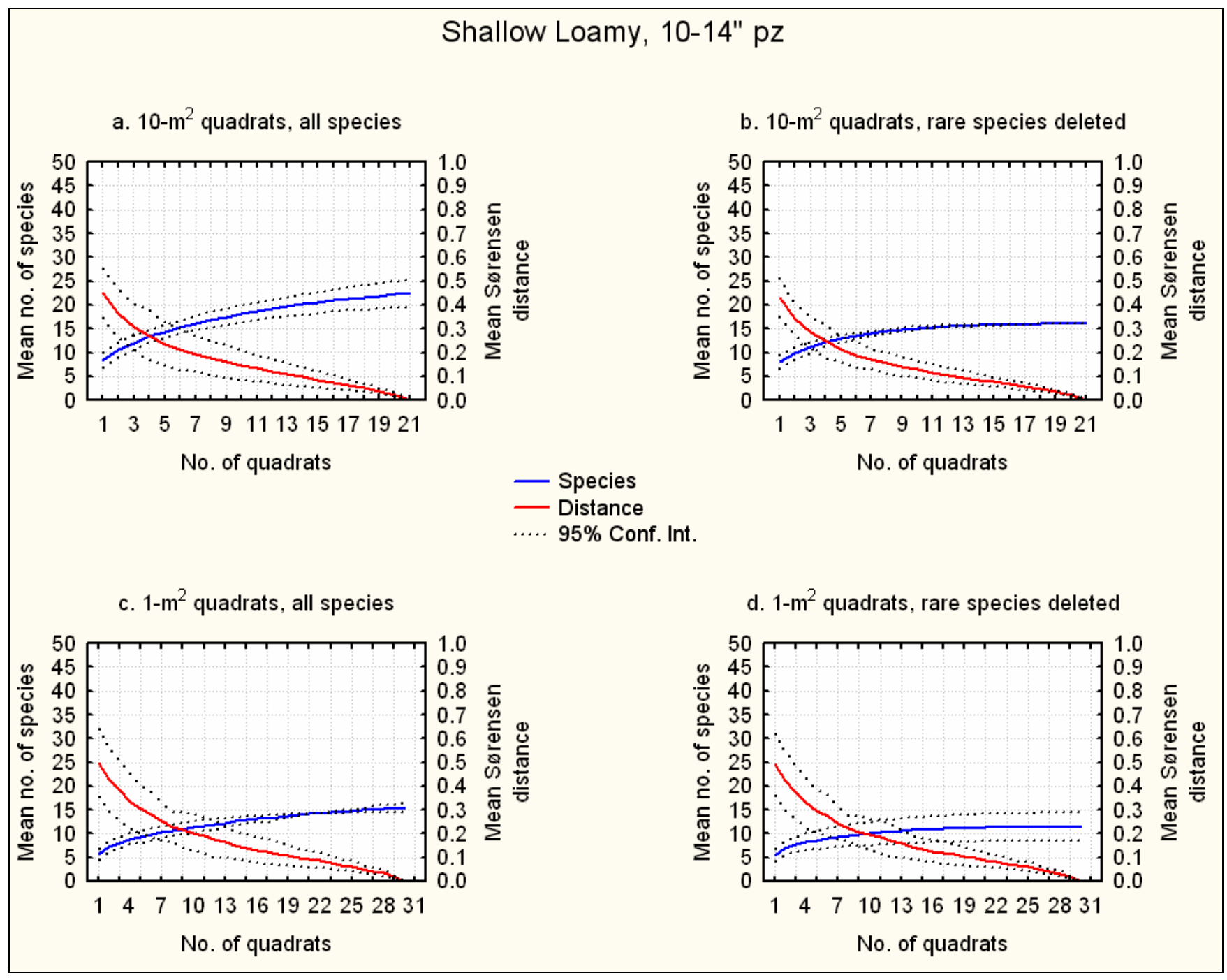

Figure E10. Mean species-area and compositional curves (mean Sørensen distances) for the Shallow Loamy ecological site at Wupatki National Monument for (a) 10- $\mathrm{m}^{2}$ quadrats, including all species; (b) 10- $\mathrm{m}^{2}$ quadrats, exluding rare (infrequent) species that occurred in only one subsample quadrat; (c) 1- $\mathrm{m}^{2}$ quadrats, including all species; and (d) 1-m² quadrats, excluding rare species. All curves are based on data from two macroplots. 


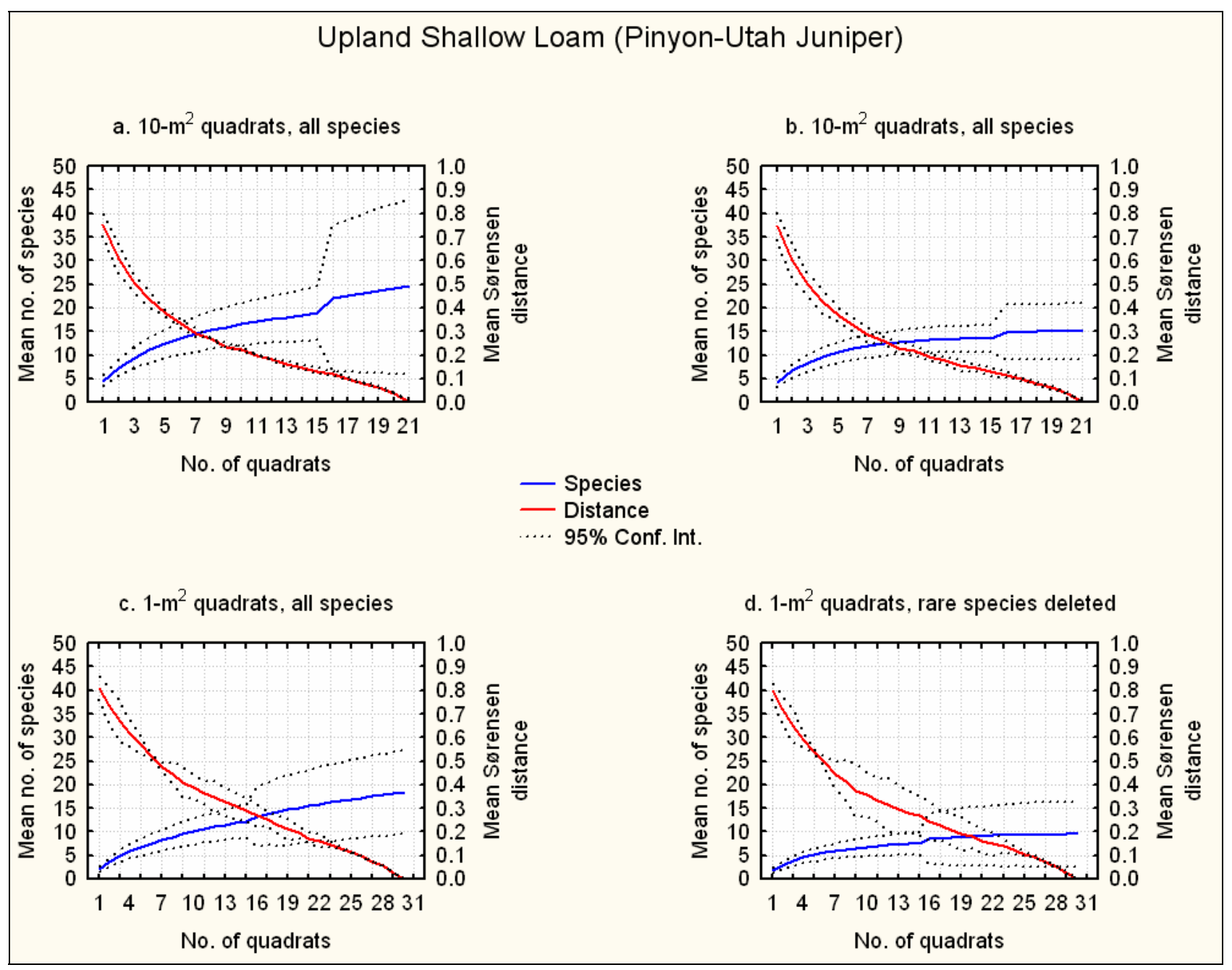

Figure E11. Mean species-area and compositional curves (mean Sørensen distances) for the Upland Shallow Loam ecological site at Capitol Reef National Park for (a) 10- $\mathrm{m}^{2}$ quadrats, including all species; (b) 10- $\mathrm{m}^{2}$ quadrats, exluding rare (infrequent) species that occurred in only one subsample quadrat; (c) $1-\mathrm{m}^{2}$ quadrats, including all species; and (d) 1 $\mathrm{m}^{2}$ quadrats, excluding rare species. Species-area curves are based on data from five macroplots for quadrats 1-15 and two macroplots for quadrats $>15$. Compositional curves are based on data from two macroplots. 


\section{Appendix F-Between-Observer Differences in Estimates of Cover and Density}

Table F1. Mean estimates of plant cover (\%) by sampling method (10- $\mathrm{m}^{2}$ quadrats, $1-\mathrm{m}^{2}$ quadrats, and line-point intercept) and observer (Obs. 1 and Obs. 2) at Colorado Plateau ecological sites sampled during Phase 3, absolute between-observer differences, and differences expressed as percent of the mean of both observations. See Appendix A for key to species codes associated with cover measures.

\begin{tabular}{|c|c|c|c|c|c|c|c|c|c|c|c|c|c|}
\hline \multirow[b]{2}{*}{$\begin{array}{l}\text { Ecological } \\
\text { site }\end{array}$} & \multirow[b]{2}{*}{$\begin{array}{l}\text { Cover } \\
\text { measure }\end{array}$} & \multicolumn{4}{|c|}{$10-m^{2}$ quadrats } & \multicolumn{4}{|c|}{ 1-m ${ }^{2}$ quadrats } & \multicolumn{4}{|c|}{ Line-point } \\
\hline & & $\begin{array}{r}\text { Obs. } \\
1 \\
\end{array}$ & $\begin{array}{r}\text { Obs. } \\
2\end{array}$ & $\begin{array}{l}\text { Abs } \\
\text { diff }\end{array}$ & $\begin{array}{c}\text { Diff \% } \\
\text { of } \\
\text { mean }\end{array}$ & $\begin{array}{r}\text { Obs. } \\
1\end{array}$ & $\begin{array}{r}\text { Obs. } \\
2 \\
\end{array}$ & $\begin{array}{l}\text { Abs } \\
\text { diff }\end{array}$ & $\begin{array}{c}\text { Diff } \% \\
\text { of } \\
\text { mean }\end{array}$ & $\begin{array}{r}\text { Obs. } \\
1 \\
\end{array}$ & $\begin{array}{r}\text { Obs. } \\
2 \\
\end{array}$ & $\begin{array}{l}\text { Abs } \\
\text { diff }\end{array}$ & $\begin{array}{c}\text { Diff \% } \\
\text { of } \\
\text { mean }\end{array}$ \\
\hline \multirow{5}{*}{$\begin{array}{l}\text { Brushy } \\
\text { Loam }\end{array}$} & QUGA & 1.2 & 1.5 & 0.3 & 22.2 & 1.3 & 1.2 & 0.1 & 8.0 & 1.5 & 1.5 & 0.0 & 0.0 \\
\hline & POFE & 12.0 & 9.8 & 2.2 & 20.2 & 8.6 & 6.0 & 2.6 & 35.6 & 17.9 & 16.9 & 1.0 & 5.7 \\
\hline & SYOR2 & 2.9 & 4.4 & 1.5 & 41.1 & 1.5 & 1.1 & 0.4 & 30.8 & 5.0 & 5.0 & 0.0 & 0.0 \\
\hline & $\begin{array}{l}\text { Total live } \\
\text { understory }\end{array}$ & 45.3 & 43.3 & 2.0 & 4.5 & 34.9 & 29.6 & 5.3 & 16.4 & 64.6 & 76.4 & 11.8 & 16.7 \\
\hline & Mean \% diff & & & 1.5 & 22.0 & & & 2.1 & 22.7 & & & 3.2 & 5.6 \\
\hline \multirow{5}{*}{$\begin{array}{l}\text { Limy } \\
\text { Upland, 6- } \\
10 " \text { pz }\end{array}$} & CHLE4 & 4.3 & 2.9 & 1.4 & 38.9 & 3.4 & 2.4 & 1.0 & 34.5 & 2.4 & 2.2 & 0.2 & 8.7 \\
\hline & HENE5 & 3.8 & 3.3 & 0.5 & 14.1 & 2.7 & 2.1 & 0.6 & 25.0 & 5.6 & 7.2 & 1.6 & 25.0 \\
\hline & PLJA & 3.3 & 3.1 & 0.2 & 6.2 & 1.6 & 2.3 & 0.7 & 35.9 & 5.5 & 6.5 & 1.0 & 16.7 \\
\hline & $\begin{array}{l}\text { Total live } \\
\text { understory }\end{array}$ & 19.9 & 16.5 & 3.4 & 18.7 & 13.9 & 12.8 & 1.1 & 8.2 & 26.9 & 31.2 & 4.3 & 14.8 \\
\hline & Mean \% diff & & & 1.4 & 19.5 & & & 0.9 & 25.9 & & & 1.8 & 16.3 \\
\hline \multirow{5}{*}{$\begin{array}{l}\text { Loamy Hills, } \\
25-33^{\prime \prime} p z\end{array}$} & POFE & 0.9 & 0.8 & 0.1 & 11.8 & 0.5 & 0.5 & 0.0 & 0.0 & 2.0 & 0.4 & 1.6 & 133.3 \\
\hline & POTR5 & 1.1 & 1.2 & 0.1 & 8.7 & 1.1 & 0.9 & 0.2 & 20.0 & 1.3 & 1.3 & 0.0 & 0.0 \\
\hline & $\begin{array}{l}\text { UNGRCA1 } \\
\text { (Carex sp.) }\end{array}$ & 1.7 & 2.2 & 0.5 & 25.6 & 1.4 & 1.4 & 0.0 & 0.0 & 8.5 & 9.2 & 0.7 & 7.9 \\
\hline & $\begin{array}{l}\text { Total live } \\
\text { understory }\end{array}$ & 12.7 & 11.7 & 1.0 & 8.2 & 9.8 & 8.9 & 0.9 & 9.6 & 18.7 & 21.4 & 2.7 & 13.5 \\
\hline & Mean \% diff & & & 0.4 & 13.6 & & & 0.3 & 7.4 & & & 1.3 & 38.7 \\
\hline \multirow{5}{*}{$\begin{array}{l}\text { Loamy Mesa } \\
\text { Top PJ }\end{array}$} & JUOS & 5.5 & 6.0 & 0.5 & 8.7 & 3.3 & 2.3 & 1.0 & 35.7 & 3.1 & 2.3 & 0.8 & 29.6 \\
\hline & PIED & 7.9 & 7.4 & 0.5 & 6.5 & 5.7 & 3.6 & 2.1 & 45.2 & 7.3 & 7.9 & 0.6 & 7.9 \\
\hline & POFE & 3.5 & 2.8 & 0.7 & 22.2 & 2.6 & 2.3 & 0.3 & 12.2 & 7.2 & 6.2 & 1.0 & 14.9 \\
\hline & $\begin{array}{l}\text { Total live } \\
\text { understory }\end{array}$ & 26.1 & 24.7 & 1.4 & 5.5 & 20.0 & 15.3 & 4.7 & 26.6 & 23.8 & 25.9 & 2.1 & 8.5 \\
\hline & Mean \% diff & & & 0.8 & 10.7 & & & 2.0 & 29.9 & & & 1.1 & 15.2 \\
\hline \multirow{5}{*}{$\begin{array}{l}\text { Semidesert } \\
\text { Alkali Sandy } \\
\text { Loam (Alkali } \\
\text { Sacaton) }\end{array}$} & ATCO & 1.2 & 0.8 & 0.4 & 40.0 & 0.9 & 0.8 & 0.1 & 11.8 & 0.6 & 0.6 & 0.0 & 0.0 \\
\hline & GIIN2 & 0.3 & 0.3 & 0.0 & 0.0 & 0.4 & 0.3 & 0.1 & 28.6 & 0.1 & 0.1 & 0.0 & 0.0 \\
\hline & $\mathrm{ORHY}$ & 0.4 & 0.5 & 0.1 & 22.2 & 0.5 & 0.5 & 0.0 & 0.0 & 0.2 & 0.2 & 0.0 & 0.0 \\
\hline & $\begin{array}{l}\text { Total live } \\
\text { understory }\end{array}$ & 14.2 & 12.9 & 1.3 & 9.6 & 14.6 & 12.9 & 1.7 & 12.4 & 19.6 & 22.3 & 2.7 & 12.9 \\
\hline & Mean \% diff & & & 0.5 & 18.0 & & & 0.5 & 13.2 & & & 0.7 & 3.2 \\
\hline \multirow{5}{*}{$\begin{array}{l}\text { Semidesert } \\
\text { Loam } \\
\text { (Wyoming } \\
\text { Big } \\
\text { Sagebrush) }\end{array}$} & ARTR2 & 10.8 & 9.7 & 1.1 & 10.7 & 5.0 & 5.4 & 0.4 & 7.7 & 5.5 & 7.9 & 2.4 & 35.8 \\
\hline & BRTE & 2.9 & 1.7 & 1.2 & 52.2 & 1.4 & 1.4 & 0.0 & 0.0 & 16.7 & 18.9 & 2.2 & 12.4 \\
\hline & STCO4 & 0.8 & 0.7 & 0.1 & 13.3 & 0.7 & 0.7 & 0.0 & 0.0 & 1.6 & 1.2 & 0.4 & 28.6 \\
\hline & $\begin{array}{l}\text { Total live } \\
\text { understory }\end{array}$ & 26.2 & 23.4 & 2.8 & 11.3 & 14.5 & 14.2 & 0.3 & 2.1 & 43.6 & 48.4 & 4.8 & 10.4 \\
\hline & Mean \% diff & & & 1.3 & 21.9 & & & 0.2 & 2.4 & & & 2.5 & 21.8 \\
\hline \multirow{5}{*}{$\begin{array}{l}\text { Semidesert } \\
\text { Shallow } \\
\text { Sandy Loam } \\
\text { (PJ) }\end{array}$} & CORA & 13.4 & 12.3 & 1.1 & 8.6 & 8.3 & 10.3 & 2.0 & 21.5 & 5.5 & 9.6 & 4.1 & 54.3 \\
\hline & FEOC3 & 0.6 & 0.5 & 0.1 & 18.2 & 0.5 & 0.7 & 0.2 & 33.3 & 0.6 & 0.4 & 0.2 & 40.0 \\
\hline & STLO4 & 0.5 & 0.5 & 0.0 & 0.0 & 0.6 & 0.7 & 0.1 & 15.4 & 0 & 0.3 & 0.3 & 200.0 \\
\hline & $\begin{array}{l}\text { Total live } \\
\text { understory }\end{array}$ & 19.7 & 18.5 & 1.2 & 6.3 & 13.6 & 15.8 & 2.2 & 15.0 & 10.7 & 15.5 & 4.8 & 36.6 \\
\hline & Mean \% diff & & & 0.6 & 8.3 & & & 1.1 & 21.3 & & & 2.4 & 82.7 \\
\hline \multirow{5}{*}{$\begin{array}{l}\text { Upland } \\
\text { Shallow } \\
\text { Loam } \\
\text { (Pinyon- } \\
\text { Utah } \\
\text { Juniper) }\end{array}$} & CEMO2 & 3.2 & 2.1 & 1.1 & 41.5 & 1.4 & 0.9 & 0.5 & 43.5 & 2 & 1.5 & 0.5 & 28.6 \\
\hline & COWR2 & 0.8 & 0.8 & 0.0 & 0.0 & 0.6 & 0.6 & 0.0 & 0.0 & 0.7 & 1 & 0.3 & 35.3 \\
\hline & JUOS & 7.7 & 5.5 & 2.2 & 33.3 & 2.1 & 0.9 & 1.2 & 80.0 & 1.4 & 0.7 & 0.7 & 66.7 \\
\hline & $\begin{array}{l}\text { Total live } \\
\text { understory }\end{array}$ & 22.2 & 16.6 & 5.6 & 28.9 & 14.1 & 11.4 & 2.7 & 21.2 & 10.5 & 10.4 & 0.1 & 1.0 \\
\hline & Mean \% diff & & & 2.2 & 25.9 & & & 1.1 & 36.2 & & & 0.4 & 32.9 \\
\hline
\end{tabular}


Table F2. Mean estimates of biological soil crust cover (\%) by sampling method (10- $\mathrm{m}^{2}$ quadrats, $1-\mathrm{m}^{2}$ quadrats, and line-point intercept) and observer (Obs. 1 and Obs. 2) at Colorado Plateau ecological sites sampled during Phase 3, absolute between-observer differences, and differences expressed as percent of the mean of both observations.

\begin{tabular}{|c|c|c|c|c|c|c|c|c|c|c|c|c|c|}
\hline \multirow[b]{2}{*}{$\begin{array}{l}\text { Ecological } \\
\text { site }\end{array}$} & \multirow[b]{2}{*}{ Cover measure } & \multicolumn{4}{|c|}{ 1-m² quadrats } & \multicolumn{4}{|c|}{$10-m^{2}$ quadrats } & \multicolumn{4}{|c|}{ Line-point } \\
\hline & & $\begin{array}{r}\text { Obs. } \\
1\end{array}$ & $\begin{array}{r}\text { Obs. } \\
2\end{array}$ & $\begin{array}{l}\text { Abs } \\
\text { diff }\end{array}$ & $\begin{array}{l}\text { Diff \% } \\
\text { of } \\
\text { mean }\end{array}$ & $\begin{array}{r}\text { Obs. } \\
1\end{array}$ & $\begin{array}{r}\text { Obs. } \\
2\end{array}$ & $\begin{array}{l}\text { Abs } \\
\text { diff }\end{array}$ & $\begin{array}{c}\text { Diff \% } \\
\text { of } \\
\text { mean }\end{array}$ & $\begin{array}{r}\text { Obs. } \\
1\end{array}$ & $\begin{array}{r}\text { Obs. } \\
2\end{array}$ & $\begin{array}{l}\text { Abs } \\
\text { diff }\end{array}$ & $\begin{array}{l}\text { Diff \% } \\
\text { of } \\
\text { mean }\end{array}$ \\
\hline \multirow{5}{*}{$\begin{array}{l}\text { Loamy Mesa } \\
\text { Top PJ }\end{array}$} & $\begin{array}{l}\text { Undifferentiated } \\
\text { crust }\end{array}$ & 46.2 & 45.1 & 1.1 & 2.4 & 43.8 & 45.8 & 2.0 & 4.5 & 43.6 & 38.9 & 4.7 & 11.4 \\
\hline & Cyanobacteria & 1.8 & 2.2 & 0.4 & 20.0 & 1.3 & 2.2 & 0.9 & 51.4 & 4.4 & 5.6 & 1.2 & 24.0 \\
\hline & Lichen & 0.7 & 1.2 & 0.5 & 52.6 & 0.9 & 0.8 & 0.1 & 11.8 & 1.1 & 1.3 & 0.2 & 16.7 \\
\hline & Moss & 1.0 & 3.0 & 2.0 & 100.0 & 2.8 & 1.0 & 1.8 & 94.7 & 3.1 & 3.3 & 0.2 & 6.2 \\
\hline & Mean \% diff & & & 1.0 & 43.8 & & & 1.2 & 40.6 & & & 1.6 & 14.6 \\
\hline \multirow{5}{*}{$\begin{array}{l}\text { Semidesert } \\
\text { Alkali Sandy } \\
\text { Loam (Alkali } \\
\text { Sacaton) }\end{array}$} & $\begin{array}{l}\text { Undifferentiated } \\
\text { crust }\end{array}$ & 83.6 & 85.3 & 1.7 & 2.0 & 82.4 & 83.6 & 1.2 & 1.4 & 84.4 & 78.2 & 6.2 & 7.6 \\
\hline & Cyanobacteria & 1.8 & 1.5 & 0.3 & 18.2 & 1.1 & 1.8 & 0.7 & 48.3 & 2.9 & 3.1 & 0.2 & 6.7 \\
\hline & Lichen & 0.4 & 0.6 & 0.2 & 40.0 & 0.5 & 0.4 & 0.1 & 22.2 & 0.2 & 0.9 & 0.7 & 127.3 \\
\hline & Moss & 0.1 & 0.2 & 0.1 & 66.7 & 0.0 & 0.2 & 0.2 & 200.0 & 0.0 & 0.2 & 0.2 & 200.0 \\
\hline & Mean \% diff & & & 0.6 & 31.7 & & & 0.5 & 68.0 & & & 1.8 & 85.4 \\
\hline \multirow{5}{*}{$\begin{array}{l}\text { Semidesert } \\
\text { Loam } \\
\text { (Wyoming } \\
\text { Big } \\
\text { Sagebrush) }\end{array}$} & $\begin{array}{l}\text { Undifferentiated } \\
\text { crust }\end{array}$ & 60.9 & 65.4 & 4.5 & 7.1 & 61.3 & 65.2 & 3.9 & 6.2 & 54.0 & 52.2 & 1.8 & 3.4 \\
\hline & Cyanobacteria & 0.5 & 0.9 & 0.4 & 57.1 & 0.8 & 0.6 & 0.2 & 28.6 & 1.1 & 1.8 & 0.7 & 48.3 \\
\hline & Lichen & 1.1 & 1.3 & 0.2 & 16.7 & 1.1 & 0.7 & 0.4 & 44.4 & 1.6 & 2.2 & 0.6 & 31.6 \\
\hline & Moss & 4.4 & 7.2 & 2.8 & 48.3 & 5.1 & 4.8 & 0.3 & 6.1 & 13.1 & 15.3 & 2.2 & 15.5 \\
\hline & Mean \% diff & & & 2.0 & 32.3 & & & 1.2 & 21.3 & & & 1.3 & 24.7 \\
\hline \multirow{5}{*}{$\begin{array}{l}\text { Semidesert } \\
\text { Shallow } \\
\text { Sandy Loam } \\
\text { (PJ) }\end{array}$} & $\begin{array}{l}\text { Undifferentiated } \\
\text { crust }\end{array}$ & 82.6 & 80.3 & 2.3 & 2.8 & 83.0 & 78.2 & 4.8 & 6.0 & 72.0 & 68.7 & 3.3 & 4.7 \\
\hline & Cyanobacteria & 0.8 & 1.5 & 0.7 & 60.9 & 1.2 & 1.4 & 0.2 & 15.4 & 2.4 & 4.0 & 1.6 & 50.0 \\
\hline & Lichen & 0.5 & 0.9 & 0.4 & 57.1 & 0.9 & 0.5 & 0.4 & 57.1 & 0.0 & 0.4 & 0.4 & 200.0 \\
\hline & Moss & 5.0 & 5.8 & 0.8 & 14.8 & 3.1 & 6.5 & 3.4 & 70.8 & 10.2 & 11.6 & 1.4 & 12.8 \\
\hline & Mean \% diff & & & 1.1 & 33.9 & & & 2.2 & 37.3 & & & 1.7 & 66.9 \\
\hline \multirow{5}{*}{$\begin{array}{l}\text { Upland } \\
\text { Shallow } \\
\text { Loam } \\
\text { (Pinyon- } \\
\text { Utah } \\
\text { Juniper) }\end{array}$} & $\begin{array}{l}\text { Undifferentiated } \\
\text { crust }\end{array}$ & 6.3 & 9.8 & 3.5 & 43.5 & 4.9 & 5.5 & 0.6 & 11.5 & 14.9 & 25.6 & 10.7 & 52.8 \\
\hline & Cyanobacteria & 0.0 & 0.0 & 0.0 & 0.0 & 0.0 & 0.0 & 0.0 & 0.0 & 0.0 & 0.0 & 0.0 & 0.0 \\
\hline & Lichen & 0.0 & 0.0 & 0.0 & 0.0 & 0.0 & 0.0 & 0.0 & 0.0 & 0.0 & 0.0 & 0.0 & 0.0 \\
\hline & Moss & 0.1 & 0.2 & 0.1 & 66.7 & 0.0 & 0.2 & 0.2 & 200.0 & 0.0 & 0.4 & 0.4 & 200.0 \\
\hline & Mean \% diff & & & 0.9 & 27.5 & & & 0.2 & 52.9 & & & 2.8 & 63.2 \\
\hline
\end{tabular}


Table F3. Mean estimates of biological soil crust cover (\%) based on the characterization of soil darkness (see table 10 and fig. 5 in main body of report) in 25 $\mathrm{cm} \times 25 \mathrm{~cm}$ BSC frames for two observers (Obs. 1 and Obs. 2) at Colorado Plateau ecological sites sampled during Phase 3 , absolute between-observer differences, and differences expressed as percent of the mean of both observations.

\begin{tabular}{|c|c|c|c|c|c|}
\hline Ecological site & $\begin{array}{l}\text { Biological soil crust } \\
\text { cover measure } \\
\text { (Soil-surface category) }\end{array}$ & Obs. 1 & Obs. 2 & Abs diff & $\begin{array}{l}\text { Diff \% } \\
\text { of } \\
\text { mean }\end{array}$ \\
\hline \multirow{7}{*}{$\begin{array}{l}\text { Loamy Mesa Top } \\
\text { PJ }\end{array}$} & Darkness 1 & 0.4 & 0.9 & 0.5 & 76.9 \\
\hline & Darkness 2 & 17.9 & 18.2 & 0.3 & 1.7 \\
\hline & Darkness 3 & 8.8 & 9.2 & 0.4 & 4.4 \\
\hline & Darkness 4 & 2.9 & 3.5 & 0.6 & 18.8 \\
\hline & Darkness 5 & 1.4 & 1.7 & 0.3 & 19.4 \\
\hline & Total & 31.4 & 33.5 & 2.1 & 6.5 \\
\hline & Mean \% diff & & & 0.7 & 21.3 \\
\hline \multirow{7}{*}{$\begin{array}{l}\text { Semidesert Alkali } \\
\text { Sandy Loam } \\
\text { (Alkali Sacaton) }\end{array}$} & Darkness 1 & 13.5 & 11.3 & 2.2 & 17.7 \\
\hline & Darkness 2 & 44.0 & 45.8 & 1.8 & 4.0 \\
\hline & Darkness 3 & 8.5 & 11.4 & 2.9 & 29.1 \\
\hline & Darkness 4 & 0.0 & 0.0 & 0.0 & 0.0 \\
\hline & Darkness 5 & 0.0 & 0.0 & 0.0 & 0.0 \\
\hline & Total & 66.1 & 68.5 & 2.4 & 3.6 \\
\hline & Mean \% diff & & & 1.6 & 9.1 \\
\hline \multirow{7}{*}{$\begin{array}{l}\text { Semidesert Loam } \\
\text { (Wyoming Big } \\
\text { Sagebrush) }\end{array}$} & Darkness 1 & 0.0 & 0.1 & 0.1 & 200.0 \\
\hline & Darkness 2 & 29.4 & 18.7 & 10.7 & 44.5 \\
\hline & Darkness 3 & 22.1 & 28.9 & 6.8 & 26.7 \\
\hline & Darkness 4 & 0.0 & 0.4 & 0.4 & 200.0 \\
\hline & Darkness 5 & 0.0 & 0.0 & 0.0 & 0.0 \\
\hline & Total & 51.5 & 48.0 & 3.5 & 7.0 \\
\hline & Mean \% diff & & & 3.6 & 79.7 \\
\hline \multirow{7}{*}{$\begin{array}{l}\text { Semidesert } \\
\text { Shallow Sandy } \\
\text { Loam (PJ) }\end{array}$} & Darkness 1 & 8.7 & 6.4 & 2.3 & 30.5 \\
\hline & Darkness 2 & 37.2 & 40.1 & 2.9 & 7.5 \\
\hline & Darkness 3 & 16.6 & 22.8 & 6.2 & 31.5 \\
\hline & Darkness 4 & 0.4 & 0.0 & 0.4 & 200.0 \\
\hline & Darkness 5 & 0.0 & 0.0 & 0.0 & 0.0 \\
\hline & Total & 62.9 & 69.4 & 6.5 & 9.8 \\
\hline & Mean \% diff & & & 3.1 & 46.5 \\
\hline \multirow{7}{*}{$\begin{array}{l}\text { Upland Shallow } \\
\text { Loam (Pinyon- } \\
\text { Utah Juniper) }\end{array}$} & Darkness 1 & 5.9 & 5.4 & 0.5 & 8.8 \\
\hline & Darkness 2 & 0.2 & 1.2 & 1.0 & 142.9 \\
\hline & Darkness 3 & 0.0 & 0.0 & 0.0 & 0.0 \\
\hline & Darkness 4 & 0.0 & 0.0 & 0.0 & 0.0 \\
\hline & Darkness 5 & 0.0 & 0.0 & 0.0 & 0.0 \\
\hline & Total & 6.1 & 6.6 & 0.5 & 7.9 \\
\hline & Mean \% diff & & & 0.3 & 26.6 \\
\hline
\end{tabular}


Table F4. Mean estimates of litter cover (\%) by sampling method $\left(10-\mathrm{m}^{2}\right.$ quadrats, $1-\mathrm{m}^{2}$ quadrats, and line-point intercept) and observer (Obs. 1 and Obs. 2) at Colorado Plateau ecological sites sampled during Phase 3, absolute between-observer differences, and differences expressed as percent of the mean of both observations.

\begin{tabular}{|c|c|c|c|c|c|c|c|c|c|c|c|c|}
\hline \multirow[b]{2}{*}{ Ecological site } & \multicolumn{4}{|c|}{ 10- $\mathrm{m}^{2}$ quadrats } & \multicolumn{4}{|c|}{ 1-m ${ }^{2}$ quadrats } & \multicolumn{4}{|c|}{ Line-point } \\
\hline & Obs. 1 & Obs. 2 & $\begin{array}{l}\text { Abs } \\
\text { diff }\end{array}$ & $\begin{array}{c}\text { Diff \% } \\
\text { of mean }\end{array}$ & Obs. 1 & Obs. 2 & Abs diff & $\begin{array}{c}\text { Diff \% } \\
\text { of mean }\end{array}$ & Obs. 1 & Obs. 2 & $\begin{array}{l}\text { Abs } \\
\text { diff }\end{array}$ & $\begin{array}{c}\text { Diff \% } \\
\text { of } \\
\text { mean }\end{array}$ \\
\hline Brushy Loam & 77.8 & 78.9 & 1.1 & 1.4 & 82.0 & 79.4 & 2.6 & 3.2 & 73.0 & 78.3 & 5.3 & 7.0 \\
\hline $\begin{array}{l}\text { Limy Upland, 6- } \\
10 " \mathrm{pz}\end{array}$ & 5.9 & 4.1 & 1.8 & 36.0 & 6.8 & 5.1 & 1.7 & 28.6 & 33.8 & 34.6 & 0.8 & 2.3 \\
\hline $\begin{array}{l}\text { Loamy Hills, 25- } \\
33 " p z\end{array}$ & 83.3 & 80.9 & 2.4 & 2.9 & 84.6 & 84.7 & 0.1 & 0.1 & 88.8 & 94.1 & 5.3 & 5.8 \\
\hline $\begin{array}{l}\text { Loamy Mesa Top } \\
\text { PJ }\end{array}$ & 43.6 & 44.7 & 1.1 & 2.5 & 43.4 & 42.2 & 1.2 & 2.8 & 54.6 & 50.9 & 3.7 & 7.0 \\
\hline $\begin{array}{l}\text { Semidesert Alkali } \\
\text { Sandy Loam } \\
\text { (Alkali Sacaton) }\end{array}$ & 6.6 & 6.0 & 0.6 & 9.5 & 8.7 & 6.8 & 1.9 & 24.5 & 15.2 & 17.8 & 2.6 & 15.8 \\
\hline $\begin{array}{l}\text { Semidesert Loam } \\
\text { (Wyoming Big } \\
\text { Sagebrush) }\end{array}$ & 23.9 & 21.0 & 2.9 & 12.9 & 21.6 & 19.1 & 2.5 & 12.3 & 40.5 & 44.4 & 3.9 & 9.2 \\
\hline $\begin{array}{l}\text { Semidesert } \\
\text { Shallow Sandy } \\
\text { Loam (PJ) }\end{array}$ & 2.9 & 3.5 & 0.6 & 18.8 & 3.3 & 3.9 & 0.6 & 16.7 & 13.3 & 16.5 & 3.2 & 21.5 \\
\hline $\begin{array}{l}\text { Upland Shallow } \\
\text { Loam (Pinyon- } \\
\text { Utah Juniper) }\end{array}$ & 15.5 & 16.6 & 1.1 & 6.9 & 23.4 & 23.4 & 0.0 & 0.0 & 23.4 & 26.2 & 2.8 & 11.3 \\
\hline & & & 1.5 & 11.4 & & & 1.3 & 11.0 & & & 3.5 & 10.0 \\
\hline
\end{tabular}


Table F5. Mean estimates of shrub density (counts per quadrat) by species, height class, and observer (Obs. 1 and Obs. 2) at Colorado Plateau ecological sites sampled during Phase 3, absolute between-observer differences, and differences expressed as percent of the mean of both observations.

\begin{tabular}{|c|c|c|c|c|c|c|c|}
\hline Species & Ecological site & Size class & Obs. 1 & Obs. 2 & Mean & Abs. Diff & $\begin{array}{r}\text { Diff \% of } \\
\text { Mean }\end{array}$ \\
\hline \multirow{14}{*}{$\begin{array}{l}\text { Amerlanchier } \\
\text { utahensis } \\
\text { (AMUT) }\end{array}$} & \multirow{7}{*}{ Brushy Loam } & $0-10 \mathrm{~cm}$ & 0 & 0.11 & 0.055 & 0.110 & 200.0 \\
\hline & & $10-25 \mathrm{~cm}$ & 0.04 & 0.18 & 0.110 & 0.140 & 127.3 \\
\hline & & $25-50 \mathrm{~cm}$ & 0.56 & 0.78 & 0.670 & 0.220 & 32.8 \\
\hline & & $50 \mathrm{~cm}-1 \mathrm{~m}$ & 2.4 & 2.4 & 2.400 & 0.000 & 0.0 \\
\hline & & $1-2 \mathrm{~m}$ & 0.8 & 0.89 & 0.845 & 0.090 & 10.7 \\
\hline & & $>2 \mathrm{~m}$ & 0.13 & 0.11 & 0.120 & 0.020 & 16.7 \\
\hline & & \multicolumn{5}{|r|}{ mean diff } & 64.6 \\
\hline & \multirow{7}{*}{$\begin{array}{l}\text { Upland Shallow } \\
\text { Loam (Pinyon- } \\
\text { Utah Juniper) }\end{array}$} & $0-10 \mathrm{~cm}$ & 0.04 & 0.02 & 0.030 & 0.020 & 66.7 \\
\hline & & $10-25 \mathrm{~cm}$ & 0.02 & 0.07 & 0.045 & 0.050 & 111.1 \\
\hline & & $25-50 \mathrm{~cm}$ & 0.04 & 0 & 0.020 & 0.040 & 200.0 \\
\hline & & $50 \mathrm{~cm}-1 \mathrm{~m}$ & 0.04 & 0.09 & 0.065 & 0.050 & 76.9 \\
\hline & & $1-2 \mathrm{~m}$ & 0.31 & 0.29 & 0.300 & 0.020 & 6.7 \\
\hline & & $>2 \mathrm{~m}$ & 0 & 0.02 & 0.010 & 0.020 & 200.0 \\
\hline & & \multicolumn{5}{|r|}{ mean diff } & 110.2 \\
\hline \multirow{7}{*}{$\begin{array}{l}\text { Artemisia } \\
\text { bigelovii } \\
\text { (ARBI3) }\end{array}$} & \multirow{7}{*}{ Brushy Loam } & $0-10 \mathrm{~cm}$ & 1.6 & 1.3 & 1.450 & 0.300 & 20.7 \\
\hline & & $10-25 \mathrm{~cm}$ & 0.09 & 0.09 & 0.090 & 0.000 & 0.0 \\
\hline & & $25-50 \mathrm{~cm}$ & 0.02 & 0.07 & 0.045 & 0.050 & 111.1 \\
\hline & & $50 \mathrm{~cm}-1 \mathrm{~m}$ & 0.02 & 0.02 & 0.020 & 0.000 & 0.0 \\
\hline & & $1-2 \mathrm{~m}$ & 0 & 0 & 0.000 & 0.000 & $\mathrm{n} / \mathrm{a}$ \\
\hline & & $>2 \mathrm{~m}$ & 0 & 0 & 0.000 & 0.000 & $\mathrm{n} / \mathrm{a}$ \\
\hline & & \multicolumn{5}{|r|}{ mean diff } & 33.0 \\
\hline \multirow{14}{*}{$\begin{array}{l}\text { Artemisia } \\
\text { tridentata } \\
\text { (ARTR2) }\end{array}$} & \multirow{7}{*}{$\begin{array}{l}\text { Loamy Mesa } \\
\text { Top PJ }\end{array}$} & $0-10 \mathrm{~cm}$ & 0.29 & 0.38 & 0.335 & 0.090 & 26.9 \\
\hline & & $10-25 \mathrm{~cm}$ & 0.13 & 0.36 & 0.245 & 0.230 & 93.9 \\
\hline & & $25-50 \mathrm{~cm}$ & 0.33 & 0.62 & 0.475 & 0.290 & 61.1 \\
\hline & & $50 \mathrm{~cm}-1 \mathrm{~m}$ & 0.76 & 0.64 & 0.700 & 0.120 & 17.1 \\
\hline & & $1-2 \mathrm{~m}$ & 0.13 & 0.16 & 0.145 & 0.030 & 20.7 \\
\hline & & $>2 \mathrm{~m}$ & 0 & 0 & 0.000 & 0.000 & $\mathrm{n} / \mathrm{a}$ \\
\hline & & \multicolumn{5}{|r|}{ mean diff } & 43.9 \\
\hline & \multirow{7}{*}{$\begin{array}{l}\text { Semidesert } \\
\text { Loam (Wyoming } \\
\text { Big Sagebrush) }\end{array}$} & $0-10 \mathrm{~cm}$ & 42.8 & 67 & 54.900 & 24.200 & 44.1 \\
\hline & & $10-25 \mathrm{~cm}$ & 1.4 & 1.3 & 1.350 & 0.100 & 7.4 \\
\hline & & $25-50 \mathrm{~cm}$ & 3.9 & 4.3 & 4.100 & 0.400 & 9.8 \\
\hline & & $50 \mathrm{~cm}-1 \mathrm{~m}$ & 3.1 & 3.2 & 3.150 & 0.100 & 3.2 \\
\hline & & $1-2 \mathrm{~m}$ & 0.11 & 0.11 & 0.110 & 0.000 & 0.0 \\
\hline & & $>2 \mathrm{~m}$ & 0 & 0 & 0.000 & 0.000 & $\mathrm{n} / \mathrm{a}$ \\
\hline & & \multicolumn{5}{|r|}{ mean diff } & 12.9 \\
\hline
\end{tabular}


Table F5.-Continued

\begin{tabular}{|c|c|c|c|c|c|c|c|}
\hline Species & Ecological site & Size class & Obs. 1 & Obs. 2 & Mean & Abs. Diff & $\begin{array}{r}\text { Diff \% of } \\
\text { Mean }\end{array}$ \\
\hline \multirow{7}{*}{$\begin{array}{l}\text { Atriplex } \\
\text { canescens } \\
\text { (ATCA2) }\end{array}$} & \multirow{7}{*}{$\begin{array}{l}\text { Semidesert } \\
\text { Alkali Sandy } \\
\text { Loam (Alkali } \\
\text { Sacaton) }\end{array}$} & $0-10 \mathrm{~cm}$ & 0 & 0 & 0.000 & 0.000 & $\mathrm{n} / \mathrm{a}$ \\
\hline & & $10-25 \mathrm{~cm}$ & 0 & 0 & 0.000 & 0.000 & $\mathrm{n} / \mathrm{a}$ \\
\hline & & $25-50 \mathrm{~cm}$ & 0.07 & 0.07 & 0.070 & 0.000 & 0.0 \\
\hline & & $50 \mathrm{~cm}-1 \mathrm{~m}$ & 0.11 & 0.09 & 0.100 & 0.020 & 20.0 \\
\hline & & $1-2 \mathrm{~m}$ & 0 & 0 & 0.000 & 0.000 & $\mathrm{n} / \mathrm{a}$ \\
\hline & & $>2 \mathrm{~m}$ & 0 & 0 & 0.000 & 0.000 & $\mathrm{n} / \mathrm{a}$ \\
\hline & & & & & & mean diff & 10.0 \\
\hline \multirow{14}{*}{$\begin{array}{l}\text { Atriplex } \\
\text { confertifolia } \\
\text { (ATCO) }\end{array}$} & \multirow{7}{*}{$\begin{array}{l}\text { Semidesert } \\
\text { Alkali Sandy } \\
\text { Loam (Alkali } \\
\text { Sacaton) }\end{array}$} & $0-10 \mathrm{~cm}$ & 2 & 2.9 & 2.450 & 0.900 & 36.7 \\
\hline & & $10-25 \mathrm{~cm}$ & 0.69 & 0.69 & 0.690 & 0.000 & 0.0 \\
\hline & & $25-50 \mathrm{~cm}$ & 0.62 & 0.82 & 0.720 & 0.200 & 27.8 \\
\hline & & $50 \mathrm{~cm}-1 \mathrm{~m}$ & 0 & 0 & 0.000 & 0.000 & $\mathrm{n} / \mathrm{a}$ \\
\hline & & $1-2 \mathrm{~m}$ & 0 & 0 & 0.000 & 0.000 & $\mathrm{n} / \mathrm{a}$ \\
\hline & & $>2 \mathrm{~m}$ & 0 & 0 & 0.000 & 0.000 & $\mathrm{n} / \mathrm{a}$ \\
\hline & & \multicolumn{5}{|r|}{ mean diff } & 21.5 \\
\hline & \multirow{7}{*}{$\begin{array}{l}\text { Semidesert } \\
\text { Loam (Wyoming } \\
\text { Big Sagebrush) }\end{array}$} & $0-10 \mathrm{~cm}$ & 0.24 & 0.24 & 0.240 & 0.000 & 0.0 \\
\hline & & $10-25 \mathrm{~cm}$ & 0.18 & 0.16 & 0.170 & 0.020 & 11.8 \\
\hline & & $25-50 \mathrm{~cm}$ & 0.11 & 0.16 & 0.135 & 0.050 & 37.0 \\
\hline & & $50 \mathrm{~cm}-1 \mathrm{~m}$ & 0.02 & 0.02 & 0.020 & 0.000 & 0.0 \\
\hline & & $1-2 m$ & 0 & 0 & 0.000 & 0.000 & $\mathrm{n} / \mathrm{a}$ \\
\hline & & $>2 \mathrm{~m}$ & 0 & 0 & 0.000 & 0.000 & $\mathrm{n} / \mathrm{a}$ \\
\hline & & & & & & mean diff & 12.2 \\
\hline \multirow{7}{*}{$\begin{array}{l}\text { Berberis } \\
\text { fremontii } \\
\text { (BEFR) }\end{array}$} & \multirow{7}{*}{$\begin{array}{l}\text { Upland Shallow } \\
\text { Loam (Pinyon- } \\
\text { Utah Juniper) }\end{array}$} & $0-10 \mathrm{~cm}$ & 0 & 0 & 0.000 & 0.000 & $\mathrm{n} / \mathrm{a}$ \\
\hline & & $10-25 \mathrm{~cm}$ & 0.02 & 0 & 0.010 & 0.020 & 200.0 \\
\hline & & $25-50 \mathrm{~cm}$ & 0 & 0 & 0.000 & 0.000 & $\mathrm{n} / \mathrm{a}$ \\
\hline & & $50 \mathrm{~cm}-1 \mathrm{~m}$ & 0.04 & 0.07 & 0.055 & 0.030 & 54.5 \\
\hline & & $1-2 \mathrm{~m}$ & 0 & 0 & 0.000 & 0.000 & $\mathrm{n} / \mathrm{a}$ \\
\hline & & $>2 \mathrm{~m}$ & 0 & 0 & 0.000 & 0.000 & $\mathrm{n} / \mathrm{a}$ \\
\hline & & & & & & mean diff & 127.3 \\
\hline \multirow{14}{*}{$\begin{array}{l}\text { Chrysothamnus } \\
\text { nauseosus } \\
\text { (CHNA2) }\end{array}$} & \multirow{7}{*}{$\begin{array}{l}\text { Limy Upland, 6- } \\
10 " \mathrm{pz}\end{array}$} & $0-10 \mathrm{~cm}$ & 0 & 0 & 0.000 & 0.000 & $\mathrm{n} / \mathrm{a}$ \\
\hline & & $10-25 \mathrm{~cm}$ & 0.04 & 0.02 & 0.030 & 0.020 & 66.7 \\
\hline & & $25-50 \mathrm{~cm}$ & 0.58 & 0.6 & 0.590 & 0.020 & 3.4 \\
\hline & & $50 \mathrm{~cm}-1 \mathrm{~m}$ & 0.02 & 0.02 & 0.020 & 0.000 & 0.0 \\
\hline & & $1-2 \mathrm{~m}$ & 0 & 0 & 0.000 & 0.000 & $\mathrm{n} / \mathrm{a}$ \\
\hline & & $>2 \mathrm{~m}$ & 0 & 0 & 0.000 & 0.000 & $\mathrm{n} / \mathrm{a}$ \\
\hline & & \multicolumn{5}{|r|}{ mean diff } & 23.4 \\
\hline & \multirow{7}{*}{$\begin{array}{l}\text { Semidesert } \\
\text { Alkali Sandy } \\
\text { Loam (Alkali } \\
\text { Sacaton) }\end{array}$} & $0-10 \mathrm{~cm}$ & 0 & 0 & 0.000 & 0.000 & $\mathrm{n} / \mathrm{a}$ \\
\hline & & $10-25 \mathrm{~cm}$ & 0 & 0 & 0.000 & 0.000 & $\mathrm{n} / \mathrm{a}$ \\
\hline & & $25-50 \mathrm{~cm}$ & 0 & 0 & 0.000 & 0.000 & $\mathrm{n} / \mathrm{a}$ \\
\hline & & $50 \mathrm{~cm}-1 \mathrm{~m}$ & 0.04 & 0.04 & 0.040 & 0.000 & 0.0 \\
\hline & & $1-2 \mathrm{~m}$ & 0 & 0 & 0.000 & 0.000 & $\mathrm{n} / \mathrm{a}$ \\
\hline & & $>2 \mathrm{~m}$ & 0 & 0 & 0.000 & 0.000 & $\mathrm{n} / \mathrm{a}$ \\
\hline & & & & & & mean diff & 0.0 \\
\hline
\end{tabular}


Table F5.-Continued

\begin{tabular}{|c|c|c|c|c|c|c|c|}
\hline Species & Ecological site & Size class & Obs. 1 & Obs. 2 & Mean & Abs. Diff & $\begin{array}{r}\text { Diff \% of } \\
\text { Mean }\end{array}$ \\
\hline \multirow{7}{*}{$\begin{array}{l}\text { Chrysothamnus } \\
\text { nauseosus } \\
\text { (CHNA2) }\end{array}$} & \multirow{7}{*}{$\begin{array}{l}\text { Semidesert } \\
\text { Loam (Wyoming } \\
\text { Big Sagebrush) }\end{array}$} & $0-10 \mathrm{~cm}$ & 0 & 0 & 0.000 & 0.000 & $\mathrm{n} / \mathrm{a}$ \\
\hline & & $10-25 \mathrm{~cm}$ & 0 & 0.02 & 0.010 & 0.020 & 200.0 \\
\hline & & $25-50 \mathrm{~cm}$ & 0.09 & 0.11 & 0.100 & 0.020 & 20.0 \\
\hline & & $50 \mathrm{~cm}-1 \mathrm{~m}$ & 0.27 & 0.22 & 0.245 & 0.050 & 20.4 \\
\hline & & $1-2 \mathrm{~m}$ & 0.04 & 0.02 & 0.030 & 0.020 & 66.7 \\
\hline & & $>2 \mathrm{~m}$ & 0 & 0 & 0.000 & 0.000 & $\mathrm{n} / \mathrm{a}$ \\
\hline & & \multicolumn{5}{|r|}{ mean diff } & 76.8 \\
\hline \multirow{7}{*}{$\begin{array}{l}\text { Coleogyne } \\
\text { ramosissima } \\
\text { (CORA) }\end{array}$} & \multirow{7}{*}{$\begin{array}{l}\text { Semidesert } \\
\text { Shallow Sandy } \\
\text { Loam PJ }\end{array}$} & $0-10 \mathrm{~cm}$ & 0.09 & 0.11 & 0.100 & 0.020 & 20.0 \\
\hline & & $10-25 \mathrm{~cm}$ & 0.58 & 0.82 & 0.700 & 0.240 & 34.3 \\
\hline & & $25-50 \mathrm{~cm}$ & 4.6 & 5.1 & 4.850 & 0.500 & 10.3 \\
\hline & & $50 \mathrm{~cm}-1 \mathrm{~m}$ & 1 & 0.9 & 0.950 & 0.100 & 10.5 \\
\hline & & $1-2 \mathrm{~m}$ & 0 & 0 & 0.000 & 0.000 & $\mathrm{n} / \mathrm{a}$ \\
\hline & & $>2 \mathrm{~m}$ & 0 & 0 & 0.000 & 0.000 & $\mathrm{n} / \mathrm{a}$ \\
\hline & & \multicolumn{5}{|r|}{ mean diff } & 18.8 \\
\hline \multirow{7}{*}{$\begin{array}{l}\text { Purshia } \\
\text { mexicana } \\
\text { (PUME) }\end{array}$} & \multirow{7}{*}{$\begin{array}{l}\text { Upland Shallow } \\
\text { Loam (Pinyon- } \\
\text { Utah Juniper) }\end{array}$} & $0-10 \mathrm{~cm}$ & 0 & 0 & 0.000 & 0.000 & $\mathrm{n} / \mathrm{a}$ \\
\hline & & $10-25 \mathrm{~cm}$ & 0 & 0 & 0.000 & 0.000 & $\mathrm{n} / \mathrm{a}$ \\
\hline & & $25-50 \mathrm{~cm}$ & 0.02 & 0.02 & 0.020 & 0.000 & 0.0 \\
\hline & & $50 \mathrm{~cm}-1 \mathrm{~m}$ & 0.04 & 0.07 & 0.055 & 0.030 & 54.5 \\
\hline & & $1-2 \mathrm{~m}$ & 0.07 & 0.07 & 0.070 & 0.000 & 0.0 \\
\hline & & $>2 \mathrm{~m}$ & 0 & 0 & 0.000 & 0.000 & $\mathrm{n} / \mathrm{a}$ \\
\hline & & \multicolumn{5}{|r|}{ mean diff } & 18.2 \\
\hline \multirow{21}{*}{$\begin{array}{l}\text { Purshia } \\
\text { tridentata } \\
\text { (PUTR2) }\end{array}$} & \multirow{7}{*}{$\begin{array}{l}\text { Upland Shallow } \\
\text { Loam (Pinyon- } \\
\text { Utah Juniper) }\end{array}$} & $0-10 \mathrm{~cm}$ & 0.02 & 0.02 & 0.020 & 0.000 & 0.0 \\
\hline & & $10-25 \mathrm{~cm}$ & 0 & 0 & 0.000 & 0.000 & $\mathrm{n} / \mathrm{a}$ \\
\hline & & $25-50 \mathrm{~cm}$ & 0 & 0 & 0.000 & 0.000 & $\mathrm{n} / \mathrm{a}$ \\
\hline & & $50 \mathrm{~cm}-1 \mathrm{~m}$ & 0.02 & 0 & 0.010 & 0.020 & 200.0 \\
\hline & & $1-2 \mathrm{~m}$ & 0 & 0 & 0.000 & 0.000 & $\mathrm{n} / \mathrm{a}$ \\
\hline & & $>2 \mathrm{~m}$ & 0 & 0 & 0.000 & 0.000 & $\mathrm{n} / \mathrm{a}$ \\
\hline & & \multicolumn{5}{|r|}{ mean diff } & 100.0 \\
\hline & \multirow{7}{*}{ Brushy Loam } & $0-10 \mathrm{~cm}$ & 0 & 0 & 0.000 & 0.000 & $\mathrm{n} / \mathrm{a}$ \\
\hline & & $10-25 \mathrm{~cm}$ & 0 & 0 & 0.000 & 0.000 & $\mathrm{n} / \mathrm{a}$ \\
\hline & & $25-50 \mathrm{~cm}$ & 0.02 & 0.02 & 0.020 & 0.000 & 0.0 \\
\hline & & $50 \mathrm{~cm}-1 \mathrm{~m}$ & 0 & 0 & 0.000 & 0.000 & $\mathrm{n} / \mathrm{a}$ \\
\hline & & $1-2 m$ & 0 & 0 & 0.000 & 0.000 & $\mathrm{n} / \mathrm{a}$ \\
\hline & & $>2 \mathrm{~m}$ & 0 & 0 & 0.000 & 0.000 & $\mathrm{n} / \mathrm{a}$ \\
\hline & & \multicolumn{5}{|r|}{ mean diff } & 0.0 \\
\hline & \multirow{7}{*}{$\begin{array}{l}\text { Loamy Mesa } \\
\text { Top PJ }\end{array}$} & $0-10 \mathrm{~cm}$ & 0.04 & 0.04 & 0.040 & 0.000 & 0.0 \\
\hline & & $10-25 \mathrm{~cm}$ & 0 & 0 & 0.000 & 0.000 & $\mathrm{n} / \mathrm{a}$ \\
\hline & & $25-50 \mathrm{~cm}$ & 0 & 0.09 & 0.045 & 0.090 & 200.0 \\
\hline & & $50 \mathrm{~cm}-1 \mathrm{~m}$ & 0.09 & 0.02 & 0.055 & 0.070 & 127.3 \\
\hline & & $1-2 \mathrm{~m}$ & 0 & 0 & 0.000 & 0.000 & $\mathrm{n} / \mathrm{a}$ \\
\hline & & $>2 \mathrm{~m}$ & 0 & 0 & 0.000 & 0.000 & $\mathrm{n} / \mathrm{a}$ \\
\hline & & & & & & mean diff & 109.1 \\
\hline
\end{tabular}


Table F5.-Continued

\begin{tabular}{|c|c|c|c|c|c|c|c|}
\hline Species & Ecological site & Size class & Obs. 1 & Obs. 2 & Mean & Abs. Diff & $\begin{array}{r}\text { Diff } \% \text { of } \\
\text { Mean }\end{array}$ \\
\hline \multirow{13}{*}{$\begin{array}{l}\text { Sarcobatus } \\
\text { vermiculatus } \\
\text { (SAVE4) }\end{array}$} & \multirow{7}{*}{$\begin{array}{l}\text { Semidesert } \\
\text { Alkali Sandy } \\
\text { Loam (Alkali } \\
\text { Sacaton) }\end{array}$} & $0-10 \mathrm{~cm}$ & 0.02 & 0 & 0.010 & 0.020 & 200.0 \\
\hline & & $10-25 \mathrm{~cm}$ & 0.07 & 0.04 & 0.055 & 0.030 & 54.5 \\
\hline & & $25-50 \mathrm{~cm}$ & 0.29 & 0.4 & 0.345 & 0.110 & 31.9 \\
\hline & & $50 \mathrm{~cm}-1 \mathrm{~m}$ & 0.58 & 0.62 & 0.600 & 0.040 & 6.7 \\
\hline & & $1-2 \mathrm{~m}$ & 0.02 & 0.02 & 0.020 & 0.000 & 0.0 \\
\hline & & $>2 \mathrm{~m}$ & 0 & 0.02 & 0.010 & 0.020 & 200.0 \\
\hline & & \multicolumn{5}{|r|}{ mean diff } & 82.2 \\
\hline & \multirow{7}{*}{$\begin{array}{l}\text { Semidesert } \\
\text { Loam (Wyoming } \\
\text { Big Sagebrush) }\end{array}$} & $0-10 \mathrm{~cm}$ & 2.8 & 3.2 & 3.000 & 0.400 & 13.3 \\
\hline & & $10-25 \mathrm{~cm}$ & 0.04 & 0.04 & 0.040 & 0.000 & 0.0 \\
\hline & & $25-50 \mathrm{~cm}$ & 0.04 & 0.02 & 0.030 & 0.020 & 66.7 \\
\hline & & $50 \mathrm{~cm}-1 \mathrm{~m}$ & 0.22 & 0.27 & 0.245 & 0.050 & 20.4 \\
\hline & & $1-2 \mathrm{~m}$ & 0.11 & 0.09 & 0.100 & 0.020 & 20.0 \\
\hline & & $>2 \mathrm{~m}$ & 0 & 0 & 0.000 & 0.000 & $\mathrm{n} / \mathrm{a}$ \\
\hline \multirow{8}{*}{$\begin{array}{l}\text { Shepherdia } \\
\text { rotundifolia } \\
\text { (SHRO) }\end{array}$} & & & & & & mean diff & 24.1 \\
\hline & \multirow{7}{*}{$\begin{array}{l}\text { Upland Shallow } \\
\text { Loam (Pinyon- } \\
\text { Utah Juniper) }\end{array}$} & $0-10 \mathrm{~cm}$ & 0 & 0 & 0.000 & 0.000 & $\mathrm{n} / \mathrm{a}$ \\
\hline & & $10-25 \mathrm{~cm}$ & 0 & 0 & 0.000 & 0.000 & $\mathrm{n} / \mathrm{a}$ \\
\hline & & $25-50 \mathrm{~cm}$ & 0.02 & 0.02 & 0.020 & 0.000 & 0.0 \\
\hline & & $50 \mathrm{~cm}-1 \mathrm{~m}$ & 0.02 & 0.02 & 0.020 & 0.000 & 0.0 \\
\hline & & $1-2 \mathrm{~m}$ & 0.02 & 0.02 & 0.020 & 0.000 & 0.0 \\
\hline & & $>2 \mathrm{~m}$ & 0 & 0 & 0.000 & 0.000 & $\mathrm{n} / \mathrm{a}$ \\
\hline & & \multicolumn{5}{|r|}{ mean diff } & 0.0 \\
\hline \multirow{7}{*}{$\begin{array}{l}\text { Symphoricarpos } \\
\text { oreophilus } \\
\text { (SYOR2) }\end{array}$} & \multirow{7}{*}{ Brushy Loam } & $0-10 \mathrm{~cm}$ & 0 & 0 & 0.000 & 0.000 & $\mathrm{n} / \mathrm{a}$ \\
\hline & & $10-25 \mathrm{~cm}$ & 0.07 & 0.07 & 0.070 & 0.000 & 0.0 \\
\hline & & $25-50 \mathrm{~cm}$ & 0.78 & 0.53 & 0.655 & 0.250 & 38.2 \\
\hline & & $50 \mathrm{~cm}-1 \mathrm{~m}$ & 1.6 & 1.7 & 1.650 & 0.100 & 6.1 \\
\hline & & $1-2 \mathrm{~m}$ & 0.78 & 0.73 & 0.755 & 0.050 & 6.6 \\
\hline & & $>2 \mathrm{~m}$ & 0 & 0 & 0.000 & 0.000 & $\mathrm{n} / \mathrm{a}$ \\
\hline & & & & & & mean diff & 12.7 \\
\hline
\end{tabular}


Table F6. Mean estimates of tree density (counts per quadrat) by species, size class, and observer (Obs. 1 and Obs. 2) at Colorado Plateau ecological sites sampled during Phase 3 , absolute between-observer differences, and differences expressed as percent of the mean of both observations.

\begin{tabular}{|c|c|c|c|c|c|c|c|}
\hline Species & Ecological site & Size class & Obs. 1 & Obs. 2 & Mean & Abs. Diff & $\begin{array}{r}\text { Diff \% of } \\
\text { Mean }\end{array}$ \\
\hline \multirow{4}{*}{$\begin{array}{l}\text { Abies concolor } \\
\text { (ABCO) }\end{array}$} & \multirow{4}{*}{$\begin{array}{l}\text { Loamy Hills, 25- } \\
\text { 33" pz }\end{array}$} & Seedling & 0.04 & 0.04 & 0.040 & 0.000 & 0.0 \\
\hline & & Pole & 0 & 0 & 0.000 & 0.000 & $\mathrm{n} / \mathrm{a}$ \\
\hline & & Overstory & 0 & 0 & 0.000 & 0.000 & $\mathrm{n} / \mathrm{a}$ \\
\hline & & \multicolumn{5}{|r|}{ mean diff } & 0.0 \\
\hline \multirow{16}{*}{$\begin{array}{l}\text { Juniperus } \\
\text { osteosperma } \\
\text { (JUOS) }\end{array}$} & \multirow{4}{*}{$\begin{array}{l}\text { Semidesert } \\
\text { Shallow Sandy } \\
\text { Loam PJ }\end{array}$} & Seedling & 0.02 & 0.02 & 0.020 & 0.000 & 0.0 \\
\hline & & Pole & 0 & 0 & 0.000 & 0.000 & $\mathrm{n} / \mathrm{a}$ \\
\hline & & Overstory & 0 & 0 & 0.000 & 0.000 & $\mathrm{n} / \mathrm{a}$ \\
\hline & & \multicolumn{5}{|r|}{ mean diff } & 0.0 \\
\hline & \multirow{4}{*}{$\begin{array}{l}\text { Upland Shallow } \\
\text { Loam (Pinyon- } \\
\text { Utah Juniper) }\end{array}$} & Seedling & 0.02 & 0.02 & 0.020 & 0.000 & 0.0 \\
\hline & & Pole & 0.04 & 0.02 & 0.030 & 0.020 & 66.7 \\
\hline & & Overstory & 0.09 & 0.13 & 0.110 & 0.040 & 36.4 \\
\hline & & \multicolumn{5}{|r|}{ mean diff } & 34.3 \\
\hline & \multirow{4}{*}{$\begin{array}{l}\text { Semidesert } \\
\text { Loam (Wyoming } \\
\text { Big Sagebrush) }\end{array}$} & Seedling & 0.04 & 0.13 & 0.085 & 0.090 & 105.9 \\
\hline & & Pole & 0.04 & 0.04 & 0.040 & 0.000 & 0.0 \\
\hline & & Overstory & 0 & 0 & 0.000 & 0.000 & $\mathrm{n} / \mathrm{a}$ \\
\hline & & \multicolumn{5}{|r|}{ mean diff } & 52.9 \\
\hline & \multirow{4}{*}{$\begin{array}{l}\text { Loamy Mesa } \\
\text { Top PJ }\end{array}$} & Seedling & 1.1 & 1 & 1.050 & 0.100 & 9.5 \\
\hline & & Pole & 0.29 & 0.33 & 0.310 & 0.040 & 12.9 \\
\hline & & Overstory & 0.18 & 0.22 & 0.200 & 0.040 & 20.0 \\
\hline & & \multicolumn{5}{|r|}{ mean diff } & 14.1 \\
\hline \multirow{12}{*}{$\begin{array}{l}\text { Pinus edulis } \\
\text { (PIED) }\end{array}$} & \multirow{4}{*}{$\begin{array}{l}\text { Upland Shallow } \\
\text { Loam (Pinyon- } \\
\text { Utah Juniper) }\end{array}$} & Seedling & 0.07 & 0.04 & 0.055 & 0.030 & 54.5 \\
\hline & & Pole & 0.07 & 0.07 & 0.070 & 0.000 & 0.0 \\
\hline & & Overstory & 0 & 0 & 0.000 & 0.000 & $\mathrm{n} / \mathrm{a}$ \\
\hline & & \multicolumn{5}{|r|}{ mean diff } & 27.3 \\
\hline & \multirow{4}{*}{$\begin{array}{l}\text { Loamy Mesa } \\
\text { Top PJ }\end{array}$} & Seedling & 1.4 & 1.3 & 1.350 & 0.100 & 7.4 \\
\hline & & Pole & 0.36 & 0.38 & 0.370 & 0.020 & 5.4 \\
\hline & & Overstory & 0.04 & 0.04 & 0.040 & 0.000 & 0.0 \\
\hline & & \multicolumn{5}{|r|}{ mean diff } & 4.3 \\
\hline & \multirow{4}{*}{ Brushy Loam } & Seedling & 0.02 & 0.02 & 0.020 & 0.000 & 0.0 \\
\hline & & Pole & 0 & 0 & 0.000 & 0.000 & $\mathrm{n} / \mathrm{a}$ \\
\hline & & Overstory & 0 & 0 & 0.000 & 0.000 & $\mathrm{n} / \mathrm{a}$ \\
\hline & & \multicolumn{5}{|r|}{ mean diff } & 0.0 \\
\hline \multirow{4}{*}{$\begin{array}{l}\text { Picea } \\
\text { engelmannii } \\
\text { (PIEN) }\end{array}$} & \multirow{4}{*}{$\begin{array}{l}\text { Loamy Hills, 25- } \\
\text { 33" pz }\end{array}$} & Seedling & 0.02 & 0.02 & 0.020 & 0.000 & 0.0 \\
\hline & & Pole & 0.07 & 0.07 & 0.070 & 0.000 & 0.0 \\
\hline & & Overstory & 0 & 0 & 0.000 & 0.000 & $\mathrm{n} / \mathrm{a}$ \\
\hline & & \multicolumn{5}{|r|}{ mean diff } & 0.0 \\
\hline \multirow{4}{*}{$\begin{array}{l}\text { Pinus ponderosa } \\
\text { (PIPO) }\end{array}$} & \multirow{4}{*}{$\begin{array}{l}\text { Loamy Hills, 25- } \\
\text { 33" pz }\end{array}$} & Seedling & 0 & 0 & 0.000 & 0.000 & $\mathrm{n} / \mathrm{a}$ \\
\hline & & Pole & 0.04 & 0.02 & 0.030 & 0.020 & 66.7 \\
\hline & & Overstory & 0.18 & 0.16 & 0.170 & 0.020 & 11.8 \\
\hline & & \multicolumn{5}{|r|}{ mean diff } & 39.2 \\
\hline
\end{tabular}


Table F6.-Continued

\begin{tabular}{|c|c|c|c|c|c|c|c|}
\hline Species & Ecological site & Size class & Obs. 1 & Obs. 2 & Mean & Abs. Diff & $\begin{array}{r}\text { Diff \% of } \\
\text { Mean }\end{array}$ \\
\hline \multirow{4}{*}{$\begin{array}{l}\text { Populus } \\
\text { tremuloides } \\
\text { (POTR5) }\end{array}$} & \multirow{4}{*}{$\begin{array}{l}\text { Loamy Hills, 25- } \\
\text { 33" pz }\end{array}$} & Seedling & 3.4 & 3.2 & 3.300 & 0.200 & 6.1 \\
\hline & & Pole & 0.29 & 0.29 & 0.290 & 0.000 & 0.0 \\
\hline & & Overstory & 0.02 & 0.02 & 0.020 & 0.000 & 0.0 \\
\hline & & \multicolumn{5}{|r|}{ mean diff } & 2.0 \\
\hline \multirow{4}{*}{$\begin{array}{l}\text { Pseudotsuga } \\
\text { menziesii } \\
\text { (PSME) }\end{array}$} & \multirow{4}{*}{$\begin{array}{l}\text { Loamy Hills, 25- } \\
\text { 33" pz }\end{array}$} & Seedling & 0.02 & 0.02 & 0.020 & 0.000 & 0.0 \\
\hline & & Pole & 0 & 0 & 0.000 & 0.000 & $\mathrm{n} / \mathrm{a}$ \\
\hline & & Overstory & 0 & 0 & 0.000 & 0.000 & $\mathrm{n} / \mathrm{a}$ \\
\hline & & \multicolumn{5}{|r|}{ mean diff } & 0.0 \\
\hline \multirow{4}{*}{$\begin{array}{l}\text { Quercus gambelii } \\
\text { (QUGA) }\end{array}$} & \multirow{4}{*}{ Brushy Loam } & Seedling & 4.3 & 5.2 & 4.750 & 0.900 & 18.9 \\
\hline & & Pole & 0.02 & 0 & 0.010 & 0.020 & 200.0 \\
\hline & & Overstory & 0 & 0 & 0.000 & 0.000 & $\mathrm{n} / \mathrm{a}$ \\
\hline & & & & & & mean diff & 109.5 \\
\hline
\end{tabular}




\section{Appendix G-Nested Frequency Data by Ecological Site}

\begin{tabular}{|l|c|c|}
\hline Ecological site & Table & Page \\
\hline \multirow{2}{*}{ Brushy Loam } & G1 & 162 \\
\cline { 2 - 3 } & G2 & 164 \\
\hline Desert Sand (Sand Sagebrush) & G3 & 166 \\
\hline \multirow{2}{*}{ Limy Upland, 6-10" pz } & G4 & 167 \\
\hline \multirow{2}{*}{ Loamy Hills, 25-33" pz } & G5 & 168 \\
\hline Loamy Hills, Cold, 25-33" pz & G7 & 169 \\
\hline \multirow{2}{*}{ Loamy Mesa Top PJ } & G8 & 170 \\
\hline \multirow{2}{*}{ Semidesert Alkali Sandy Loam (Alkali Sacaton) } & G9 & 171 \\
\hline \multirow{2}{*}{ Semidesert Loam (Wyoming Big Sagebrush) } & G10 & 173 \\
\cline { 2 - 3 } & G11 & 174 \\
\hline \multirow{2}{*}{ Semidesert Shallow Sandy Loam PJ } & G12 & 176 \\
\cline { 2 - 3 } & G14 & 178 \\
\hline Shallow Loamy, 10-14" pz & G15 & 179 \\
\cline { 2 - 3 } & G16 & 182 \\
\cline { 2 - 3 } Upland Shallow Loam (Pinyon-Utah Juniper) & G17 & 184 \\
\hline
\end{tabular}


Table G1. Frequency (\%) of plant species in different-sized quadrats at three macroplots (MEVE1, MEVE2, and MEVE3) associated with the Brushy Loam ecological site at Mesa Verde National Park. See Appendix A for key to species codes.

\begin{tabular}{|c|c|c|c|c|c|c|c|c|c|c|c|c|}
\hline \multirow[b]{3}{*}{ Species code } & \multicolumn{12}{|c|}{ Frequency (\%) by macroplot and quadrat size } \\
\hline & \multicolumn{4}{|c|}{ MEVE1 } & \multicolumn{4}{|c|}{ MEVE2 } & \multicolumn{4}{|c|}{ MEVE5 } \\
\hline & $0.01 \mathrm{~m}^{2}$ & $0.1 \mathrm{~m}^{2}$ & $1 \mathrm{~m}^{2}$ & $10 \mathrm{~m}^{2}$ & $0.01 \mathrm{~m}^{2}$ & $0.1 \mathrm{~m}^{2}$ & $1 \mathrm{~m}^{2}$ & $10 \mathrm{~m}^{2}$ & $0.01 \mathrm{~m}^{2}$ & $0.1 \mathrm{~m}^{2}$ & $1 \mathrm{~m}^{2}$ & $10 \mathrm{~m}^{2}$ \\
\hline ACMI2 & 0 & 0 & 0 & 10 & 13 & 13 & 37 & 94 & 13 & 23 & 43 & 80 \\
\hline AGCR & 0 & 0 & 0 & 0 & 0 & 0 & 0 & 0 & 7 & 13 & 17 & 17 \\
\hline ALAC4 & 0 & 3 & 10 & 24 & 0 & 0 & 23 & 42 & 0 & 0 & 0 & 0 \\
\hline AMUT & 3 & 3 & 37 & 70 & 0 & 7 & 13 & 47 & 3 & 7 & 13 & 47 \\
\hline ARBI3 & 0 & 0 & 0 & 0 & 0 & 0 & 0 & 0 & 0 & 0 & 7 & 7 \\
\hline ARDR4 & 0 & 0 & 0 & 0 & 0 & 0 & 0 & 0 & 0 & 0 & 0 & 3 \\
\hline BASA3 & 0 & 0 & 0 & 0 & 0 & 0 & 0 & 5 & 0 & 0 & 0 & 0 \\
\hline BRTE & 0 & 0 & 0 & 0 & 3 & 3 & 7 & 16 & 0 & 0 & 0 & 7 \\
\hline CANU3 & 0 & 0 & 0 & 0 & 0 & 0 & 3 & 8 & 0 & 0 & 0 & 0 \\
\hline CANU4 & 0 & 0 & 0 & 0 & 0 & 0 & 10 & 48 & 0 & 0 & 0 & 0 \\
\hline CEMO2 & 0 & 0 & 3 & 22 & 0 & 0 & 0 & 0 & 0 & 0 & 0 & 0 \\
\hline CHAL7 & 0 & 0 & 0 & 0 & 0 & 7 & 27 & 79 & 0 & 0 & 0 & 0 \\
\hline CHLE4 & 0 & 0 & 0 & 0 & 0 & 0 & 0 & 0 & 0 & 0 & 7 & 17 \\
\hline CHVI8 & 0 & 0 & 0 & 0 & 0 & 0 & 7 & 16 & 0 & 0 & 0 & 0 \\
\hline COUM & 0 & 0 & 0 & 5 & 0 & 0 & 0 & 10 & 0 & 0 & 0 & 0 \\
\hline DEPI & 0 & 0 & 0 & 5 & 0 & 0 & 0 & 5 & 0 & 0 & 0 & 7 \\
\hline ELEL5 & 0 & 0 & 0 & 5 & 3 & 3 & 10 & 29 & 13 & 40 & 73 & 83 \\
\hline ERUM & 0 & 0 & 0 & 0 & 0 & 0 & 0 & 0 & 0 & 0 & 3 & 7 \\
\hline FERU & 0 & 0 & 3 & 18 & 0 & 0 & 0 & 0 & 0 & 0 & 0 & 3 \\
\hline HECO26 & 0 & 0 & 0 & 0 & 0 & 0 & 0 & 0 & 0 & 0 & 3 & 17 \\
\hline IPAG & 0 & 3 & 3 & 13 & 0 & 0 & 0 & 0 & 0 & 0 & 0 & 0 \\
\hline JuOS & 0 & 0 & 0 & 10 & 0 & 0 & 0 & 0 & 0 & 0 & 0 & 0 \\
\hline KOMA & 0 & 0 & 0 & 0 & 0 & 0 & 0 & 0 & 0 & 0 & 13 & 47 \\
\hline LATA & 0 & 0 & 0 & 0 & 10 & 33 & 70 & 89 & 0 & 0 & 0 & 0 \\
\hline LUCA & 0 & 3 & 10 & 24 & 0 & 0 & 0 & 0 & 7 & 7 & 57 & 80 \\
\hline MARE11 & 0 & 0 & 0 & 5 & 0 & 7 & 13 & 23 & 0 & 0 & 0 & 13 \\
\hline PAMY & 0 & 0 & 3 & 8 & 0 & 0 & 0 & 0 & 0 & 0 & 0 & 0 \\
\hline PASM & 0 & 0 & 0 & 0 & 0 & 0 & 0 & 5 & 3 & 20 & 27 & 47 \\
\hline PEPU7 & 0 & 0 & 0 & 5 & 0 & 0 & 0 & 5 & 0 & 7 & 40 & 63 \\
\hline PHHE2 & 0 & 0 & 0 & 0 & 0 & 0 & 0 & 0 & 0 & 0 & 7 & 23 \\
\hline PIED & 0 & 0 & 13 & 61 & 0 & 0 & 0 & 0 & 0 & 0 & 0 & 7 \\
\hline POFE & 0 & 7 & 33 & 62 & 0 & 0 & 3 & 8 & 43 & 63 & 80 & 87 \\
\hline PUTR2 & 0 & 0 & 0 & 0 & 0 & 0 & 0 & 0 & 0 & 0 & 0 & 0 \\
\hline QUGA & 20 & 43 & 70 & 94 & 17 & 23 & 50 & 100 & 0 & 0 & 10 & 17 \\
\hline SIAL2 & 0 & 0 & 0 & 0 & 0 & 0 & 3 & 13 & 0 & 0 & 0 & 0 \\
\hline
\end{tabular}


Table G1.-Continued

\begin{tabular}{|c|c|c|c|c|c|c|c|c|c|c|c|c|}
\hline \multirow[b]{3}{*}{ Species code } & \multicolumn{12}{|c|}{ Frequency (\%) by macroplot and quadrat size } \\
\hline & \multicolumn{4}{|c|}{ MEVE1 } & \multicolumn{4}{|c|}{ MEVE2 } & \multicolumn{4}{|c|}{ MEVE5 } \\
\hline & $0.01 \mathrm{~m}^{2}$ & $0.1 \mathrm{~m}^{2}$ & $1 \mathrm{~m}^{2}$ & $10 \mathrm{~m}^{2}$ & $0.01 \mathrm{~m}^{2}$ & $0.1 \mathrm{~m}^{2}$ & $1 \mathrm{~m}^{2}$ & $10 \mathrm{~m}^{2}$ & $0.01 \mathrm{~m}^{2}$ & $0.1 \mathrm{~m}^{2}$ & $1 \mathrm{~m}^{2}$ & $10 \mathrm{~m}^{2}$ \\
\hline SPCO & 0 & 0 & 0 & 0 & 0 & 0 & 0 & 0 & 0 & 0 & 0 & 0 \\
\hline STLO4 & 3 & 3 & 20 & 34 & 0 & 0 & 0 & 0 & 0 & 0 & 0 & 0 \\
\hline SYOR2 & 0 & 13 & 40 & 69 & 3 & 10 & 20 & 39 & 0 & 0 & 13 & 83 \\
\hline WYAR & 0 & 0 & 0 & 0 & 0 & 3 & 10 & 24 & 0 & 0 & 17 & 43 \\
\hline YUBA & 0 & 3 & 3 & 8 & 0 & 0 & 0 & 0 & 0 & 0 & 0 & 0 \\
\hline
\end{tabular}


Table G2. Frequency (\%) of plant species in different-sized quadrats at two Brushy Loam macroplots (MEVE6 and MEVE7) and combined frequency values for all five macroplots associated with the Brushy Loam ecological site at Mesa Verde National Park. See Appendix A for key to species codes.

\begin{tabular}{|c|c|c|c|c|c|c|c|c|c|c|c|c|}
\hline \multirow[b]{3}{*}{ Species code } & \multicolumn{12}{|c|}{ Frequency (\%) by macroplot and quadrat size } \\
\hline & \multicolumn{4}{|c|}{ MEVE6 } & \multicolumn{4}{|c|}{ MEVE7b } & \multicolumn{4}{|c|}{ All macroplots combined $(n=5)$} \\
\hline & $0.01 \mathrm{~m}^{2}$ & $0.1 \mathrm{~m}^{2}$ & $1 \mathrm{~m}^{2}$ & $10 \mathrm{~m}^{2}$ & $0.01 \mathrm{~m}^{2}$ & $0.1 \mathrm{~m}^{2}$ & $1 \mathrm{~m}^{2}$ & $10 \mathrm{~m}^{2}$ & $0.01 \mathrm{~m}^{2}$ & $0.1 \mathrm{~m}^{2}$ & $1 \mathrm{~m}^{2}$ & $10 \mathrm{~m}^{2}$ \\
\hline ACMI2 & 0 & 10 & 27 & 43 & 10 & 20 & 53 & 93 & 7 & 13 & 32 & 64 \\
\hline AGCR & 0 & 0 & 0 & 0 & 0 & 0 & 0 & 0 & 1 & 3 & 3 & 3 \\
\hline ALAC4 & 0 & 0 & 0 & 0 & 0 & 0 & 0 & 0 & 0 & 1 & 7 & 13 \\
\hline AMUT & 0 & 3 & 3 & 13 & 0 & 13 & 43 & 93 & 1 & 7 & 22 & 54 \\
\hline ARBI3 & 0 & 0 & 7 & 17 & 0 & 0 & 0 & 0 & 0 & 0 & 3 & 5 \\
\hline ARDR4 & 0 & 0 & 0 & 0 & 0 & 0 & 0 & 23 & 0 & 0 & 0 & 5 \\
\hline BASA3 & 0 & 0 & 0 & 0 & 0 & 0 & 0 & 0 & 0 & 0 & 0 & 1 \\
\hline BRTE & 0 & 0 & 10 & 30 & 0 & 3 & 27 & 50 & 1 & 1 & 9 & 21 \\
\hline CANU3 & 0 & 0 & 0 & 0 & 0 & 3 & 3 & 3 & 0 & 1 & 1 & 2 \\
\hline CANU4 & 0 & 7 & 13 & 13 & 0 & 0 & 13 & 50 & 0 & 1 & 7 & 22 \\
\hline CEMO2 & 0 & 0 & 0 & 0 & 0 & 0 & 0 & 0 & 0 & 0 & 1 & 4 \\
\hline CHAL7 & 0 & 0 & 0 & 0 & 0 & 0 & 0 & 0 & 0 & 1 & 5 & 16 \\
\hline CHLE4 & 10 & 27 & 50 & 53 & 0 & 0 & 0 & 7 & 2 & 5 & 11 & 15 \\
\hline CHVI8 & 0 & 0 & 0 & 0 & 0 & 0 & 0 & 0 & 0 & 0 & 1 & 3 \\
\hline COUM & 0 & 0 & 0 & 0 & 0 & 0 & 0 & 0 & 0 & 0 & 0 & 3 \\
\hline DEPI & 0 & 0 & 0 & 0 & 0 & 0 & 0 & 0 & 0 & 0 & 0 & 3 \\
\hline ELEL5 & 27 & 50 & 80 & 87 & 3 & 13 & 33 & 47 & 9 & 21 & 39 & 50 \\
\hline ERUM & 0 & 0 & 3 & 23 & 0 & 0 & 0 & 7 & 0 & 0 & 1 & 7 \\
\hline FERU & 0 & 0 & 0 & 0 & 0 & 0 & 0 & 0 & 0 & 0 & 1 & 4 \\
\hline HECO26 & 10 & 20 & 27 & 30 & 0 & 0 & 0 & 0 & 2 & 4 & 6 & 9 \\
\hline IPAG & 0 & 0 & 0 & 0 & 0 & 0 & 0 & 0 & 0 & 1 & 1 & 3 \\
\hline JUOS & 0 & 0 & 0 & 0 & 0 & 0 & 0 & 0 & 0 & 0 & 0 & 2 \\
\hline KOMA & 7 & 13 & 30 & 80 & 0 & 3 & 17 & 47 & 1 & 3 & 12 & 35 \\
\hline LATA & 0 & 0 & 0 & 3 & 0 & 0 & 0 & 0 & 2 & 7 & 14 & 18 \\
\hline LUCA & 0 & 3 & 23 & 70 & 3 & 3 & 40 & 63 & 2 & 3 & 26 & 48 \\
\hline MARE11 & 0 & 0 & 0 & 0 & 0 & 0 & 0 & 0 & 0 & 1 & 3 & 8 \\
\hline PAMY & 0 & 0 & 0 & 0 & 0 & 0 & 0 & 0 & 0 & 0 & 1 & 2 \\
\hline PASM & 7 & 7 & 7 & 17 & 0 & 0 & 0 & 0 & 2 & 5 & 7 & 14 \\
\hline PEPU7 & 23 & 27 & 67 & 80 & 0 & 0 & 0 & 27 & 5 & 7 & 21 & 36 \\
\hline PHHE2 & 0 & 0 & 0 & 0 & 0 & 0 & 13 & 30 & 0 & 0 & 4 & 11 \\
\hline
\end{tabular}


Table G2.-Continued

\begin{tabular}{|c|c|c|c|c|c|c|c|c|c|c|c|c|}
\hline \multirow[b]{3}{*}{ Species code } & \multicolumn{12}{|c|}{ Frequency (\%) by macroplot and quadrat size } \\
\hline & \multicolumn{4}{|c|}{ MEVE6 } & \multicolumn{4}{|c|}{ MEVE7b } & \multicolumn{4}{|c|}{ All macroplots combined $(n=5)$} \\
\hline & $0.01 \mathrm{~m}^{2}$ & $0.1 \mathrm{~m}^{2}$ & $1 \mathrm{~m}^{2}$ & $10 \mathrm{~m}^{2}$ & $0.01 \mathrm{~m}^{2}$ & $0.1 \mathrm{~m}^{2}$ & $1 \mathrm{~m}^{2}$ & $10 \mathrm{~m}^{2}$ & $0.01 \mathrm{~m}^{2}$ & $0.1 \mathrm{~m}^{2}$ & $1 \mathrm{~m}^{2}$ & $10 \mathrm{~m}^{2}$ \\
\hline PIED & 0 & 0 & 0 & 0 & 0 & 0 & 0 & 0 & 0 & 0 & 3 & 14 \\
\hline POFE & 13 & 47 & 70 & 80 & 80 & 87 & 100 & 100 & 27 & 41 & 57 & 67 \\
\hline PUTR2 & 0 & 0 & 0 & 7 & 0 & 0 & 0 & 0 & 0 & 0 & 0 & 1 \\
\hline QUGA & 0 & 0 & 7 & 20 & 7 & 13 & 27 & 30 & 9 & 16 & 33 & 52 \\
\hline SIAL2 & 0 & 0 & 0 & 0 & 0 & 0 & 0 & 0 & 0 & 0 & 1 & 3 \\
\hline SPCO & 0 & 0 & 0 & 0 & 0 & 0 & 0 & 7 & 0 & 0 & 0 & 1 \\
\hline STLO4 & 0 & 0 & 0 & 0 & 0 & 0 & 0 & 0 & 1 & 1 & 4 & 7 \\
\hline SYOR2 & 0 & 0 & 3 & 37 & 17 & 27 & 40 & 87 & 4 & 10 & 23 & 63 \\
\hline WYAR & 0 & 0 & 17 & 53 & 0 & 0 & 13 & 23 & 0 & 1 & 11 & 29 \\
\hline YUBA & 0 & 0 & 0 & 0 & 0 & 0 & 0 & 0 & 0 & 1 & 1 & 2 \\
\hline
\end{tabular}


Table G3. Frequency (\%) of plant species in different-sized quadrats at two Desert Sand macroplots (CANY1 and CANY2b) and combined frequency values for both macroplots associated with the Desert Sand ecological site at Canyonlands National Park. See Appendix A for key to species codes.

\begin{tabular}{|c|c|c|c|c|c|c|c|c|c|c|c|c|}
\hline \multirow[b]{3}{*}{ Species code } & \multicolumn{12}{|c|}{ Frequency (\%) by macroplot and quadrat size } \\
\hline & \multicolumn{4}{|c|}{ CANY1 } & \multicolumn{4}{|c|}{ CANY2b } & \multicolumn{4}{|c|}{ Both macroplots combined $(n=2)$} \\
\hline & $0.01 \mathrm{~m}^{2}$ & $0.1 \mathrm{~m}^{2}$ & $1 \mathrm{~m}^{2}$ & $10 \mathrm{~m}^{2}$ & $0.01 \mathrm{~m}^{2}$ & $0.1 \mathrm{~m}^{2}$ & $1 \mathrm{~m}^{2}$ & $10 \mathrm{~m}^{2}$ & $0.01 \mathrm{~m}^{2}$ & $0.1 \mathrm{~m}^{2}$ & $1 \mathrm{~m}^{2}$ & $10 \mathrm{~m}^{2}$ \\
\hline ABFR2 & 0 & 0 & 0 & 0 & 0 & 3 & 7 & 11 & 0 & 2 & 3 & 6 \\
\hline ARPU9 & 0 & 0 & 3 & 3 & 0 & 0 & 0 & 0 & 0 & 0 & 2 & 2 \\
\hline ATCA2 & 0 & 0 & 10 & 53 & 0 & 3 & 10 & 29 & 0 & 2 & 10 & 41 \\
\hline BRTE & 0 & 0 & 0 & 0 & 0 & 3 & 3 & 3 & 0 & 2 & 2 & 2 \\
\hline CELA4 & 0 & 0 & 0 & 0 & 0 & 0 & 0 & 10 & 0 & 0 & 0 & 5 \\
\hline CHAL7 & 0 & 0 & 13 & 28 & 0 & 0 & 0 & 0 & 0 & 0 & 7 & 14 \\
\hline CHST & 0 & 0 & 0 & 0 & 0 & 0 & 0 & 5 & 0 & 0 & 0 & 2 \\
\hline CORA & 0 & 0 & 0 & 0 & 0 & 0 & 0 & 5 & 0 & 0 & 0 & 2 \\
\hline EPVI & 0 & 0 & 0 & 5 & 0 & 0 & 0 & 0 & 0 & 0 & 0 & 2 \\
\hline ERCE2 & 0 & 0 & 3 & 8 & 0 & 0 & 0 & 0 & 0 & 0 & 2 & 4 \\
\hline FEOC3 & 10 & 30 & 63 & 78 & 0 & 13 & 47 & 90 & 5 & 22 & 55 & 84 \\
\hline GAPI & 0 & 17 & 40 & 88 & 7 & 27 & 70 & 99 & 3 & 22 & 55 & 93 \\
\hline HIJA & 3 & 17 & 23 & 33 & 7 & 10 & 43 & 86 & 5 & 13 & 33 & 60 \\
\hline LAOC3 & 0 & 13 & 50 & 83 & 20 & 77 & 100 & 100 & 10 & 45 & 75 & 92 \\
\hline LIAR3 & 0 & 3 & 43 & 72 & 0 & 13 & 40 & 69 & 0 & 8 & 42 & 70 \\
\hline MACA2 & 0 & 0 & 3 & 3 & 0 & 10 & 37 & 84 & 0 & 5 & 20 & 44 \\
\hline MEAL6 & 3 & 3 & 20 & 63 & 3 & 10 & 40 & 92 & 3 & 7 & 30 & 78 \\
\hline OEPA & 0 & 0 & 0 & 14 & 0 & 0 & 7 & 16 & 0 & 0 & 3 & 15 \\
\hline OPPO & 0 & 0 & 0 & 10 & 0 & 0 & 0 & 0 & 0 & 0 & 0 & 5 \\
\hline PLPA2 & 7 & 37 & 60 & 89 & 10 & 27 & 57 & 80 & 8 & 32 & 58 & 85 \\
\hline SAPA8 & 0 & 3 & 27 & 84 & 0 & 0 & 3 & 3 & 0 & 2 & 15 & 44 \\
\hline SAPE10 & 3 & 7 & 20 & 68 & 0 & 0 & 17 & 55 & 2 & 3 & 18 & 61 \\
\hline SPCO & 0 & 0 & 0 & 0 & 0 & 3 & 7 & 11 & 0 & 2 & 3 & 6 \\
\hline SPGR2 & 3 & 30 & 70 & 94 & 10 & 43 & 77 & 100 & 7 & 37 & 73 & 97 \\
\hline STEX & 0 & 3 & 17 & 36 & 0 & 10 & 30 & 40 & 0 & 7 & 23 & 38 \\
\hline STHY6 & 0 & 7 & 10 & 39 & 3 & 27 & 70 & 100 & 2 & 17 & 40 & 69 \\
\hline STLO4 & 0 & 0 & 0 & 0 & 0 & 0 & 10 & 29 & 0 & 0 & 5 & 15 \\
\hline TOAN & 0 & 10 & 27 & 46 & 0 & 0 & 10 & 15 & 0 & 5 & 18 & 30 \\
\hline
\end{tabular}


Table G4. Frequency (\%) of plant species in different-sized quadrats at three macroplots (WUPA1, WUPA2, and WUPA5) associated with the Limy Upland ecological site at Wupatki National Monument. See Appendix A for key to species codes.

\begin{tabular}{|c|c|c|c|c|c|c|c|c|c|c|c|c|}
\hline \multirow[b]{3}{*}{ Species code } & \multicolumn{12}{|c|}{ Frequency (\%) by macroplot and quadrat size } \\
\hline & \multicolumn{4}{|c|}{ WUPA1 } & \multicolumn{4}{|c|}{ WUPA2 } & \multicolumn{4}{|c|}{ WUPA5 } \\
\hline & $0.01 \mathrm{~m}^{2}$ & $0.1 \mathrm{~m}^{2}$ & $1 \mathrm{~m}^{2}$ & $10 \mathrm{~m}^{2}$ & $0.01 \mathrm{~m}^{2}$ & $0.1 \mathrm{~m}^{2}$ & $1 \mathrm{~m}^{2}$ & $10 \mathrm{~m}^{2}$ & $0.01 \mathrm{~m}^{2}$ & $0.1 \mathrm{~m}^{2}$ & $1 \mathrm{~m}^{2}$ & $10 \mathrm{~m}^{2}$ \\
\hline $\mathrm{ACHY}$ & 0 & 0 & 0 & 10 & 0 & 0 & 0 & 0 & 0 & 0 & 0 & 0 \\
\hline ARPU9 & 0 & 0 & 0 & 0 & 0 & 0 & 0 & 5 & 0 & 0 & 0 & 0 \\
\hline BOER4 & 7 & 53 & 90 & 95 & 3 & 20 & 47 & 94 & 0 & 0 & 0 & 0 \\
\hline BOGR2 & 0 & 0 & 0 & 0 & 0 & 0 & 0 & 0 & 0 & 0 & 0 & 0 \\
\hline BRTE & 0 & 0 & 0 & 0 & 0 & 0 & 0 & 0 & 0 & 0 & 0 & 0 \\
\hline CHLE4 & 17 & 77 & 100 & 100 & 0 & 3 & 27 & 74 & 33 & 80 & 93 & 100 \\
\hline CHNA2 & 0 & 3 & 7 & 50 & 3 & 7 & 40 & 92 & 0 & 0 & 3 & 63 \\
\hline $\mathrm{CRCl} 3$ & 0 & 7 & 10 & 20 & 0 & 0 & 0 & 0 & 0 & 0 & 0 & 0 \\
\hline DEPI & 3 & 3 & 23 & 76 & 3 & 3 & 7 & 30 & 0 & 7 & 23 & 23 \\
\hline ELEL5 & 0 & 0 & 0 & 0 & 0 & 0 & 0 & 0 & 0 & 0 & 3 & 13 \\
\hline GIIN2 & 37 & 83 & 93 & 100 & 0 & 7 & 27 & 41 & 30 & 70 & 93 & 100 \\
\hline HENE5 & 7 & 17 & 53 & 100 & 0 & 20 & 73 & 92 & 0 & 0 & 7 & 37 \\
\hline LAOC3 & 0 & 0 & 0 & 0 & 0 & 0 & 0 & 0 & 0 & 0 & 0 & 0 \\
\hline MEAL6 & 20 & 50 & 83 & 98 & 3 & 27 & 60 & 89 & 23 & 43 & 67 & 87 \\
\hline OPER & 0 & 0 & 0 & 0 & 0 & 0 & 0 & 0 & 0 & 0 & 0 & 13 \\
\hline PHCR & 0 & 0 & 0 & 0 & 0 & 0 & 0 & 0 & 0 & 0 & 10 & 43 \\
\hline PLJA & 0 & 7 & 13 & 23 & 33 & 67 & 100 & 100 & 47 & 73 & 100 & 100 \\
\hline PSSP & 0 & 0 & 0 & 5 & 0 & 0 & 0 & 0 & 0 & 0 & 0 & 7 \\
\hline SAKA & 3 & 3 & 23 & 52 & 0 & 0 & 0 & 5 & 0 & 0 & 0 & 0 \\
\hline SPAI & 0 & 0 & 0 & 0 & 0 & 0 & 0 & 5 & 0 & 0 & 0 & 0 \\
\hline SPHA & 0 & 0 & 0 & 0 & 0 & 0 & 0 & 14 & 0 & 0 & 0 & 0 \\
\hline SPPA2 & 0 & 3 & 13 & 51 & 0 & 0 & 0 & 0 & 0 & 0 & 0 & 0 \\
\hline ZIGR & 0 & 0 & 3 & 3 & 0 & 7 & 7 & 7 & 0 & 0 & 0 & 0 \\
\hline
\end{tabular}


Table G5. Frequency (\%) of plant species in different-sized quadrats at two Limy Upland macroplots (WUPA6 and WUPA7) and combined frequency values for all five macroplots associated with the Limy Upland ecological site at Wupatki National Monument. See Appendix A for key to species codes.

\begin{tabular}{|c|c|c|c|c|c|c|c|c|c|c|c|c|}
\hline \multirow[b]{3}{*}{ Species code } & \multicolumn{12}{|c|}{ Frequency (\%) by macroplot and quadrat size } \\
\hline & \multicolumn{4}{|c|}{ WUPA6 } & \multicolumn{4}{|c|}{ WUPA7 } & \multicolumn{4}{|c|}{ All macroplots combined $(n=5)$} \\
\hline & $0.01 \mathrm{~m}^{2}$ & $0.1 \mathrm{~m}^{2}$ & $1 \mathrm{~m}^{2}$ & $10 \mathrm{~m}^{2}$ & $0.01 \mathrm{~m}^{2}$ & $0.1 \mathrm{~m}^{2}$ & $1 \mathrm{~m}^{2}$ & $10 \mathrm{~m}^{2}$ & $0.01 \mathrm{~m}^{2}$ & $0.1 \mathrm{~m}^{2}$ & $1 \mathrm{~m}^{2}$ & $10 \mathrm{~m}^{2}$ \\
\hline $\mathrm{ACHY}$ & 0 & 0 & 0 & 0 & 0 & 0 & 0 & 0 & 0 & 0 & 0 & 2 \\
\hline ARPU9 & 0 & 0 & 0 & 0 & 0 & 0 & 0 & 0 & 0 & 0 & 0 & 1 \\
\hline BOER4 & 3 & 23 & 80 & 90 & 10 & 20 & 57 & 87 & 5 & 23 & 55 & 73 \\
\hline BOGR2 & 0 & 0 & 0 & 3 & 0 & 0 & 0 & 0 & 0 & 0 & 0 & 1 \\
\hline BRTE & 0 & 0 & 3 & 3 & 0 & 0 & 0 & 3 & 0 & 0 & 1 & 1 \\
\hline CHLE4 & 43 & 83 & 100 & 100 & 30 & 57 & 77 & 100 & 25 & 60 & 79 & 95 \\
\hline CHNA2 & 0 & 0 & 0 & 0 & 0 & 0 & 10 & 60 & 1 & 2 & 12 & 53 \\
\hline $\mathrm{CRCl} 3$ & 0 & 0 & 0 & 0 & 0 & 0 & 0 & 0 & 0 & 1 & 2 & 4 \\
\hline DEPI & 3 & 17 & 70 & 93 & 0 & 0 & 0 & 10 & 2 & 6 & 25 & 47 \\
\hline ELEL5 & 0 & 0 & 0 & 0 & 0 & 0 & 0 & 0 & 0 & 0 & 1 & 3 \\
\hline GIIN2 & 10 & 50 & 93 & 97 & 0 & 0 & 3 & 17 & 15 & 42 & 62 & 71 \\
\hline HENE5 & 17 & 43 & 97 & 100 & 0 & 0 & 0 & 0 & 5 & 16 & 46 & 66 \\
\hline LAOC3 & 0 & 0 & 0 & 7 & 0 & 0 & 0 & 0 & 0 & 0 & 0 & 1 \\
\hline MEAL6 & 0 & 0 & 0 & 0 & 0 & 0 & 0 & 0 & 9 & 24 & 42 & 55 \\
\hline OPER & 0 & 0 & 0 & 0 & 0 & 0 & 0 & 0 & 0 & 0 & 0 & 3 \\
\hline PHCR & 0 & 0 & 0 & 3 & 0 & 0 & 0 & 0 & 0 & 0 & 2 & 9 \\
\hline PLJA & 7 & 10 & 43 & 63 & 17 & 53 & 93 & 100 & 21 & 42 & 70 & 77 \\
\hline PSSP & 0 & 0 & 0 & 0 & 0 & 0 & 0 & 0 & 0 & 0 & 0 & 2 \\
\hline SAKA & 0 & 0 & 20 & 53 & 0 & 0 & 0 & 23 & 1 & 1 & 9 & 27 \\
\hline SPAI & 0 & 0 & 0 & 0 & 0 & 0 & 0 & 0 & 0 & 0 & 0 & 1 \\
\hline SPHA & 0 & 0 & 0 & 0 & 0 & 0 & 0 & 0 & 0 & 0 & 0 & 3 \\
\hline SPPA2 & 0 & 0 & 57 & 90 & 0 & 0 & 17 & 53 & 0 & 1 & 17 & 39 \\
\hline ZIGR & 0 & 0 & 3 & 10 & 0 & 0 & 0 & 7 & 0 & 1 & 3 & 5 \\
\hline
\end{tabular}


Table G6. Frequency (\%) of plant species in different-sized quadrats at three macroplots (GRCA3, GRCA4, and GRCA5) associated with the Loamy Hills ecological site at Grand Canyon National Park. See Appendix A for key to species codes.

\begin{tabular}{|c|c|c|c|c|c|c|c|c|c|c|c|c|}
\hline \multirow[b]{3}{*}{ Species code } & \multicolumn{12}{|c|}{ Frequency (\%) by macroplot and quadrat size } \\
\hline & \multicolumn{4}{|c|}{ GRCA3 } & \multicolumn{4}{|c|}{ GRCA4 } & \multicolumn{4}{|c|}{ GRCA5 } \\
\hline & $0.01 \mathrm{~m}^{2}$ & $0.1 \mathrm{~m}^{2}$ & $1 \mathrm{~m}^{2}$ & $10 \mathrm{~m}^{2}$ & $0.01 \mathrm{~m}^{2}$ & $0.1 \mathrm{~m}^{2}$ & $1 \mathrm{~m}^{2}$ & $10 \mathrm{~m}^{2}$ & $0.01 \mathrm{~m}^{2}$ & $0.1 \mathrm{~m}^{2}$ & $1 \mathrm{~m}^{2}$ & $10 \mathrm{~m}^{2}$ \\
\hline $\mathrm{ABCO}$ & 0 & 0 & 13 & 28 & 0 & 3 & 23 & 90 & 0 & 0 & 0 & 7 \\
\hline ABLA & 0 & 0 & 0 & 29 & 0 & 0 & 3 & 37 & 0 & 0 & 0 & 0 \\
\hline ACMI2 & 0 & 0 & 0 & 0 & 3 & 3 & 10 & 24 & 0 & 0 & 7 & 13 \\
\hline ANPA5 & 0 & 0 & 0 & 0 & 0 & 0 & 0 & 0 & 0 & 0 & 0 & 7 \\
\hline BRIN2 & 0 & 0 & 0 & 0 & 0 & 0 & 3 & 22 & 0 & 3 & 7 & 7 \\
\hline BRTE & 0 & 0 & 0 & 0 & 0 & 0 & 0 & 0 & 0 & 0 & 3 & 7 \\
\hline CHAL7 & 0 & 0 & 0 & 0 & 0 & 0 & 0 & 0 & 7 & 20 & 30 & 30 \\
\hline ELEL5 & 0 & 0 & 0 & 0 & 0 & 3 & 3 & 13 & 0 & 3 & 17 & 30 \\
\hline EPAN & 0 & 0 & 3 & 3 & 0 & 0 & 0 & 0 & 0 & 0 & 0 & 0 \\
\hline FRVI & 0 & 0 & 0 & 5 & 0 & 3 & 10 & 29 & 0 & 0 & 0 & 0 \\
\hline GECA3 & 0 & 0 & 0 & 0 & 0 & 7 & 10 & 24 & 0 & 0 & 0 & 0 \\
\hline GOOB2 & 3 & 3 & 23 & 38 & 0 & 0 & 0 & 0 & 0 & 0 & 0 & 0 \\
\hline JUCO6 & 0 & 0 & 0 & 5 & 0 & 0 & 0 & 0 & 0 & 0 & 0 & 0 \\
\hline LUAR3 & 0 & 0 & 0 & 0 & 0 & 0 & 0 & 0 & 0 & 0 & 0 & 0 \\
\hline MARE11 & 0 & 3 & 3 & 13 & 3 & 7 & 13 & 23 & 0 & 0 & 0 & 23 \\
\hline PIEN & 0 & 0 & 0 & 38 & 0 & 3 & 7 & 40 & 0 & 0 & 0 & 0 \\
\hline PIPO & 0 & 0 & 0 & 0 & 0 & 0 & 0 & 5 & 0 & 0 & 0 & 7 \\
\hline POFE & 0 & 0 & 0 & 0 & 0 & 0 & 7 & 11 & 3 & 13 & 27 & 43 \\
\hline POTR5 & 0 & 7 & 37 & 89 & 0 & 0 & 10 & 58 & 0 & 13 & 63 & 80 \\
\hline PSME & 0 & 3 & 20 & 44 & 0 & 0 & 7 & 40 & 0 & 0 & 0 & 0 \\
\hline PTAQ & 0 & 0 & 0 & 0 & 0 & 3 & 3 & 3 & 0 & 0 & 0 & 0 \\
\hline PYCH & 0 & 0 & 0 & 10 & 0 & 0 & 0 & 0 & 0 & 0 & 0 & 0 \\
\hline SEMU3 & 0 & 0 & 0 & 0 & 0 & 0 & 0 & 0 & 3 & 3 & 43 & 70 \\
\hline SYOR2 & 0 & 0 & 0 & 0 & 0 & 0 & 3 & 22 & 0 & 0 & 0 & 0 \\
\hline THFE & 0 & 0 & 0 & 0 & 0 & 0 & 0 & 0 & 0 & 0 & 0 & 0 \\
\hline UNGRCA1 & 0 & 0 & 7 & 11 & 23 & 63 & 80 & 94 & 10 & 33 & 53 & 93 \\
\hline
\end{tabular}


Table G7. Frequency (\%) of plant species in different-sized quadrats at two Loamy Hills macroplots (GRCA6 and GRCA7) and combined frequency values for all five macroplots associated with the Loamy Hills ecological site at Grand Canyon National Park. See Appendix A for key to species codes.

\begin{tabular}{|c|c|c|c|c|c|c|c|c|c|c|c|c|}
\hline \multirow[b]{3}{*}{ Species code } & \multicolumn{12}{|c|}{ Frequency (\%) by macroplot and quadrat size } \\
\hline & \multicolumn{4}{|c|}{ GRCA6 } & \multicolumn{4}{|c|}{ GRCA7 } & \multicolumn{4}{|c|}{ All macroplots combined $(n=5)$} \\
\hline & $0.01 \mathrm{~m}^{2}$ & $0.1 \mathrm{~m}^{2}$ & $1 \mathrm{~m}^{2}$ & $10 \mathrm{~m}^{2}$ & $0.01 \mathrm{~m}^{2}$ & $0.1 \mathrm{~m}^{2}$ & $1 \mathrm{~m}^{2}$ & $10 \mathrm{~m}^{2}$ & $0.01 \mathrm{~m}^{2}$ & $0.1 \mathrm{~m}^{2}$ & $1 \mathrm{~m}^{2}$ & $10 \mathrm{~m}^{2}$ \\
\hline $\mathrm{ABCO}$ & 0 & 0 & 7 & 7 & 0 & 0 & 0 & 0 & 0 & 1 & 9 & 26 \\
\hline ABLA & 0 & 0 & 0 & 0 & 0 & 0 & 0 & 0 & 0 & 0 & 1 & 13 \\
\hline ACMI2 & 0 & 0 & 0 & 0 & 0 & 0 & 0 & 0 & 1 & 1 & 3 & 8 \\
\hline ANPA5 & 0 & 7 & 10 & 17 & 0 & 0 & 0 & 0 & 0 & 1 & 2 & 5 \\
\hline BRIN2 & 0 & 7 & 17 & 40 & 0 & 0 & 0 & 0 & 0 & 2 & 5 & 14 \\
\hline BRTE & 0 & 0 & 0 & 0 & 0 & 0 & 0 & 0 & 0 & 0 & 1 & 1 \\
\hline CHAL7 & 0 & 0 & 0 & 0 & 0 & 0 & 0 & 0 & 1 & 4 & 6 & 6 \\
\hline ELEL5 & 0 & 0 & 10 & 50 & 0 & 7 & 17 & 40 & 0 & 3 & 9 & 27 \\
\hline EPAN & 0 & 0 & 0 & 0 & 0 & 0 & 0 & 0 & 0 & 0 & 1 & 1 \\
\hline FRVI & 0 & 0 & 0 & 0 & 0 & 0 & 0 & 0 & 0 & 1 & 2 & 7 \\
\hline GECA3 & 0 & 0 & 0 & 0 & 0 & 0 & 0 & 0 & 0 & 1 & 2 & 5 \\
\hline GOOB2 & 0 & 0 & 0 & 0 & 0 & 0 & 0 & 0 & 1 & 1 & 5 & 8 \\
\hline JuCO6 & 0 & 0 & 0 & 7 & 0 & 0 & 0 & 0 & 0 & 0 & 0 & 2 \\
\hline LUAR3 & 0 & 0 & 0 & 0 & 3 & 20 & 27 & 47 & 1 & 4 & 5 & 9 \\
\hline MARE11 & 0 & 0 & 0 & 0 & 0 & 0 & 7 & 27 & 1 & 2 & 5 & 17 \\
\hline PIEN & 0 & 0 & 0 & 20 & 0 & 0 & 0 & 0 & 0 & 1 & 1 & 20 \\
\hline PIPO & 0 & 0 & 0 & 30 & 0 & 0 & 0 & 20 & 0 & 0 & 0 & 12 \\
\hline POFE & 7 & 13 & 27 & 73 & 7 & 33 & 70 & 93 & 3 & 12 & 26 & 44 \\
\hline POTR5 & 0 & 3 & 13 & 33 & 0 & 0 & 13 & 20 & 0 & 5 & 27 & 56 \\
\hline PSME & 0 & 0 & 0 & 7 & 0 & 0 & 0 & 0 & 0 & 1 & 5 & 18 \\
\hline PTAQ & 0 & 3 & 37 & 67 & 0 & 0 & 0 & 0 & 0 & 1 & 8 & 14 \\
\hline $\mathrm{PYCH}$ & 0 & 0 & 0 & 0 & 0 & 0 & 0 & 0 & 0 & 0 & 0 & 2 \\
\hline SEMU3 & 0 & 0 & 7 & 33 & 0 & 0 & 0 & 0 & 1 & 1 & 10 & 21 \\
\hline SYOR2 & 0 & 0 & 0 & 0 & 0 & 0 & 0 & 0 & 0 & 0 & 1 & 4 \\
\hline THFE & 0 & 0 & 0 & 13 & 0 & 0 & 0 & 0 & 0 & 0 & 0 & 3 \\
\hline UNGRCA1 & 37 & 63 & 70 & 100 & 10 & 43 & 60 & 87 & 16 & 41 & 54 & 77 \\
\hline
\end{tabular}


Table G8. Frequency (\%) of plant species in different-sized quadrats at two Loamy Hills, Cold, macroplots (GRCA1 and GRCA2) and combined frequency values for both macroplots associated with the Loamy Hills, Cold, ecological site at Grand Canyon National Park. See Appendix A for key to species codes.

\begin{tabular}{|c|c|c|c|c|c|c|c|c|c|c|c|c|}
\hline \multirow[b]{3}{*}{ Species code } & \multicolumn{12}{|c|}{ Frequency (\%) by macroplot and quadrat size } \\
\hline & \multicolumn{4}{|c|}{ GRCA1 } & \multicolumn{4}{|c|}{ GRCA2 } & \multicolumn{4}{|c|}{ Both macroplots combined $(n=2)$} \\
\hline & $0.01 \mathrm{~m}^{2}$ & $0.1 \mathrm{~m}^{2}$ & $1 \mathrm{~m}^{2}$ & $10 \mathrm{~m}^{2}$ & $0.01 \mathrm{~m}^{2}$ & $0.1 \mathrm{~m}^{2}$ & $1 \mathrm{~m}^{2}$ & $10 \mathrm{~m}^{2}$ & $0.01 \mathrm{~m}^{2}$ & $0.1 \mathrm{~m}^{2}$ & $1 \mathrm{~m}^{2}$ & $10 \mathrm{~m}^{2}$ \\
\hline $\mathrm{ABCO}$ & 0 & 0 & 0 & 0 & 0 & 3 & 37 & 84 & 0 & 2 & 18 & 42 \\
\hline ABLA & 0 & 0 & 10 & 43 & 0 & 0 & 0 & 0 & 0 & 0 & 5 & 22 \\
\hline ACMI2 & 0 & 0 & 0 & 0 & 0 & 10 & 10 & 20 & 0 & 5 & 5 & 10 \\
\hline ANPA5 & 3 & 3 & 7 & 7 & 0 & 0 & 0 & 5 & 2 & 2 & 3 & 6 \\
\hline BRIN2 & 0 & 10 & 23 & 66 & 0 & 7 & 13 & 37 & 0 & 8 & 18 & 52 \\
\hline ELEL5 & 0 & 0 & 10 & 24 & 0 & 0 & 3 & 8 & 0 & 0 & 7 & 16 \\
\hline ERFO3 & 0 & 3 & 10 & 24 & 3 & 7 & 7 & 11 & 2 & 5 & 8 & 18 \\
\hline FRVI & 0 & 0 & 10 & 24 & 7 & 10 & 27 & 46 & 3 & 5 & 18 & 35 \\
\hline GECA3 & 0 & 3 & 3 & 13 & 0 & 3 & 17 & 26 & 0 & 3 & 10 & 20 \\
\hline GOOB2 & 0 & 3 & 13 & 47 & 0 & 0 & 0 & 14 & 0 & 2 & 7 & 30 \\
\hline JUCO6 & 0 & 0 & 17 & 40 & 0 & 0 & 0 & 0 & 0 & 0 & 8 & 20 \\
\hline MARE11 & 0 & 3 & 10 & 29 & 0 & 0 & 27 & 60 & 0 & 2 & 18 & 45 \\
\hline PIED & 0 & 0 & 0 & 0 & 0 & 0 & 3 & 8 & 0 & 0 & 2 & 4 \\
\hline PIEN & 0 & 0 & 20 & 68 & 0 & 0 & 0 & 5 & 0 & 0 & 10 & 36 \\
\hline PIPO & 0 & 0 & 0 & 14 & 0 & 0 & 0 & 5 & 0 & 0 & 0 & 10 \\
\hline POFE & 0 & 3 & 7 & 26 & 3 & 13 & 17 & 31 & 2 & 8 & 12 & 28 \\
\hline POTR5 & 3 & 7 & 33 & 81 & 3 & 7 & 7 & 50 & 3 & 7 & 20 & 65 \\
\hline PSME & 0 & 7 & 37 & 75 & 0 & 3 & 17 & 55 & 0 & 5 & 27 & 65 \\
\hline PTAQ & 0 & 0 & 0 & 0 & 0 & 0 & 7 & 16 & 0 & 0 & 3 & 8 \\
\hline $\mathrm{PYCH}$ & 0 & 0 & 0 & 0 & 0 & 0 & 3 & 3 & 0 & 0 & 2 & 2 \\
\hline SEMU3 & 0 & 0 & 0 & 5 & 3 & 10 & 13 & 18 & 2 & 5 & 7 & 11 \\
\hline SISC7 & 0 & 0 & 0 & 5 & 0 & 0 & 0 & 10 & 0 & 0 & 0 & 7 \\
\hline UNGRCA1 & 3 & 20 & 37 & 70 & 10 & 17 & 53 & 77 & 7 & 18 & 45 & 74 \\
\hline
\end{tabular}


Table G9. Frequency (\%) of plant species in different-sized quadrats at three macroplots (MEVE3, MEVE4, and MEVE8) associated with the Loamy Mesa Top PJ ecological site at Mesa Verde National Park. See Appendix A for key to species codes.

\begin{tabular}{|c|c|c|c|c|c|c|c|c|c|c|c|c|}
\hline \multirow[b]{3}{*}{ Species code } & \multicolumn{12}{|c|}{ Frequency (\%) by macroplot and quadrat size } \\
\hline & \multicolumn{4}{|c|}{ MEVE3 } & \multicolumn{4}{|c|}{ MEVE4 } & \multicolumn{4}{|c|}{ MEVE8 } \\
\hline & $0.01 \mathrm{~m}^{2}$ & $0.1 \mathrm{~m}^{2}$ & $1 \mathrm{~m}^{2}$ & $10 \mathrm{~m}^{2}$ & $0.01 \mathrm{~m}^{2}$ & $0.1 \mathrm{~m}^{2}$ & $1 \mathrm{~m}^{2}$ & $10 \mathrm{~m}^{2}$ & $0.01 \mathrm{~m}^{2}$ & $0.1 \mathrm{~m}^{2}$ & $1 \mathrm{~m}^{2}$ & $10 \mathrm{~m}^{2}$ \\
\hline ARTR2 & 0 & 0 & 0 & 0 & 0 & 0 & 0 & 0 & 0 & 0 & 0 & 0 \\
\hline BRTE & 0 & 0 & 0 & 0 & 0 & 0 & 0 & 0 & 0 & 0 & 3 & 20 \\
\hline CANU3 & 0 & 0 & 0 & 0 & 0 & 0 & 3 & 3 & 0 & 0 & 0 & 0 \\
\hline CANU4 & 0 & 0 & 0 & 0 & 0 & 0 & 0 & 0 & 0 & 0 & 7 & 53 \\
\hline CHAL7 & 0 & 0 & 0 & 5 & 0 & 0 & 3 & 13 & 0 & 0 & 0 & 0 \\
\hline CHLE4 & 0 & 0 & 0 & 0 & 0 & 0 & 0 & 0 & 0 & 0 & 0 & 0 \\
\hline COWR2 & 0 & 0 & 0 & 0 & 0 & 0 & 0 & 0 & 0 & 0 & 13 & 73 \\
\hline DEPI & 0 & 0 & 0 & 0 & 0 & 0 & 0 & 0 & 0 & 0 & 0 & 0 \\
\hline ELEL5 & 0 & 0 & 0 & 0 & 0 & 0 & 0 & 10 & 0 & 0 & 0 & 0 \\
\hline ERUM & 0 & 0 & 13 & 37 & 0 & 0 & 0 & 0 & 0 & 0 & 0 & 0 \\
\hline ESVI2 & 0 & 0 & 0 & 0 & 0 & 0 & 0 & 5 & 0 & 0 & 0 & 0 \\
\hline GUSA2 & 0 & 0 & 0 & 0 & 0 & 0 & 0 & 0 & 0 & 0 & 0 & 0 \\
\hline HECO26 & 0 & 0 & 0 & 0 & 0 & 0 & 0 & 5 & 0 & 0 & 0 & 0 \\
\hline JUOS & 0 & 0 & 10 & 48 & 0 & 3 & 33 & 86 & 3 & 20 & 27 & 87 \\
\hline KOMA & 0 & 0 & 0 & 0 & 0 & 0 & 0 & 5 & 0 & 0 & 0 & 0 \\
\hline LAOC3 & 0 & 0 & 0 & 0 & 0 & 0 & 0 & 0 & 0 & 0 & 0 & 0 \\
\hline LATA & 0 & 0 & 0 & 0 & 0 & 0 & 0 & 0 & 0 & 0 & 10 & 47 \\
\hline LEPE2 & 0 & 0 & 3 & 3 & 0 & 0 & 0 & 0 & 0 & 0 & 0 & 0 \\
\hline LEPU & 0 & 7 & 37 & 84 & 0 & 0 & 0 & 0 & 0 & 0 & 0 & 0 \\
\hline LEPU & 0 & 0 & 0 & 0 & 3 & 10 & 27 & 50 & 0 & 0 & 0 & 0 \\
\hline LUCA & 0 & 0 & 3 & 8 & 0 & 0 & 0 & 10 & 0 & 0 & 0 & 0 \\
\hline OPER & 0 & 0 & 7 & 78 & 0 & 0 & 3 & 65 & 0 & 0 & 7 & 47 \\
\hline PEPU7 & 0 & 0 & 3 & 13 & 0 & 0 & 0 & 0 & 0 & 0 & 0 & 0 \\
\hline PIED & 0 & 0 & 23 & 61 & 0 & 0 & 23 & 80 & 0 & 0 & 27 & 47 \\
\hline POFE & 10 & 57 & 97 & 100 & 20 & 57 & 97 & 100 & 27 & 60 & 100 & 100 \\
\hline PUTR2 & 0 & 3 & 20 & 72 & 0 & 0 & 0 & 10 & 0 & 0 & 0 & 20 \\
\hline RATE & 0 & 0 & 0 & 0 & 0 & 0 & 3 & 3 & 0 & 0 & 3 & 3 \\
\hline SEMU3 & 0 & 0 & 0 & 0 & 0 & 0 & 0 & 0 & 0 & 0 & 0 & 0 \\
\hline SPCO & 0 & 0 & 0 & 0 & 0 & 0 & 0 & 5 & 0 & 0 & 0 & 0 \\
\hline STHY6 & 0 & 0 & 0 & 0 & 0 & 0 & 0 & 0 & 0 & 0 & 0 & 7 \\
\hline STLO4 & 0 & 0 & 0 & 5 & 3 & 3 & 3 & 27 & 0 & 0 & 0 & 30 \\
\hline YUBA & 0 & 0 & 3 & 8 & 0 & 3 & 7 & 30 & 0 & 0 & 0 & 17 \\
\hline
\end{tabular}


Table G10. Frequency (\%) of plant species in different-sized quadrats at two Loamy Mesa Top PJ macroplots (MEVE9 and MEVE10) and combined frequency values for all five macroplots associated with the Loamy Mesa Top PJ ecological site at Mesa Verde National Park. See Appendix A for key to species codes.

\begin{tabular}{|c|c|c|c|c|c|c|c|c|c|c|c|c|}
\hline \multirow[b]{3}{*}{ Species code } & \multicolumn{12}{|c|}{ Frequency (\%) by macroplot and quadrat size } \\
\hline & \multicolumn{4}{|c|}{ MEVE9 } & \multicolumn{4}{|c|}{ MEVE10 } & \multicolumn{4}{|c|}{ All macroplots combined $(n=5)$} \\
\hline & $0.01 \mathrm{~m}^{2}$ & $0.1 \mathrm{~m}^{2}$ & $1 \mathrm{~m}^{2}$ & $10 \mathrm{~m}^{2}$ & $0.01 \mathrm{~m}^{2}$ & $0.1 \mathrm{~m}^{2}$ & $1 \mathrm{~m}^{2}$ & $10 \mathrm{~m}^{2}$ & $0.01 \mathrm{~m}^{2}$ & $0.1 \mathrm{~m}^{2}$ & $1 \mathrm{~m}^{2}$ & $10 \mathrm{~m}^{2}$ \\
\hline ARTR2 & 0 & 0 & 0 & 0 & 7 & 13 & 67 & 97 & 1 & 3 & 13 & 19 \\
\hline BRTE & 0 & 0 & 3 & 17 & 0 & 7 & 20 & 33 & 0 & 1 & 5 & 14 \\
\hline CANU3 & 0 & 0 & 0 & 0 & 0 & 0 & 0 & 0 & 0 & 0 & 1 & 1 \\
\hline CANU4 & 0 & 0 & 0 & 17 & 0 & 0 & 0 & 3 & 0 & 0 & 1 & 15 \\
\hline CHAL7 & 0 & 0 & 0 & 0 & 0 & 0 & 7 & 10 & 0 & 0 & 2 & 6 \\
\hline CHLE4 & 0 & 0 & 0 & 3 & 0 & 0 & 0 & 3 & 0 & 0 & 0 & 1 \\
\hline COWR2 & 0 & 10 & 33 & 77 & 0 & 0 & 43 & 83 & 0 & 2 & 18 & 47 \\
\hline DEPI & 0 & 0 & 0 & 0 & 0 & 0 & 7 & 17 & 0 & 0 & 1 & 3 \\
\hline ELEL5 & 0 & 0 & 0 & 7 & 0 & 0 & 13 & 37 & 0 & 0 & 3 & 11 \\
\hline ERUM & 0 & 0 & 0 & 0 & 0 & 0 & 0 & 0 & 0 & 0 & 3 & 7 \\
\hline ESVI2 & 0 & 0 & 0 & 0 & 0 & 0 & 0 & 0 & 0 & 0 & 0 & 1 \\
\hline GUSA2 & 0 & 0 & 0 & 0 & 0 & 0 & 0 & 30 & 0 & 0 & 0 & 6 \\
\hline HECO26 & 0 & 0 & 0 & 0 & 3 & 7 & 7 & 13 & 1 & 1 & 1 & 4 \\
\hline JuOS & 0 & 17 & 20 & 63 & 7 & 7 & 13 & 70 & 2 & 9 & 21 & 71 \\
\hline KOMA & 0 & 0 & 0 & 0 & 0 & 0 & 0 & 0 & 0 & 0 & 0 & 1 \\
\hline LAOC3 & 0 & 0 & 0 & 0 & 0 & 0 & 3 & 10 & 0 & 0 & 1 & 2 \\
\hline LATA & 0 & 0 & 13 & 13 & 0 & 0 & 0 & 10 & 0 & 0 & 5 & 14 \\
\hline LEPE2 & 0 & 0 & 0 & 0 & 0 & 0 & 0 & 0 & 0 & 0 & 1 & 1 \\
\hline LEPU & 0 & 0 & 0 & 0 & 0 & 0 & 0 & 0 & 0 & 1 & 7 & 17 \\
\hline LEPU & 0 & 0 & 0 & 33 & 0 & 0 & 0 & 0 & 1 & 2 & 5 & 17 \\
\hline LUCA & 0 & 0 & 3 & 10 & 0 & 0 & 7 & 10 & 0 & 0 & 3 & 8 \\
\hline OPER & 0 & 0 & 13 & 67 & 0 & 0 & 33 & 67 & 0 & 0 & 13 & 65 \\
\hline PEPU7 & 0 & 0 & 0 & 0 & 0 & 0 & 0 & 0 & 0 & 0 & 1 & 3 \\
\hline PIED & 0 & 3 & 17 & 50 & 0 & 0 & 20 & 63 & 0 & 1 & 22 & 60 \\
\hline POFE & 13 & 30 & 87 & 100 & 3 & 10 & 53 & 87 & 15 & 43 & 87 & 97 \\
\hline PUTR2 & 0 & 0 & 7 & 13 & 0 & 0 & 0 & 0 & 0 & 1 & 5 & 23 \\
\hline RATE & 0 & 0 & 0 & 0 & 0 & 7 & 13 & 27 & 0 & 1 & 4 & 7 \\
\hline SEMU3 & 0 & 0 & 0 & 10 & 0 & 0 & 0 & 0 & 0 & 0 & 0 & 2 \\
\hline SPCO & 0 & 0 & 0 & 0 & 0 & 0 & 0 & 10 & 0 & 0 & 0 & 3 \\
\hline STHY6 & 0 & 0 & 0 & 0 & 0 & 0 & 0 & 0 & 0 & 0 & 0 & 1 \\
\hline STLO4 & 0 & 7 & 7 & 17 & 0 & 0 & 13 & 20 & 1 & 2 & 5 & 20 \\
\hline YUBA & 0 & 3 & 7 & 53 & 0 & 0 & 0 & 7 & 0 & 1 & 3 & 23 \\
\hline
\end{tabular}


Table G11. Frequency (\%) of plant species in different-sized quadrats at three macroplots (CARE1, CARE2b, and CARE5) associated with the Semidesert Alkali Sandy Loam ecological site at Capitol Reef National Park. See Appendix A for key to species codes.

\begin{tabular}{|c|c|c|c|c|c|c|c|c|c|c|c|c|}
\hline \multirow[b]{3}{*}{ Species code } & \multicolumn{12}{|c|}{ Frequency (\%) by macroplot and quadrat size } \\
\hline & \multicolumn{4}{|c|}{ CARE1 } & \multicolumn{4}{|c|}{ CARE2b } & \multicolumn{4}{|c|}{ CARE5 } \\
\hline & $0.01 \mathrm{~m}^{2}$ & $0.1 \mathrm{~m}^{2}$ & $1 \mathrm{~m}^{2}$ & $10 \mathrm{~m}^{2}$ & $0.01 \mathrm{~m}^{2}$ & $0.1 \mathrm{~m}^{2}$ & $1 \mathrm{~m}^{2}$ & $10 \mathrm{~m}^{2}$ & $0.01 \mathrm{~m}^{2}$ & $0.1 \mathrm{~m}^{2}$ & $1 \mathrm{~m}^{2}$ & $10 \mathrm{~m}^{2}$ \\
\hline AMAC2 & 0 & 3 & 33 & 48 & 0 & 0 & 3 & 3 & 0 & 0 & 7 & 20 \\
\hline ARBI3 & 0 & 0 & 0 & 0 & 0 & 0 & 0 & 10 & 0 & 0 & 0 & 0 \\
\hline ARDR4 & 0 & 0 & 0 & 0 & 0 & 0 & 0 & 0 & 0 & 0 & 0 & 7 \\
\hline ARFI2 & 0 & 0 & 0 & 0 & 0 & 0 & 0 & 5 & 0 & 0 & 0 & 0 \\
\hline ARTR2 & 0 & 0 & 0 & 0 & 0 & 0 & 0 & 10 & 0 & 0 & 0 & 0 \\
\hline ATCA2 & 0 & 0 & 0 & 0 & 0 & 0 & 0 & 0 & 0 & 0 & 10 & 33 \\
\hline ATCO & 0 & 3 & 30 & 97 & 3 & 13 & 50 & 98 & 0 & 7 & 30 & 57 \\
\hline BOER4 & 3 & 10 & 13 & 18 & 0 & 0 & 0 & 0 & 0 & 0 & 0 & 0 \\
\hline BOGR2 & 3 & 3 & 23 & 57 & 3 & 7 & 10 & 29 & 0 & 0 & 0 & 7 \\
\hline BRIN2 & 0 & 0 & 0 & 0 & 0 & 0 & 0 & 0 & 0 & 3 & 3 & 7 \\
\hline BRTE & 0 & 0 & 0 & 5 & 0 & 0 & 0 & 5 & 0 & 3 & 7 & 43 \\
\hline CELA4 & 0 & 3 & 17 & 50 & 0 & 0 & 7 & 21 & 0 & 0 & 7 & 33 \\
\hline CHAL7 & 7 & 13 & 20 & 63 & 7 & 37 & 47 & 80 & 0 & 10 & 20 & 50 \\
\hline CHLE4 & 0 & 13 & 33 & 67 & 0 & 0 & 0 & 0 & 7 & 10 & 37 & 67 \\
\hline CHNA2 & 0 & 0 & 0 & 0 & 0 & 0 & 0 & 0 & 0 & 0 & 0 & 0 \\
\hline CHST & 0 & 0 & 0 & 0 & 0 & 0 & 0 & 5 & 0 & 20 & 60 & 90 \\
\hline COWR2 & 0 & 0 & 0 & 0 & 0 & 0 & 0 & 0 & 0 & 0 & 7 & 13 \\
\hline DEPI & 0 & 0 & 0 & 0 & 0 & 0 & 0 & 14 & 0 & 0 & 0 & 10 \\
\hline ERCE2 & 17 & 40 & 73 & 100 & 0 & 10 & 30 & 44 & 3 & 10 & 23 & 50 \\
\hline ERIN4 & 0 & 0 & 0 & 0 & 0 & 0 & 0 & 0 & 0 & 0 & 0 & 0 \\
\hline GIIN2 & 0 & 10 & 33 & 48 & 0 & 3 & 20 & 44 & 3 & 20 & 50 & 80 \\
\hline GUSA2 & 0 & 3 & 43 & 96 & 0 & 3 & 37 & 70 & 0 & 3 & 7 & 33 \\
\hline HAGL & 0 & 0 & 0 & 0 & 0 & 0 & 0 & 0 & 0 & 0 & 0 & 0 \\
\hline HIJA & 0 & 7 & 7 & 21 & 7 & 10 & 10 & 15 & 0 & 0 & 7 & 30 \\
\hline LAOC3 & 0 & 7 & 17 & 45 & 0 & 3 & 3 & 18 & 3 & 37 & 70 & 90 \\
\hline LIAR3 & 0 & 0 & 0 & 0 & 0 & 0 & 7 & 11 & 0 & 0 & 0 & 0 \\
\hline MACA2 & 0 & 3 & 13 & 51 & 0 & 0 & 7 & 11 & 0 & 3 & 7 & 23 \\
\hline MATA2 & 3 & 7 & 17 & 36 & 0 & 10 & 30 & 68 & 0 & 7 & 30 & 80 \\
\hline MEAL6 & 0 & 3 & 3 & 18 & 0 & 0 & 0 & 0 & 0 & 33 & 67 & 93 \\
\hline MUSQ & 0 & 0 & 0 & 0 & 0 & 0 & 0 & 5 & 0 & 0 & 0 & 0 \\
\hline OECE2 & 0 & 0 & 0 & 10 & 0 & 0 & 0 & 0 & 0 & 0 & 0 & 0 \\
\hline OEPA & 0 & 0 & 0 & 0 & 0 & 0 & 0 & 10 & 0 & 0 & 0 & 7 \\
\hline OPER & 3 & 17 & 57 & 100 & 0 & 13 & 37 & 75 & 0 & 0 & 0 & 7 \\
\hline ORHY & 0 & 10 & 53 & 100 & 7 & 20 & 53 & 100 & 3 & 23 & 67 & 90 \\
\hline PHCR & 0 & 0 & 0 & 0 & 0 & 0 & 0 & 0 & 0 & 0 & 0 & 10 \\
\hline
\end{tabular}


Table G11.-Continued

\begin{tabular}{|c|c|c|c|c|c|c|c|c|c|c|c|c|}
\hline \multirow[b]{3}{*}{ Species code } & \multicolumn{12}{|c|}{ Frequency (\%) by macroplot and quadrat size } \\
\hline & \multicolumn{4}{|c|}{ CARE1 } & \multicolumn{4}{|c|}{ CARE2b } & \multicolumn{4}{|c|}{ CARE5 } \\
\hline & $0.01 \mathrm{~m}^{2}$ & $0.1 \mathrm{~m}^{2}$ & $1 \mathrm{~m}^{2}$ & $10 \mathrm{~m}^{2}$ & $0.01 \mathrm{~m}^{2}$ & $0.1 \mathrm{~m}^{2}$ & $1 \mathrm{~m}^{2}$ & $10 \mathrm{~m}^{2}$ & $0.01 \mathrm{~m}^{2}$ & $0.1 \mathrm{~m}^{2}$ & $1 \mathrm{~m}^{2}$ & $10 \mathrm{~m}^{2}$ \\
\hline PLPA2 & 40 & 80 & 100 & 100 & 47 & 70 & 83 & 93 & 0 & 3 & 30 & 63 \\
\hline SAIB & 13 & 57 & 80 & 90 & 0 & 0 & 0 & 0 & 53 & 77 & 93 & 100 \\
\hline SAPA8 & 0 & 0 & 0 & 0 & 3 & 23 & 63 & 73 & 0 & 0 & 0 & 0 \\
\hline SAVE4 & 0 & 7 & 17 & 55 & 0 & 0 & 10 & 72 & 0 & 0 & 17 & 53 \\
\hline SIHY & 0 & 3 & 7 & 73 & 0 & 0 & 3 & 22 & 0 & 0 & 0 & 7 \\
\hline SPAI & 0 & 0 & 3 & 3 & 0 & 0 & 0 & 0 & 0 & 0 & 0 & 3 \\
\hline SPCO & 0 & 0 & 20 & 49 & 0 & 7 & 13 & 56 & 0 & 0 & 0 & 13 \\
\hline SPCO4 & 37 & 57 & 87 & 96 & 7 & 17 & 57 & 80 & 3 & 7 & 13 & 27 \\
\hline SPCR & 0 & 0 & 0 & 0 & 0 & 3 & 10 & 10 & 0 & 0 & 0 & 0 \\
\hline SPPA2 & 0 & 0 & 0 & 0 & 0 & 0 & 0 & 0 & 3 & 7 & 10 & 63 \\
\hline STLO4 & 0 & 0 & 0 & 0 & 0 & 0 & 0 & 0 & 0 & 0 & 0 & 0 \\
\hline TESP2 & 0 & 0 & 0 & 5 & 0 & 0 & 0 & 0 & 0 & 0 & 0 & 0 \\
\hline THSU & 0 & 0 & 0 & 0 & 0 & 0 & 0 & 10 & 0 & 0 & 0 & 0 \\
\hline VUOC & 0 & 3 & 10 & 29 & 0 & 0 & 0 & 10 & 10 & 23 & 63 & 90 \\
\hline
\end{tabular}


Table G12. Frequency (\%) of plant species in different-sized quadrats at two Semidesert Alkali Sandy Loam macroplots (CARE6 and CARE7) and combined frequency values for all five macroplots associated with the Semidesert Alkali Sandy Loam ecological site at Capitol Reef National Park. See Appendix A for key to species codes.

\begin{tabular}{|c|c|c|c|c|c|c|c|c|c|c|c|c|}
\hline \multirow[b]{3}{*}{ Species code } & \multicolumn{12}{|c|}{ Frequency (\%) by macroplot and quadrat size } \\
\hline & \multicolumn{4}{|c|}{ CARE6 } & \multicolumn{4}{|c|}{ CARE7 } & \multicolumn{4}{|c|}{ All macroplots combined $(n=5)$} \\
\hline & $0.01 \mathrm{~m}^{2}$ & $0.1 \mathrm{~m}^{2}$ & $1 \mathrm{~m}^{2}$ & $10 \mathrm{~m}^{2}$ & $0.01 \mathrm{~m}^{2}$ & $0.1 \mathrm{~m}^{2}$ & $1 \mathrm{~m}^{2}$ & $10 \mathrm{~m}^{2}$ & $0.01 \mathrm{~m}^{2}$ & $0.1 \mathrm{~m}^{2}$ & $1 \mathrm{~m}^{2}$ & $10 \mathrm{~m}^{2}$ \\
\hline AMAC2 & 0 & 0 & 7 & 23 & 7 & 13 & 47 & 70 & 1 & 3 & 19 & 33 \\
\hline ARBI3 & 0 & 0 & 0 & 0 & 0 & 0 & 0 & 0 & 0 & 0 & 0 & 2 \\
\hline ARDR4 & 0 & 0 & 0 & 0 & 0 & 0 & 0 & 0 & 0 & 0 & 0 & 1 \\
\hline ARFI2 & 0 & 0 & 0 & 0 & 0 & 0 & 0 & 0 & 0 & 0 & 0 & 1 \\
\hline ARTR2 & 0 & 0 & 0 & 0 & 0 & 0 & 0 & 0 & 0 & 0 & 0 & 2 \\
\hline ATCA2 & 0 & 0 & 0 & 0 & 0 & 0 & 0 & 0 & 0 & 0 & 2 & 7 \\
\hline ATCO & 0 & 7 & 20 & 47 & 0 & 3 & 60 & 100 & 1 & 7 & 38 & 80 \\
\hline BOER4 & 0 & 0 & 0 & 0 & 0 & 0 & 0 & 0 & 1 & 2 & 3 & 4 \\
\hline BOGR2 & 0 & 0 & 0 & 0 & 0 & 0 & 0 & 0 & 1 & 2 & 7 & 18 \\
\hline BRIN2 & 0 & 0 & 0 & 0 & 0 & 0 & 0 & 0 & 0 & 1 & 1 & 1 \\
\hline BRTE & 0 & 0 & 0 & 0 & 3 & 3 & 7 & 33 & 1 & 1 & 3 & 17 \\
\hline CELA4 & 0 & 0 & 0 & 0 & 7 & 10 & 17 & 23 & 1 & 3 & 9 & 26 \\
\hline CHAL7 & 0 & 0 & 0 & 0 & 0 & 0 & 0 & 0 & 3 & 12 & 17 & 39 \\
\hline CHLE4 & 0 & 0 & 0 & 0 & 0 & 7 & 13 & 23 & 1 & 6 & 17 & 31 \\
\hline CHNA2 & 0 & 0 & 0 & 7 & 0 & 0 & 0 & 0 & 0 & 0 & 0 & 1 \\
\hline CHST & 0 & 0 & 0 & 0 & 0 & 3 & 3 & 3 & 0 & 5 & 13 & 20 \\
\hline COWR2 & 0 & 0 & 0 & 0 & 0 & 0 & 0 & 0 & 0 & 0 & 1 & 3 \\
\hline DEPI & 0 & 0 & 0 & 0 & 0 & 0 & 7 & 7 & 0 & 0 & 1 & 6 \\
\hline ERCE2 & 0 & 3 & 7 & 20 & 0 & 0 & 23 & 47 & 4 & 13 & 31 & 52 \\
\hline ERIN4 & 0 & 0 & 0 & 0 & 0 & 0 & 0 & 20 & 0 & 0 & 0 & 4 \\
\hline GIIN2 & 3 & 17 & 27 & 33 & 3 & 20 & 43 & 83 & 2 & 14 & 35 & 58 \\
\hline GUSA2 & 0 & 10 & 17 & 17 & 0 & 7 & 13 & 37 & 0 & 5 & 23 & 50 \\
\hline HAGL & 0 & 0 & 0 & 0 & 7 & 13 & 33 & 47 & 1 & 3 & 7 & 9 \\
\hline HIJA & 7 & 23 & 30 & 63 & 0 & 3 & 27 & 57 & 3 & 9 & 16 & 37 \\
\hline LAOC3 & 0 & 10 & 30 & 60 & 17 & 70 & 93 & 100 & 4 & 25 & 43 & 63 \\
\hline LIAR3 & 0 & 0 & 0 & 0 & 0 & 0 & 0 & 0 & 0 & 0 & 1 & 2 \\
\hline MACA2 & 0 & 3 & 3 & 10 & 0 & 0 & 0 & 0 & 0 & 2 & 6 & 19 \\
\hline MATA2 & 0 & 0 & 0 & 0 & 0 & 0 & 0 & 0 & 1 & 5 & 15 & 37 \\
\hline MEAL6 & 0 & 0 & 0 & 3 & 0 & 0 & 33 & 63 & 0 & 7 & 21 & 36 \\
\hline MUSQ & 0 & 0 & 0 & 0 & 0 & 0 & 0 & 0 & 0 & 0 & 0 & 1 \\
\hline OECE2 & 0 & 0 & 0 & 0 & 0 & 0 & 0 & 0 & 0 & 0 & 0 & 2 \\
\hline OEPA & 0 & 0 & 0 & 0 & 0 & 0 & 0 & 0 & 0 & 0 & 0 & 3 \\
\hline OPER & 0 & 0 & 7 & 13 & 0 & 0 & 0 & 47 & 1 & 6 & 20 & 48 \\
\hline ORHY & 0 & 10 & 33 & 63 & 0 & 3 & 60 & 93 & 2 & 13 & 53 & 89 \\
\hline PHCR & 0 & 0 & 0 & 0 & 0 & 0 & 0 & 0 & 0 & 0 & 0 & 2 \\
\hline
\end{tabular}


Table G12.-Continued

\begin{tabular}{|c|c|c|c|c|c|c|c|c|c|c|c|c|}
\hline \multirow[b]{3}{*}{ Species code } & \multicolumn{12}{|c|}{ Frequency (\%) by macroplot and quadrat size } \\
\hline & \multicolumn{4}{|c|}{ CARE6 } & \multicolumn{4}{|c|}{ CARE7 } & \multicolumn{4}{|c|}{ All macroplots combined $(n=5)$} \\
\hline & $0.01 \mathrm{~m}^{2}$ & $0.1 \mathrm{~m}^{2}$ & $1 \mathrm{~m}^{2}$ & $10 \mathrm{~m}^{2}$ & $0.01 \mathrm{~m}^{2}$ & $0.1 \mathrm{~m}^{2}$ & $1 \mathrm{~m}^{2}$ & $10 \mathrm{~m}^{2}$ & $0.01 \mathrm{~m}^{2}$ & $0.1 \mathrm{~m}^{2}$ & $1 \mathrm{~m}^{2}$ & $10 \mathrm{~m}^{2}$ \\
\hline PLPA2 & 0 & 0 & 7 & 13 & 0 & 23 & 87 & 100 & 17 & 35 & 61 & 74 \\
\hline SAIB & 0 & 0 & 0 & 13 & 20 & 73 & 93 & 97 & 17 & 41 & 53 & 60 \\
\hline SAPA8 & 0 & 0 & 0 & 0 & 0 & 0 & 0 & 0 & 1 & 5 & 13 & 15 \\
\hline SAVE4 & 0 & 0 & 0 & 7 & 0 & 3 & 23 & 50 & 0 & 2 & 13 & 47 \\
\hline SIHY & 0 & 0 & 7 & 7 & 0 & 0 & 0 & 7 & 0 & 1 & 3 & 23 \\
\hline SPAI & 0 & 3 & 20 & 60 & 0 & 0 & 0 & 13 & 0 & 1 & 5 & 16 \\
\hline SPCO & 0 & 0 & 0 & 7 & 0 & 0 & 0 & 7 & 0 & 1 & 7 & 26 \\
\hline SPCO4 & 0 & 0 & 0 & 0 & 0 & 0 & 0 & 0 & 9 & 16 & 31 & 41 \\
\hline SPCR & 0 & 0 & 0 & 0 & 0 & 0 & 0 & 0 & 0 & 1 & 2 & 2 \\
\hline SPPA2 & 0 & 0 & 7 & 7 & 0 & 0 & 3 & 10 & 1 & 1 & 4 & 16 \\
\hline STLO4 & 0 & 0 & 0 & 0 & 0 & 0 & 7 & 63 & 0 & 0 & 1 & 13 \\
\hline TESP2 & 0 & 0 & 0 & 0 & 0 & 0 & 0 & 0 & 0 & 0 & 0 & 1 \\
\hline THSU & 0 & 0 & 0 & 0 & 0 & 0 & 0 & 0 & 0 & 0 & 0 & 2 \\
\hline VUOC & 0 & 0 & 0 & 0 & 0 & 0 & 3 & 7 & 2 & 5 & 15 & 27 \\
\hline
\end{tabular}


Table G13. Frequency (\%) of plant species in different-sized quadrats at three macroplots (DINO1, DINO2b, and DINO3) associated with the Semidesert Loam ecological site at Dinosaur National Monument. See Appendix A for key to species codes.

\begin{tabular}{|c|c|c|c|c|c|c|c|c|c|c|c|c|}
\hline \multirow[b]{3}{*}{ Species code } & \multicolumn{12}{|c|}{ Frequency (\%) by macroplot and quadrat size } \\
\hline & \multicolumn{4}{|c|}{ DINO1 } & \multicolumn{4}{|c|}{ DINO2b } & \multicolumn{4}{|c|}{ DINO3 } \\
\hline & $0.01 \mathrm{~m}^{2}$ & $0.1 \mathrm{~m}^{2}$ & $1 \mathrm{~m}^{2}$ & $10 \mathrm{~m}^{2}$ & $0.01 \mathrm{~m}^{2}$ & $0.1 \mathrm{~m}^{2}$ & $1 \mathrm{~m}^{2}$ & $10 \mathrm{~m}^{2}$ & $0.01 \mathrm{~m}^{2}$ & $0.1 \mathrm{~m}^{2}$ & $1 \mathrm{~m}^{2}$ & $10 \mathrm{~m}^{2}$ \\
\hline AGSM & 0 & 13 & 33 & 52 & 0 & 0 & 0 & 0 & 0 & 0 & 0 & 10 \\
\hline ARTR2 & 0 & 0 & 3 & 41 & 7 & 23 & 70 & 99 & 30 & 57 & 73 & 100 \\
\hline ASMO7 & 0 & 0 & 0 & 0 & 0 & 0 & 0 & 0 & 0 & 0 & 0 & 0 \\
\hline ATCA2 & 0 & 0 & 0 & 5 & 0 & 0 & 0 & 0 & 0 & 0 & 0 & 0 \\
\hline ATCO & 0 & 0 & 0 & 10 & 0 & 0 & 3 & 51 & 0 & 0 & 3 & 37 \\
\hline BRTE & 73 & 97 & 100 & 100 & 87 & 93 & 93 & 93 & 27 & 60 & 67 & 100 \\
\hline CANU3 & 0 & 7 & 27 & 70 & 0 & 0 & 0 & 0 & 0 & 0 & 0 & 0 \\
\hline CANU3 & 0 & 0 & 0 & 0 & 0 & 0 & 0 & 0 & 0 & 0 & 0 & 0 \\
\hline CELA4 & 0 & 0 & 0 & 0 & 0 & 0 & 0 & 0 & 0 & 0 & 3 & 7 \\
\hline CHLE4 & 0 & 0 & 0 & 0 & 0 & 0 & 0 & 0 & 0 & 3 & 3 & 7 \\
\hline CHNA2 & 0 & 0 & 0 & 0 & 0 & 0 & 0 & 0 & 0 & 0 & 0 & 0 \\
\hline DEPI & 0 & 7 & 30 & 82 & 0 & 7 & 23 & 52 & 0 & 7 & 37 & 87 \\
\hline ERCE2 & 0 & 0 & 0 & 0 & 0 & 0 & 0 & 0 & 0 & 0 & 7 & 13 \\
\hline GIIN2 & 0 & 0 & 33 & 67 & 0 & 0 & 0 & 0 & 0 & 0 & 7 & 10 \\
\hline GUSA2 & 0 & 0 & 3 & 3 & 0 & 7 & 20 & 63 & 0 & 0 & 0 & 0 \\
\hline HIJA & 7 & 7 & 7 & 11 & 3 & 3 & 13 & 23 & 7 & 17 & 37 & 53 \\
\hline JUOS & 0 & 0 & 0 & 0 & 0 & 0 & 0 & 0 & 0 & 0 & 0 & 0 \\
\hline LAOC3 & 0 & 0 & 0 & 0 & 0 & 0 & 0 & 0 & 0 & 0 & 17 & 33 \\
\hline LARE & 0 & 3 & 20 & 30 & 10 & 30 & 70 & 94 & 0 & 0 & 0 & 0 \\
\hline LASE & 0 & 0 & 0 & 5 & 0 & 0 & 0 & 0 & 0 & 0 & 0 & 0 \\
\hline LEPU & 0 & 0 & 0 & 0 & 0 & 0 & 0 & 0 & 0 & 0 & 0 & 7 \\
\hline OPER & 0 & 0 & 3 & 18 & 0 & 3 & 3 & 3 & 0 & 0 & 7 & 60 \\
\hline ORHY & 0 & 3 & 7 & 21 & 0 & 0 & 0 & 0 & 0 & 0 & 0 & 37 \\
\hline PLPA2 & 0 & 0 & 3 & 27 & 0 & 0 & 0 & 0 & 0 & 0 & 0 & 0 \\
\hline POSE & 0 & 10 & 23 & 52 & 0 & 0 & 0 & 0 & 0 & 0 & 20 & 40 \\
\hline RATE & 0 & 0 & 0 & 0 & 0 & 0 & 0 & 0 & 0 & 0 & 0 & 0 \\
\hline SAIB & 0 & 0 & 0 & 0 & 0 & 0 & 3 & 8 & 0 & 0 & 10 & 17 \\
\hline SAVE4 & 0 & 0 & 3 & 8 & 0 & 0 & 0 & 0 & 0 & 0 & 0 & 0 \\
\hline SIAL2 & 0 & 0 & 0 & 0 & 0 & 0 & 3 & 46 & 0 & 0 & 0 & 0 \\
\hline SIHY & 0 & 0 & 3 & 3 & 3 & 20 & 47 & 99 & 0 & 3 & 17 & 53 \\
\hline SPCO & 0 & 20 & 57 & 80 & 0 & 0 & 0 & 38 & 0 & 10 & 37 & 77 \\
\hline STCO4 & 17 & 37 & 73 & 88 & 0 & 0 & 0 & 0 & 3 & 23 & 77 & 93 \\
\hline STLO4 & 0 & 0 & 0 & 0 & 0 & 0 & 0 & 0 & 0 & 0 & 0 & 0 \\
\hline VUOC & 77 & 97 & 97 & 97 & 3 & 7 & 13 & 23 & 0 & 0 & 0 & 0 \\
\hline ZIPA2 & 0 & 0 & 0 & 5 & 0 & 0 & 0 & 0 & 0 & 0 & 0 & 0 \\
\hline
\end{tabular}


Table G14. Frequency (\%) of plant species in different-sized quadrats at two Semidesert Loam macroplots (DINO4b and DINO5) and combined frequency values for all five macroplots associated with the Semidesert Loam ecological site at Dinosaur National Monument. See Appendix A for key to species codes.

\begin{tabular}{|c|c|c|c|c|c|c|c|c|c|c|c|c|}
\hline \multirow[b]{3}{*}{ Species code } & \multicolumn{12}{|c|}{ Frequency (\%) by macroplot and quadrat size } \\
\hline & \multicolumn{4}{|c|}{ DINO4b } & \multicolumn{4}{|c|}{ DINO5 } & \multicolumn{4}{|c|}{ All macroplots combined $(n=5)$} \\
\hline & $0.01 \mathrm{~m}^{2}$ & $0.1 \mathrm{~m}^{2}$ & $1 \mathrm{~m}^{2}$ & $10 \mathrm{~m}^{2}$ & $0.01 \mathrm{~m}^{2}$ & $0.1 \mathrm{~m}^{2}$ & $1 \mathrm{~m}^{2}$ & $10 \mathrm{~m}^{2}$ & $0.01 \mathrm{~m}^{2}$ & $0.1 \mathrm{~m}^{2}$ & $1 \mathrm{~m}^{2}$ & $10 \mathrm{~m}^{2}$ \\
\hline AGSM & 0 & 0 & 0 & 0 & 3 & 17 & 30 & 47 & 1 & 6 & 13 & 22 \\
\hline ARTR2 & 0 & 10 & 43 & 100 & 10 & 13 & 67 & 100 & 9 & 21 & 51 & 88 \\
\hline ASMO7 & 0 & 0 & 0 & 7 & 0 & 0 & 0 & 0 & 0 & 0 & 0 & 1 \\
\hline ATCA2 & 0 & 0 & 0 & 0 & 0 & 0 & 0 & 0 & 0 & 0 & 0 & 1 \\
\hline ATCO & 0 & 0 & 0 & 13 & 0 & 0 & 0 & 0 & 0 & 0 & 1 & 22 \\
\hline BRTE & 87 & 100 & 100 & 100 & 30 & 43 & 53 & 83 & 61 & 79 & 83 & 95 \\
\hline CANU3 & 0 & 0 & 0 & 0 & 0 & 0 & 0 & 0 & 0 & 1 & 5 & 14 \\
\hline CANU3 & 0 & 0 & 0 & 0 & 3 & 10 & 23 & 73 & 1 & 2 & 5 & 15 \\
\hline CELA4 & 0 & 0 & 0 & 0 & 7 & 13 & 27 & 57 & 1 & 3 & 6 & 13 \\
\hline CHLE4 & 0 & 0 & 0 & 0 & 0 & 0 & 0 & 0 & 0 & 1 & 1 & 1 \\
\hline CHNA2 & 0 & 0 & 0 & 33 & 0 & 0 & 0 & 0 & 0 & 0 & 0 & 7 \\
\hline DEPI & 0 & 3 & 7 & 47 & 0 & 0 & 0 & 10 & 0 & 5 & 19 & 56 \\
\hline ERCE2 & 0 & 0 & 0 & 0 & 0 & 0 & 0 & 0 & 0 & 0 & 1 & 3 \\
\hline GIIN2 & 0 & 0 & 7 & 13 & 0 & 0 & 0 & 3 & 0 & 0 & 9 & 19 \\
\hline GUSA2 & 3 & 7 & 53 & 83 & 0 & 0 & 0 & 20 & 1 & 3 & 15 & 34 \\
\hline HIJA & 0 & 0 & 7 & 20 & 7 & 20 & 20 & 23 & 5 & 9 & 17 & 26 \\
\hline JUOS & 0 & 0 & 0 & 23 & 0 & 0 & 0 & 17 & 0 & 0 & 0 & 8 \\
\hline LAOC3 & 0 & 0 & 0 & 3 & 0 & 0 & 0 & 0 & 0 & 0 & 3 & 7 \\
\hline LARE & 0 & 0 & 0 & 0 & 0 & 0 & 0 & 0 & 2 & 7 & 18 & 25 \\
\hline LASE & 0 & 0 & 0 & 3 & 0 & 0 & 0 & 0 & 0 & 0 & 0 & 2 \\
\hline LEPU & 0 & 0 & 0 & 0 & 0 & 0 & 7 & 30 & 0 & 0 & 1 & 7 \\
\hline OPER & 0 & 0 & 7 & 43 & 0 & 0 & 20 & 60 & 0 & 1 & 8 & 37 \\
\hline ORHY & 0 & 0 & 0 & 0 & 0 & 0 & 0 & 7 & 0 & 1 & 1 & 13 \\
\hline PLPA2 & 0 & 0 & 0 & 0 & 10 & 20 & 33 & 63 & 2 & 4 & 7 & 18 \\
\hline POSE & 3 & 10 & 20 & 67 & 43 & 73 & 100 & 100 & 9 & 19 & 33 & 52 \\
\hline RATE & 3 & 10 & 20 & 37 & 0 & 0 & 0 & 0 & 1 & 2 & 4 & 7 \\
\hline SAIB & 0 & 0 & 0 & 0 & 0 & 0 & 0 & 0 & 0 & 0 & 3 & 5 \\
\hline SAVE4 & 0 & 0 & 7 & 67 & 0 & 0 & 0 & 0 & 0 & 0 & 2 & 15 \\
\hline SIAL2 & 0 & 0 & 0 & 0 & 0 & 0 & 0 & 0 & 0 & 0 & 1 & 9 \\
\hline SIHY & 0 & 0 & 3 & 13 & 0 & 0 & 0 & 7 & 1 & 5 & 14 & 35 \\
\hline SPCO & 3 & 7 & 7 & 17 & 7 & 13 & 30 & 67 & 2 & 10 & 26 & 56 \\
\hline STCO4 & 0 & 3 & 17 & 50 & 7 & 17 & 77 & 97 & 5 & 16 & 49 & 66 \\
\hline STLO4 & 3 & 3 & 3 & 10 & 0 & 0 & 0 & 0 & 1 & 1 & 1 & 2 \\
\hline VUOC & 13 & 40 & 63 & 83 & 10 & 27 & 87 & 97 & 21 & 34 & 52 & 60 \\
\hline ZIPA2 & 0 & 0 & 0 & 0 & 0 & 0 & 0 & 0 & 0 & 0 & 0 & 1 \\
\hline
\end{tabular}


Table G15. Frequency (\%) of plant species in different-sized quadrats at three macroplots (ARCH1b, ARCH2, and ARCH3) associated with the Semidesert Shallow Sandy Loam ecological site at Arches National Park. See Appendix A for key to species codes.

\begin{tabular}{|c|c|c|c|c|c|c|c|c|c|c|c|c|}
\hline \multirow[b]{3}{*}{ Code } & \multicolumn{12}{|c|}{ Frequency (\%) by macroplot and quadrat size } \\
\hline & \multicolumn{4}{|c|}{ ARCH1b } & \multicolumn{4}{|c|}{ ARCH2 } & \multicolumn{4}{|c|}{ ARCH3 } \\
\hline & $0.01 \mathrm{~m}^{2}$ & $0.1 \mathrm{~m}^{2}$ & $1 \mathrm{~m}^{2}$ & $10 \mathrm{~m}^{2}$ & $0.01 \mathrm{~m}^{2}$ & $0.1 \mathrm{~m}^{2}$ & $1 \mathrm{~m}^{2}$ & $10 \mathrm{~m}^{2}$ & $0.01 \mathrm{~m}^{2}$ & $0.1 \mathrm{~m}^{2}$ & $1 \mathrm{~m}^{2}$ & $10 \mathrm{~m}^{2}$ \\
\hline ARFI2 & 0 & 0 & 0 & 0 & 0 & 0 & 0 & 0 & 0 & 0 & 0 & 3 \\
\hline ASMA10 & 0 & 0 & 0 & 10 & 0 & 0 & 0 & 0 & 0 & 0 & 0 & 0 \\
\hline ASMO7 & 0 & 0 & 0 & 0 & 0 & 0 & 0 & 0 & 0 & 0 & 0 & 0 \\
\hline ATCA2 & 0 & 0 & 0 & 0 & 0 & 0 & 0 & 0 & 0 & 0 & 0 & 0 \\
\hline BRTE & 0 & 0 & 0 & 0 & 0 & 0 & 0 & 5 & 0 & 0 & 7 & 10 \\
\hline CANU3 & 0 & 0 & 0 & 0 & 0 & 0 & 0 & 0 & 0 & 0 & 0 & 0 \\
\hline CHAL7 & 0 & 0 & 0 & 0 & 0 & 0 & 0 & 0 & 0 & 0 & 0 & 0 \\
\hline CHST & 0 & 0 & 0 & 0 & 0 & 0 & 0 & 0 & 0 & 3 & 20 & 40 \\
\hline $\mathrm{CHVI8}$ & 0 & 0 & 7 & 35 & 0 & 0 & 0 & 0 & 0 & 0 & 0 & 0 \\
\hline CORA & 3 & 20 & 77 & 100 & 17 & 47 & 97 & 100 & 0 & 10 & 67 & 100 \\
\hline COWR2 & 0 & 0 & 0 & 0 & 0 & 0 & 0 & 0 & 0 & 0 & 0 & 0 \\
\hline DAFL & 0 & 3 & 20 & 53 & 0 & 0 & 0 & 0 & 0 & 0 & 0 & 0 \\
\hline DEPI & 0 & 0 & 0 & 0 & 0 & 0 & 0 & 5 & 0 & 0 & 0 & 20 \\
\hline ELEL5 & 0 & 0 & 0 & 0 & 0 & 0 & 0 & 0 & 0 & 0 & 0 & 0 \\
\hline EPVI & 0 & 3 & 7 & 64 & 0 & 0 & 13 & 47 & 0 & 7 & 7 & 17 \\
\hline ERCE2 & 0 & 0 & 0 & 0 & 0 & 0 & 0 & 0 & 0 & 0 & 0 & 0 \\
\hline ERCO14 & 0 & 0 & 0 & 0 & 0 & 0 & 0 & 0 & 0 & 0 & 0 & 0 \\
\hline ERIN4 & 0 & 3 & 7 & 11 & 0 & 0 & 0 & 0 & 0 & 0 & 0 & 0 \\
\hline ERMI4 & 0 & 0 & 3 & 8 & 0 & 0 & 0 & 0 & 0 & 0 & 0 & 0 \\
\hline EUFE2 & 3 & 10 & 23 & 52 & 0 & 0 & 0 & 0 & 0 & 0 & 0 & 0 \\
\hline FEOC3 & 0 & 7 & 10 & 24 & 0 & 3 & 27 & 46 & 10 & 30 & 50 & 83 \\
\hline FRAN2 & 0 & 0 & 0 & 0 & 0 & 0 & 0 & 0 & 0 & 0 & 0 & 0 \\
\hline GIIN2 & 0 & 0 & 10 & 15 & 0 & 3 & 37 & 56 & 0 & 3 & 3 & 7 \\
\hline GUSA2 & 0 & 0 & 0 & 0 & 0 & 0 & 0 & 0 & 0 & 0 & 0 & 0 \\
\hline HIJA & 3 & 10 & 53 & 77 & 0 & 0 & 0 & 0 & 0 & 0 & 0 & 10 \\
\hline JuOS & 0 & 0 & 0 & 5 & 0 & 0 & 0 & 5 & 0 & 0 & 0 & 7 \\
\hline LAOC3 & 0 & 0 & 0 & 0 & 3 & 7 & 33 & 48 & 0 & 0 & 0 & 0 \\
\hline LEMO2 & 0 & 0 & 0 & 0 & 0 & 0 & 0 & 0 & 0 & 0 & 0 & 0 \\
\hline LEPE2 & 0 & 0 & 0 & 0 & 0 & 0 & 0 & 0 & 0 & 0 & 0 & 0 \\
\hline MAFR3 & 0 & 0 & 0 & 0 & 0 & 0 & 0 & 0 & 0 & 0 & 0 & 0 \\
\hline MEAL6 & 0 & 0 & 3 & 3 & 0 & 0 & 3 & 8 & 0 & 0 & 0 & 0 \\
\hline OECE2 & 0 & 0 & 0 & 5 & 0 & 0 & 0 & 0 & 0 & 0 & 0 & 0 \\
\hline OPER & 0 & 0 & 0 & 0 & 3 & 10 & 47 & 70 & 0 & 3 & 23 & 53 \\
\hline OPPO & 0 & 0 & 0 & 0 & 0 & 0 & 0 & 0 & 0 & 0 & 0 & 0 \\
\hline PEPU7 & 0 & 0 & 0 & 0 & 0 & 0 & 0 & 5 & 0 & 0 & 0 & 0 \\
\hline
\end{tabular}


Table G15.-Continued

\begin{tabular}{|c|c|c|c|c|c|c|c|c|c|c|c|c|}
\hline \multirow[b]{3}{*}{ Code } & \multicolumn{12}{|c|}{ Frequency (\%) by macroplot and quadrat size } \\
\hline & \multicolumn{4}{|c|}{ ARCH1b } & \multicolumn{4}{|c|}{ ARCH2 } & \multicolumn{4}{|c|}{$\mathrm{ARCH} 3$} \\
\hline & $0.01 \mathrm{~m}^{2}$ & $0.1 \mathrm{~m}^{2}$ & $1 \mathrm{~m}^{2}$ & $10 \mathrm{~m}^{2}$ & $0.01 \mathrm{~m}^{2}$ & $0.1 \mathrm{~m}^{2}$ & $1 \mathrm{~m}^{2}$ & $10 \mathrm{~m}^{2}$ & $0.01 \mathrm{~m}^{2}$ & $0.1 \mathrm{~m}^{2}$ & $1 \mathrm{~m}^{2}$ & $10 \mathrm{~m}^{2}$ \\
\hline PHCR & 0 & 0 & 0 & 0 & 0 & 0 & 3 & 13 & 0 & 0 & 0 & 7 \\
\hline PIED & 0 & 0 & 0 & 0 & 0 & 0 & 0 & 0 & 0 & 0 & 0 & 0 \\
\hline PLPA2 & 0 & 0 & 0 & 0 & 0 & 0 & 0 & 0 & 0 & 0 & 0 & 0 \\
\hline PUME & 0 & 0 & 0 & 0 & 0 & 0 & 0 & 0 & 0 & 0 & 0 & 7 \\
\hline SAPE10 & 0 & 0 & 0 & 0 & 0 & 0 & 0 & 0 & 0 & 0 & 0 & 0 \\
\hline SCWH & 0 & 0 & 0 & 0 & 0 & 0 & 0 & 0 & 0 & 0 & 0 & 0 \\
\hline SEMU3 & 0 & 0 & 0 & 0 & 0 & 0 & 0 & 0 & 0 & 0 & 0 & 0 \\
\hline SPCO & 0 & 0 & 0 & 0 & 0 & 0 & 0 & 0 & 0 & 0 & 0 & 0 \\
\hline STEX & 0 & 0 & 0 & 0 & 0 & 0 & 0 & 0 & 0 & 0 & 0 & 0 \\
\hline STHY6 & 0 & 0 & 3 & 8 & 0 & 0 & 0 & 5 & 0 & 0 & 0 & 0 \\
\hline STLO4 & 0 & 7 & 13 & 18 & 3 & 23 & 83 & 93 & 23 & 37 & 80 & 93 \\
\hline YUHA & 0 & 0 & 0 & 5 & 0 & 0 & 0 & 0 & 0 & 0 & 0 & 7 \\
\hline ZIPA2 & 0 & 0 & 0 & 0 & 0 & 0 & 0 & 0 & 0 & 0 & 0 & 0 \\
\hline
\end{tabular}


Table G16. Frequency (\%) of plant species in different-sized quadrats at three macroplots (ARCH4b, ARCH5, and CANY3) associated with the Semidesert Shallow Sandy Loam ecological site at Arches and Canyonlands National Parks. See Appendix A for key to species codes.

\begin{tabular}{|c|c|c|c|c|c|c|c|c|c|c|c|c|}
\hline \multirow[b]{3}{*}{ Species code } & \multicolumn{12}{|c|}{ Frequency (\%) by macroplot and quadrat size } \\
\hline & \multicolumn{4}{|c|}{$\mathrm{ARCH} 4 \mathrm{~b}$} & \multicolumn{4}{|c|}{ ARCH5 } & \multicolumn{4}{|c|}{ CANY3 } \\
\hline & $0.01 \mathrm{~m}^{2}$ & $0.1 \mathrm{~m}^{2}$ & $1 \mathrm{~m}^{2}$ & $10 \mathrm{~m}^{2}$ & $0.01 \mathrm{~m}^{2}$ & $0.1 \mathrm{~m}^{2}$ & $1 \mathrm{~m}^{2}$ & $10 \mathrm{~m}^{2}$ & $0.01 \mathrm{~m}^{2}$ & $0.1 \mathrm{~m}^{2}$ & $1 \mathrm{~m}^{2}$ & $10 \mathrm{~m}^{2}$ \\
\hline ARFI2 & 0 & 0 & 0 & 0 & 0 & 0 & 0 & 0 & 0 & 0 & 0 & 0 \\
\hline ASMA10 & 0 & 0 & 0 & 0 & 0 & 0 & 0 & 0 & 0 & 0 & 0 & 0 \\
\hline ASMO7 & 0 & 0 & 0 & 0 & 0 & 0 & 0 & 0 & 0 & 0 & 0 & 10 \\
\hline ATCA2 & 0 & 0 & 0 & 0 & 0 & 0 & 0 & 0 & 0 & 0 & 0 & 5 \\
\hline BRTE & 0 & 0 & 3 & 7 & 0 & 3 & 23 & 50 & 0 & 7 & 43 & 72 \\
\hline CANU3 & 0 & 0 & 0 & 0 & 0 & 0 & 0 & 0 & 0 & 0 & 0 & 0 \\
\hline CHAL7 & 0 & 0 & 0 & 0 & 0 & 0 & 0 & 0 & 0 & 0 & 3 & 3 \\
\hline CHST & 0 & 0 & 7 & 47 & 3 & 43 & 83 & 97 & 0 & 0 & 3 & 3 \\
\hline $\mathrm{CHVI8}$ & 0 & 0 & 0 & 0 & 0 & 0 & 0 & 0 & 0 & 3 & 3 & 3 \\
\hline CORA & 0 & 10 & 43 & 97 & 3 & 7 & 73 & 100 & 3 & 7 & 40 & 73 \\
\hline COWR2 & 0 & 0 & 0 & 0 & 0 & 0 & 0 & 0 & 0 & 13 & 53 & 100 \\
\hline DAFL & 0 & 0 & 0 & 0 & 0 & 0 & 0 & 0 & 0 & 0 & 0 & 0 \\
\hline DEPI & 0 & 0 & 7 & 23 & 0 & 0 & 0 & 0 & 0 & 10 & 17 & 55 \\
\hline ELEL5 & 0 & 0 & 0 & 0 & 0 & 0 & 0 & 0 & 0 & 0 & 3 & 8 \\
\hline EPVI & 0 & 0 & 13 & 27 & 0 & 10 & 33 & 40 & 0 & 3 & 7 & 11 \\
\hline ERCE2 & 0 & 0 & 0 & 0 & 0 & 0 & 0 & 0 & 0 & 0 & 0 & 5 \\
\hline ERCO14 & 0 & 0 & 0 & 0 & 0 & 0 & 0 & 0 & 0 & 0 & 13 & 47 \\
\hline ERIN4 & 0 & 0 & 0 & 0 & 0 & 0 & 0 & 0 & 0 & 0 & 0 & 0 \\
\hline ERMI4 & 0 & 0 & 0 & 0 & 0 & 0 & 0 & 0 & 0 & 0 & 0 & 0 \\
\hline EUFE2 & 0 & 0 & 3 & 10 & 0 & 0 & 7 & 13 & 3 & 10 & 13 & 13 \\
\hline FEOC3 & 13 & 13 & 53 & 90 & 27 & 77 & 97 & 97 & 3 & 30 & 83 & 83 \\
\hline FRAN2 & 0 & 0 & 0 & 0 & 0 & 0 & 0 & 0 & 0 & 0 & 0 & 0 \\
\hline GIIN2 & 3 & 3 & 47 & 87 & 30 & 60 & 80 & 87 & 3 & 13 & 47 & 80 \\
\hline GUSA2 & 0 & 0 & 0 & 7 & 0 & 0 & 0 & 0 & 0 & 3 & 13 & 42 \\
\hline HIJA & 0 & 0 & 0 & 0 & 0 & 0 & 0 & 0 & 0 & 0 & 0 & 0 \\
\hline JUOS & 0 & 0 & 0 & 0 & 0 & 0 & 0 & 0 & 0 & 0 & 0 & 10 \\
\hline LAOC3 & 0 & 0 & 0 & 17 & 7 & 17 & 27 & 57 & 0 & 10 & 23 & 33 \\
\hline LEMO2 & 0 & 0 & 0 & 0 & 0 & 0 & 0 & 0 & 0 & 0 & 17 & 50 \\
\hline LEPE2 & 0 & 0 & 30 & 43 & 0 & 0 & 0 & 0 & 0 & 0 & 0 & 0 \\
\hline MAFR3 & 0 & 0 & 0 & 0 & 0 & 0 & 0 & 0 & 0 & 0 & 0 & 10 \\
\hline MEAL6 & 0 & 0 & 0 & 13 & 0 & 0 & 0 & 0 & 0 & 0 & 0 & 0 \\
\hline OECE2 & 0 & 0 & 0 & 0 & 0 & 0 & 0 & 0 & 0 & 0 & 0 & 0 \\
\hline OPER & 3 & 3 & 7 & 13 & 3 & 17 & 77 & 100 & 0 & 0 & 0 & 0 \\
\hline OPPO & 0 & 0 & 0 & 0 & 0 & 0 & 0 & 0 & 3 & 3 & 17 & 40 \\
\hline PEPU7 & 0 & 0 & 0 & 0 & 0 & 0 & 0 & 0 & 0 & 0 & 0 & 0 \\
\hline
\end{tabular}


Table G16.-Continued

\begin{tabular}{|c|c|c|c|c|c|c|c|c|c|c|c|c|}
\hline \multirow[b]{3}{*}{ Species code } & \multicolumn{12}{|c|}{ Frequency (\%) by macroplot and quadrat size } \\
\hline & \multicolumn{4}{|c|}{$\mathrm{ARCH} 4 \mathrm{~b}$} & \multicolumn{4}{|c|}{ ARCH5 } & \multicolumn{4}{|c|}{ CANY3 } \\
\hline & $0.01 \mathrm{~m}^{2}$ & $0.1 \mathrm{~m}^{2}$ & $1 \mathrm{~m}^{2}$ & $10 \mathrm{~m}^{2}$ & $0.01 \mathrm{~m}^{2}$ & $0.1 \mathrm{~m}^{2}$ & $1 \mathrm{~m}^{2}$ & $10 \mathrm{~m}^{2}$ & $0.01 \mathrm{~m}^{2}$ & $0.1 \mathrm{~m}^{2}$ & $1 \mathrm{~m}^{2}$ & $10 \mathrm{~m}^{2}$ \\
\hline PHCR & 20 & 43 & 67 & 80 & 0 & 0 & 0 & 0 & 0 & 0 & 3 & 3 \\
\hline PIED & 0 & 0 & 0 & 0 & 0 & 0 & 0 & 0 & 0 & 0 & 0 & 5 \\
\hline PLPA2 & 0 & 0 & 0 & 0 & 0 & 0 & 0 & 13 & 0 & 0 & 0 & 0 \\
\hline PUME & 0 & 0 & 0 & 0 & 0 & 0 & 0 & 0 & 0 & 0 & 0 & 0 \\
\hline SAPE10 & 0 & 0 & 3 & 13 & 0 & 0 & 0 & 0 & 0 & 0 & 0 & 0 \\
\hline SCWH & 0 & 0 & 0 & 0 & 0 & 0 & 0 & 0 & 0 & 0 & 0 & 5 \\
\hline SEMU3 & 0 & 0 & 0 & 0 & 0 & 0 & 0 & 0 & 0 & 0 & 3 & 8 \\
\hline SPCO & 0 & 0 & 0 & 3 & 0 & 0 & 3 & 3 & 0 & 0 & 0 & 0 \\
\hline STEX & 0 & 0 & 0 & 0 & 0 & 0 & 0 & 0 & 0 & 0 & 0 & 5 \\
\hline STHY6 & 0 & 0 & 0 & 0 & 0 & 0 & 0 & 0 & 0 & 0 & 7 & 26 \\
\hline STLO4 & 0 & 13 & 30 & 100 & 37 & 50 & 93 & 100 & 0 & 0 & 7 & 21 \\
\hline YUHA & 0 & 0 & 0 & 0 & 0 & 0 & 0 & 0 & 0 & 0 & 0 & 0 \\
\hline ZIPA2 & 0 & 0 & 0 & 0 & 0 & 0 & 0 & 0 & 0 & 0 & 0 & 0 \\
\hline
\end{tabular}


Table G17. Frequency (\%) of plant species in different-sized quadrats at one Semidesert Shallow Sandy Loam macroplot (CANY4) at Canyonlands National Park and combined frequency values for all seven macroplots associated with the Semidesert Shallow Sandy Loam ecological site at Arches and Canyonlands National Parks. See Appendix A for key to species codes.

\begin{tabular}{|c|c|c|c|c|c|c|c|c|}
\hline \multirow[b]{3}{*}{ Species code } & \multicolumn{8}{|c|}{ Frequency (\%) by macroplot and quadrat size } \\
\hline & \multicolumn{4}{|c|}{ CANY4 } & \multicolumn{4}{|c|}{ All macroplots combined $(n=7)$} \\
\hline & $0.01 \mathrm{~m}^{2}$ & $0.1 \mathrm{~m}^{2}$ & $1 \mathrm{~m}^{2}$ & $10 \mathrm{~m}^{2}$ & $0.01 \mathrm{~m}^{2}$ & $0.1 \mathrm{~m}^{2}$ & $1 \mathrm{~m}^{2}$ & $10 \mathrm{~m}^{2}$ \\
\hline ARFI2 & 0 & 0 & 0 & 0 & 0 & 0 & 0 & 0.5 \\
\hline ASMA10 & 0 & 0 & 0 & 0 & 0 & 0 & 0 & 1 \\
\hline ASMO7 & 0 & 0 & 10 & 34 & 0 & 0 & 1 & 6 \\
\hline ATCA2 & 0 & 0 & 0 & 0 & 0 & 0 & 0 & 1 \\
\hline BRTE & 0 & 3 & 7 & 30 & 0 & 2 & 12 & 25 \\
\hline CANU3 & 0 & 3 & 3 & 8 & 0 & 0.5 & 0.5 & 1 \\
\hline CHAL7 & 0 & 0 & 0 & 10 & 0 & 0 & 0.5 & 2 \\
\hline CHST & 0 & 0 & 3 & 22 & 0.5 & 7 & 17 & 30 \\
\hline $\mathrm{CHVI8}$ & 0 & 0 & 0 & 0 & 0 & 0.5 & 1 & 6 \\
\hline CORA & 0 & 3 & 17 & 31 & 4 & 15 & 59 & 86 \\
\hline COWR2 & 3 & 13 & 33 & 62 & 0.5 & 4 & 12 & 23 \\
\hline DAFL & 0 & 0 & 0 & 0 & 0 & 0.5 & 3 & 8 \\
\hline DEPI & 0 & 0 & 20 & 49 & 0 & 1 & 6 & 22 \\
\hline ELEL5 & 0 & 3 & 10 & 10 & 0 & 0.5 & 2 & 3 \\
\hline EPVI & 0 & 3 & 10 & 24 & 0 & 4 & 13 & 33 \\
\hline ERCE2 & 0 & 0 & 0 & 0 & 0 & 0 & 0 & 1 \\
\hline ERCO14 & 0 & 0 & 0 & 0 & 0 & 0 & 2 & 7 \\
\hline ERIN4 & 0 & 0 & 0 & 0 & 0 & 0.5 & 1 & 2 \\
\hline ERMI4 & 0 & 0 & 0 & 0 & 0 & 0 & 0.5 & 1 \\
\hline EUFE2 & 0 & 0 & 0 & 0 & 1 & 3 & 7 & 13 \\
\hline FEOC3 & 3 & 13 & 50 & 69 & 8 & 25 & 53 & 70 \\
\hline FRAN2 & 0 & 0 & 3 & 3 & 0 & 0 & 0.5 & 0.5 \\
\hline GIIN2 & 0 & 10 & 37 & 70 & 5 & 13 & 37 & 57 \\
\hline GUSA2 & 0 & 0 & 3 & 13 & 0 & 0.5 & 2 & 9 \\
\hline HIJA & 0 & 0 & 0 & 0 & 0.5 & 1 & 8 & 12 \\
\hline JUOS & 0 & 0 & 0 & 0 & 0 & 0 & 0 & 4 \\
\hline LAOC3 & 3 & 3 & 7 & 16 & 2 & 5 & 13 & 24 \\
\hline LEMO2 & 0 & 0 & 0 & 0 & 0 & 0 & 2 & 7 \\
\hline LEPE2 & 0 & 0 & 0 & 0 & 0 & 0 & 4 & 6 \\
\hline MAFR3 & 0 & 0 & 0 & 0 & 0 & 0 & 0 & 1 \\
\hline
\end{tabular}


Table G17.-Continued

\begin{tabular}{|c|c|c|c|c|c|c|c|c|}
\hline \multirow[b]{3}{*}{ Species code } & \multicolumn{8}{|c|}{ Frequency (\%) by macroplot and quadrat size } \\
\hline & \multicolumn{4}{|c|}{ CANY4 } & \multicolumn{4}{|c|}{ All macroplots combined $(n=7)$} \\
\hline & $0.01 \mathrm{~m}^{2}$ & $0.1 \mathrm{~m}^{2}$ & $1 \mathrm{~m}^{2}$ & $10 \mathrm{~m}^{2}$ & $0.01 \mathrm{~m}^{2}$ & $0.1 \mathrm{~m}^{2}$ & $1 \mathrm{~m}^{2}$ & $10 \mathrm{~m}^{2}$ \\
\hline MEAL6 & 0 & 0 & 0 & 0 & 0 & 0 & 1 & 4 \\
\hline OECE2 & 0 & 0 & 0 & 0 & 0 & 0 & 0 & 1 \\
\hline OPER & 0 & 0 & 0 & 0 & 1 & 5 & 22 & 34 \\
\hline OPPO & 0 & 3 & 7 & 35 & 0.5 & 1 & 3 & 11 \\
\hline PEPU7 & 0 & 0 & 0 & 0 & 0 & 0 & 0 & 1 \\
\hline PHCR & 0 & 0 & 0 & 0 & 3 & 6 & 10 & 15 \\
\hline PIED & 0 & 0 & 0 & 10 & 0 & 0 & 0 & 2 \\
\hline PLPA2 & 0 & 0 & 0 & 0 & 0 & 0 & 0 & 2 \\
\hline PUME & 0 & 0 & 0 & 0 & 0 & 0 & 0 & 1 \\
\hline SAPE10 & 0 & 0 & 0 & 0 & 0 & 0 & 0.5 & 2 \\
\hline SCWH & 0 & 0 & 0 & 0 & 0 & 0 & 0 & 1 \\
\hline SEMU3 & 0 & 3 & 3 & 22 & 0 & 0.5 & 1 & 4 \\
\hline SPCO & 0 & 0 & 0 & 0 & 0 & 0 & 0.5 & 1 \\
\hline STEX & 0 & 0 & 3 & 18 & 0 & 0 & 0.5 & 3 \\
\hline STHY6 & 3 & 3 & 17 & 26 & 0.5 & 0.5 & 4 & 9 \\
\hline STLO4 & 0 & 0 & 10 & 43 & 9 & 19 & 45 & 67 \\
\hline YUHA & 0 & 0 & 0 & 14 & 0 & 0 & 0 & 4 \\
\hline ZIPA2 & 0 & 0 & 3 & 8 & 0 & 0 & 0.5 & 1 \\
\hline
\end{tabular}


Table G18. Frequency (\%) of plant species in different-sized quadrats at two Shallow Loamy macroplots (WUPA3 and WUPA4) and combined frequency values for both macroplots associated with the Shallow Loamy ecological site at Wupatki National Monument. See Appendix A for key to species codes.

\begin{tabular}{|c|c|c|c|c|c|c|c|c|c|c|c|c|}
\hline \multirow[b]{3}{*}{ Species code } & \multicolumn{12}{|c|}{ Frequency (\%) by macroplot and quadrat size } \\
\hline & \multicolumn{4}{|c|}{ WUPA3 } & \multicolumn{4}{|c|}{ WUPA4 } & \multicolumn{4}{|c|}{ Both macroplots combined $(n=2)$} \\
\hline & $0.01 \mathrm{~m}^{2}$ & $0.1 \mathrm{~m}^{2}$ & $1 \mathrm{~m}^{2}$ & $10 \mathrm{~m}^{2}$ & $0.01 \mathrm{~m}^{2}$ & $0.1 \mathrm{~m}^{2}$ & $1 \mathrm{~m}^{2}$ & $10 \mathrm{~m}^{2}$ & $0.01 \mathrm{~m}^{2}$ & $0.1 \mathrm{~m}^{2}$ & $1 \mathrm{~m}^{2}$ & $10 \mathrm{~m}^{2}$ \\
\hline $\mathrm{ACHY}$ & 0 & 0 & 0 & 0 & 0 & 0 & 0 & 33 & 0 & 0 & 0 & 17 \\
\hline ATCA2 & 0 & 0 & 0 & 0 & 0 & 0 & 0 & 10 & 0 & 0 & 0 & 5 \\
\hline BOER4 & 7 & 7 & 47 & 90 & 0 & 3 & 13 & 18 & 3 & 5 & 30 & 54 \\
\hline CHLE4 & 7 & 40 & 77 & 91 & 10 & 30 & 70 & 99 & 8 & 35 & 73 & 95 \\
\hline CHNA2 & 0 & 0 & 7 & 16 & 0 & 0 & 3 & 22 & 0 & 0 & 5 & 19 \\
\hline $\mathrm{CRCl} 3$ & 0 & 0 & 0 & 5 & 0 & 0 & 0 & 0 & 0 & 0 & 0 & 2 \\
\hline DEPI & 0 & 0 & 17 & 69 & 0 & 0 & 7 & 7 & 0 & 0 & 12 & 38 \\
\hline ELEL5 & 0 & 0 & 0 & 0 & 0 & 0 & 3 & 13 & 0 & 0 & 2 & 6 \\
\hline EPVI & 0 & 0 & 0 & 0 & 0 & 3 & 7 & 16 & 0 & 2 & 3 & 8 \\
\hline GACO5 & 0 & 0 & 0 & 5 & 0 & 0 & 0 & 0 & 0 & 0 & 0 & 2 \\
\hline GIIN2 & 47 & 87 & 100 & 100 & 0 & 33 & 77 & 86 & 23 & 60 & 88 & 93 \\
\hline HENE5 & 17 & 50 & 87 & 100 & 10 & 33 & 80 & 99 & 13 & 42 & 83 & 100 \\
\hline MEAL6 & 10 & 23 & 60 & 84 & 13 & 43 & 83 & 100 & 12 & 33 & 72 & 92 \\
\hline OPER & 0 & 0 & 0 & 5 & 0 & 0 & 0 & 0 & 0 & 0 & 0 & 2 \\
\hline PLJA & 23 & 57 & 97 & 97 & 10 & 53 & 87 & 100 & 17 & 55 & 92 & 98 \\
\hline SAKA & 0 & 0 & 3 & 3 & 0 & 0 & 0 & 5 & 0 & 0 & 2 & 4 \\
\hline SPAI & 0 & 3 & 10 & 15 & 0 & 0 & 10 & 10 & 0 & 2 & 10 & 12 \\
\hline SPPA2 & 0 & 0 & 0 & 0 & 0 & 0 & 3 & 13 & 0 & 0 & 2 & 6 \\
\hline STPI & 0 & 0 & 0 & 0 & 0 & 0 & 0 & 5 & 0 & 0 & 0 & 2 \\
\hline
\end{tabular}


Table G19. Frequency (\%) of plant species in different-sized quadrats at three macroplots (CARE3, CARE4b, and CARE8) associated with the Upland Shallow Loam ecological site at Capitol Reef National Park. See Appendix A for key to species codes.

\begin{tabular}{|c|c|c|c|c|c|c|c|c|c|c|c|c|}
\hline \multirow[b]{3}{*}{ Species code } & \multicolumn{12}{|c|}{ Frequency (\%) by macroplot and quadrat size } \\
\hline & \multicolumn{4}{|c|}{ CARE3 } & \multicolumn{4}{|c|}{ CARE4b } & \multicolumn{4}{|c|}{ CARE8 } \\
\hline & $0.01 \mathrm{~m}^{2}$ & $0.1 \mathrm{~m}^{2}$ & $1 \mathrm{~m}^{2}$ & $10 \mathrm{~m}^{2}$ & $0.01 \mathrm{~m}^{2}$ & $0.1 \mathrm{~m}^{2}$ & $1 \mathrm{~m}^{2}$ & $10 \mathrm{~m}^{2}$ & $0.01 \mathrm{~m}^{2}$ & $0.1 \mathrm{~m}^{2}$ & $1 \mathrm{~m}^{2}$ & $10 \mathrm{~m}^{2}$ \\
\hline AMUT & 0 & 0 & 0 & 0 & 0 & 3 & 3 & 13 & 0 & 0 & 0 & 0 \\
\hline BEFR & 0 & 0 & 0 & 5 & 0 & 0 & 0 & 0 & 0 & 0 & 3 & 17 \\
\hline BRTE & 0 & 0 & 0 & 0 & 0 & 0 & 0 & 0 & 0 & 0 & 0 & 7 \\
\hline CEMO2 & 0 & 0 & 0 & 0 & 0 & 0 & 0 & 0 & 0 & 0 & 3 & 37 \\
\hline CHAL7 & 0 & 0 & 0 & 0 & 0 & 0 & 0 & 0 & 0 & 0 & 0 & 3 \\
\hline CHVI8 & 0 & 0 & 3 & 3 & 0 & 0 & 0 & 0 & 0 & 0 & 0 & 0 \\
\hline COME5 & 0 & 0 & 0 & 0 & 0 & 3 & 3 & 3 & 0 & 0 & 0 & 0 \\
\hline COWR2 & 17 & 53 & 90 & 95 & 17 & 47 & 80 & 99 & 3 & 7 & 60 & 80 \\
\hline CRFL5 & 0 & 0 & 7 & 30 & 0 & 0 & 7 & 35 & 0 & 0 & 3 & 40 \\
\hline DEPI & 0 & 3 & 10 & 20 & 0 & 0 & 20 & 25 & 0 & 3 & 33 & 57 \\
\hline EPVI & 0 & 0 & 0 & 14 & 0 & 0 & 0 & 5 & 0 & 3 & 13 & 30 \\
\hline ERCE2 & 0 & 0 & 0 & 5 & 0 & 0 & 0 & 0 & 0 & 0 & 0 & 0 \\
\hline ERMI4 & 0 & 0 & 7 & 21 & 0 & 0 & 3 & 3 & 0 & 0 & 0 & 0 \\
\hline FRAN2 & 0 & 0 & 0 & 5 & 0 & 0 & 0 & 0 & 0 & 0 & 0 & 0 \\
\hline GIIN2 & 0 & 10 & 17 & 21 & 0 & 0 & 0 & 0 & 0 & 7 & 20 & 43 \\
\hline GUSA2 & 0 & 0 & 0 & 5 & 0 & 0 & 0 & 0 & 0 & 3 & 7 & 30 \\
\hline HIJA & 0 & 0 & 7 & 30 & 0 & 0 & 0 & 0 & 0 & 0 & 0 & 0 \\
\hline JUOS & 0 & 0 & 0 & 14 & 0 & 0 & 0 & 5 & 0 & 3 & 3 & 23 \\
\hline ORHY & 0 & 0 & 0 & 14 & 0 & 0 & 0 & 10 & 0 & 7 & 7 & 10 \\
\hline PEPU7 & 0 & 0 & 0 & 0 & 0 & 0 & 0 & 14 & 0 & 0 & 0 & 7 \\
\hline PIED & 0 & 0 & 0 & 19 & 0 & 0 & 3 & 18 & 0 & 0 & 0 & 7 \\
\hline POFE & 0 & 3 & 3 & 3 & 0 & 0 & 0 & 0 & 0 & 0 & 0 & 0 \\
\hline POSA12 & 0 & 0 & 3 & 3 & 0 & 0 & 0 & 0 & 0 & 0 & 0 & 0 \\
\hline PUME & 0 & 0 & 0 & 0 & 0 & 0 & 0 & 0 & 0 & 0 & 0 & 7 \\
\hline PUTR2 & 0 & 0 & 0 & 0 & 0 & 0 & 0 & 0 & 0 & 0 & 0 & 0 \\
\hline SHRO & 0 & 0 & 0 & 5 & 3 & 3 & 3 & 3 & 0 & 0 & 0 & 3 \\
\hline SIHY & 3 & 3 & 3 & 3 & 0 & 0 & 0 & 0 & 0 & 0 & 0 & 0 \\
\hline STPI & 0 & 0 & 7 & 30 & 0 & 0 & 3 & 22 & 0 & 0 & 0 & 7 \\
\hline
\end{tabular}


Table G20. Frequency (\%) of plant species in different-sized quadrats at two Upland Shallow Loam macroplots (CARE9 and CARE10) and combined frequency values for all five macroplots associated with the Upland Shallow Loam ecological site at Capitol Reef National Park. See Appendix A for key to species codes.

\begin{tabular}{|c|c|c|c|c|c|c|c|c|c|c|c|c|}
\hline \multirow[b]{3}{*}{ Species code } & \multicolumn{12}{|c|}{ Frequency (\%) by macroplot and quadrat size } \\
\hline & \multicolumn{4}{|c|}{ CARE9 } & \multicolumn{4}{|c|}{ CARE10 } & \multicolumn{4}{|c|}{ Ecological Site Mean } \\
\hline & $0.01 \mathrm{~m}^{2}$ & $0.1 \mathrm{~m}^{2}$ & $1 \mathrm{~m}^{2}$ & $10 \mathrm{~m}^{2}$ & $0.01 \mathrm{~m}^{2}$ & $0.1 \mathrm{~m}^{2}$ & $1 \mathrm{~m}^{2}$ & $10 \mathrm{~m}^{2}$ & $0.01 \mathrm{~m}^{2}$ & $0.1 \mathrm{~m}^{2}$ & $1 \mathrm{~m}^{2}$ & $10 \mathrm{~m}^{2}$ \\
\hline AMUT & 0 & 0 & 0 & 0 & 0 & 0 & 0 & 0 & 0 & 1 & 1 & 3 \\
\hline BEFR & 0 & 0 & 0 & 0 & 0 & 0 & 0 & 0 & 0 & 0 & 1 & 4 \\
\hline BRTE & 0 & 0 & 0 & 0 & 0 & 0 & 0 & 0 & 0 & 0 & 0 & 1 \\
\hline CEMO2 & 0 & 0 & 7 & 13 & 0 & 3 & 10 & 27 & 0 & 1 & 4 & 15 \\
\hline CHAL7 & 0 & 0 & 0 & 0 & 0 & 0 & 0 & 0 & 0 & 0 & 0 & 1 \\
\hline CHVI8 & 0 & 0 & 0 & 0 & 0 & 0 & 0 & 0 & 0 & 0 & 1 & 1 \\
\hline COME5 & 0 & 0 & 0 & 0 & 0 & 0 & 0 & 0 & 0 & 1 & 1 & 1 \\
\hline COWR2 & 20 & 37 & 47 & 67 & 17 & 33 & 47 & 80 & 15 & 35 & 65 & 84 \\
\hline CRFL5 & 0 & 0 & 0 & 0 & 0 & 0 & 7 & 43 & 0 & 0 & 5 & 30 \\
\hline DEPI & 0 & 3 & 20 & 53 & 7 & 13 & 20 & 23 & 1 & 5 & 21 & 36 \\
\hline EPVI & 0 & 0 & 0 & 7 & 0 & 0 & 17 & 37 & 0 & 1 & 6 & 18 \\
\hline ERCE2 & 0 & 0 & 0 & 0 & 0 & 0 & 0 & 0 & 0 & 0 & 0 & 1 \\
\hline ERMI4 & 0 & 0 & 0 & 0 & 0 & 0 & 0 & 0 & 0 & 0 & 2 & 5 \\
\hline FRAN2 & 0 & 0 & 0 & 0 & 0 & 0 & 0 & 0 & 0 & 0 & 0 & 1 \\
\hline GIIN2 & 0 & 0 & 0 & 13 & 0 & 0 & 0 & 0 & 0 & 3 & 7 & 16 \\
\hline GUSA2 & 0 & 0 & 10 & 20 & 0 & 0 & 0 & 7 & 0 & 1 & 3 & 12 \\
\hline HIJA & 0 & 0 & 0 & 0 & 0 & 0 & 0 & 0 & 0 & 0 & 1 & 6 \\
\hline JUOS & 0 & 0 & 0 & 0 & 0 & 0 & 0 & 27 & 0 & 1 & 1 & 14 \\
\hline ORHY & 0 & 0 & 0 & 3 & 0 & 0 & 7 & 10 & 0 & 1 & 3 & 9 \\
\hline PEPU7 & 0 & 0 & 0 & 13 & 0 & 0 & 0 & 0 & 0 & 0 & 0 & 7 \\
\hline PIED & 0 & 0 & 0 & 0 & 0 & 0 & 3 & 23 & 0 & 0 & 1 & 13 \\
\hline POFE & 0 & 0 & 0 & 0 & 0 & 0 & 0 & 0 & 0 & 1 & 1 & 1 \\
\hline POSA12 & 0 & 0 & 0 & 0 & 0 & 0 & 0 & 0 & 0 & 0 & 1 & 1 \\
\hline PUME & 0 & 0 & 0 & 30 & 0 & 0 & 0 & 0 & 0 & 0 & 0 & 7 \\
\hline PUTR2 & 0 & 0 & 0 & 10 & 0 & 0 & 0 & 0 & 0 & 0 & 0 & 2 \\
\hline SHRO & 0 & 0 & 0 & 7 & 0 & 0 & 0 & 10 & 1 & 1 & 1 & 6 \\
\hline SIHY & 0 & 0 & 0 & 0 & 0 & 0 & 0 & 0 & 1 & 1 & 1 & 1 \\
\hline STPI & 0 & 0 & 0 & 0 & 0 & 0 & 0 & 0 & 0 & 0 & 2 & 12 \\
\hline
\end{tabular}

